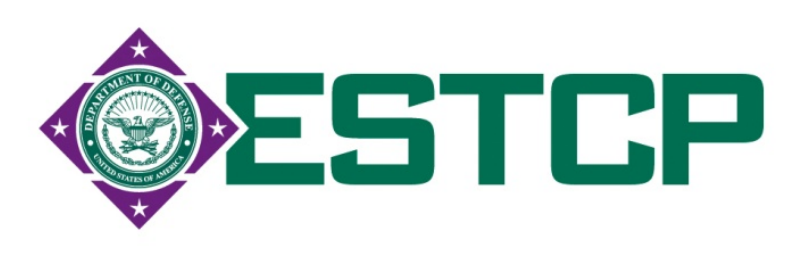

\title{
Dew Point Evaporative Comfort Cooling
}

Energy and Water Projects Demonstration Plan SI-0821

\author{
TP-7A40-56256-1
}

November 2012

Jesse Dean, Lesley Herrmann, Eric Kozubal, and Jesse Geiger (National Renewable Energy Laboratory) Mark Eastment (Eastment Consulting Inc.) Steve Slayzak (Coolerado)

Link to Summary Report 


\section{NOTICE}

This manuscript has been authored by employees of the Alliance for Sustainable Energy, LLC ("Alliance") under Contract No. DE-AC36-08GO28308 with the U.S. Department of Energy ("DOE"). The work described in this report (NREL/TP-7A40-56256) was funded under task number WFG7.1000.

This report was prepared as an account of work sponsored by an agency of the United States government. Neither the United States government nor any agency thereof, nor any of their employees, makes any warranty, express or implied, or assumes any legal liability or responsibility for the accuracy, completeness, or usefulness of any information, apparatus, product, or process disclosed, or represents that its use would not infringe privately owned rights. Reference herein to any specific commercial product, process, or service by trade name, trademark, manufacturer, or otherwise does not necessarily constitute or imply its endorsement, recommendation, or favoring by the United States government or any agency thereof. The views and opinions of authors expressed herein do not necessarily state or reflect those of the United States government or any agency thereof.

Available electronically at http://www.osti.gov/bridge

Available for a processing fee to U.S. Department of Energy and its contractors, in paper, from:

U.S. Department of Energy

Office of Scientific and Technical Information

P.O. Box 62

Oak Ridge, TN 37831-0062

phone: 865.576 .8401

fax: 865.576 .5728

email: mailto:reports@adonis.osti.gov

Available for sale to the public, in paper, from:

U.S. Department of Commerce

National Technical Information Service

5285 Port Royal Road

Springfield, VA 22161

phone: 800.553 .6847

fax: 703.605.6900

email: orders@ntis.fedworld.gov

online ordering: http://www.ntis.gov/help/ordermethods.aspx

Printed on paper containing at least 50\% wastepaper, including $10 \%$ post-consumer waste. 


\section{ACKNOWLEDGMENTS}

The authors would like to thank the ESTCP project team members for their creativity, persistence, and willingness to support this project. Scott Clark, the Energy Program Coordinator for Fort Carson, was instrumental in setting up the demonstration and has provided countless hours assisting with the installation of the data acquisition system and multiyear performance testing. Fort Carson engineers worked with the project partners to design and integrate the Coolerado units into five facilities and designed an innovative rain water catchment system for four units at the Theater. Mountain Energy Partnership provided invaluable assistance with the design and installation of the data acquisition system, as well as data analysis support. Onsite heating, ventilation, and air-conditioning technicians diligently recorded operation and maintenance activities and provided valuable insights into operation and maintenance costs of the units. Several members of the Coolerado team, including Tim Heaton, Steve Slayzak, Leland Gillian, and Daniel Zube, also went out of their way to accommodate the, requests of the Fort Carson and NREL staff members. Various members of NREL's Commercial Buildings Research team, including James Page, Andrew Parker, Michael Deru, and Brent Griffith, provided laboratory and field testing assistance and modeling support. Finally, the project would not have been possible without financial support from ESTCP program, whose members also provided valuable insights into the types of data analysis procedures and results that would be most beneficial to DoD facilities and engineers. 


\section{ACronyms AND AbBreviations}

\begin{tabular}{|c|c|}
\hline AHU & air handling unit \\
\hline ASHRAE & American Society of Heating, Refrigerating and Air-Conditioning Engineers \\
\hline Btu & British thermal units \\
\hline cfm & cubic feet per minute \\
\hline CT & current transducer \\
\hline $\mathrm{CoC}$ & cycle of concentration \\
\hline COP & coefficient of performance \\
\hline CRAC & computer room air-conditioning \\
\hline DAS & data acquisition system \\
\hline DAT & discharge air temperature \\
\hline DC-kW & direct-current kilowatt \\
\hline DEC & direct evaporative cooler, direct evaporative cooling \\
\hline DoD & U.S. Department of Defense \\
\hline DX & direct expansion \\
\hline EA & exhaust air \\
\hline EAT & exhaust air temperature \\
\hline ECM & electronically commutated motor \\
\hline EER & energy efficiency ratio \\
\hline eGrid & Emissions \& Generation Resource Integrated Database \\
\hline EISA & Energy Independence and Security Act of 2007 \\
\hline E.O. & Executive Order \\
\hline ESTCP & Environmental Security Technology Certification Program \\
\hline EUI & energy use intensity \\
\hline HMX & heat mass exchanger \\
\hline hp & horsepower \\
\hline HVAC & heating, ventilating, and air-conditioning \\
\hline IEC & indirect evaporative cooler, indirect evaporative cooling \\
\hline IEER & integrated energy efficiency ratio \\
\hline $\mathbf{k W}$ & kilowatt \\
\hline kWh & kilowatt-hour \\
\hline $\mathbf{L}$ & liter \\
\hline MCDB & mean coincident dry bulb \\
\hline MMBtu & million British thermal units \\
\hline NERC & North American Reliability Corporation \\
\hline NREL & National Renewable Energy Laboratory \\
\hline NPV & net present value \\
\hline $\mathbf{O A}$ & outside air \\
\hline OAR & outside air ratio \\
\hline OAT & outside air temperature \\
\hline ppm & parts per million \\
\hline RA & return air \\
\hline RAT & return air temperature \\
\hline
\end{tabular}


RH relative humidity

RMSE root mean square error

RTU rooftop unit

SA supply air

SAT supply air temperature

SHR sensible heat ratio

SP static pressure

SPP simple payback

TDS total dissolved solids

TTF Thermal Test Facility

TMY typical meteorological year

W Watt 


\section{TABle Of Contents}

ACKNOWLEDGMENTS ....................................................................................................................... III

ACRONYMS AND ABBREVIATIONS ...................................................................................................IV

TABLE OF CONTENTS ………………................................................................................................

LIST OF FIGURES ..............................................................................................................................

LIST OF TABLES ..............................................................................................................................XIV

EXECUTIVE SUMMARY ……......................................................................................................... 1

1.0 INTRODUCTION ....................................................................................................................... 4

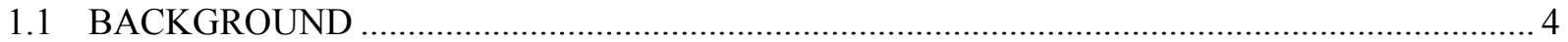

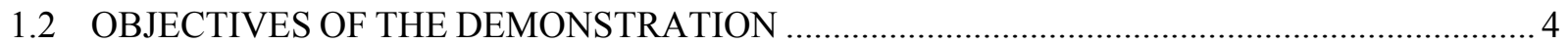

1.3 REGULATORY DRIVERS ………………………………………………………. 5

2.0 TECHNOLOGY DESCRIPTION ................................................................................................. 6

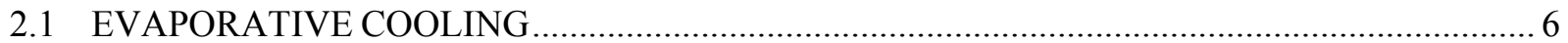

2.2 TECHNOLOGY OVERVIEW ……………………………………………………. 7

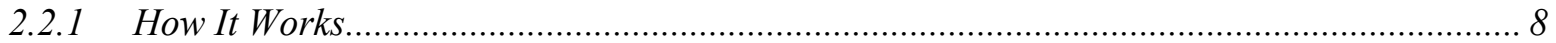

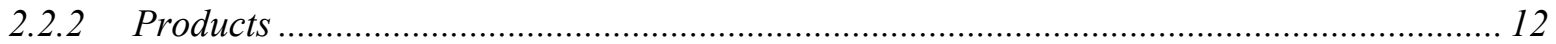

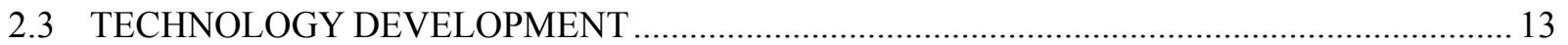

2.4 ADVANTAGES AND LIMITATIONS OF THE TECHNOLOGY ……………………………. 14

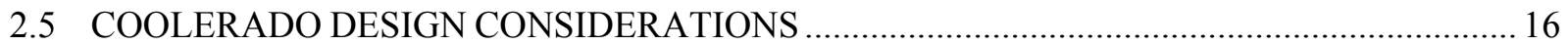

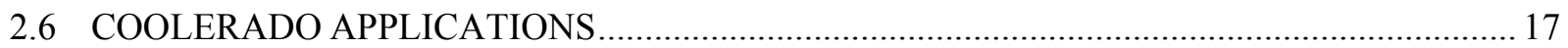

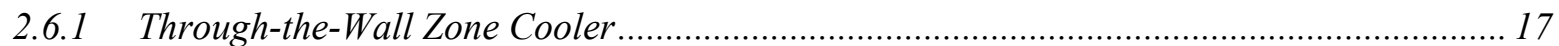

2.6.2 Outside Air Pre-conditioner ...................................................................................... 18

2.6.3 Zone Cooler with Return Air..................................................................................... 19

2.6.4 Integrated into Air Handling Unit Mixing Boxes........................................................ 20

3.0 PERFORMANCE OBJECTIVES ....................................................................................22

3.1 IMPROVE COMFORT PROVIDED BY EVAPORATIVE COOLING .....................................2.

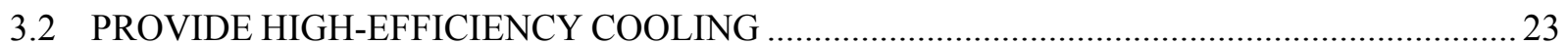

3.3 SUSTAIN HIGH COOLING PERFORMANCE .................................................................. 24

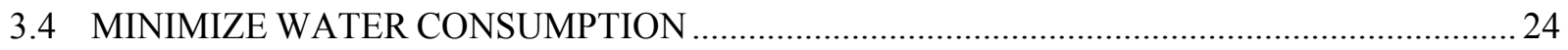

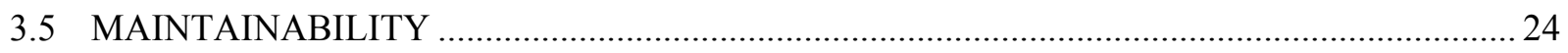

4.0 FACILITY/SITE DESCRIPTION .............................................................................................25

$4.1 \quad$ FACILITY/SITE LOCATION AND OPERATIONS ………………………………………..... 26

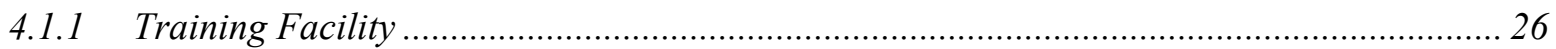

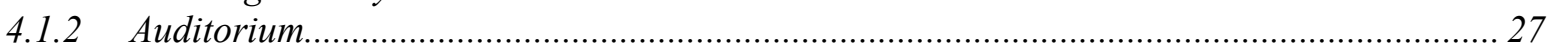

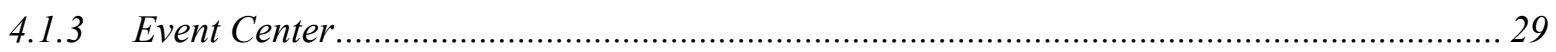

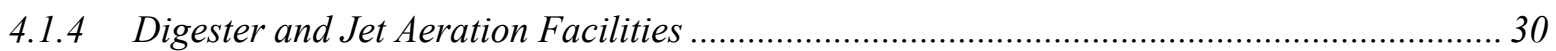

4.1.5 Wastewater Treatment Plant ..................................................................................... 32

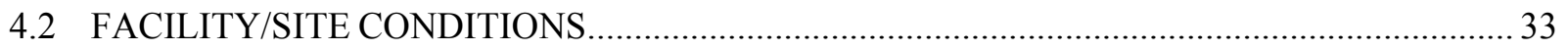

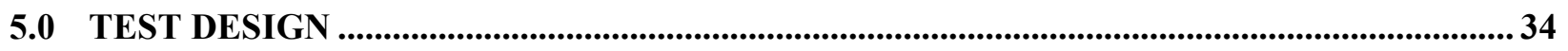

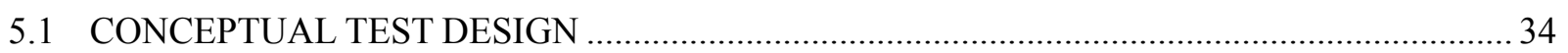

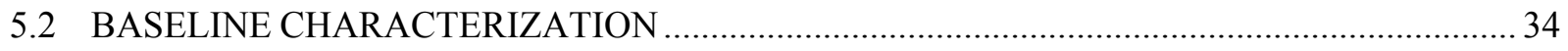

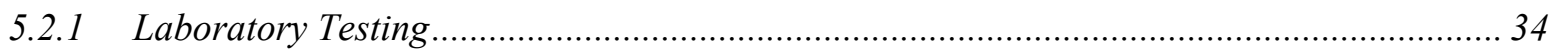




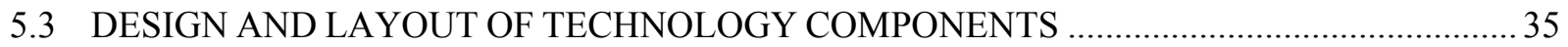

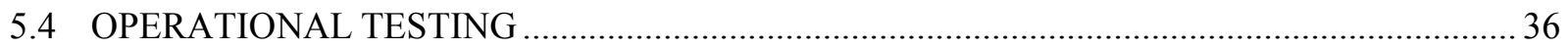

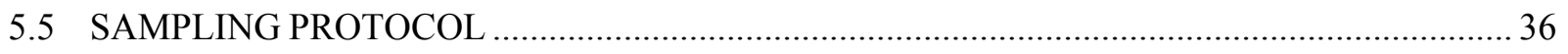

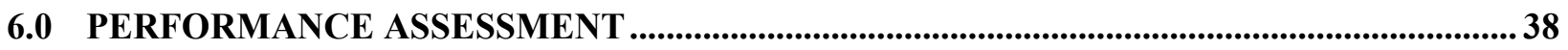

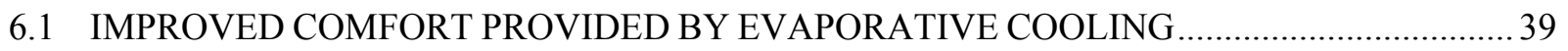

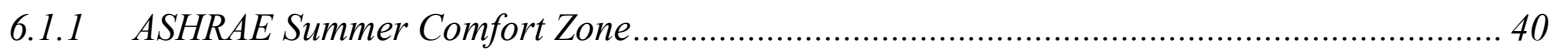

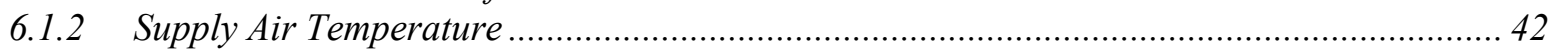

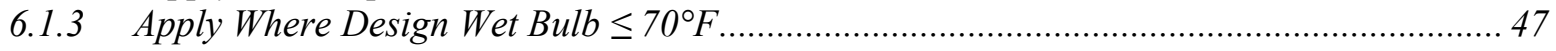

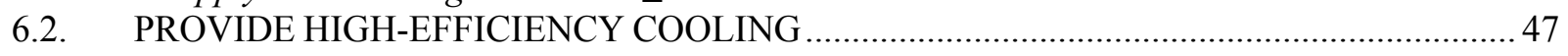

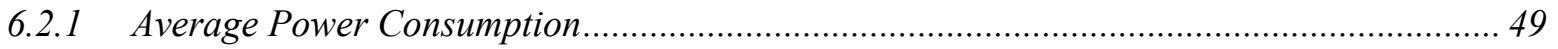

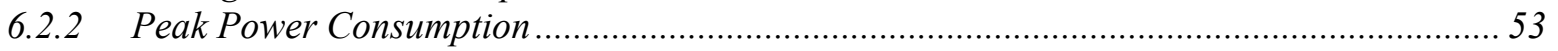

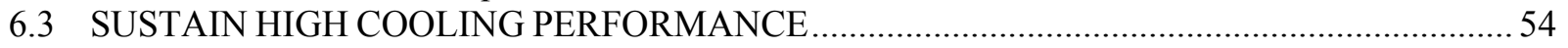

6.3.1 Less Than 5\% Degradation of Wet Bulb Effectiveness Over 3 Years ................................. 54

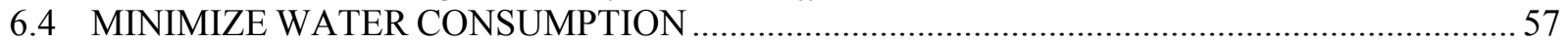

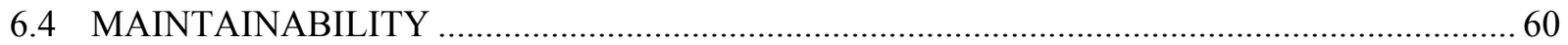

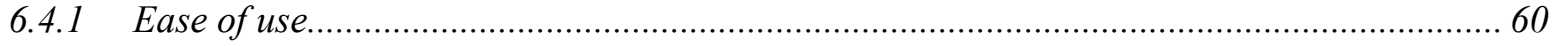

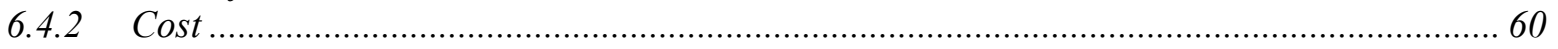

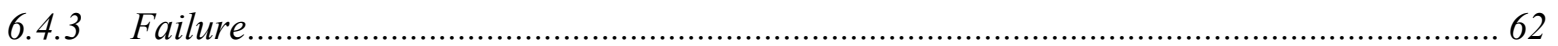

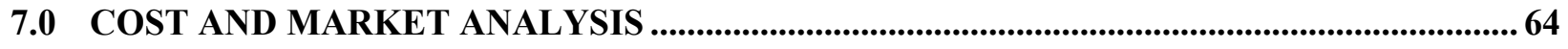

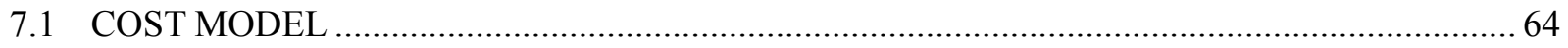

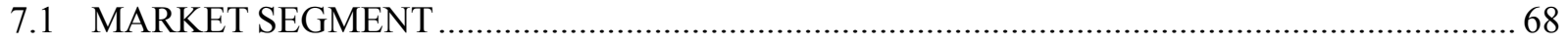

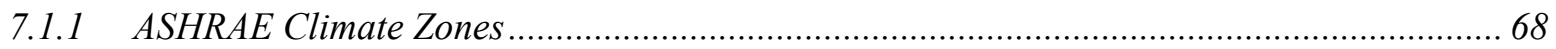

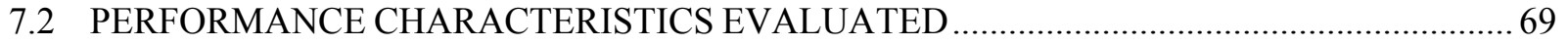

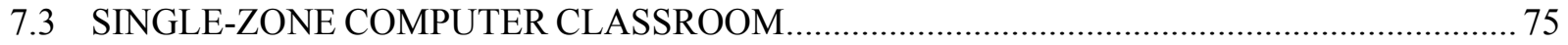

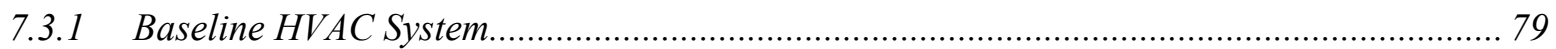

7.3.2 Single-Zone Variable Air Volume Retrofit ........................................................................ 79

7.3.3 Single-Zone Variable Air Volume Retrofit with Evaporative Technologies ........................ 79

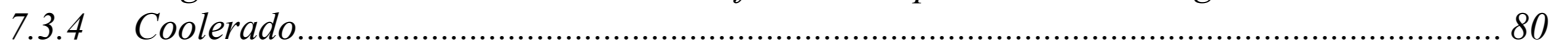

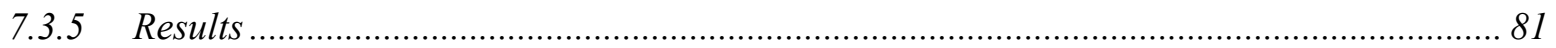

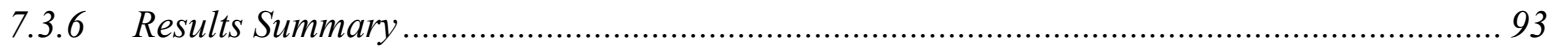

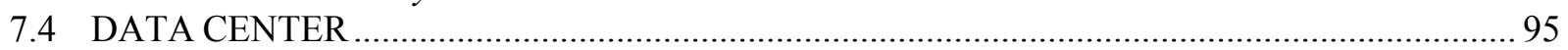

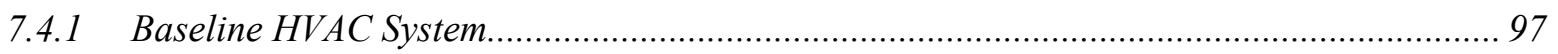

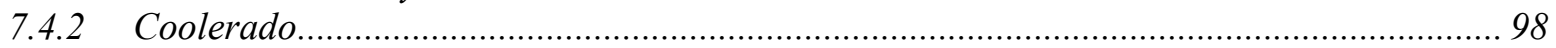

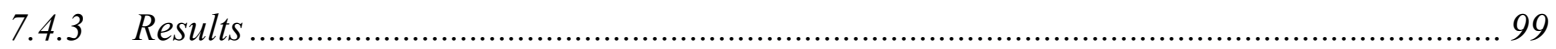

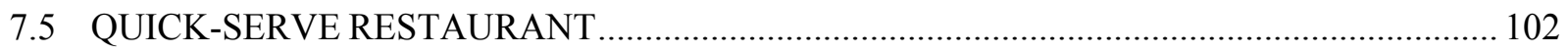

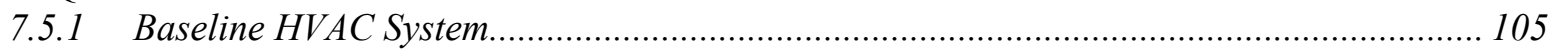

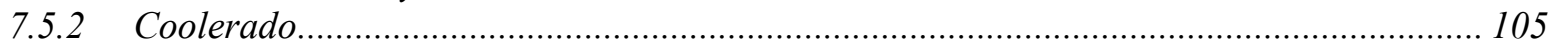

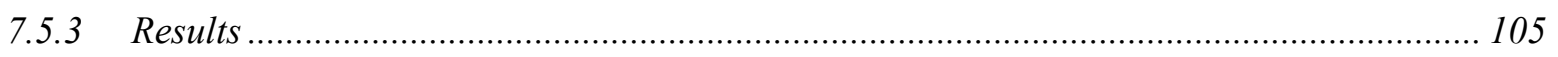

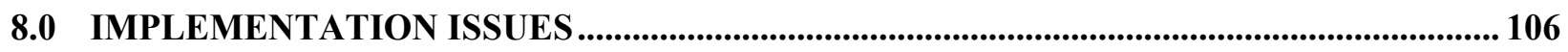

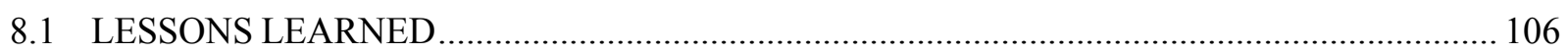

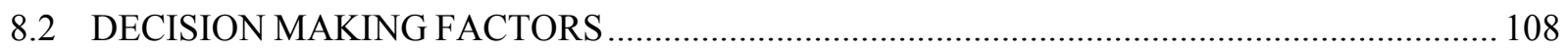

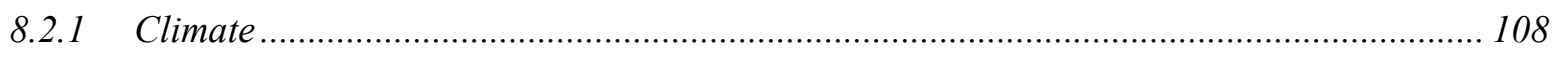

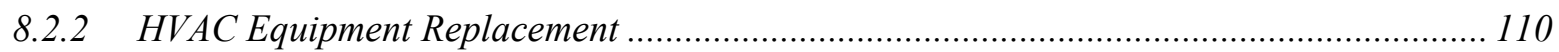

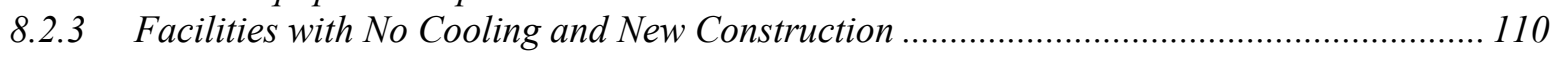

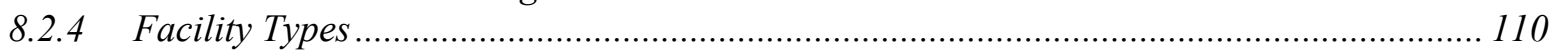

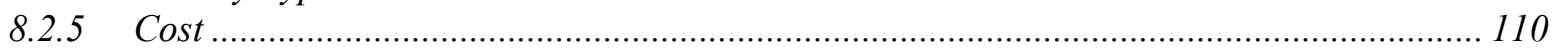

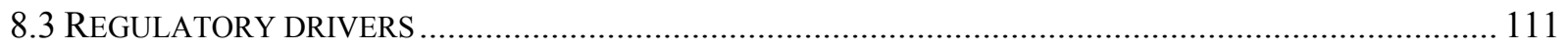




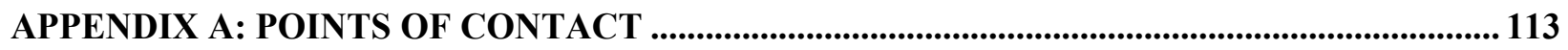

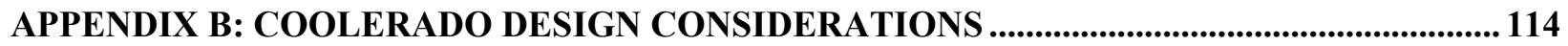

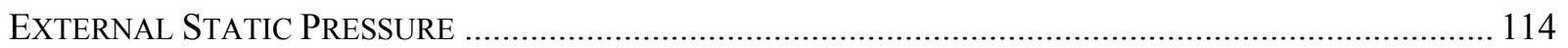

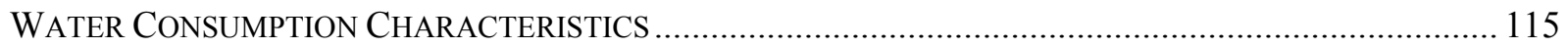

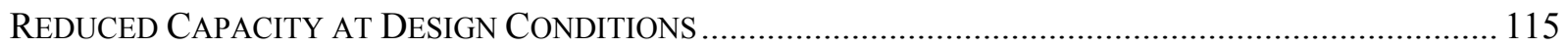

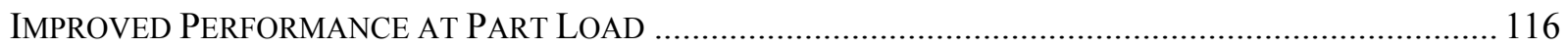

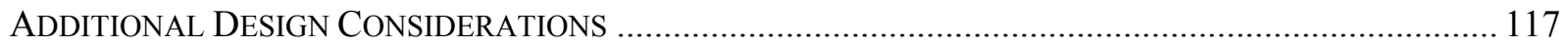

APPENDIX C: FIELD MEASUREMENT SENSOR DESCRIPTION AND SPECIFICATION... 118

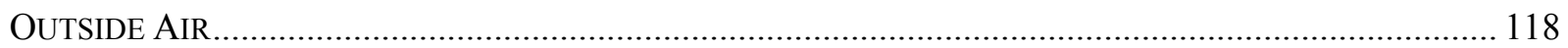

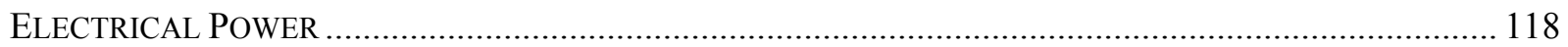

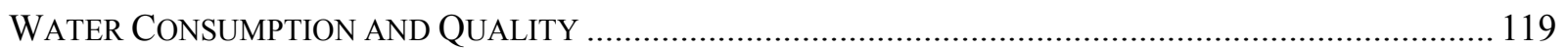

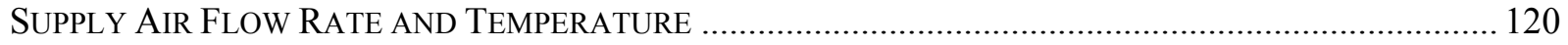

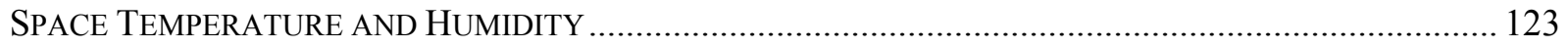

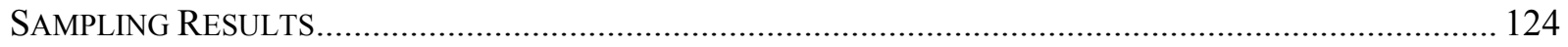

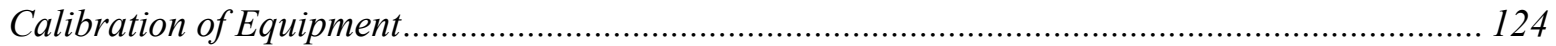

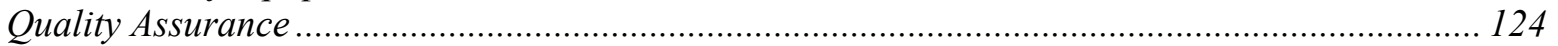

APPENDIX D: DEVELOPMENT AND VALIDATION OF COOLERADO PERFORMANCE

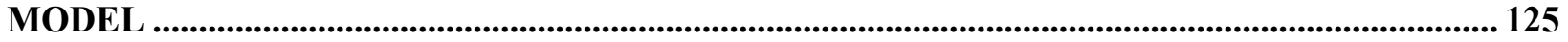

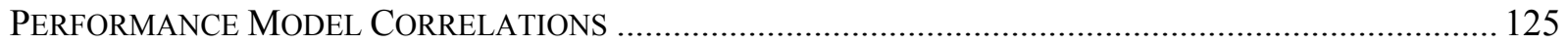

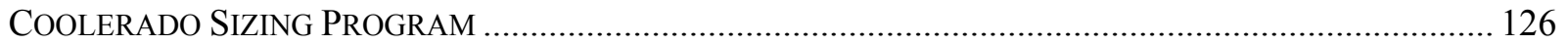

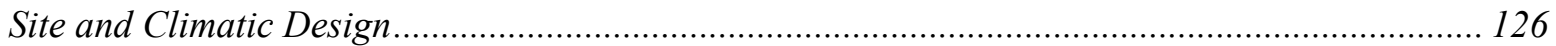

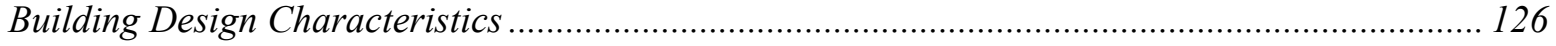

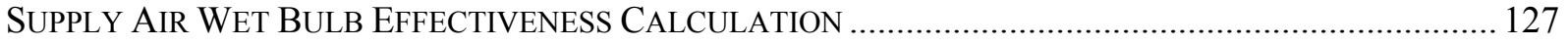

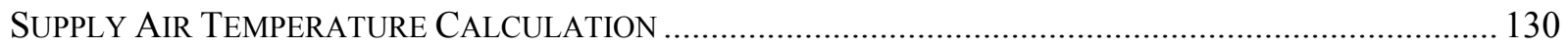

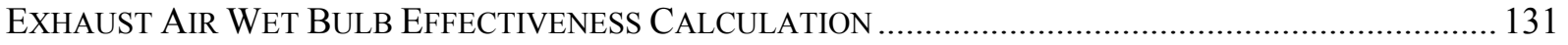

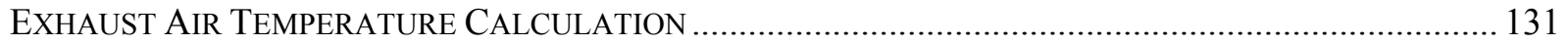

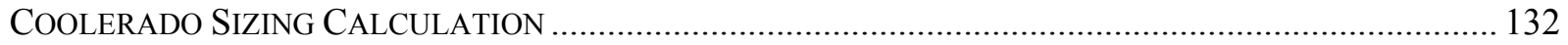

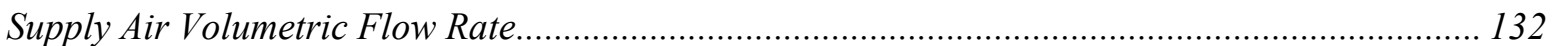

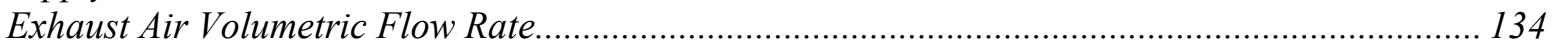

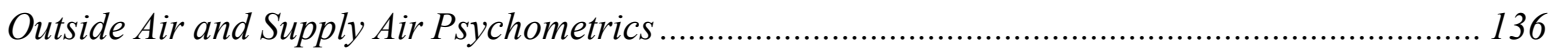

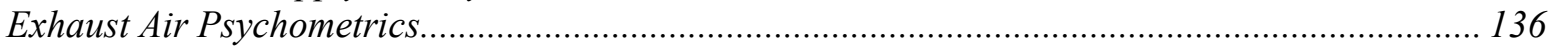

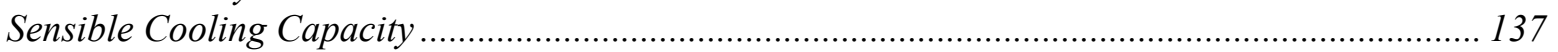

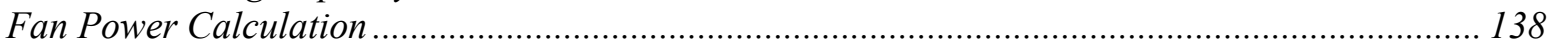

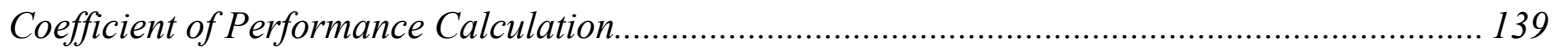

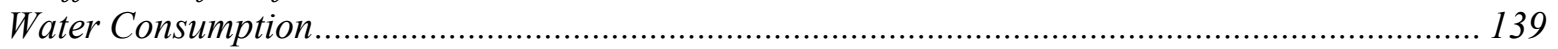

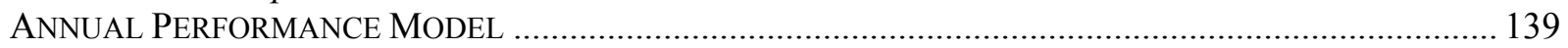

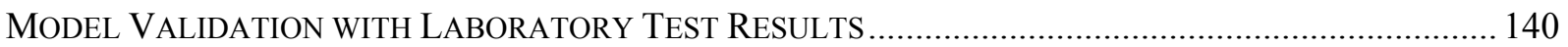

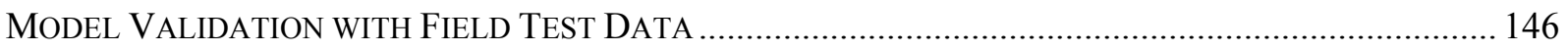

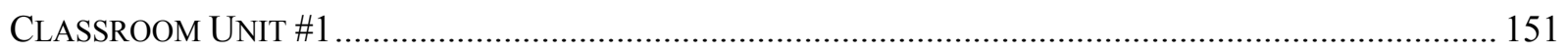

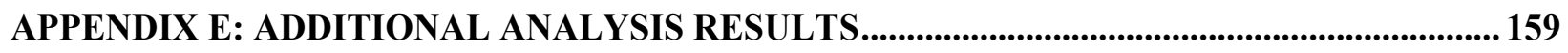

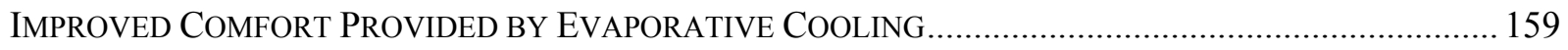

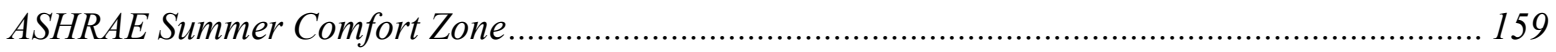

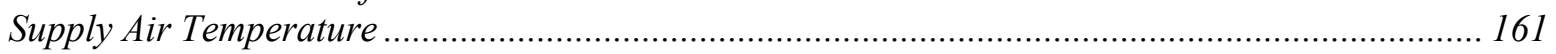

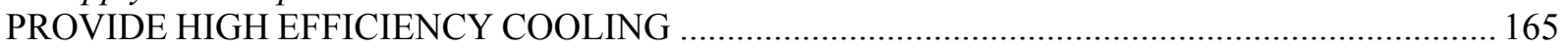

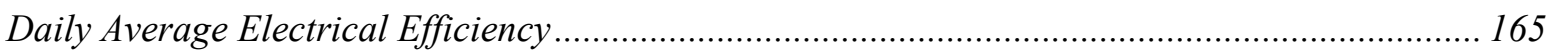

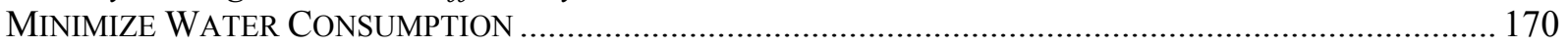

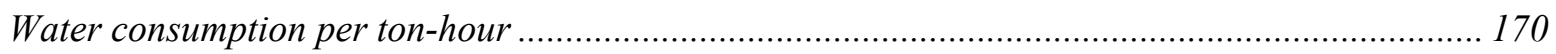

viii 


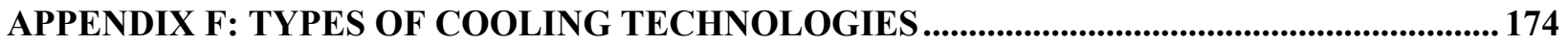

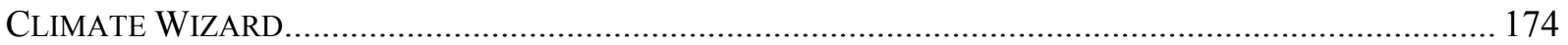

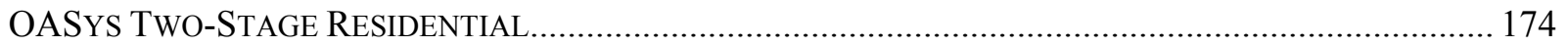

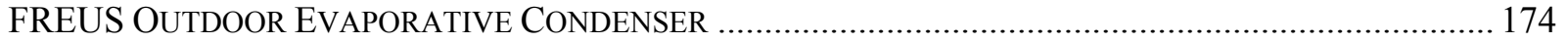

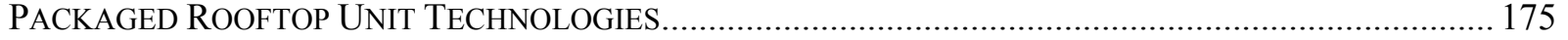

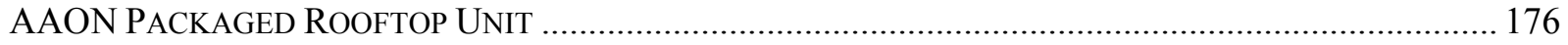

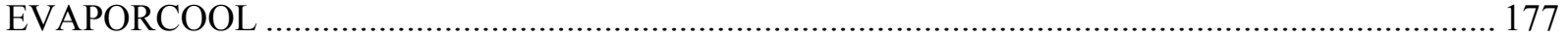

MUNTERS OASIS EPX

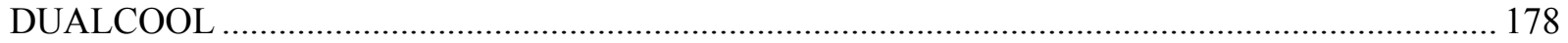

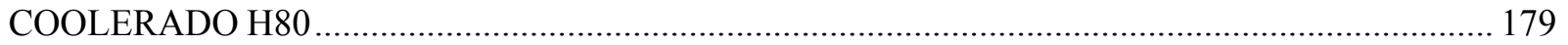

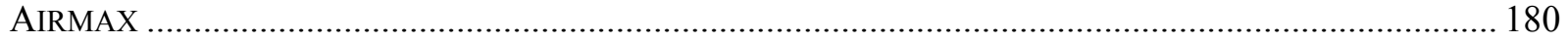

MEDIUM TO LARGE COMMERCIAL BUILDING TECHNOLOGIES ........................................................ 181

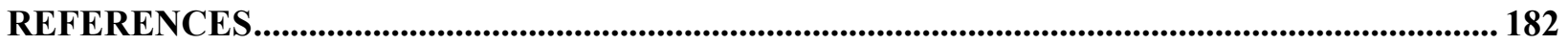




\section{LIST OF FIGURES}

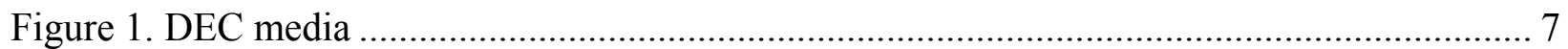

Figure 2. Internal HMX process airstream and EA stream airflow .......................................... 9

Figure 3. Side view of Coolerado airflow process.................................................................. 9

Figure 4. Conceptual psychrometric representation of the staged indirect cooling process......... 10

Figure 5. Staged flow of the IEC/DEC process ................................................................ 11

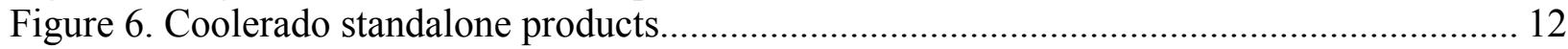

Figure 7. 2009 free form Coolerado HMX .............................................................................. 12

Figure 8. 2011 Modular Coolerado HMX ........................................................................... 13

Figure 9. Fiero Fluid Power solenoid and regulator comparison.......................................... 14

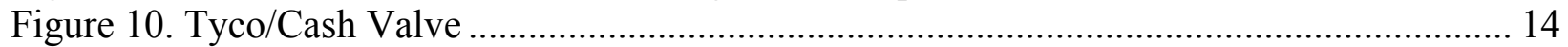

Figure 11. ASHRAE climate zone map ...................................................................... 15

Figure 12. Through-the-wall zone cooler .......................................................................... 18

Figure 13. Coolerado Cooler as OA pre conditioner ............................................................... 19

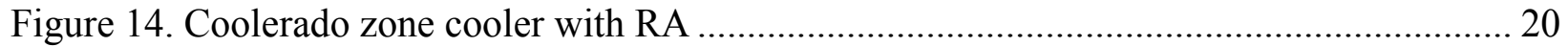

Figure 15. Coolerado integrated into AHU mixing box ...................................................... 21

Figure 16. Coolerado integrated into AHU mixing box ...................................................... 21

Figure 17. Final training center design .......................................................................... 27

Figure 18. Training center exterior installation (right); training center interior vent (left) ......... 27

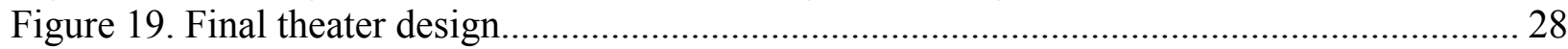

Figure 20. Theater exterior installation............................................................................. 28

Figure 21. Final event center design ............................................................................... 29

Figure 22. Event center exterior installation .................................................................. 30

Figure 23. Section view of Coolerado installation at the event center .................................... 30

Figure 24. Right side view of roof-mounted Coolerado .................................................. 31

Figure 25. Final digester facility design ..................................................................... 31

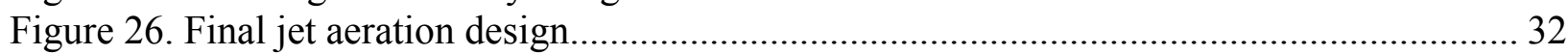

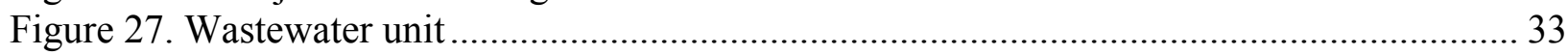

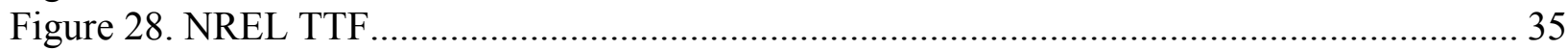

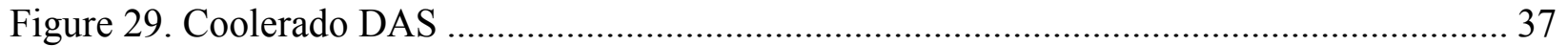

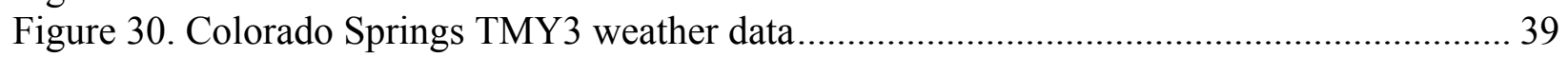

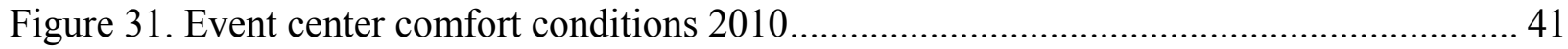

Figure 32. Classroom unit \#2 comfort conditions, 2011 ..................................................... 42

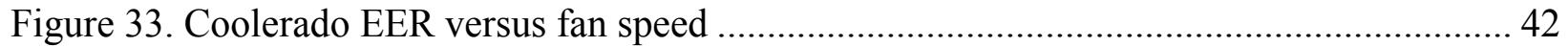

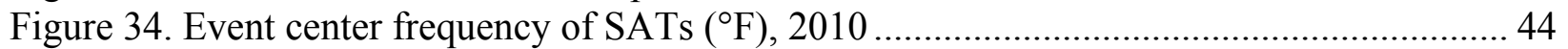

Figure 35. July 2010 event center SAT versus wet bulb temperature ...................................... 44

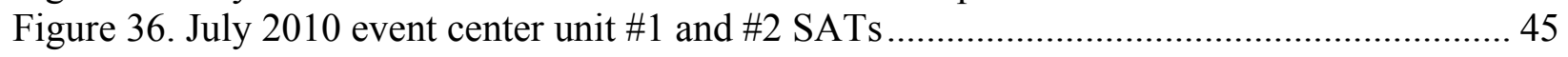

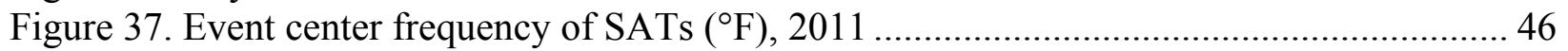

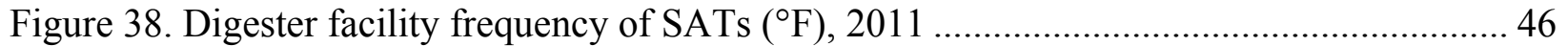

Figure 39. Digester facility hourly average WBE .......................................................... 47

Figure 40. Event center unit \#1 cooling capacity (indoor) versus OAT ................................... 48

Figure 41. Event center \#1 cooling capacity (OA) versus OAT ............................................. 49

Figure 42. Training facility daily average electrical efficiency (kW/ton), 2010 ..................... 51

Figure 43. Training facility daily average electrical efficiency (kW/ton), 2011 .................... 51 
Figure 44. Event center unit \#1 daily average electrical efficiency (building cool) (kW/ton),

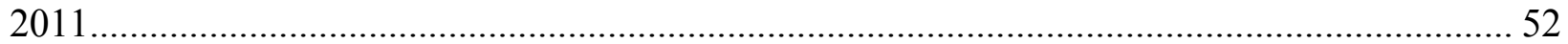

Figure 45. Digester facility daily average electrical efficiency (kW/ton), $2011 \ldots \ldots \ldots \ldots \ldots \ldots \ldots \ldots \ldots . . .53$

Figure 46. Coolerado classroom unit peak demand savings.........................................................5 54

Figure 47. Event center unit \#1 2010 measured versus modeled SAT ......................................... 55

Figure 48. Event center unit \#1 percent difference between measured and modeled SAT ...........56 56

Figure 49. Event center unit \#1 2011 measured versus modeled SAT .........................................56

Figure 50. Event center unit \#1 2011 percent difference in measured versus modeled SAT........55 57

Figure 51. Event center daily average water use efficiency (gal/ton $\cdot \mathrm{h}), 2010 \ldots \ldots \ldots \ldots \ldots \ldots \ldots \ldots \ldots \ldots . . .58$

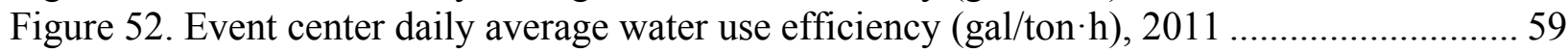

Figure 53. Jet aeration facility daily average water use efficiency $(\mathrm{gal} / \mathrm{ton} \cdot \mathrm{h})$.................................... 60

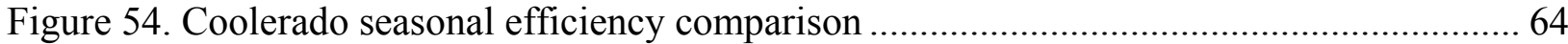

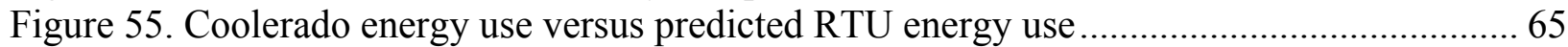

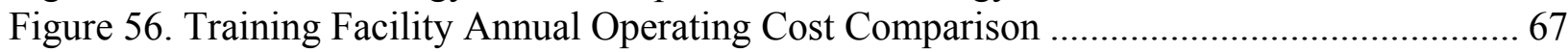

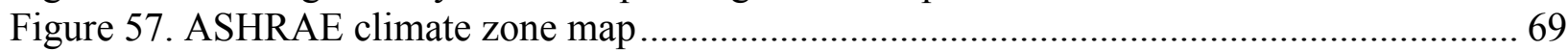

Figure 58. NERC split into grid interconnect regions. Note the Hawaiian Islands and Alaskan

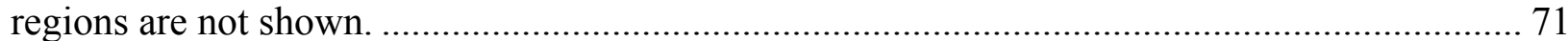

Figure 59. Water consumption rates and overall water consumption by NERC region............... 72

Figure 60. Computer room classroom Coolerado units ........................................................... 76

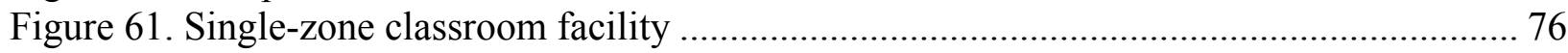

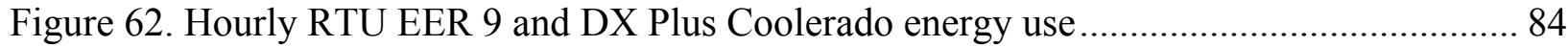

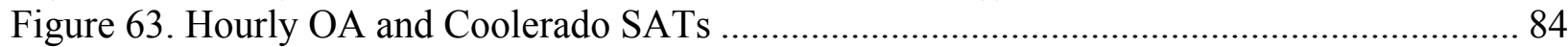

Figure 64. Hourly RTU EER 9 and DX Plus Coolerado energy use .......................................... 86

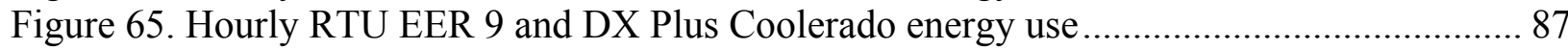

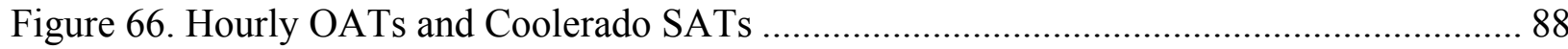

Figure 67. Hourly RTU EER 9 and DX Plus Coolerado energy use ............................................ 89

Figure 68. Hourly RTU EER 9 and DX Plus Coolerado energy use ............................................. 91

Figure 69. Hourly OAT versus Coolerado SAT ..................................................................... 91

Figure 70. Hourly RTU EER 9 and DX Plus Coolerado energy use .......................................... 93

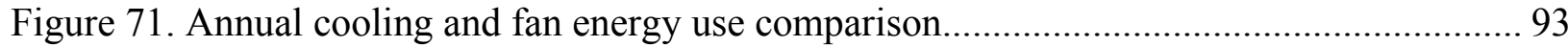

Figure 72. Annual cooling and fan energy use comparison....................................................... 94

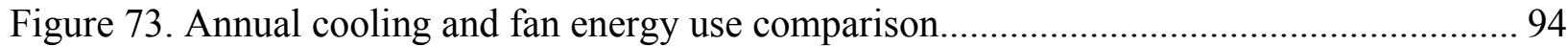

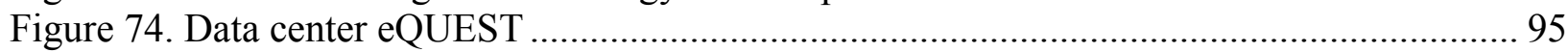

Figure 75. National Snow and Ice Data Center Coolerado winter operation ............................... 98

Figure 76. Data center annual cooling and fan energy comparison across climate zones........... 100

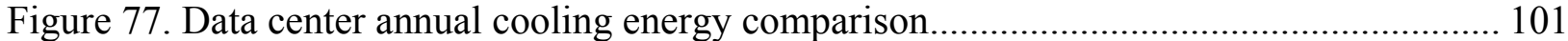

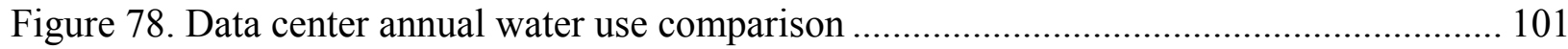

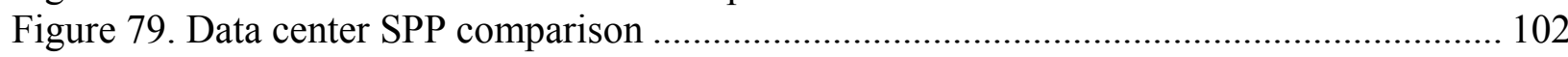

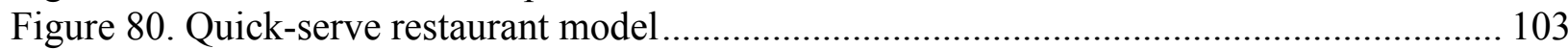

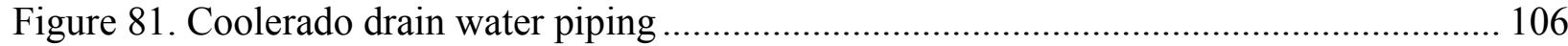

Figure 82. Coolerado units and manhole over water storage tank................................................ 107

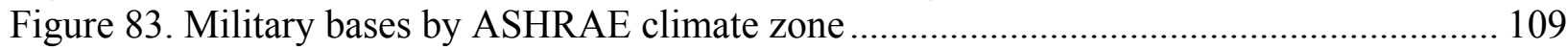

Figure 84. Coolerado cooling capacity and airflow rate versus SP .......................................... 114

Figure 85. Coolerado energy efficiency ratio versus fan speed.............................................. 117

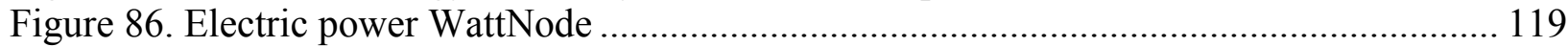

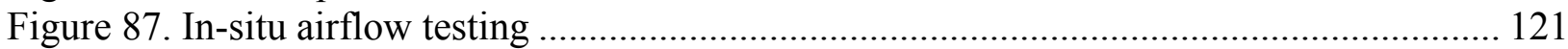


Figure 88. In-situ measured flow rate versus fan power................................................. 122

Figure 89. SA WBE versus external sp at 100\% fan speed ............................................... 128

Figure 90. SA WBE versus percent fan speed at 0.5 in. external static..................................... 128

Figure 91. SA WBE versus percent fan speed at 0.5 in. static .............................................. 130

Figure 92. EA WBE versus external static at 100\% fan speed.......................................... 131

Figure 93. SA volumetric airflow rate versus external SP at 100\% fan speed ........................ 132

Figure 94. SA volumetric airflow rate versus percent fan speed at 0.5 in. static ..................... 133

Figure 95. EA volumetric airflow rate versus external SP at 100\% fan speed........................ 134

Figure 96. EA volumetric airflow rate versus percent flow rate at 0.5 in. static ..................... 135

Figure 97. Fan power versus percent fan speed ............................................................... 138

Figure 98. Modeled versus Measured Key Parameters Linear Regression ............................. 145

Figure 99. Modeled versus measured key parameters \#2 linear regression ............................ 146

Figure 100. Modeled versus measured key parameters \#2 linear regression ........................... 149

Figure 101. Modeled versus measured key parameters \#2 linear regression ............................ 149

Figure 102. Modeled versus measured annual performance and 15-min RMSE .................... 151

Figure 103. Modeled versus measured interval SAT, energy use, and water use ................... 152

Figure 104. Modeled versus measured interval SAT, energy use, and water use .................... 153

Figure 105. Modeled versus measured interval cooling capacity, SAT and daily water

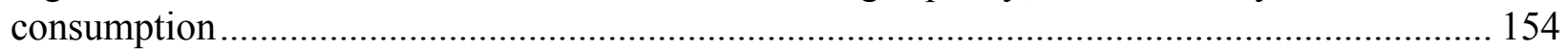

Figure 106. Modeled versus measured annual performance and 15-min RMSE .................... 155

Figure 107. Modeled versus measured interval SAT, energy use, and water use .................... 156

Figure 108. Modeled versus measured interval SAT, energy use, and water use .................... 157

Figure 109. Modeled versus measured interval cooling capacity, SAT, and daily water

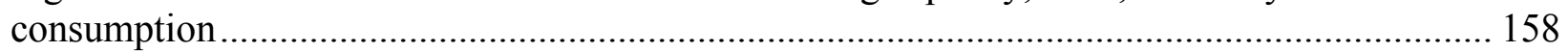

Figure 110. Theater unit summer 2010 thermal comfort ..................................................... 159

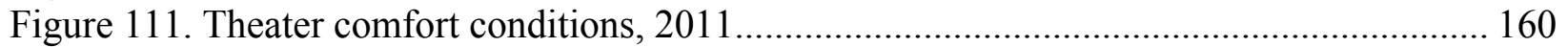

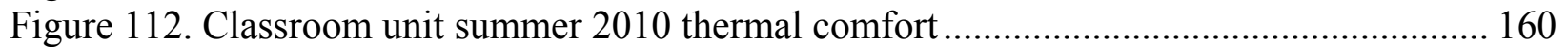

Figure 113. Classroom unit \#2 summer 2010 thermal comfort ........................................... 161

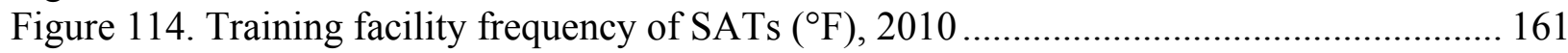

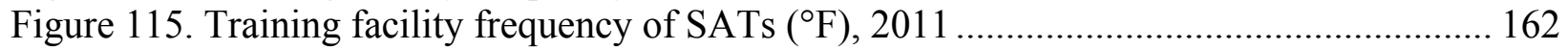

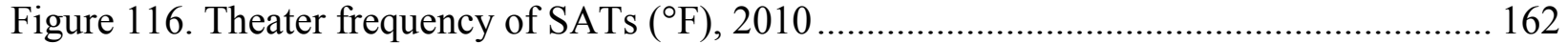

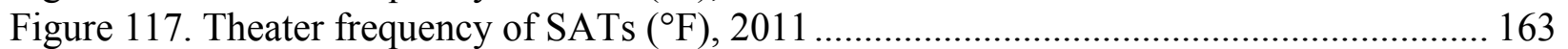

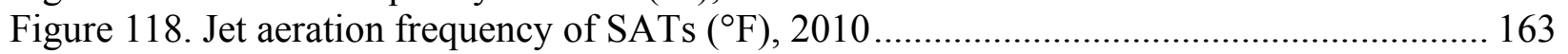

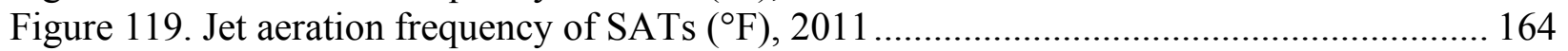

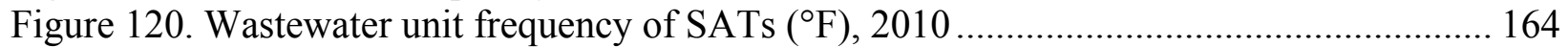

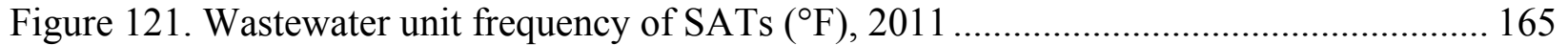

Figure 122. Event center daily average electrical efficiency (kW/ton), 2010 ......................... 165

Figure 123. Event center daily average electrical efficiency (kW/ton), 2011 ......................... 166

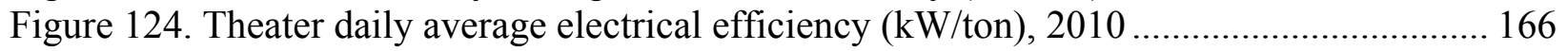

Figure 125. Theater daily average electrical efficiency (kW/ton), 2011 ................................ 167

Figure 126. Jet aeration daily average electrical efficiency (kW/ton), 2010 ......................... 167

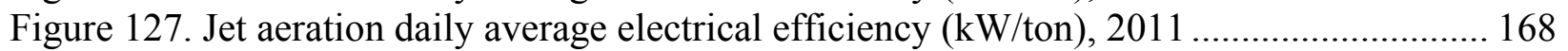

Figure 128. Digester facility daily average electrical efficiency (kW/ton), 2010 .................. 168

Figure 129. Wastewater unit daily average electrical efficiency (kW/ton), 2010 .................. 169

Figure 130. Wastewater unit daily average electrical efficiency (kW/ton), 2011 .................. 169

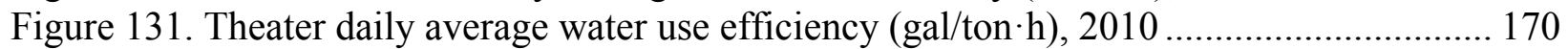




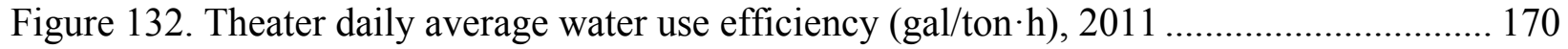

Figure 133. Digester facility daily average water use efficiency (gal/ton·h), $2010 \ldots \ldots \ldots \ldots \ldots \ldots . . . .171$

Figure 134. Digester facility daily average water use efficiency (gal/ton·h), $2011 \ldots \ldots \ldots \ldots \ldots . . . . .171$

Figure 135. Jet aeration daily average water use efficiency (gal/ton·h), $2010 \ldots \ldots \ldots \ldots \ldots \ldots \ldots \ldots . . . . . . . . . .172$

Figure 136. Jet aeration daily average water use efficiency (gal/ton·h), $2011 \ldots \ldots \ldots \ldots \ldots \ldots \ldots \ldots . . . . . . . . .172$

Figure 137. Wastewater unit daily average water use efficiency (gal/ton·h), 2010 ............... 173

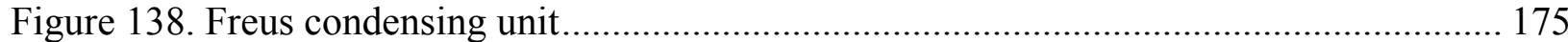

Figure 139. Coolerado H80 RTU airflow schematic ........................................................ 179

Figure 140. Water-cooled chilled water plant with primary/secondary configuration............. 181 


\section{LIST OF TABLES}

Table 1. Quantitative Performance Objectives ........................................................................... 2

Table 2. Qualitative Performance Objectives ...................................................................... 2

Table 3. Coolerado Product Manufacturer's Design Information ............................................ 12

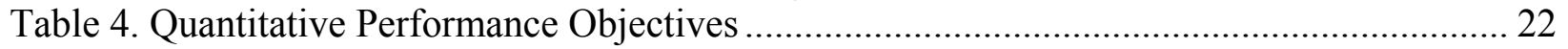

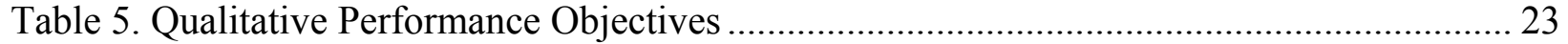

Table 6. Building Types at Fort Carson............................................................................. 25

Table 7. TMY3 and Measured Climate Data......................................................................... 25

Table 8. Quantitative Performance Objectives ........................................................................ 38

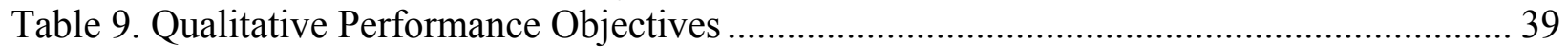

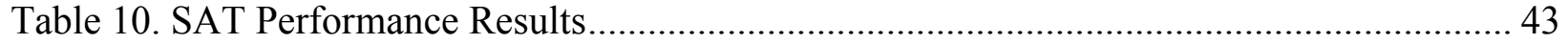

Table 11. Percent of Days That the Average Electrical Efficiency $<0.6 \mathrm{~kW} /$ ton..................... 50

Table 12. 2010 Coolerado Maintenance Hours ......................................................................... 61

Table 13. 2011 Coolerado Maintenance Hours ....................................................................... 61

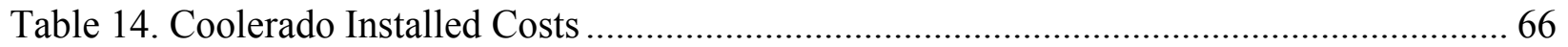

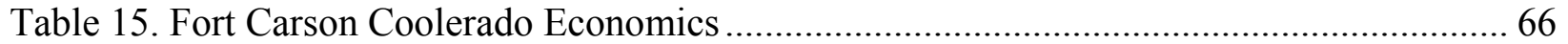

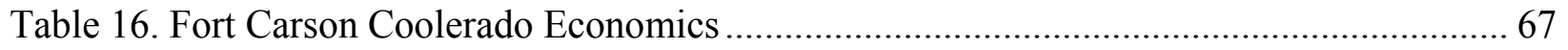

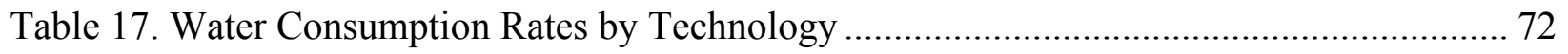

Table 18. Packaged RTU Installed Costs ........................................................................... 74

Table 19. RSMeans City Cost Adjustment Factors …........................................................... 74

Table 20. Regional Utility Rates and Labor Rates .................................................................. 75

Table 21. Single-Zone Classroom eQUEST Inputs Summary ................................................. 77

Table 22. Single-Zone Classroom eQUEST Inputs Summary ............................................... 78

Table 23. Small Office Building Reference Wall and Roof R-Value........................................ 79

Table 24. Small Classroom Baseline DX Unit Design Characteristics ................................... 81

Table 25. Small Classroom Coolerado Design and Operational Characteristics......................... 82

Table 26. Annual Energy and Water Use Comparison.......................................................... 83

Table 27. Annual Energy Savings and Economics ............................................................... 83

Table 28. Annual Energy and Water Use Comparison.......................................................... 85

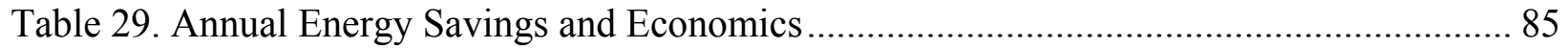

Table 30. Annual Energy and Water Use Comparison........................................................... 86

Table 31. Annual Energy Savings and Economics ............................................................... 87

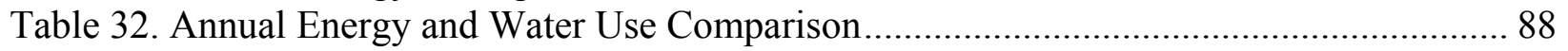

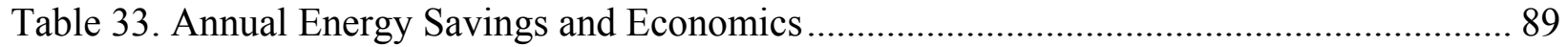

Table 34. Annual Energy and Water Use Comparison........................................................ 90

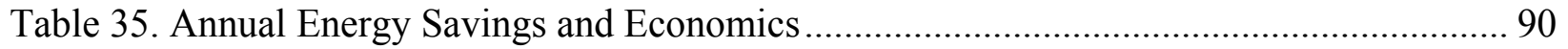

Table 36. Annual Energy and Water Use Comparison........................................................... 92

Table 37. Annual Energy Savings and Economics ............................................................ 92

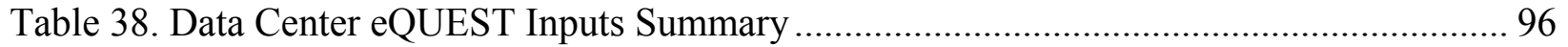

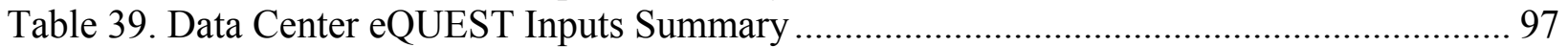

Table 40. Data Center Energy Savings and Economics Phoenix ............................................ 99

Table 41. Data Center Energy Savings and Economics Phoenix Las Vegas............................. 99

Table 42. Data Center Energy Savings and Economics Los Angeles ...................................... 99

Table 43. Data Center Energy Savings and Economics Albuquerque..................................... 100

Table 44. Data Center Energy Savings and Economics Colorado Springs ............................. 100 
Table 45. Data Center Energy Savings and Economics Helena ................................................. 100

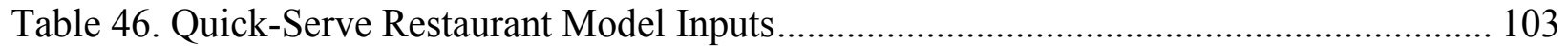

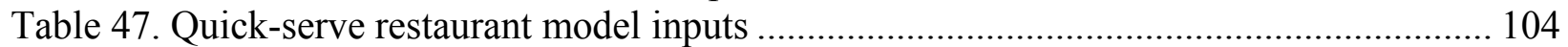

Table 48. Quick Service Restaurant Energy Savings and Economics Phoenix.......................... 105

Table 49. Quick Service Restaurant Energy Savings and Economics Colorado Springs............ 105

Table 50. Coolerado Cooler Cost Components .................................................................... 111

Table 51. Federal Energy Management Program Requirements and Mandates for Energy

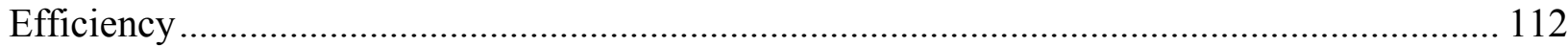

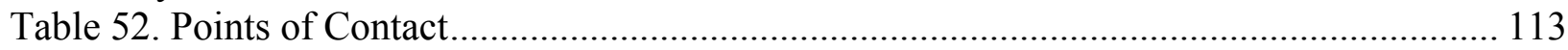

Table 53. Volumetric Flow Rate Versus SP and Elevation.................................................... 115

Table 54. Coolerado C60 Performance Characteristics at Different Wet Bulb Temperatures.. 116

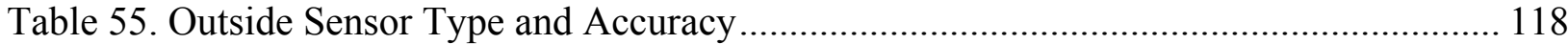

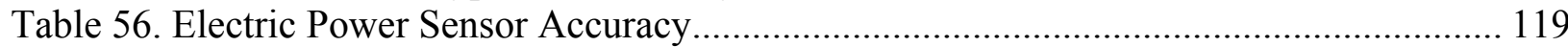

Table 57. Water Consumption Sensor Type and Accuracy ....................................................... 120

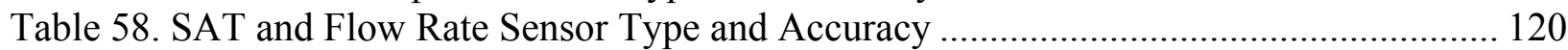

Table 59. Curve Fit Coefficients for Blower Door Tests............................................................ 123

Table 60. Space Temperature and Humidity Sensor Type and Accuracy ................................... 123

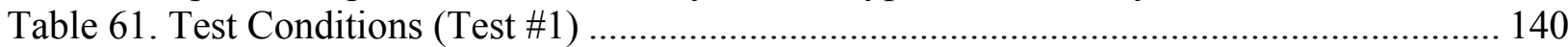

Table 62. Test \#1 Modeled Versus Measured Results............................................................ 140

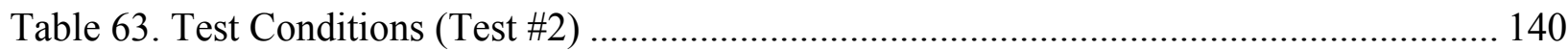

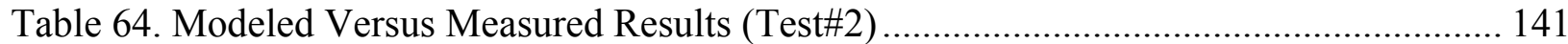

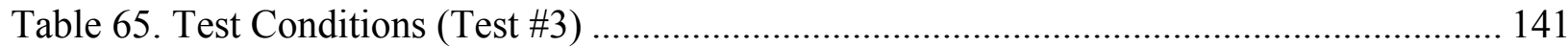

Table 66. Modeled Versus Measured Results (Test \#3) ............................................................ 141

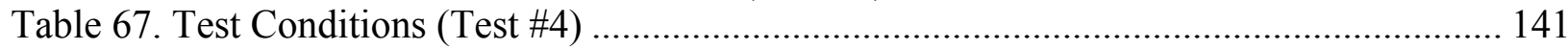

Table 68. Modeled Versus Measured Results (Test \#4) …………………………………...... 142

Table 69. Test Conditions (Test \#5) ................................................................................ 142

Table 70. Modeled Versus Measured Results (Test \#5) ..................................................... 143

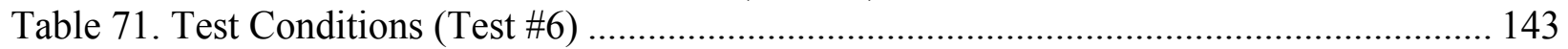

Table 72. Modeled Versus Measured Results (Test \#6) ………............................................... 143

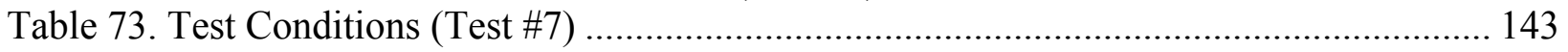

Table 74. Modeled Versus Measured Results (Test \#7) ............................................................ 144

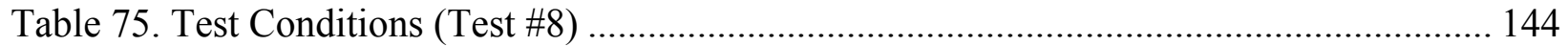

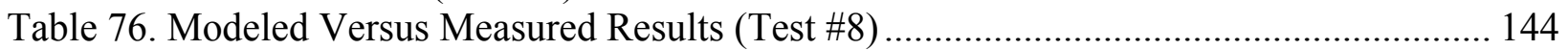

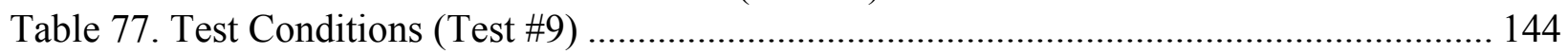

Table 78. Modeled Versus Measured Results (Test \#9) …….................................................. 145

Table 79. Modeled Versus Measured Annual Energy Use, Water Use, and Cooling Energy.... 147

Table 80. Modeled Versus Measured Annual Energy Use, Water Use, and Cooling Energy \#2148

Table 81. Commercially Available Packaged RTUs .............................................................. 176

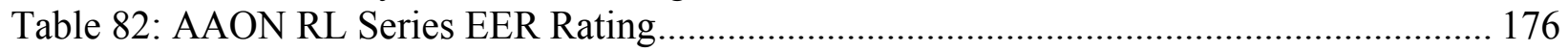

Table 83. Coolerado H80 Laboratory Test Results ................................................................ 180

Table 84: Summary of AirMax Western Cooling Challenge Results.......................................... 181 


\section{EXECUTIVE SUMMARY}

Air-conditioning is the single largest contributor to peak demand on U.S. electricity grids and is the primary cause of grid failures and blackouts. ${ }^{i}$ Power generators and refrigeration-based airconditioning units are least efficient at high ambient temperatures, when cooling demand is highest. This leads to increased pollution, excessive investment in standby generation capacity, and poor utilization of peaking assets. Air-conditioning accounts for approximately $15 \%$ of all source energy used for electricity production in the United States alone (nearly 4 quadrillion Btu), which results in the release of about 343 million tons of carbon dioxide into the atmosphere every year. ${ }^{\text {ii }}$ Evaporative air conditioners can mitigate the environmental impacts and help meet Energy Independence and Security Act (EISA) 2007 and U.S. Department of Defense (DoD) energy policy goals by eliminating energy waste and reducing electricity demand.

Researchers have developed a new multi-staged indirect evaporative cooling (IEC) technology known as the Coolerado Cooler. This technology uses a unique design that maximizes the effectiveness of the direct and indirect stages of its cooling process. The cycle works by cooling both the primary (or product) air and the secondary (or working) air in a 20-stage process. Each stage contributes to cooling by combining multiple direct stages with a single indirect stage. The cumulative result is a lower product air temperature than is possible with conventional evaporative cooling technologies, as the unit can achieve wet bulb effectiveness (WBE) of $90 \%-$ $120 \%$. The key difference between this and other direct/indirect processes is that the working air that accumulates moisture is exhausted at each stage, enabling the product air to be delivered at a lower dry bulb temperature. This thermodynamic cycle is referred to as the Maisotsenko Cycle (or M-Cycle).

The project objective was to demonstrate the capabilities of the high-performance multi-staged IEC technology and its ability to enhance energy efficiency and interior comfort in dry climates, while substantially reducing electric-peak demand. The project was designed to test 24 cooling units in five commercial building types at Fort Carson Army Base in Colorado Springs, Colorado, to provide an analysis of energy use, water use, energy performance, and interior thermal comfort. The five buildings selected for the demonstration included the training facility, event center, theater, jet aeration facility, and the digester facility. The event center, digester facility, and jet aeration facility did not have air-conditioning prior to the demonstration. The training center was using small spot coolers that did not have sufficient cooling capacity to meet the cooling load, and the theater had an antiquated heating, ventilation, and air-conditioning (HVAC) system that had insufficient capacity.

In addition to these buildings, a stand-alone unit was installed at the wastewater treatment plant to test the technology's ability to operate using gray water. Table 1 and Table 2 summarize the performance objectives, success criteria, and results. 
Table 1. Quantitative Performance Objectives

\begin{tabular}{|l|l|l||}
\hline \multicolumn{1}{|c|}{ Performance Objective } & \multicolumn{1}{|c||}{ Success Criteria } & \multicolumn{1}{c||}{ Results } \\
\hline $\begin{array}{l}\text { Improve comfort provided by } \\
\text { evaporative cooling } \\
\text { (Performance) }\end{array}$ & $\begin{array}{l}<1 \% \text { outside ASHRAE summer } \\
\text { comfort zone } \\
\text { Supply air }<70^{\circ} \mathrm{F}\end{array}$ & $\begin{array}{l}\text { Comfort Zone }=\text { Pass } \\
\text { Supply air }<70^{\circ} \mathrm{F}=\text { Pass } \text { for } 80 \% \text { of } \\
\text { units monitored }\end{array}$ \\
\hline $\begin{array}{l}\text { Provide high-efficiency cooling } \\
\text { (Energy Efficiency) }\end{array}$ & $\begin{array}{l}\text { Peak power }<1 \mathrm{~kW} / \text { ton } \\
\text { Average power }<0.6 \mathrm{~kW} / \mathrm{ton}\end{array}$ & Peak Power $=$ Pass \\
\hline $\begin{array}{l}\text { Sustain high cooling performance } \\
\text { (Service Life) }\end{array}$ & $\begin{array}{l}<5 \% \text { degradation of WBE over } 3 \\
\text { years } \\
\text { Negligible increase in supply air } \\
\text { pressure drop }\end{array}$ & $\begin{array}{l}\text { Negligible Increase pressure drop }= \\
\text { Pass }=\text { Pass }\end{array}$ \\
\hline $\begin{array}{l}\text { Minimize water consumption } \\
\text { (Water Conservation) }\end{array}$ & $\begin{array}{l}\text { Demonstrate conservation approach } \\
\text { consuming }<2.5 \text { gal/ton } \mathrm{h} h\end{array}$ & Water use $=$ Fail \\
\hline \hline
\end{tabular}

Table 2. Qualitative Performance Objectives

\begin{tabular}{||l|l|l||}
\hline \multicolumn{1}{|c|}{ Performance Objective } & \multicolumn{1}{c|}{ Success Criteria } & \multicolumn{1}{c||}{ Results } \\
\hline Maintainability (Ease of use) & $\begin{array}{l}\text { A single facility technician able to effectively operate and } \\
\text { maintain equipment with minimal training }\end{array}$ & Pass \\
\hline Maintainability (Cost) & $\begin{array}{l}>90 \% \text { of units fall within nominal IEC maintenance } \\
\text { schedule by project end }\end{array}$ & Pass \\
\hline Maintainability (Failure) & $\begin{array}{l}\text { No signs of biological growth, including gray-water unit } \\
\text { No ruptured water lines }\end{array}$ & Pass \\
\hline
\end{tabular}

In general, the units met all performance objectives other than the supply air temperature limit for select units and the water draw requirement. The increased water draw was due to high water consumption settings in the Coolerado controls, which were modified near the end of the 2011 cooling season. These modifications reduced water consumption to levels that were slightly higher than the original performance metric and were around $3 \mathrm{gal} / \mathrm{ton} \cdot \mathrm{h}$.

The Coolerado units demonstrated the ability to operate with an average seasonal efficiency as low as $0.157 \mathrm{~kW} /$ ton (energy efficiency ratio [EER] $=76.4$ ) when calculated as a function of the total cooling provided by the unit and as low as $0.262 \mathrm{~kW} /$ ton $(\mathrm{EER}=45.8)$ when calculated as a function of building cooling, which is considerably better than the specified performance metric. The lessons learned during this demonstration project will aid in future implementation of the technology. The two primary lessons learned from the demonstration are that wastewater runoff should be diverted or collected for irrigation to use the water runoff and eliminate any potential water damage from pooling or freezing and the cycles of concentration (CoCs) setting (parts water evaporated to parts wastewater) has a significant impact on water consumption; the CoC should be set to 5 when the inlet water has low calcium carbonate concentrations and low Langlier indexes.

The total installed costs, seasonal energy efficiency, energy use, and projected water consumption of the Coolerado units were used to compare the economics and performance to a 
code-minimum packaged rooftop unit (RTU) with an integrated energy efficiency ratio (IEER) of 12. Given the measured performance of the Coolerado units during the 2011 cooling season, the annual energy savings were estimated at $63.3 \%$ compared to a code-minimum RTU. The estimated simple payback was 7.62-41.8 years, depending on the facility that the unit was installed in when the maintenance costs were assumed to be equivalent to a packaged RTU. The primary driver for the shorter paybacks was equipment runtime, the buildings with $24 \mathrm{hr}$ per day cooling loads had better economics. The economics are sensitive to operations and maintenance (O\&M) costs; any increase or decrease in O\&M costs has a significant impact on the economics of the installation. For example, if the O\&M costs are deemed to be substantially higher than those of an equivalent sized RTU, the O\&M costs outweigh the energy cost savings. The O\&M costs were estimated to be $\$ 39 /$ year/unit more expensive than a standard air cooled RTU.

The performance of the Coolerado technology was also evaluated in a retrofit scenario using the energy simulation software tools eQuest and EnergyPlus in three building types across six applicable climate zones (Phoenix, Arizona, Las Vegas, Nevada, Los Angeles, California, Albuquerque, New Mexico, Colorado Springs, Colorado, Helena, Montana). Building types included a small classroom $\left(400 \mathrm{ft}^{2}\right)$, a data center $\left(19,994 \mathrm{ft}^{2}\right)$, and a quick-serve restaurant $\left(2,500 \mathrm{ft}^{2}\right)$. The performance of the Coolerado units was compared to common cooling technologies with respect to energy use, water consumption, and O\&M costs. The technology was evaluated as a retrofit to existing air-conditioning systems or as a standalone zone cooler. The economics were calculated using the federal life cycle costing procedures outlined in the Federal Energy Management Program Building Life Cycle Costing. ${ }^{\text {iii }}$

The Coolerado technology can reduce energy use by 57\%-92\% relative to standard air-cooled, refrigeration-based air-conditioning units, depending on facility type, location, baseline HVAC equipment, and technology application. The Coolerado technology has the best economics when applied to data centers, which had a positive NPV in all climate zones, with net present value (NPV) of \$1.06-\$1.66 million and simple paybacks (SPP) of 13-17.7 years. The data center application had the best economics because of the constant cooling load and need for airconditioning throughout the year. If the data center cooling equipment is at the end of its useful life and needs to be replaced, the simple paybacks can be reduced to 3 to 4 years. The quick service restaurant had favorable economics in Phoenix (NPV $=\$ 1,999$, and $\mathrm{SPP}=9.9$ years) and unfavorable economics in Colorado Springs (NPV $=\$-6,835$, SPP $=61.8)$ and the SPP was better in both climate zones than the single-zone classroom. The single-zone classroom unit showed favorable economics in Phoenix and Las Vegas (SPP $=11$ years, and SPP $=12.7$ years, respectively), and unfavorable economics with payback periods of 52-345 years in Los Angeles, Albuquerque, Colorado Springs, and Helena.

The economic analysis indicates that the Coolerado technology has the best economics as a retrofit technology when it is competing against smaller air-cooled air-conditioning systems with EERs of 8-12. DoD should target facility types with high internal loads and/or high ventilation rates that require year-round cooling. A detailed description of applicable DoD bases, building types, and design guidelines is provided in the body of the report. 


\subsection{INTRODUCTION}

Evaporative cooling is an environmentally beneficial technology that is losing ground in parts of the country where it provides the greatest pollution reduction benefits and electricity grid congestion relief. The overall value proposition of evaporative coolers has failed to prevent overreliance on electric-peaking mechanical air conditioning, largely because of perceptions of inferior comfort. Innovative, high-performance, multi-staged IEC units have been developed that surpass evaporative cooling paradigms for comfort-cooling applications and have demonstrated the ability to significantly reduce air-conditioning energy use.

\subsection{BACKGROUND}

Air-conditioning is the single largest contributor to peak demand on U.S. electricity grids and is the primary cause of grid failures and blackouts. Power generators and refrigeration-based airconditioning units are least efficient at high ambient temperatures, when cooling demand is highest. This leads to increased pollution, excessive investment in standby generation capacity, and poor utilization of peaking assets. Evaporative air conditioners can help meet EISA 2007 and DoD energy policy goals by eliminating energy waste and reducing electricity demand.

A common misconception is that evaporative coolers do not supply cold enough air to meet accepted comfort standards. New dew point evaporative cooler configurations can provide colder supply air temperatures (SATs) and more comfortable indoor conditions than traditional evaporative cooling systems. This technology can lower air-conditioning energy consumption by $50 \%-90 \%$ relative to standard air-cooled, refrigeration-based air-conditioning units, and reduce the total peak demand of a base in arid western states. In California, for example air-conditioning energy use comprises $30 \%$ of the summer peak electricity demand ${ }^{\text {iv }}$.

In addition to the energy benefits the technology will also reduce inventories of ozone depleting refrigerants and enhance health, comfort, and productivity by providing ventilation rates in compliance with or exceeding ASHRAE Standard 62.1-2010 Ventilation for Acceptable Indoor Air Quality, Leadership in Engineering and Environmental Design 2009 v2.2 requirements. ${ }^{\text {v, vi }}$

\subsection{OBJECTIVES OF THE DEMONSTRATION}

The primary objective was to demonstrate the capabilities of a new high-performance, multistaged IEC technology to enhance energy efficiency and interior comfort in dry climates, while substantially reducing electric peak demand. The project was designed to test 24 cooling units in five commercial building types to provide a side-by-side comparison of energy use, water use, energy performance, and interior thermal comfort. The objectives are provided below:

- Validate the performance of the units relative to predefined qualitative and quantitative performance metrics

- Improve comfort provided by evaporative cooling

- Provide high efficiency cooling

- Sustain high cooling performance

- Minimize water consumption

- Increase maintainability - ease of use, cost, and failure mode

- Outline the advantages and disadvantages of the technology

- Create a detailed application guide for DoD energy managers and engineers 
- Present a market analysis that compares the economic feasibility of IECs to standard direct expansion (DX) cooling units in different climate zones

- Create a new performance model of the IEC that can be used by design engineers and energy analysts to model the units in various building types and locations.

The performance of each unit was evaluated under different operational characteristics and the water consumption characteristics of the units were validated throughout the two-year demonstration.

\subsection{REGULATORY DRIVERS}

The DoD ESTCP program awarded this new technology demonstration project as a means to identify programmatic changes that could be applied to the design and construction of energyefficient, evaporative-based air-conditioning equipment on new and existing facilities. A new high-performance, multi-staged IEC unit could be implemented throughout the western half of the United States to help the agency meet and exceed the requirements set forth in Executive Order (E.O.) 13423, Energy Policy Act of 2005, and the EISA 2007.

E.O. 13423 and E.O. 13514 list requirements for water conservation at federal facilities. E.O. 13514 expands on the requirements set by E.O. 13423, mandating federal agencies to reduce potable water consumption intensity $2 \%$ annually through FY 2020. This would result in a $26 \%$ reduction by the end of FY 2020, relative to a FY 2007 baseline. E.O. 13514 also mandates a reduction in industrial, landscaping, and agricultural water consumption by $2 \%$ annually, or $20 \%$ by the end of FY 2020, relative to a FY 2010 baseline.

The key features of EISA 2007 that pertain to this technology are outlined in section 431 and requires a reduction in energy use intensity (EUI) $\left(\mathrm{kBtu} / \mathrm{ft}^{2} / \mathrm{yr}\right)$ of federal buildings of 3\%/year, from a 2003 baseline, resulting in a 30\% EUI reduction by 2015. The EISA 2007 legislation has superseded all previous EUI reduction mandates.

The new multi-staged IEC unit will substantially reduce energy use and peak demand, which will help meet EISA 2007 requirements, but it also has the potential to increase potable water consumption, which will be detrimental to the E.O. 13514 requirements. Although the technology can increase onsite water use, it was shown to reduce regional water consumption. A detailed description of regional power plant water consumption characteristics is provided in Section 7.0. Each DoD installation is encouraged to try to identify alternative sources of water for the units and recapture excess water for reuse in irrigation systems, if this is permitted by local jurisdictions. 


\subsection{TECHNOLOGY DESCRIPTION}

\subsection{EVAPORATIVE COOLING}

Direct evaporative coolers (DECs) cool air by directly evaporating water into an airstream. As the water changes phases from a liquid to a vapor through heat of vaporization principles, heat is drawn from the air and the air temperature is reduced. In low-humidity areas, evaporating water into the air provides a natural and energy-efficient means of cooling. DECs, also called swamp coolers, rely on this principle, cooling outdoor air (OA) by passing it over water-saturated pads, causing the water to evaporate into it. Unlike central air-conditioning systems that recirculate the same air, residential DECs provide a steady stream of fresh air into the house and require an exhaust air (EA) path through the house.

Conventional evaporative cooling has high potential for significant energy savings in dry climates. Evaporative systems have competitive first costs and significantly reduce operating energy use and peak loads. The primary concern with traditional evaporative cooling units is their ability to maintain comfortable interior conditions. DECs are typically rated with a supply air (SA) cfm, rather than a cooling capacity. The temperature of the SA that an evaporative cooling unit can provide is typically rated as a WBE with the following equation

Where

$$
\varepsilon=\frac{T_{D B}-T_{\text {supply }}}{T_{D B}-T_{W B}}
$$

$\mathrm{T}_{\mathrm{DB}}=$ dry bulb temperature of entering air

$\mathrm{T}_{\text {supply }}=\quad$ supply air temperature

$\mathrm{T}_{\mathrm{WB}}=$ wet bulb temperature of entering air

The efficiency of a DEC is a function of the following:

- $\quad$ Evaporative pad effectiveness. The typical residential swamp cooler will use an aspen pad that has a WBE of $65 \%-78 \%$. The pads are typically made from aspen trees, plastic, or paper. A more efficient option for the evaporative pad is a rigid media cooler, which has more surface area per cubic volume and the medium is rigid, which prevents it from sagging over time and can achieve a WBE as high as $90 \%$. ${ }^{\text {vii }}$ The WBE is also a function of pad thickness, the air velocity through the pad, and the effectiveness of the water distribution through the pad (Figure 1). 


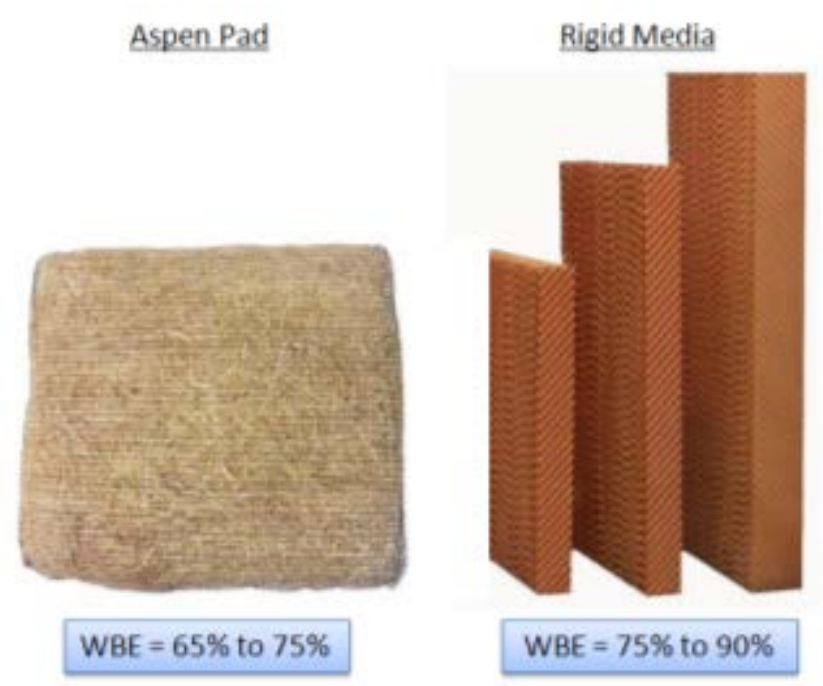

Figure 1. DEC media

(Source: Jesse Dean, NREL)

- $\quad$ Supply fan and motor efficiency. The efficiencies of the fan, motor, and belt/drive have a significant impact on unit efficiency. Typical DECs use a centrifugal fan, belt drive, and single-phase induction motor. The motors are typically one or two speed. Single-phase asynchronous induction motors are not subject to the same efficiency standards as three-phase motors and can have poor efficiencies, with electrical motor efficiencies as low as $50 \%$. The most efficient designs use highefficiency centrifugal fans, direct drive supply, and electronically commutated motors (ECMs). ECMs have significantly higher electrical efficiencies and allow for fully variable-speed operation.

The standard DEC also includes a circulation pump that will draw a small amount of power when it is circulating fluid through the direct evaporative pad.

There are number of commercially available residential and commercial evaporative cooling systems. Appendix D provides an overview of commercially available evaporative cooling technologies and their design characteristics.

\subsection{TECHNOLOGY OVERVIEW}

An internally manifolded IEC designed by Coolerado of Arvada, Colorado, has made dew point temperature - rather than wet bulb - the new low temperature limit for evaporative cooling. Wet bulb is the temperature at which air will cool when water is evaporated in unsaturated air. U.S. Department of Energy (DOE) laboratory testing has proven this cooler's ability to supply air at or below ambient wet bulb temperature (100\%-120\% WBE), surpassing state-of the-art IECs (about 70\% effective) and even swamp coolers (about 90\% effective) without adding humidity to the SA. Accomplished by elegant use of multistage IEC, this approach is 2-4 times as energy efficient as conventional air-conditioning and significantly enhances occupant comfort and the climate range for non-compressive, non-refrigerant-based air conditioners. DEC uses about 1.37 
gal per sensible ton $h$ of cooling to the SA (Note: DECs are adiabatic coolers, meaning that they do not significantly change the enthalpy of the cooled airstream.) However, DECs only work with $100 \%$ OA. If more OA is supplied than stipulated by ventilation requirements (ASHRAE 62.1-2010 and 62.2-2010), the instantaneous sensible cooling for airflow above minimum ventilation must be de-rated by the factor:

$$
\text { Derating ratio }=\frac{R A T-S A T}{O A T-S A T}
$$

The water evaporation rate (in gal/ton'h) must then be divided by this de-rating ratio.

The Coolerado cooler heat mass exchanger (HMX) have an evaporative water consumption rate of $2.5 \mathrm{gal} / \mathrm{ton} \cdot \mathrm{h}$. These coolers may have the same issue if supplying more outdoor air than ventilation requirements, and thus require the same method of de-rating. However, these air conditioners can run down to $45 \%$ outdoor air ratio if return air (RA) is used, which will limit the amount of de-rated cooling. Thus, water consumption can be compared case-by-case only, using an annual simulation of building loads. At certain times during the season, a Coolerado Cooler can have a de-rating ratio that makes up for the difference in evaporation rate. During these hours, usually during high ambient wet bulb periods, the water evaporation by a Coolerado Cooler may be less than a DEC. In summary, in a climate like Colorado Springs a DEC will use roughly the same amount of water as the Coolerado Cooler, and the Coolerado Cooler will use less energy than a standard residential DEC with a standard, constant speed fan motor.

Scalable for residential or commercial application, the evaporative cores are made of plastic to separate the dry SA flows from the wet, EA flows, and can be mass produced by an automated assembly line. The wet exhaust flows serve as progressively colder heat sinks to produce the colder supply temperatures unique to this all-indirect technology. Fresh air is provided to the building at temperatures and relative humidities (RHs) that achieve indoor comfort in climates with design wet bulb temperatures below $70^{\circ} \mathrm{F}$, which includes most of the western United States. Ambient dry bulb temperature is irrelevant, as the wet bulb temperature is the dominant factor in determining the SAT provided by the IEC.

\subsubsection{How It Works}

The Coolerado Cooler has a unique design that maximizes the effectiveness of the direct and indirect stages of its cooling process. The schematic in Figure 2 illustrates fluid movement through the patented HMX. The HMX is made of plastic HMX in a geometric design that cools both the product and working airstreams in an isolated heat exchange process. 


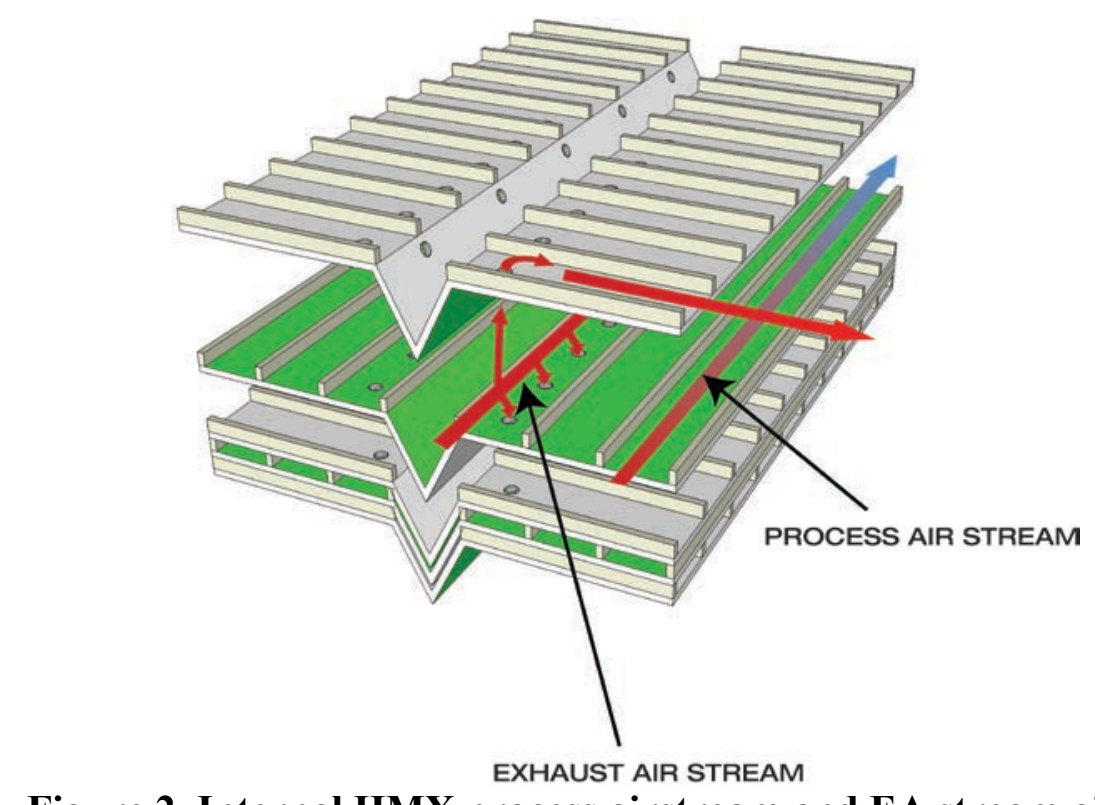

Figure 2. Internal HMX process airstream and EA stream airflow

(Source: NREL)

Figure 3 proivides a side view of the Coolerado Cooler and an illustration of the main components.

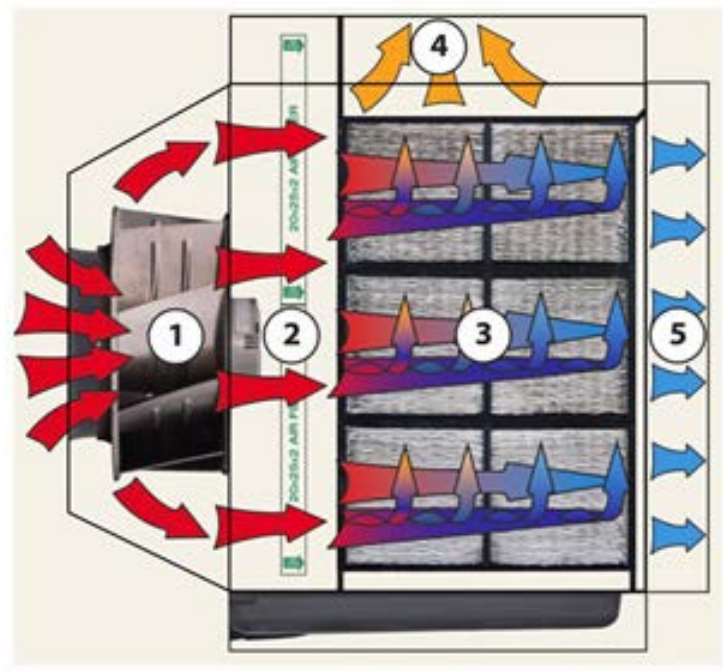

\section{HOW IT WORKS}

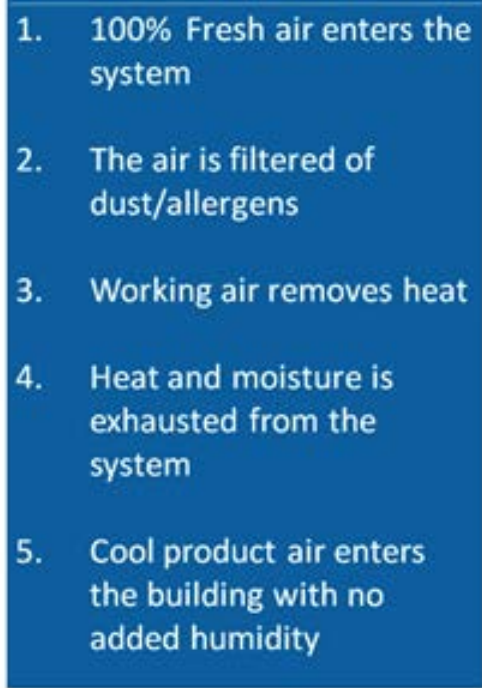

Figure 3. Side view of Coolerado airflow process

(Source: Coolerado) 
Fan energy is the only form of electrical energy input into the system. The fan is driven by an ECM that is $>90 \%$ efficient and is variable down to a near $0 \%$ flow rate. The inlet air passes through a filter before it enters the unit. The top portion of the inlet air is supplied to the space as the primary/product air stream. The air that flows through the bottom part of the HMX is the seccondary/working air. The system of cascading incremental airflows creates a thermodynamic cycle called the Maisotsenko Cycle (or M-Cycle) (see Figure 2). The cycle works by cooling both the primary/product air and the secondary/working air in a 20-stage process. The cumulative result is a lower primary/product air temperature than is possible with conventional evaporative cooling technologies. The key difference between this and other direct/indirect processes is that the secondary/working air that is accumulating moisture is exhausted at each stage, enabling the primary/product air to be delivered at a lower dry bulb temperature.

In the psychrometric chart shown in Figure 4, the red arrows indicate the DEC taking place in the secondary/working airstream, which is exhausted at each of the 20 stages. The blue arrows represent indirect cooling of the primary/product airstreem through the plastic heat exchange material; no moisture is added to this air stream during this process. This portion of the secondary/working air mixes with the seconday/working airstream during the purge process, so it will mix with air at higher humidities but only in the secondary/working airstream.

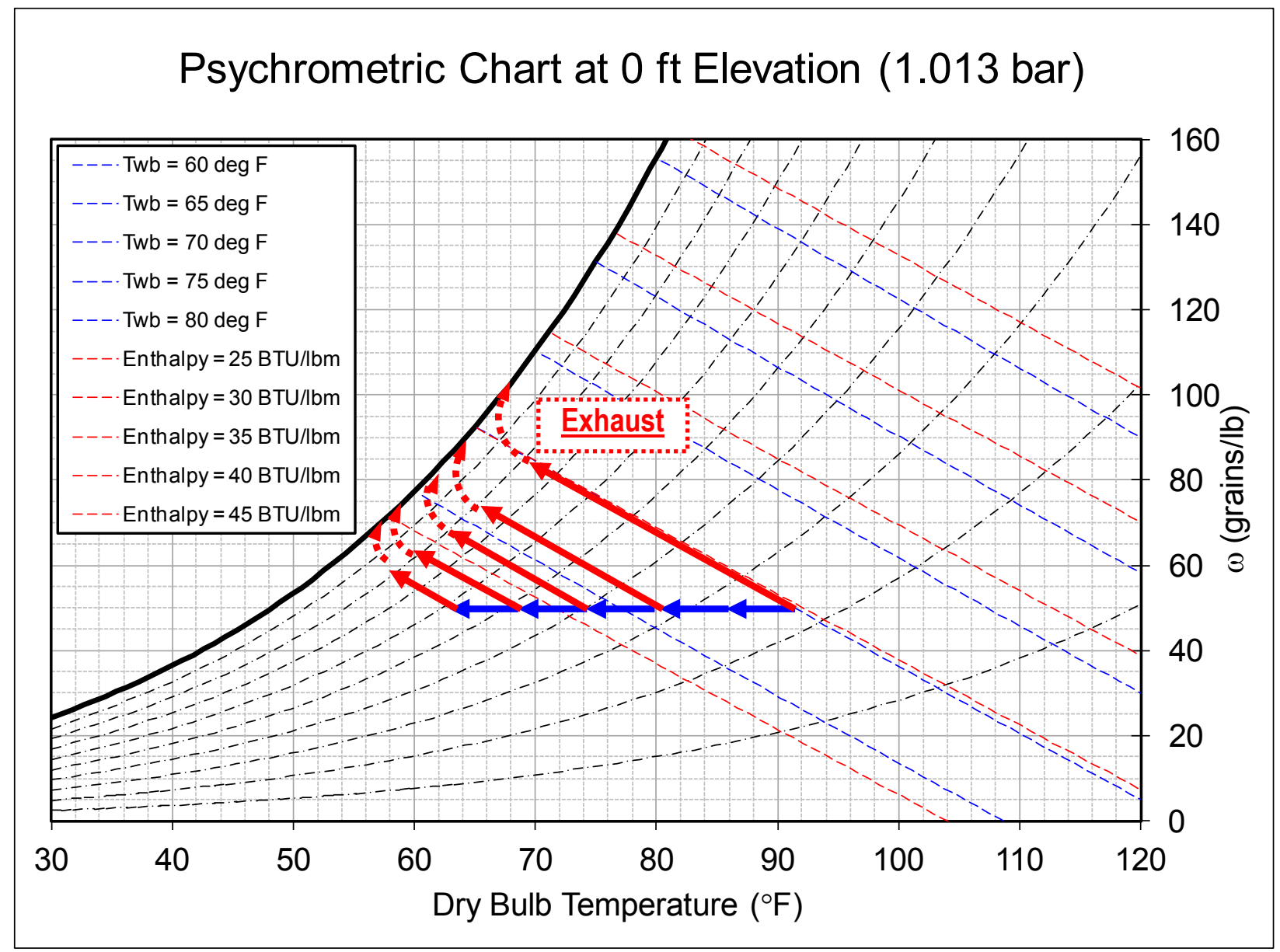

Figure 4. Conceptual psychrometric representation of the staged indirect cooling process 
The advantage of the M-Cycle is that the working air is purged repeatedly so the initial conditions are essentially reset, as lower dry bulb and wet bulb temperatures are established with each purge cycle. This allows the eventual SAT to be below what the original initial conditions would indicate possible - below the thermodynamic wet bulb temperature. This key stagedcooling process is essentially what sets the Coolerado Cooler apart from other IEC and DEC systems and enables greater cooling performance. During this process, no moisture is added to the primary/product air.

Figure 3 and Figure 5 illustrate the continuous purge process. Because of this purging, the Coolerado Cooler requires greater total airflow than other types of cooling systems. However, because the SAT is lower than that possible with DEC and IEC systems, less SA is required to meet space conditioning needs. ${ }^{\text {viii }}$

(1) Outside air is pushed into the Coolerado Cooler heat exchanger with a single fan.

(2)

Product Air Channels.

(3) Working Air Channels.

4) Heat from the Product Air is transferred through the thin plastic, and into the Wet Channels below.

(5) Working Air is bocked from entering the building.

(6) The Blocked Working Air is turned and passed through small holes into Wet Channels below the Product Air stream.

(7) The Working Air is now moving through Wet Channels perpendicular or cross flow above and below the Dry Channels.

(8) The heat that is passed from the Dry Channel is converted into water vapor.

9 Heat from the Product Air has been converted into water vapor and is now rejected as exhaust to the outside air.

(10) The Product Air which has now traveled the length of the heat exchanger, enters the desired space,

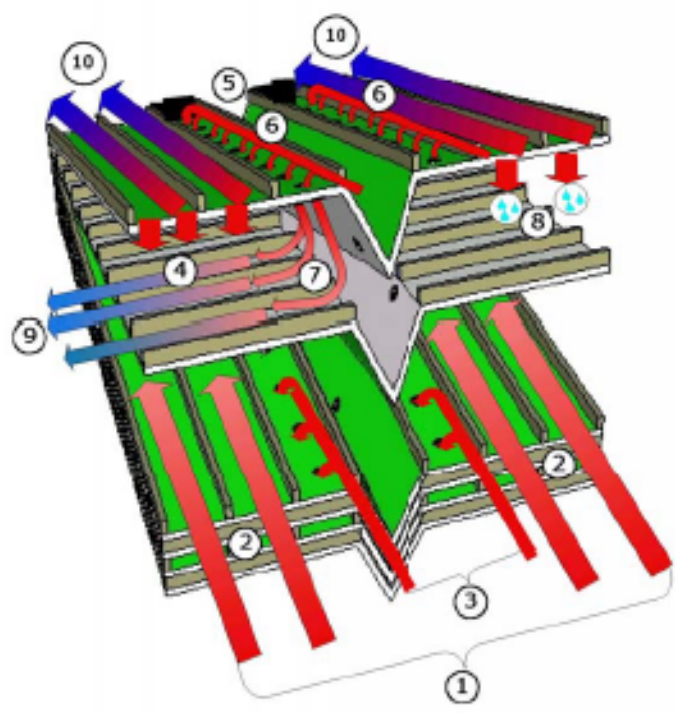

(1)

The green side is the plastic coating that is used to create a Dry Channel.

The gray is the open paper side that is used to create a Wet Channel. cold and dry.

Figure 5. Staged flow of the IEC/DEC process

(Source: Coolerado) 


\subsubsection{Products}

Coolerado offers three standalone products, the M30, M50, and C60. The M30 is the smallest unit and is typically applied to residential and small commercial units (Figure 6).

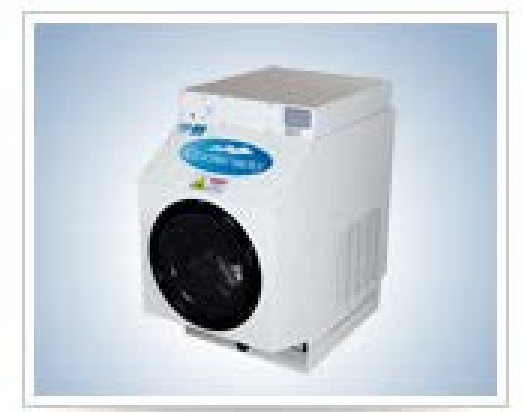

M30

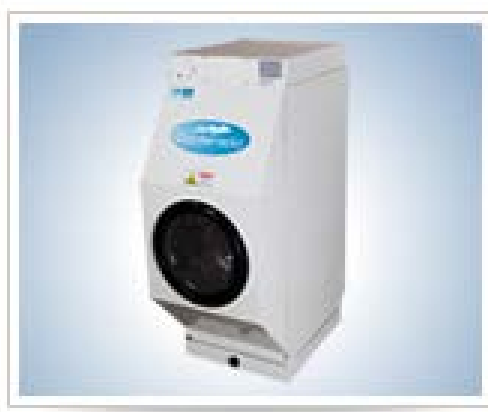

M50

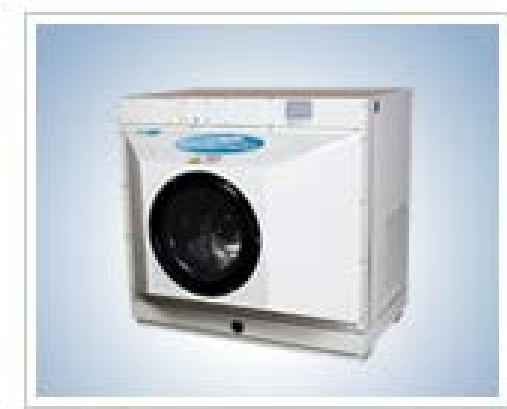

C60

Figure 6. Coolerado standalone products

(Source: Coolerado)

The M30 has three cooling cores known as HMX cores, the M50 has five HMX cores, and the C60 has six HMX cores. A picture of an HMX core and detailed description is provided in Figure 7. The rated SA flow rate at 0 in. of external static pressure (SP) from the manufacturer is provided in Table 3.
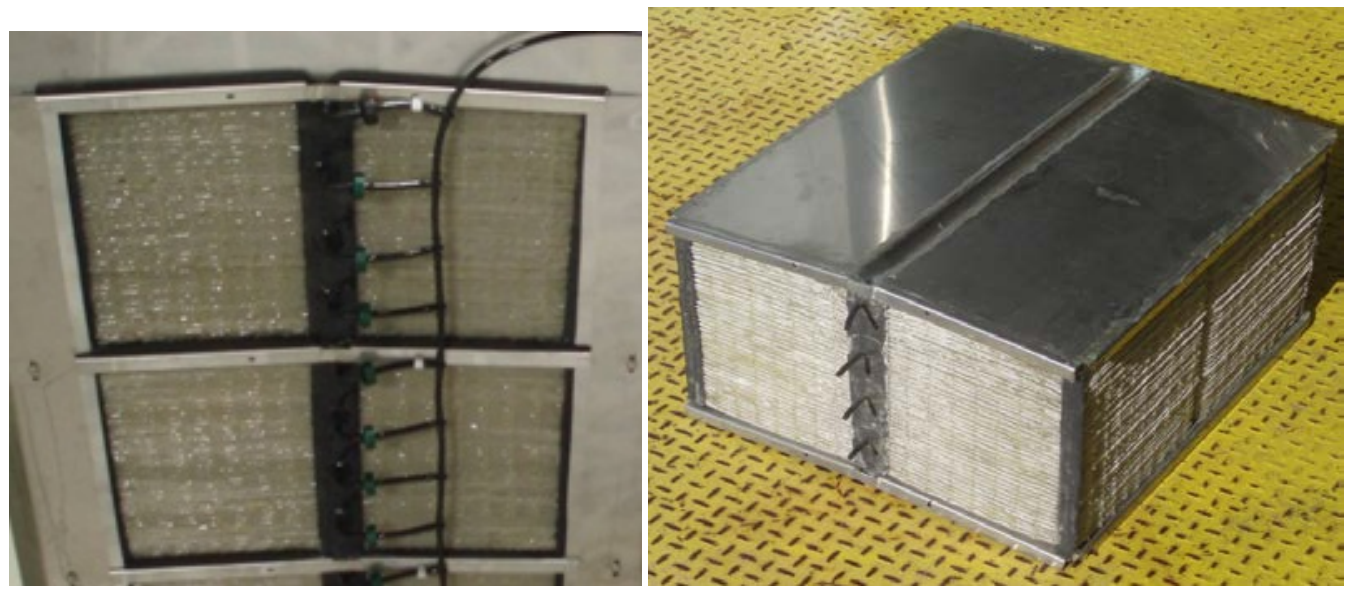

Figure 7. 2009 free form Coolerado HMX

(Source: Coolerado) 
Table 3. Coolerado Product Manufacturer's Design Information

\begin{tabular}{||l|c|c|c||}
\hline \hline & M30 & M50 & C60 \\
\hline $\begin{array}{l}\text { Supply Air Flow Rate } \\
\text { (cfm) }\end{array}$ & 900 & 1,450 & 1,670 \\
\hline $\begin{array}{l}\text { Wet Bulb } \\
\text { Effectiveness (\%) }\end{array}$ & $93 \%$ & $94 \%$ & $94 \%$ \\
\hline
\end{tabular}

The C60 unit was installed at each facility in Fort Carson and tested at the Thermal Test Facility (TTF) at the National Renewable Energy Laboratory (NREL).

\subsection{TECHNOLOGY DEVELOPMENT}

No technology development activities took place before the field demonstration as part of the ESTCP project. Before the ESTCP project, a Federal Energy Management Program report was published titled Coolerado Cooler Helps to Save Cooling Energy and Dollars. ${ }^{i x}$ The report provides a detailed description of the technology and preliminary test results from a firstgeneration Coolerado cooling unit that used a paper-based HMX. The technology tested at NREL's TTF and installed in Fort Carson had a plastic-based heat exchanger and design characteristics described above. Since the Coolerado units were installed in 2009, Coolerado has modified the HMX and water solenoid and regulator. The 2009 version of the HMX had a metallic cassette and multiple points of entry for the inlet water.

The 2011 version of the HMX is manufactured as a modular cassette (Figure 8). The new HMX is more economical, easier to replace and install, and yields a more reliable product. The selfsupporting structure preserves the HMX integrity over time and the integrated water distribution with a single point of entry per HMX reduces water use.

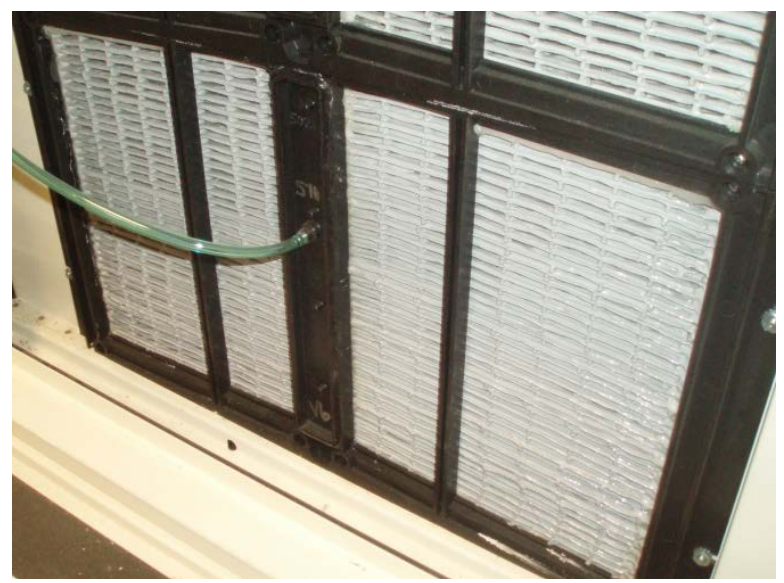

Figure 8. 2011 Modular Coolerado HMX

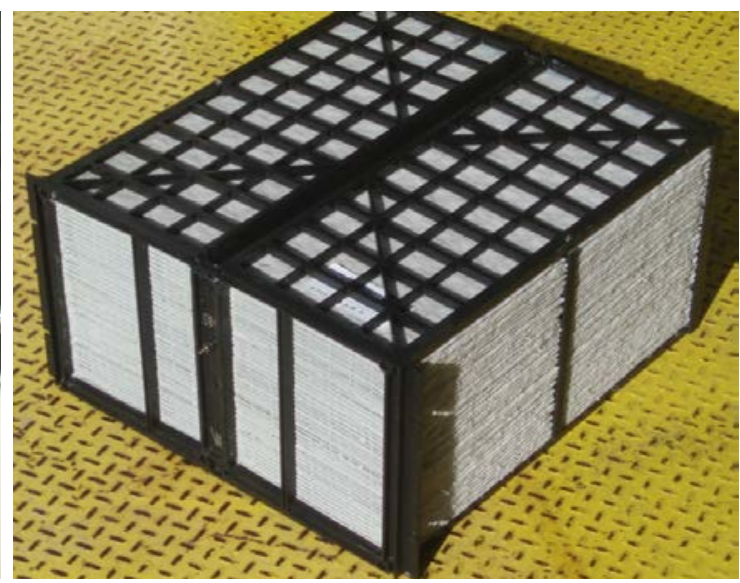

(Source: Coolerado)

The Coolerado water solenoid and regulator have also been redesigned (Figure 9). The 2009 version was a Feiro Fluid Power version used a regulator that is sensitive to building water pressure fluctuations and required a narrow range of building water pressures (40-60 psi). 


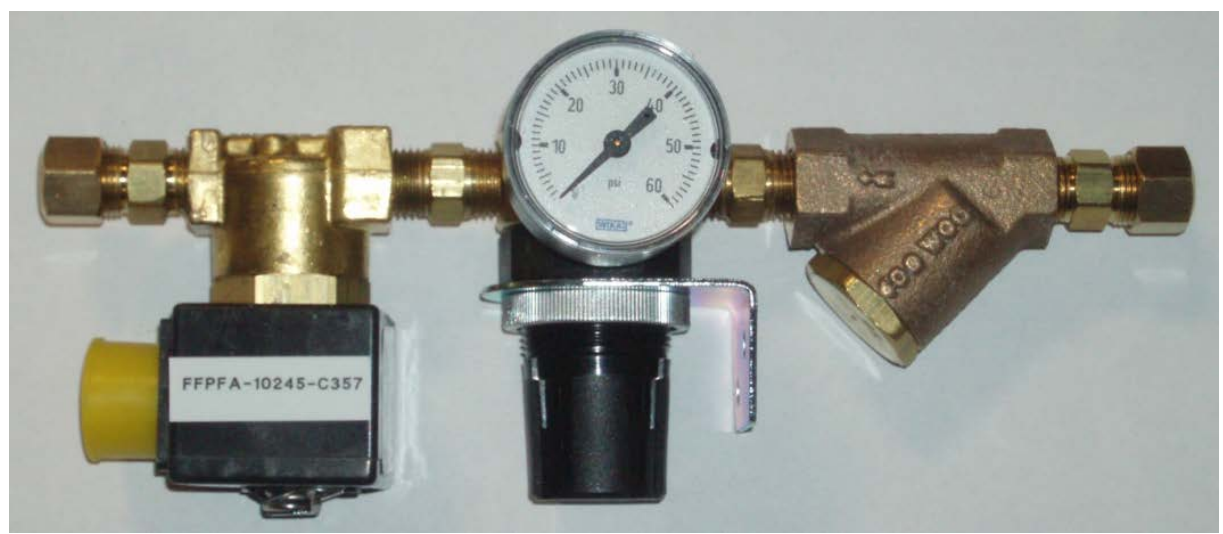

Figure 9. Fiero Fluid Power solenoid and regulator comparison

(Source: Coolerado)

The installation contractors must set the working pressure at the worksite. This unit was installed outside the Coolerado enclosure, which made it susceptible to damage from freezing, requiring it to be drained before winter or installed indoors.

The new regulator (Figure 10) is more robust and can accommodate a wider range of building water pressures $(20-75 \mathrm{psi})$. The working pressure is set in the factory before shipment and the self-draining design prevents damage from freezing, so it can be installed inside the outdoor unit.

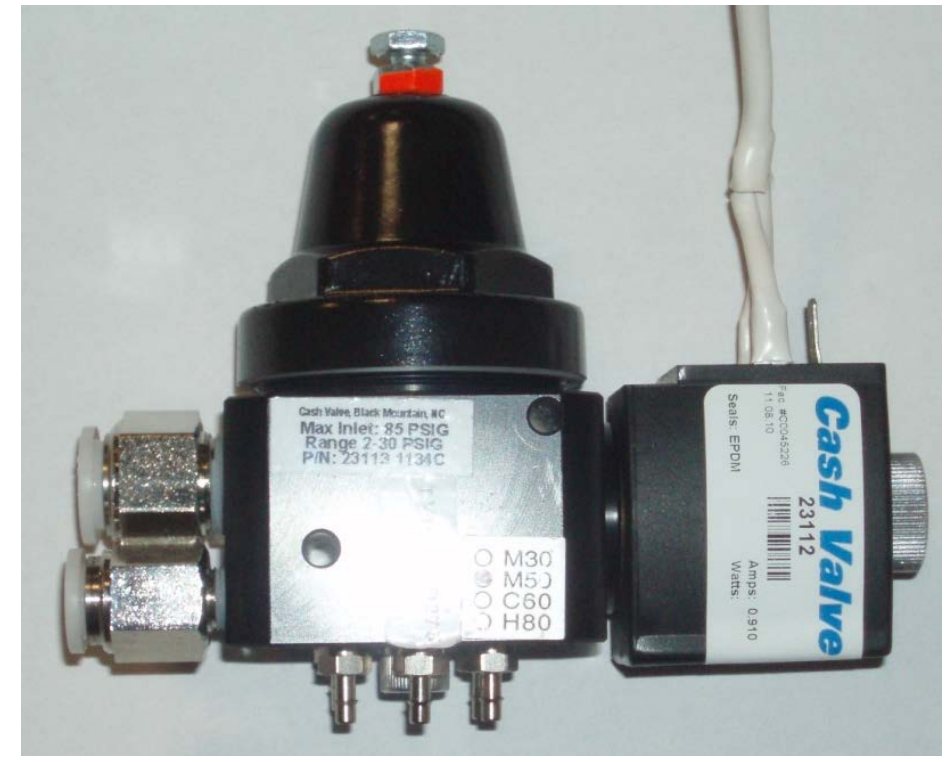

Figure 10. Tyco/Cash Valve

(Source: Coolerado)

\subsection{ADVANTAGES AND LIMITATIONS OF THE TECHNOLOGY}

The primary advantage of dew point IEC is its ability to supply colder SATs than traditional evaporative cooling units, which extends the range of applicable climate zones and increases 
thermal comfort. The increased performance over traditional evaporative cooling units comes at a fraction of the energy use and energy cost of mechanical air-conditioning. An IEC may have diverse applications; it can be applied as a single-zone dedicated outside air system, as an OA pre-conditioner or mixed air (OA and RA) conditioner that feeds into an RTU or air handling unit (AHU). Additional benefits include improved ventilation rates versus traditional airconditioning, reduced strain on and investment in power distribution grids, and reduction in harmful refrigerant gases. The energy savings improve energy security and reduce pollution. The Coolerado can provide up to $30 \%$ colder SATs than traditional DECs without adding moisture to the SA stream. The Coolerado can also reduce air-conditioning energy use by $57 \%-92 \%$ depending on facility type, location, baseline HVAC equipment efficiency, and application.

The target climates for the Coolerado are ASHRAE climate zones $2 \mathrm{~B}, 3 \mathrm{~B}, 4 \mathrm{~B}, 5 \mathrm{~B}$, and $6 \mathrm{~B}$. The system should be installed as an OA pre-conditioner in climate zones $2 \mathrm{~B}$ and $3 \mathrm{~B}$ and can be applied as a zone cooler for climate zones 4B, 5B, and 6B. An ASHRAE climate zone map is provided in Figure 11.

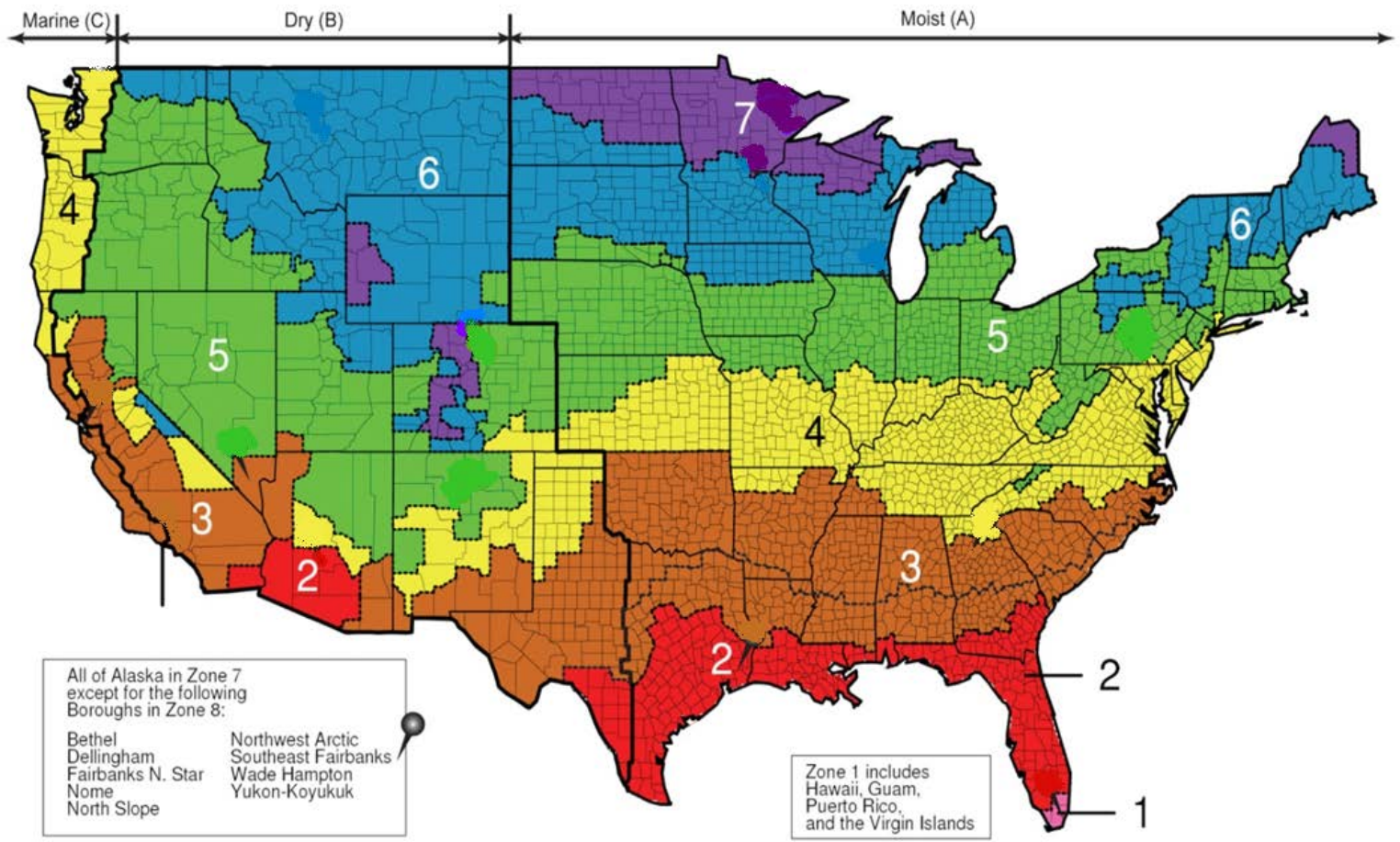

Figure 11. ASHRAE climate zone map

(Source: Joelynn Schroeder, NREL)

Although the technology can be installed in ASHRAE climate zones 1A-7A, the increased outdoor air humidity levels reduce the cooling capacity of the unit and the overall energy savings to the point that the technology cannot provide a favorable return on investment. Other limitations include increased onsite water consumption, inability to dehumidify, and sensitivity to inlet air conditions. Coolerado has developed a dew point IEC with mechanical airconditioning to extend energy savings benefits to all climates. The 5-ton $\mathrm{H} 80$ unit recently 
exceeded Western Cooling Efficiency Challenge goals; a description of the technology is provided in Appendix D. ${ }^{\mathrm{x}}$

The advantages and limitations of the technology are further characterized by the design considerations and appropriate applications in the next two sections.

\subsection{COOLERADO DESIGN CONSIDERATIONS}

Although the variable-flow, multi-staged IEC can significantly reduce cooling energy use in $\mathrm{DoD}$ facilities, it also has a number of unique design and operational characteristics that need to be understood and accounted for. Appendix A provides a full description of the design considerations summarized here:

- External SP. As the external SP on the SA increases, a larger fraction of the inlet air is forced through the EA channels by the natural physics of the HMX. The external SP on the SA consists of pressure drop associated with air filter fouling, duct SP, and building SP. This reduces cooling capacity and the total SA flow rate (cfm).

For example, using inlet air conditions of $63^{\circ} \mathrm{F}$ wet bulb, $95^{\circ} \mathrm{F}$ dry bulb, $80^{\circ} \mathrm{F}$ return air temperature (RAT), and an elevation of $5,702 \mathrm{ft}$, the airflow rate at $0 \mathrm{in}$. of external SP is approximately $1,950 \mathrm{cfm}$ for the C60 unit, dropping to $<500$ $\mathrm{cfm}$ at $1 \mathrm{in}$. of SP. At the given set of inlet air design conditions, the cooling capacity at 0 in. of external SP is close to 2 tons and less than $1 / 2$ ton at 1 in. of external SP. Thus, duct and building SP should be reduced as much as possible and designs with more than 0.25 in. of SP should be avoided.

- $\quad$ Water consumption settings. The Coolerado technology is configured with single pass cooling water. Some inlet water is evaporated in the EA stream and some passes through the unit and drains from the outlet piping. One $\mathrm{CoC}$ indicates half the water is evaporated and the mineral concentration of the drain water doubles (for example would go from $100 \mathrm{ppm}$ to $200 \mathrm{ppm}$ ). Two CoCs means 2 parts evaporated for one part drained and the mineral concentration of the drained water triples. A dip switch is used to set the $\mathrm{CoC}$ for the unit. The Coolerado units were set up with a $\mathrm{CoC}$ of 1.4-1.6 for most of the demonstration, which significantly increased onsite water consumption for most of the summer. As a best practice the onsite water consumption should be minimized by setting the $\mathrm{CoC}$ to 5 , reusing excess water for irrigation, and potentially capturing rainwater as an inlet water supply for the units.

- $\quad$ Reduced capacity at design conditions. A common design issue with all standalone evaporative cooling units is reduced cooling capacity at design conditions. At ASHRAE 0.4\% evaporative design conditions, the design wet bulb temperatures reduce the temperature difference between the achievable SAT and space temperature (or RAT). Depending on the extremity of the climate, the cooling capacity of the Coolerado could be as low as $25 \%$ of the cooling capacity at off-design conditions. Assuming a design RAT of $80^{\circ} \mathrm{F}$ and an altitude of 5,702 $\mathrm{ft}$, the $\mathrm{C} 60$ unit can provide $>3$ tons of cooling when the wet bulb temperature is 
$50^{\circ} \mathrm{F}$, and a $<1$ ton of cooling at wet bulb temperature of $70^{\circ} \mathrm{F}$. This is arguably the largest barrier to the adoption of standalone evaporative cooling units, because a design engineer would need to install a number of additional cooling units to meet the design space cooling load or let the space temperature float up to higher values under peak conditions.

- $\quad$ Improved performance at part load. The Coolerado unit's WBE and part load performance significantly increase at partial loads. The WBE at $100 \%$ fan speed with 0 in. of external SP is $88 \%$ at an elevation of 5,702 ft; the WBE is $116 \%$ at $20 \%$ fan speed. If the external SP applied to the unit is 0.25 in. at $100 \%$ fan speed, the WBE is $91 \%$ and $119 \%$ at $20 \%$ fan speed. In addition, the part load electrical efficiency increases nonlinearly with fan speed; EERs of 50-120 are achievable.

If the Coolerado is installed as an outdoor air pre-conditioner and the fan speed is set to $<100 \%$, the unit can continuously achieve WBEs greater than $100 \%$ and operate with high annual EERs.

- $\quad$ External SP. As the external SP on the SA increases, a larger fraction of the inlet air is forced through the EA channels through the natural physics of the HMX. The external SP on the SA consists of pressure drop associated with air filter fouling, duct SP, and building SP. This reduces cooling capacity and the total SA flow rate $(\mathrm{cfm})$.

\subsection{COOLERADO APPLICATIONS}

The Coolerado cooling units can be set to condition 100\% OA or a combination of OA and RA. They can also be configured as standalone air-conditioning units or integrated into a variety of HVAC systems.

\subsubsection{Through-the-Wall Zone Cooler}

The most common application of the Coolerado units is a through-the-wall or roof-mounted zone cooler that conditions $100 \%$ OA (Figure 12). This type of system is limited to ASHRAE climate zones $4 \mathrm{~B}, 5 \mathrm{~B}, 6 \mathrm{~B}$ because the unit cannot supply cold enough air temperatures in more humid environments. The advantages of this system are related to its simple installation, increased ventilation rates, and potential for significant energy savings relative to standard packaged RTUs with DX cooling systems. A graphical representation of a standard unit is provided below. 


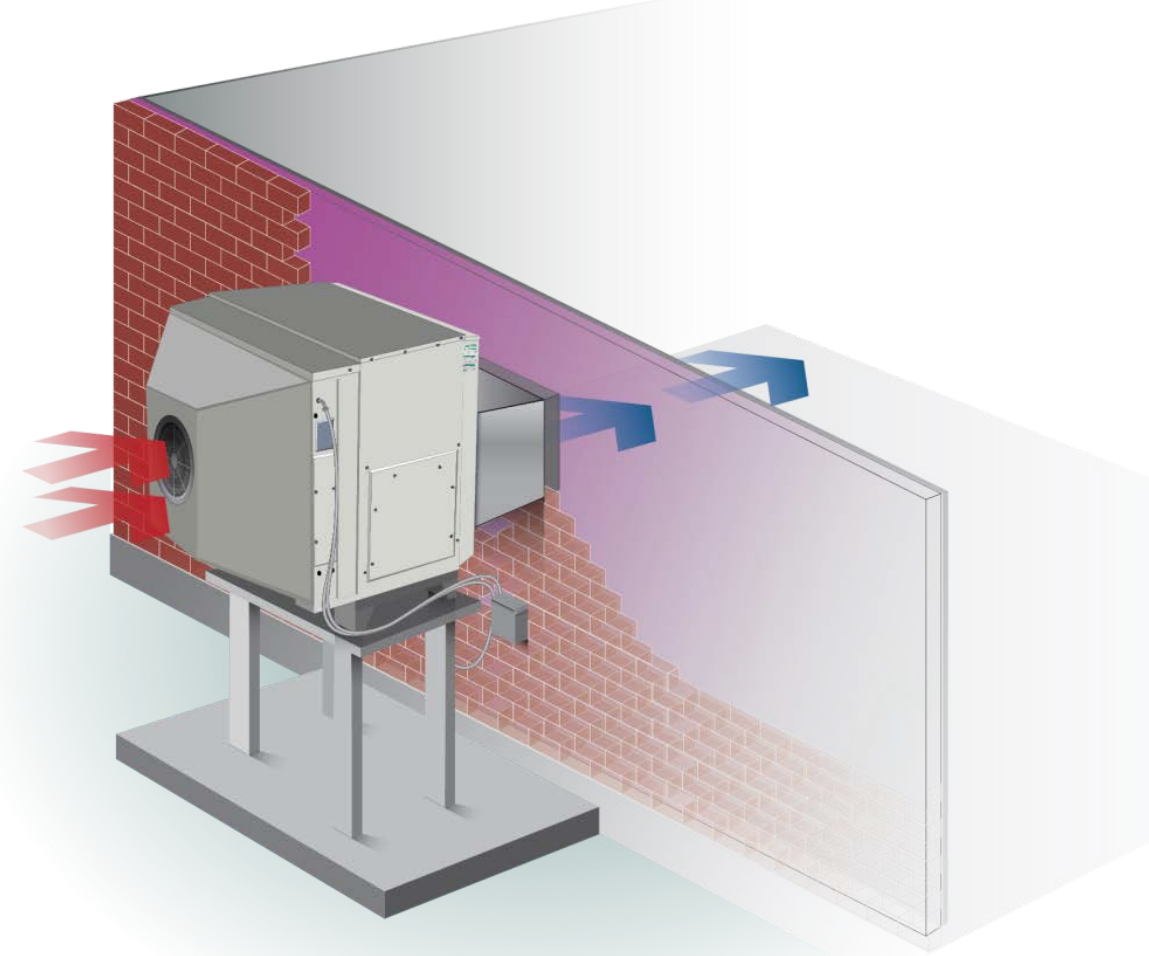

Figure 12. Through-the-wall zone cooler

(Source: Joshua Bauer, NREL)

For a through-the-wall installation, a hole is typically cut through the exterior wall and a short duct-run is installed between the interior zone and the Coolerado Cooler. From there, SA is either discharged directly into the space or is ducted further into the zone. The system is typically a standalone air-conditioning unit and the local thermostat can be set up as a programmable thermostat or integrated into the building automation system. Its disadvantages include the inability to integrate with the existing HVAC system, an increase in energy and water use compared to a unit designed to incorporate return air, limited range of applicable climate zones, and the need to shut down and winterize each unit at the end of the cooling season in climates that experience freezing, which is most of climate zones $4 \mathrm{~B}, 5 \mathrm{~B}$ and $6 \mathrm{~B}$.

\subsubsection{Outside Air Pre-conditioner}

The Coolerado unit can be set up to precondition OA for packaged RTUs or larger AHUs (Figure 13). This type of design can be applied to most U.S. climate zones and is particularly effective in climate zones $2 \mathrm{~B}$ and $3 \mathrm{~B}$. Its primary advantages are its extended range of climate zones, integration with the existing HVAC system, and ability to integrate into larger AHUs. The Coolerado Cooler can be sized appropriately to meet the ventilation requirements of the facility and not over ventilate the space. Figure 13 illustrates a two-dimensional schematic of how this design can be integrated into an AHU. 


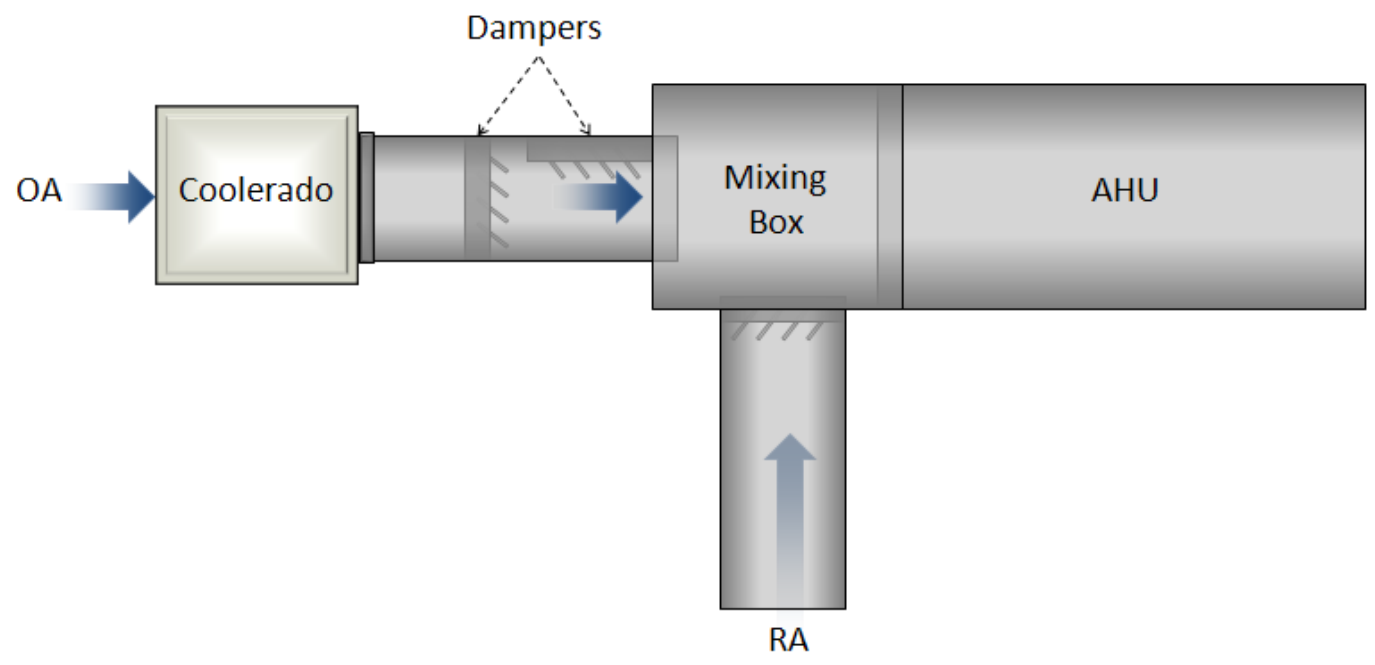

Figure 13. Coolerado Cooler as OA pre conditioner

(Source: Joshua Bauer, NREL)

The graphic shows how the Coolerado Cooler preconditions OA for an AHU. The two damper banks are set up as bypass dampers that allow the AHU to operate in heating mode or in economizer mode without drawing OA through the Coolerado.

Coolerado has developed a product that allows the Coolerado Cooler to be integrated into a standard RTU. The system is designed to work with the M 50 model Coolerado units. It is recommended that the Coolerado be the first stage of cooling in the sequence of operations; if the Coolerado can provide $100 \%$ of the cooling needs, the refrigeration system should be disabled and only the supply fan of the RTU or AHU should operate. This will reduce the SP drop that the Coolerado has to overcome. When the Coolerado cannot meet $100 \%$ of the load, the refrigeration system is then enabled to meet the building load. During high wet bulb hours of operation, the fan speed on the Coolerado can be set to match the OA ventilation requirements; this will allow the Coolerado to reduce the temperature of the OA and ventilation load on the building. This system should be applied to RTUs that have fairly high OA fractions in climate zones $2 \mathrm{~B}$ and 3B. When the fan speed is turned down to meet the ventilation, the unit will operate at a higher WBE, which further reduces the SAT from the Coolerado unit.

The disadvantages of this system design include an increase in energy and water use compared to a unit designed to incorporate RA and the need to shut down and winterize each unit at the end of the cooling season in climates that require freeze protection.

\subsubsection{Zone Cooler with Return Air}

The Coolerado can be installed as a zone cooler with OA and RA provided at the inlet of the unit. This type of design can be applied to roof- and wall-mounted installations, and installations where the Coolerado sits inside the space, such as high-bay, single-story facilities. Figure 14 is a graphical representation of an indoor installation. 


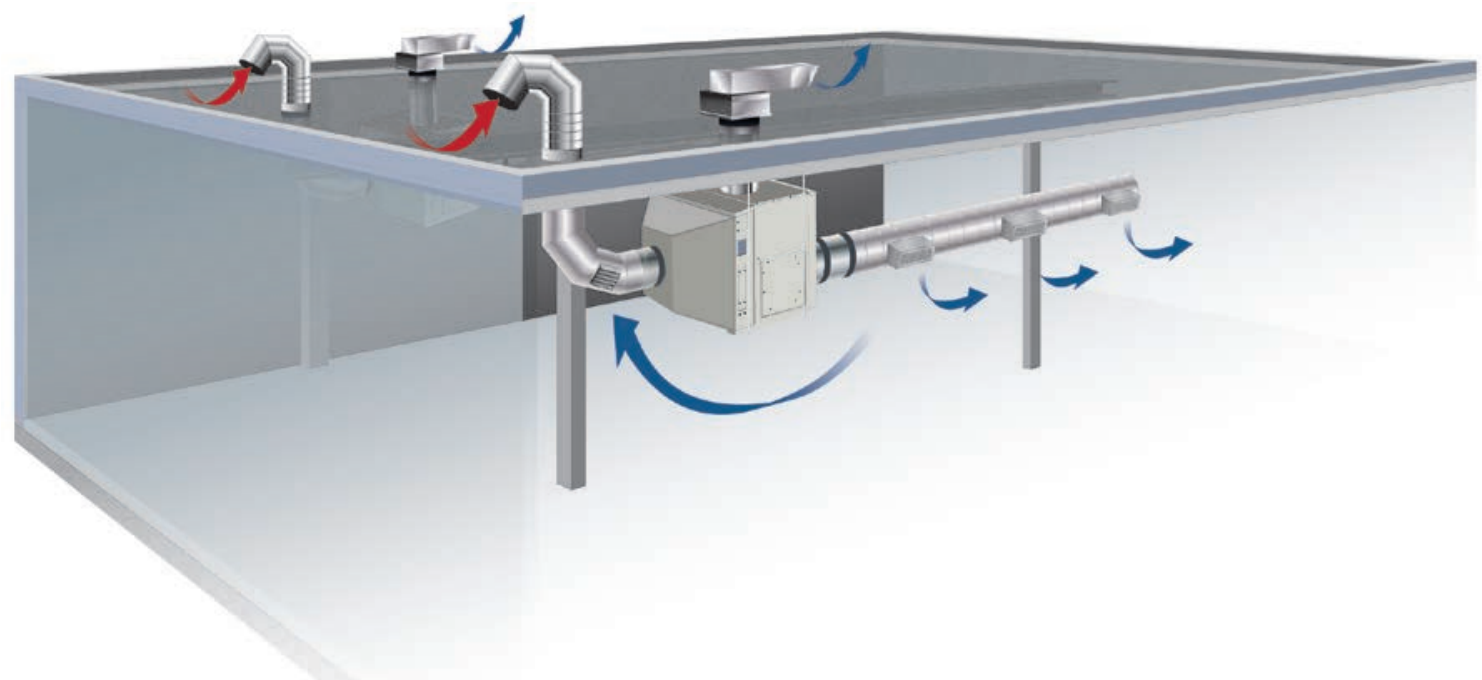

Figure 14. Coolerado zone cooler with RA

(Source: Joshua Bauer, NREL)

This type of system can be designed such that the OA rates are set based on ASHRAE 62.1-2010 ventilation standards, with the percentage of RA typically $>50 \%$. This type of design significantly extends the climate range for the unit and will reduce the cooling energy use and water consumption. The disadvantages of this type of system include a potential increase in installed costs, and the need to integrate the unit's controls into those of the other HVAC components if supplementary heating or cooling is required in the facility. This application also works best in single-story facilities.

\subsubsection{Integrated into Air Handling Unit Mixing Boxes}

The Coolerado unit can be integrated into an AHU or RTU mixing box. With this design, it could be placed in a mechanical room that has a common plenum return, or integrated directly into the AHU ductwork for new construction or major renovations. This design may have the greatest energy savings, and has a number of potential integration challenges. Figure 15 shows a 2-D graphical representation of the OA, RA, EA, and slip stream for the Coolerado unit. 


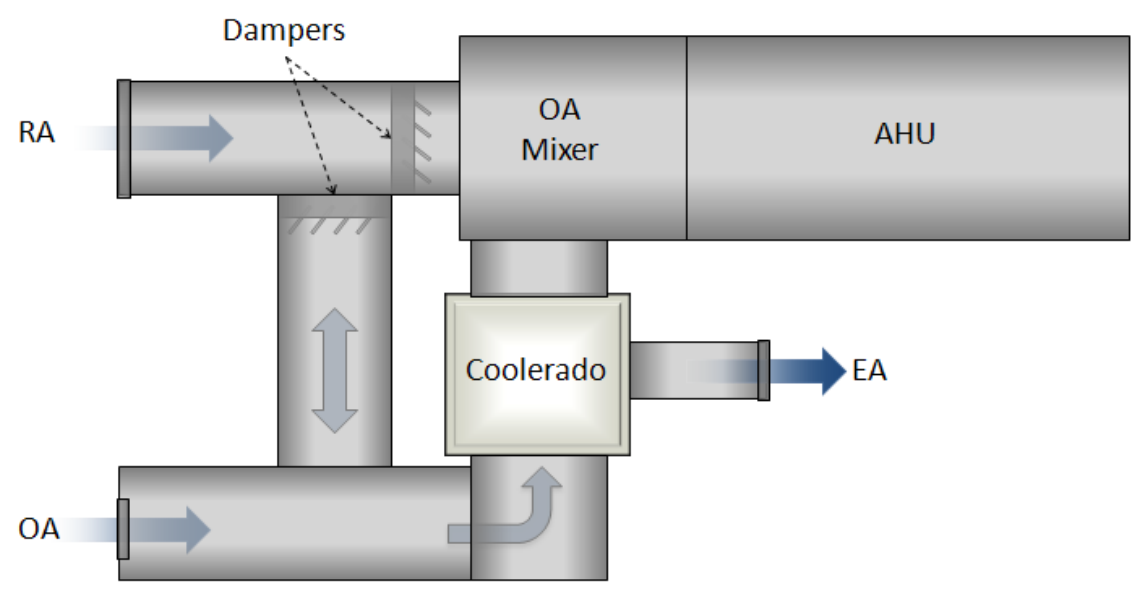

Figure 15. Coolerado integrated into AHU mixing box

(Source: Joshua Bauer, NREL)

Figure 16 shows a 3-D representation of the same concept with ductwork directly routing the RA and $\mathrm{OA}$ into the Coolerado unit.

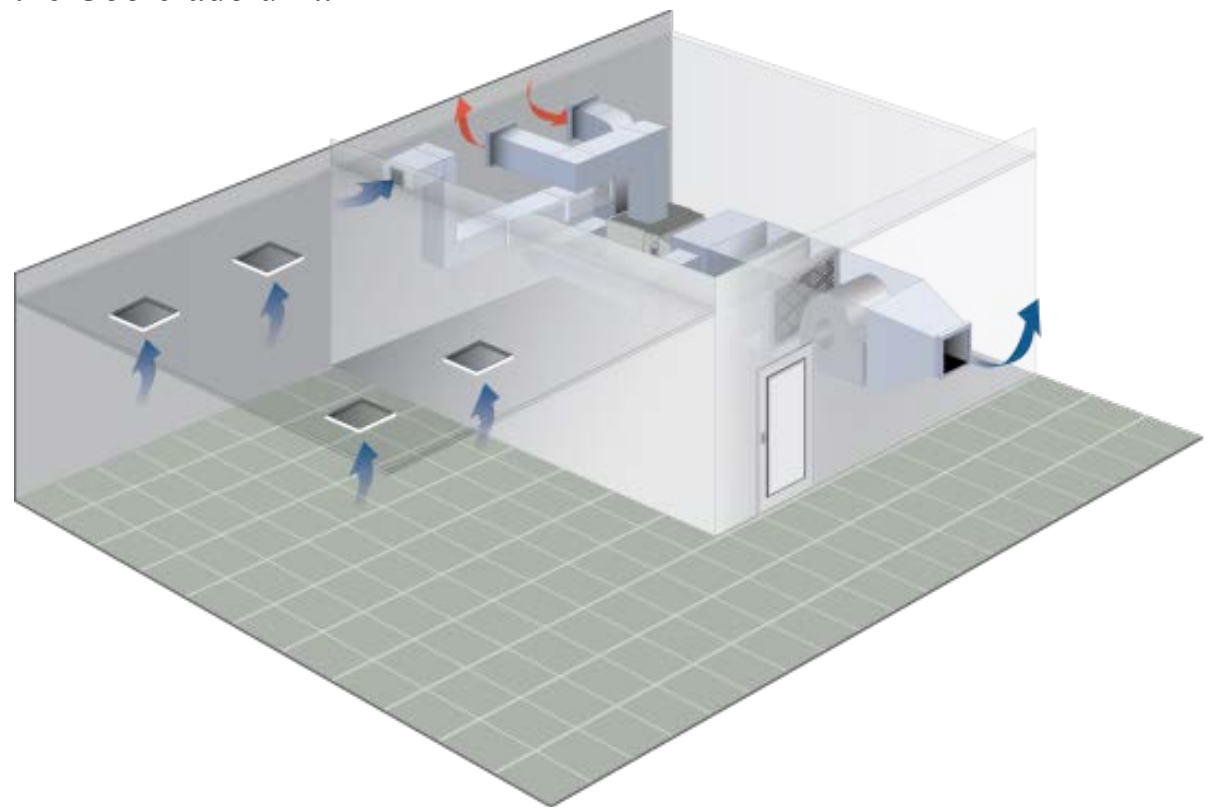

Figure 16. Coolerado integrated into AHU mixing box

(Source: Joshua Bauer, NREL)

One challenge with this design in a retrofit is that a path must be provided for the EA; ductwork may also need to be installed to bypass the Coolerado when it is not operating in cooling mode. In certain retrofit applications, this concept could be applied where the Coolerado sits in the AHU closet (mixing box). In this case, the discharge air from the Coolerado would mix with the RA from the space as it is supplied to the unit. Although this design has the potential to save the most energy and water, it faces formidable installation challenges, which could significantly increase the installed costs of the unit, and is most applicable to new construction. 


\subsection{PERFORMANCE OBJECTIVES}

Table 4 and Table 5 summarize the quantitative and qualitative performance objectives outlined for the evaluation of the Coolerado Cooler. The quantitative objectives include interior thermal comfort, energy efficiency, service life, and water use metrics; qualitative performance objectives include ease of use, cost, and failure, which address the maintainability of the system. Each performance objective is described in detail below. The results presented in Section 6 highlight how the Coolerado units in this demonstration project met or did not meet these performance objectives.

Table 4. Quantitative Performance Objectives

\begin{tabular}{|c|c|c|c|}
\hline $\begin{array}{c}\text { Performance } \\
\text { Objective }\end{array}$ & Metric & Data Requirements & Success Criteria \\
\hline $\begin{array}{l}\text { Improve comfort } \\
\text { provided by } \\
\text { evaporative cooling } \\
\text { (Performance) }\end{array}$ & $\begin{array}{l}\text { - Hours outside } \\
\text { psychometric } \\
\text { comfort zone } \\
\text { - } \quad \text { SAT }\end{array}$ & $\begin{array}{ll}\text { - } & \text { Interior space } \\
\text { temperature } \\
\text { Indoor humidity } \\
\text { - } & \text { SAT }\end{array}$ & $\begin{array}{ll}\text { - } & <1 \% \text { outside ASHRAE } \\
& \text { summer comfort zone } \\
\text { - } & \mathrm{SA}<70^{\circ} \mathrm{F} \\
\text { - } & \mathrm{OK} \text { to apply where design } \\
& \text { wet bulb } \leq 70^{\circ} \mathrm{F}\end{array}$ \\
\hline $\begin{array}{l}\text { Provide high } \\
\text { efficiency cooling } \\
\text { (Energy Efficiency) }\end{array}$ & $\begin{array}{l}\text { - } \quad \mathrm{kW} / \text { ton of } \\
\text { building cooling }\end{array}$ & $\begin{array}{ll}\text { - } & \text { SAT } \\
\text { - } & \text { Building EA temperature } \\
& \text { (EAT) } \\
\text { - } & \text { Coolerado power } \\
& \text { consumption } \\
\text { - } & \text { SA flow rate }\end{array}$ & $\begin{array}{ll}\text { - } & \text { Peak power }<1 \mathrm{~kW} / \text { ton } \\
\text { - } & \text { Average power }<0.6 \\
\mathrm{~kW} / \text { ton }\end{array}$ \\
\hline $\begin{array}{l}\text { Sustain high cooling } \\
\text { performance } \\
\text { (Service Life) }\end{array}$ & $\begin{array}{ll}\text { - } & \text { WBE } \\
\text { - } & \text { SA pressure } \\
\text { drop }\end{array}$ & $\begin{array}{ll}\text { - } & \text { SAT } \\
\text { - } & \text { Outdoor air temperature } \\
\text { - } & \text { Core pressure drop } \\
\text { - } & \text { Outdoor air humidity }\end{array}$ & $\begin{array}{l}-\quad<5 \% \text { degradation of WBE } \\
\text { over } 3 \text { years } \\
\text { - Negligible increase in SA } \\
\text { pressure drop }\end{array}$ \\
\hline $\begin{array}{l}\text { Minimize water } \\
\text { consumption } \\
\text { (Water Conservation) }\end{array}$ & $\begin{array}{l}\text { Gal/ton } \cdot h \text { of } \\
\text { building cooling } \\
\text { Site water } \\
\text { quality (total } \\
\text { dissolved solids } \\
\text { [TDS]) }\end{array}$ & $\begin{array}{ll}\text { - } & \text { Water inlet flow } \\
\text { - } & \text { Water outlet flow } \\
\text { - } & \text { Water conductivity }\end{array}$ & $\begin{array}{l}\text { Demonstrate conservation } \\
\text { approach consuming }<2.5 \\
\text { gal/ton } \cdot h\end{array}$ \\
\hline
\end{tabular}


Table 5. Qualitative Performance Objectives

\begin{tabular}{||l|l|l|l||}
\hline \multicolumn{1}{|c|}{$\begin{array}{c}\text { Performance } \\
\text { Objective }\end{array}$} & \multicolumn{1}{|c|}{ Metric } & \multicolumn{1}{|c||}{ Data Requirements } & \multicolumn{1}{c|}{ Success Criteria } \\
\hline $\begin{array}{l}\text { Maintainability } \\
\text { (Ease of Use) }\end{array}$ & $\begin{array}{l}\text { Ability of an HVAC } \\
\text { technician to operate } \\
\text { and maintain the } \\
\text { technology }\end{array}$ & $\begin{array}{l}\text { Standard form feedback from } \\
\text { the HVAC technician on } \\
\text { time required to maintain }\end{array}$ & $\begin{array}{l}\text { A single facility technician able } \\
\text { to effectively operate and } \\
\text { maintain equipment with } \\
\text { minimal training }\end{array}$ \\
\hline $\begin{array}{l}\text { Maintainability } \\
\text { (Cost) }\end{array}$ & Service Frequency & $\begin{array}{l}\text { Standard form feedback from } \\
\text { the HVAC technician on } \\
\text { time required to maintain }\end{array}$ & $\begin{array}{l}>\text { 90\% of units fall within } \\
\text { nominal IEC maintenance } \\
\text { schedule by project end }\end{array}$ \\
\hline $\begin{array}{l}\text { Maintainability } \\
\text { (Failure) }\end{array}$ & $\begin{array}{l}\text { Biological Fouling } \\
\text { Freezing }\end{array}$ & Visual inspection & $\begin{array}{l}\text { No signs of biological growth, } \\
\text { including gray-water unit } \\
\text { No ruptured water lines }\end{array}$ \\
\hline \hline
\end{tabular}

\subsection{IMPROVE COMFORT PROVIDED BY EVAPORATIVE COOLING}

A significant barrier to full utilization of energy-efficient evaporative cooling is the common complaint that it is a "lesser" cooling technology in that it simply does not supply cold enough air to ensure comfort, even in dry climates suited to the technology. Successful evaporative designs should be able to provide comfortable indoor set point conditions in climates with wet bulb design temperatures $\leq 70^{\circ} \mathrm{F}$, which is representative of ASHRAE climate zones $4 \mathrm{~B}, 5 \mathrm{~B}$, and 6B. This objective criterion is intended to demonstrate that the Coolerado Cooler produces significantly colder SA to the space than current evaporative coolers and produces comfort conditions similar to mechanical air-conditioning throughout the cooling season. A "comfort zone" of combined temperature and humidity ranges has been established by ASHRAE, and a technology's ability to provide comfort is typically represented by the number of hours per year indoor conditions leave this established zone.

\subsection{PROVIDE HIGH-EFFICIENCY COOLING}

Power measurements are straightforward for the Coolerado Cooler, as all electrical energy enters the unit at one point - the ECM for the fan. The fan uses approximately $550-650 \mathrm{~W}$; the controls use about 15-18 W. The key element needed to properly compare the two technologies is an accurate determination of the Coolerado Cooler's cooling effect on the building. Because the Coolerado is a $100 \%$ outdoor air system, it cools the building by supplying a flow of cold air that moves through the occupied space, into unoccupied spaces such as ceiling plenums and wall cavities, and exits the building through breaks in its envelope, picking up building heat loads in the process. The cooling effect was determined by the temperature difference between the air supplied by the Coolerado units and the air exiting the building, multiplied by the total mass flow of SA and its specific heat. The cooling capacity was also calculated relative to the outside air temperature (OAT). Mass flow rates were inferred from fan power consumption. 


\subsection{SUSTAIN HIGH COOLING PERFORMANCE}

A common concern about evaporative coolers is that minerals accumulate on their evaporative surfaces and degrade cooling performance over time, exhibited as decreasing WBE or increasing SA pressure drop. WBE is defined as the actual temperature reduction achieved divided by the maximum possible adiabatic temperature drop (the ambient wet bulb depression). WBE is a fundamental evaporative heat exchanger parameter that is strongly correlated to airflow rate for a given device over a broad range of operating conditions.

The Coolerado Cooler is set up with single pass cooling water, so the risk of mineralization is lower than with traditional evaporative cooling units that continuously recirculate water. The Coolerado unit controls its water use in response to an inlet dry bulb/wet bulb temperature differential signal that predicts the amount of water needed for cooling and maintains the minimum excess water required to prevent mineral deposition.

WBE and pressure drop were monitored to ensure minerals are being successfully managed to preserve cooling performance over a projected service life of 10 years.

\subsection{MINIMIZE WATER CONSUMPTION}

The perception of increased water consumption associated with evaporative cooling is an important concern. An ideal IEC, infinitely large and operating on distilled water, would consume $1.6 \mathrm{gal} / \mathrm{ton} \cdot \mathrm{h}$. This represents a lower limit without excess drain water; $100 \%$ of the water use is associated with the evaporation process. Although consumptive use is a standard term, it is misleading in that water is a renewable resource, albeit one that must be used at sustainable rates regionally. Power plants consume $1-4 \mathrm{gal} / \mathrm{kWh}$ and the electricity use associated with the operation of air-conditioning equipment should be accounted for regionally. Further discussion of power plant water consumption is provided in Section 7.0. The goal of this project is to demonstrate that the Coolerado can successfully operate with $<2.5 \mathrm{gal} / \mathrm{ton} \cdot \mathrm{h}$ without compromising its WBE.

\subsection{MAINTAINABILITY}

The Fort Carson facilities maintenance contractors were responsible for maintaining the Coolerado units during the demonstration, as they do other evaporative coolers and onsite HVAC equipment. They received the manufacturer's instructions and reported all problems. There are many ways for a building technology to fail if its operation requires more than the current standard of care, which is minimal. The Coolerado will succeed in this performance objective if $>90 \%$ of the demonstration units settle into autonomous operation after the first season and if one technician can manage the equipment following Fort Carson's standard IEC maintenance schedule. In addition, units were to show no signs of biological fouling or water leaks caused by freezing. 


\subsection{FACILITY/SITE DESCRIPTION}

For Carson Army Base is located in Colorado Springs, Colorado. The base sits atop a high plane at 5,835 $\mathrm{ft}$ against the foothills of the Rocky Mountains. The base covers more than $8.7 \mathrm{mi}^{2}$ and includes more than 11 million $\mathrm{ft}^{2}$ of building area. Facilities include offices, headquarter buildings, commissaries (on-base grocery stores), a hospital, barracks, and retail spaces. Other spaces that do not fall into these categories include - but are not limited to - a training facility, auditorium, and event center. Table 6 summarizes the percentage of total facility square footage based on building type.

Table 6. Building Types at Fort Carson

\begin{tabular}{|c|c||}
\hline Building type & $\begin{array}{c}\text { Percent of } \\
\text { Total }\end{array}$ \\
\hline Other & 41 \\
\hline Barracks & 29 \\
\hline Headquarters & 17 \\
\hline Offices & 5.7 \\
\hline Hospital & 4.6 \\
\hline Retail space & 1.8 \\
\hline Commissaries & 0.9 \\
\hline
\end{tabular}

The OATs are typically $80^{\circ}-90^{\circ} \mathrm{F}$ during the cooling season and are rarely above $100^{\circ} \mathrm{F}$. The outside air (OA) wet bulb temperatures are low during the cooling season $\left(50^{\circ}-60^{\circ} \mathrm{F}\right)$, making Colorado Springs ideal for evaporative cooling technologies. One disadvantage is that the cooling season is relatively short, typically June-August, with fewer than 500 cooling degree days (base $65^{\circ} \mathrm{F}$ ). Table 7 summarizes the Typical Meteorological Year 3 (TMY3) weather data for Colorado Springs and the maximum measured OA conditions at Fort Carson during July 2010.

Table 7. TMY3 and Measured Climate Data

\begin{tabular}{|l|c||}
\hline \multicolumn{1}{|c|}{ Climate Data } & $\begin{array}{c}\text { TMY3 Data for } \\
\text { Colorado Springs }\end{array}$ \\
\hline Cooling design day (0.4\%) Dry bulb & $90.3^{\circ} \mathrm{F}$ \\
\hline Cooling design day (0.4\%) mean coincident wet bulb & $58.8^{\circ} \mathrm{F}$ \\
\hline Evaporative design day (0.4\%) Wet bulb & $63.3^{\circ} \mathrm{F}$ \\
\hline $\begin{array}{l}\text { Evaporative design day (0.4\%) mean coincident dry bulb } \\
\text { (MCDB) }\end{array}$ & $78.3^{\circ} \mathrm{F}$ \\
\hline Measured maximum dry bulb (July 2010) & $97.8^{\circ} \mathrm{F}$ \\
\hline Measured maximum mean coincident wet bulb (July 2010) & $62.9^{\circ} \mathrm{F}$ \\
\hline Maximum wet bulb (July 2010) & $70.8^{\circ} \mathrm{F}$ \\
\hline Number (percent) of hours above 0.4\% design conditions & 113 hours $(1.3 \%)$ \\
\hline \hline
\end{tabular}


The measured wet bulb temperature is significantly higher than the ASHRAE $0.4 \%$ design condition $\left(70.8^{\circ} \mathrm{F}\right.$ versus $\left.63.3^{\circ} \mathrm{F}\right)$ and there were 113 hours above the $0.4 \%$ design condition. A similar trend was also monitored for the 2011 cooling season. The increased outdoor wet bulb temperatures made it more difficult for the Coolerado Cooler to meet the SAT and thermal comfort performance metrics.

\subsection{FACILITY/SITE LOCATION AND OPERATIONS}

Twenty-four Coolerado C60 units were installed across five facilities at Fort Carson, including a training center (classrooms), auditorium, events center, a digester facility, and a jet aeration facility. One additional Coolerado unit was installed as a standalone unit at the wastewater treatment facility to test its performance with wastewater. These facilities were selected based on their different end uses, occupant densities, cooling loads, schedules, and physical constraints. All the systems were set up as zone coolers with $100 \%$ OA. Most were installed as ground or stand mounted; a few were roof mounted.

\subsubsection{Training Facility}

The training facility was constructed in 1966 as a small dining facility and has had several renovations. This 13,280 $\mathrm{ft}^{2}$ one-story building now includes five classrooms, two small offices, two restrooms, and storage. The facility was selected because of its consistent occupancy patterns (50 weeks per year from 8:00 a.m. to 5:00 p.m., 5 days per week) and its use of small, inefficient, portable air-conditioning units. The building had no central air-conditioning system and was cooled with portable, inefficient air-conditioning units. Poor thermal comfort in the training areas was a consistent complaint. One Coolerado C60 unit was installed in each of four classrooms, two on the northeast wall and two on the southwest wall (see Figure 17). These units were stand-mounted and ducted into the space through wall vents (see Figure 18). The temperature set points were set to maintain a constant temperature of $65^{\circ}-70^{\circ} \mathrm{F}$, and were occupant controlled. In future installations the site should install thermostats that are tied into

and controlled by the building automation system and all set points should be controlled by the building automation system. 


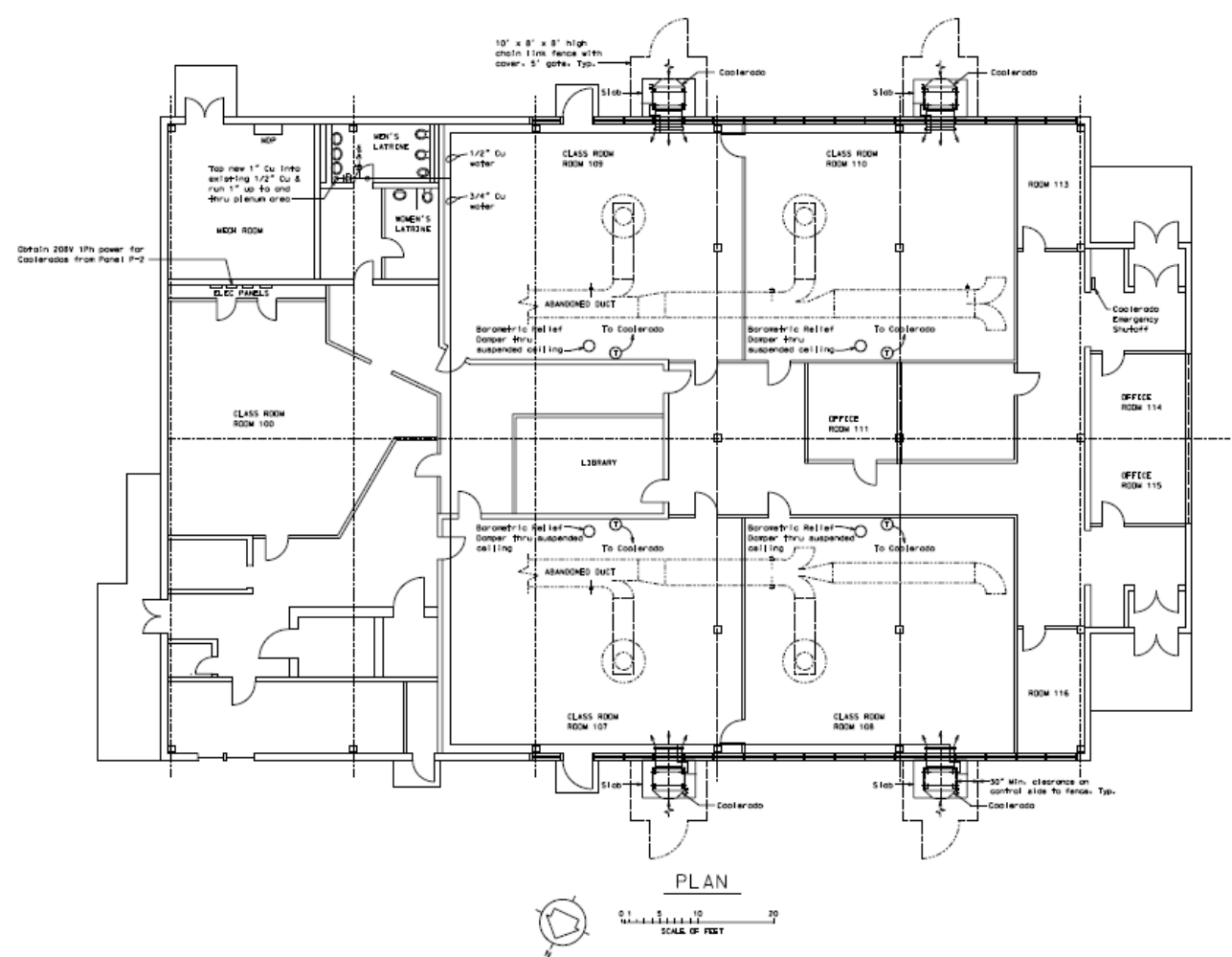

Figure 17. Final training center design

(Source: Fort Carson DPW Engineering Department)
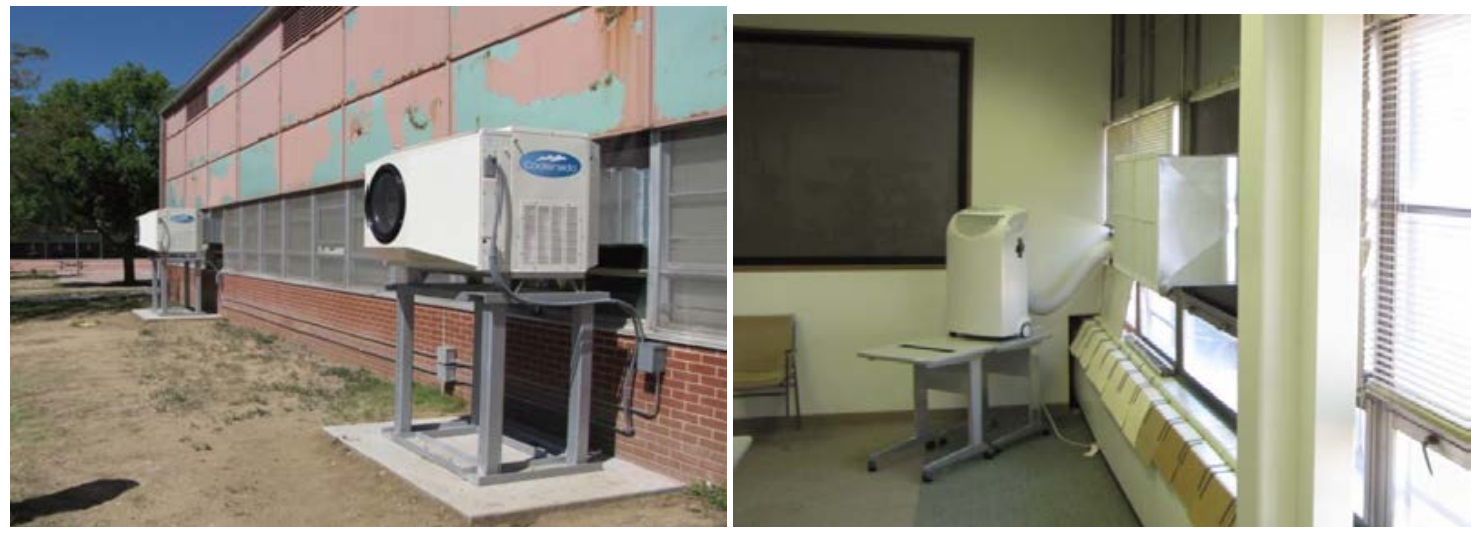

Figure 18. Training center exterior installation (right); training center interior vent (left)

(Source: Eric Kozubal, NREL)

\subsubsection{Auditorium}

The 6,700- $\mathrm{ft}^{2}$ auditorium was built in 1969 and has undergone minor renovations. The facility includes a foyer, a large auditorium, two small restrooms, and an office. The office is occupied most days from 7:30 a.m. to 9:00 p.m. and the theater is occupied quite frequently for small group meetings, ceremonies, and movies (Figure 19). The space is designed for a maximum of 
960 people. This facility was selected because of the poor condition of the original ac system, which was not providing sufficient cooling. Eight Coolerado C60 units replaced two 33-ton aircooled McQuay chillers; Figure 20 shows the location of the IEC installations. Each IEC was controlled by an independent thermostat set to $65^{\circ} \mathrm{F}$ by the occupants in the facility.
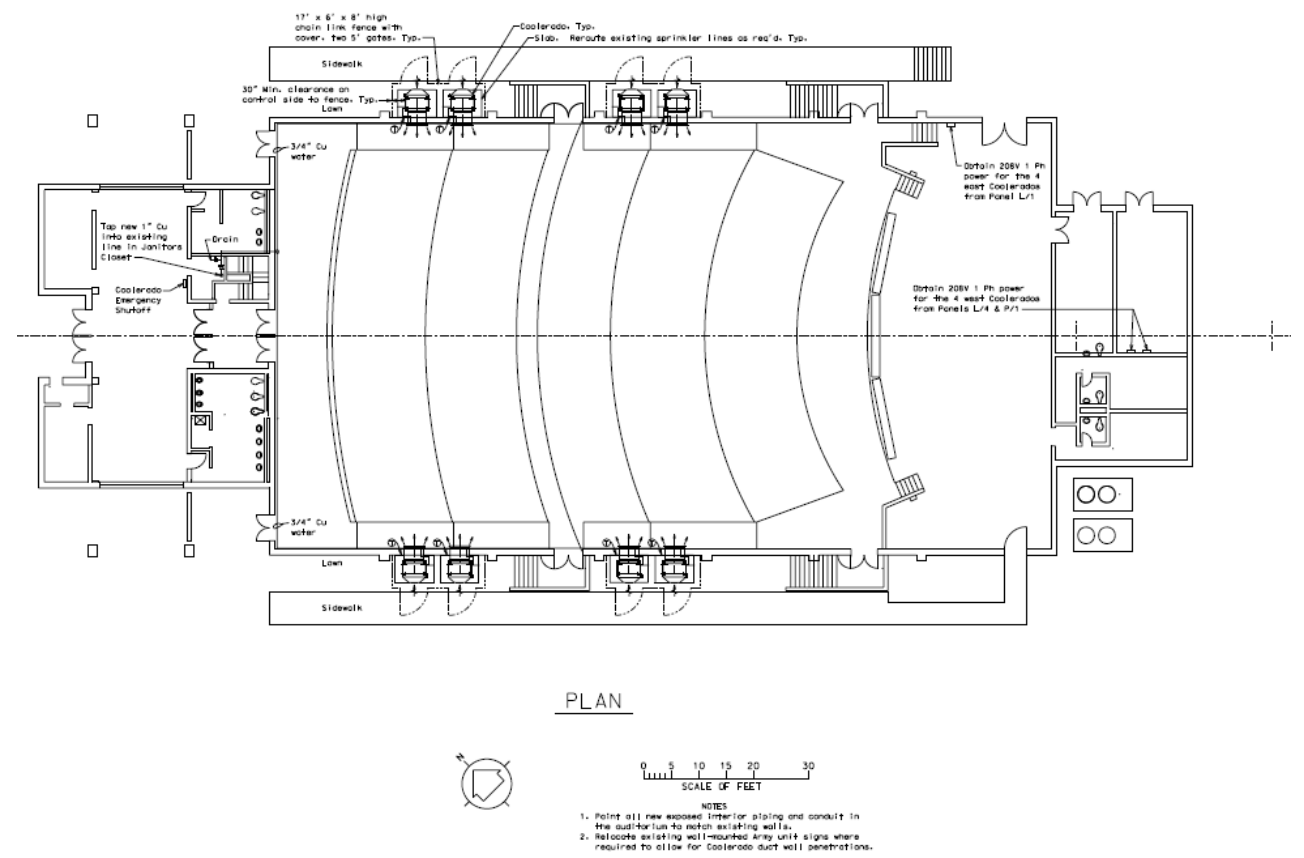

Figure 19. Final theater design

(Source: Fort Carson DPW Engineering Department)

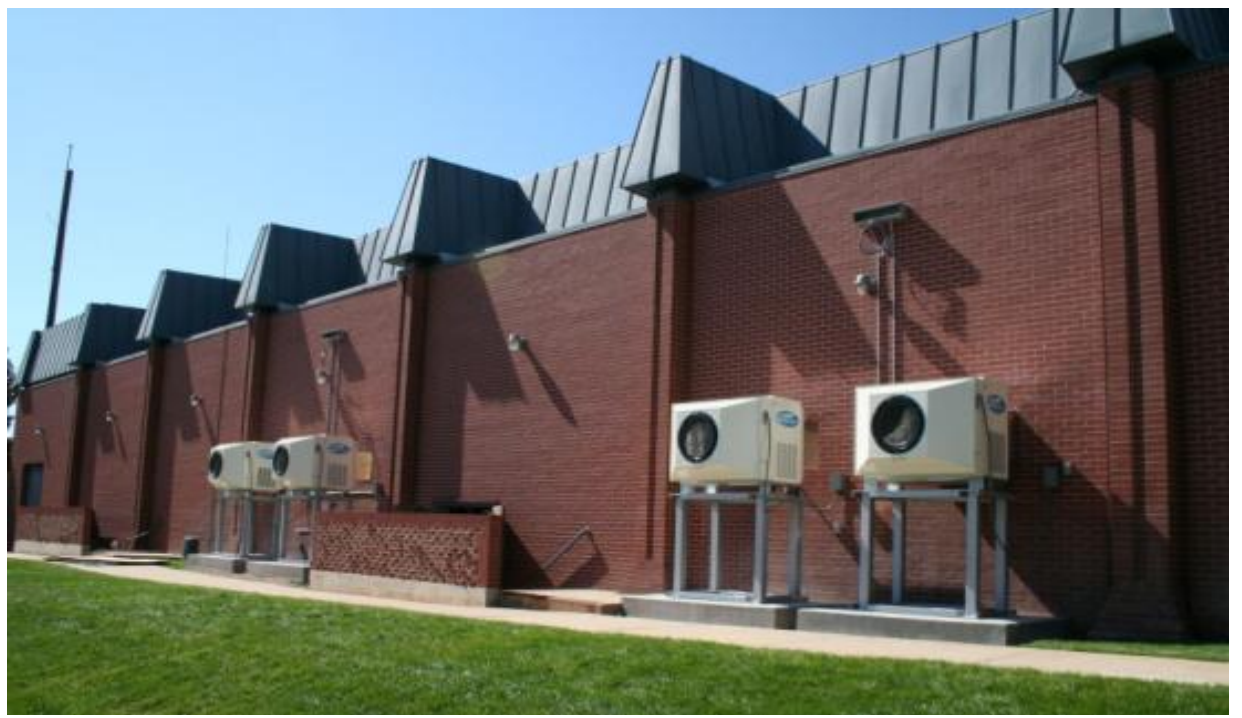

Figure 20. Theater exterior installation

(Source: Eric Kozubal, NREL) 


\subsubsection{Event Center}

The 24,626- $\mathrm{ft}^{2}$ Event Center, built in 1942, served as the original gymnasium. Only minor interior retrofits were performed during the retrofit. The facility is used throughout the year for a variety of events. The facility is a typical gymnasium configuration with a bleacher section on one side of the court (Figure 21). The facility has a maximum capacity of 1,500 and is occupied for roughly $70 \%$ of the time during cooling season. This building was selected for the demonstration because it did not have an air conditioning system before the Coolerado units were installed. Eight Coolerado C60 units were installed along the top of the northeast-facing wall (see Figure 22 and Figure 23). Each unit included its own thermostat, which was set to maintain $65^{\circ} \mathrm{F}$, which was quite cool because the units were undersized and intended to cool only the bleachers.

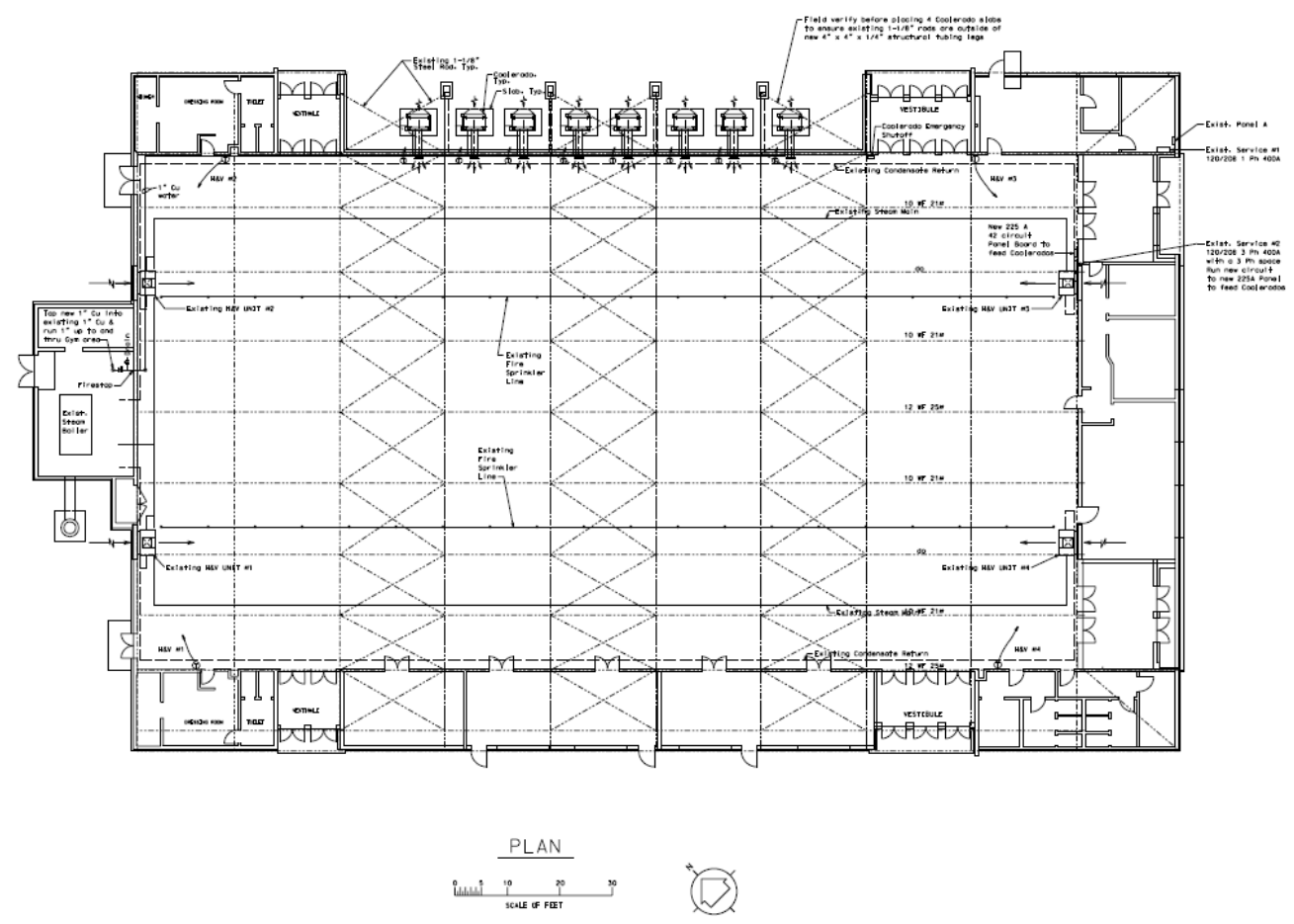

Figure 21. Final event center design

(Source: Fort Carson DPW Engineering Department) 


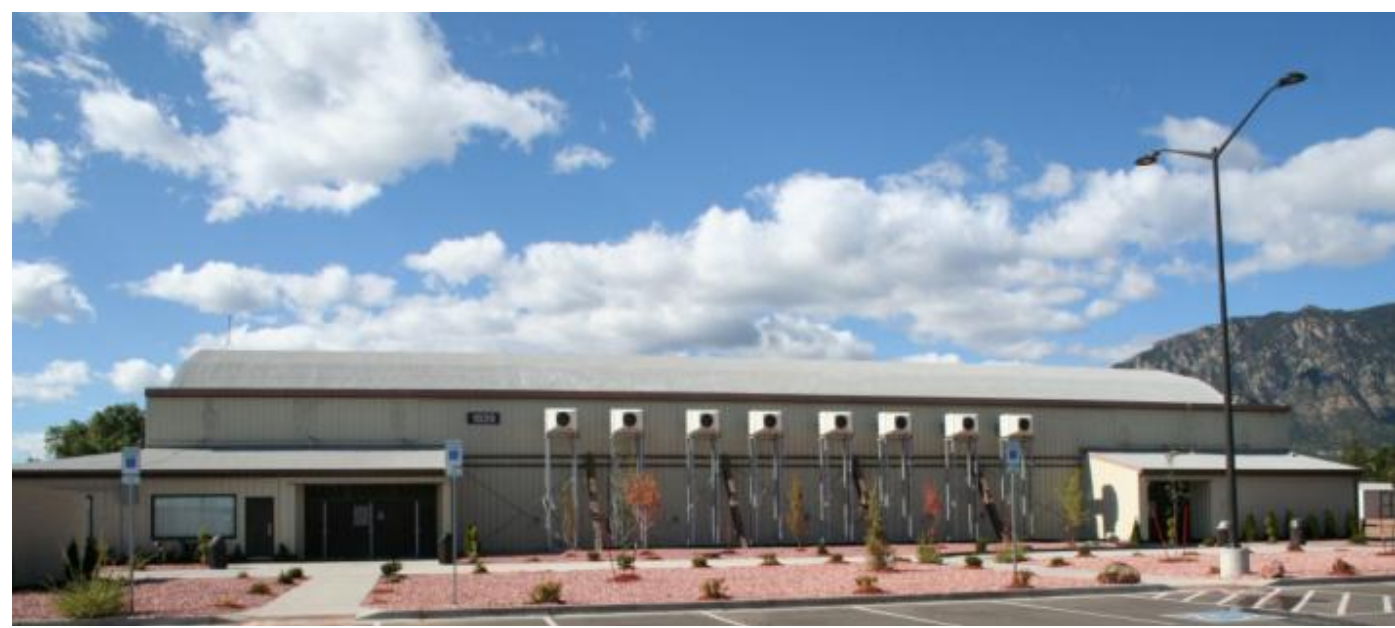

Figure 22. Event center exterior installation

(Source: Eric Kozubal, NREL)

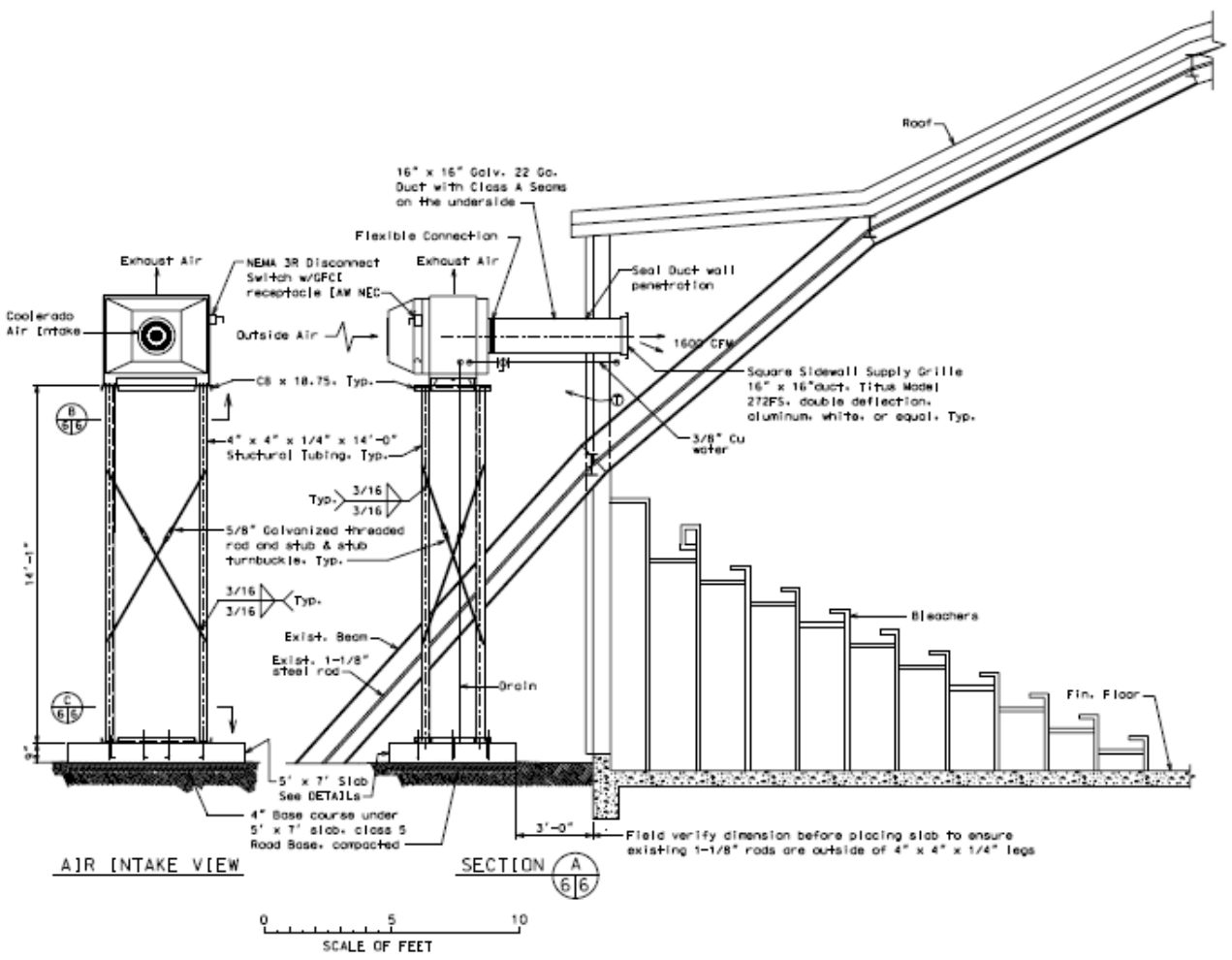

Figure 23. Section view of Coolerado installation at the event center

(Source: Fort Carson DPW Engineering Department)

\subsubsection{Digester and Jet Aeration Facilities}

The digester and jet aeration buildings (about 1,300 $\mathrm{ft}^{2}$ and 2,500 $\mathrm{ft}^{2}$, respectively) are industriallike facilities built in 1999 (see Figure 24 to Figure 26). These buildings house equipment used for wastewater treatment processes and are generally unoccupied except when maintenance is being performed. One Coolerado was installed on the roof of the digester facility and two on the 
roof of the jet aeration facility. Each was operated by an individual thermostat set to maintain $70^{\circ} \mathrm{F}$. No mechanical cooling system was in use before the Coolerado C60 units were installed. The units were installed to keep the equipment cool while maintaining reasonable indoor temperatures during summer maintenance. Before installation, these facilities were reported as being unbearably hot, and the pumps that are operating the wastewater treatment plant were reportedly shorting out because they were running above the allowable operating temperatures.

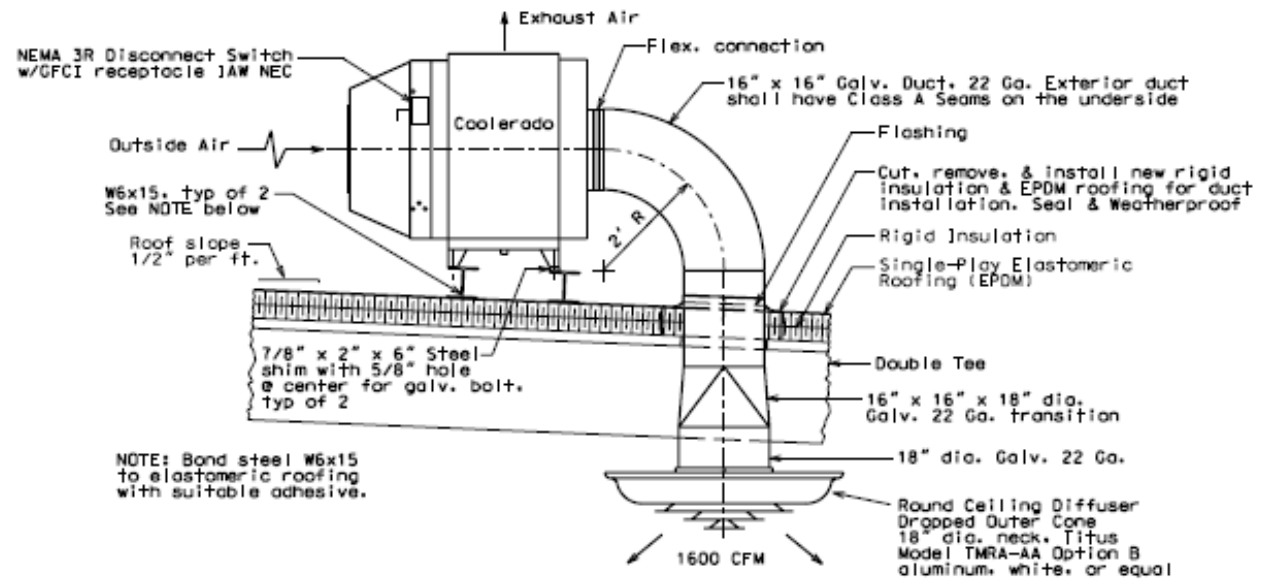

Figure 24. Right side view of roof-mounted Coolerado

(Source: Fort Carson DPW Engineering Department)

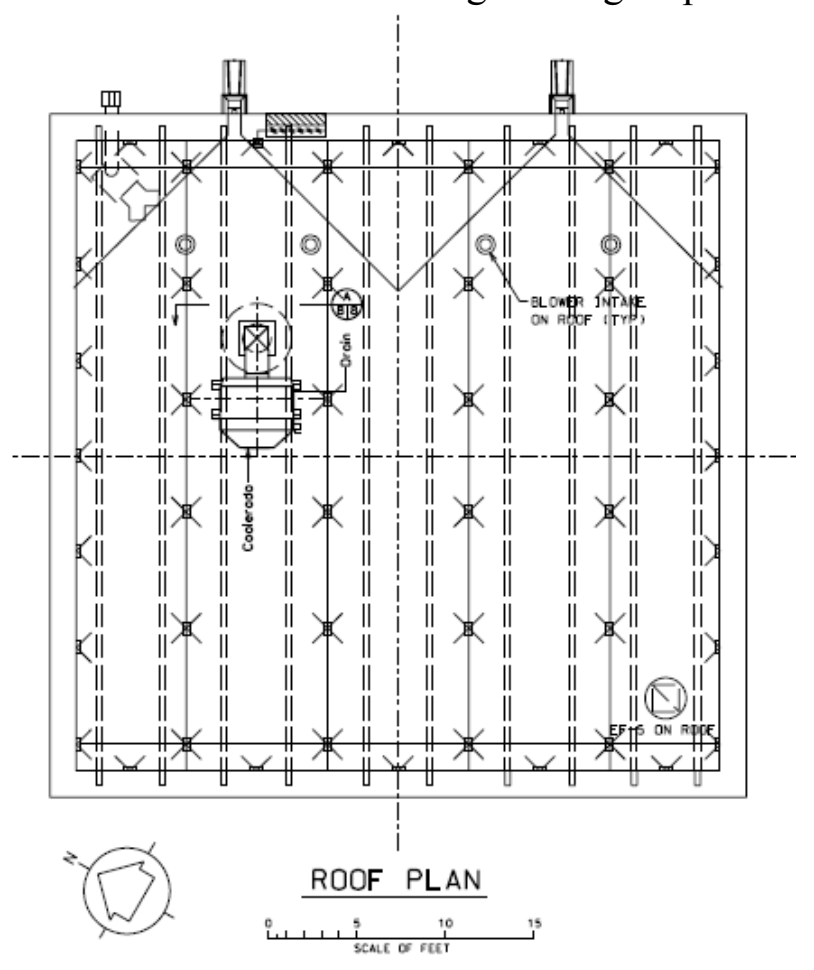

Figure 25. Final digester facility design

(Source: Fort Carson DPW Engineering Department) 


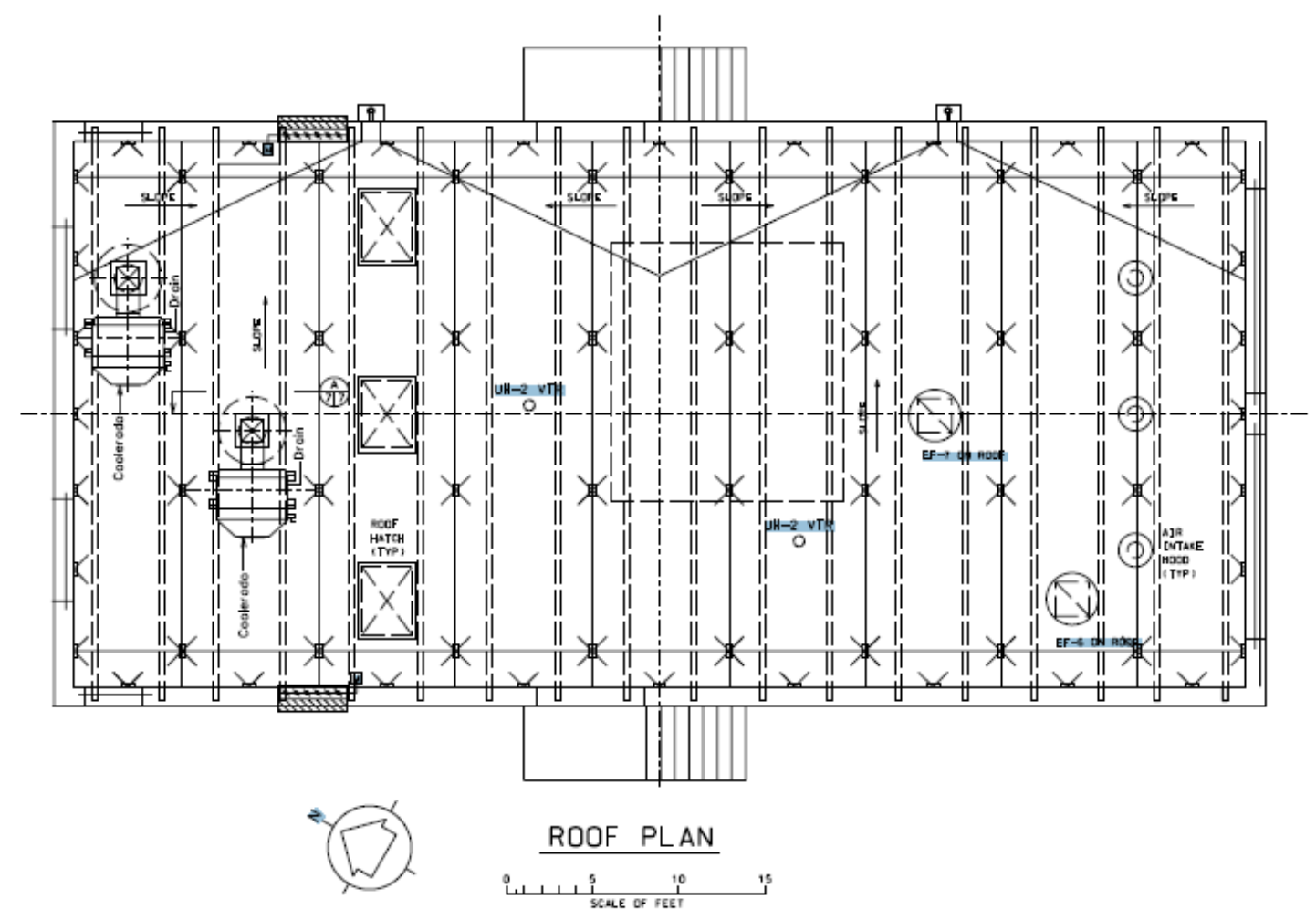

Figure 26. Final jet aeration design

(Source: Fort Carson DPW Engineering Department)

\subsubsection{Wastewater Treatment Plant}

Evaporative coolers consume water to provide useful cooling. The Coolerado Cooler generally receives water from the domestic water supply to a building, a fresh water source. However, in arid regions, widespread fresh water consumption generates competition for this limited resource. Thus, it is desirable to run the Coolerado Coolers using water sources that do not compete. Wastewater effluent has been processed by water treatment facilities and is discharged into the environment. Although not fit for reintroduction into the fresh water system, this water could be used in an IEC such as the Coolerado Cooler. An IEC maintains separation of water and the product air stream. This separation has led to the hypothesis that byproducts in the wastewater would not enter the building space. The challenge in using this effluent is the nature of what is still left in the water after treatment. Fresh water is filtered and chemically treated to inhibit sustaining organisms. Wastewater is not treated to this level of cleanliness.

The wastewater effluent test bed was set up at Fort Carson to determine its feasibility (Figure 27). The unit was set up to run in an open environment and discharge all EA and product air to the ambient environment. A stream of wastewater effluent was diverted from the treatment plant 
to the Coolerado Cooler, which was located nearby. The goal of the experiment was to determine:

- $\quad$ The performance over time of the unit

- $\quad$ The expected lifetime of the components

- The maintenance implications.

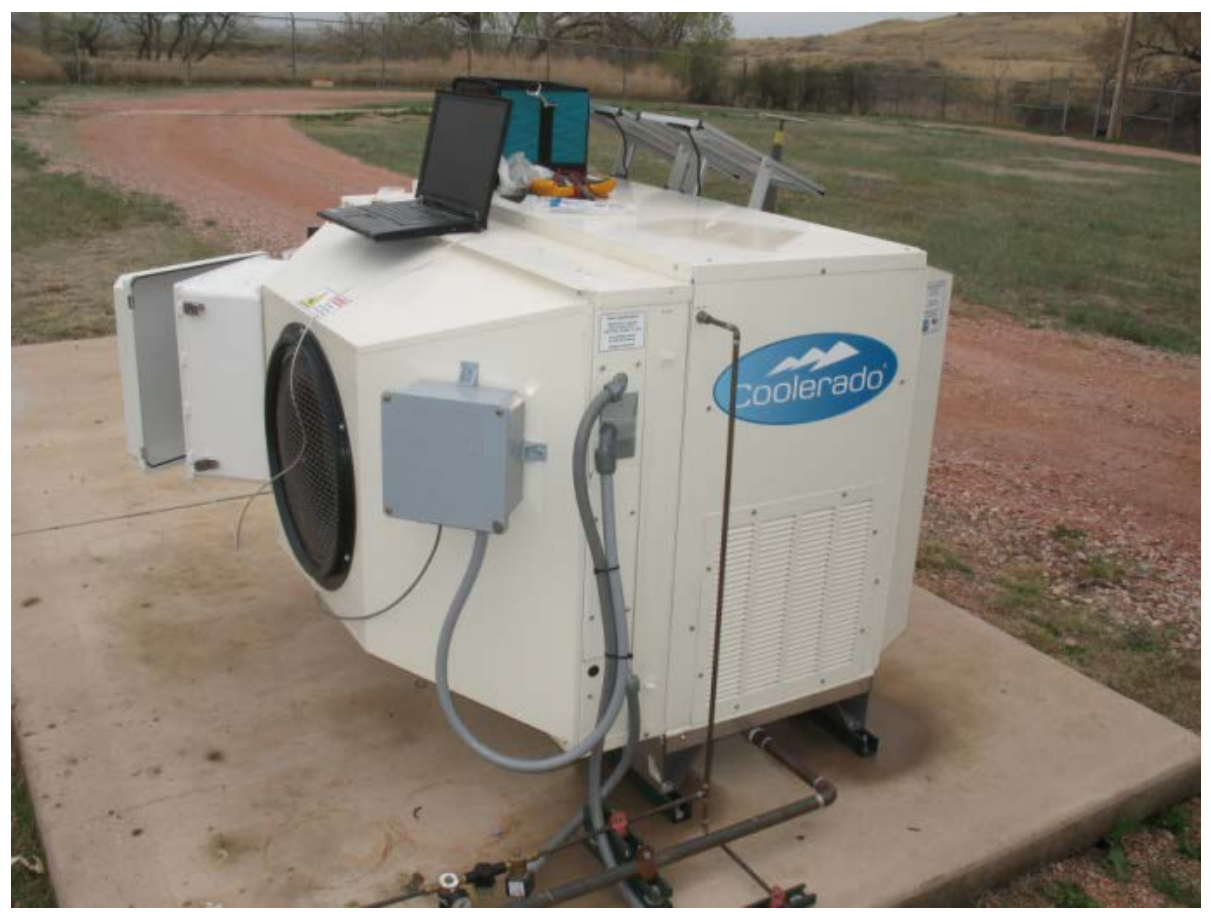

Figure 27. Wastewater unit

(Source: Eric Kozubal, NREL)

After approximately two weeks of operation during the 2010 cooling season, the assessment team discovered that the water filtration had already clogged full of an algae-like substance, restricting water to starvation levels. The wastewater effluent contained sufficient algae and nutrients that support algae growth and prohibit sufficient water flow rates, so the unit was shut down for the summer. Additional information about the wastewater unit is provided in the performance assessment section.

\subsection{FACILITY/SITE CONDITIONS}

Many of the facilities selected for the demonstration used old HVAC systems that did not provide adequate cooling; therefore, installing the Coolerado units had the potential to save energy and improve occupant comfort. Additionally, all the selected facilities are of older vintages and had significant air leakage, so it was not necessary to install pressure relief dampers in conjunction with the Coolerado units, which saved installation costs. 


\subsection{TEST DESIGN}

\subsection{CONCEPTUAL TEST DESIGN}

The conceptual test design consisted of a combination of controlled laboratory testing and field testing. NREL tested two units in the TTF before the installation and installed instrumentation and data acquisition equipment on 20 of the 24 Coolerado C60 units. The two units tested at the laboratory were used to pre-calibrate the field monitoring systems to improve the accuracy of field data. These two units were installed at the training center.

\subsection{BASELINE CHARACTERIZATION}

Because mechanical air-conditioning is a well-understood technology, baseline measurements were not required for individual sites to project energy savings relative to conventional equipment at various efficiency levels. Once cooling loads were established for each demonstration site, comparisons of Coolerado energy use versus energy needs of mechanical airconditioning were straightforward. The efficiencies of competing cooling technologies, including DX RTUs and chillers, were analyzed using manufacturer's data and performance algorithms used in building energy modeling tools such as eQUEST and EnergyPlus.

\subsubsection{Laboratory Testing}

Two of the Coolerado units that were installed at Fort Carson were tested at NREL's TTF in 2008 (see Figure 28). ${ }^{\mathrm{xi}}$ The two model C60 units (serial numbers 540 and 539) were tested under a variety of climatic conditions and full load and part load conditions. Seventeen laboratory tests were conducted; the results were used to develop a series of regression-based performance curves. These curves were created to characterize the performance of the units under any operating condition. The laboratory tests were conducted in accordance with ASHRAE Standard 143-2000 Method of Test for Rating Indirect Evaporative Coolers requirements. ${ }^{\text {xii }}$ The accuracy of each laboratory measurement is provided below:

- Temperature measurements have an accuracy of $\pm 0.2^{\circ} \mathrm{C}$ with $<0.1^{\circ} \mathrm{C}$ deviation.

- $\quad$ Airflow measurements have an accuracy of $\pm 2 \%$.

- Humidity is calculated with dew-point hydrometers and has an accuracy of $0.15^{\circ} \mathrm{C}$.

- Differential pressure measurements have an accuracy of \pm 0.025 in. w.c.

- $\quad$ Barometric pressure has an accuracy of $0.15 \%$. 


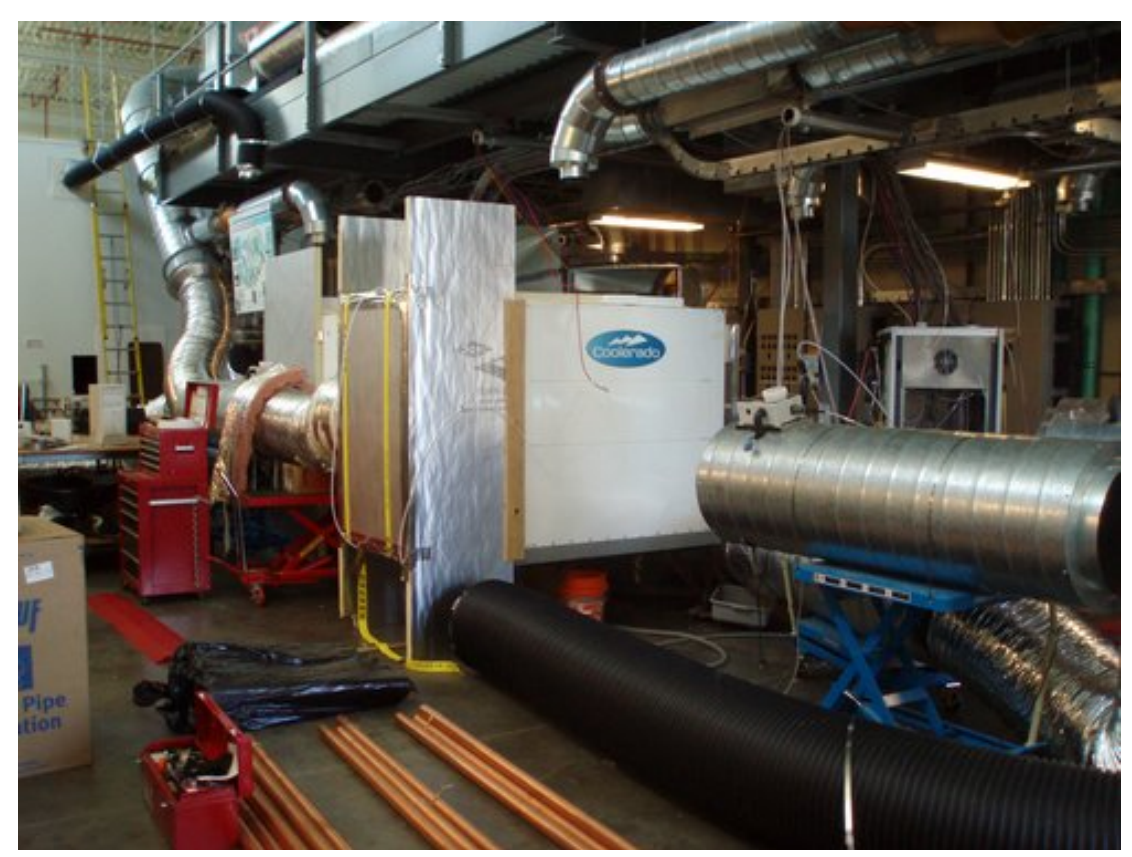

Figure 28. NREL TTF

(Source: NREL PIX 16929)

ASHRAE Standard 143-2000 provides requirements for testing and rating IECs under steadystate conditions. The regression-based curve fits that were generated based on the laboratory testing were used to create a sizing program that determines the number of Coolerado cooling cores required to meet a space cooling load, given a set of building design and climatic design conditions. The sizing information was then passed to an annual simulation that calculated the part load performance of the unit to meet a space cooling load, given a set of inlet air conditions.

Appendix C contains a detailed description of the performance model, which was validated against laboratory test data and used to compare measured performance of the units in the field to controlled laboratory test results. The laboratory testing was instrumental to the overall success of the project. The data were used to validate manufacturer's performance claims, develop a new performance model, and compare predicted to measured performance. The controlled laboratory bench testing enabled field measurement validation and new performance model development. Engineers can use these measurements and models on future projects to analyze technology performance.

\subsection{DESIGN AND LAYOUT OF TECHNOLOGY COMPONENTS}

Figure 29 shows the experimental layout for the training facility and represents all the demonstration buildings except the wastewater demonstration, which discharged to the outdoors because of the experimental nature of gray water use in the Coolerado unit. The figure describes a 100\% OA displacement cooling application, where no cooling air is recirculated and cooling and dehumidification loads are carried from the building by exfiltrating EA. All units employ MERV 15 filters, have minimal duct SP losses, and conserve water by modulating makeup water in response to a wet bulb depression sensor that predicts evaporation rates at current ambient 
conditions. For through-the-wall units, SA is ducted in at low elevations to ensure the occupied zone is maintained at the coolest temperature possible, while air that has already picked up internal loads is still cool enough to buffer the space by carrying away solar loads in unoccupied volumes, such as ceiling plenums. For rooftop installations, where ceiling discharge is required, special diffusers force air downward and encourage cooling air throw to the floor to achieve the same displacement effect. Barometric exhaust dampers close when the Coolerado units are not pressurizing the space to ensure maximum displacement cooling without compromising envelope integrity during non-cooling hours.

Each unit modulated its SA flow with an ECM in response to a thermostat control signal. The wastewater unit was an exception; it operated continuously at full flow to accelerate any negative impacts of operating on gray water and discharged its process air to the outdoors to avoid concerns about potential biological growth.

\subsection{OPERATIONAL TESTING}

Testing was conducted in startup and monitoring phases. During startup, Coolerado and NREL engineers installed sensors and confirmed that HVAC and data systems operated properly. Startup commenced as the equipment installation proceeded in July 2009 and concluded in September 2009. Systems performance was monitored during the 2010 and 2011 cooling seasons (July, August, and September). NREL removed the monitoring equipment after the demonstration ended in September 2011. The onsite O\&M contractor took responsibility for operating the units from the beginning of the demonstration, and the units will be used for space conditioning into the foreseeable future.

\subsection{SAMPLING PROTOCOL}

A data acquisition system (DAS) was installed on 20 of the 24 Coolerado units installed at Fort Carson. The DAS was designed to capture information on the energy and water performance of the Coolerado unit, as well as space temperature and EAT. Multiple DASs were installed at Fort Carson, and the data from all the sensors were stored and partially processed on Campbell Scientific Data Loggers. The data loggers were equipped with cellular modems that allowed for remote monitoring and analysis of metered data. All sensors were sampled every $10 \mathrm{~s}$ and any mathematical manipulations of those primary measurements were made on the same 10-s interval. Data are stored as averages or totals in four separate data tables identical in field description but varying in storage interval: 1-min, 15-min, 60-min, and 24-h (midnight-tomidnight). Figure 29 shows the DAS points for the typical Coolerado unit. Appendix B contains a list of sensors and associated accuracy specifications. 


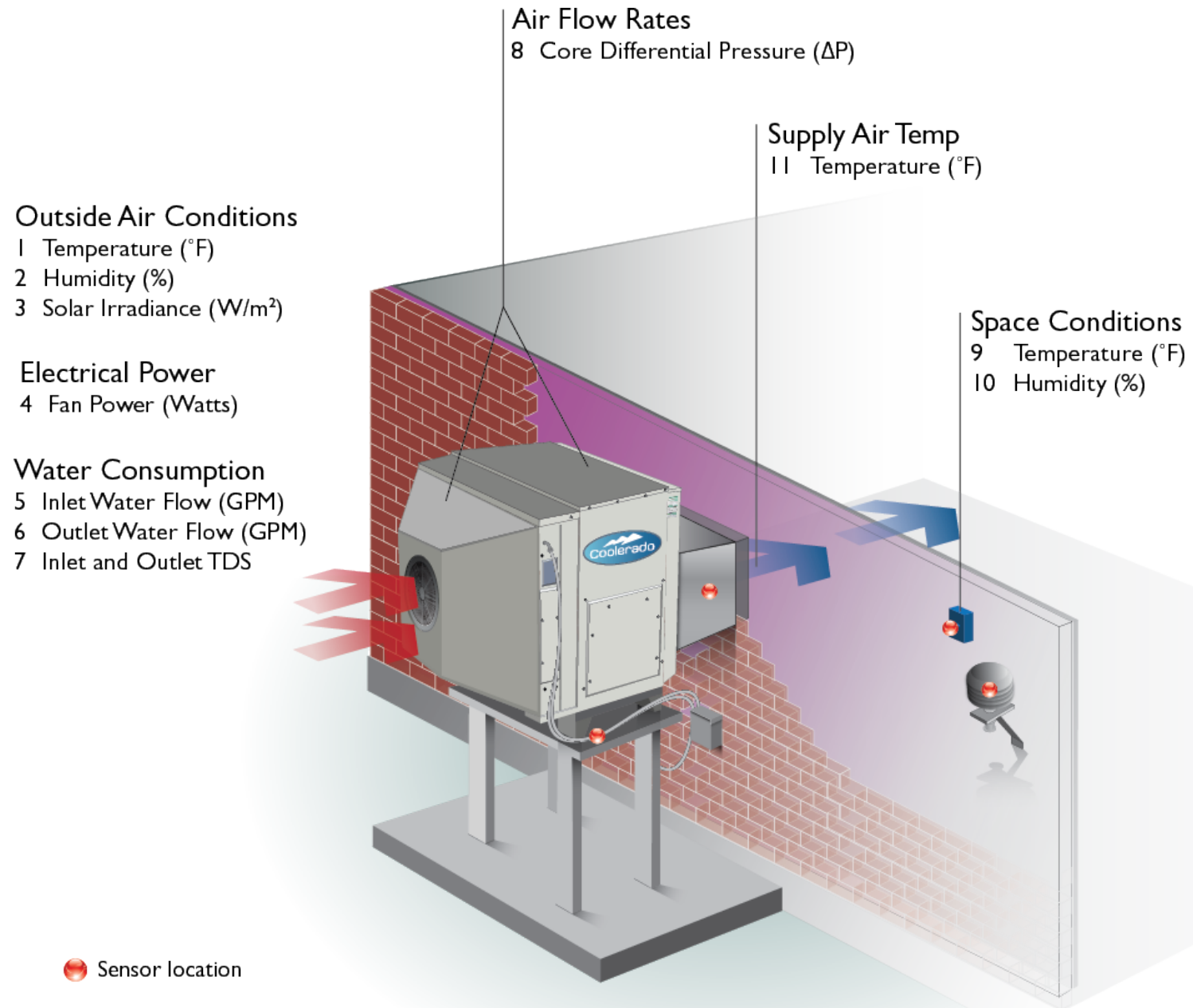

Figure 29. Coolerado DAS

(Source: Joshua Bauer, NREL) 


\subsection{PERFORMANCE ASSESSMENT}

Performance data were collected during the 2010 and 2011 cooling seasons, which included July, August, and September. The results presented in this section highlight the performance objective results of the best- and worst-performing units from those seasons (see Table 8). Appendix B provides additional time series graphs with supplemental performance results.

Table 8. Quantitative Performance Objectives

\begin{tabular}{|c|c|c|c|c|}
\hline $\begin{array}{c}\text { Performance } \\
\text { Objective }\end{array}$ & Metric & Data Requirements & Success Criteria & Results \\
\hline $\begin{array}{l}\text { Improve comfort } \\
\text { provided by } \\
\text { evaporative cooling } \\
\text { (Performance) }\end{array}$ & $\begin{array}{l}\text { - Hours outside } \\
\text { psychometric } \\
\text { comfort zone } \\
\text { - SAT }\end{array}$ & $\begin{array}{l}\text { - Interior space } \\
\text { temperature } \\
\text { Indoor humidity } \\
\text { - } \quad \text { SAT }\end{array}$ & $\begin{array}{ll}- & <1 \% \text { outside } \\
& \text { ASHRAE } \\
\text { summer } \\
\text { comfort zone } \\
\text { - } & \text { SA }<70^{\circ} \mathrm{F} \\
- & \text { OK to apply } \\
\text { where design } \\
\text { wet bulb } \leq< \\
70^{\circ} \mathrm{F} \\
\end{array}$ & $\begin{array}{l}\text { Comfort Zone }= \\
\text { Pass } \\
\text { SA }<0^{\circ} \mathrm{F}= \\
\text { Pass for 80\% of } \\
\text { unit monitored } \\
\text { Wet Bulb = } \\
\text { Pass }\end{array}$ \\
\hline $\begin{array}{l}\text { Provide high- } \\
\text { efficiency cooling } \\
\text { (Energy Efficiency) }\end{array}$ & $\begin{array}{l}\text { - } \mathrm{kW} / \text { ton of } \\
\text { building } \\
\text { cooling }\end{array}$ & $\begin{array}{ll}\text { - } & \text { SAT } \\
\text { - } & \text { Building EAT } \\
\text { - } & \text { Coolerado power } \\
& \text { consumption } \\
\text { - } & \text { SA flow rate }\end{array}$ & $\begin{array}{l}\text { - } \quad \text { Peak power }<1 \\
\mathrm{~kW} / \text { ton } \\
\text { Average power } \\
<0.6 \mathrm{~kW} / \text { ton }\end{array}$ & $\begin{array}{l}\text { Peak Power }= \\
\text { Pass } \\
\text { Average Power } \\
=\text { Pass }\end{array}$ \\
\hline $\begin{array}{l}\text { Sustain high cooling } \\
\text { performance (Service } \\
\text { Life) }\end{array}$ & $\begin{array}{ll}\text { - } & \text { WBE } \\
\text { - } & \text { SA pressure } \\
\text { drop }\end{array}$ & $\begin{array}{ll}\text { - } & \text { SAT } \\
\text { - } & \text { Outdoor air } \\
& \text { temperature } \\
\text { - } & \text { Core pressure drop } \\
\text { - } & \text { Outdoor air } \\
& \text { humidity }\end{array}$ & $\begin{array}{l}<5 \% \\
\text { degradation of } \\
\text { wet-bulb eff. } \\
\text { over } 3 \text { years } \\
\text { Negligible } \\
\text { increase in SA } \\
\text { pressure drop }\end{array}$ & $\begin{array}{l}\text { WBE }=\text { Pass } \\
\text { Negligible } \\
\text { Increase } \\
\text { pressure drop = } \\
\text { Pass }\end{array}$ \\
\hline $\begin{array}{l}\text { Minimize water } \\
\text { consumption } \\
\text { (Water Conservation) }\end{array}$ & $\begin{array}{l}\text { Gallons/ton-hr } \\
\text { of building } \\
\text { cooling } \\
\text { Site water } \\
\text { quality (TDS) }\end{array}$ & $\begin{array}{ll}\text { - } & \text { Water inlet flow } \\
\text { - } & \text { Water outlet flow } \\
\text { - } & \text { Water conductivity }\end{array}$ & $\begin{array}{l}\text { Demonstrate } \\
\text { conservation } \\
\text { approach } \\
\text { consuming }< \\
2.5 \mathrm{gal} / \mathrm{ton} \cdot \mathrm{h}\end{array}$ & $\begin{array}{l}\text { Water use = } \\
\text { Fail }\end{array}$ \\
\hline
\end{tabular}


Table 9. Qualitative Performance Objectives

\begin{tabular}{|c|c|c|c|c|}
\hline $\begin{array}{l}\text { Performance } \\
\text { Objective }\end{array}$ & Metric & Data Requirements & Success Criteria & Results \\
\hline $\begin{array}{l}\text { Maintainability } \\
\text { (Ease of use) }\end{array}$ & $\begin{array}{l}\text { Ability of an } \\
\text { HVAC } \\
\text { technician to } \\
\text { operate and } \\
\text { maintain the } \\
\text { technology }\end{array}$ & $\begin{array}{l}\text { Standard form } \\
\text { feedback from the } \\
\text { HVAC technician on } \\
\text { time required to } \\
\text { maintain }\end{array}$ & $\begin{array}{l}\text { A single facility } \\
\text { technician able to } \\
\text { effectively operate and } \\
\text { maintain equipment } \\
\text { with minimal training }\end{array}$ & Pass \\
\hline $\begin{array}{l}\text { Maintainability } \\
\text { (Cost) }\end{array}$ & $\begin{array}{l}\text { Service } \\
\text { Frequency }\end{array}$ & $\begin{array}{l}\text { Standard form } \\
\text { feedback from the } \\
\text { HVAC technician on } \\
\text { time required to } \\
\text { maintain }\end{array}$ & $\begin{array}{l}>90 \% \text { of units fall } \\
\text { within nominal IEC } \\
\text { maintenance schedule } \\
\text { by project end }\end{array}$ & Pass \\
\hline $\begin{array}{l}\text { Maintainability } \\
\text { (Failure) }\end{array}$ & $\begin{array}{l}\text { Biological } \\
\text { Fouling } \\
\text { Freezing }\end{array}$ & Visual inspection & $\begin{array}{l}\text { No signs of biological } \\
\text { growth, including gray } \\
\text { water unit } \\
\text { No ruptured water lines }\end{array}$ & Pass \\
\hline
\end{tabular}

\subsection{IMPROVED COMFORT PROVIDED BY EVAPORATIVE COOLING}

The ASHRAE $0.4 \%$ evaporative design day for Colorado Springs specifies as design wet bulb temperature of $63.3^{\circ} \mathrm{F}$ with an MCDB temperature of $78.3^{\circ} \mathrm{F}$. There are 8,760 hours in a given year and the ASHRAE design day indicates that these conditions would not be exceeded for more than 35 hours per year. The TMY3 weather data for Colorado Springs are plotted on the psychometric chart in Figure 30.

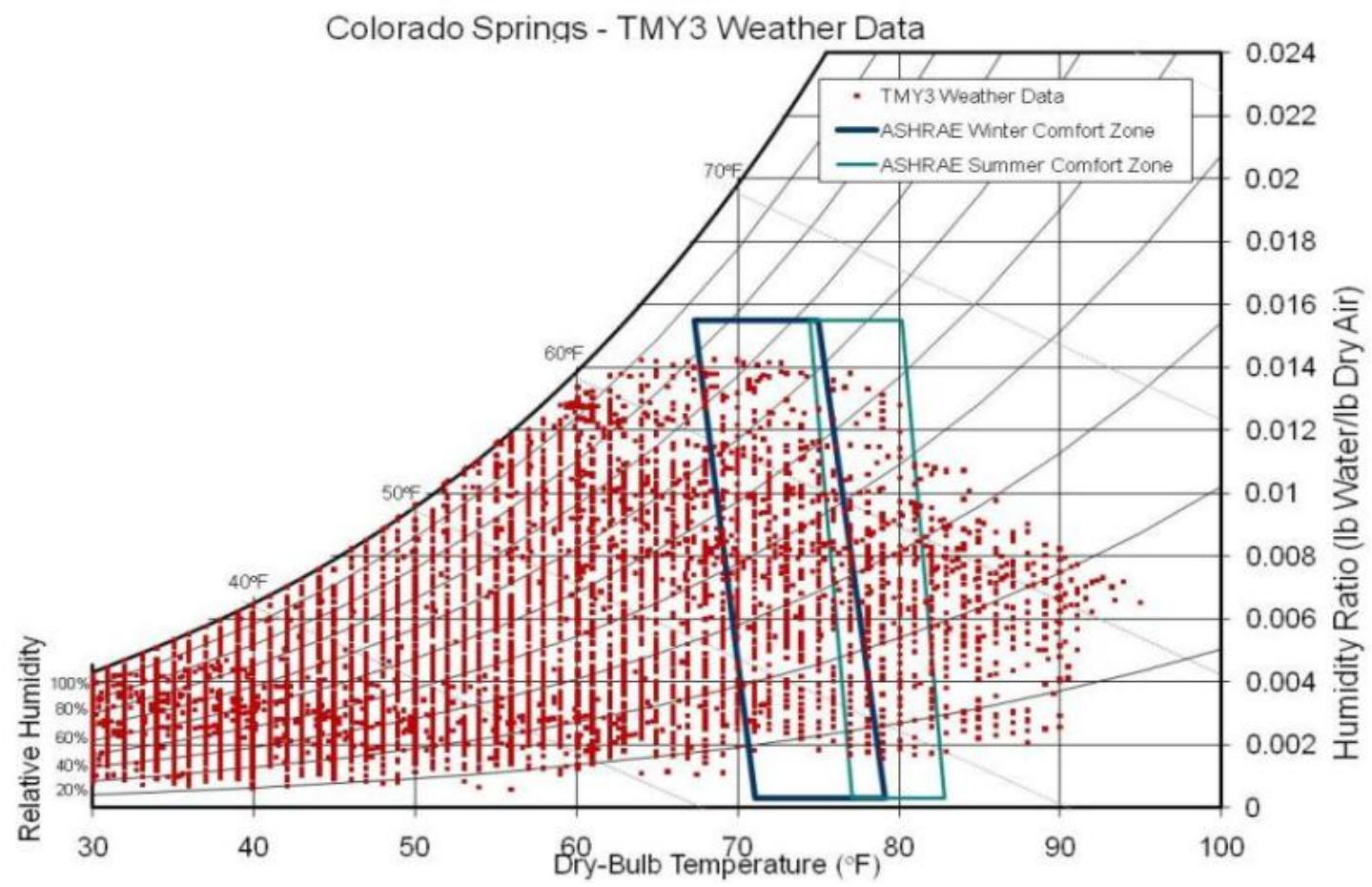

Figure 30. Colorado Springs TMY3 weather data 
Figure 30 shows that the dry bulb temperature is above $90^{\circ} \mathrm{F}$ for only a few hours per year and the wet bulb temperature does not increase above $65^{\circ} \mathrm{F}$. The SAT of the Coolerado unit is defined by its WBE and the OA conditions have a significant impact on unit performance.

The OA conditions in Colorado Springs for the 2010 and 2011 cooling seasons were more extreme than they had been in previous years. In 2010 the maximum recorded OA dry bulb temperature was $97.8^{\circ} \mathrm{F}$ and the $\mathrm{MCDB}$ was $62.9^{\circ} \mathrm{F}$. The maximum recorded dry bulb temperature was $70.79^{\circ} \mathrm{F}$, which is significantly higher than the design wet bulb temperature and makes it difficult for the units to meet the performance metric that sets a maximum SAT of $70^{\circ} \mathrm{F}$. In 2010 the OA wet bulb temperature was above the $0.4 \%$ design condition for 113 hours or $1.3 \%$ of the year.

In 2011 the maximum dry bulb temperature was recorded as $98.85^{\circ} \mathrm{F}$ with a coincident wet bulb temperature of $65.5^{\circ} \mathrm{F}$. The maximum wet bulb temperature was recorded as $67.74^{\circ} \mathrm{F}$, and the OA wet bulb temperature was above the $0.4 \%$ design condition for 161 hours or $1.8 \%$ of the time. The extreme OA conditions during the 2010 and 2011 cooling season resulted in 10-20 days per year that the OA wet bulb temperatures were above the $0.4 \%$ design condition. Although the conditions during the 2010 and 2011 cooling seasons were more extreme than the ASHRAE $0.4 \%$ conditions, the units were still able to meet the ASHRAE comfort zone requirements, and energy performance requirements.

\subsubsection{ASHRAE Summer Comfort Zone}

Performance data were collected during the 2010 and 2011 cooling seasons. The results presented in this section highlight the performance objective results of the best- and worstperforming units from those seasons.

This performance metric set a success criterion that all facilities must maintain the space within the ASHRAE summer comfort zone for $>99 \%$ of the time that the units are operating. All units were able to maintain room air conditions (temperature and RH) within the ASHRAE thermal comfort zone $>99 \%$ of the time for both cooling seasons. The measured space temperature and $\mathrm{RH}$ data are plotted in Figure 31 for the event center for the 2010 cooling season. The measured space conditions are shown in blue and the measured OA conditions are shown in red. 


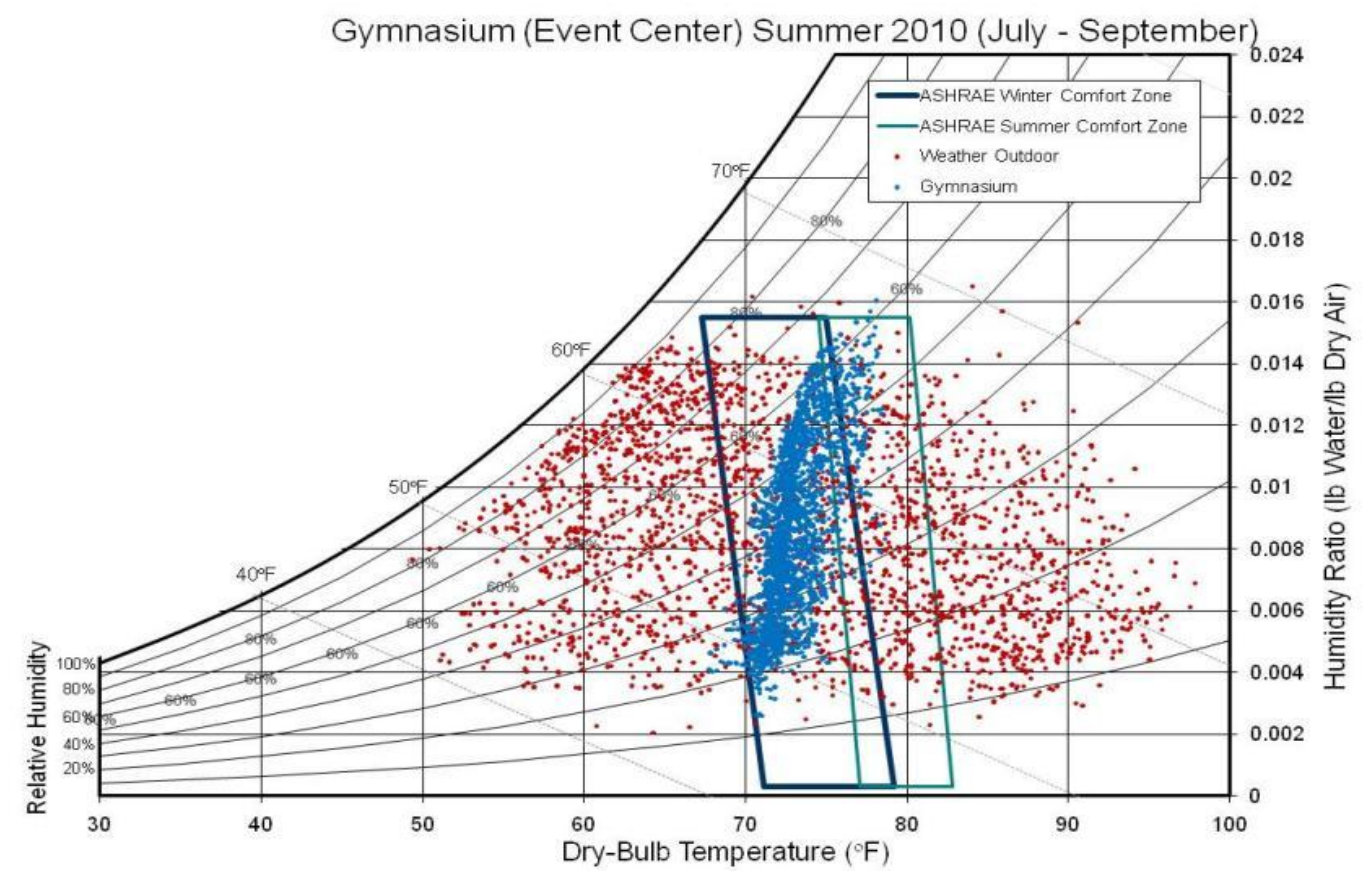

Figure 31. Event center comfort conditions 2010

The Coolerado units that serve the event center are undersized for the given facility and are intended to condition only the bleachers directly under the Coolerado units. These units will typically turn on and run at $100 \%$ fan speed throughout the day to meet the space temperature set point. For 2010, these units operated for 2,117 hours and the maximum recorded indoor air temperature was $78.8^{\circ} \mathrm{F}$. The localized recorded space temperature was above the ASHRAE comfort zone for 2 hours and was below the comfort zone for 25 hours per year. For this particular performance metric any hours below the thermal comfort zone are considered acceptable, as the demonstration focused primarily on ensuring that the space temperature did not rise above the ASHRAE thermal comfort zone for more $1 \%$ of the recorded hours. The energy consumption associated with the hours below the ASHRAE thermal comfort zone was marginal, because there were only a few hours below the lower temperature limit.

For the 2011 cooling season, classroom unit \#2 operated for 2,208 hours and the maximum recorded space temperature was $78.6^{\circ} \mathrm{F}$. Figure 32 shows that all the hours were within the ASHRAE comfort zone, other than a few hours when the temperature was below the winter comfort zone. The classroom units are sized to meet the entire cooling load and spend more time operating at partial fan speeds and at a higher WBE than the event center. Although most hours are below the summer comfort zone and within the summer comfort zone, the troops in the Classroom are in military uniforms (clothing level $=1$ ). In this case the winter rather than the summer comfort zone is recommended. 


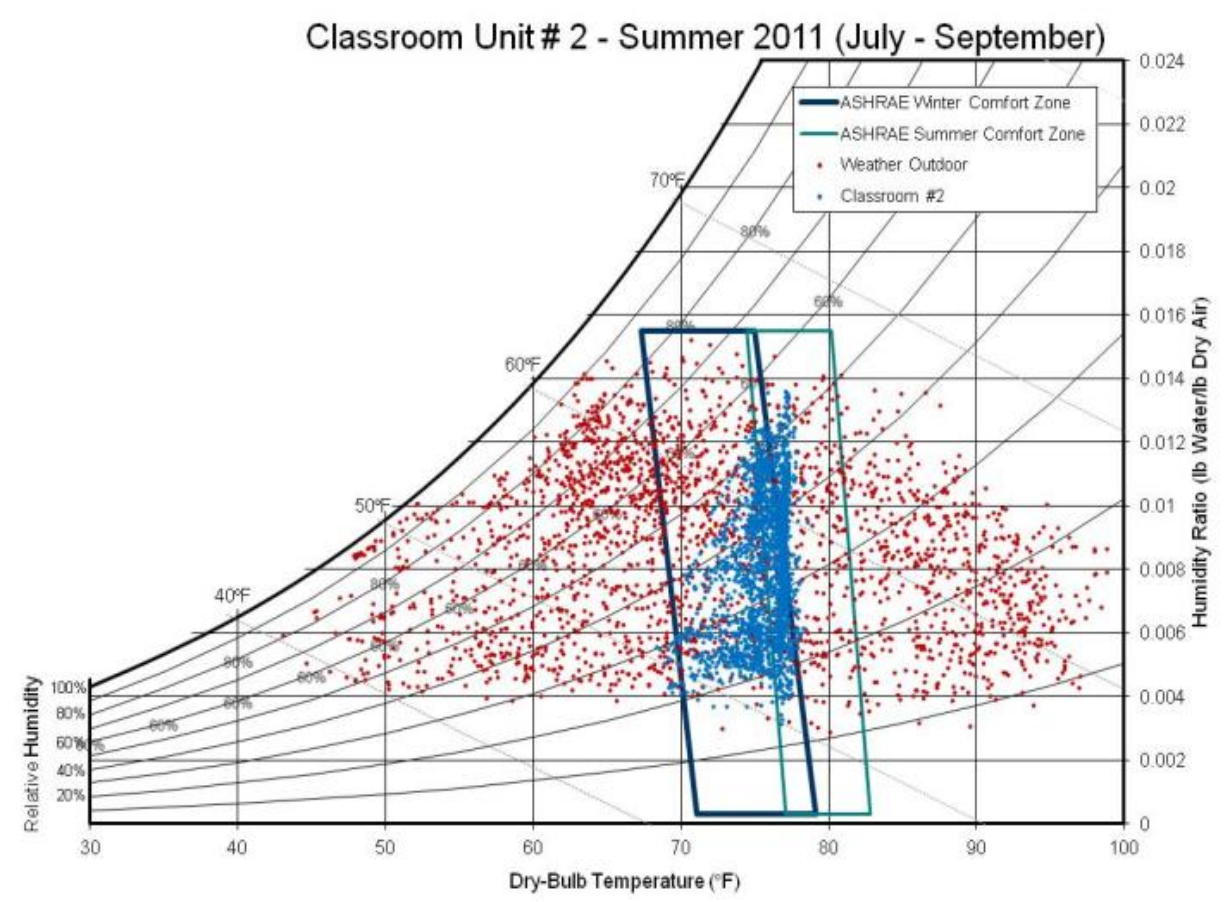

Figure 32. Classroom unit \#2 comfort conditions, 2011

The psychometric data for the remaining units for the 2010 and 2011 cooling season are provided in the appendix.

\subsubsection{Supply Air Temperature}

The SAT is a function of the OA conditions and coincident fan speed. The WBE at $100 \%$ fan speed with 0 in. of external SP is $89.4 \%$ at an elevation of $5,702 \mathrm{ft}$; the WBE is $118.3 \%$ at $20 \%$ fan speed (Figure 33). If the unit is operating at partial fan speeds, the WBE increases and the SAT decreases.

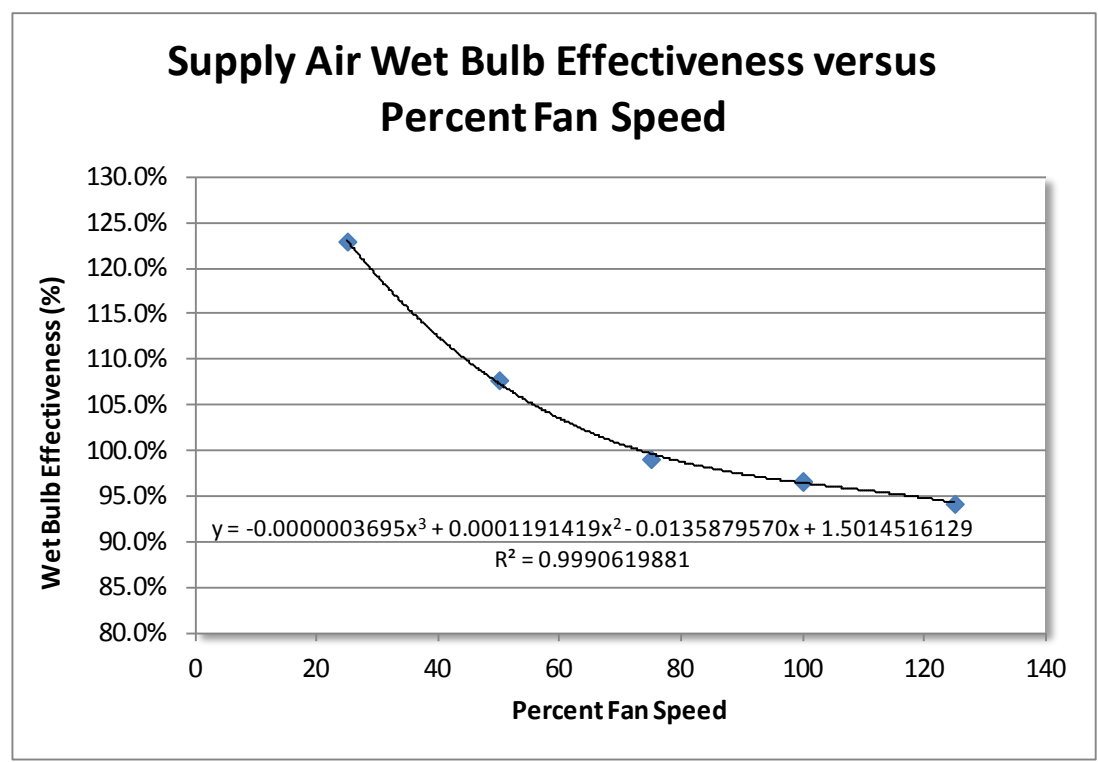

Figure 33. Coolerado EER versus fan speed 
Given the extremity of the 2010 and 2011 cooling seasons, if the units were operating at $100 \%$ fan speed during the periods when the OA wet bulb temperature is above $67^{\circ}-68^{\circ} \mathrm{F}$, the units could not discharge air cooler than $70^{\circ} \mathrm{F}$. For the smaller facilities where the Coolerado unit can meet $100 \%$ of the cooling load, they will operate at partial fan speeds for most of the cooling season and can supply colder air temperatures. For the larger facilities such as the event center and the theater, the units could not meet the thermostat set point temperature for most of the time they were operating and operated at $100 \%$ fan speed to provide as much cooling as possible.

Four of the 15 units that were monitored supplied air cooler than $70^{\circ} \mathrm{F}$ for either the 2010 or the 2011 cooling season. Although the units could not supply air cooler than $70^{\circ} \mathrm{F} 100 \%$ of the time, most could supply air cooler than $70^{\circ} \mathrm{F}$ for $>95 \%$ of the hours.

Table 10. SAT Performance Results

\begin{tabular}{||c|c|c|c||}
\hline \multirow{4}{*}{ Facility } & \multirow{3}{*}{ Unit } & \multicolumn{2}{|c|}{$\begin{array}{c}\text { Percent of Hours Average SA } \\
\text { Temperature }<\mathbf{7 0}^{\circ} \mathbf{F}\end{array}$} \\
\cline { 2 - 4 } & & $\mathbf{2 0 1 0}$ & $\mathbf{2 0 1 1}$ \\
\hline \multirow{4}{*}{ Training facility } & 1 & 59.2 & 96.5 \\
\cline { 2 - 4 } & 2 & 76.6 & 99.5 \\
\cline { 2 - 4 } & 3 & 99.4 & 100 \\
\cline { 2 - 4 } & 4 & 96.3 & 97.5 \\
\hline \multirow{4}{*}{ Event center } & 1 & 100 & 100 \\
\cline { 2 - 4 } & 3 & 99.7 & 99.8 \\
\cline { 2 - 4 } & 5 & 95.1 & 99.7 \\
\cline { 2 - 4 } & 7 & 98.2 & 99.8 \\
\hline \multirow{3}{*}{ Theater } & 9 & 99.3 & 97.0 \\
\cline { 2 - 4 } & 10 & 94.9 & 100 \\
\cline { 2 - 4 } & 11 & 62.7 & 99.9 \\
\cline { 2 - 4 } & 12 & 99.3 & 98.0 \\
\hline Digester & 1 & 57.9 & 77.4 \\
\hline \multirow{2}{*}{ Jet aeration facility } & West & 68.8 & 77.0 \\
\hline & East & No data & 84.3 \\
\hline Wastewater unit & 1 & 41.7 & 70.2 \\
\hline \hline
\end{tabular}

A few units consistently supplied higher discharge air temperatures (DATs) than the others. In particular, the jet aeration facility units consistently discharged warmer air. Figure 34 shows the SATs for the event center units for the 2010 cooling season. The SATs were $50^{\circ}-67^{\circ} \mathrm{F}$ for most hours. 


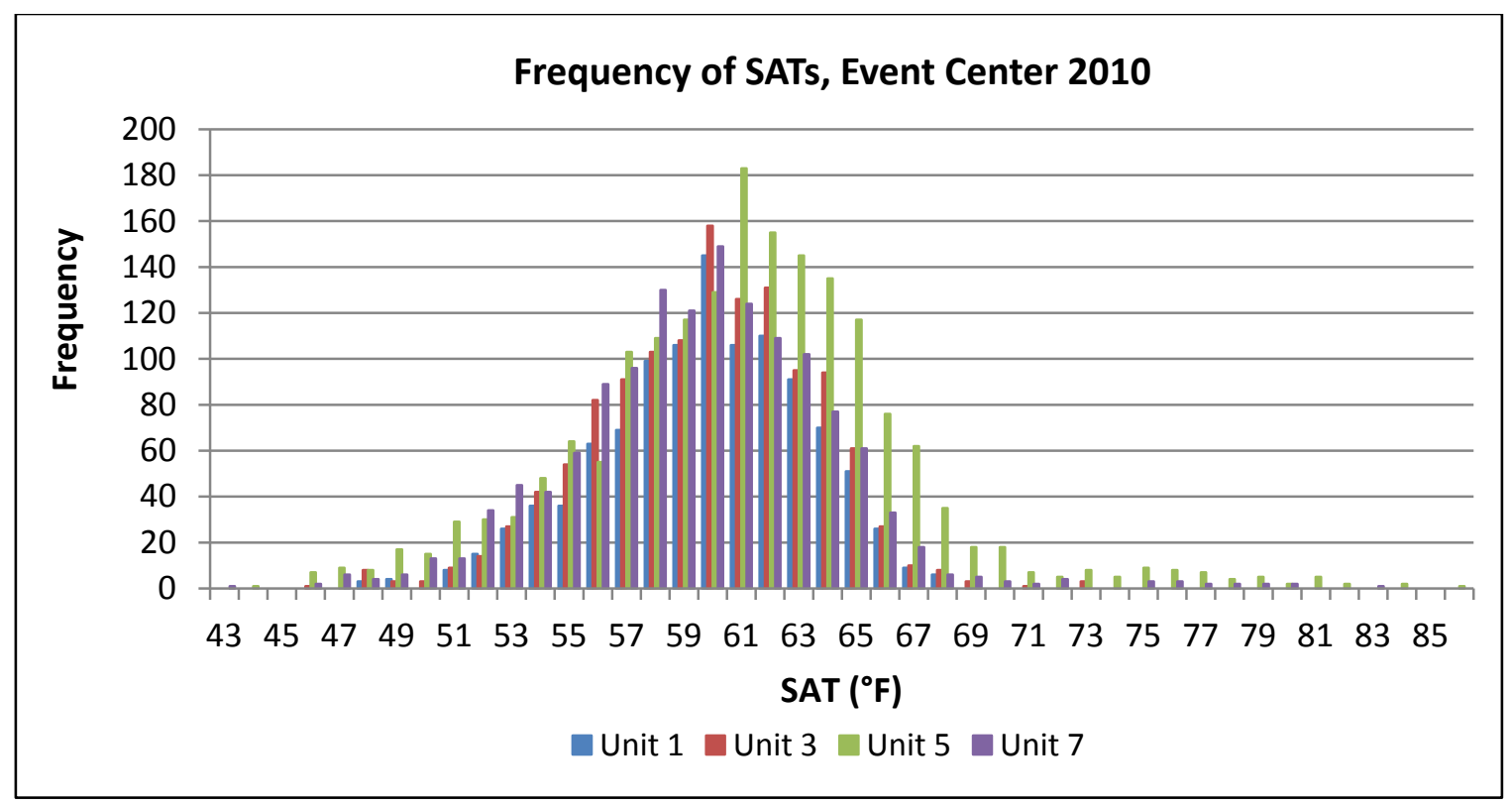

Figure 34. Event center frequency of SATs $\left({ }^{\circ} \mathrm{F}\right), 2010$

The units at the event center all consistently operated at $100 \%$ fan speed for most of the time, so they should have had similar SATs throughout the year. During the 2010 cooling season, three of the four units serving the event center supplied consistent SATs and unit \#5 had consistently higher SATs. Figure 35 shows the hourly average SAT for the four event center units as a function of OA wet bulb temperature for July 2010.

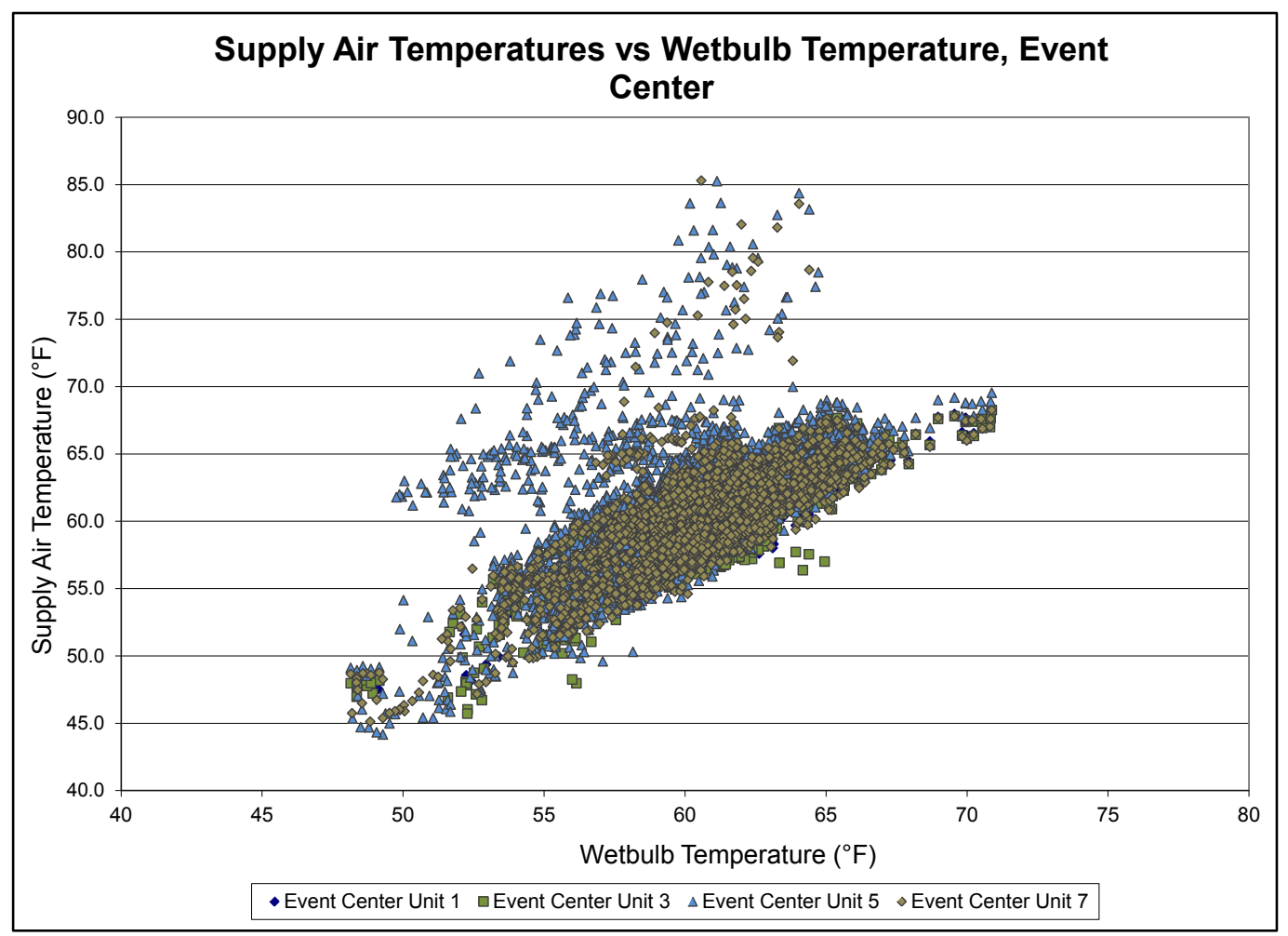

Figure 35. July 2010 event center SAT versus wet bulb temperature 
Figure 35 shows that there are periods of time when units \#5 and \#7 operated with a poor WBE and supplied air at much warmer temperatures than the other units. This is likely due to HMX cores drying out for short periods of time. These units also had slightly poorer performance during the 2011 cooling season. Figure 36 shows the same information for units \#1 and \#2.

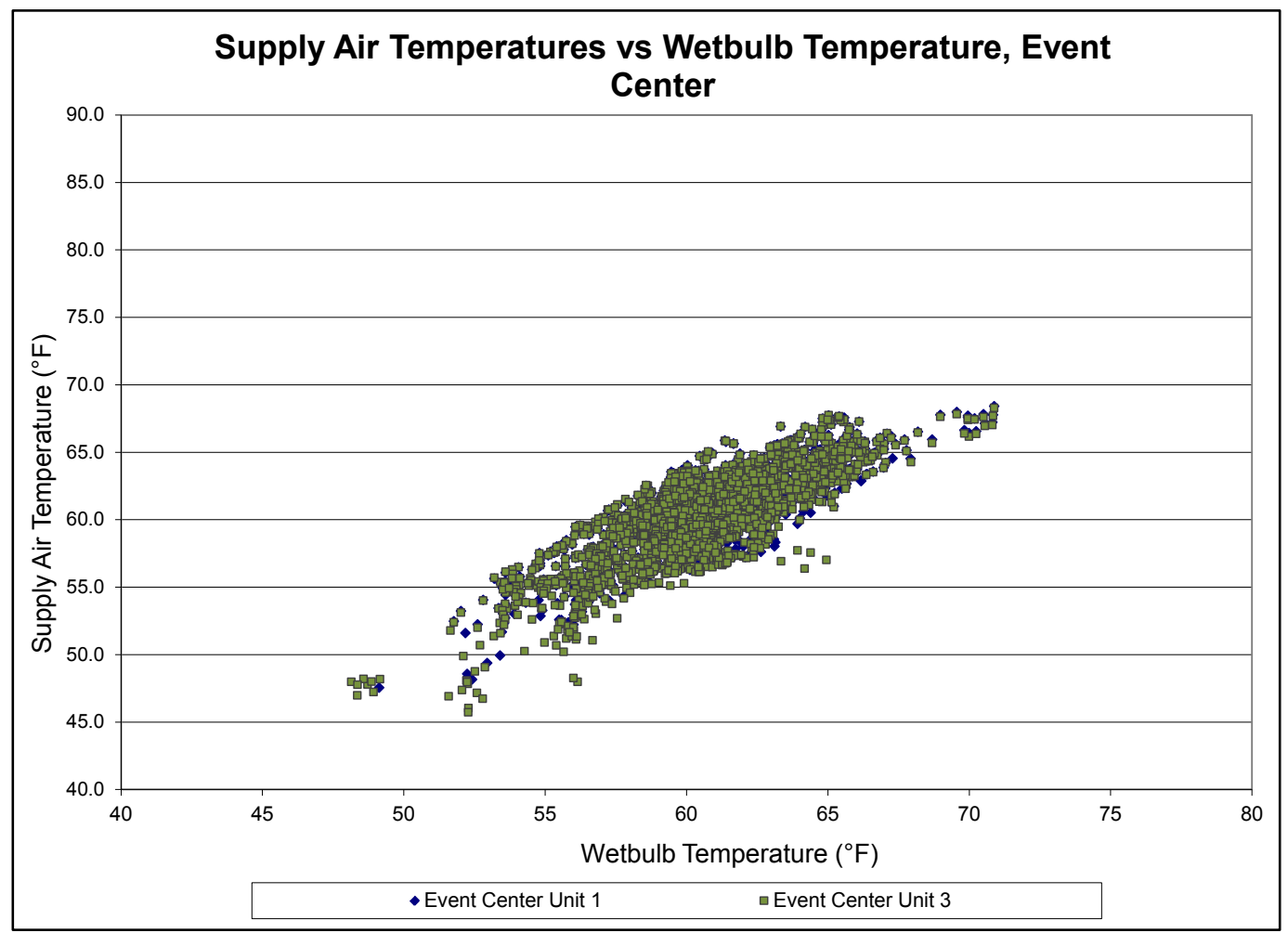

Figure 36. July 2010 event center unit \#1 and \#2 SATs

The SAT for these two units was consistently cooler than the wet bulb temperature and both units performed as expected. The units always discharged air cooler than $70^{\circ} \mathrm{F}$, even when the OA wet bulb temperature exceeded $70^{\circ} \mathrm{F}$.

Figure 37 shows that all the event center units supplied air at temperatures of $40^{\circ}-70^{\circ} \mathrm{F}$. There were very few hours when the DAT exceeded $70^{\circ} \mathrm{F}$. 


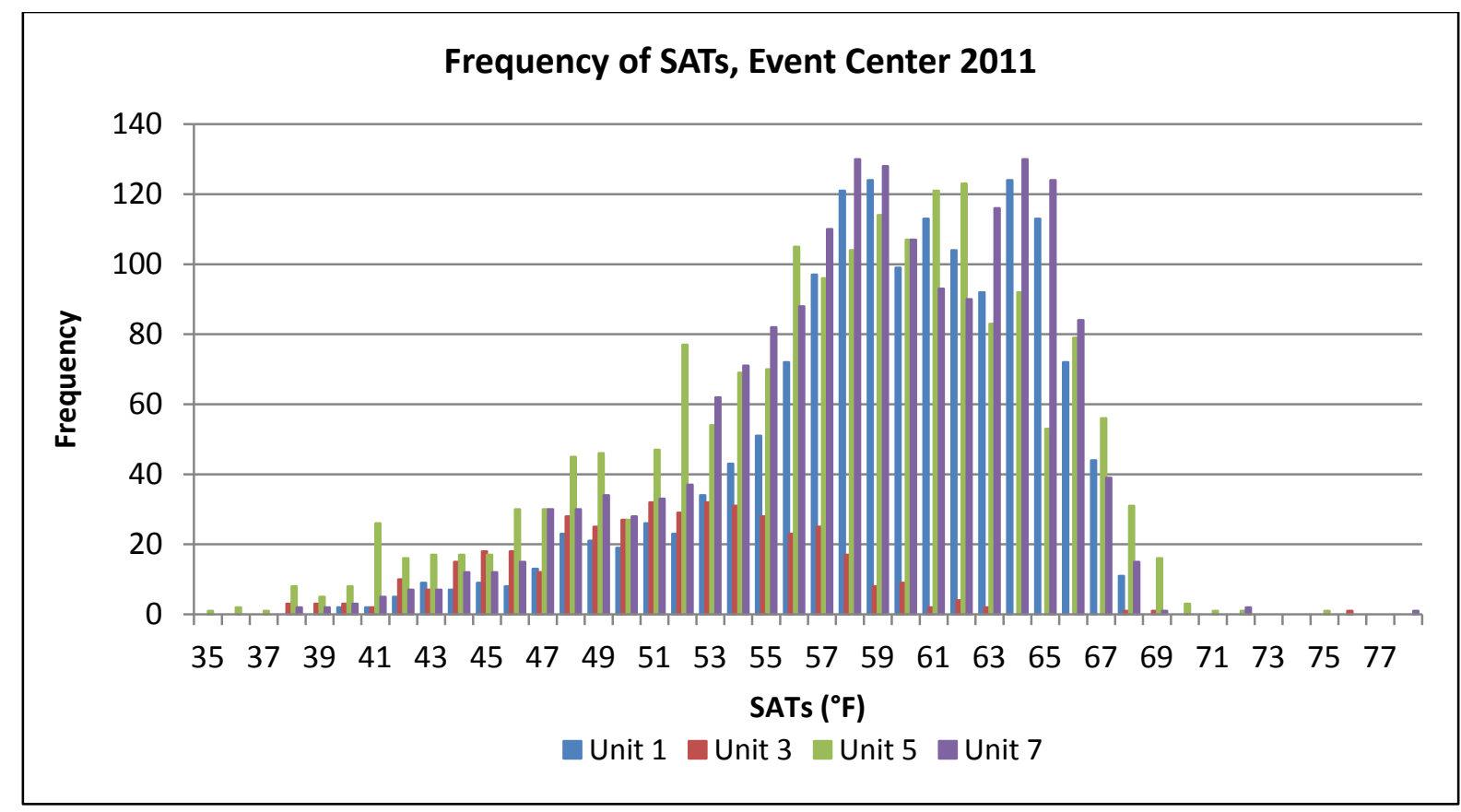

Figure 37. Event center frequency of SATs $\left({ }^{\circ}\right.$ F), 2011

The SAT for the digester facility was consistently higher than the other facilities for both cooling seasons. Figure 38 shows that the DAT exceeded $70^{\circ} \mathrm{F}$ for a significant amount of time and was as high as $78^{\circ} \mathrm{F}$ for a period of time.

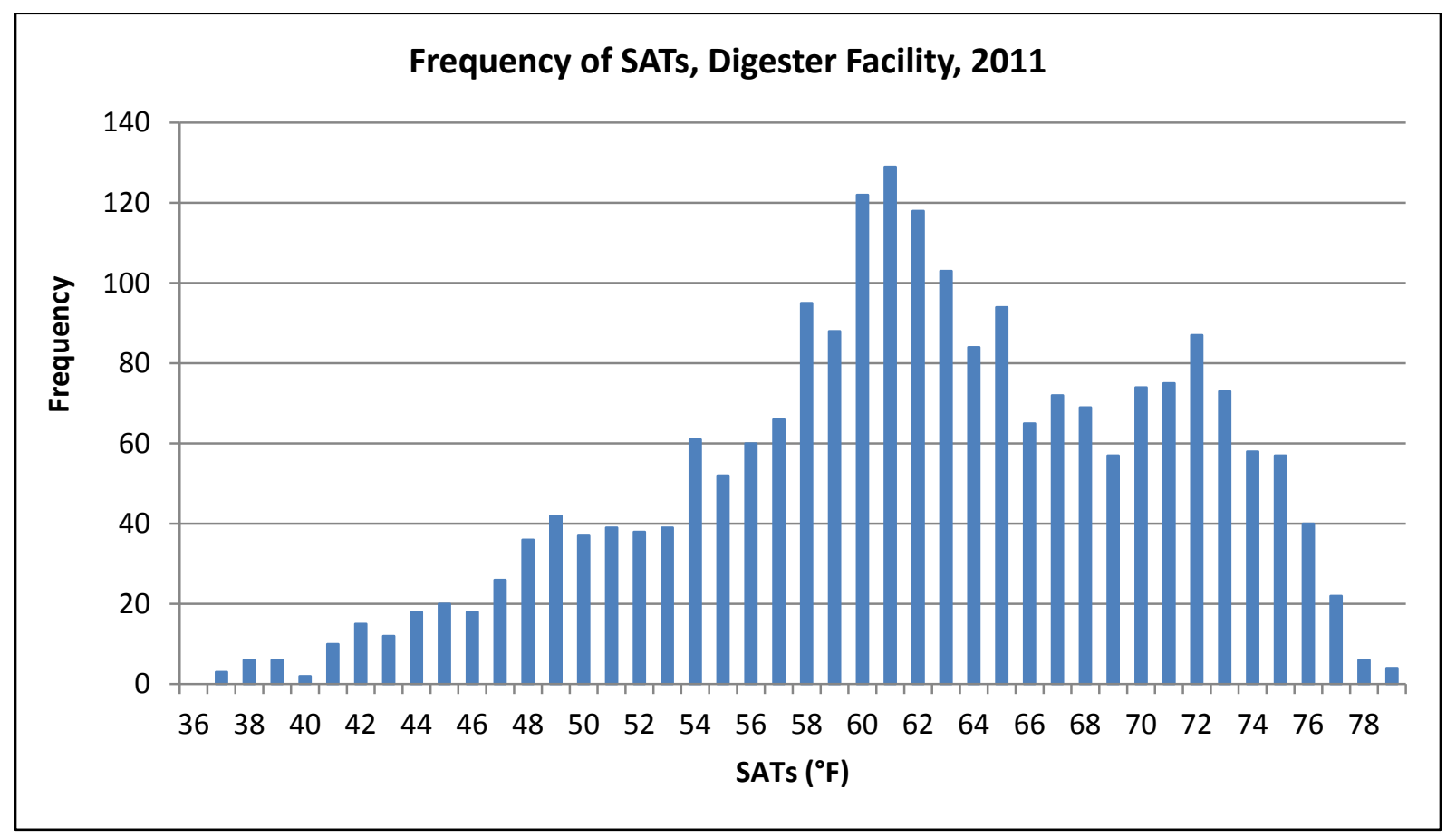

Figure 38. Digester facility frequency of SATs $\left({ }^{\circ} \mathrm{F}\right), 2011$ 
The hourly average WBE for the 2011 cooling season for the digester facility indicates that the WBE was $50 \%-60 \%$ and was significantly lower than the other units (see Figure 39 ). This low WBE is the primary driver for the higher SATs.

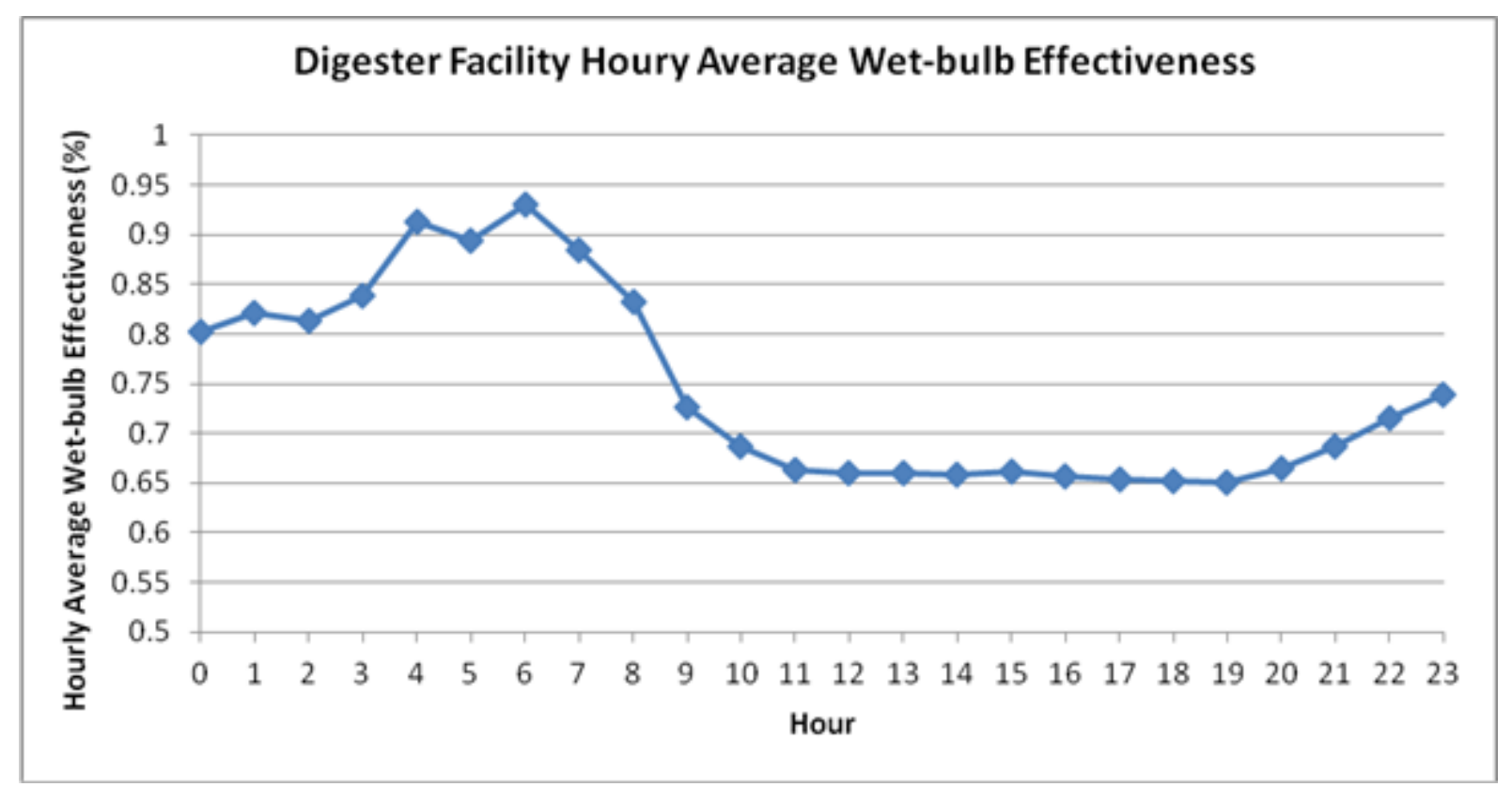

Figure 39. Digester facility hourly average WBE

In summary, more than $80 \%$ of the monitored Coolerado units supplied air at temperatures cooler than $70^{\circ} \mathrm{F}$ for most of the summer and $20 \%$ of the units discharged warmer air. The specific reason for this inconsistency is likely an issue with HMX water distribution. Based on the new HMX cassette and water distribution system, these issues should have been addressed with the latest version of the technology, and Coolerado currently takes thermal images of the HMX core of each unit to ensure that core is performing per design intent.

\subsubsection{Apply Where Design Wet Bulb $\leq 70^{\circ} \mathrm{F}$}

Given the hotter than normal 2010 and 2011 cooling seasons, the installations at Fort Carson were able to maintain the space within the ASHRAE comfort zone $>99 \%$ of the time, even when the OA wet bulb temperature exceeded $70^{\circ} \mathrm{F}$. Although this metric has been met at this demonstration, the technology should be evaluated on a case by case basis in ASHRAE climate zones 2B, 3B, and 4B with the Microsoft Excel-based modeling tool that was developed as a part of this project. The internal loads in the facility and ventilation rate requirements will impact the technology's ability to meet a given space temperature set point in different climate zones. Further information about cost effectiveness and appropriate applications based on climate zone are provided in Section 7.0.

\subsection{PROVIDE HIGH-EFFICIENCY COOLING}

The unit's cooling capacity is a function of the difference between the SAT and OAT when the cooling capacity is calculated as a function of OAT, and a function of the difference between the SAT and EAT when the cooling capacity is calculated as a function of EAT (or RAT). 
The cooling capacity relative to the EAT as a function of SAT shows that the peak cooling capacity was provided when the OAT was $55^{\circ}-60^{\circ} \mathrm{F}$ and was about 2.55 tons. These data are provided for Event Center unit \#1 for July 2010, but are indicative of the cooling capacity provided for the other units (see Figure 40).

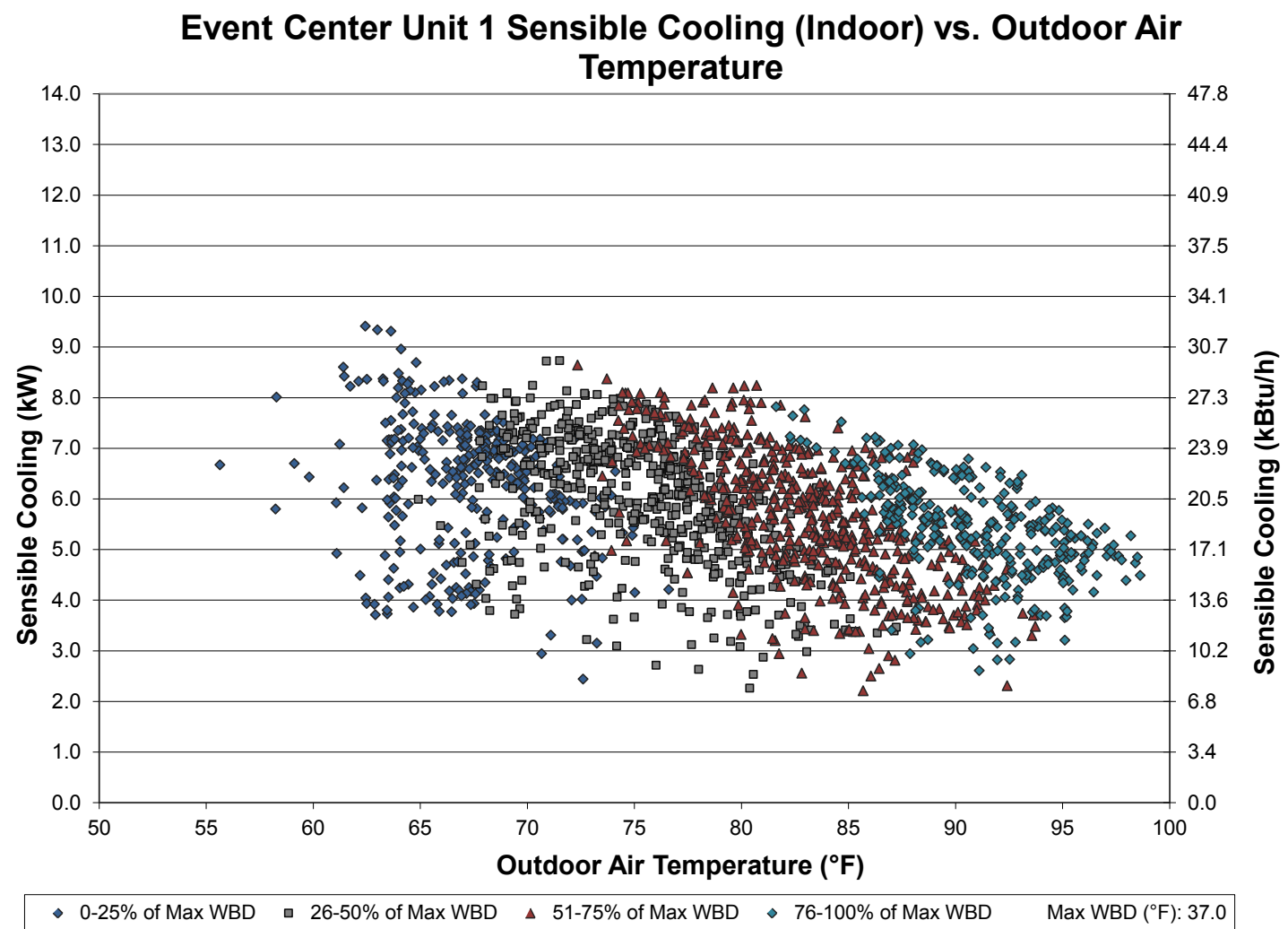

Figure 40. Event center unit \#1 cooling capacity (indoor) versus OAT

The data are plotted in four bins based on the wet bulb depression for a bin. Wet bulb depression is defined as the difference between the OAT and OA wet bulb temperature. The maximum wet bulb depression for the month was $37^{\circ} \mathrm{F}$. The cooling capacity relative to EAT was about 1.5 tons of cooling when the OAT was above $95^{\circ} \mathrm{F}$.

When the cooling capacity is calculated as a function of OAT, the total cooling capacity increases because the $\Delta \mathrm{T}$ between the SAT and OAT is greater than the $\Delta \mathrm{T}$ between the SAT and EAT (see Figure 41). The sensible cooling capacity peaked at about 4 tons for this unit during July 2010. 


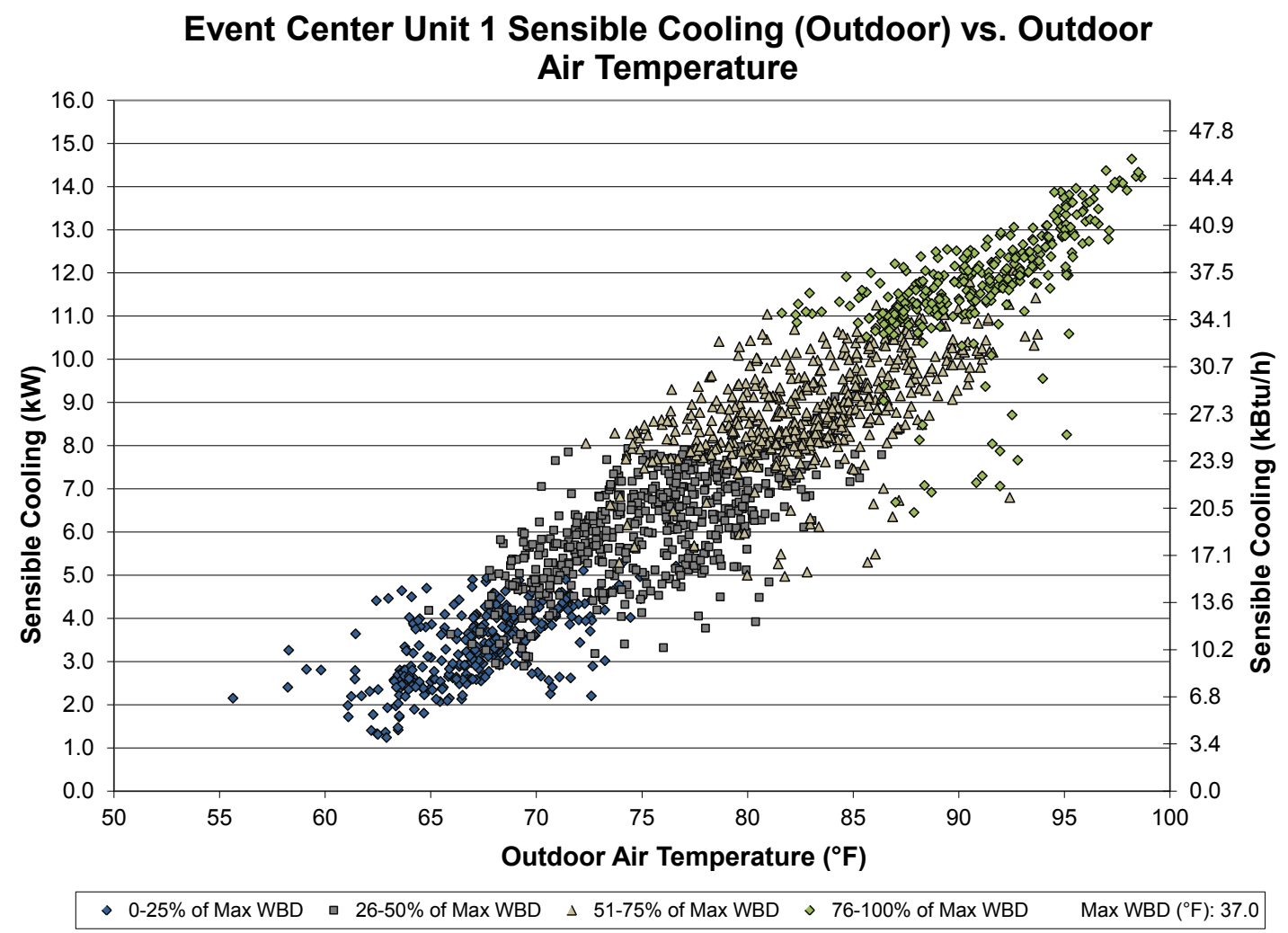

Figure 41. Event center \#1 cooling capacity (OA) versus OAT

The units at Fort Carson processed 100\% OA, so the cooling capacity relative to OA represents the total cooling the Coolerado unit provided. The cooling capacity relative to the space conditions indicates the cooling capacity relative to the building cooling load, which indicates the load that a traditional air-cooled DX unit would have to meet.

For this report the cooling efficiency (kW/ton) is reported using both cooling capacity calculations. When the cooling efficiency is calculated relative to the building cooling, the efficiency decreases relative to the outdoor air cooling efficiency. A similar trend occurs when calculating the water consumption on a gal/ton $\mathrm{h}$ basis. The water consumption increases when the cooling capacity is calculated as a function of building cooling. Specific results for each unit are provided in the following sections.

\subsubsection{Average Power Consumption}

All the units, except for the digester facility unit and the west unit of the jet aeration facility during the 2010 season, had an average electrical efficiency that was significantly lower than 0.6 $\mathrm{kW} /$ ton when the cooling capacity was calculated as a function of OAT. The average electrical efficiency was calculated daily for each unit during both cooling seasons, and most units had daily electrical efficiencies lower than $0.6 \mathrm{~kW} /$ ton for $>96 \%$ of the days that they operated (see Table 11). 
Table 11. Percent of Days That the Average Electrical Efficiency $<0.6 \mathrm{~kW} / \mathrm{ton}$

\begin{tabular}{|c|c|c|c|}
\hline \multirow[t]{2}{*}{ Facility } & \multirow[t]{2}{*}{ Unit } & \multicolumn{2}{|c|}{$\begin{array}{c}\text { Percent of Days Average } \\
\text { Efficiency } \\
<0.6 \mathrm{~kW} / \text { ton }\end{array}$} \\
\hline & & 2010 & 2011 \\
\hline \multirow{3}{*}{ Training center } & 1 & 100 & 100 \\
\hline & 2 & 100 & 98.7 \\
\hline & 3 & 100 & 100 \\
\hline \multirow{4}{*}{ Event center } & 7 & 100 & 100 \\
\hline & 3 & 100 & 100 \\
\hline & 5 & 96.7 & 98.8 \\
\hline & 7 & 98.9 & 96.5 \\
\hline \multirow{4}{*}{ Theater } & 9 & 96 & 85.5 \\
\hline & 10 & 96 & 93.3 \\
\hline & 11 & 90.9 & 96.7 \\
\hline & 12 & 100 & 96.9 \\
\hline \multirow{2}{*}{ Jet aeration facility } & West & 0.0 & 97.8 \\
\hline & East & 95.3 & 97.8 \\
\hline Digester & 1 & 2.3 & 93.5 \\
\hline Wastewater unit & 1 & 100 & 75.8 \\
\hline
\end{tabular}

The cooling capacity relative to the OAT represents the total cooling provided by the unit. If the Coolerado units had been installed with RA, the total cooling they provided would be closer to the building cooling.

The electrical efficiency relative to OA is significantly better for the training center than for the other facilities. The training center units are sized to meet $100 \%$ of the cooling load and can operate at partial fan speeds for most of the year. When the unit operates at partial fan speeds, the fan power is significantly reduced and the unit can operate at a higher WBE. Both advantages lead to a better electrical efficiency. The average electrical efficiency for the training center units was $0.2-0.3 \mathrm{~kW} /$ ton most days they operated, which is $50 \%-67 \%$ better than the performance metric requirement. An average $\mathrm{kW} /$ ton of 0.2 is equivalent to an EER of 60 , and would save $80 \%$ relative to a minimally code-compliant packaged RTU with an EER of 12 (see Figure 42). 


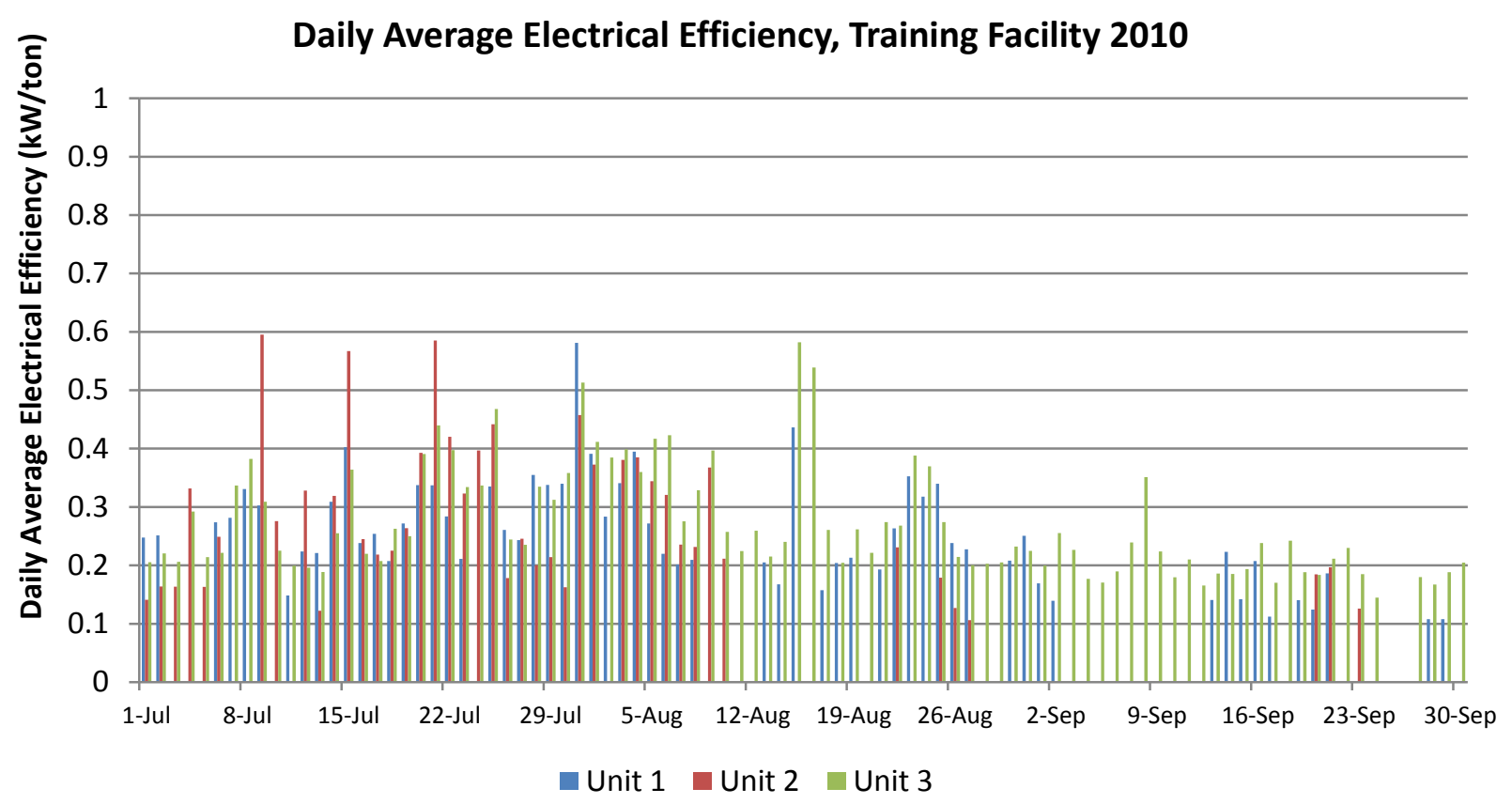

Figure 42. Training facility daily average electrical efficiency $(\mathrm{kW} / \mathrm{ton}), 2010$

The electrical efficiency for the 2011 cooling season was about $0.2 \mathrm{~kW} /$ ton for most of the summer. The data for the training center units for the 2011 cooling seasons show that the units could operate at a very low specific electric usage when they were sized to meet the cooling load for the entire year (see Figure 43).

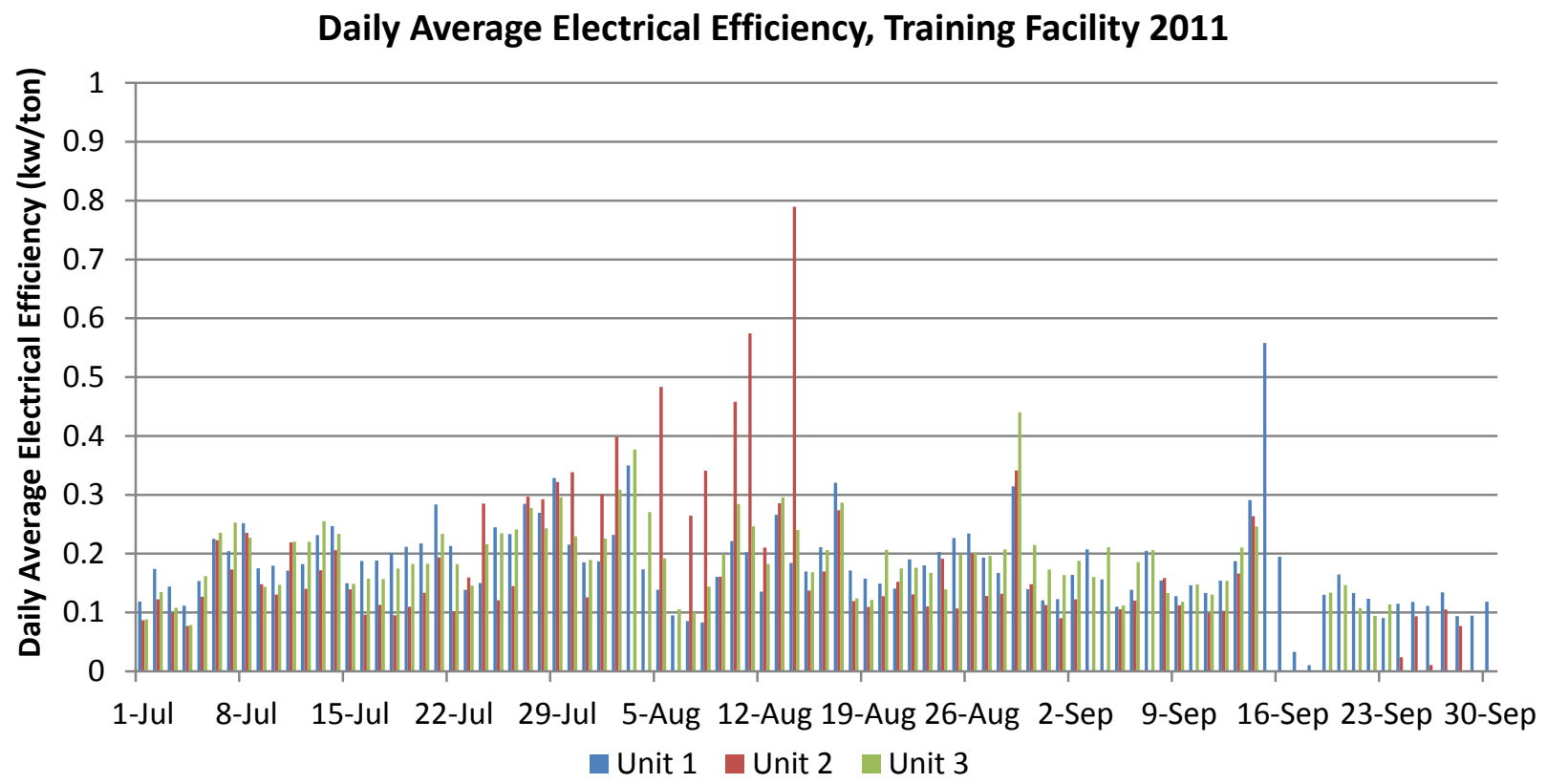

Figure 43. Training facility daily average electrical efficiency (kW/ton), 2011 
The theater and event center units had slightly higher specific electricity use that averaged about $0.3 \mathrm{~kW} /$ ton $(\mathrm{EER}=40)$ because they mostly operated at $100 \%$ fan speed.

The average daily specific electricity use was calculated for event center unit \#1 for the 2010 cooling season. The specific electricity use relative to OA for the summer was $0.26 \mathrm{~kW} /$ ton and was $0.33 \mathrm{~kW} /$ ton when calculated relative to building cooling. This represents a $20 \%$ decrease in cooling efficiency, but is still significantly lower than the average $0.6 \mathrm{~kW} /$ ton requirement (see Figure 44).

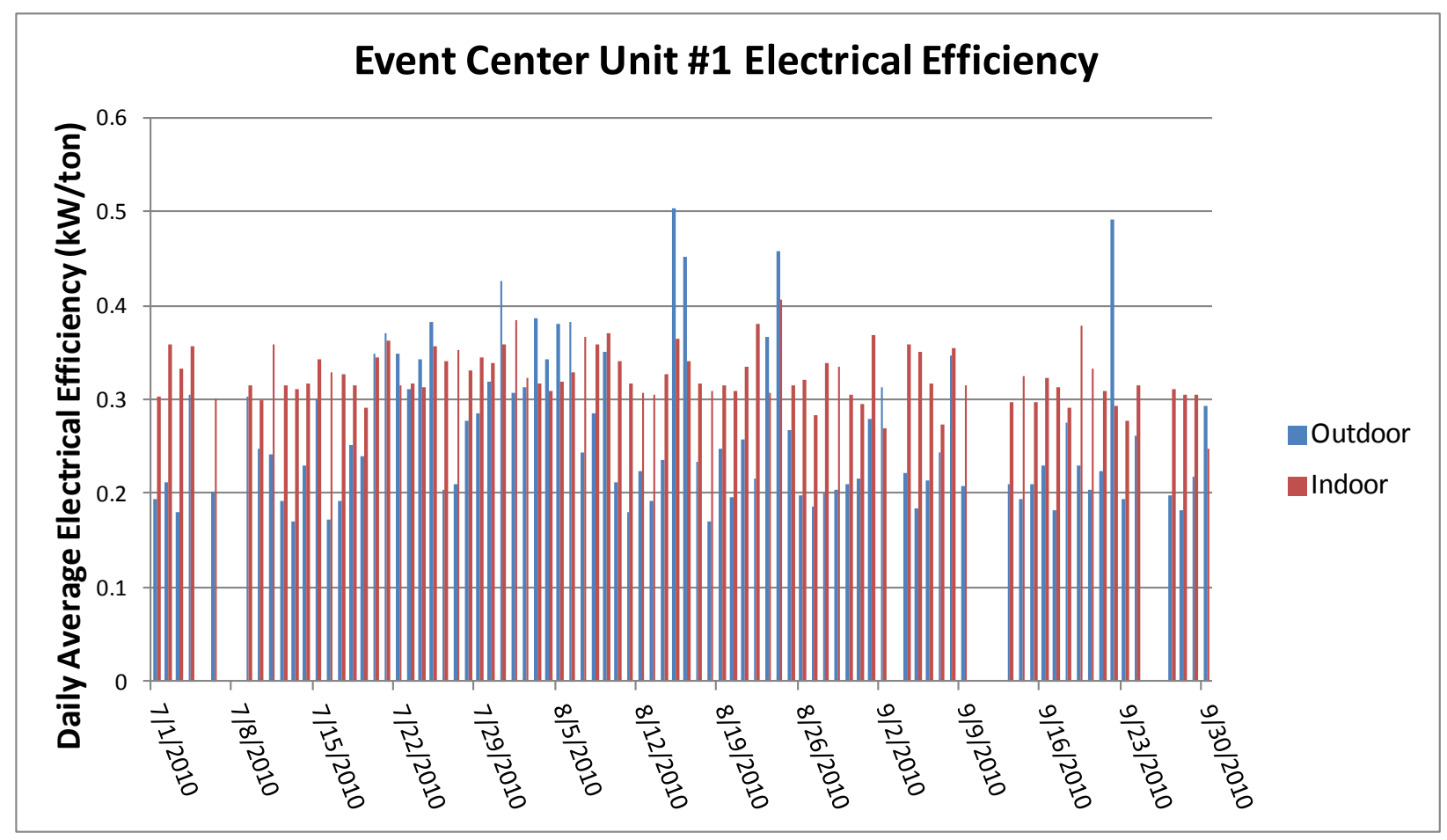

Figure 44. Event center unit \#1 daily average electrical efficiency (building cool) (kW/ton), 2011

The daily average specific electricity use for the digester facility as a function of OAT was significantly higher than for the other facilities because of the higher DATs, but still had an annual average efficiency below the threshold of $0.6 \mathrm{~kW} /$ ton (see Figure 45). 


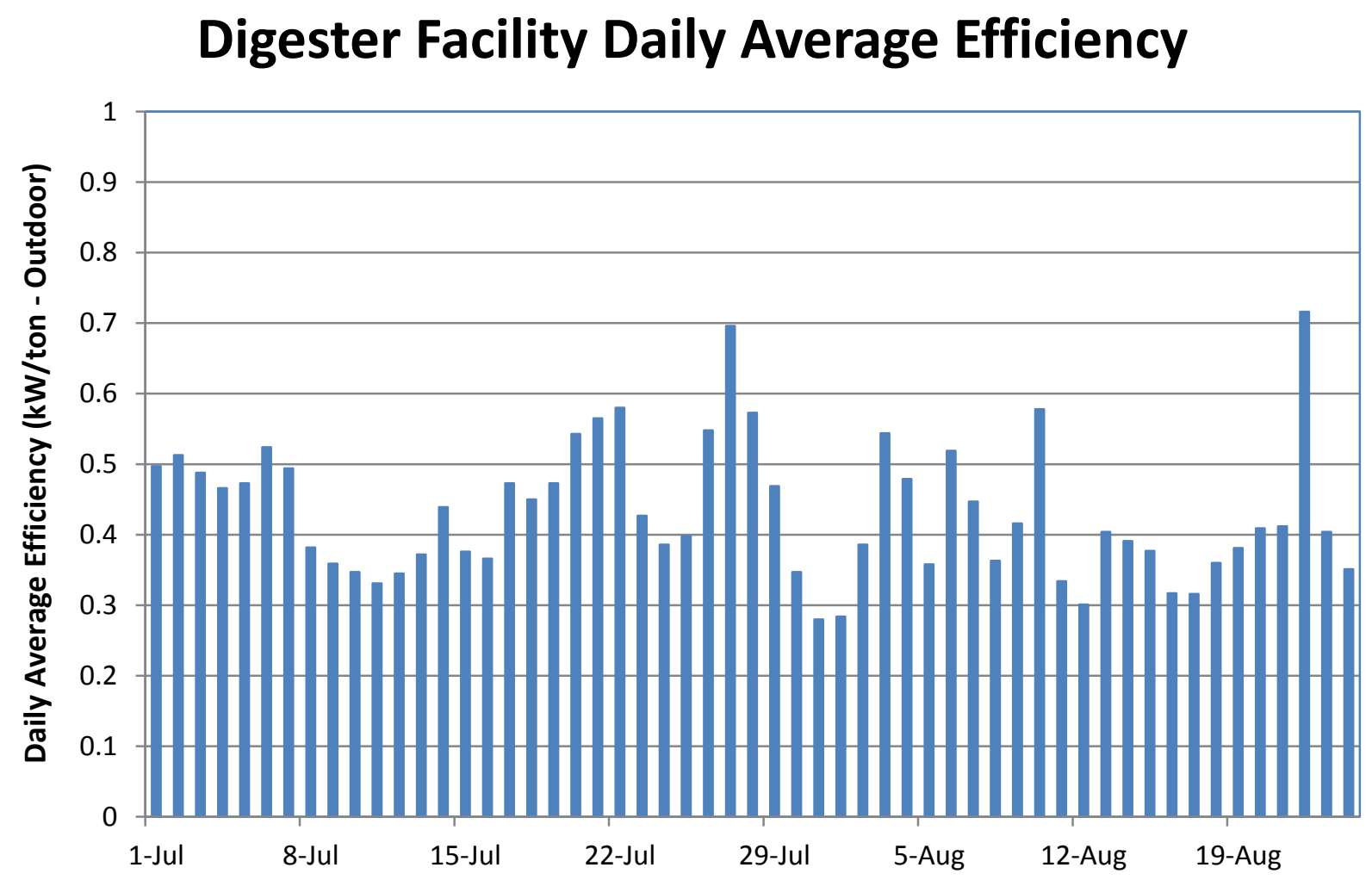

Figure 45. Digester facility daily average electrical efficiency (kW/ton), 2011

\subsubsection{Peak Power Consumption}

The daily average specific electricity use was $<1 \mathrm{~kW} /$ ton for all demonstrations when the cooling capacity was calculated as a function of OAT. The peak power for all units was around $570 \mathrm{~W}$. An energy model was developed for the training facility and detailed descriptions of the model and results are provided in Section 7.0. The peak demand savings for one classroom unit was calculated assuming an older packaged RTU with an EER of 9 was conditioning the facility (see Figure 46). Pacific Northwest National Laboratory has monitored the performance of older packaged RTUs with measured EERs of 8-9, which is typical of these units. ${ }^{\text {xiii }}$ The Coolerado unit reduced the peak demand from $1.8 \mathrm{~kW}$ to $0.57 \mathrm{~kW}$, which is equivalent to a $68 \%$ reduction in peak demand for this case. The Coolerado unit has the potential to significantly reduce peak demand when the baseline HVAC system is an air-cooled, refrigeration-based system with an EER of 8-12 in Colorado Springs. 


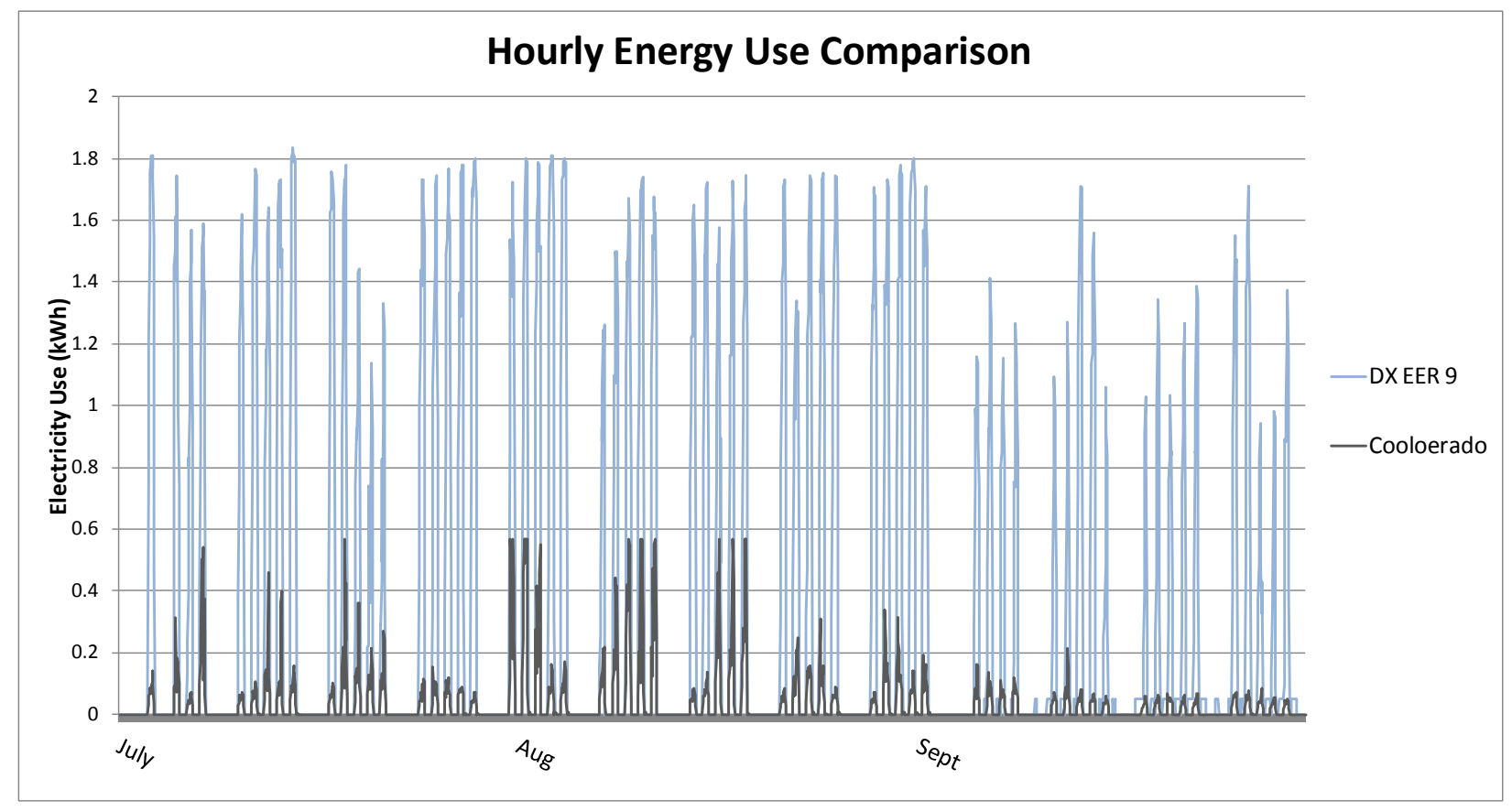

Figure 46. Coolerado classroom unit peak demand savings

The hourly energy use of the DX unit with an EER of 9 is plotted in blue and the modeled energy use of a Coolerado C60 unit is shown in gray. Peak demand savings are represented on an hourly basis as the difference between the blue and grey lines, and are significant for the three-month period and generally exceed $68 \%$. Larger chilled water plants with water-cooled condensers can operate with annual average EERs of 30-40, and the energy savings relative to these more energy-efficient cooling plants would be $10 \%-30 \%$.

\subsection{SUSTAIN HIGH COOLING PERFORMANCE}

\subsubsection{Less Than 5\% Degradation of Wet Bulb Effectiveness Over 3 Years}

The original demonstration plan included three years of field demonstrations. The installation of the units took longer than expected because too few contractors were qualified to install the units at a reasonable cost. The units were monitored for two cooling seasons. Calculating a reduction in WBE is not a trivial task, because a number of variables need to be accounted for in the comparisons. The WBE at any given point in time depends on the OA conditions and supply fan speed. These variables are continuously changing, so directly comparing the WBEs at a given time from one season to the next is challenging. The WBE was compared for select units with the use of the performance model that was created and is outlined in Appendix C. The performance model allows for the comparison of the predicted SAT versus the measured SAT. If the percent difference in measured and modeled SAT increased from the 2010 to the 2011 cooling season, the unit WBE likely degraded and the SAT increased. 
The modeled versus measured SAT for event center unit \#1 shows that the unit supplied slightly colder air than the model predicted (see Figure 47). A perfect agreement for the two datasets is shown by the blue line.

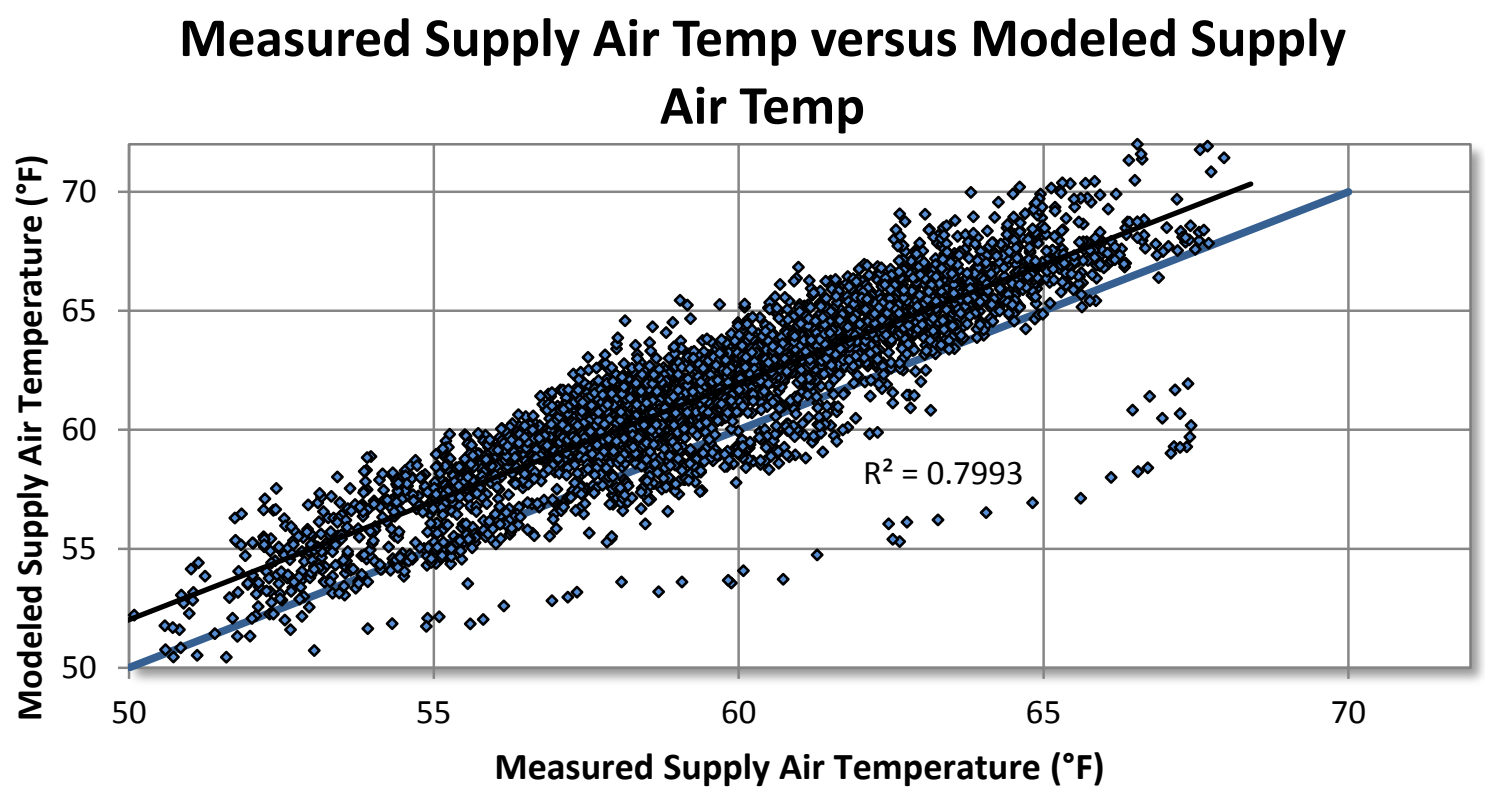

Figure 47. Event center unit \#1 2010 measured versus modeled SAT

The percent difference between the measured SAT and modeled SAT indicates that the measured SAT was $5 \%-10 \%$ colder than the modeled SAT (Figure 48 ). The trend reversed for a short time at the end of the summer and at the very end of the summer the unit started supplying colder air again. 


\section{Modeled SAT versus Measured SAT Percent Difference}

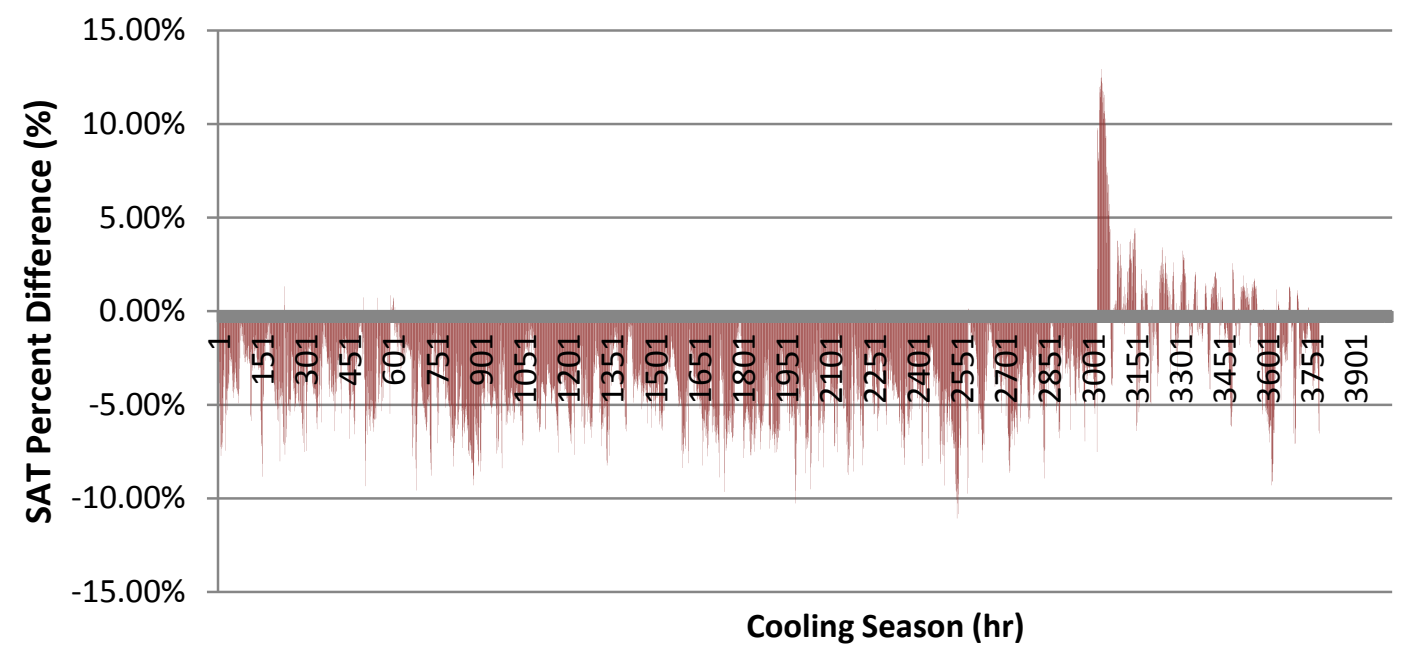

Figure 48. Event center unit \#1 percent difference between measured and modeled SAT

The modeled versus measured SAT for the 2011 cooling season is plotted in Figure 49 and shows a similar trend: the measured SAT is slightly colder than the modeled SAT. Although the measured SAT is lower than the modeled SAT, about half the units supplied air at warmer temperatures than the model predicted.

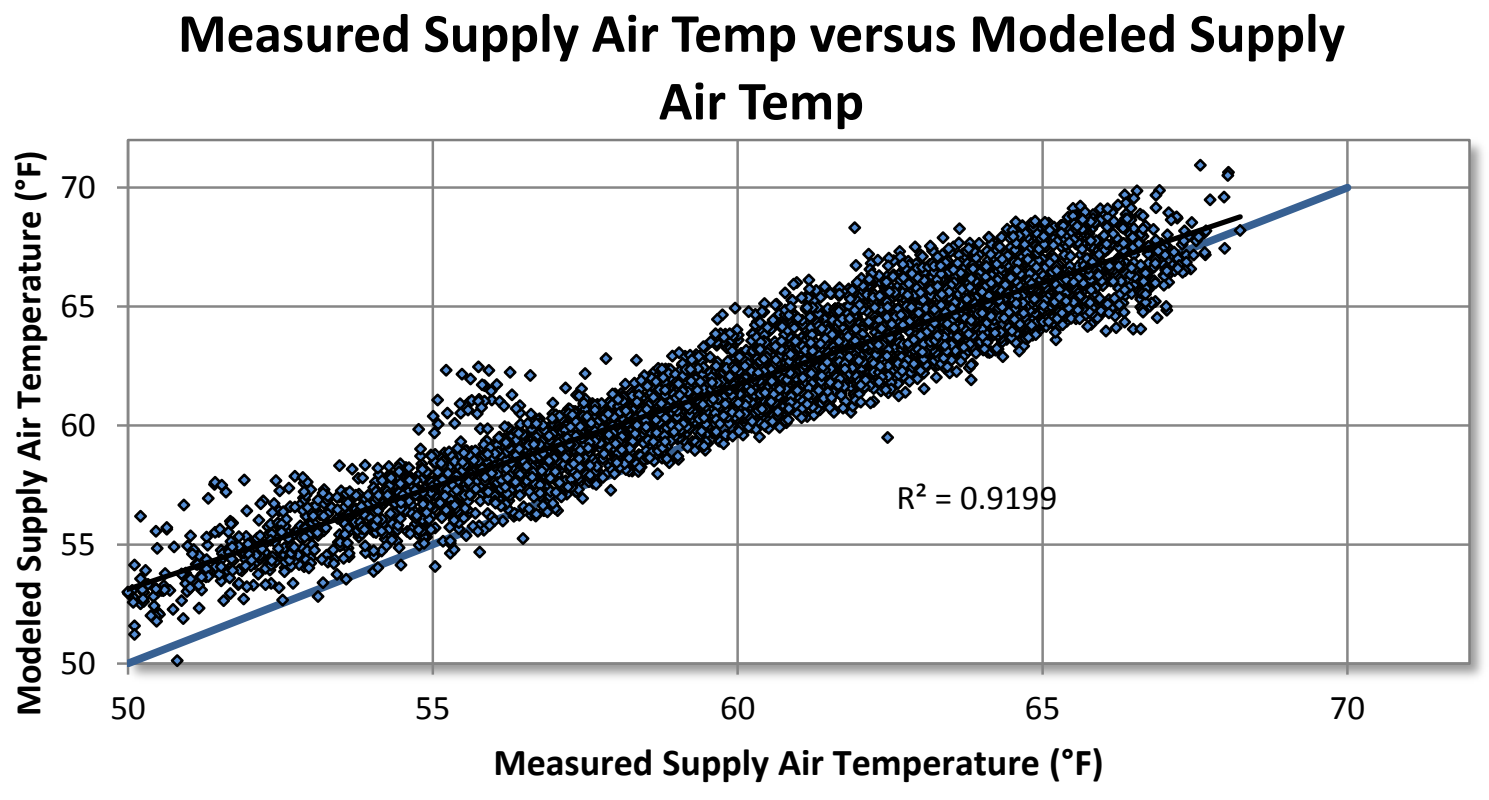

Figure 49. Event center unit \#1 2011 measured versus modeled SAT 
The percent difference between the measured SAT and modeled SAT shows a similar trend in 2011 (see Figure 50). The measured SAT was colder than the modeled SAT for the entire 2011 cooling season. The percent difference between the annual modeled cooling capacity versus the measured cooling capacity was $<0.5 \%$ between the two years. There was no degradation in WBE for this particular unit, and the same trend was seen for all the event center units.

\section{Modeled SAT versus Measured SAT Percent Difference}

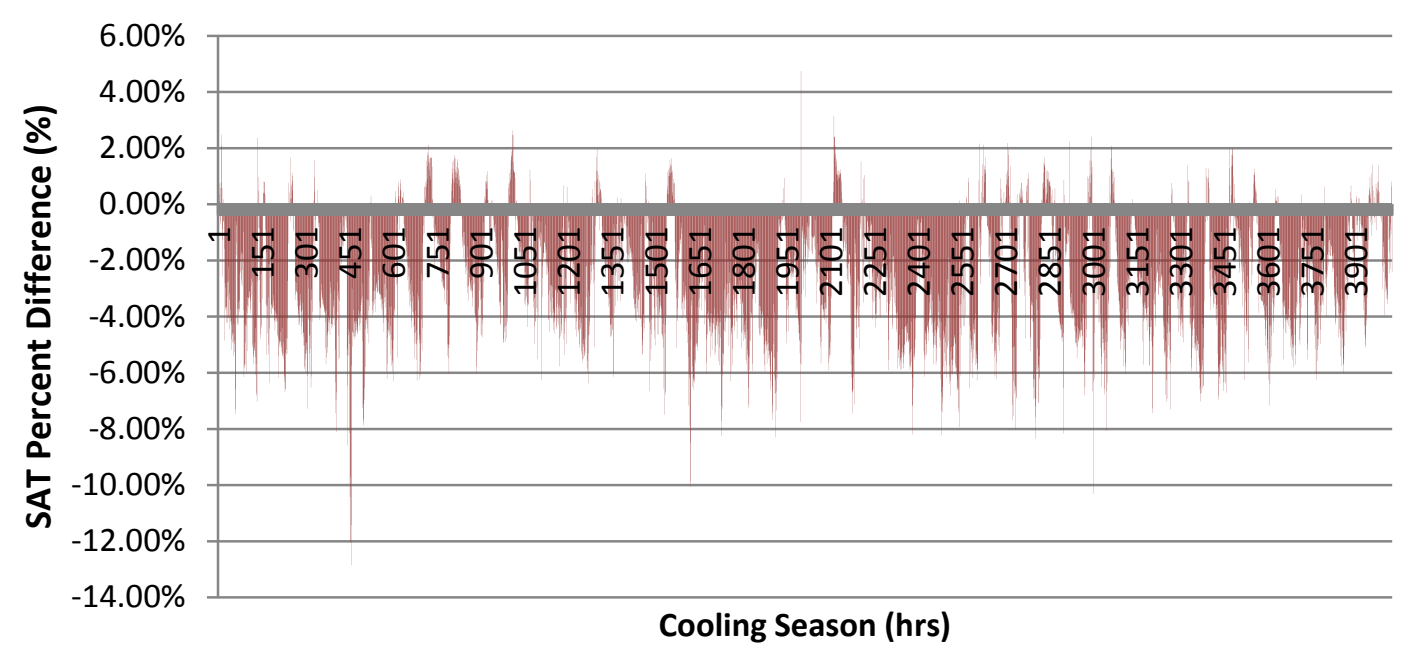

Figure 50. Event center unit \#1 2011 percent difference in measured versus modeled SAT

\subsection{MINIMIZE WATER CONSUMPTION}

Only one unit was able to meet the $2.5 \mathrm{gal} / \mathrm{ton} \cdot \mathrm{h}$ water consumption requirement, a jet aeration unit for a short time during the 2011 cooling season. The water consumption was calculated daily and the total cooling was calculated relative to OAT. If the cooling rate had been calculated for each building, the water consumption rate would have increased by approximately $20 \%$. Figure 51 shows the daily water consumption rate for the event center for the 2010 and 2011 cooling seasons. The water consumption rate was about $6 \mathrm{gal} / \mathrm{ton} \cdot \mathrm{h}$ for the 2010 cooling season and 6-7 $\mathrm{gal} / \mathrm{ton} \cdot \mathrm{h}$ for the 2011 cooling season. The classroom, event center, and theater units all used $6-$ $10 \mathrm{gal} / \mathrm{ton} \cdot \mathrm{h}$ for the 2010 cooling season and most of the 2011 cooling season. 
Daily Average Water Use Efficiency, Event Center 2010

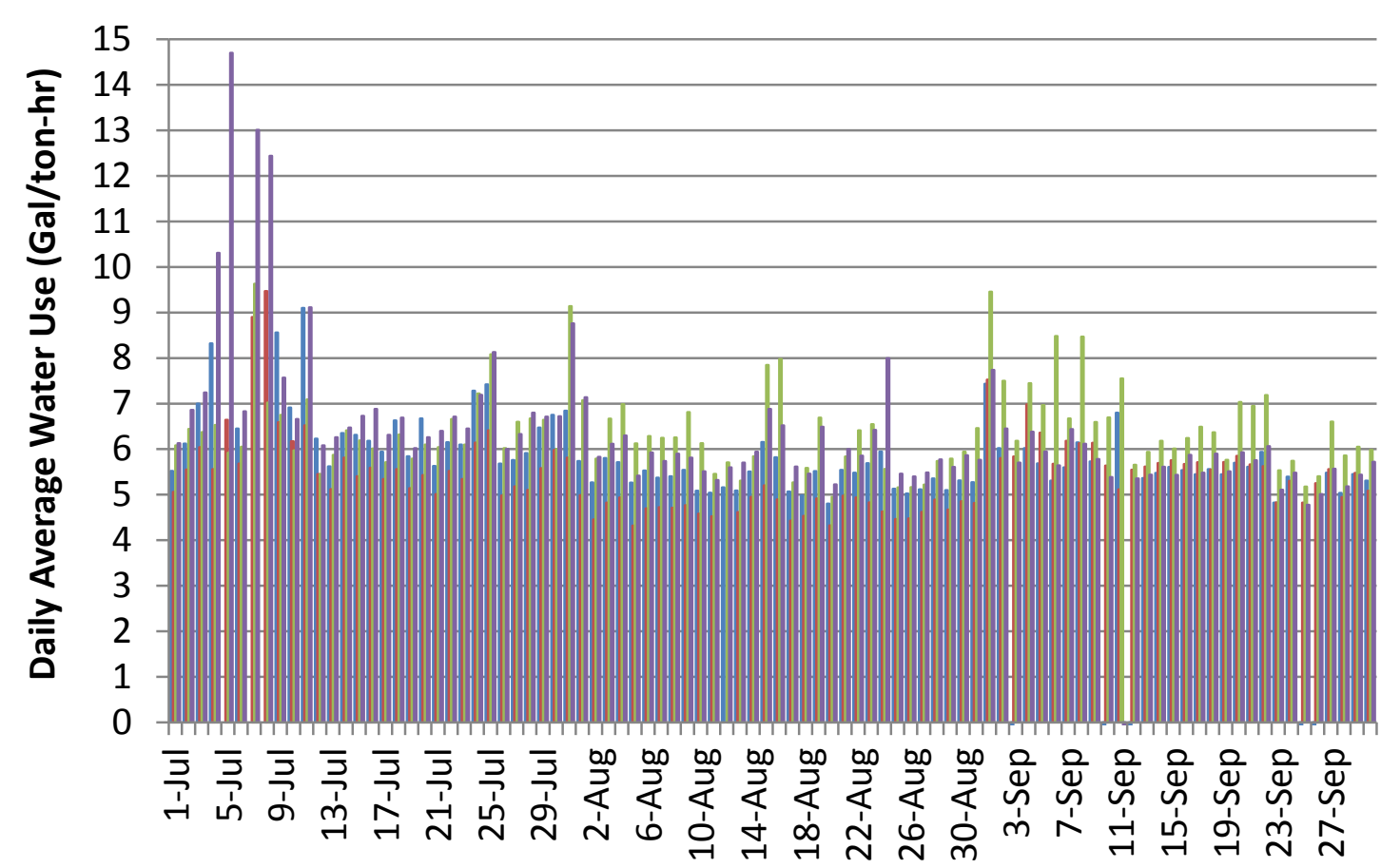

Unit 1 Unit 3 Unit 5 Unit 7

Figure 51. Event center daily average water use efficiency (gal/ton·h), 2010

The water use is set on the control board of the unit as a CoC setting. For the 2010 and most of the 2011 cooling season the $\mathrm{CoC}$ was set to $1.5-1.6$ by Coolerado. This was standard practice at the time. The recommended set point for the Coolerado unit is $5 \mathrm{CoCs}$, with 4 parts evaporated for every 1 part drained. At the end of the 2011 cooling season, the settings were modified with the $\mathrm{CoC}$ setting of 5 . With the higher $\mathrm{CoC}$ setting the unit uses less water, which should not affect cooling performance as long as there are no manufacturer defects in the HMX cores. Figure 52 shows that all four units monitored at the event center during the 2011 cooling season were able to achieve a water use rate of about $2.8 \mathrm{gal} / \mathrm{ton} \cdot \mathrm{h}$, which is slightly higher than the requirement in the performance metric. 


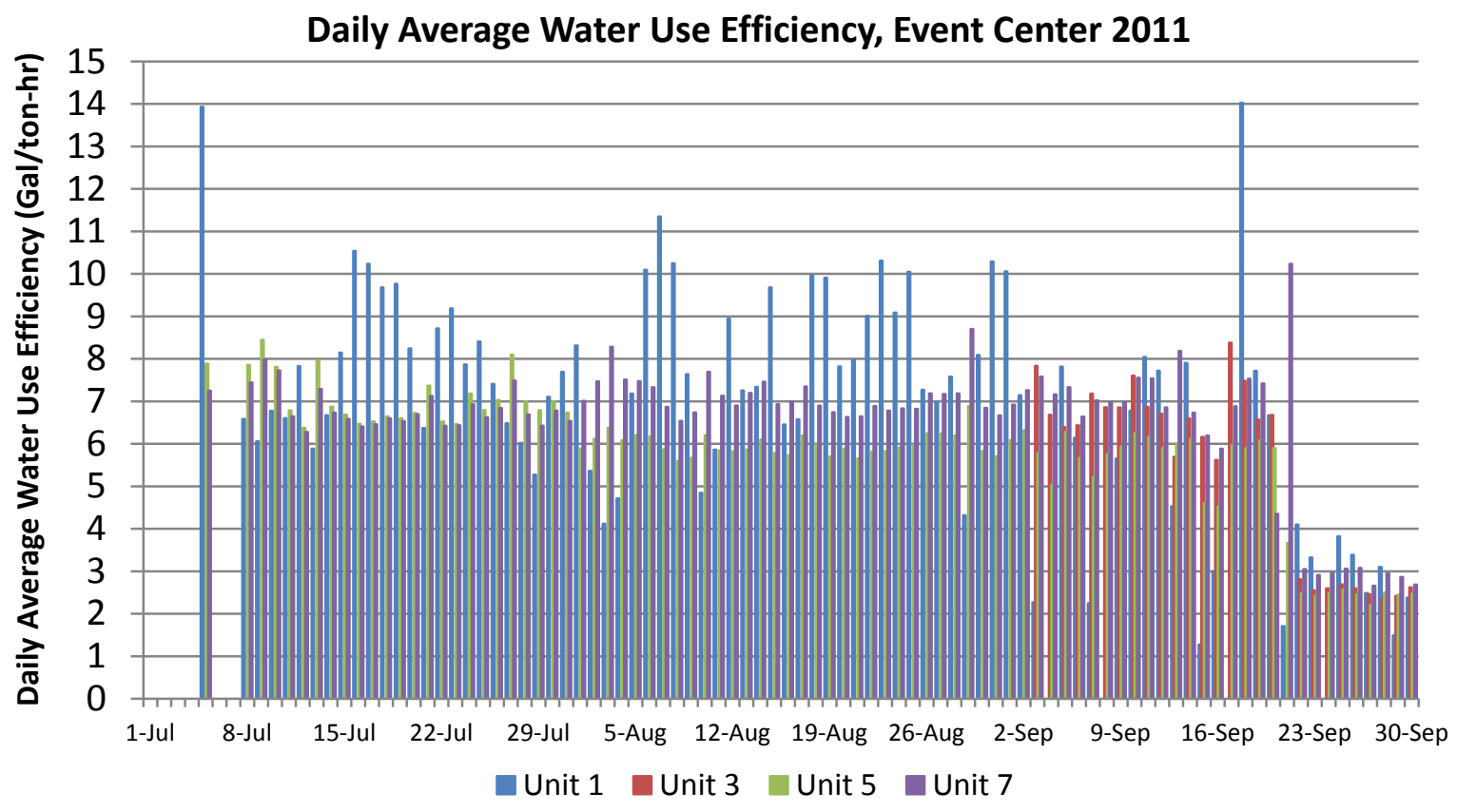

Figure 52. Event center daily average water use efficiency (gal/ton·h), 2011

The jet aeration facility consumed significantly less water than the other facilities (Figure 53). The specific reason for this is unknown, as Coolerado reported applying the same control sequence to all units. The probable cause is issues related to water pressure at the facility and the type of regulator and water control valve that were used. Although these two units had lower water consumption, they also had difficulty discharging slightly warmer air.

The water use was about $4 \mathrm{gal} / \mathrm{ton} \cdot \mathrm{h}$ and dropped to slightly below $2 \mathrm{gal} / \mathrm{ton} \cdot \mathrm{h}$ once the control board changes were made. 


\section{Jet-Aeration Facility Daily Water Use Efficiency}

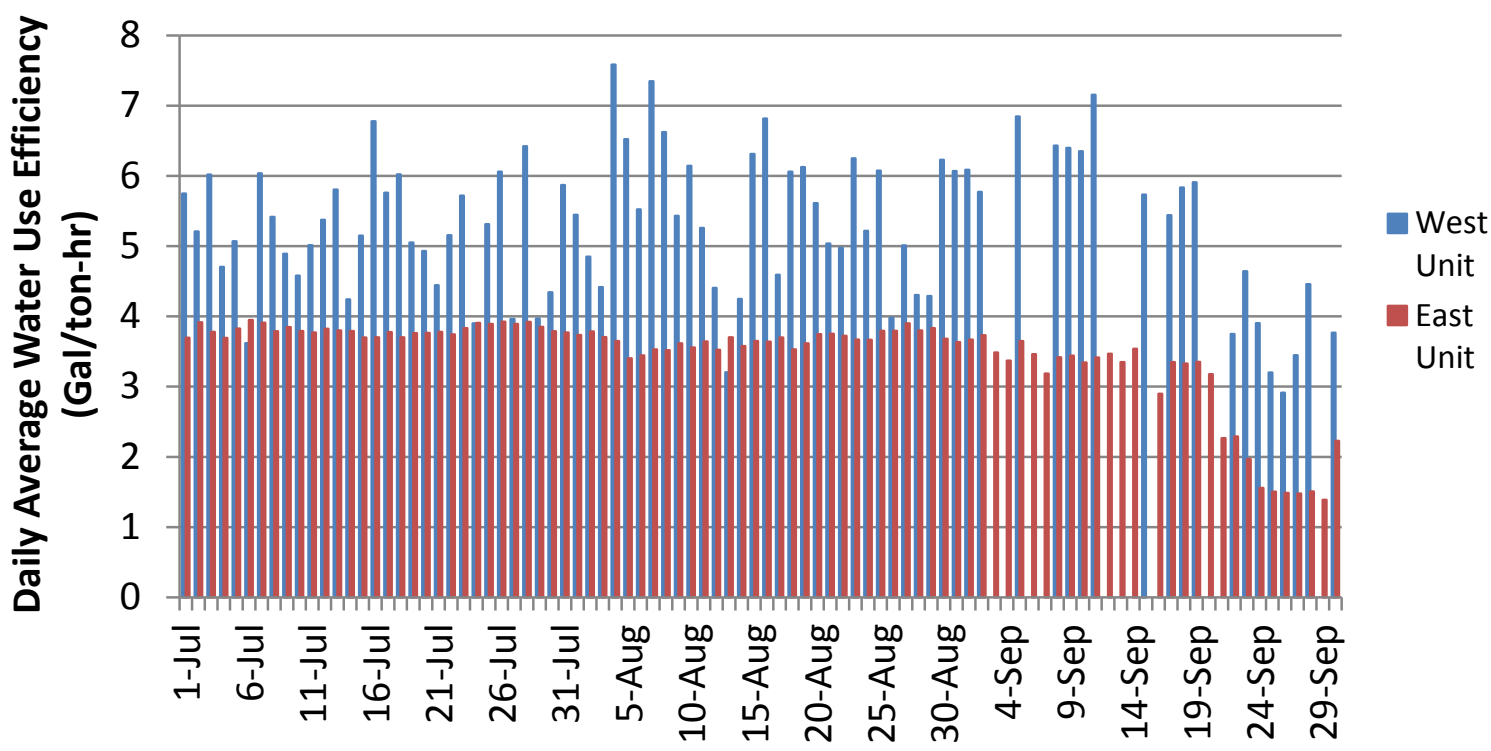

Figure 53. Jet aeration facility daily average water use efficiency $(\mathrm{gal} / \mathrm{ton} \cdot \mathbf{h})$

\subsection{MAINTAINABILITY}

\subsubsection{Ease of use}

This performance metric requires that a single facility technician must be able to effectively operate and maintain the equipment with minimal training. This performance metric was met. The onsite O\&M contractors received O\&M training on the units at the beginning of the project. They performed O\&M at the beginning of each summer to start the unit and at the end of the summer when the units were shut down. The seasonal startup consisted of turning on the water supply, checking for water leaks throughout the line, replacing air filters, and adding detergent bowls, which are used as surfactants to keep the heat exchangers wetted throughout the summer. At the end of the cooling season the units were winterized by turning off the water supply, draining the water lines, and using a compressed air system to blow all the water from the lines. The refrigerant bowl and water filter were removed, and a metallic panel was installed in the ductwork to avoid infiltration during the winter.

\subsubsection{Cost}

The maintenance costs were tracked for the 2010 and 2011 cooling seasons. The costs were recorded for each facility as regular maintenance associated with startup and shutdown costs and maintenance that was performed that was not part of the regularly scheduled maintenance. The startup and shutdown costs were also tracked directly.

Table 12 shows the 2010 maintenance hours. Startup hours were not included for the three facilities, as the units were turned on and commissioned by Coolerado staff. 
Table 12. 2010 Coolerado Maintenance Hours

\begin{tabular}{|c|c|c|c|c|c|c|c|}
\hline Building Name & $\begin{array}{c}\text { \# of } \\
\text { Units }\end{array}$ & $\begin{array}{c}\text { Startup } \\
\text { (hrs) }\end{array}$ & $\begin{array}{c}\text { Shutdown } \\
\text { (hrs) }\end{array}$ & $\begin{array}{l}\text { Other } \\
\text { (hrs) }\end{array}$ & $\begin{array}{c}\text { Startup } \\
\text { Time Per } \\
\text { Unit (hrs) }\end{array}$ & $\begin{array}{l}\text { Shutdown } \\
\text { Time Per } \\
\text { Unit (hrs) }\end{array}$ & $\begin{array}{c}\text { Other } \\
\text { Time Per } \\
\text { Unit (hrs) }\end{array}$ \\
\hline Training Center & 4.0 & 8.0 & 12.0 & 3.0 & 2.0 & 3.0 & 0.8 \\
\hline Theater & 8.0 & 6.0 & 7.5 & 3.5 & 0.8 & 0.9 & 0.4 \\
\hline Event Center & 8.0 & 8.8 & 8.0 & 21.0 & 1.1 & 1.0 & 2.6 \\
\hline Jet Aeration & 2.0 & 0.0 & 7.0 & 0.0 & 0.0 & 3.5 & 0.0 \\
\hline Digester & 1.0 & 0.0 & 5.0 & 0.0 & 0.0 & 5.0 & 0.0 \\
\hline Waste Water & 1.0 & 0.0 & 1.5 & 0.0 & 0.0 & 1.5 & 0.0 \\
\hline \multicolumn{5}{|c|}{ Average Time (hrs) } & 1.3 & 2.5 & 0.6 \\
\hline
\end{tabular}

The average startup time per unit was $1.3 \mathrm{~h}$ and the average shutdown time per unit was $2.5 \mathrm{~h}$. Most of the unscheduled maintenance costs at the event center were associated with a failed solenoid valve that had to be replaced.

Table 13 shows the maintenance hours for the 2011 cooling season.

Table 13. 2011 Coolerado Maintenance Hours

\begin{tabular}{|c|c|c|c|c|c|c|c|}
\hline Building Name & $\begin{array}{c}\text { \# of } \\
\text { Units }\end{array}$ & $\begin{array}{c}\text { Startup } \\
\text { (hrs) }\end{array}$ & $\begin{array}{c}\text { Shutdown } \\
\text { (hrs) }\end{array}$ & $\begin{array}{l}\text { Other } \\
\text { (hrs) }\end{array}$ & $\begin{array}{c}\text { Startup } \\
\text { Time Per } \\
\text { Unit (hrs) }\end{array}$ & $\begin{array}{l}\text { Shutdown } \\
\text { Time Per } \\
\text { Unit (hrs) }\end{array}$ & $\begin{array}{c}\text { Other } \\
\text { Time Per } \\
\text { Unit (hrs) }\end{array}$ \\
\hline Training Center & 4.0 & 3.0 & 8.0 & 10.0 & 0.8 & 2.0 & 2.5 \\
\hline Theater & 8.0 & 9.0 & 8.0 & 4.5 & 1.1 & 1.0 & 0.6 \\
\hline Event Center & 8.0 & 0.0 & 0.0 & 3.5 & 0.0 & 0.0 & 0.4 \\
\hline Jet Aeration & 2.0 & 10.0 & 4.5 & 0.0 & 5.0 & 2.3 & 0.0 \\
\hline Digester & 1.0 & 5.0 & 2.5 & 0.0 & 5.0 & 2.5 & 0.0 \\
\hline Waste Water & 1.0 & 4.5 & 2.0 & 0.0 & 4.5 & 2.0 & 0.0 \\
\hline \multicolumn{5}{|c|}{ Average Time (hrs) } & 3.3 & 2.0 & 0.6 \\
\hline
\end{tabular}

The average startup time per unit was $3.3 \mathrm{~h}$ and the average shutdown time was $2 \mathrm{~h}$. The following maintenance items were also encountered during the 2010 or 2011 cooling seasons:

- $\quad$ Three water pipes that were inside the classroom froze during the 2010 winter and had to be repaired. When the units were installed, the installers thought the temperature inside of the building would not fall below $32^{\circ} \mathrm{F}$, but the building was un-insulated and the plenum space experienced temperatures below freezing. As 
an alternative to copper tubing, cross-linked polyethylene tubing could be installed to address this problem.

- $\quad$ Additional caulking was needed around the ductwork of one unit after a rainwater leak.

- $\quad$ One unit stopped working because of a bad fuse in the control board that had to be replaced.

- $\quad$ A thermostat had to be replaced on one unit.

- $\quad$ Leaking water lines in one installation had to be repaired.

- $\quad$ Three solenoid failures were identified during the first cooling season and were replaced.

These activities increased maintenance costs and should be rolled into the commissioning costs encountered in the first 1-2 years. Several maintenance items, such as thermostat failures and leaking ductwork, were unrelated to issues with the Coolerado unit. These items would need to be repaired regardless of the type of installation or air conditioning equipment. The standard maintenance time per unit was 7.25-1.7 h/unit/yr, depending on the installation and on the extent of the maintenance required. Given the average maintenance time of $3.8-5.5 \mathrm{~h} / \mathrm{unit} / \mathrm{yr}>90 \%$ of units fall within nominal IEC maintenance schedule. The need to shut down and start up the units each year for freeze protection increased the total maintenance costs per year. If the unit is installed in a conditioned space, such as a warehouse or data center, or in a climate that does not experience freezing temperatures, it does not need to be shut down and winterized and annual maintenance costs are significantly reduced.

\subsubsection{Failure}

The first metric required no signs of biological growth inside the Coolerado unit on the HMX for all standard building installations. After approximately 2 weeks of operation during the 2010 cooling season, Tim Heaton (Coolerado Corporation) and Eric Kozubal (NREL) visited the wastewater unit and noticed that measured WBE values had dropped below 30\%. This was indicative of poor evaporation and/or poor air movement through the cooling cores. They discovered that the water filtration had clogged full of algae-like substance, restricting water to starvation levels. They inspected the cooling cores, which had significant algae-like growth in the wetted wicking material and mixed into the effluent. Several conclusions were drawn as to why the unit failed:

- $\quad$ The wastewater effluent contained significant algae and nutrients that support algae growth.

- $\quad$ The algae in the water immediately clogged the $20-\mu$ filter system within 2 weeks. The filter was a standard 12 -in. canister with a $20-\mu$ filter cartridge.

- $\quad$ Some algae were able to bypass the filter and embed into the wicking material of the cooling cores, where they could further collect and reproduce.

- $\quad$ The combination of symptoms restricted the supply water flow to the cooling cores and reduced evaporative cooling effectiveness to unacceptable levels. 
- Unacceptable algae growth in the filter housing and cooling cores proved that the current water source and pretreatment created an unacceptable expected lifetime and maintenance profile.

It was later discovered that filtration and treatment of the wastewater effluent would likely be expensive and nontrivial. Larger filters with finer filtration capability and treatment to sanitize the effluent would be required. Given project priorities and a low probability of a successful engineering solution, no further action was taken with this experiment. Although this demonstration was not successful, the demonstration likely would have been successful if a cleaner gray water source had been used that did not contain algae. For example, rainwater harvesting should be further explored.

The second metric required no ruptured water lines. This metric was met for all facilities except the classroom. Although the water lines ruptured at this facility, it was not due to the characteristics of the technology; rather, it was an unforeseen issue with the installation. 


\subsection{COST AND MARKET ANALYSIS}

\subsection{COST MODEL}

Twenty-four Coolerado C60 units were installed across five facilities at Fort Carson including a training center (classrooms), auditorium, events center, a digester facility, and a jet aeration facility. All the systems were set up as zone coolers with 100\% OA. Most were ground or stand mounted; a few were roof mounted. The event center, digester facility, and jet aeration facility did not have air-conditioning before the demonstration. The training center was using small spot coolers that could not meet the cooling load and the theater had an antiquated HVAC system that had insufficient cooling capacity.

Because the facilities had insufficient air-conditioning capacity before the Coolerado units were installed, the economics of the Coolerado installation were compared to the economics of installing an appropriately sized packaged RTU and the associated ductwork and controls. The total installed costs, seasonal energy efficiency, energy use, and projected water consumption of the Coolerado units were used to compare the economics and performance to a code-minimum packaged RTU with an IEER of 12.

The seasonal efficiency of each Coolerado unit was calculated as a function of the total building cooling provided over the 2011 cooling season and total electrical energy use. The cooling capacity was calculated as a function of space temperature (building cooling) and OAT (total cooling). Figure 54 shows the annual average operational cooling efficiency for each unit.

\section{Seasonal Efficiency Comparison}

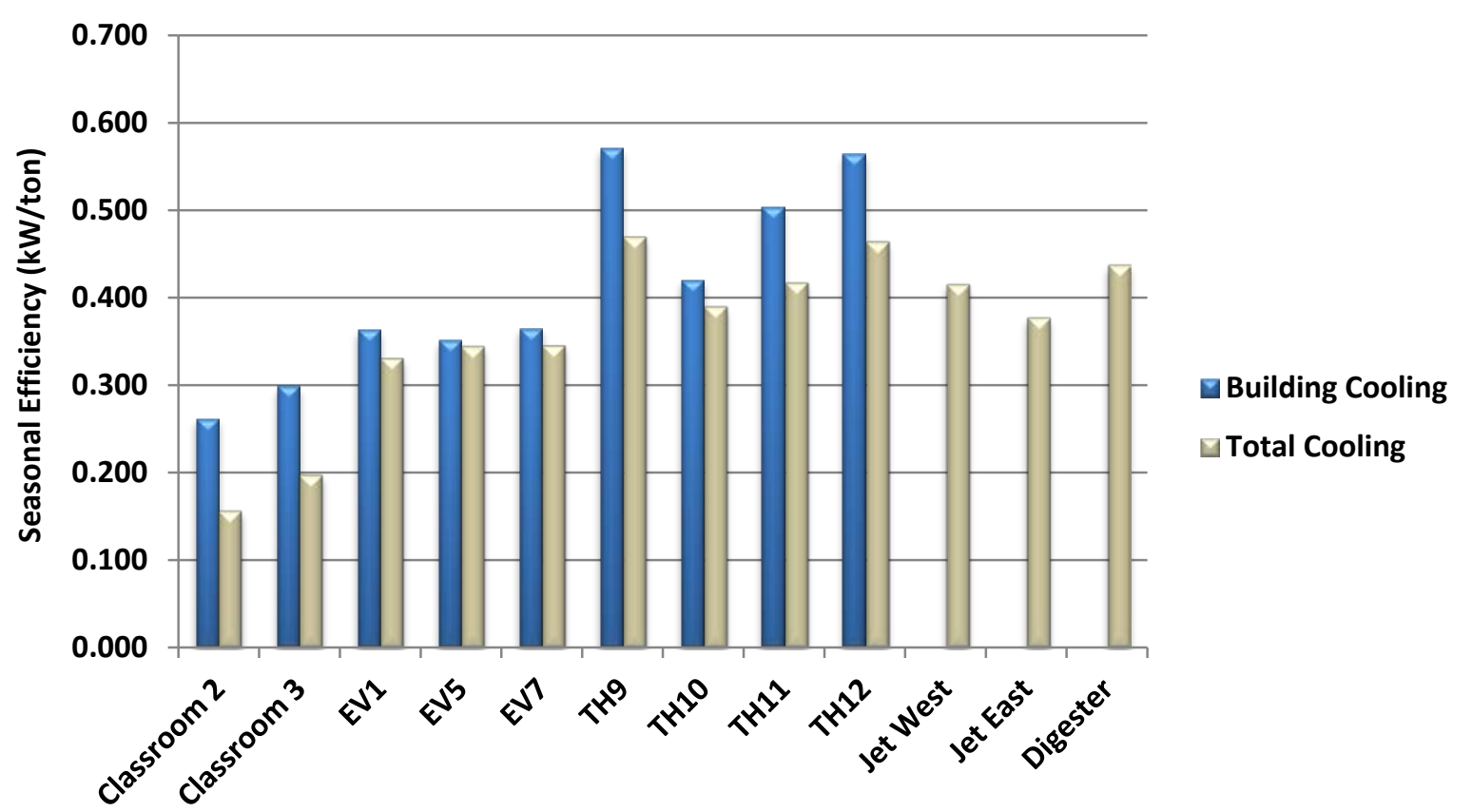

Figure 54. Coolerado seasonal efficiency comparison 
The total energy use for each unit was multiplied by the ratio of the seasonal building efficiency of the Coolerado unit and the IEER of the proposed packaged unit (in $\mathrm{kW} / \mathrm{ton}$ ). The seasonal efficiency was calculated as a function of building cooling for all facilities except the jet aeration and digester units, where the total cooling efficiency was increased by $20 \%$ to properly model the seasonal building cooling efficiency.

The annual energy use for the 2011 cooling season was taken directly from measured energy use data and the water consumption was calculated based on the total cooling provided over the 2011 cooling season, assuming a water consumption rate of $3 \mathrm{gal} / \mathrm{ton} \cdot \mathrm{h}$. Because the water settings were modified during the 2010 and 2011 cooling seasons, the water consumption rate during the first part of the summer was higher than at the end of the 2011 cooling season. The water consumption rate for the later part of the summer when the $\mathrm{CoC}$ setting was set to 5 was approximately $3 \mathrm{gal} / \mathrm{ton} \cdot \mathrm{h}$ and is indicative of future operation. The electricity rate at Fort Carson is $\$ 0.07 / \mathrm{kWh}$ and the water rate is $\$ 3.80 / 1000$ gal.

The O\&M costs of the Coolerado unit were based on maintenance logs from the Fort Carson demonstration. The maintenance time per unit was $7.25-2.65 \mathrm{~h} / \mathrm{unit} / \mathrm{yr}$, depending on the installation and required maintenance. For this analysis, the annual O\&M time is assumed to be $2.65 \mathrm{~h}$. Using a standard maintenance labor rate from RSMeans $(\$ 54.375 / \mathrm{h})$, the labor cost was assumed to be $\$ 144 /$ unit and the material cost was assumed to be $\$ 15 /$ unit for a total O\&M cost of $\$ 160 /$ unit/yr and the total cost premium per Coolerado unit was assumed to be $\$ 34 / \mathrm{yr} .{ }^{\text {xiv }}$

Figure 55 shows the measured energy use of each Coolerado unit and the predicted RTU energy use, assuming an IEER of 12.

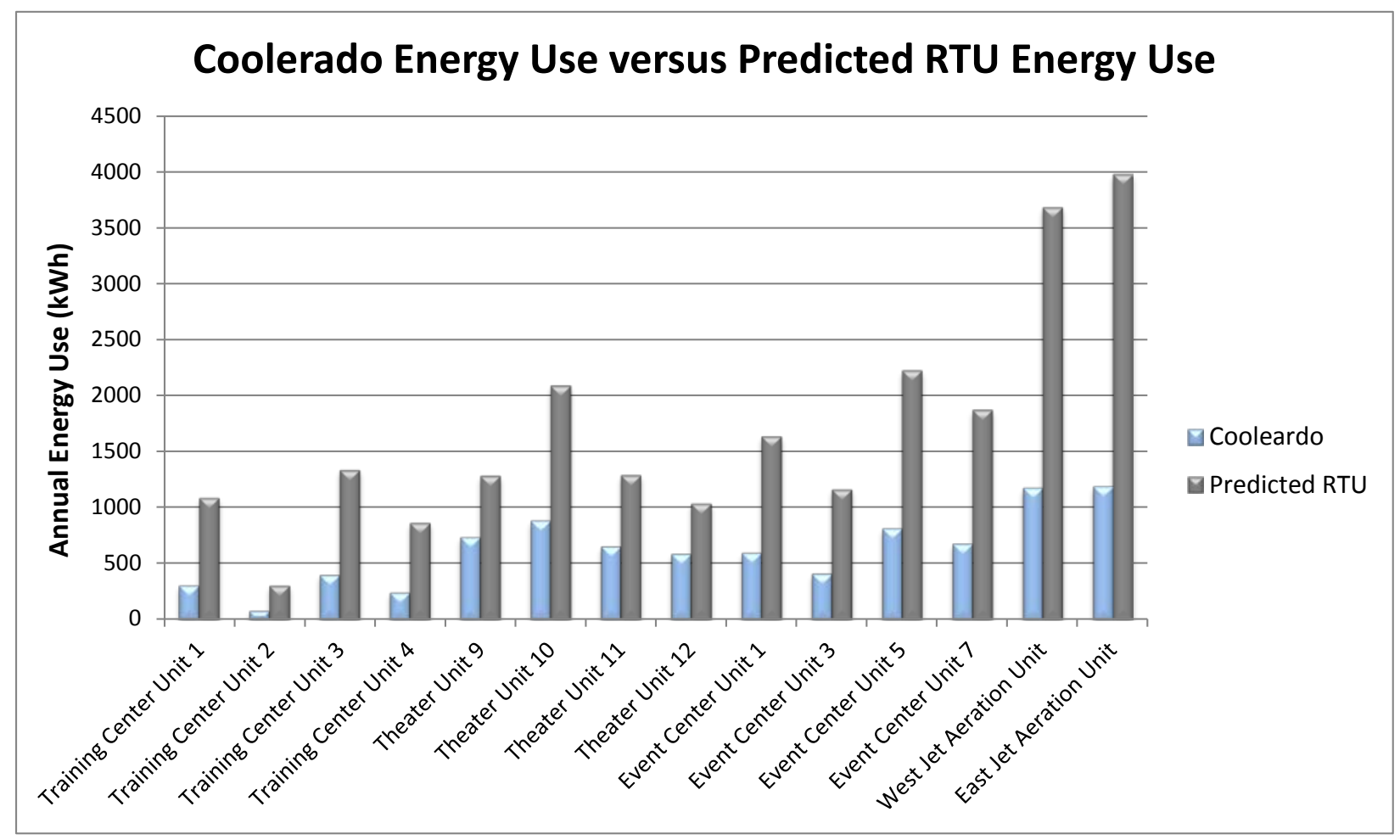

Figure 55. Coolerado energy use versus predicted RTU energy use 
Given the measured performance of the Coolerado units, the annual energy savings are estimated at $63.3 \%$ compared to a code-minimum RTU. The energy savings would be greater if compared to an older packaged RTU with an EER of 8-9.

Table 14 shows the installed costs for the five facilities and the wastewater unit.

Table 14. Coolerado Installed Costs

\begin{tabular}{|c|c|c|c||}
\hline Location & $\begin{array}{c}\text { Number of } \\
\text { Units }\end{array}$ & $\begin{array}{c}\text { Total Cost } \\
\mathbf{( \$ )}\end{array}$ & $\begin{array}{c}\text { Cost per Unit } \\
\mathbf{( \$ )}\end{array}$ \\
\hline Training center & 4 & $\$ 67,416$ & $\$ 16,854$ \\
\hline Event center & 8 & $\$ 131,770$ & $\$ 16,471$ \\
\hline Theater & 8 & $\$ 126,099$ & $\$ 15,762$ \\
\hline Jet aeration & 2 & $\$ 25,625$ & $\$ 12,813$ \\
\hline Wastewater facility & 1 & $\$ 13,141$ & $\$ 13,141$ \\
\hline Wastewater unit $(\$)$ & 1 & $\$ 8,170$ & $\$ 8,170$ \\
\hline
\end{tabular}

The installed costs for the packaged RTUs was assumed to be $\$ 4,000-\$ 5,200$ per cooling ton and includes installed costs for the RTU and associated ductwork. The range was based on the amount of internal ductwork that would be needed. The RTU capacity was calculated assuming each Coolerado unit was rated at 3 tons of cooling, and one to two RTUs were assumed to be installed at each facility.

Table 15 shows the annual cost savings, incremental installed costs, and simple payback (SPP).

Table 15. Fort Carson Coolerado Economics

\begin{tabular}{||l|c|c|c|c||}
\hline \hline Facility Name & $\begin{array}{c}\text { Annual Cost } \\
\text { Savings (\$) }\end{array}$ & $\begin{array}{c}\text { Incremental } \\
\text { Installed Cost } \\
\mathbf{( \$ )}\end{array}$ & $\begin{array}{c}\text { Simple } \\
\text { Payback (yrs) }\end{array}$ & $\begin{array}{c}\text { NPV } \\
\text { (\$) }\end{array}$ \\
\hline Training facility & $-\$ 16$ & $\$ 5,016$ & -312.6 & $-\$ 5,416$ \\
\hline Theater & $-\$ 38$ & $\$ 1,299$ & -33.8 & $-\$ 2,249$ \\
\hline Event center & $\$ 65$ & $\$ 6,970$ & 107.9 & $-\$ 5,344$ \\
\hline Jet aeration & $\$ 111$ & $\$ 1,625$ & 14.60 & $\$ 1,151$ \\
\hline
\end{tabular}

The jet aeration facility had the best payback period, primarily because the units ran $24 / 7$ throughout the cooling season because of the high internal loads. The increased runtime increased annual kilowatt-hour energy savings. The event center also had positive annual cost savings. The other facilities would have shown positive cost savings if the savings had been compared to an older RTU with an EER of 8-9.

Although the units significantly reduced energy use, the increased O\&M and water consumption costs increased annual operating costs for facilities with reduced cooling loads and runtimes. Figure 56 shows the annual operating costs for the four units at the training facility compared to 
the annual energy costs of the RTU. The O\&M costs represent a higher percentage of the total annual costs than the energy costs.

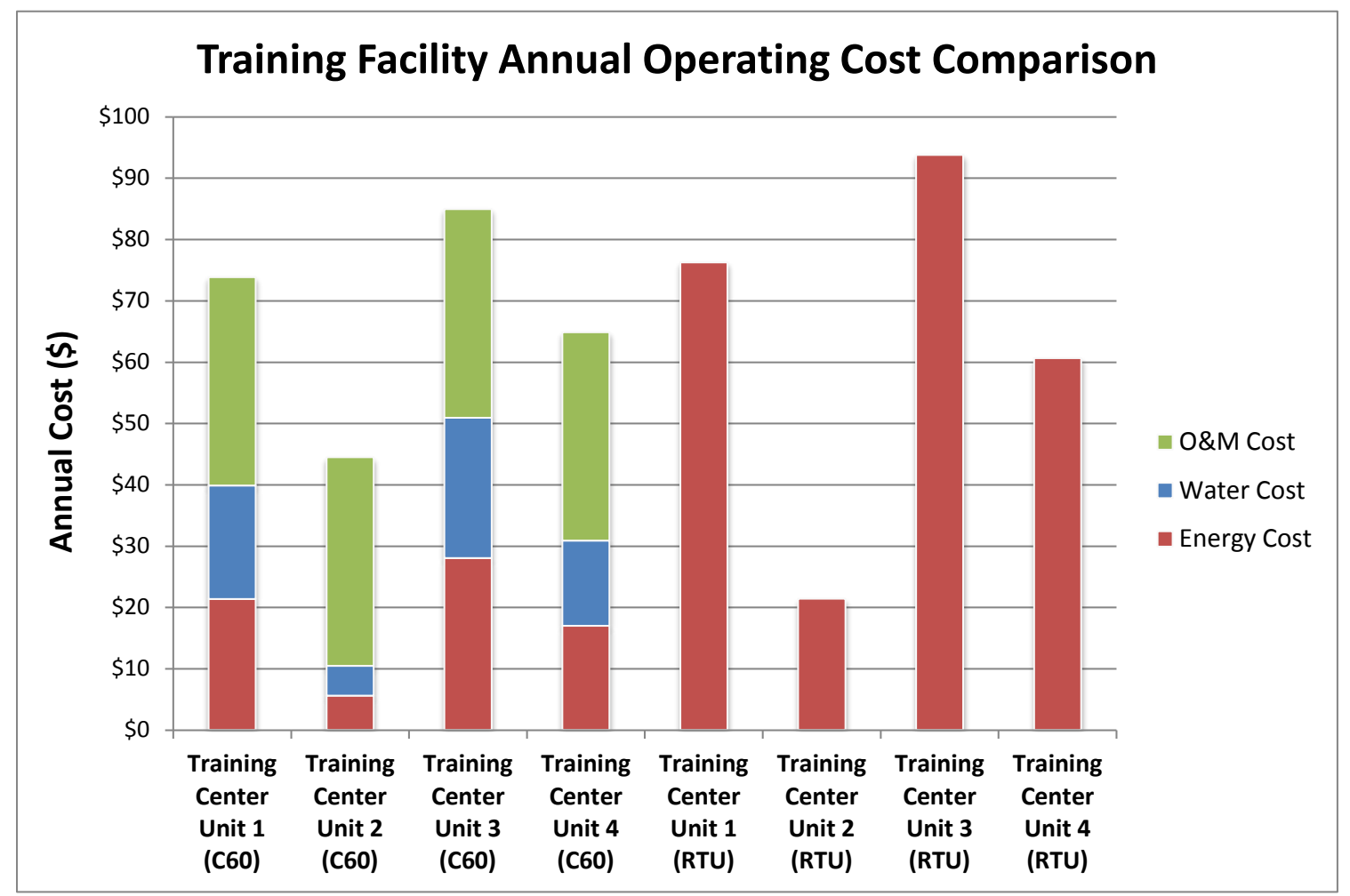

Figure 56. Training Facility Annual Operating Cost Comparison

The economics are very sensitive to O\&M costs; any increase or decrease in O\&M costs has a significant impact on the economics of the installation (see Table 16). Given that the O\&M costs are subjective and the O\&M costs for packaged RTUs can exceed the costs assumed here, the economics of the installation are provided without incremental increase in O\&M.

Table 16. Fort Carson Coolerado Economics

\begin{tabular}{||l|c|c|c|c||}
\hline Facility Name & $\begin{array}{c}\text { Annual } \\
\text { Cost } \\
\text { Savings } \\
\mathbf{( \$ )}\end{array}$ & $\begin{array}{c}\text { Incremental } \\
\text { Installed } \\
\text { Cost } \mathbf{( \$ )}\end{array}$ & $\begin{array}{c}\text { Simple } \\
\text { Payback } \\
\mathbf{( y r s )}\end{array}$ & $\begin{array}{c}\text { Net } \\
\text { Present } \\
\text { Value } \\
\mathbf{( \$ )}\end{array}$ \\
\hline Training facility & $\$ 120$ & $\$ 5,016$ & 41.8 & $-\$ 2,015$ \\
\hline Theater & $\$ 98$ & $\$ 1,299$ & 13.3 & $\$ 1,152$ \\
\hline Event center & $\$ 201$ & $\$ 6,970$ & 34.7 & $-\$ 1,943$ \\
\hline Jet aeration & $\$ 213$ & $\$ 1,625$ & 7.62 & $\$ 3,703$ \\
\hline \hline
\end{tabular}

The estimated SPP was 7.62-41.8 yr, depending on the facility where the unit was installed. 


\subsection{MARKET SEGMENT}

The Coolerado technology was evaluated in three facility types across six climate zones. The system was analyzed in a retrofit scenario against competing technologies for one facility type and evaluated against a standard air-cooled, refrigeration-based air-conditioning system for the other two facility types. The study included an analysis of installed costs, O\&M costs, energy performance, and water performance of commercially available cooling technologies. The characterization of commercially available evaporative cooling technologies allows for the sideby-side comparison of the Coolerado technology with competing products. The tradeoffs between thermal comfort, energy savings, O\&M costs, and increased water consumption that result from the application of this technology as affected by regional climatic conditions, as well as and thermally driven/hydroelectric power plant water consumption, were analyzed.

\subsubsection{ASHRAE Climate Zones}

Evaporative cooling units can significantly reduce cooling energy use in residential and commercial buildings, and are most effective in dry climates. The ASHRAE climate zones are split into eight zones, with sub-regional divisions for moist (A), dry (B), and marine (C) climates, for a total of 16 discrete climate zones. The performances of the Coolerado unit and the competing evaporative-based technologies were analyzed in the following climate zones:
- $\quad$ Phoenix, Arizona (2B)
- $\quad$ Las Vegas, Nevada (3B)
- $\quad$ Los Angeles, California (3B)
- $\quad$ Albuquerque, New Mexico (4B)
- $\quad$ Colorado Springs, Colorado (5B)
- $\quad$ Helena, Montana (6B)

For the single-zone classroom analysis the technology was also evaluated in Tucson, Arizona, San Diego, California, Dagget, California, and El Paso, Texas. These locations are shown on the map of the ASHRAE climate zones in Figure 57. 


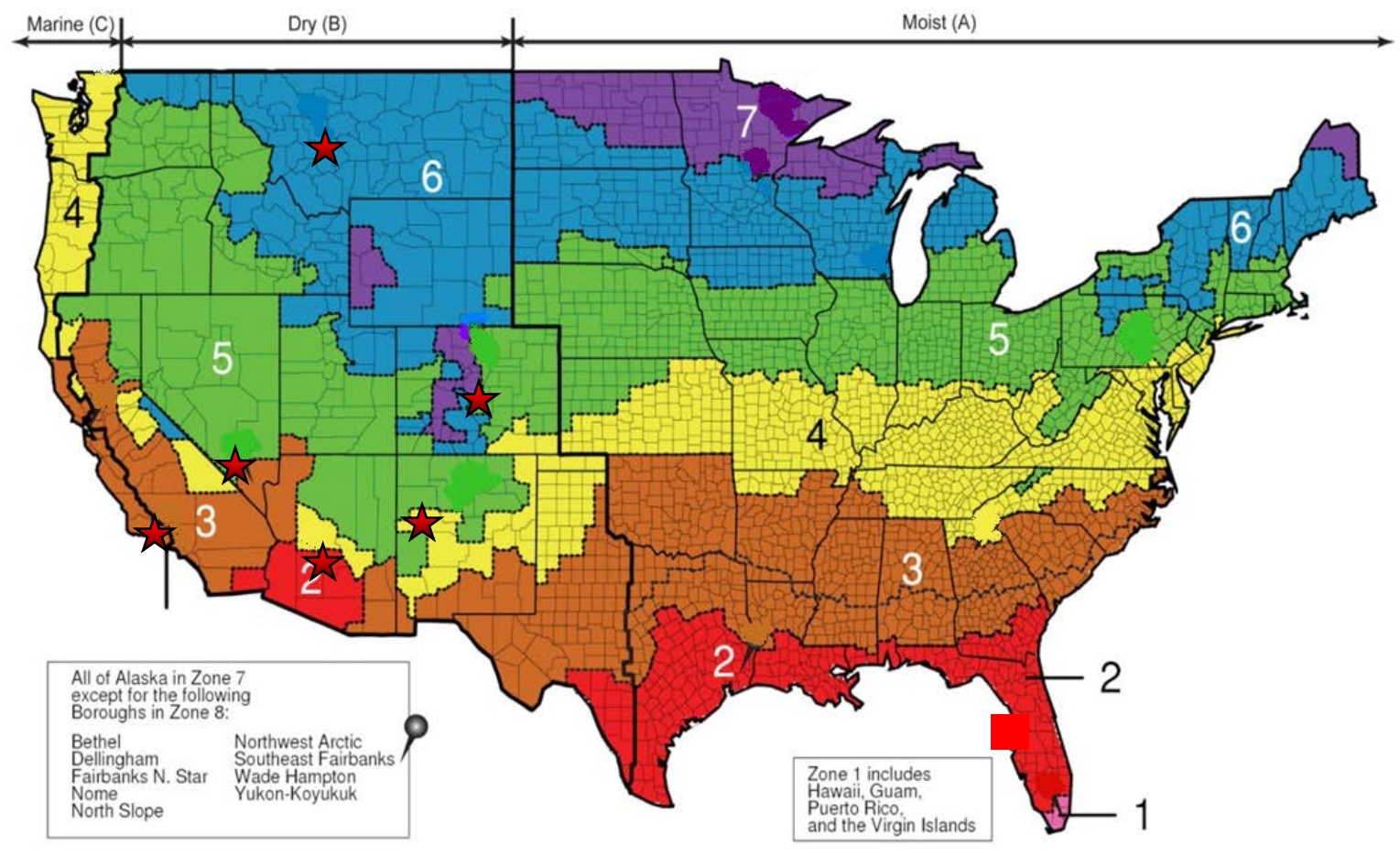

Figure 57. ASHRAE climate zone map

(Source: Joelynn Schroeder, NREL)

Climate zones $2 \mathrm{~B}$ and $3 \mathrm{~B}$ have more extreme annual climatic cooling conditions, with more hours per year with high wet bulb and dry bulb temperatures, making it difficult to meet the space cooling loads with standalone evaporative cooling technologies. In these climate zones, evaporative cooling technologies have historically been installed as pre-conditioners or zone coolers with secondary DX cooling systems that provide supplementary cooling when the evaporative cooling units cannot meet the space temperature set point. Evaporative cooling technologies can meet cooling loads a greater percentage of the time when applied in climate zones $4 \mathrm{~B}, 5 \mathrm{~B}$, and $6 \mathrm{~B}$, although the annual cooling demands and baseline cooling energy use is lower in these climates.

\subsection{PERFORMANCE CHARACTERISTICS EVALUATED}

The following performance characteristics were evaluated for all systems in each climate zone.

- $\quad$ Thermal comfort. The interior temperature set point was set to $74^{\circ} \mathrm{F}$ during occupied hours. The Coolerado unit was analyzed as a zone cooler in all climate zones, and if the unit could not meet the space temperature set point of $74^{\circ} \mathrm{F}$ for $>$ $98 \%$ of the hours in cooling mode, it was assumed to operate as an OA preconditioner, where the RTU would pick up the cooling load that the Coolerado unit could not meet. 
- $\quad$ Energy use. The energy use of the baseline cooling system was analyzed. For RTUs the hourly energy use of the compressor, condenser fan, and supply fan was included in the analysis when the unit was operating in cooling mode. The Coolerado unit's energy use was combined with the supplementary refrigeration system's energy use when the system was installed as an OA pre-conditioner.

- $\quad$ Onsite water use. The onsite water use of evaporative cooling equipment was calculated assuming a water consumption rate of $2.2 \mathrm{gal} / \mathrm{ton} \cdot \mathrm{h}$. The water consumption of the Coolerado unit was calculated assuming a $\mathrm{CoC}$ set point of 5 .

- $\quad$ Power plant water use. Evaporative cooling technologies can reduce overall water consumption in place of air-cooled DX cooling units in certain utility markets. A literature search and analysis of the amount of water involved for power production provide a baseline for the power plant-related water consumption. The U.S. electricity grid is divided into three major interconnections and further split into seven North American Reliability Corporation (NERC) sectors. Figure 58 shows the grid dividing lines for the major grid sectors and the NERC regions. Each NERC region is responsible for enforcing bulk electricity grid reliability within its region and ensuring electricity supply standards ${ }^{1}$. Total power generation and water consumption for all power production technologies were collected through the Emissions \& Generation Resource Integrated Database

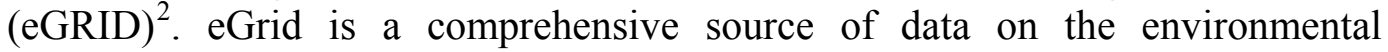
characteristics of almost all electric power generated in the United States, divided up into NERC regions.

${ }^{1}$ NERC Webpage: http://www.nerc.com/page.php?cid=1|7

${ }^{2}$ eGRID http://www.epa.gov/cleanenergy/energy-resources/egrid/index.html 


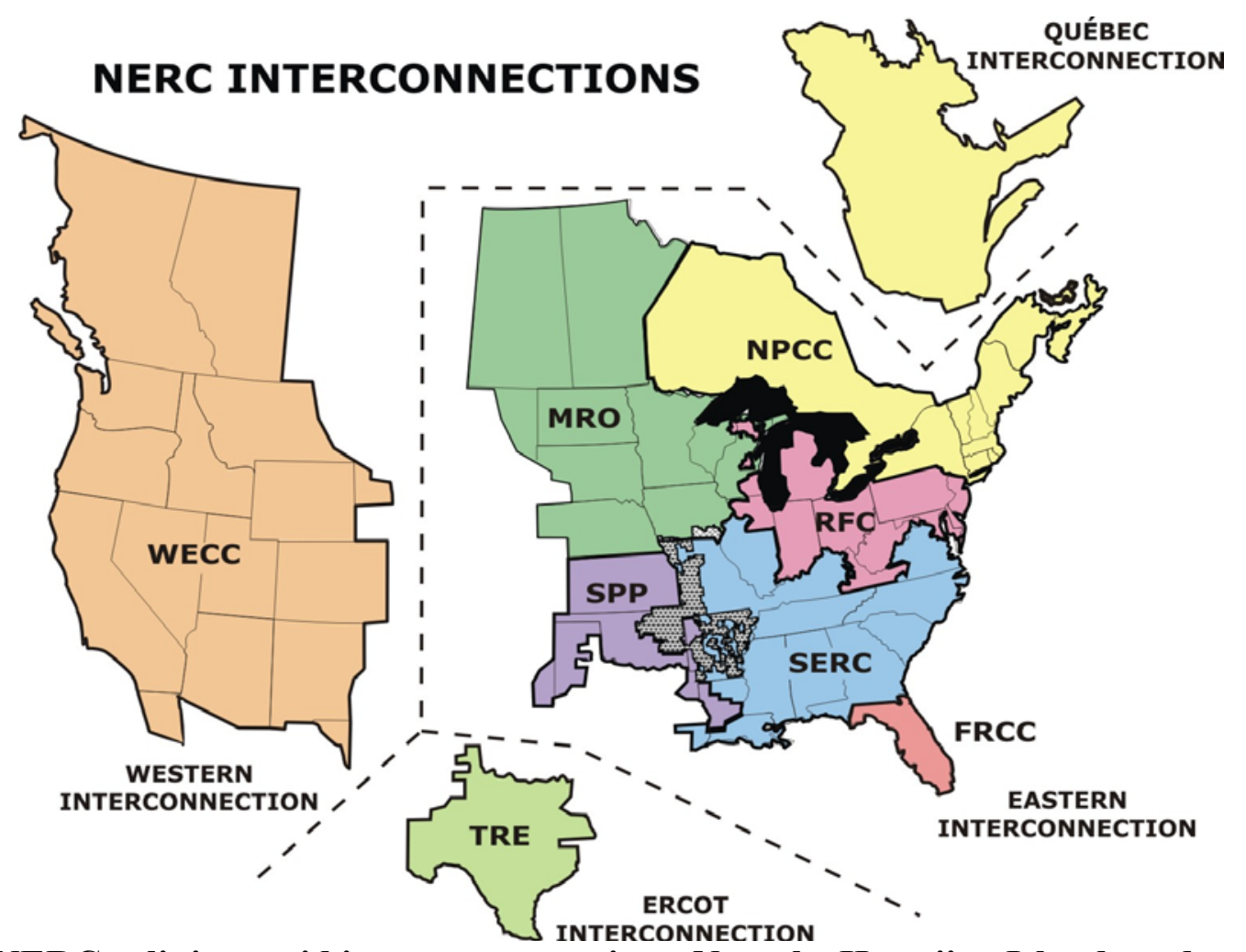

Figure 58. NERC split into grid interconnect regions. Note the Hawaiian Islands and Alaskan regions are not shown.

(Source: ERCOT)

For this study, electricity generation is split into thermoelectric, nuclear, hydroelectric, and waterless renewable. No distinction was made based on fuel type, and weighted averages for water consumption were determined for each generation type. Water consumption for thermally driven power plants is primarily associated with evaporation losses from large cooling towers. Thermoelectric power has the broadest production base and covers steam turbines (coal, biomass, oil, possibly gas) and internal combustion engines (oil and natural gas). Nuclear power water use was averaged among the nuclear cooling systems. Water loss is highest for hydroelectric power, because of evaporation rates on the high fresh water surface area and seepage to porous foundations. These losses are complicated by the indirect use of the reservoir water for power, as most dams have more uses than power production. Wind and solar are considered waterless at the system boundary, and geothermal power plants are considered binary. 


\section{Table 17. Water Consumption Rates by Technology}

\begin{tabular}{||l|c|c||}
\hline Technology & $\begin{array}{c}\text { Total Power } \\
\text { Production } \\
\text { (kWh) }\end{array}$ & $\begin{array}{c}\text { Water } \\
\text { Consumption } \\
\text { Rate } \\
\text { (gal/kWh) }\end{array}$ \\
\hline Thermoelectric & $2,973,686,287,600$ & 0.5 \\
\hline Nuclear & $781,986,365,000$ & 0.5 \\
\hline Hydropower & $263,624,069,100$ & $10.9^{\underline{x V}}$ \\
\hline $\begin{array}{l}\text { Waterless } \\
\text { renewables }\end{array}$ & $33,049,843,000$ & 0 \\
\hline
\end{tabular}

In 2005, the United States consumed 5,233,103,191,068 gallons of water to produce 4,056,441,933 MWh of energy. ${ }^{3}$ This is approximately 1.48 gal to produce $1 \mathrm{kWh}$ of energy for the entire United States. Although each region may transfer electricity to another, for this analysis each region consumes the electricity it generates. Figure 59 shows the total water consumption on the right axis and average water consumption per $\mathrm{kWh}$ (red line) on the left axis for each region.

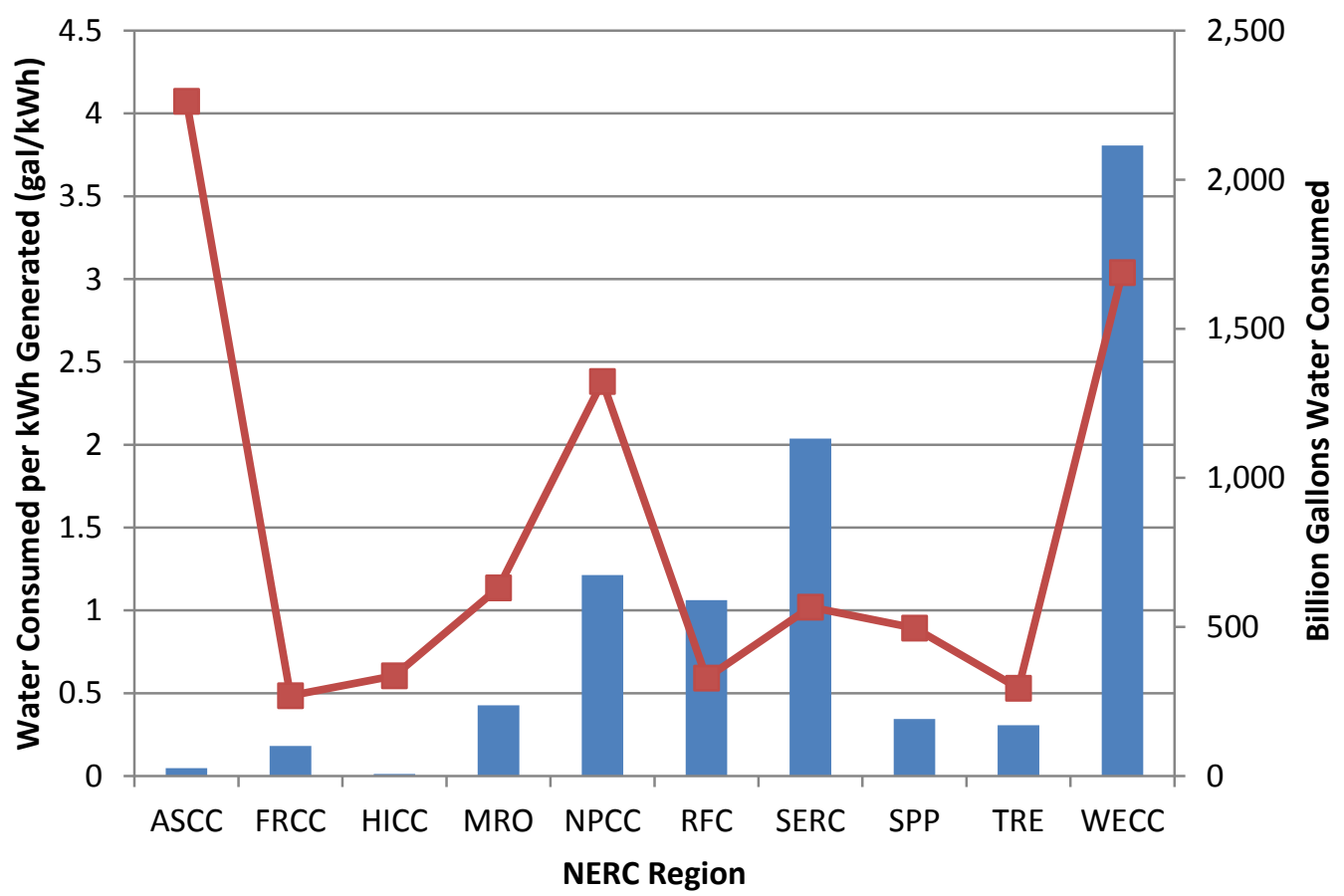

Figure 59. Water consumption rates and overall water consumption by NERC region

${ }^{3}$ eGRID http://www.epa.gov/cleanenergy/energy-resources/egrid/index.html 
Power production does not necessarily mean power consumption. Losses are associated with the transmission and direct use of electricity to run parts of the power plants. In 2005 , the combination of these losses accounted for $10 \%$ of the power generated at a national level. This means $1 \mathrm{kWh}$ electricity saved means that $1.1 \mathrm{kWh}$ less power needs to be produced.

Another consideration is that the amount of water consumed at the power plant does not represent the amount of water they need. Thermoelectric power plants require water withdrawal rates that are many times higher than their actual consumption rates. Availability of water (nearby rivers or oceans) and water rights determine whether the thermoelectric system can even be built. The large water withdrawal rates have large impacts on the ecology and water use hierarchy that are not considered in this study. Nevertheless, evaporative cooling technologies would be expected to easily overcome utility-scale water withdrawal rates.

As an example, an evaluation of an evaporative cooling technology in Colorado will focus on the Western Electricity Coordinating Council, which guarantees power supply for Colorado. Water consumption rate for this region is approximately $3 \mathrm{gal} / \mathrm{kWh}$ energy produced. After transmission and leeching losses, power consumed in Colorado consumes approximately 3.3 gal of water at the power plant $(3.3 \mathrm{gal} / \mathrm{kWh})$. This rate is higher than the national average, mostly because of the region's considerable hydroelectric power production.

- $\quad O \& M$ costs. The O\&M costs of the Coolerado unit were based on maintenance logs from the Fort Carson demonstration. The maintenance time was 7.25-2.65 $\mathrm{h} / \mathrm{unit} / \mathrm{yr}$, depending on the installation and on required maintenance. For this report, the annual O\&M time is assumed to be $2.65 \mathrm{~h}$. Using a standard maintenance labor rate from RSMeans $(\$ 54.375 / \mathrm{h})$, the labor cost was assumed to be $\$ 144 /$ unit and the material cost was assumed to be $\$ 15 /$ unit for a total O\&M cost of $\$ 160 /$ unit/yr. $^{\text {xvi }}$

The baseline O\&M costs for packaged RTUs and AHUs were determined with data from RS Means Facilities Maintenance and Repair 2011 Cost Data Book. ${ }^{\text {xiv }}$ The preventive maintenance costs for 3- to 24-ton RTUs and AHUs are \$121/yr (including overhead and profit), which includes $\$ 43.5$ for labor, $\$ 43.5$ for material, and $0.8 \mathrm{~h}$ of time. This cost was assumed as the baseline O\&M cost. The difference in O\&M costs was calculated as $\$ 39 / \mathrm{yr}$ more for the Coolerado unit.

Capital costs. For the single-zone classroom unit, the capital costs for the baseline packaged RTUs were taken from the RS Means Facilities Maintenance and Repair Data Book. Table 18 shows the removal and installation costs for 3-, 5-, 7.5-, and 10-ton units. 
Table 18. Packaged RTU Installed Costs

\begin{tabular}{|c|c|c|c|c||}
\hline System Size & $\begin{array}{c}\text { Removal } \\
\text { Cost } \mathbf{( \$ )}\end{array}$ & $\begin{array}{c}\text { Installation } \\
\text { Cost } \mathbf{( \$ )}\end{array}$ & Total Cost $\mathbf{( \$ )}$ & $\begin{array}{c}\text { Total } \\
\text { Cost } \\
\text { (\$/ton) }\end{array}$ \\
\hline 3 Tons & $\$ 600$ & $\$ 6,800$ & $\$ 7,400$ & $\$ 2,467$ \\
5 Tons & $\$ 1,400$ & $\$ 9,705$ & $\$ 11,105$ & $\$ 2,221$ \\
7.5 Tons & $\$ 1,950$ & $\$ 12,800$ & $\$ 14,750$ & $\$ 1,967$ \\
10 Tons & $\$ 2,650$ & $\$ 17,000$ & $\$ 19,650$ & $\$ 1,965$ \\
\hline
\end{tabular}

The average RTU installed cost was estimated at $\$ 2,000 /$ ton for an ASHRAE 90.1 2007 code-compliant RTU, and $\$ 2,600 /$ ton for the RTU with add-on evaporative cooling elements. The capital cost of the Coolerado unit was taken from installed costs at Fort Carson. The installed costs were $\$ 12,800-\$ 16,800 /$ unit, depending on the installation and supporting structure requirements. Because these units were installed in 2009 and Coolerado has automated parts of the manufacturing process, the installed cost was assumed to be $\$ 11,000 /$ unit (model C60), or $\$ 1,833$ per cooling core. The O\&M and capital costs of all systems were adjusted based on the RSMeans city cost adjustment factors (see Table 19).

\section{Table 19. RSMeans City Cost Adjustment Factors}

\begin{tabular}{||c|c||}
\hline Location & $\begin{array}{c}\text { Cost Adjustment } \\
\text { Factor }\end{array}$ \\
\hline Phoenix & $93.70 \%$ \\
\hline Las Vegas & $104.20 \%$ \\
\hline Los Angeles & $105.30 \%$ \\
\hline Albuquerque & $87.40 \%$ \\
\hline Colorado Springs & $90.00 \%$ \\
\hline Helena & $88.20 \%$ \\
\hline Tucson & $88.50 \%$ \\
\hline San Diego & $105.00 \%$ \\
\hline Dagget & $102.60 \%$ \\
\hline El Paso & $73.50 \%$ \\
\hline
\end{tabular}

- Utility rates. The electricity and natural gas rates were taken from the commercial building benchmark data, which were updated in 2010. The domestic water rate was set to $\$ 3.75 / 1000$ gal based on data from Fort Carson (see Table 20). ${ }^{\text {xii }}$ 
Table 20. Regional Utility Rates and Labor Rates

\begin{tabular}{|c|c|c|c|c|c|}
\hline City & $\begin{array}{c}\text { Electricity } \\
\text { Rate } \\
(\$ / \mathbf{k W h}) \\
\end{array}$ & $\begin{array}{c}\text { Natural } \\
\text { Gas Rate } \\
\text { (\$/MMBtu) }\end{array}$ & $\begin{array}{c}\text { Water Rate } \\
\text { (\$/Gal) }\end{array}$ & $\begin{array}{l}\text { Power Plant } \\
\text { Water Use } \\
\text { (gal/kWh) }\end{array}$ & $\begin{array}{c}\text { Labor Rate } \\
\text { (\$) }\end{array}$ \\
\hline Phoenix & $\$ 0.12$ & $\$ 7.81$ & $\$ 0.0038$ & 3.037 & $\$ 50.95$ \\
\hline Las Vegas & $\$ 0.14$ & $\$ 8.13$ & $\$ 0.0038$ & 3.037 & $\$ 56.66$ \\
\hline Los Angeles & $\$ 0.10$ & $\$ 7.29$ & $\$ 0.0038$ & 3.037 & $\$ 57.26$ \\
\hline Albuquerque & $\$ 0.07$ & $\$ 6.52$ & $\$ 0.0038$ & 3.037 & $\$ 47.52$ \\
\hline Colorado Springs & $\$ 0.07$ & $\$ 6.53$ & $\$ 0.0038$ & 3.037 & $\$ 48.94$ \\
\hline Helena & $\$ 0.08$ & $\$ 7.48$ & $\$ 0.0038$ & 3.037 & $\$ 47.96$ \\
\hline Tucson (2B) & $\$ 0.12$ & $\$ 7.03$ & $\$ 0.0030$ & 3.037 & $\$ 48.12$ \\
\hline San Diego (3B) & $\$ 0.09$ & $\$ 5.62$ & $\$ 0.0050$ & 3.037 & $\$ 57.09$ \\
\hline Dagget (3B) & $\$ 0.09$ & $\$ 4.87$ & $\$ 0.0034$ & 3.037 & $\$ 55.79$ \\
\hline El Paso (6B) & $\$ 0.08$ & $\$ 7.24$ & $\$ 0.0047$ & 3.037 & $\$ 39.97$ \\
\hline
\end{tabular}

- Economic rates. The economic rates were based on the federally mandated building life cycle costing rates and procedures. The real discount rate for 2012 is $2 \%$, with an inflation rate of $3.6 \%$ and a nominal discount rate of $5.6 \%$. The real electricity escalation rate was set to $-0.54 \%$, which the nominal rate slightly less than the inflation rate. ${ }^{\text {xiii }}$

- $\quad S P P$ and NPV. The economics of installing the Coolerado technology was evaluated using a SPP and NPV calculation based on energy consumption, water use, utility rates, and $\mathrm{O} \& \mathrm{M}$ costs.

The following sections provide the modeling results for each building type in different geographic areas.

\subsection{SINGLE-ZONE COMPUTER CLASSROOM}

The single-zone computer classroom was modeled after a classroom facility at Fort Carson and was set up as a single-zone facility. The Fort Carson facility was constructed in 1966 as a small dining facility and been renovated several times. The building includes five training rooms, two small offices, two restrooms, and storage spaces. The facility operates $50 \mathrm{wks} / \mathrm{yr}$ from 8:00 a.m. to 5:00 p.m., five days per week. The classroom was modeled as a south-facing individual classroom and included one Coolerado unit, as in the actual design (see Figure 60). 


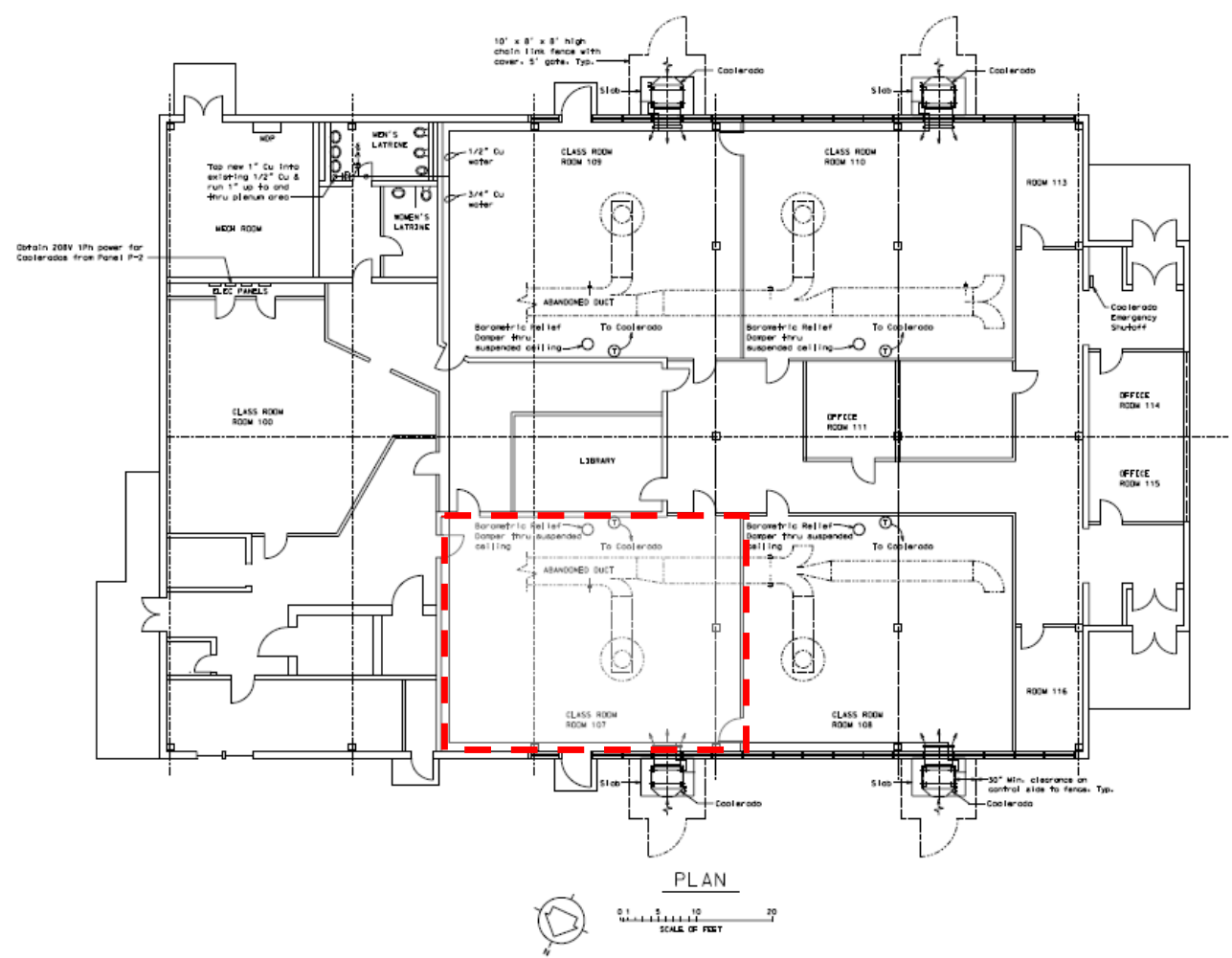

Figure 60. Computer room classroom Coolerado units

(Source: Fort Carson DPW Engineering Department)

The east, west, and north walls were modeled as adiabatic. The space was modeled as a $400-\mathrm{ft}^{2}$ room with 20 people, occupied Monday through Friday (see Figure 61). Internal loads included standard overhead lighting, electric plug loads, and 20 computers. Table 21 and Table 22 summarize the model inputs.

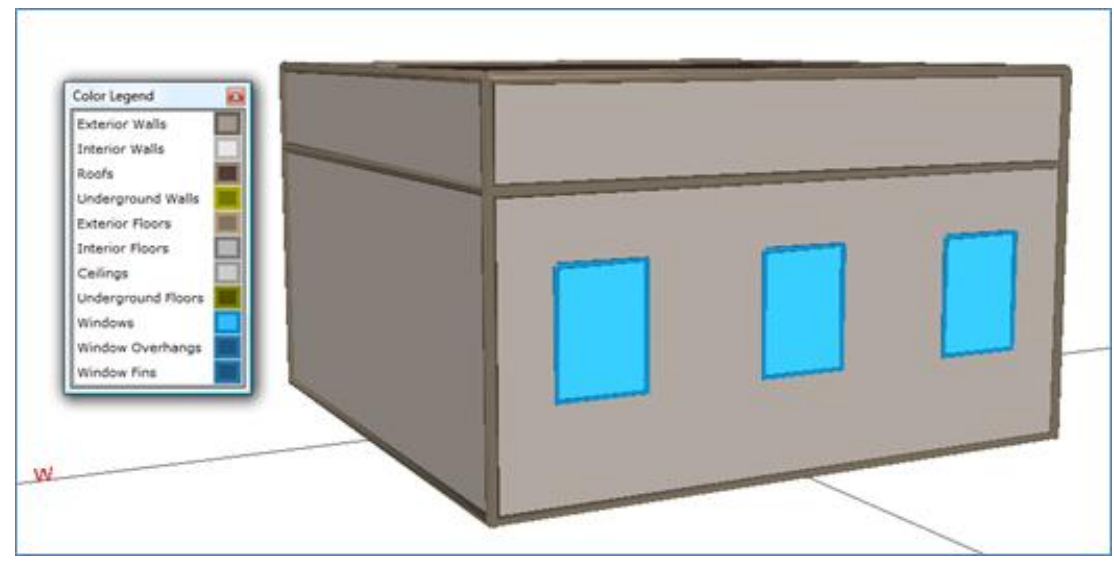

Figure 61. Single-zone classroom facility 
Table 21. Single-Zone Classroom eQUEST Inputs Summary

(Source: NREL)

\begin{tabular}{|c|c|c|}
\hline \multicolumn{3}{|c|}{ Single Zone Classroom } \\
\hline \multicolumn{3}{|l|}{ Project } \\
\hline & Building Type & Small Office / Computer Classroom \\
\hline & Building Area & $400 \mathrm{ft}^{2}$ \\
\hline & Above Grade Floors & 1 \\
\hline & Below Grade Floors & 0 \\
\hline \multicolumn{3}{|c|}{ Building Footprint } \\
\hline & Building Orientation & Plan North \\
\hline & Zoning Pattern & Perimeter / Core \\
\hline & Flr to Flr Height & $12 \mathrm{ft}$ \\
\hline & Flr to Ceil Height & $9 \mathrm{ft}$ \\
\hline & Roof Pitch & $0 \mathrm{deg}$ \\
\hline \multicolumn{3}{|l|}{ Roof } \\
\hline & Construction & Metal Frame $24 "$ o.c. \\
\hline & Roof, Built Up & Medium \\
\hline & Ext. Insulation & R Value Dependent on Location \\
\hline \multicolumn{3}{|l|}{ Walls } \\
\hline & Construction & Metal Frame 24 " o.c. \\
\hline & Finish & Brick, Medium \\
\hline & Ext. Insulation & - \\
\hline & Interior Insulation & R Value Dependent on Location \\
\hline \multicolumn{3}{|c|}{ Ground Floor } \\
\hline & Earth Contact & 6 in Concrete \\
\hline & & No perimeter insulation \\
\hline \multicolumn{3}{|c|}{ Infiltration } \\
\hline & Perimeter & $0.5 \mathrm{ACH}$ \\
\hline \multicolumn{3}{|l|}{ Ceilings } \\
\hline & Int. Finish & Lay-In Acoustic Tile \\
\hline \multicolumn{3}{|c|}{ Vertical Walls } \\
\hline & Wall Type & Frame \\
\hline
\end{tabular}


Table 22. Single-Zone Classroom eQUEST Inputs Summary

\begin{tabular}{|c|c|c|}
\hline \multicolumn{3}{|c|}{ Single Zone Classroom } \\
\hline \multirow[t]{3}{*}{ Exterior Doors } & & \\
\hline & Door Type & Opaque \\
\hline & & None \\
\hline \multicolumn{3}{|c|}{ Exterior Windows } \\
\hline & Type & Single Pane, $1 / 8$ " Clear, Aluminum frame \\
\hline & NRFC U Factor & 1.21 \\
\hline & NFRC SHGC & 0.86 \\
\hline & Visible Transmittance & 0.9 \\
\hline & Percent of Gross Wall Area & $20 \%$ south \\
\hline \multicolumn{3}{|c|}{ Building Operation } \\
\hline & Schedule & 8:00 am to $5: 00 \mathrm{pm} \mathrm{M-F}$ \\
\hline & Area Type & Office \\
\hline & Design Occupancy & $50 \mathrm{ft}^{2} /$ person \\
\hline & Design Ventilation & $20 \mathrm{CFM} /$ person \\
\hline \multicolumn{3}{|c|}{ Equipment Power Density } \\
\hline & Lighting & 1.49 (Watts $\left./ \mathrm{ft}^{2}\right)$ \\
\hline & Misc. Loads & 5 (Watts $/ \mathrm{ft}^{2}$ ) el ectric \\
\hline \multicolumn{3}{|l|}{ HVAC System } \\
\hline & $\begin{array}{l}\text { Packaged Single Zone DX w/ } \\
\text { Furnace }\end{array}$ & Return Air - Ducted \\
\hline & Cooling Source & DX Coils \\
\hline & Heating System & Furnace \\
\hline & Thermostat & $74 \mathrm{~F}$ - Cooling - Occupied \\
\hline & & $70 \mathrm{~F}$ - Heating - Occupied \\
\hline & & $82 \mathrm{~F}$ - Cooling - Un-Occupied \\
\hline & & $64 \mathrm{~F}-$ Heating - Un-Occupied \\
\hline \multicolumn{3}{|l|}{ Fan Schedules } \\
\hline & Operates & Intermittent - based on load \\
\hline \multicolumn{3}{|c|}{ Chilled Water Plant } \\
\hline & DX Coil & $\mathrm{EER}=9$ \\
\hline \multicolumn{3}{|c|}{ Heating Primary Equipment } \\
\hline & Furnace & Efficiency $=0.806$ \\
\hline
\end{tabular}

The high occupant density results in a higher than normal OA fraction, which is typically above $40 \%$. The large electrical equipment load also results in year-round cooling loads in most climates. The high OA fraction limits the energy savings potential of an airside economizer and the year-round cooling requirement provides opportunities to operate the Coolerado unit during lower temperature and humidity conditions, both of which improve its efficiency. The window properties and wall R-values were taken from the commercial reference building models for pre1980 small office buildings and are modified based on each climate zone. The window characteristics were modeled as single-paned clear windows in all climate zones (Table 23). ${ }^{\text {xix }}$ 
Table 23. Small Office Building Reference Wall and Roof R-Value

\begin{tabular}{|c|c|c|c|c|c|c|}
\hline & $\begin{array}{c}\text { Phoenix } \\
\text { (2B) }\end{array}$ & $\begin{array}{c}\text { Los } \\
\text { Angeles } \\
(3 B)\end{array}$ & $\begin{array}{c}\text { Las Vegas } \\
\text { (3B) }\end{array}$ & $\begin{array}{c}\text { Albuquerque } \\
\text { (4B) }\end{array}$ & $\begin{array}{c}\text { Colorado } \\
\text { Springs } \\
\text { (5B) }\end{array}$ & $\begin{array}{c}\text { Helena } \\
(6 B)\end{array}$ \\
\hline \multicolumn{7}{|l|}{ Exterior walls } \\
\hline Construction Type & $\begin{array}{c}\text { Steel-frame } \\
\text { w all }\end{array}$ & $\begin{array}{c}\text { Steel-frame } \\
\text { w all }\end{array}$ & $\begin{array}{c}\text { Steel-frame } \\
\text { w all }\end{array}$ & Steel-frame w all & $\begin{array}{c}\text { Steel-frame } \\
\text { w all }\end{array}$ & $\begin{array}{c}\text { Steel-frame } \\
\text { w all }\end{array}$ \\
\hline R-value $\left(\mathrm{h} \cdot \mathrm{ft}^{2} \cdot{ }^{\circ} \mathrm{F} / \mathrm{Btu}\right)$ & 4.35 & 4.35 & 4.35 & 5.43 & 6.21 & 6.90 \\
\hline \multicolumn{7}{|l|}{ Roof } \\
\hline Construction Type & $\begin{array}{c}\text { Steel-frame } \\
\text { w all }\end{array}$ & $\begin{array}{c}\text { Steel-frame } \\
\text { w all }\end{array}$ & $\begin{array}{c}\text { Steel-frame } \\
\text { w all }\end{array}$ & Steel-frame w all & $\begin{array}{c}\text { Steel-frame } \\
\text { w all }\end{array}$ & $\begin{array}{c}\text { Steel-frame } \\
\text { w all }\end{array}$ \\
\hline R-value $\left(\mathrm{h} \cdot \mathrm{ft}^{2} \cdot{ }^{\circ} \mathrm{F} / \mathrm{Btu}\right)$ & 9.98 & 9.98 & 9.98 & 11.22 & 13.46 & 16.95 \\
\hline
\end{tabular}

\subsubsection{Baseline HVAC System}

The baseline HVAC system was modeled as a packaged single-zone unit. The thermostat was modeled as a proportional thermostat with a $2^{\circ} \mathrm{F}$ throttling range. The supply fan was modeled with 1.25 in. of SP. The DX unit was modeled with an EER of 9 based on measured performance data from packaged RTUs; ${ }^{\mathrm{xx}}$ the default performance curves were used to model the part load performance. The compressor and condenser fans were modeled as single speed and the fan mode for the condenser fan was set to intermittent, which allowed the fan to cycle on and off based on load.

A second baseline system was modeled that included an airside economizer. A temperaturebased economizer was modeled in climate zones $6 \mathrm{~B}$ and $5 \mathrm{~B}$ and an enthalpy-based economizer was modeled in climate zones $4 \mathrm{~B}, 3 \mathrm{~B}$, and $2 \mathrm{~B}$. The temperature-based economizer specifies that the economizer is enabled whenever the OAT is below the maximum allowed temperature of $70^{\circ} \mathrm{F}$. The compressor was not locked, meaning the economizer ran simultaneously with the DX compressor. The economizer's lower OAT limit was not specified. From an operational perspective, there is no need to specify a low temperature limit for OA as long as the mixed air temperature and SAT stay above $55^{\circ} \mathrm{F}$. The enthalpy-based economizer was modeled with the same inputs as the temperature-based economizer with the addition of a 30 Btu maximum allowable OA enthalpy for which the economizer was enabled.

\subsubsection{Single-Zone Variable Air Volume Retrofit}

The first retrofit that was analyzed was a new packaged RTU. It was modeled as an ASHRAE 90.1 2010 code-compliant RTU that is similar to a commercially available Trane or Lennox RTU. Its EER was modeled as 12 . The supply fan was modeled as variable speed with a minimum allowable flow rate of $30 \%$. The compressor and condenser fans were modeled as single speed and the condenser fan control and economizer control sequence was modeled with the same inputs as the baseline RTU.

\subsubsection{Single-Zone Variable Air Volume Retrofit with Evaporative Technologies}

The single-zone variable air volume RTU with an EER of 12 was also modeled with an evaporatively precooled condenser and IEC. A few products offer evaporative precooling and a couple include an indirect evaporative coil. 
The evaporative pre-cooler was set up with a standard air cooled condenser coil and a separate direct evaporative pad that precools the condenser air before it is drawn through the coil. This type of system can be retrofitted in the field or built into predesigned packaged units. The inputs for the air-cooled condenser remain the same with new inputs for the evaporative pad effectiveness (set to 80\%), and evaporative condenser electricity W/Btu, which provides an input for the electric power consumption of the evaporative precooling unit divided by the cooling system output capacity at Air-Conditioning and Refrigeration Institute conditions and was input as $0.001 \mathrm{~W} /$ Btu

The indirect evaporative coil was modeled as integrated with the DX coil. The indirect effectiveness was set to $60 \%$ and the pump and secondary pump power were set to 0.0001 $\mathrm{kW} / \mathrm{cfm}$, which is equivalent of $100 \mathrm{~W} / 1,000 \mathrm{cfm}$ of SA (which was validated with test data from the TTF). RA was modeled as being used at the indirect stage, which indicates that the secondary airstream of the indirect cooler includes RA. The dry bulb high limit, defined as the OA dry bulb temperature above which the evaporative cooler will be turned off, was set to $105^{\circ} \mathrm{F}$. The indirect evaporative coil adds a pressure drop to the system, which increases the supply fan power; the direct evaporative pad for the condenser fan increases the pressure drop across the condenser fan.

\subsubsection{Coolerado}

The space temperature set point was set to $74^{\circ} \mathrm{F}$ in the annual performance model. The hourly cooling load on the DX coil from the eQUEST model was input into the Coolerado model, as well as the hourly outdoor air temperature, humidity, and pressure. Each classroom was modeled with the appropriate number of Coolerado units and their performance at peak conditions was calculated using the peak cooling load and coincident OAT and RH. The SP was set to 0.15 in. of static if the system was modeled as a standalone zone cooler at $0 \mathrm{in}$. of static if installed as an OA pre-conditioner. The water use $\mathrm{CoC}$ was set to 5 . At design conditions the unit capacity was calculated based on a space temperature of $80^{\circ} \mathrm{F}$. The Coolerado control sequence was set up to turn on the Coolerado unit when the space cooling load was $>0$. The program iterated through a series of equations to determine the appropriate fan speed to meet a given cooling load. When the Coolerado unit was not running, it was programmed to have a residual electrical load of 15 $\mathrm{W} / 6$ cooling cores based on the power draw of the control board. If the unit could not meet the space load, an increase in space temperature was calculated. A detailed description of the performance model and validation with laboratory test results and field test results is provided in Appendix C.

When the Coolerado unit could meet $>98 \%$ of the hourly cooling load requirements and space temperature remained below $80^{\circ} \mathrm{F}$, it was modeled as a zone cooler with $100 \% \mathrm{OA} /$ inlet air. With this type of system, the hourly cooling loads exclude infiltration and additional ventilation loads because the Coolerado pressurizes the space and pushes the ventilation air though the facility; thus, the infiltration and ventilation loads are zero.

If the Coolerado unit could not meet the space load for $98 \%$ of the hours, it was modeled as a pre-cooler for the existing constant volume EER 9 RTU. In this case, it served as the first stage of cooling while the residual cooling load was passed to the RTU. In this case the hourly cooling 
load of the Coolerado was the same as the baseline system and no adjustments were made. For the hours that the Coolerado could handle $100 \%$ of the cooling load, the supply fan from the RTU was assumed to operate in conjunction with the Coolerado unit while the compressor and condenser fans were turned off. Based on the SP drop of 1.25 in. through the system, the RTU fans would have to operate in conjunction with the Coolerado to overcome the SP losses. When the Coolerado unit could not meet the entire load, its fan speed was reduced to match the OA flow rate and the new mixed air conditions were calculated. The hourly RAT, RA humidity, RTU DAT, fan power, and compressor/condenser power were retrieved from the energy simulation and used in conjunction with the new DAT from the Coolerado to determine the mixed air conditions, the residual cooling load required by the DX, and total power consumption. The annual average EER of the DX system was used to calculate the residual power and was considered an appropriate representation of DX cooling efficiency, because the condensing temperature had one of the most significant impacts on EER with a given design while the condenser temperature was not affected with this design.

\subsubsection{Results}

Table 24 shows the cooling design characteristics of the baseline RTU. The size of the unit required to cool the space was $16-36 \mathrm{kBtu} / \mathrm{h}$ and the associated sensible heat ratio, supply fan $\mathrm{cfm}$, outside air ratio (OAR), and power demand changed from one climate to another.

Table 24. Small Classroom Baseline DX Unit Design Characteristics

\begin{tabular}{|l|c|c|c|c|c|c|} 
System Design Parameters & Phoenix (2B) & $\begin{array}{c}\text { Las Vegas } \\
\text { (3B) }\end{array}$ & $\begin{array}{c}\text { Los Angeles } \\
\text { (3B) }\end{array}$ & $\begin{array}{c}\text { Albuquerque } \\
\text { (4B) }\end{array}$ & $\begin{array}{c}\text { Colorado } \\
\text { Springs (5B) }\end{array}$ & $\begin{array}{c}\text { Helena (6B) } \\
\text { Cooling Capacity (kBtu/hr) }\end{array}$ \\
\hline \hline Sensible Heat Ratio (SHR) & 65.9 & 32.3 & 18.0 & 21.1 & 16.0 & 18.0 \\
Cooling EIR (Btu/Btu) & 0.379 & $61.8 \%$ & $89.1 \%$ & $78.3 \%$ & $94.0 \%$ & $85.3 \%$ \\
Supply Fan Capacity (CFM) & 1054 & 1063 & 873 & 1060 & 1018 & 947 \\
Outside Air Ratio (\%) & $39.5 \%$ & $40.6 \%$ & $45.8 \%$ & $46.0 \%$ & $48.7 \%$ & $48.6 \%$ \\
Static Pressure (in. water) & 1.3 & 1.3 & 1.3 & 1.3 & 1.3 & 1.3 \\
Fan Placement & BLOW-THRU & BLOW-THRU & BLOW-THRU & BLOW-THRU & BLOW-THRU & BLOW-THRU \\
Fan Control & CONSTANT & CONSTANT & CONSTANT & CONSTANT & CONSTANT & CONSTANT
\end{tabular}

Table 25 shows the performance of the Coolerado at design conditions. The $\mathrm{C} 60$ unit was analyzed in climate zones 5B, 6B and 3; the M30 unit was analyzed in climate zone 4B. Smaller M30 units were analyzed in climate zones $2 \mathrm{~B}$ and $3 \mathrm{~B}$ where they must be installed as an RTU pre-conditioner to match the peak SA flow rates (about $1000 \mathrm{cfm}$ ). The peak space load and coincident OA dry bulb and wet bulb temperature were used to determine unit performance at peak conditions. The cooling capacity at design conditions were $6.5-2.4 \mathrm{kBtu} / \mathrm{h}$, depending on OA conditions. 
Table 25. Small Classroom Coolerado Design and Operational Characteristics

\begin{tabular}{|c|c|c|c|c|c|c|}
\hline System Design Parameters & Phoenix (2B) & $\begin{array}{c}\text { Las Vegas } \\
\text { (3B) }\end{array}$ & $\begin{array}{c}\text { Los Angeles } \\
\text { (3B) }\end{array}$ & $\begin{array}{c}\text { Albuquerque } \\
\text { (4B) }\end{array}$ & $\begin{array}{c}\text { Colorado } \\
\text { Springs (5B) }\end{array}$ & Helena (6B) \\
\hline Sizing Space Temp. $\left({ }^{\circ} \mathrm{F}\right)$ & 80 & 80 & 80 & 80 & 80 & 80 \\
\hline Peak Space Load (Btu/hr) & 37,238 & 32,158 & 23,021 & 20,545 & 18,446 & 19,370 \\
\hline Coincident Wet Bulb Temp. ( $\left.{ }^{\circ} \mathrm{F}\right)$ & 73.7 & 74.4 & 71.0 & 62.2 & 61.3 & 62.1 \\
\hline Coincident Dry Bulb Temp. $\left({ }^{\circ} \mathrm{F}\right)$ & 97.3 & 93.9 & 78.1 & 81.0 & 82.0 & 77.4 \\
\hline Number of Coolerado's & 1 & 1 & 1 & 3 & 1 & 1 \\
\hline Model & M30 & M30 & M30 & M30 & $\mathrm{C} 60$ & $\mathrm{C} 60$ \\
\hline Cooling Cap. at Design Cond. (Btu/hr) & 3,168 & 2,993 & 8,400 & 36,260 & 24,428 & 26,279 \\
\hline Product Flow (cfm) & 974 & 974 & 974 & 2,550 & 1,692 & 1,712 \\
\hline Supply Air Temperature $\left({ }^{\circ} \mathrm{F}\right)$ & 76.8 & 76.9 & 72.0 & 64.3 & 63.5 & 63.9 \\
\hline Wet Bulb Effectiveness (\%) & $86.86 \%$ & $87.20 \%$ & $86.45 \%$ & $89.11 \%$ & $89.43 \%$ & $88.66 \%$ \\
\hline Peak Fan Power (hp) & 0.448 & 0.432 & 0.466 & 1.158 & 0.746 & 0.811 \\
\hline EER at Design Conditions (EER) & 9.5 & 9.3 & 24.2 & 42.0 & 43.9 & 43.5 \\
\hline Exhaust Flow (cfm) & 544 & 544 & 544 & 1,795 & 1,201 & 1,192 \\
\hline Actual Evaporation Rate (gph) & 3.65 & 2.92 & 0.87 & 7.02 & 5.09 & 3.82 \\
\hline Total Water Consumption (gph) & 4.56 & 3.64 & 1.09 & 8.77 & 6.36 & 4.78 \\
\hline Gal per Ton/hr OA (Gal/ton-hr) & 2.67 & 2.66 & 2.05 & 2.74 & 2.78 & 2.61 \\
\hline Annual Operational Parameters & Phoenix (2B) & $\begin{array}{c}\text { Las Vegas } \\
\text { (3B) }\end{array}$ & $\begin{array}{c}\text { Los Angeles } \\
\text { (3B) }\end{array}$ & $\begin{array}{c}\text { Albuquerque } \\
\text { (4B) }\end{array}$ & $\begin{array}{c}\text { Colorado } \\
\text { Springs (5B) }\end{array}$ & Helena (6B) \\
\hline Annual Avg. EER (EER) & 20.4 & 21.6 & 19.5 & 71 & 88 & 86 \\
\hline Annual Avg. Supply Temp. $\left({ }^{\circ} \mathrm{F}\right)$ & 58.3 & 53.0 & 58.0 & 55 & 53 & 61 \\
\hline Percent of Time Load Met (\%) & $43.4 \%$ & $58.7 \%$ & $71.3 \%$ & $97.9 \%$ & $99.1 \%$ & $98.6 \%$ \\
\hline Percent of Time SAT > RAT (\%) & $9.9 \%$ & $1.4 \%$ & $0.0 \%$ & $0.0 \%$ & $0.0 \%$ & $0.0 \%$ \\
\hline
\end{tabular}

\section{Phoenix}

The baseline RTU was sized at 3 tons with a sensible heat ratio (SHR) of $66 \%$ and an OAR of $39.5 \%$. The peak coincident $\mathrm{OA}$ wet bulb temperature was $73.7^{\circ} \mathrm{F}$, with a design space temperature set point of $80^{\circ} \mathrm{F}$ the unit can provide only $1 / 2$ ton of cooling. Based on the annual climatic conditions in Phoenix, the M30 Coolerado unit can meet the space cooling requirements for only $55.3 \%$ of the time that cooling is required and has to be installed as an OA preconditioner. In addition, for $0.6 \%$ of the hours that cooling is required, the Coolerado would be discharging air above $74^{\circ} \mathrm{F}$ if it were running at $100 \%$ fan speed.

The total energy use required to air condition the facility is significantly higher in Phoenix than it is in the other climate zones that were analyzed (see Table 26). The total energy use was calculated when the cooling system was operating and the hourly RTU fan power was calculated while the system was in cooling mode. The onsite water consumption and power plant water use were calculated. In this case the Coolerado was set up as the first stage of cooling; the RTU was the second stage. 
Table 26. Annual Energy and Water Use Comparison

\begin{tabular}{|c|c|c|c|c|c|c|c|c|c|}
\hline & $\begin{array}{c}\text { Cooling } \\
\text { Energy } \\
\text { (kWh) }\end{array}$ & $\begin{array}{c}\text { Fan } \\
\text { Energy } \\
\text { (kWh) }\end{array}$ & $\begin{array}{l}\text { Total } \\
\text { Energy } \\
\text { (kWh) }\end{array}$ & $\begin{array}{c}\text { Onsite } \\
\text { Water Use } \\
\text { (Gal) }\end{array}$ & $\begin{array}{c}\text { Power } \\
\text { Plant } \\
\text { Water } \\
\text { (Gal) }\end{array}$ & $\begin{array}{c}\text { Total } \\
\text { Water Use } \\
\text { (Gal) }\end{array}$ & $\begin{array}{c}\text { Annual } \\
\text { Energy } \\
\text { Costs (\$) }\end{array}$ & $\begin{array}{c}\text { Annual } \\
\text { Water } \\
\text { Costs (\$) }\end{array}$ & $\begin{array}{c}\text { Total } \\
\text { Annual } \\
\text { Costs (\$) }\end{array}$ \\
\hline DX EER 9 & 6,329 & 1,018 & 7,347 & 0 & 22,313 & 22,313 & $\$ 850$ & $\$ 0$ & $\$ 850$ \\
\hline DX EER $9+$ OA Econ & 5,994 & 904 & 6,898 & 0 & 20,948 & 20,948 & $\$ 798$ & $\$ 0$ & $\$ 798$ \\
\hline DX EER 12+OA Econ & 4,409 & 413 & 4,822 & 0 & 14,644 & 14,644 & $\$ 558$ & $\$ 0$ & $\$ 558$ \\
\hline DX EER 12+OA Econ+Evap & 3,334 & 328 & 3,662 & 2,976 & 11,121 & 14,097 & $\$ 424$ & $\$ 11$ & $\$ 435$ \\
\hline Coolerado & 2,640 & - & 2,640 & 10,966 & 8,016 & 18,983 & $\$ 305$ & $\$ 41$ & $\$ 347$ \\
\hline
\end{tabular}

The energy savings from the airside economizer were marginal because the facility has high ventilation rates. The new RTU with an EER of 12 reduces energy use by $34 \%$ and the new RTU with an EER of 12, an OA economizer, indirect evaporative cooling, and condenser air evaporative precooling saves $50 \%$ energy annually. The O\&M costs for the evaporatively cooled DX unit and Coolerado are listed as the O\&M cost premium over the cost of a standard RTU. The Coolerado pre-cooler for the older RTU with an EER of 9 saves the most energy and is the most expensive retrofit option. The percent reduction in energy use is represented as the reduction in cooling energy use for the purposes of comparison. The annual cost savings presented in Table 27 for the DX EER 12 cases include the fan energy savings in heating mode, and the reduction in heating energy use (as denoted by the double asterisk). Thus, the annual costs savings are greater for the DX EER 12 case with evaporative technologies, even though the cooling savings are not as great as for the Coolerado OA pre-conditioner. All the retrofit options have a positive NPV (assuming a 40-yr project lifetime, which is recommended for federal life cycle costing) and the DX EER with evaporative technologies has the highest NPV.

Table 27. Annual Energy Savings and Economics

\begin{tabular}{|c|c|c|c|c|c|c|c|c|c|}
\hline & $\begin{array}{l}\text { Total } \\
\text { Energy } \\
\text { (kWh) }\end{array}$ & $\begin{array}{c}\text { Total } \\
\text { Water } \\
\text { Use (Gal) }\end{array}$ & $\begin{array}{c}\text { Total } \\
\text { Annual } \\
\text { Costs (\$) }\end{array}$ & $\begin{array}{c}\text { Percent } \\
\text { Reduction } \\
\text { Energy Use } \\
\text { (\%) }\end{array}$ & \begin{tabular}{|} 
**Annual \\
Cost \\
Savings \\
(\$)
\end{tabular} & $\begin{array}{l}\text { Installed } \\
\text { Costs (\$) }\end{array}$ & $\begin{array}{c}\text { Annual } \\
\text { O\&M } \\
\text { Costs (\$) }\end{array}$ & $\begin{array}{c}\text { Simple } \\
\text { Payback } \\
\text { (yrs) }\end{array}$ & $\begin{array}{c}\text { Net } \\
\text { Present } \\
\text { Value (\$) }\end{array}$ \\
\hline DX EER 9 & 7,347 & 22,313 & $\$ 850$ & - & - & - & - & - & - \\
\hline DX EER 9 + OA Econ & 6,898 & 20,948 & $\$ 798$ & $6 \%$ & $\$ 52$ & $\$ 500$ & $\$ 0$ & 9.6 & $\$ 801$ \\
\hline DX EER 12+OA Econ & 4,822 & 14,644 & $\$ 558$ & $34 \%$ & $\$ 426$ & $\$ 5,622$ & $\$ 0$ & 13.2 & $\$ 5,033$ \\
\hline DX EER 12+OA Econ+Evap & 3,662 & 14,097 & $\$ 435$ & $50 \%$ & $\$ 549$ & $\$ 6,848$ & $\$ 36$ & 13.3 & $\$ 5,983$ \\
\hline Coolerado & 2,640 & 18,983 & $\$ 347$ & $64 \%$ & $\$ 504$ & $\$ 5,154$ & $\$ 36$ & 11.0 & $\$ 6,552$ \\
\hline
\end{tabular}

Space cooling is required throughout the year because the classroom has internal loads, and the Coolerado pre-cooler can provide the necessary cooling for approximately six months per year. Phoenix experiences temperatures below freezing for only $8 \mathrm{~h} / \mathrm{yr}$, so the system was assumed to be operable throughout the year. During the summer the RTU refrigeration system has to kick on to meet the space cooling load. The annual operational EER with the combined Coolerado and packaged RTU is 20.4 and the combined system significantly reduces the peak demand each month (see Figure 62). 


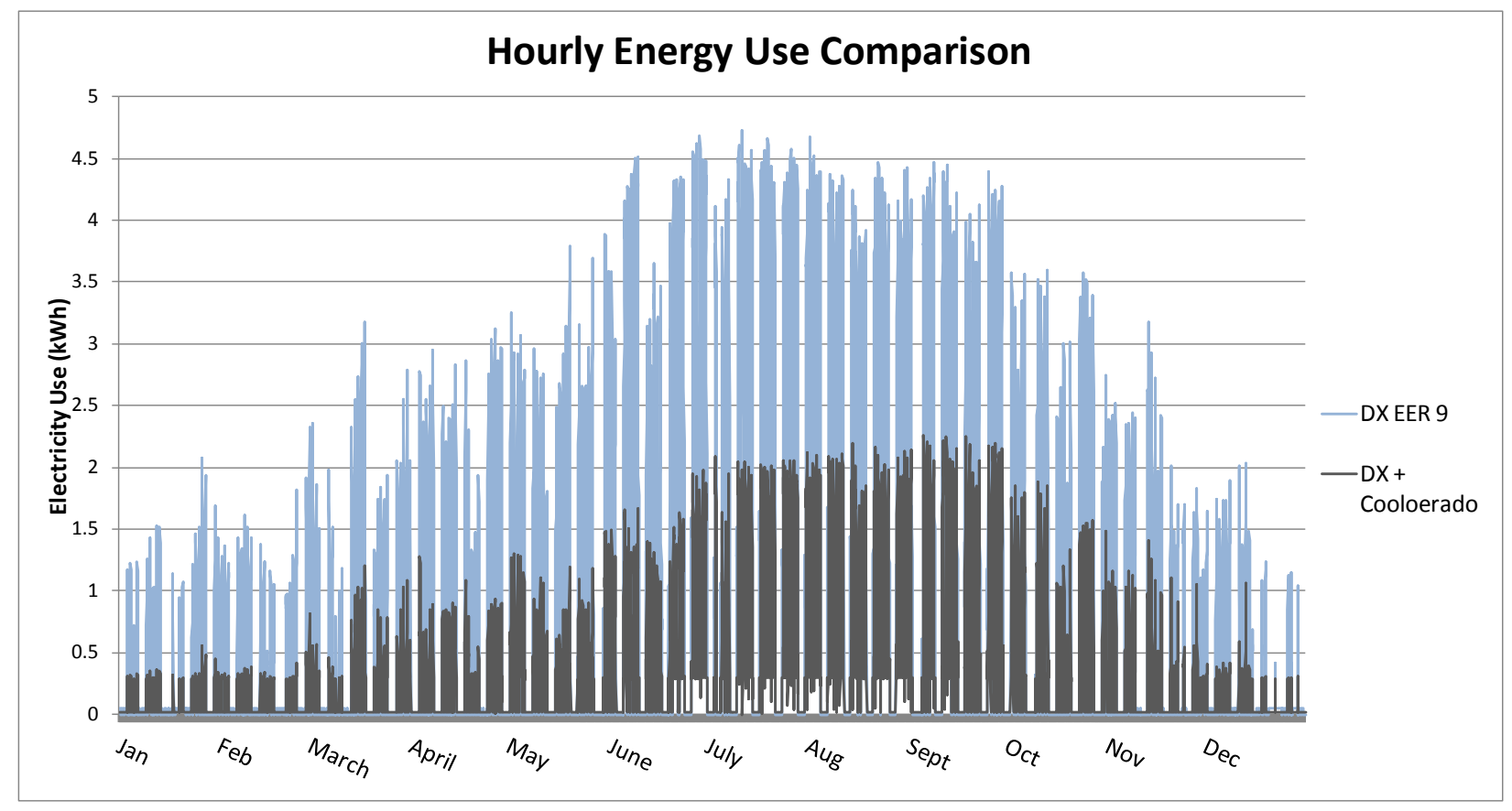

Figure 62. Hourly RTU EER 9 and DX Plus Coolerado energy use

Figure 63 shows the hourly OAT, OA wet bulb temperature, and OA SAT for the Coolerado unit. Although the OATs in Phoenix are consistently $85^{\circ}-105^{\circ} \mathrm{F}$, the wet bulb temperatures are significantly lower and peak around $75^{\circ} \mathrm{F}$ in July. The Coolerado SATs (shown in black) indicate that the unit operates with a WBE $>100 \%$ for parts of the year, especially when the fan is turned down to $400 \mathrm{cfm}$ to cool OA during the peak summer months.

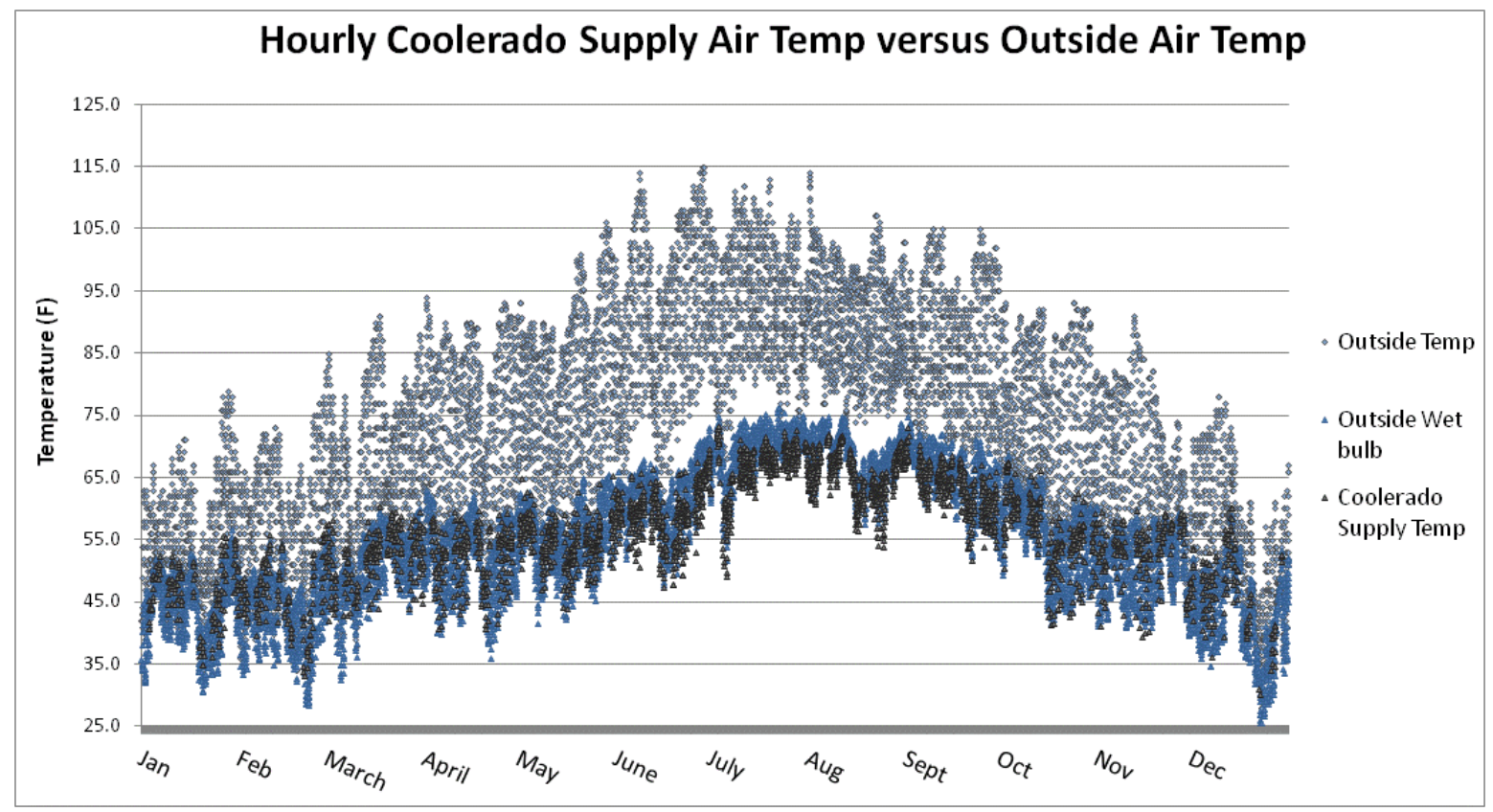

Figure 63. Hourly OA and Coolerado SATs 


\section{Las Vegas}

The baseline RTU was sized at $<3$ tons with an SHR of $61.8 \%$ and an OAR of $40.6 \%$. The peak coincident $\mathrm{OA}$ wet bulb temperature was $74.4^{\circ} \mathrm{F}$. With a design space temperature set point of $80^{\circ} \mathrm{F}$, the unit can provide less than $1 / 2$ ton of cooling. Based on the annual climatic conditions in Las Vegas, the M30 Coolerado unit can meet the space cooling requirements for only $58.7 \%$ of the time cooling is required and has to be installed as an OA pre-conditioner. In addition, for $1.4 \%$ of the hours cooling is required, the Coolerado would discharge air warmer than $74^{\circ} \mathrm{F}$ at $100 \%$ fan speed.

The total energy use required for air-conditioning the facility is relatively high in Las Vegas, but lower than in Phoenix (see Table 28). The total energy use of the cooling system and the RTU fans when the system was in cooling mode was calculated, as well as the onsite water consumption and power plant water consumption. In this case the Coolerado was set up as the first stage of cooling; the RTU was the second stage.

Table 28. Annual Energy and Water Use Comparison

\begin{tabular}{|c|c|c|c|c|c|c|c|c|c|}
\hline & $\begin{array}{c}\text { Cooling } \\
\text { Energy } \\
\text { (kWh) }\end{array}$ & $\begin{array}{c}\text { Fan } \\
\text { Energy } \\
\text { (kWh) } \\
\end{array}$ & $\begin{array}{c}\text { Total } \\
\text { Energy } \\
\text { (kWh) } \\
\end{array}$ & $\begin{array}{c}\text { Onsite } \\
\text { Water Use } \\
\text { (Gal) }\end{array}$ & $\begin{array}{c}\text { Power } \\
\text { Plant } \\
\text { Water } \\
\text { (Gal) } \\
\end{array}$ & $\begin{array}{c}\text { Total } \\
\text { Water Use } \\
\text { (Gal) } \\
\end{array}$ & $\begin{array}{c}\text { Annual } \\
\text { Energy } \\
\text { Costs (\$) }\end{array}$ & $\begin{array}{l}\text { Annual } \\
\text { Water } \\
\text { Costs (\$) }\end{array}$ & $\begin{array}{c}\text { Total } \\
\text { Annual } \\
\text { Costs (\$) }\end{array}$ \\
\hline DX EER 9 & 4,766 & 864 & 5,630 & 0 & 17,098 & 17,098 & $\$ 782$ & $\$ 0$ & $\$ 782$ \\
\hline DX EER $9+$ OA Econ & 4,351 & 707 & 5,059 & 0 & 15,363 & 15,363 & $\$ 703$ & $\$ 0$ & $\$ 703$ \\
\hline DX EER 12+OA Econ & 3,371 & 380 & 3,752 & 0 & 11,394 & 11,394 & $\$ 521$ & $\$ 0$ & $\$ 521$ \\
\hline DX EER 12+OA Econ+Evap & 2,463 & 283 & 2,747 & 2,711 & 8,341 & 11,052 & $\$ 382$ & $\$ 10$ & $\$ 392$ \\
\hline Coolerado & 1,855 & - & 1,855 & 8,494 & 5,634 & 14,128 & $\$ 258$ & $\$ 32$ & $\$ 290$ \\
\hline
\end{tabular}

The energy savings from an airside economizer are marginal because the facility has high ventilation rates. The new RTU with an EER of 12 reduces energy use by $33 \%$ and the new RTU with an EER of 12, an OA economizer, IEC, and condenser air evaporative precooling saves $51 \%$ of energy annually. The Coolerado pre-cooler for the older RTU with an EER of 9 saves the most energy annually and is the most expensive retrofit option. All the retrofit options have a positive NPV (assuming a 40-yr project lifetime, which is recommended for federal life cycle costing) and the DX EER with evaporative technologies has the highest NPV (see Table 29).

Table 29. Annual Energy Savings and Economics

\begin{tabular}{|c|c|c|c|c|c|c|c|c|c|}
\hline & $\begin{array}{c}\text { Total } \\
\text { Energy } \\
\text { (kWh) }\end{array}$ & $\begin{array}{c}\text { Total } \\
\text { Water } \\
\text { Use (Gal) }\end{array}$ & $\begin{array}{c}\text { Total } \\
\text { Annual } \\
\text { Costs (\$) }\end{array}$ & \begin{tabular}{|c} 
Percent \\
Reduction \\
Energy Use \\
$(\%)$ \\
\end{tabular} & $\begin{array}{c}* * \text { Annual } \\
\text { Cost } \\
\text { Savings } \\
\text { (\$) }\end{array}$ & $\begin{array}{l}\text { Installed } \\
\text { Costs (\$) }\end{array}$ & $\begin{array}{c}\text { Annual } \\
\text { O\&M } \\
\text { Costs (\$) }\end{array}$ & $\begin{array}{c}\text { Simple } \\
\text { Payback } \\
\text { (yrs) }\end{array}$ & \begin{tabular}{|c} 
Net \\
Present \\
Value (\$)
\end{tabular} \\
\hline DX EER 9 & 5,630 & 17,098 & $\$ 782$ & - & - & - & - & - & - \\
\hline DX EER $9+$ OA Econ & 5,059 & 15,363 & $\$ 703$ & $10 \%$ & $\$ 79$ & $\$ 500$ & $\$ 0$ & 6.3 & $\$ 1,476$ \\
\hline DX EER 12+OA Econ & 3,752 & 11,394 & $\$ 521$ & $33 \%$ & $\$ 493$ & $\$ 6,252$ & $\$ 0$ & 12.7 & $\$ 6,079$ \\
\hline DX EER 12+OA Econ+Evap & 2,747 & 11,052 & $\$ 392$ & $51 \%$ & $\$ 623$ & $\$ 8,469$ & $\$ 40$ & 14.5 & $\$ 6,113$ \\
\hline Coolerado & 1,855 & 14,128 & $\$ 290$ & $67 \%$ & $\$ 492$ & $\$ 5,731$ & $\$ 40$ & 12.7 & $\$ 5,599$ \\
\hline
\end{tabular}

Space cooling is required throughout the year because the classroom has high internal loads. The Coolerado pre-cooler can provide the necessary cooling for approximately seven months per 
year. During the summer the RTU refrigeration system has to kick on to meet the space cooling load. The annual operational EER with the combined Coolerado and packaged RTU is 21.6 and the combined system significantly reduces the peak demand each month (see Figure 64).

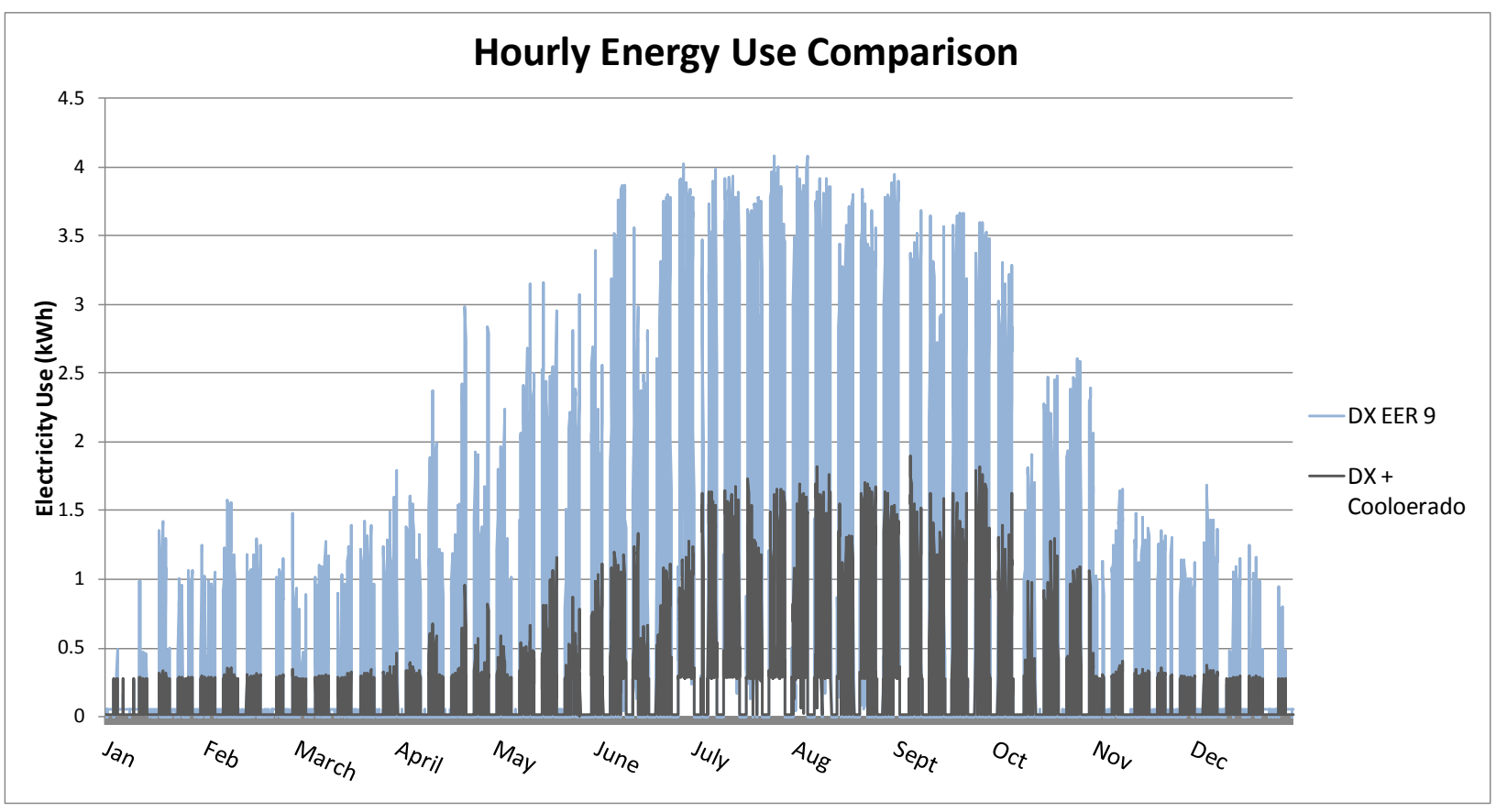

Figure 64. Hourly RTU EER 9 and DX Plus Coolerado energy use

\section{Los Angeles}

The baseline RTU was sized at $<2$ tons with an SHR of $89.1 \%$ and an OAR of $45.8 \%$. The peak coincident $\mathrm{OA}$ wet bulb temperature was $71^{\circ} \mathrm{F}$. With a design space temperature set point of $80^{\circ} \mathrm{F}$ the unit can provide $<1.5$ tons of cooling. Based on the annual climatic conditions in Los Angeles, the M60 Coolerado unit can meet the space cooling requirements for $71.3 \%$ of the time cooling is required and has to be installed as an OA pre-conditioner. Although Los Angles is in the same climate zone as Las Vegas, the climate has lower outdoor air temperatures and the total annual cooling energy requirements are significantly lower (see Table 30 ).

Table 30. Annual Energy and Water Use Comparison

\begin{tabular}{|l|c|c|c|c|c|c|c|c|c|} 
& $\begin{array}{c}\text { Cooling } \\
\text { Energy } \\
\text { (kWh) }\end{array}$ & $\begin{array}{c}\text { Fan } \\
\text { Energy } \\
\text { (kWh) }\end{array}$ & $\begin{array}{c}\text { Total } \\
\text { Energy } \\
\text { (kWh) }\end{array}$ & $\begin{array}{c}\text { Onsite } \\
\text { Water Use } \\
\text { (Gal) }\end{array}$ & $\begin{array}{c}\text { Power } \\
\text { Plant } \\
\text { Water } \\
\text { (Gal) }\end{array}$ & $\begin{array}{c}\text { Total } \\
\text { Water Use } \\
\text { (Gal) }\end{array}$ & $\begin{array}{c}\text { Annual } \\
\text { Energy } \\
\text { Costs (\$) }\end{array}$ & $\begin{array}{c}\text { Annual } \\
\text { Water } \\
\text { Costs (\$) }\end{array}$ & $\begin{array}{c}\text { Total } \\
\text { Annual } \\
\text { Costs (\$) }\end{array}$ \\
\hline \hline DX EER 9 & 2,130 & 598 & 2,728 & 0 & 8,286 & 8,286 & $\$ 275$ & $\$ 0$ & $\$ 275$ \\
DX EER 9 + OA Econ & 1,437 & 387 & 1,824 & 0 & 5,538 & 5,538 & $\$ 184$ & $\$ 0$ & $\$ 184$ \\
DX EER 12+OA Econ & 1,789 & 235 & 2,024 & 0 & 6,148 & 6,148 & $\$ 204$ & $\$ 0$ & $\$ 204$ \\
DX EER 12+OA Econ+Evap & 1,805 & 194 & 1,999 & 565 & 6,071 & 6,636 & $\$ 202$ & $\$ 2$ & $\$ 204$ \\
Coolerado & 1,152 & - & 1,152 & 2,140 & 3,498 & 5,638 & $\$ 116$ & $\$ 8$ & $\$ 124$
\end{tabular}

The energy savings from an airside economizer are higher in Los Angeles than in the previous two climates because of the mild climate. The new RTU with an EER of 12 reduces energy use by $26 \%$ and the new RTU with an EER of 12, an OA economizer, IEC, and condenser air 
evaporative precooling saves $27 \%$ in energy annually. The Coolerado pre-cooler for the older RTU with an EER of 9 saves the most energy and is the most expensive retrofit option. In this case, the annual cooling loads are reduced, so only adding an outside economizer and replacing the unit with a new RTU with an EER of 12 and an OA economizer are cost effective (see Table $31)$.

Table 31. Annual Energy Savings and Economics

\begin{tabular}{|c|c|c|c|c|c|c|c|c|c|}
\hline & $\begin{array}{l}\text { Total } \\
\text { Energy } \\
\text { (kWh) } \\
\end{array}$ & $\begin{array}{c}\text { Total } \\
\text { Water } \\
\text { Use (Gal) }\end{array}$ & $\begin{array}{c}\text { Total } \\
\text { Annual } \\
\text { Costs (\$) }\end{array}$ & \begin{tabular}{|c} 
Percent \\
Reduction \\
Energy Use \\
$(\%)$ \\
\end{tabular} & $\begin{array}{c}* * \text { Annual } \\
\text { Cost } \\
\text { Savings } \\
\text { (\$) }\end{array}$ & $\begin{array}{l}\text { Installed } \\
\text { Costs (\$) }\end{array}$ & $\begin{array}{c}\text { Annual } \\
\text { O\&M } \\
\text { Costs (\$) }\end{array}$ & $\begin{array}{c}\text { Simple } \\
\text { Payback } \\
\text { (yrs) }\end{array}$ & $\begin{array}{c}\text { Net } \\
\text { Present } \\
\text { Value (\$) }\end{array}$ \\
\hline DX EER 9 & 2,728 & 8,286 & $\$ 275$ & - & - & - & - & - & - \\
\hline DX EER $9+$ OA Econ & 1,824 & 5,538 & $\$ 184$ & $33 \%$ & $\$ 91$ & $\$ 500$ & $\$ 0$ & 5.5 & $\$ 1,776$ \\
\hline DX EER 12+OA Econ & 2,024 & 6,148 & $\$ 204$ & $26 \%$ & $\$ 199$ & $\$ 3,159$ & $\$ 0$ & 15.9 & $\$ 1,818$ \\
\hline DX EER 12+OA Econ+Evap & 1,999 & 6,636 & $\$ 204$ & $27 \%$ & $\$ 197$ & $\$ 4,324$ & $\$ 40$ & 27.6 & $-\$ 397$ \\
\hline Coolerado & 1,152 & 5,638 & $\$ 124$ & $58 \%$ & $\$ 151$ & $\$ 5,792$ & $\$ 40$ & 52.1 & $-\$ 3,016$ \\
\hline
\end{tabular}

Space cooling is required throughout the year because the classroom's internal loads are high, and the Coolerado pre-cooler can provide the necessary cooling for approximately eight months per year. During the summer the RTU refrigeration system has to kick on to meet the space cooling load. The annual operational EER with the combined Coolerado and packaged RTU is 19.5 and the combined system significantly reduces the peak demand each month of the year (see Figure 65).

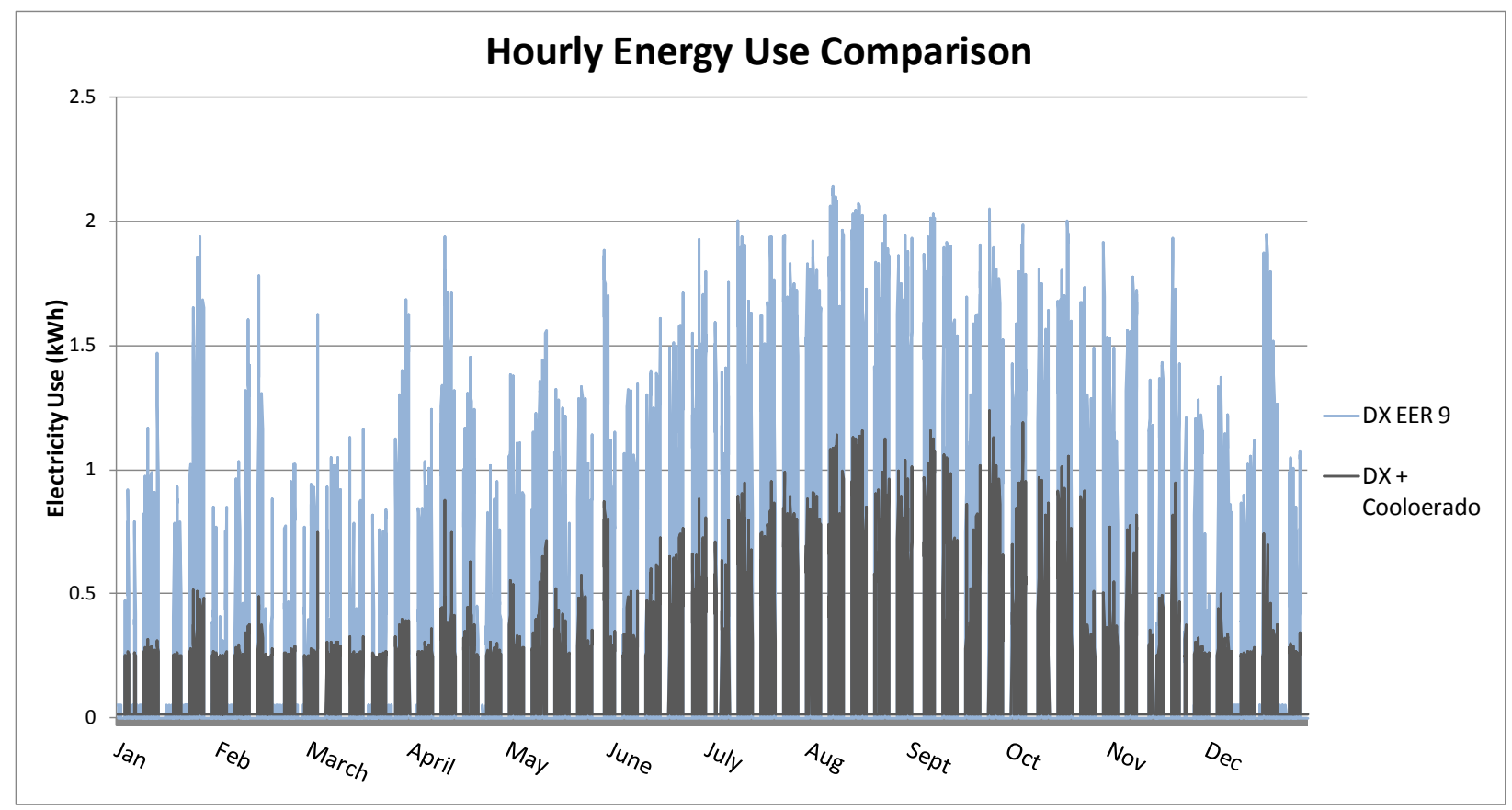

Figure 65. Hourly RTU EER 9 and DX Plus Coolerado energy use

Figure 66 shows the hourly OAT, OA wet bulb temperature, and OA SAT from the Coolerado. The climate in Los Angeles is significantly different than the two previous climates, with much 
lower OATs and higher relative humidities. The Coolerado SATs (shown in black) indicate that the unit operates with a WBE $>100 \%$ for fewer months of the year, especially when the fan is turned to $400 \mathrm{cfm}$ to just cool OA during the peak summer months.

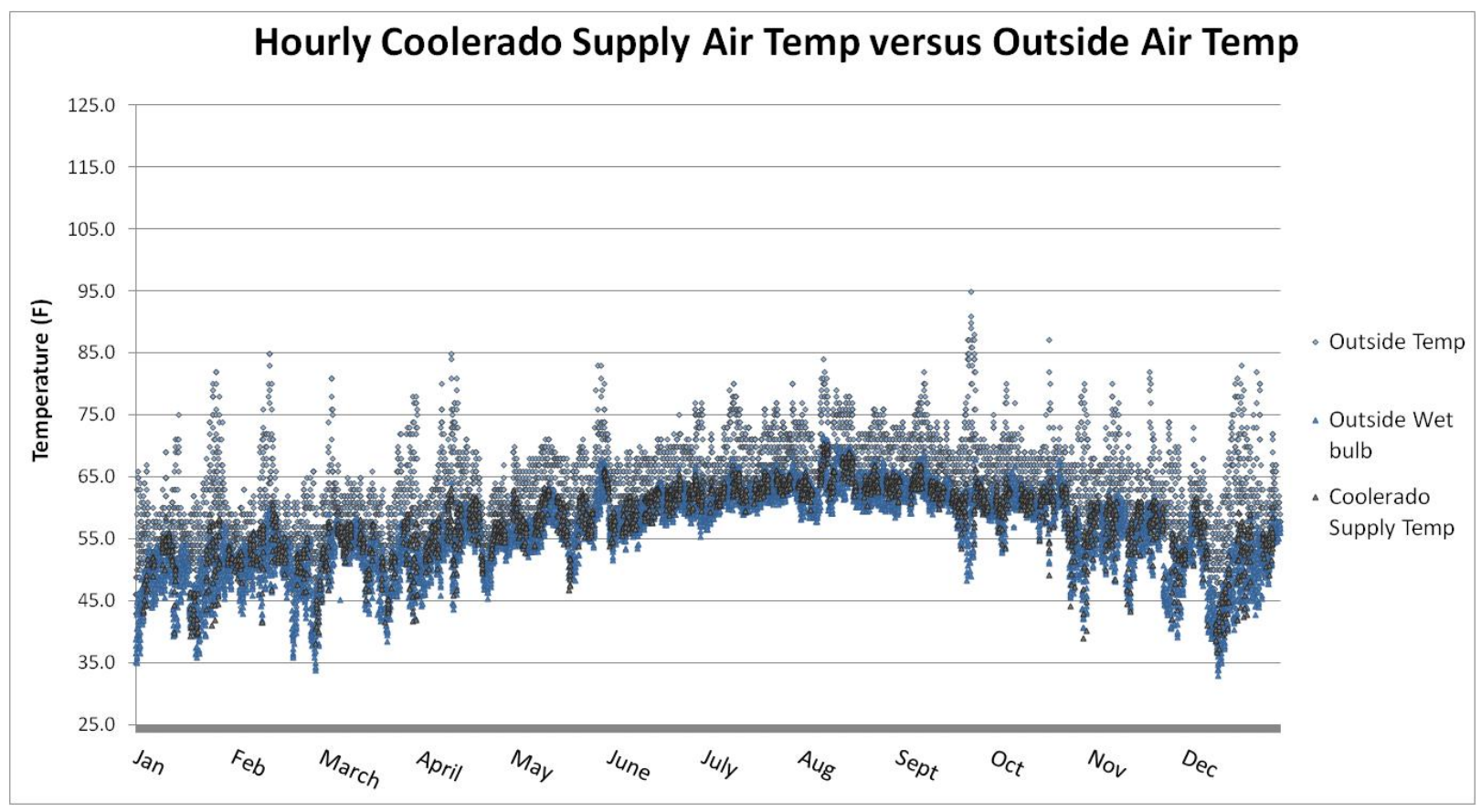

Figure 66. Hourly OATs and Coolerado SATs

\section{Albuquerque}

The baseline RTU was sized at $<2$ tons with an SHR of $78.3 \%$ and an OAR of $46 \%$. The peak coincident $\mathrm{OA}$ wet bulb temperature was $62.2^{\circ} \mathrm{F}$. With a design space temperature set point of $80^{\circ} \mathrm{F}$, the unit can provide approximately 3 tons of cooling. Based on the annual climatic conditions in Albuquerque, the C60 Coolerado unit can meet the space cooling requirements for $97.8 \%$ of the time cooling is required and was designed as a standalone zone cooler (see Table $32)$.

Table 32. Annual Energy and Water Use Comparison

\begin{tabular}{|l|c|c|c|c|c|c|c|c|c||}
\hline & $\begin{array}{c}\text { Cooling } \\
\text { Energy } \\
\text { (kWh) }\end{array}$ & $\begin{array}{c}\text { Fan } \\
\text { Energy } \\
\text { (kWh) }\end{array}$ & $\begin{array}{c}\text { Total } \\
\text { Energy } \\
\text { (kWh) }\end{array}$ & $\begin{array}{c}\text { Onsite } \\
\text { Water Use } \\
\text { (Gal) }\end{array}$ & $\begin{array}{c}\text { Power } \\
\text { Plant } \\
\text { Water } \\
\text { (Gal) }\end{array}$ & $\begin{array}{c}\text { Total } \\
\text { Water Use } \\
\text { (Gal) }\end{array}$ & $\begin{array}{c}\text { Annual } \\
\text { Energy } \\
\text { Costs (\$) }\end{array}$ & $\begin{array}{c}\text { Annual } \\
\text { Water } \\
\text { Costs (\$) }\end{array}$ & $\begin{array}{c}\text { Total } \\
\text { Annual } \\
\text { Costs (\$) }\end{array}$ \\
\hline \hline DX EER 9 & 2,230 & 455 & 2,685 & 0 & 8,154 & 8,154 & $\$ 201$ & $\$ 0$ & $\$ 201$ \\
DX EER 9+ OA Econ & 1,969 & 346 & 2,315 & 0 & 7,032 & 7,032 & $\$ 173$ & $\$ 0$ & $\$ 173$ \\
DX EER 12+OA Econ & 1,735 & 220 & 1,956 & 0 & 5,939 & 5,939 & $\$ 146$ & $\$ 0$ & $\$ 146$ \\
DX EER 12+OA Econ+Evap & 1,455 & 159 & 1,614 & 1,402 & 4,902 & 6,303 & $\$ 121$ & $\$ 5$ & $\$ 126$ \\
Coolerado & 910 & - & 910 & 4,377 & 2,762 & 7,139 & $\$ 68$ & $\$ 16$ & $\$ 84$ \\
\hline
\end{tabular}

An airside economizer reduces annual energy use by 14\%. The new RTU with an EER of 12 reduces energy use by $27 \%$ and the new RTU with an EER of 12 , an OA economizer, IEC, and 
condenser air evaporative precooling saves $40 \%$ in annual energy use. The zone-level Coolerado saves $66 \%$ in energy use annually. The unit needs to be shut down and winterized, so it was assumed to be turned off from October through April, when freezing temperatures may occur. For this climate zone, additional Coolerado cooling cores were added to the model to increase the number of hours the zone load is met, and 3 M30 units were modeled to supply air to this space. In this case all the retrofit options except the Coolerado have a positive NPV, because of the relatively small annual cooling load, the increased number of Coolerado cooling cores, and the need to shut down and winterize the unit (see Table 33).

Table 33. Annual Energy Savings and Economics

\begin{tabular}{|l|c|c|c|c|c|c|c|c|c||}
\hline & $\begin{array}{c}\text { Total } \\
\text { Energy } \\
\text { (kWh) }\end{array}$ & $\begin{array}{c}\text { Total } \\
\text { Water } \\
\text { Use (Gal) }\end{array}$ & $\begin{array}{c}\text { Total } \\
\text { Annual } \\
\text { Costs (\$) }\end{array}$ & $\begin{array}{c}\text { Percent } \\
\text { Reduction } \\
\text { Energy Use } \\
(\%)\end{array}$ & $\begin{array}{c}\text { Annual } \\
\text { Cost } \\
\text { Savings } \\
(\mathbf{\$})\end{array}$ & $\begin{array}{c}\text { Installed } \\
\text { Costs (\$) }\end{array}$ & $\begin{array}{c}\text { Annual } \\
\text { O\&M } \\
\text { Costs (\$) }\end{array}$ & $\begin{array}{c}\text { Simple } \\
\text { Payback } \\
\text { (yrs) }\end{array}$ & $\begin{array}{c}\text { Net } \\
\text { Present } \\
\text { Value (\$) }\end{array}$ \\
\hline \hline DX EER 9 & 2,685 & 8,154 & $\$ 201$ & - & - & - & - & - & - \\
DX EER 9+OA Econ & 2,315 & 7,032 & $\$ 173$ & $14 \%$ & $\$ 28$ & $\$ 500$ & $\$ 0$ & 18.1 & $\$ 200$ \\
DX EER 12+OA Econ & 1,956 & 5,939 & $\$ 146$ & $27 \%$ & $\$ 349$ & $\$ 3,496$ & $\$ 0$ & 10.0 & $\$ 5,233$ \\
DX EER 12+OA Econ+Evap & 1,614 & 6,303 & $\$ 126$ & $40 \%$ & $\$ 369$ & $\$ 3,972$ & $\$ 33$ & 11.8 & $\$ 4,432$ \\
Coolerado & 910 & 7,139 & $\$ 84$ & $66 \%$ & $\$ 116$ & $\$ 14,421$ & $\$ 33$ & 173.5 & $-\$ 12,345$ \\
\hline
\end{tabular}

The winter cooling load is lower in Albuquerque, and is assumed to be picked up by the RTU. During the summer the Coolerado unit can handle the space load most of the time. During July, August, and part of September the unit will operate at 100\% fan speed, and for a few hours per year the space temperature will exceed $74^{\circ} \mathrm{F}$. The annual operational EER for the Coolerado is 71 , and the combined annual EER, including the RTU operation during the winter is 54.5. The Coolerado unit significantly reduces the peak demand in the summer and has no energy benefit in the winter if it has to be winterized (see Figure 67).

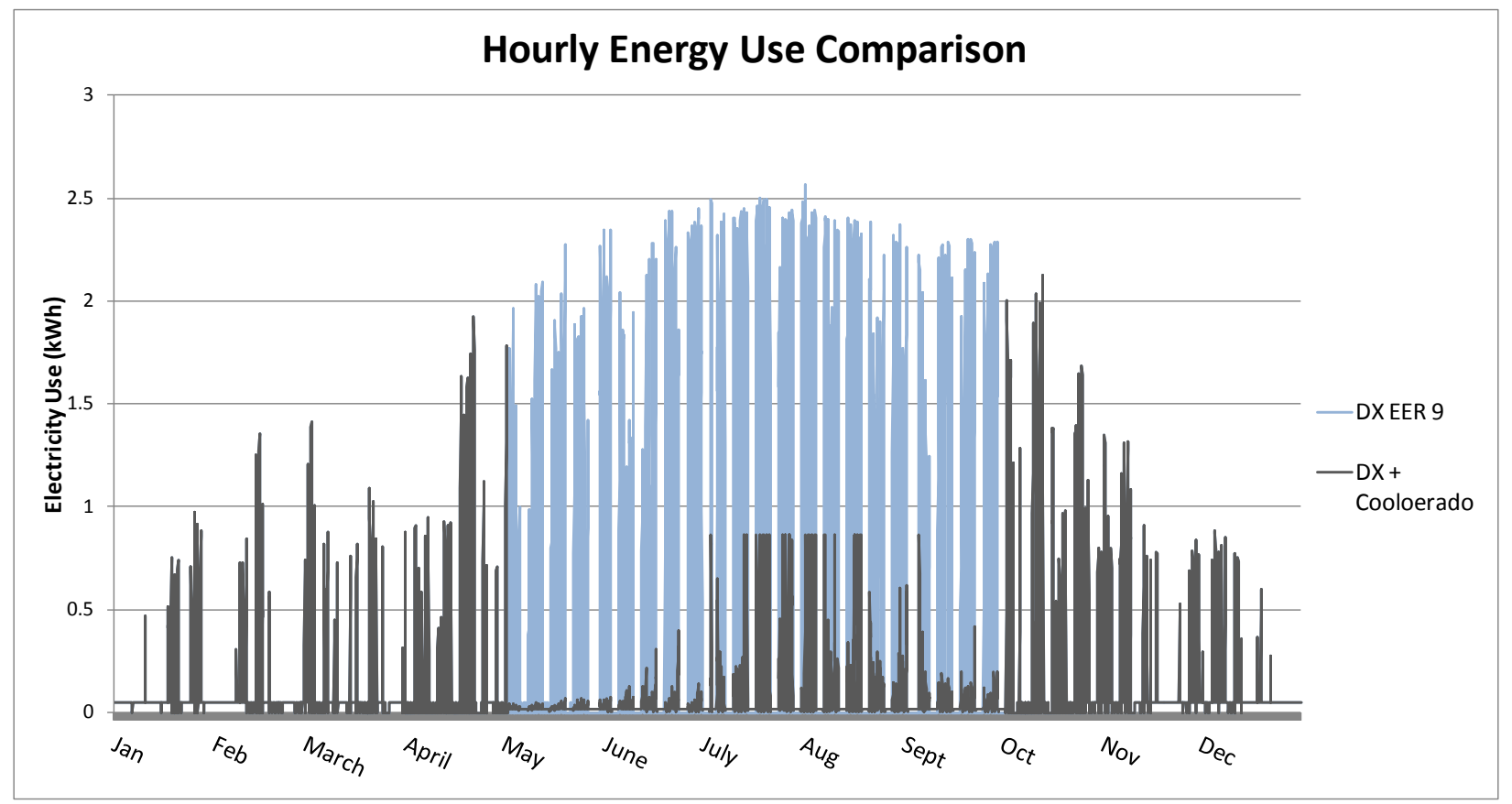

Figure 67. Hourly RTU EER 9 and DX Plus Coolerado energy use 


\section{Colorado Springs}

The baseline RTU was sized at $<1.5$ tons with an SHR of $94 \%$ and an OAR of $48.7 \%$. The peak coincident $\mathrm{OA}$ wet bulb temperature was $61.3^{\circ} \mathrm{F}$. With a design space temperature set point of $80^{\circ} \mathrm{F}$ the unit can provide approximately 1.5 tons of cooling. Based on the annual climatic conditions in Colorado Springs, the unit can meet the space cooling requirements for $99.1 \%$ of the time cooling is required and was designed as a standalone zone cooler (see Table 34).

Table 34. Annual Energy and Water Use Comparison

\begin{tabular}{|c|c|c|c|c|c|c|c|c|c|}
\hline & $\begin{array}{c}\text { Cooling } \\
\text { Energy } \\
\text { (kWh) }\end{array}$ & $\begin{array}{c}\text { Fan } \\
\text { Energy } \\
\text { (kWh) }\end{array}$ & $\begin{array}{c}\text { Total } \\
\text { Energy } \\
\text { (kWh) } \\
\end{array}$ & $\begin{array}{c}\text { Onsite } \\
\text { Water Use } \\
\text { (Gal) }\end{array}$ & $\begin{array}{c}\text { Power } \\
\text { Plant } \\
\text { Water } \\
\text { (Gal) }\end{array}$ & $\begin{array}{c}\text { Total } \\
\text { Water Use } \\
\text { (Gal) }\end{array}$ & $\begin{array}{c}\text { Annual } \\
\text { Energy } \\
\text { Costs (\$) }\end{array}$ & $\begin{array}{c}\text { Annual } \\
\text { Water } \\
\text { Costs (\$) }\end{array}$ & $\begin{array}{c}\text { Total } \\
\text { Annual } \\
\text { Costs (\$) }\end{array}$ \\
\hline DX EER 9 & 1,335 & 309 & 1,644 & 0 & 4,993 & 4,993 & $\$ 123$ & $\$ 0$ & $\$ 123$ \\
\hline DX EER $9+$ OA Econ & 1,139 & 221 & 1,359 & 0 & 4,127 & 4,127 & $\$ 102$ & $\$ 0$ & $\$ 102$ \\
\hline DX EER 12+OA Econ & 1,108 & 158 & 1,266 & 0 & 3,844 & 3,844 & $\$ 95$ & $\$ 0$ & $\$ 95$ \\
\hline DX EER 12+OA Econ+Evap & 995 & 104 & 1,098 & 903 & 3,336 & 4,239 & $\$ 82$ & $\$ 3$ & $\$ 86$ \\
\hline Coolerado & 584 & - & 584 & 2,622 & 1,774 & 4,395 & $\$ 44$ & $\$ 10$ & $\$ 54$ \\
\hline
\end{tabular}

An airside economizer reduces energy use by 17\% annually. The new RTU with an EER of 12 saves $23 \%$ in energy use and the new RTU with an EER of 12, an OA economizer, IIEC, and condenser air evaporative precooling saves 33\% in energy use annually. The zone level Coolerado saves $64 \%$ in energy use. The unit needs to be shut down and winterized, so it was assumed to be turned off from October through April, when freezing conditions may occur. In this case all the retrofit options except the Coolerado unit have a positive NPV because of the relatively small annual cooling load, the cost of the Coolerado installation, and the need to shut down and winterize the unit (see Table 35).

Table 35. Annual Energy Savings and Economics

\begin{tabular}{|l|c|c|c|c|c|c|c|c|c||}
\hline & $\begin{array}{c}\text { Total } \\
\text { Energy } \\
(\mathbf{k W h})\end{array}$ & $\begin{array}{c}\text { Total } \\
\text { Water } \\
\text { Use (Gal) }\end{array}$ & $\begin{array}{c}\text { Total } \\
\text { Annual } \\
\text { Costs (\$) }\end{array}$ & $\begin{array}{c}\text { Percent } \\
\text { Reduction } \\
\text { Energy Use } \\
\mathbf{( \% )}\end{array}$ & $\begin{array}{c}\text { Annual } \\
\text { Cost } \\
\text { Savings } \\
\mathbf{( \$ )}\end{array}$ & $\begin{array}{c}\text { Installed } \\
\text { Costs (\$) }\end{array}$ & $\begin{array}{c}\text { Annual } \\
\text { O\&M } \\
\text { Costs (\$) }\end{array}$ & $\begin{array}{c}\text { Simple } \\
\text { Payback } \\
\text { (yrs) }\end{array}$ & $\begin{array}{c}\text { Net } \\
\text { Present } \\
\text { Value (\$) }\end{array}$ \\
\hline \hline DX EER 9 & 1,644 & 4,993 & $\$ 123$ & - & - & - & - & - & - \\
DX EER 9+OA Econ & 1,359 & 4,127 & $\$ 102$ & $17 \%$ & $\$ 21$ & $\$ 500$ & $\$ 0$ & 23.5 & $\$ 25$ \\
DX EER 12+OA Econ & 1,266 & 3,844 & $\$ 95$ & $23 \%$ & $\$ 460$ & $\$ 2,700$ & $\$ 0$ & 5.9 & $\$ 8,806$ \\
DX EER 12+OA Econ+Evap & 1,098 & 4,239 & $\$ 86$ & $33 \%$ & $\$ 469$ & $\$ 3,159$ & $\$ 34$ & 7.3 & $\$ 7,696$ \\
Coolerado & 584 & 4,395 & $\$ 54$ & $64 \%$ & $\$ 69$ & $\$ 9,702$ & $\$ 34$ & 275.2 & $-\$ 8,827$ \\
\hline
\end{tabular}

The winter cooling load is lower in Colorado Springs, and is assumed to be picked up by the RTU. During the summer the Coolerado unit can handle the space load for most of the time. During August the unit will operate at $100 \%$ fan speed, and for a few hours per year the space temperature will exceed $74^{\circ} \mathrm{F}$. The annual operational EER for the Coolerado is 88 , and the combined annual EER, including the RTU operation during winter months, is 53.5. The Coolerado unit significantly reduces the peak demand in the summer and has no energy benefit in the winter if it has to be winterized (see Figure 68). 


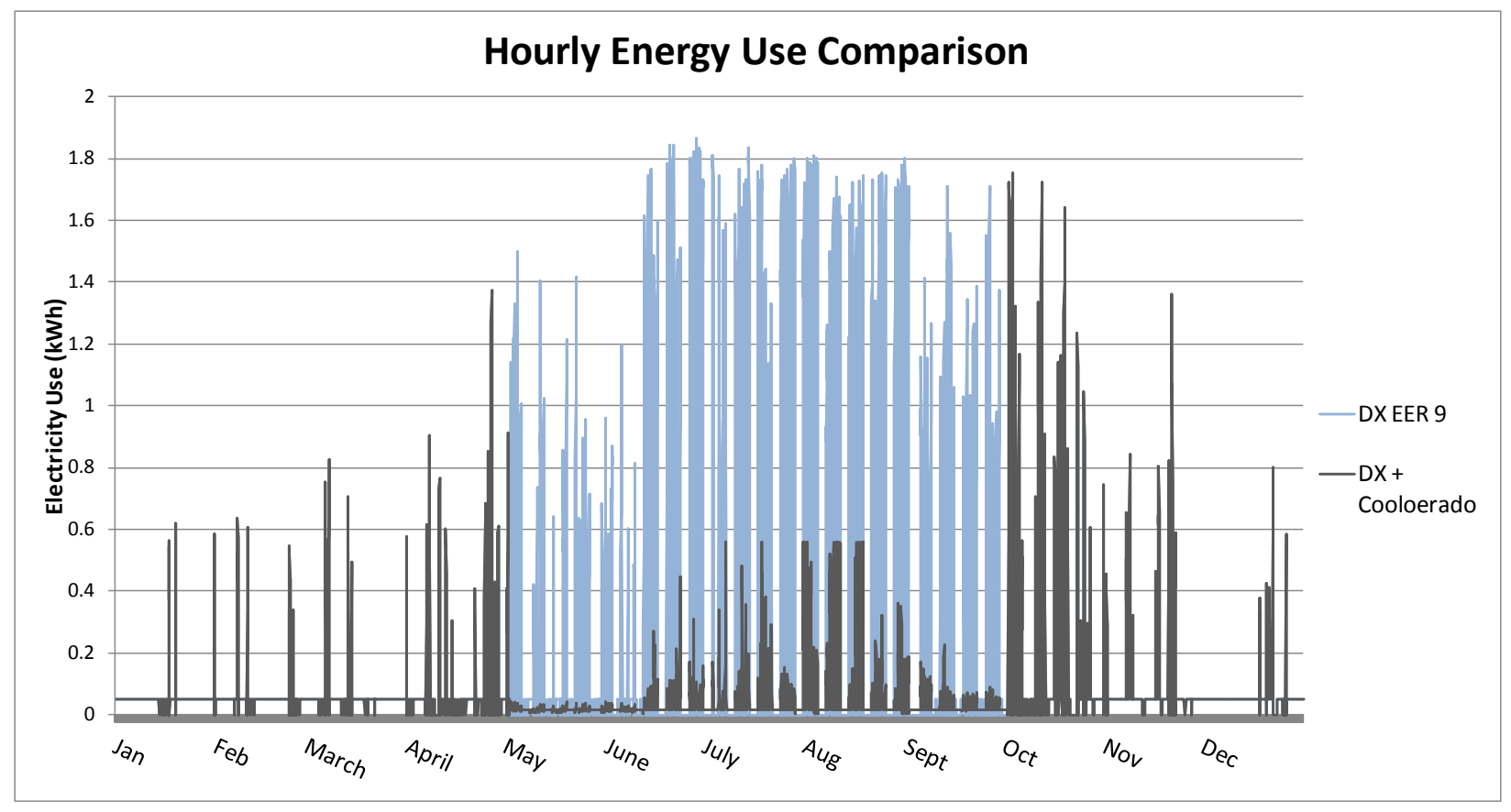

Figure 68. Hourly RTU EER 9 and DX Plus Coolerado energy use

Figure 69 shows the hourly OAT, OA wet bulb temperature, and OA SAT from the Coolerado. The unit is turned off during the winter, so the SAT for May through October are provided. The wet bulb temperatures are regularly below $65^{\circ} \mathrm{F}$ in Colorado Springs, and the Coolerado unit can achieve greater than $100 \% \mathrm{WBE}$ for parts of the year.

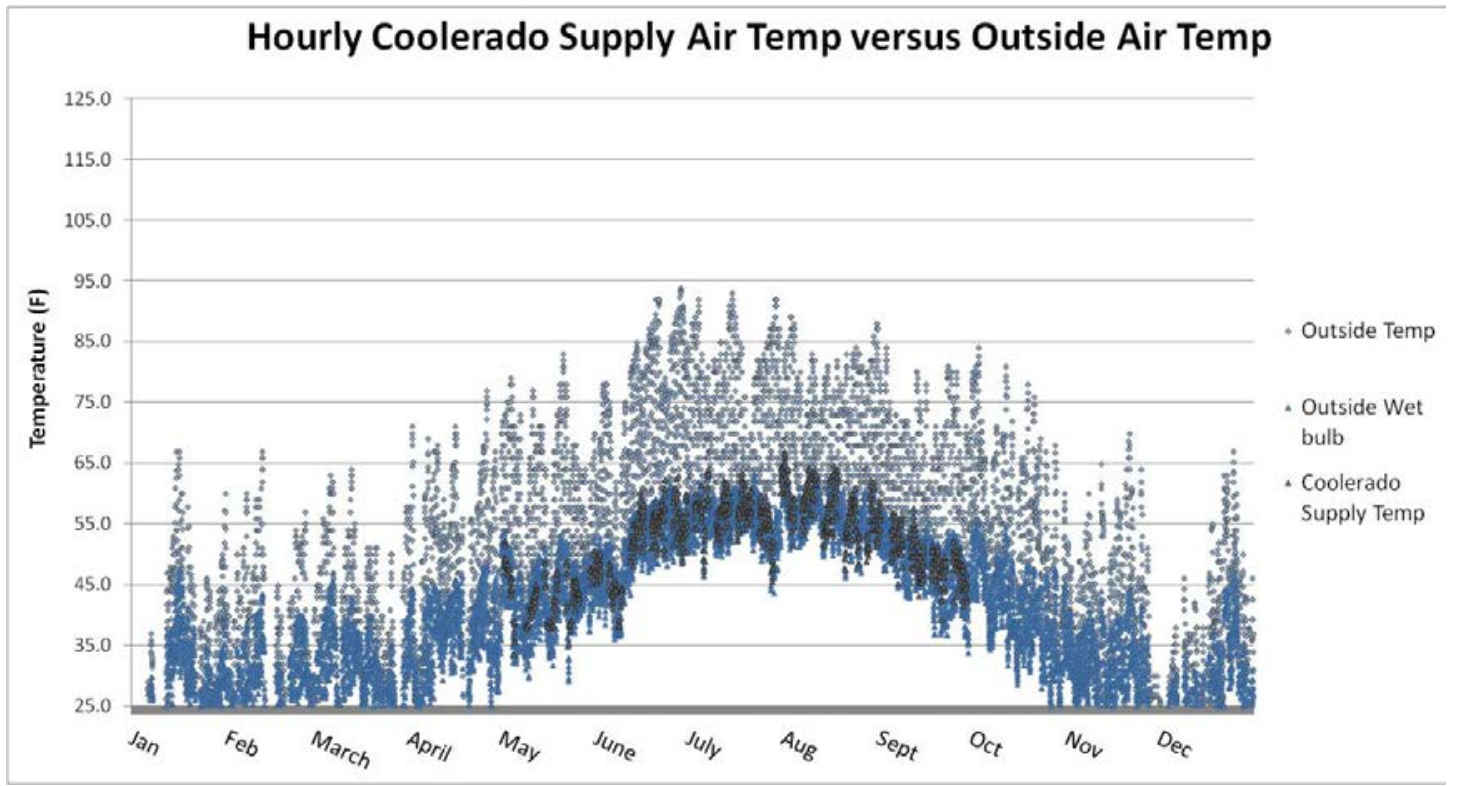

Figure 69. Hourly OAT versus Coolerado SAT 


\section{Helena}

The baseline RTU was sized at 1.5 tons with an SHR of $85.3 \%$ and an OAR of $48.6 \%$. The peak coincident $\mathrm{OA}$ wet bulb temperature was $62.1^{\circ} \mathrm{F}$. With a design space temperature set point of $80^{\circ} \mathrm{F}$, the unit can provide a little more than 1.5 tons of cooling. Based on the annual climatic conditions in Helena, the unit can meet the space cooling requirements for $98.6 . \%$ of the time cooling is required and was designed as a standalone zone cooler (see Table 36).

Table 36. Annual Energy and Water Use Comparison

\begin{tabular}{|l|c|c|c|c|c|c|c|c|c||}
\hline & $\begin{array}{c}\text { Cooling } \\
\text { Energy } \\
(\mathbf{k W h})\end{array}$ & $\begin{array}{c}\text { Fan } \\
\text { Energy } \\
\mathbf{( k W h )}\end{array}$ & $\begin{array}{c}\text { Total } \\
\text { Energy } \\
\text { (kWh) }\end{array}$ & $\begin{array}{c}\text { Onsite } \\
\text { Water Use } \\
\text { (Gal) }\end{array}$ & $\begin{array}{c}\text { Power } \\
\text { Plant } \\
\text { Water } \\
\text { (Gal) }\end{array}$ & $\begin{array}{c}\text { Total } \\
\text { Water Use } \\
\text { (Gal) }\end{array}$ & $\begin{array}{c}\text { Annual } \\
\text { Energy } \\
\text { Costs (\$) }\end{array}$ & $\begin{array}{c}\text { Annual } \\
\text { Water } \\
\text { Costs (\$) }\end{array}$ & $\begin{array}{c}\text { Total } \\
\text { Annual } \\
\text { Costs (\$) }\end{array}$ \\
\hline \hline DX EER 9 & 1,130 & 154 & 1,284 & 0 & 3,900 & 3,900 & $\$ 97$ & $\$ 0$ & $\$ 97$ \\
DX EER 9+OA Econ & 1,026 & 150 & 1,176 & 0 & 3,572 & 3,572 & $\$ 89$ & $\$ 0$ & $\$ 89$ \\
DX EER 12+OA Econ & 960 & 78 & 1,038 & 0 & 3,153 & 3,153 & $\$ 79$ & $\$ 0$ & $\$ 79$ \\
DX EER 12+OA Econ+Evap & 882 & 45 & 928 & 575 & 2,817 & 3,392 & $\$ 70$ & $\$ 2$ & $\$ 73$ \\
Coolerado & 450 & - & 450 & 283 & 1,366 & 1,649 & $\$ 34$ & $\$ 1$ & $\$ 35$ \\
\hline
\end{tabular}

An airside economizer reduces energy use by $8 \%$ annually. The new RTU with an EER of 12 saves $19 \%$ in energy use and the new RTU with an EER of 12, an OA economizer, IEC, and condenser air evaporative precooling saves $28 \%$ in energy use annually. The zone level Coolerado saves $65 \%$ annually. The unit needs to be shut down and winterized, so it was assumed to be turned off from October through April, when freezing temperatures may occur. In this case all the retrofit options except the Coolerado unit and OA economizer have a positive NPV, because of the relatively small annual cooling load, the cost of the Coolerado installation, and the need to shut down and winterize the unit (see Table 37).

Table 37. Annual Energy Savings and Economics

\begin{tabular}{|c|c|c|c|c|c|c|c|c|c|}
\hline & $\begin{array}{c}\text { Total } \\
\text { Energy } \\
\text { (kWh) }\end{array}$ & $\begin{array}{c}\text { Total } \\
\text { Water } \\
\text { Use (Gal) }\end{array}$ & $\begin{array}{c}\text { Total } \\
\text { Annual } \\
\text { Costs (\$) }\end{array}$ & \begin{tabular}{|c|} 
Percent \\
Reduction \\
Energy Use \\
$(\%)$
\end{tabular} & $\begin{array}{l}\text { Annual } \\
\text { Cost } \\
\text { Savings } \\
\text { (\$) }\end{array}$ & $\begin{array}{l}\text { Installed } \\
\text { Costs (\$) }\end{array}$ & $\begin{array}{c}\text { Annual } \\
\text { O\&M } \\
\text { Costs (\$) }\end{array}$ & $\begin{array}{c}\text { Simple } \\
\text { Payback } \\
\text { (yrs) }\end{array}$ & $\begin{array}{c}\text { Net } \\
\text { Present } \\
\text { Value (\$) }\end{array}$ \\
\hline DX EER 9 & 1,284 & 3,900 & $\$ 97$ & - & - & - & - & - & - \\
\hline DX EER 9 + OA Econ & 1,176 & 3,572 & $\$ 89$ & $8 \%$ & $\$ 8$ & $\$ 500$ & $\$ 0$ & 61.1 & $-\$ 300$ \\
\hline DX EER 12+OA Econ & 1,038 & 3,153 & $\$ 79$ & $19 \%$ & $\$ 581$ & $\$ 2,646$ & $\$ 0$ & 4.6 & $\$ 11,886$ \\
\hline DX EER 12+OA Econ+Evap & 928 & 3,392 & $\$ 73$ & $28 \%$ & $\$ 589$ & $\$ 3,034$ & $\$ 34$ & 5.5 & $\$ 10,848$ \\
\hline Coolerado & 450 & 1,649 & $\$ 35$ & $65 \%$ & $\$ 62$ & $\$ 9,702$ & $\$ 34$ & 346.4 & $-\$ 9,002$ \\
\hline
\end{tabular}

The winter cooling load is lower in Helena, and is assumed to be picked up by the RTU. During the summer the Coolerado unit can handle the space load most of the time. During August the unit will operate at $100 \%$ fan speed, and for a few hours per year the space temperature will exceed $74^{\circ} \mathrm{F}$. The annual operational EER for the Coolerado is 86 , and the combined annual EER, including the RTU operation during winter, is 33.29. The Coolerado unit significantly reduces the peak demand in the summer and has no energy benefit in the winter if it has to be winterized (see Figure 70). 


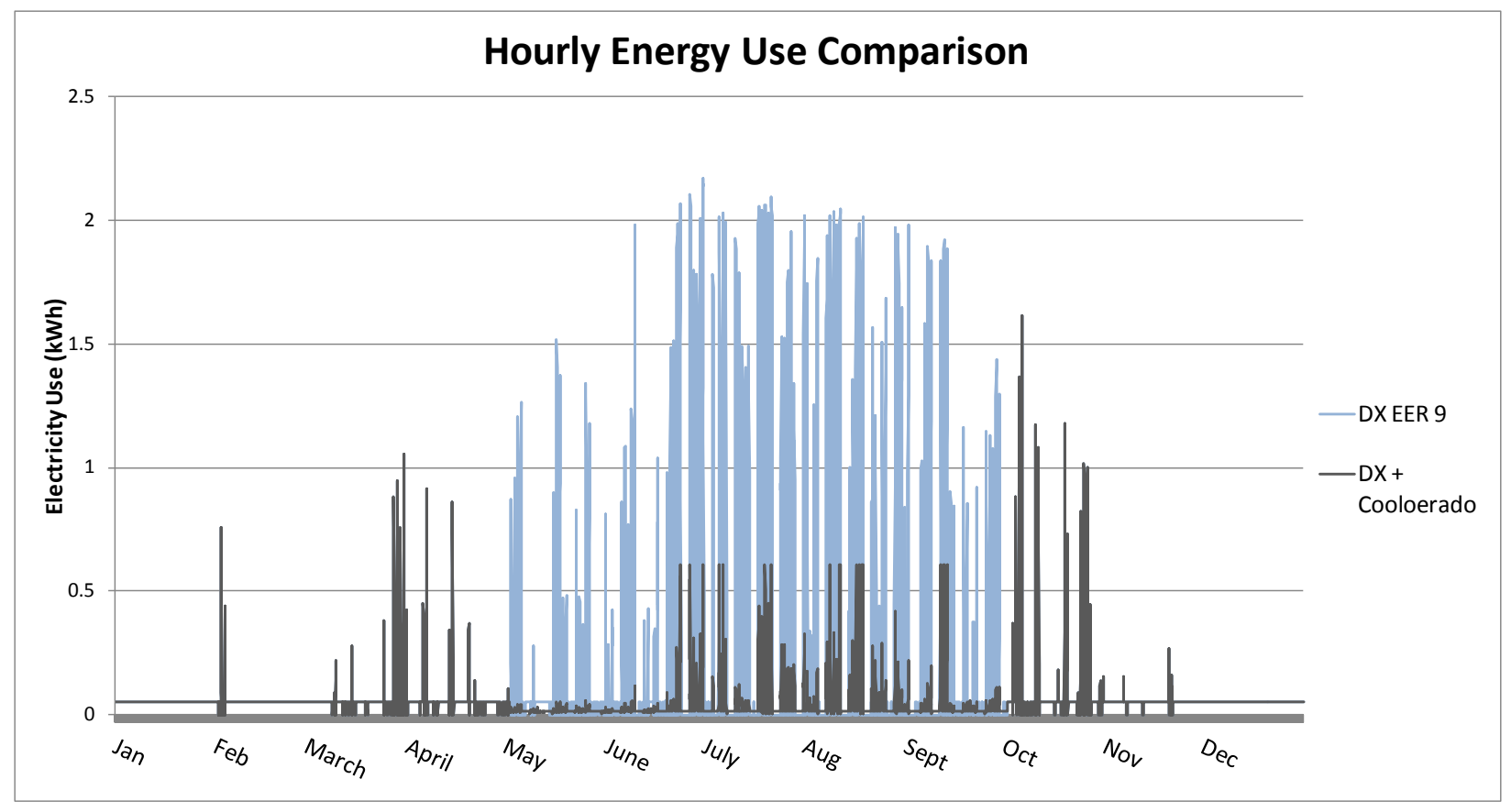

Figure 70. Hourly RTU EER 9 and DX Plus Coolerado energy use

\subsubsection{Results Summary}

The annual cooling load is significantly higher in Phoenix and Las Vegas than in the other climates, and if the Coolerado unit can operate all year without having to be winterized it can save significant energy. Figure 71 shows the cooling energy use and fan power while in cooling mode for each climate.

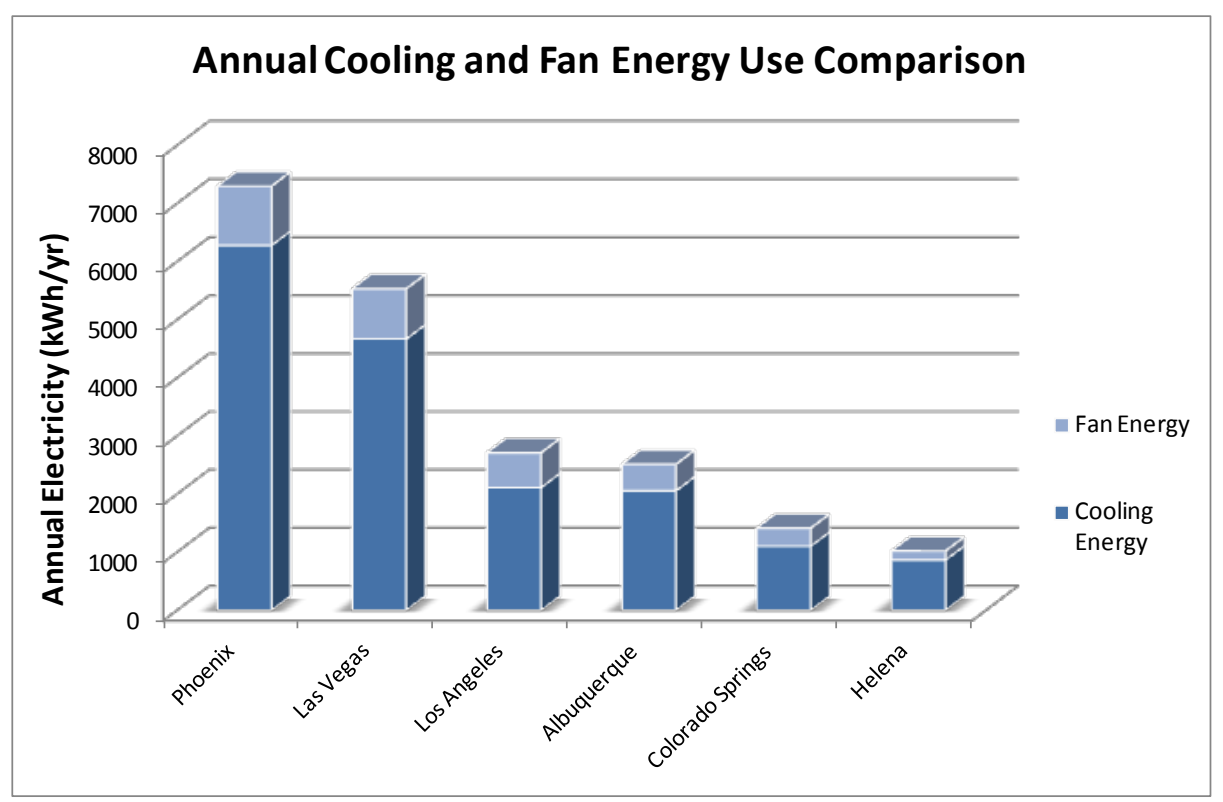

Figure 71. Annual cooling and fan energy use comparison 
The cooling loads in Phoenix and Las Vegas are two to three times higher than in the other climate zones for this space type. Figure 72 shows the energy savings of the Coolerado relative to the baseline in each climate zone.

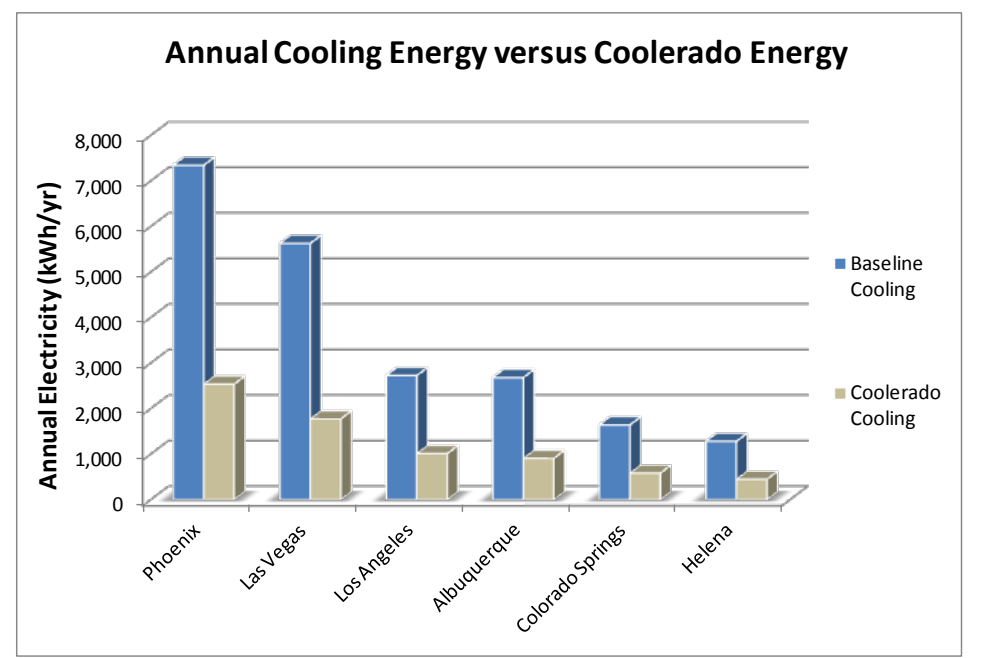

Figure 72. Annual cooling and fan energy use comparison

The annual energy savings were $63 \%-68 \%$ in all climate zones. The energy savings were as high as $88 \%$ when the Coolerado unit could meet $100 \%$ of the load, and illustrates significant energy savings. The NPV of the Coolerado installation was positive only in Phoenix and Las Vegas because of the capital costs of the system, the reduced economic value of the energy savings with reduced cooling loads, the onsite water use costs, and O\&M costs.

Figure 73 shows the baseline power plant-related water consumption compared to the power plant plus water consumption with the addition of the Coolerado unit and indicates that the unit saves water on a regional basis in all cases, assuming $3.03 \mathrm{gal} / \mathrm{kWh}$. If the assumption for power plant water consumption trends closer to $1.4 \mathrm{gal} / \mathrm{kWh}$, or the water control set point is set to 1.6 $\mathrm{CoC}$, Coolerado units will use more water on a regional basis.

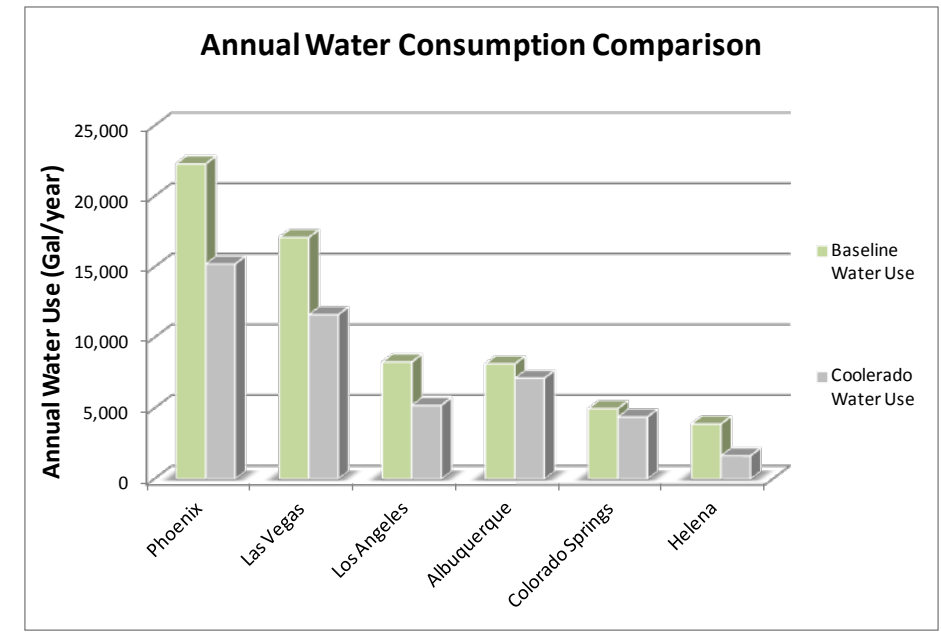

Figure 73. Annual cooling and fan energy use comparison 


\subsection{DATA CENTER}

The data center was modeled after Building 1510 at Fort Carson, which houses an 8,000- $\mathrm{ft}^{2}$ data center (see Figure 74). The 8,000- $\mathrm{ft}^{2}$ data center is currently served by numerous computer room air-conditioning (CRAC) units. Air is supplied to the front of the server racks (cold isle) via an under floor air distribution plenum through floor diffusers. Chilled water is produced by a central air-cooled chiller that is sized to serve systems throughout other areas of the building.

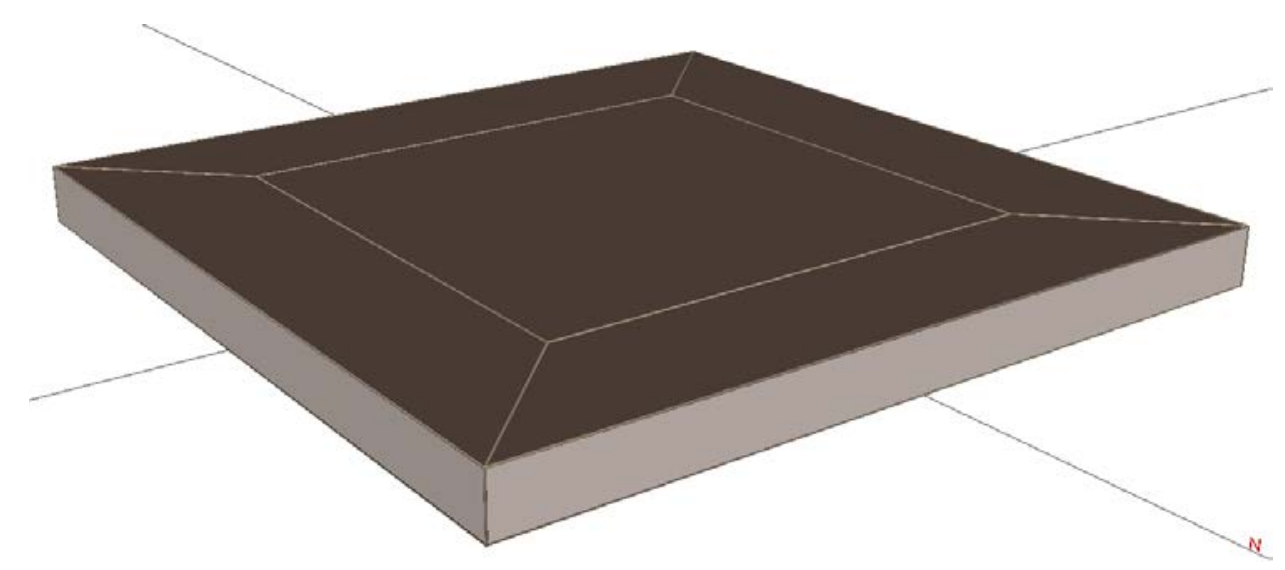

Figure 74. Data center eQUEST

(Source: NREL)

Data center EUI or energy use per square foot of building area is known to be the highest of all building types. Table 38 and Table 39 describe the energy model. 
Table 38. Data Center eQUEST Inputs Summary

\begin{tabular}{|c|c|c|}
\hline \multicolumn{3}{|c|}{ Data Center } \\
\hline \multicolumn{3}{|l|}{ Project } \\
\hline & Building Type & Data Center \\
\hline & Building Area & $19,994 \mathrm{ft}^{2}$ \\
\hline & Above Grade Floors & 1 \\
\hline & Below Grade Floors & 0 \\
\hline \multicolumn{3}{|c|}{ Building Footprint } \\
\hline & Building Orientation & Plan North \\
\hline & Zoning Pattern & Perimeter / Core \\
\hline & Flr to Flr Height & $10 \mathrm{ft}$ \\
\hline & Flr to Ceil Height & $9 \mathrm{ft}$ \\
\hline & Roof Pitch & $0 \mathrm{deg}$ \\
\hline \multicolumn{3}{|l|}{ Roof } \\
\hline & Construction & Metal Frame 24 " o.c. \\
\hline & Roof, Built Up & Medium \\
\hline & Ext. Insulation & 24 \\
\hline \multicolumn{3}{|l|}{ Walls } \\
\hline & Construction & Metal Frame 24 " o.c. \\
\hline & Finish & Brick, Medium \\
\hline & Ext. Insulation & - \\
\hline & Interior Insulation & 12.5 \\
\hline \multicolumn{3}{|c|}{ Ground Floor } \\
\hline & Earth Contact & 6 in Concrete \\
\hline & & No perimeter insulation \\
\hline \multicolumn{3}{|c|}{ Infiltration } \\
\hline & Perimeter & $0.5 \mathrm{ACH}$ \\
\hline \multicolumn{3}{|l|}{ Ceilings } \\
\hline & Int. Finish & Lay-In Acoustic Tile \\
\hline \multicolumn{3}{|c|}{ Vertical Walls } \\
\hline & Wall Type & Air \\
\hline
\end{tabular}


Table 39. Data Center eQUEST Inputs Summary

\begin{tabular}{|c|c|c|}
\hline \multicolumn{3}{|c|}{ Data Center } \\
\hline \multicolumn{3}{|l|}{ Exterior Doors } \\
\hline & Door Type & Opaque \\
\hline & & None \\
\hline \multicolumn{3}{|c|}{ Exterior Windows } \\
\hline & Type & None \\
\hline & Percent of Gross Wall Area & $0 \%$ \\
\hline \multicolumn{3}{|c|}{ Building Operation } \\
\hline & Schedule & $24 / 7$ \\
\hline & Area Type & Data Center \\
\hline \multicolumn{3}{|c|}{ Equipment Power Density } \\
\hline & Lighting & 1.06 to $1.49\left(\right.$ Watts $\left./ \mathrm{ft}^{2}\right)$ \\
\hline & Misc. Loads & 200 kW Data Center - core zone \\
\hline \multicolumn{3}{|l|}{ HVAC System } \\
\hline & $\begin{array}{l}\text { Packaged Single Zone DX w/ } \\
\text { Reheat }\end{array}$ & Return Air - Ducted \\
\hline & Cooling Source & Chilled Water \\
\hline & Heating System & Hot Water \\
\hline & Thermostat & 74 F - Cooling - Occupied \\
\hline & & $70 \mathrm{~F}$ - Heating - Occupied \\
\hline & & $74 \mathrm{~F}$ - Cooling - Un-Occupied \\
\hline & & $70 \mathrm{~F}$ - Heating - Un-Occupied \\
\hline \multicolumn{3}{|l|}{ Fan Schedules } \\
\hline & Operates & Intermittent - based on load \\
\hline \multicolumn{3}{|c|}{ Chilled Water Plant } \\
\hline & DX Coil & $\mathrm{EER}=8.76$ \\
\hline \multicolumn{3}{|c|}{ Heating Primary Equipment } \\
\hline & Hot Water Boiler & Efficiency $=0.806$ \\
\hline
\end{tabular}

The electrical power of the data center was measured at $200 \mathrm{~kW}$ on April 9, 2010; this baseline power consumption was assumed to be constant over a $24-\mathrm{h}$ period. The $200-\mathrm{kW}$ data center load requires cooling throughout the year. The building envelope construction and geographic location have little effect on the cooling energy use, because the CRAC units continually cool the space without an OA economizer.

\subsubsection{Baseline HVAC System}

The space temperature was set to a constant $74^{\circ} \mathrm{F}$. The total airflow of the constant-volume CRAC units is $109,800 \mathrm{cfm}$ at $52^{\circ} \mathrm{F}$ with a total capacity of 170 tons. The system was modeled in eQUEST as a single-zone constant-volume AHU with air-cooled screw chillers and a rated EER of 8.76. A humidistat was modeled with a low humidity limit of $20 \%$ and an electric humidifier. The OA flow rate for the data center zone is set to near zero, which is representative of this data center and of most data centers throughout the country. 


\subsubsection{Coolerado}

The space temperature set point was $74^{\circ} \mathrm{F}$ in the annual performance model and the hourly cooling load on the HVAC system was used in the Coolerado model, as well as the outdoor air temperature, humidity, and pressure. Each data center was modeled with the appropriate number of Coolerado units. The SP on the unit was set to $0.15 \mathrm{in}$. of static and the system was modeled assuming that the Coolerado units were in the space. The system was modeled assuming the inlet air for the Coolerado is $100 \% \mathrm{OA}$ and was partially modeled after a Coolerado data center retrofit at the National Snow and Ice Data Center at the University of Colorado. The baseline cooling system was identical to the one at Fort Carson and the Coolerado retrofit reduced energy use by $70 \%$ during the summer and by $<90 \%$ during the winter. Additional energy savings are achievable if RA is used advantageously.

The system that was installed at the National Snow and Ice Data Center consists of a rooftop AHU powered by a $7.5-\mathrm{kW}(10-\mathrm{hp})$ fan motor via a variable frequency drive, eight multistage IEC air conditioners (M-30 Coolerado units), and hot aisle containment. Figure 75 shows a schematic of this system. The AHU is completely responsible for the airside economization. It regulates the OA; when the $\mathrm{OA}$ is cool enough, the AHU introduces a mixture of this cool air with some RA from the backside of the server racks. Using the variable frequency drive and controls, the cooling system operates at $50 \%$ or lower flow rate $90 \%$ of the time. Because of the fan law, when airflow is reduced by $50 \%$, horsepower is reduced by $87.5 \%$. This mixed SA is introduced into the room and allowed to flow out from beneath the multistage IEC air conditioners to keep the cool areas around $72^{\circ} \mathrm{F}$. The multistage IEC air conditioners are used only when the AHU can no longer supply enough cool air to the data center. The multistage indirect evaporative cooling units are located in the room with the servers so that cool SA can be delivered directly to the front side of the servers.

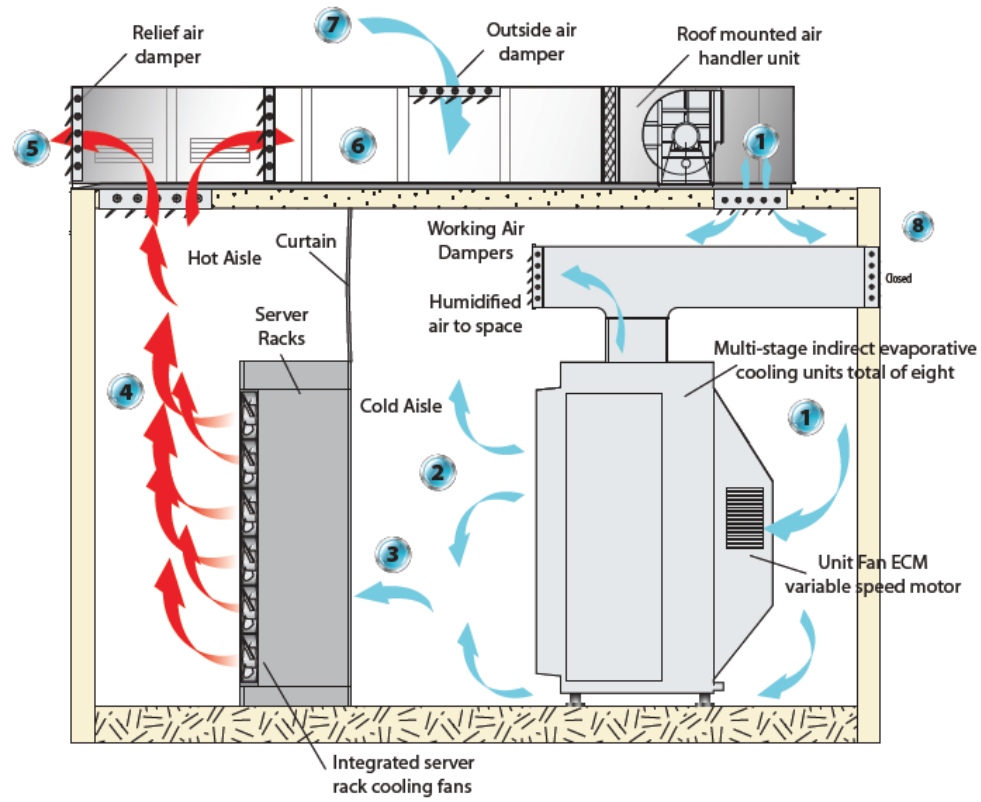

ECONOMIZER SUPPLY AIR - The air handler unit mixes outside air with hot aisle return air to provide minimum $75^{\circ} \mathrm{F}$ economizer supply air temperature.

2) MULTI-STAGE INDIRECT EVAPORATIVE COOLING PRODUCT SUPPLY AIR - Provide either sensible cooled or humidified supply air as a needed to maintain cold aisle temperature and humidity setpoints.

3. MULTI-STAGE INDIRECT EVAPORATIVE COOLING AISLE SUPPLY AIR - A combination of outside air and product air. Setpoint is $72^{\circ} \mathrm{F}$ and 30 percent minimum relative humidity.

HOT AISLE RETURN AIR - Exhaust air off server racks will normally be around $95^{\circ} \mathrm{F}$.

RELIEF AIR - Relief air damper will modulate in response to space pressure.

6 RETURN AIR DAMPER - Return air damper will control quantity of warn hot aisle return air with outside air in standard economizer mode.

7) OUTSIDE AIR - Outside air is utilized in all cooling modes. When outside air temperature is above $75^{\circ} \mathrm{F}$ the air handling unit provides 100 percent outside air meeting system requirements in both product and working air. Quantity of outside air increases as cooling units operate in cooling mode.

3) MULTI-STAGE INDIRECT EVAPORATIVE COOLING WORKING AIR EXHAUST - When the outside air temperature is too high to directly cool the space, the cooling units sensibly cool the product air by pulling the economizer air throughout the cooling unit heat exchange. The humid working air is directly exhausted outside without adding any humidity to the space.

Figure 75. National Snow and Ice Data Center Coolerado winter operation

(Source: Joshua Bauer, NREL) 
The system can direct EA into the space when additional humidity is required, which reduces the energy used to humidify the space. The baseline CRAC units used single pass water for humidification and the Coolerado installation reduced onsite water consumption. Although this system cannot be modeled directly, the Coolerado model can provide an approximation of energy savings. Its main problem is that it does not include RA or estimate energy savings from the use of the EA for humidification, which would reduce the energy use beyond the energy savings modeled by the current Coolerado model.

The fan horsepower for the 8 M50 units is $5 \mathrm{hp}$ and the mechanical designer installed a 10-hp supply fan for the AHU. Because it is not possible to model the AHU directly in the Coolerado model, the fan energy use from the Coolerado model was doubled to account for the AHU fan energy use.

\subsubsection{Results}

Thirty M30 Coolerado units were modeled at each location. The energy savings for this building type are significant and the year-round cooling load results in a payback period of $<20$ years for every climate zone. The energy savings are greatest for climate zones $4 \mathrm{~B}, 5 \mathrm{~B}$, and $6 \mathrm{~B}$ for this building type because the colder OATs can provide greater OA economizer-based savings than the other climate zones (see Table 40 through Table 45).

Table 40. Data Center Energy Savings and Economics Phoenix

\begin{tabular}{|l|c|c|c|c|c|c|c|c|c|} 
& $\begin{array}{c}\text { Total } \\
\text { Energy }\end{array}$ & $\begin{array}{c}\text { Total } \\
\text { Water }\end{array}$ & $\begin{array}{c}\text { Total } \\
\text { Annual } \\
\text { Costs (\$) }\end{array}$ & $\begin{array}{c}\text { Percent } \\
\text { Reduction } \\
\text { Energy Use } \\
(\%)\end{array}$ & $\begin{array}{c}\text { Annual } \\
\text { Cost } \\
\text { Savings } \\
\text { (\$) }\end{array}$ & $\begin{array}{c}\text { Installed } \\
\text { Costs (\$) }\end{array}$ & $\begin{array}{c}\text { Annual } \\
\text { O\&M } \\
\text { Costs (\$) }\end{array}$ & $\begin{array}{c}\text { Simple } \\
\text { Payback } \\
\text { (yrs) }\end{array}$ & $\begin{array}{c}\text { Net } \\
\text { Present } \\
\text { Value (\$) }\end{array}$ \\
\hline \hline DX EER 8.75 & $1,372,493$ & $4,168,263$ & $\$ 158,794$ & - & - & - & - & - & - \\
Coolerado + DX & 315,014 & $2,648,24 \lambda$ & $\$ 42,790$ & $77 \%$ & $\$ 116,004$ & $\$ 1,659,859$ & $\$ 0$ & 14.3 & $\$ 1,241,631$ \\
\hline
\end{tabular}

Table 41. Data Center Energy Savings and Economics Phoenix Las Vegas

\begin{tabular}{|c|c|c|c|c|c|c|c|c|c|}
\hline Cooling System & $\begin{array}{c}\text { Total } \\
\text { Energy } \\
\text { (kWh) }\end{array}$ & $\begin{array}{c}\text { Total } \\
\text { Water } \\
\text { Use (Gal) }\end{array}$ & $\begin{array}{c}\text { Total } \\
\text { Annual } \\
\text { Costs (\$) }\end{array}$ & $\begin{array}{c}\text { Percent } \\
\text { Reduction } \\
\text { Energy Use } \\
(\%) \\
\end{array}$ & $\begin{array}{l}\text { Annual } \\
\text { Cost } \\
\text { Savings } \\
\text { (\$) }\end{array}$ & $\begin{array}{l}\text { Installed } \\
\text { Costs (\$) }\end{array}$ & $\begin{array}{c}\text { Annual } \\
\text { O\&M } \\
\text { Costs (\$) }\end{array}$ & $\begin{array}{c}\text { Simple } \\
\text { Payback } \\
\text { (yrs) }\end{array}$ & $\begin{array}{c}\text { Net } \\
\text { Present } \\
\text { Value (\$) }\end{array}$ \\
\hline DX EER 8.75 & $1,381,552$ & $4,195,773$ & $\$ 191,905$ & - & & & - & - & - \\
\hline Coolerado + DX & 331,099 & $2,469,486$ & $\$ 51,481$ & $76 \%$ & $\$ 140,424$ & $\$ 1,845,860$ & $\$ 0$ & 13.1 & $\$ 1,666,419$ \\
\hline
\end{tabular}

Table 42. Data Center Energy Savings and Economics Los Angeles

\begin{tabular}{|c|c|c|c|c|c|c|c|c|c|}
\hline Cooling System & $\begin{array}{c}\text { Total } \\
\text { Energy } \\
\text { (kWh) }\end{array}$ & $\begin{array}{c}\text { Total } \\
\text { Water } \\
\text { Use (Gal) }\end{array}$ & $\begin{array}{c}\text { Total } \\
\text { Annual } \\
\text { Costs (\$) }\end{array}$ & \begin{tabular}{|c|} 
Percent \\
Reduction \\
Energy Use \\
$(\%)$
\end{tabular} & $\begin{array}{l}\text { Annual } \\
\text { Cost } \\
\text { Savings } \\
\text { (\$) }\end{array}$ & $\begin{array}{l}\text { Installed } \\
\text { Costs (\$) }\end{array}$ & $\begin{array}{c}\text { Annual } \\
\text { O\&M } \\
\text { Costs (\$) }\end{array}$ & $\begin{array}{c}\text { Simple } \\
\text { Payback } \\
\text { (yrs) }\end{array}$ & $\begin{array}{c}\text { Net } \\
\text { Present } \\
\text { Value (\$) }\end{array}$ \\
\hline DX EER 8.75 & $1,404,839$ & $4,266,497$ & $\$ 141,789$ & - & - & 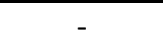 & - & - & - \\
\hline Coolerado + DX & 267,413 & $1,202,431$ & $\$ 28,453$ & $81 \%$ & $\$ 113,335$ & $\$ 1,865,346$ & $\$ 0$ & 16.5 & $\$ 969,384$ \\
\hline
\end{tabular}


Table 43. Data Center Energy Savings and Economics Albuquerque

\begin{tabular}{|c|c|c|c|c|c|c|c|c|c|}
\hline Cooling System & $\begin{array}{c}\text { Total } \\
\text { Energy } \\
\text { (kWh) }\end{array}$ & $\begin{array}{c}\text { Total } \\
\text { Water } \\
\text { Use (Gal) }\end{array}$ & $\begin{array}{c}\text { Total } \\
\text { Annual } \\
\text { Costs (\$) }\end{array}$ & $\begin{array}{c}\text { Percent } \\
\text { Reduction } \\
\text { Energy Use } \\
(\%)\end{array}$ & $\begin{array}{l}\text { Annual } \\
\text { Cost } \\
\text { Savings } \\
\text { (\$) }\end{array}$ & $\begin{array}{l}\text { Installed } \\
\text { Costs (\$) }\end{array}$ & $\begin{array}{c}\text { Annual } \\
\text { O\&M } \\
\text { Costs (\$) }\end{array}$ & $\begin{array}{c}\text { Simple } \\
\text { Payback } \\
\text { (yrs) }\end{array}$ & $\begin{array}{c}\text { Net } \\
\text { Present } \\
\text { Value (\$) }\end{array}$ \\
\hline DX EER 8.75 & $1,411,409$ & $4,286,449$ & $\$ 105,528$ & - & - & - & - & - & - \\
\hline Coolerado + DX & 202,997 & $1,400,541$ & $\$ 18,118$ & $86 \%$ & $\$ 87,410$ & $\$ 1,548,255$ & $\$ 0$ & 17.7 & $\$ 638,040$ \\
\hline
\end{tabular}

Table 44. Data Center Energy Savings and Economics Colorado Springs

\begin{tabular}{|c|c|c|c|c|c|c|c|c|c|}
\hline Cooling System & $\begin{array}{c}\text { Total } \\
\text { Energy } \\
\text { (kWh) }\end{array}$ & $\begin{array}{c}\text { Total } \\
\text { Water } \\
\text { Use (Gal) }\end{array}$ & $\begin{array}{c}\text { Total } \\
\text { Annual } \\
\text { Costs (\$) }\end{array}$ & $\begin{array}{c}\text { Percent } \\
\text { Reduction } \\
\text { Energy Use } \\
(\%)\end{array}$ & $\begin{array}{l}\text { Annual } \\
\text { Cost } \\
\text { Savings } \\
\text { (\$) }\end{array}$ & $\begin{array}{l}\text { Installed } \\
\text { Costs (\$) }\end{array}$ & $\begin{array}{c}\text { Annual } \\
\text { O\&M } \\
\text { Costs (\$) }\end{array}$ & $\begin{array}{c}\text { Simple } \\
\text { Payback } \\
\text { (yrs) }\end{array}$ & $\begin{array}{c}\text { Net } \\
\text { Present } \\
\text { Value (\$) }\end{array}$ \\
\hline DX EER 8.75 & $1,410,000$ & $4,282,170$ & $\$ 105,476$ & - & - & - & - & - & - \\
\hline Coolerado + DX & 167,531 & 997,978 & $\$ 14,367$ & $88 \%$ & $\$ 91,109$ & $\$ 1,187,444$ & $\$ 0$ & 13.0 & $\$ 1,091,370$ \\
\hline
\end{tabular}

Table 45. Data Center Energy Savings and Economics Helena

\begin{tabular}{|c|c|c|c|c|c|c|c|c|c|}
\hline Cooling System & $\begin{array}{c}\text { Total } \\
\text { Energy } \\
\text { (kWh) }\end{array}$ & $\begin{array}{c}\text { Total } \\
\text { Water } \\
\text { Use (Gal) }\end{array}$ & $\begin{array}{c}\text { Total } \\
\text { Annual } \\
\text { Costs (\$) }\end{array}$ & $\begin{array}{c}\text { Percent } \\
\text { Reduction } \\
\text { Energy Use } \\
(\%)\end{array}$ & $\begin{array}{l}\text { Annual } \\
\text { Cost } \\
\text { Savings } \\
\text { (\$) }\end{array}$ & $\begin{array}{l}\text { Installed } \\
\text { Costs (\$) }\end{array}$ & $\begin{array}{c}\text { Annual } \\
\text { O\&M } \\
\text { Costs (\$) }\end{array}$ & $\begin{array}{c}\text { Simple } \\
\text { Payback } \\
\text { (yrs) }\end{array}$ & $\begin{array}{c}\text { Net } \\
\text { Present } \\
\text { Value (\$) }\end{array}$ \\
\hline DX EER 8.75 & $1,387,425$ & $4,213,611$ & $\$ 105,221$ & - & - & - & - & - & - \\
\hline Coolerado + DX & 116,650 & 757,366 & $\$ 10,358$ & $92 \%$ & $\$ 94,863$ & $\$ 1,312,438$ & $\$ 4,000$ & 14.4 & $\$ 1,060,271$ \\
\hline
\end{tabular}

The annual cooling load was constant from one climate zone to the next (see Figure 76). The building envelope has little effect on the energy use of this facility type and the system has no OA, so the climate does not significant affect the baseline cooling energy use.

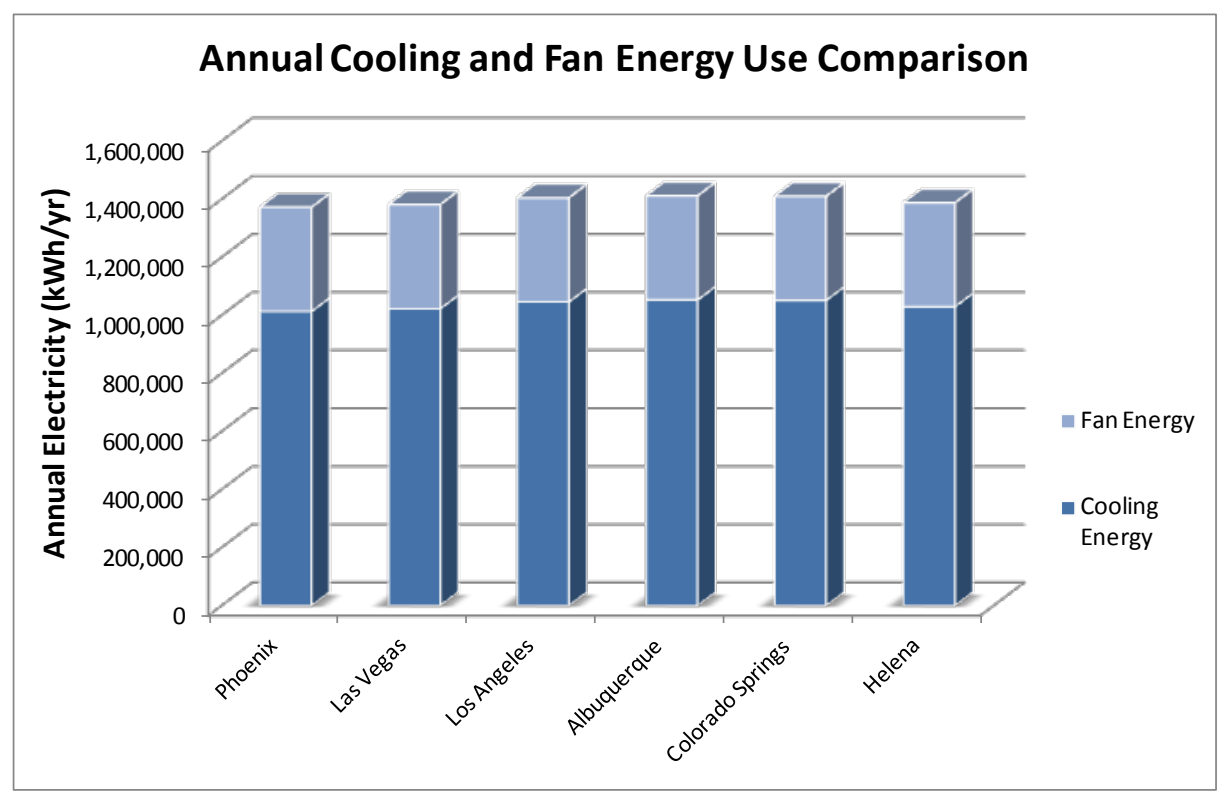

Figure 76. Data center annual cooling and fan energy comparison across climate zones 
The energy savings are greatest in Helena and Colorado Springs based on the increased savings from the outside air economizer in these two locations, although all climate zones showed significant energy savings (Figure 77).

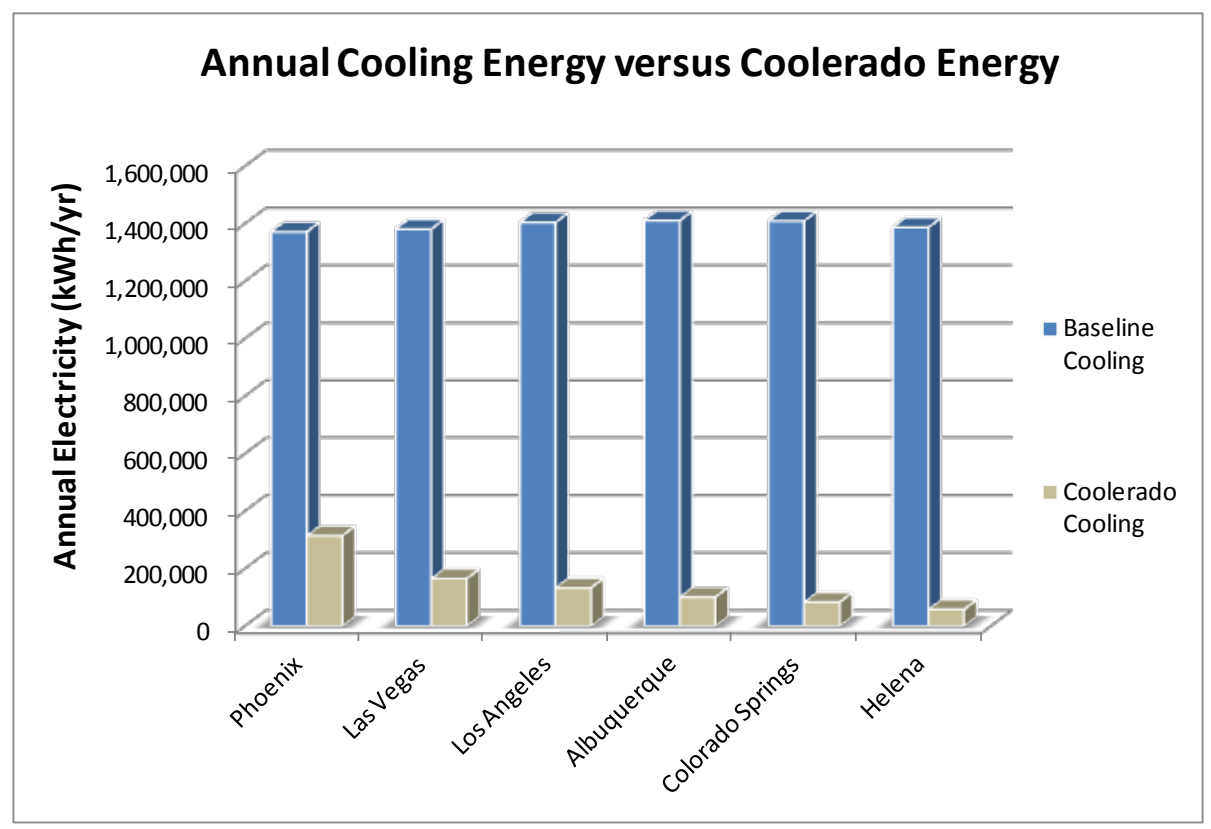

Figure 77. Data center annual cooling energy comparison

In all cases the Coolerado unit uses less water than the baseline water consumption on a regional basis (see Figure 78). The water consumption associated with humidifying the space is not captured in the following water use comparisons. The added benefit that the EA from the Coolerado can be used to humidify the space was not captured, which would reduce onsite water consumption,

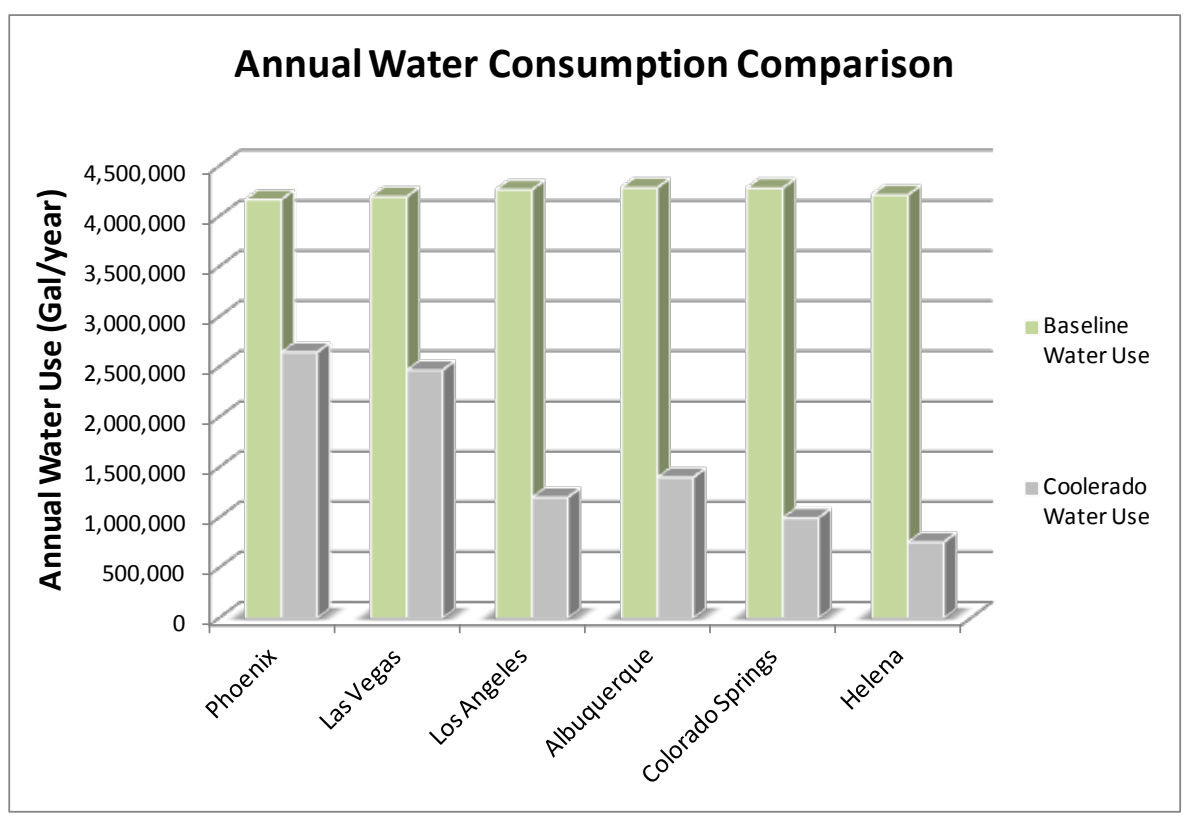

Figure 78. Data center annual water use comparison 
The SPP was $<20$ years for all locations when the installed costs from the National Snow and Ice Data Center project were used and the SPP is $<8$ years when the costs from Fort Carson are used (see Figure 79).

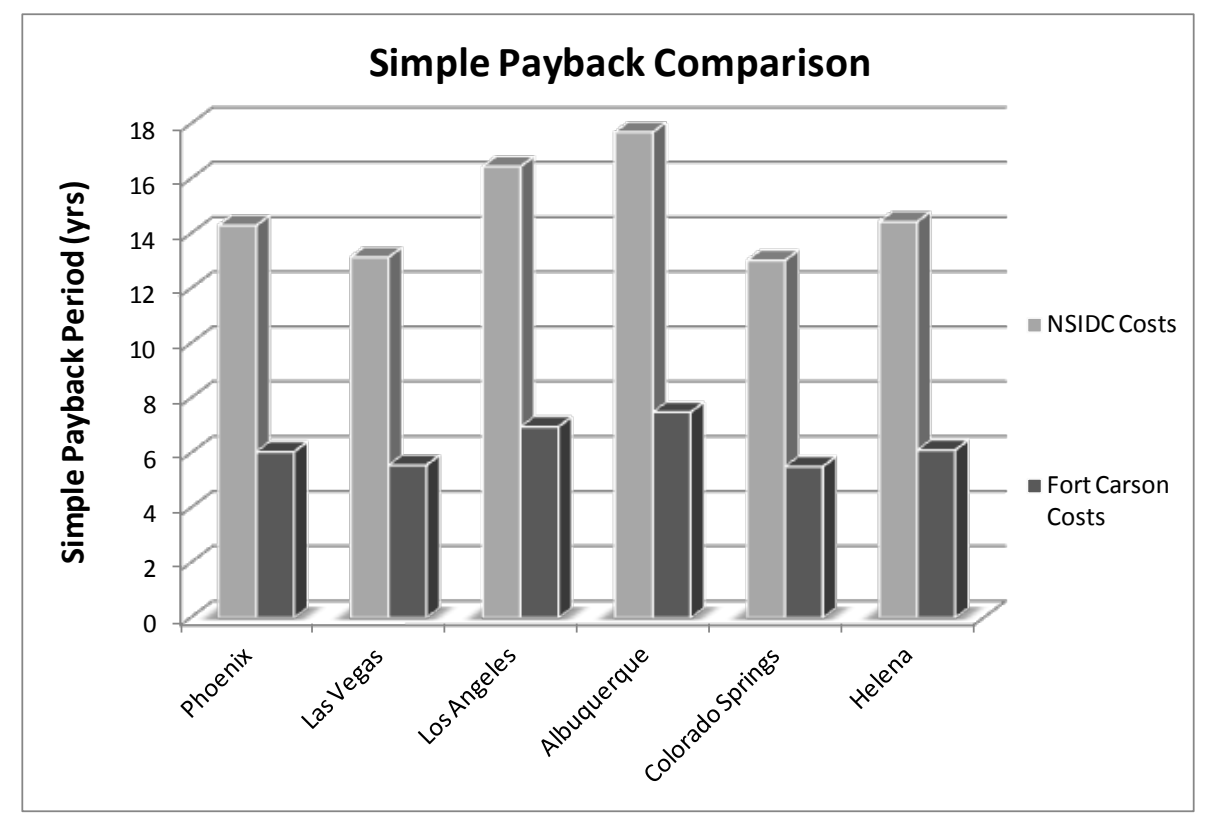

Figure 79. Data center SPP comparison

\subsection{QUICK-SERVE RESTAURANT}

The quick-serve restaurant was modeled to demonstrate the application of the Coolerado technology in a facility type with very high ventilation loads and internal loads. The quick-serve restaurant model is a 2,500- $\mathrm{ft}^{2}$, one-story building and includes a kitchen and a dining area. The building operates 52 weeks per year from 8:00 a.m. to 11:00 p.m., seven days per week. Internal loads in the dining area include standard overhead lighting, plug loads, and occupants. Internal loads in the kitchen include electric and gas cooking equipment loads, electric lighting, and occupants. The kitchen also includes a walk-in freezer and a walk-in cooler. The wall, roof, floor, and window constructions are modeled based on CBECS 2003 and are modified based on each climate zone. The window characteristics were modeled as single-paned clear windows in all climate zones. ${ }^{\text {xxi }}$

The conventional HVAC system used in the model includes a packaged single-zone system in both the kitchen and dining area with DX cooling coils and a gas furnace; equipment efficiencies were taken from an analysis of historical equipment efficiencies. ${ }^{\text {xxii }}$ The domestic hot water system included a gas-fired storage tank.

Figure 80 shows the EnergyPlus schematic of the quick-serve restaurant. Additional model inputs and HVAC system details are listed in Table 46 and Table 47. 


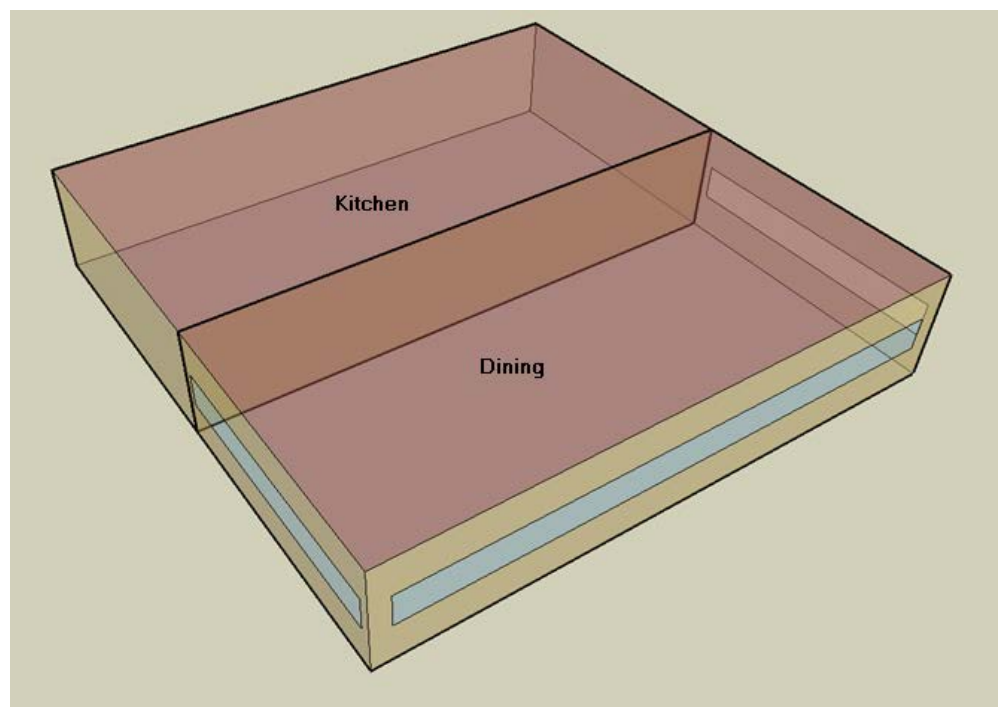

Figure 80. Quick-serve restaurant model

(Source: NREL)

Table 46. Quick-Serve Restaurant Model Inputs

\begin{tabular}{|c|c|c|}
\hline \multicolumn{3}{|c|}{ Quick Service Restaurant } \\
\hline \multicolumn{3}{|l|}{ Project } \\
\hline & Building Type & Quick Service Restaurant \\
\hline & Building Area & $2,500 \mathrm{ft}^{2}$ \\
\hline & Above Grade Floors & 1 \\
\hline & Below Grade Floors & 0 \\
\hline \multicolumn{3}{|c|}{ Building Footprint } \\
\hline & Building Orientation & Plan North \\
\hline & Zoning Pattern & 2-Zone (Kitchen and Dining) \\
\hline & Flr to Flr Height & $10 \mathrm{ft}$ \\
\hline & FIr to Ceil Height & $10 \mathrm{ft}$ \\
\hline & Roof Pitch & $0 \mathrm{deg}$ \\
\hline \multicolumn{3}{|l|}{ Roof } \\
\hline & Construction & IEAD \\
\hline & Roof, Built Up & Medium \\
\hline & Ext. Insulation & R Value Dependent on Location \\
\hline \multicolumn{3}{|l|}{ Walls } \\
\hline & Construction & Mass wall \\
\hline & Finish & Stucco \\
\hline & Ext. Insulation & - \\
\hline & Interior Insulation & R Value Dependent on Location \\
\hline \multicolumn{3}{|c|}{ Ground Floor } \\
\hline & Earth Contact & 4 in Concrete \\
\hline & & No perimeter insulation \\
\hline \multicolumn{3}{|c|}{ Infiltration } \\
\hline & Perimeter & 2.41 ACH in each zone \\
\hline \multicolumn{3}{|l|}{ Ceilings } \\
\hline & Int. Finish & Lay-In Acoustic Tile \\
\hline \multicolumn{3}{|c|}{ Vertical Walls } \\
\hline & Wall Type & Mass wall \\
\hline
\end{tabular}


Table 47. Quick-serve restaurant model inputs

\begin{tabular}{|c|c|c|}
\hline \multicolumn{3}{|c|}{ Quick Service Restaurant } \\
\hline \multirow[t]{3}{*}{ Exterior Doors } & & \\
\hline & Door Type & Opaque \\
\hline & & None \\
\hline \multicolumn{3}{|c|}{ Exterior Windows } \\
\hline & Type & 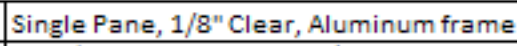 \\
\hline & & 5.84 (Climate zones $1 \mathrm{~A}-4 \mathrm{C})$ \\
\hline & NRFC U Factor & 3.53 (Climate zones 5A-8) \\
\hline & & 0.54 (Climate zones 1A-4C) \\
\hline & NFRC SHGC & 0.41 (Climate zones 5A-8) \\
\hline & & 0.38 (Climate zones 1A-4C) \\
\hline & Visible Transmittance & 0.32 (Climate zones 5A.-8) \\
\hline & Percent of Gross Wall Area & $13 \%$ south; 6.5196 east/west \\
\hline \multicolumn{3}{|c|}{ Building Operatio } \\
\hline & Schedule & 8:00 am to $11: 00$ pm 7-days/week \\
\hline & Area Type & Quick Service Restaurant \\
\hline & Design Occupancy & $\begin{array}{l}15 \mathrm{ft}^{2} / \text { person (Dining) } \\
200 \mathrm{ft}^{2} / \text { person (Kitchen) }\end{array}$ \\
\hline & Design Ventilation & $\begin{array}{l}21 \text { CFM/person (Dining) } \\
17 \text { CFM/person (Kitchen) }\end{array}$ \\
\hline \multicolumn{3}{|c|}{ Equipment Power Density } \\
\hline & Lighting & $\begin{array}{l}1.44 \text { Watts } / \mathrm{ft}^{2} \text { (Dining) } \\
1.55 \text { Watts } / \mathrm{ft}^{2} \text { (Kitchen) }\end{array}$ \\
\hline & Misc. Electrical Loads & $\begin{array}{l}12 \text { Watts } / \mathrm{ft}^{2} \text { (Dining) } \\
28 \text { Watts } / \mathrm{ft}^{2} \text { (Kitchen) } \\
\end{array}$ \\
\hline & Misc. Gas Loads & 120 Watts $/ \mathrm{ft}^{2}$ (Kitchen) \\
\hline \multicolumn{3}{|l|}{ HVAC System } \\
\hline & $\begin{array}{l}\text { Packaged Single Zone DX w/ } \\
\text { Furnace } \\
\end{array}$ & Return Air - Ducted \\
\hline & Cooling Source & DX Coils \\
\hline & Heating System & Furnace \\
\hline & Thermostat & $\begin{array}{l}\text { 75.2 F-Cooling - Occupied (Dining) } \\
78.8 \text { F-Cooling - Occupied (Kitchen) }\end{array}$ \\
\hline & & $\begin{array}{l}\text { 69.8 F- Heating - Occupied (Dining) } \\
\text { 66.2 F-Heating - Occupied (Kitchen) }\end{array}$ \\
\hline & & $\begin{array}{l}86 \mathrm{~F} \text {-Cooling - Un-Occupied (Dining) } \\
86 \mathrm{~F} \text {-Cooling-Un-Occupied (Kitchen) }\end{array}$ \\
\hline & & $60 \mathrm{~F}$ - Heating - Un-Occupied (Dining) \\
\hline & & $60 \mathrm{~F}$-Heating-Un-Occupied (Kitchen) \\
\hline & Kitchen Ventilation & 3300 CFM, 5496 make-up air from Dining \\
\hline \multicolumn{3}{|c|}{ Domestic Hot Water } \\
\hline & Type & Natural Gas Storage Tank \\
\hline & Efficiency & 0.8 \\
\hline \multicolumn{3}{|l|}{ Refrigeration } \\
\hline & Food Storage Systems & $\begin{array}{l}\text { Walk-in Freezer } \\
\text { Walk-in Cooler }\end{array}$ \\
\hline \multicolumn{3}{|l|}{ Fan Schedules } \\
\hline & Operates & On/Off \\
\hline \multicolumn{3}{|c|}{ Chilled Water Plant } \\
\hline & DX Coil & $\mathrm{EER}=10.88$ \\
\hline \multicolumn{3}{|c|}{ Heating Primary Equipment } \\
\hline & Furnace & Efficiency $=0.78$ \\
\hline
\end{tabular}




\subsubsection{Baseline HVAC System}

The space temperature was set to a constant $75.8^{\circ} \mathrm{F}$ in the kitchen. The energy model was set up with two packaged units, one serving the kitchen and one serving the dining facility. For this analysis the Coolerado was applied to the kitchen unit as this unit has high ventilation rates and internal loads that require year-round cooling. The total airflow of the constant volume packaged RTU that serves the kitchen is rated at 1,600 cfm. The system was modeled in EnergyPlus with a cooling EER of 10.8. The OA flow rate depended on the climate zone. but was $80 \%-95 \%$.

\subsubsection{Coolerado}

The Coolerado was modeled in a similar fashion to the classroom unit. All climate zones were modeled assuming the Coolerado would be installed as a retrofit pre-cooler for the packaged RTU. A C60 unit was applied to the kitchen unit based on its design SA flow rates.

\subsubsection{Results}

The system was analyzed in Phoenix and Colorado Springs (see Table 48 and Table 49). The high internal loads and ventilation rates made this an ideal facility type for the Coolerado system. The economics are better than the single-zone classroom economics, but poorer than the data center economics. The SPP was $<10$ yrs in Phoenix and about 60 yrs in Colorado Springs.

Table 48. Quick Service Restaurant Energy Savings and Economics Phoenix

\begin{tabular}{|c|c|c|c|c|c|c|c|c|c|}
\hline & $\begin{array}{c}\text { Total } \\
\text { Energy } \\
(\mathrm{kWh}) \\
\end{array}$ & $\begin{array}{c}\text { Total } \\
\text { Water } \\
\text { Use (Gal) }\end{array}$ & $\begin{array}{c}\text { Total } \\
\text { Annual } \\
\text { Costs (\$) }\end{array}$ & \begin{tabular}{|c|} 
Percent \\
Reduction \\
Energy Use \\
$(\%)$ \\
\end{tabular} & $\begin{array}{c}\text { **Annual } \\
\text { Cost } \\
\text { Savings } \\
\text { (\$) }\end{array}$ & $\begin{array}{l}\text { Installed } \\
\text { Costs (\$) }\end{array}$ & $\begin{array}{c}\text { Annual } \\
\text { O\&M } \\
\text { Costs (\$) }\end{array}$ & $\begin{array}{c}\text { Simple } \\
\text { Payback } \\
\text { (yrs) }\end{array}$ & $\begin{array}{c}\text { Net } \\
\text { Present } \\
\text { Value (\$) }\end{array}$ \\
\hline DX EER 10.8 & 14,580 & 44,280 & $\$ 1,687$ & - & - & - & - & - & - \\
\hline Coolerado & 4,376 & 41,349 & $\$ 612$ & $70 \%$ & $\$ 1,075$ & $\$ 10,307$ & $\$ 36$ & 9.9 & $\$ 1,999$ \\
\hline
\end{tabular}

Table 49. Quick Service Restaurant Energy Savings and Economics Colorado Springs

\begin{tabular}{|c|c|c|c|c|c|c|c|c|c|}
\hline & $\begin{array}{l}\text { Total } \\
\text { Energy } \\
\text { (kWh) }\end{array}$ & $\begin{array}{c}\text { Total } \\
\text { Water } \\
\text { Use (Gal) }\end{array}$ & $\begin{array}{c}\text { Total } \\
\text { Annual } \\
\text { Costs (\$) }\end{array}$ & \begin{tabular}{|c} 
Percent \\
Reduction \\
Energy Use \\
$(\%)$
\end{tabular} & $\begin{array}{l}\text { **Annual } \\
\text { Cost } \\
\text { Savings } \\
\text { (\$) }\end{array}$ & $\begin{array}{l}\text { Installed } \\
\text { Costs (\$) }\end{array}$ & $\begin{array}{c}\text { Annual } \\
\text { O\&M } \\
\text { Costs (\$) }\end{array}$ & $\begin{array}{c}\text { Simple } \\
\text { Payback } \\
\text { (yrs) }\end{array}$ & $\begin{array}{c}\text { Net } \\
\text { Present } \\
\text { Value (\$) }\end{array}$ \\
\hline DX EER 10.8 & 3,417 & 10,376 & $\$ 475$ & - & - & - & - & - & - \\
\hline Coolerado & 1,465 & 17,144 & $\$ 251$ & $57 \%$ & $\$ 223$ & $\$ 11,462$ & $\$ 38$ & 61.8 & $-\$ 6,835$ \\
\hline
\end{tabular}




\subsection{IMPLEMENTATION ISSUES}

\subsection{LESSONS LEARNED}

Demonstration projects are an effective way to uncover hidden issues that can arise during operation. The following is a list of lessons learned during the demonstration at Fort Carson, which provide design considerations for future installations:

- Water runoff. Wastewater from the units installed at the theater was collected through polyvinyl chloride piping and flowed across a cement sidewalk to the adjoining grass. The water eventually created a safety hazard. Wastewater that will not be used for irrigation needs to be routed to a sewer drain or diverted to avoid puddles and prevent safety hazards. Another solution that should be explored is underground water storage tanks. Two 800-gal storage tanks were installed to collect wastewater for four Coolerado units at the theater before the 2011 cooling season. The tanks were tied into the local irrigation system and sump pumps supplied the water to the irrigation system (see Figure 81 and Figure 82).

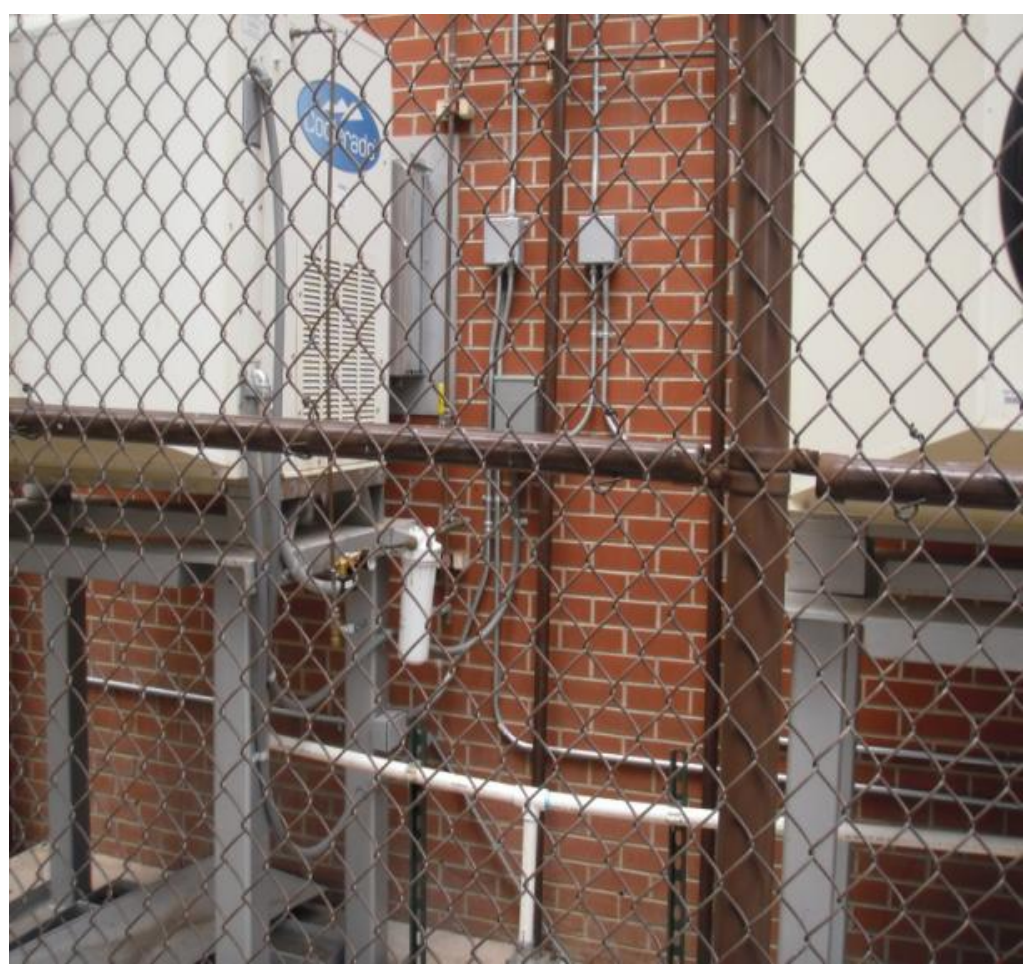

Figure 81. Coolerado drain water piping

(Source: Jesse Dean, NREL) 


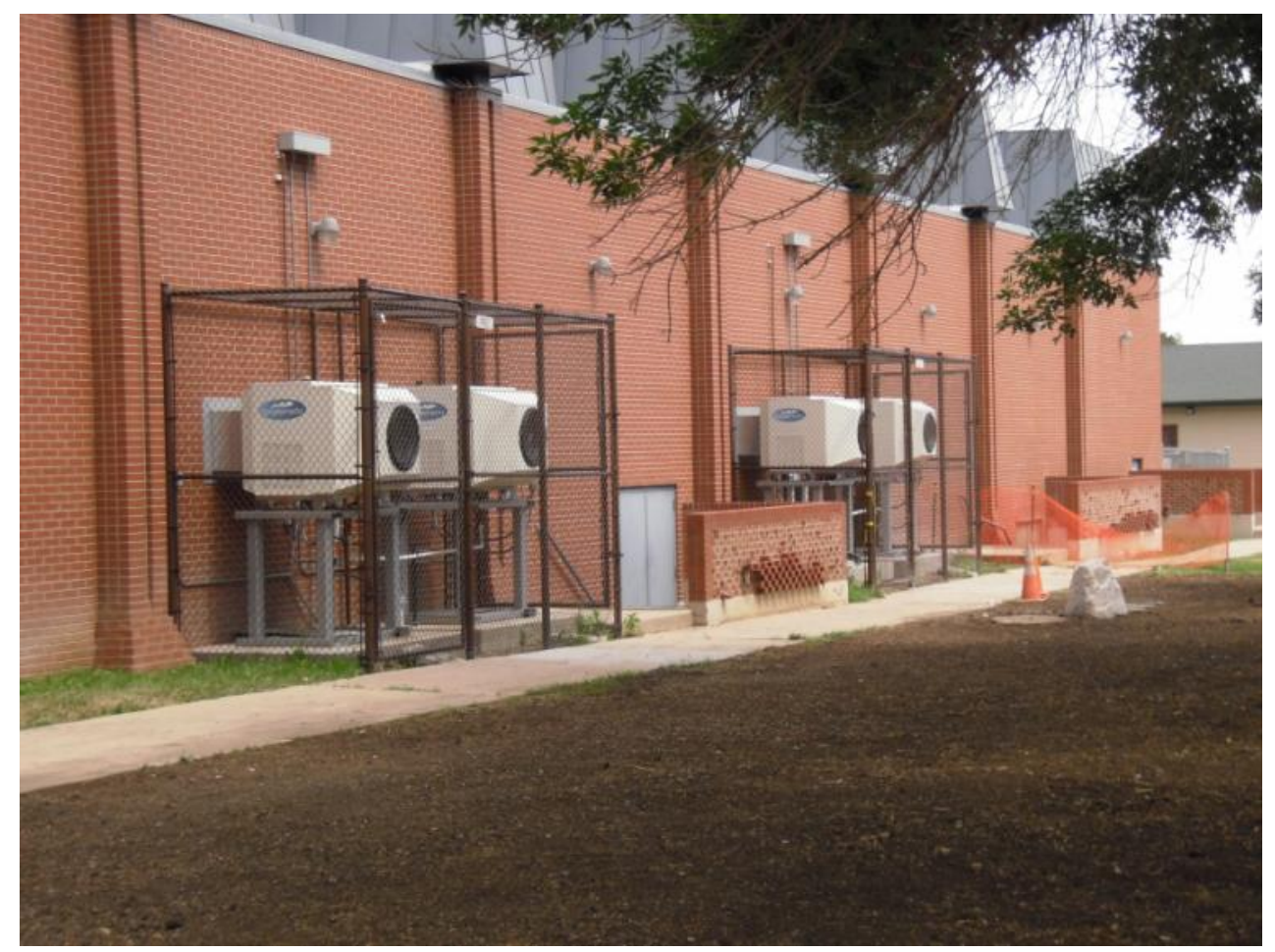

Figure 82. Coolerado units and manhole over water storage tank

(Source: Jesse Dean, NREL)

- $\quad$ CoCs. The CoC setting (ratio of parts water evaporated to parts wastewater) has a significant impact on water consumption. For the 2010 and most of the 2011 cooling seasons, the $\mathrm{CoC}$ was set at $1.5-1.6$ by Coolerado. This was standard practice at the time. Water consumption was 6-10 gal/ton $h$. However, the recommended set point for the Coolerado is $5 \mathrm{CoC}$, with four parts evaporated for every one part drained. A CoC of 5 should be considered the upper limit for $\mathrm{CoC}$ in order to ensure cooling performance per design intent. At the end of the 2011 cooling season the settings were modified with the $\mathrm{CoC}$ setting of 5 . As a result, the units were able achieve a water use rate of about $2.8 \mathrm{gal} / \mathrm{ton} \cdot \mathrm{h}$, which is slightly higher than the requirement in the performance metric.

- $\quad$ Sizing. The Coolerado properly must be sized properly to achieve the highest possible efficiency. To meet indoor comfort conditions with undersized units, the temperature set points must be at a low setting, which could in turn lead to higher energy consumption and lower efficiencies than if the units were slightly bigger. Properly sized units will spend more time operating at partial fan speeds and at higher WBEs.

- $\quad$ Sealing and winterization. All units should be sealed with caulk when installed and winterized during the off season to minimize infiltration in climate zones that experience freezing. Observations showed air gaps around the ductwork on the through-the-wall units. Also, diligent winterization of units not used in the off- 
season will prevent drafts, reduce heating energy consumption, and maintain indoor comfort.

\subsection{DECISION MAKING FACTORS}

The following factors should be considered when evaluating the applicability of Coolerado Coolers in a particular area.

\subsubsection{Climate}

The target climate zones for the Coolerado technology are ASHRAE climate zones $2 \mathrm{~B}, 3 \mathrm{~B}, 4 \mathrm{~B}$, $5 \mathrm{~B}$, and $6 \mathrm{~B}$. The system should be installed as an $\mathrm{OA}$ pre-conditioner in climate zones $2 \mathrm{~B}$ and $3 \mathrm{~B}$ and can be applied as a zone cooler for climate zones $4 \mathrm{~B}, 5 \mathrm{~B}$, and $6 \mathrm{~B}$.

Figure 83 shows a list of applicable military bases. 


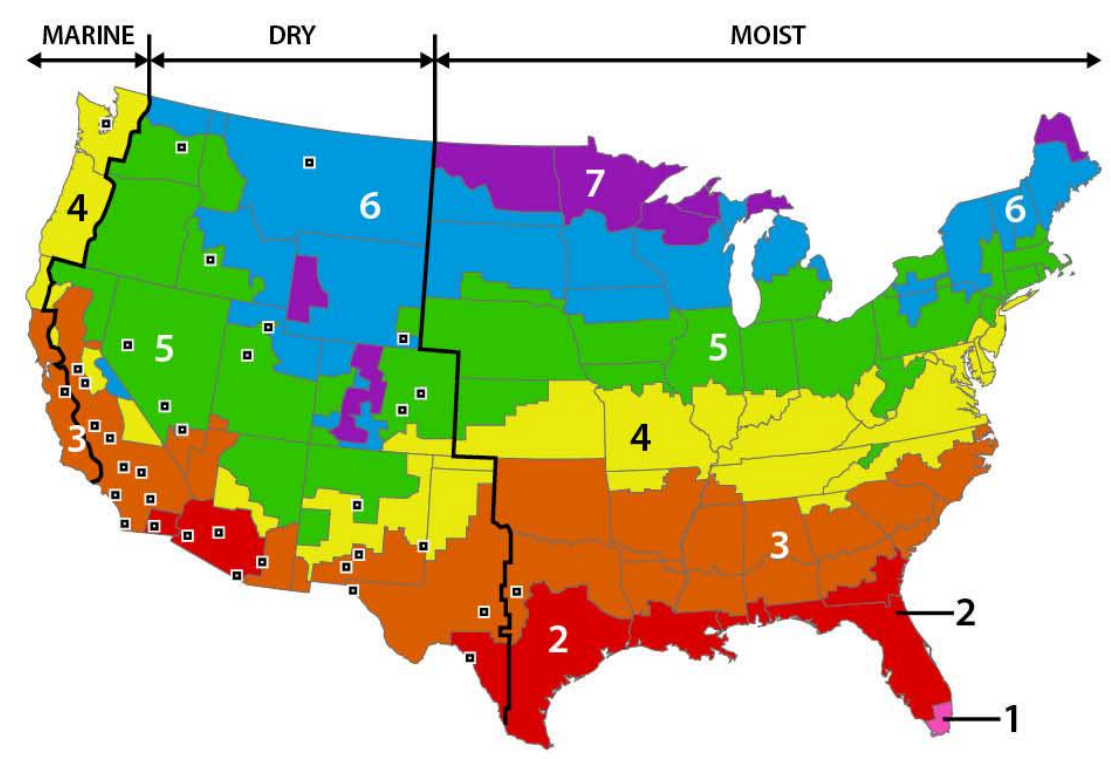

\begin{tabular}{|c|c|c|}
\hline DYESSAFB & Abilene, TX & Air Force \\
\hline GOODFELLOW AFB & San Angelo, TX & AirForce \\
\hline LAUGHLIN AFB & Del Rio, TX & AirForce \\
\hline HOLLOMAN AFB & HOLLOMAN AFB, NM & Air Force \\
\hline WHITESANDS MISSILERANGE & WHITESANDS, NM & Army \\
\hline FORT BLISS & FORT BLISS, TX & Army \\
\hline CANNON AFB & CANNON AFB, NM & Air Force \\
\hline KIRTLAND AFB & KIRTLAND, NM & AirForce \\
\hline EDWARDS AFB & California city, CA & Air Force \\
\hline CHINA LAKE NAVAL AIR WEAPONSSTATION & Ridgecrest, CA & Navy \\
\hline DAVIS-MONTHAN AFB & Tucson, $A Z$ & Air Force \\
\hline FORT HUACHUCA & Huachuca City, AZ & Army \\
\hline YUMA PROVING GROUND & Yuma, $A Z$ & Army \\
\hline YUMAMCAS & Yuma, $A Z$ & Marine Corps \\
\hline EL CENTRO NAVAL AIR FACIIITY & EL CENTRO, CA & Navy \\
\hline FORT IRWIN & Barstow, CA & Army \\
\hline LEMOORENAS & LEMOORE, CA & Navy \\
\hline BARSTOW MC LOGISTICS BASE & BARSTOW, CA & Marine Corps \\
\hline $\begin{array}{l}\text { TWENTYNINE PALMS MC AIR-GROUND } \\
\text { COMBAT CENTER }\end{array}$ & $\begin{array}{l}\text { TWENTYNINE } \\
\text { PALMS, }\end{array}$ & Marine Corps \\
\hline NELLIS AFB & NELLIS AFB, NV & Air Force \\
\hline Creech Air Force Base & Indian Springs, NV & AirForce \\
\hline LOS ANGELES AFB & LOSANGELES, CA & Air Force \\
\hline FORT MacARTHUR & Los Angeles, CA & Army \\
\hline LUKE AFB & Luke AFB, AZ & Air Force \\
\hline CORONADO NAVAL AMPHIBIOUS BASE & CORONADO, CA & Navy \\
\hline
\end{tabular}

\begin{tabular}{|c|c|c|}
\hline NORTHISLANDNAS & San Diego, CA & Navy \\
\hline $\begin{array}{l}\text { FLEET ANTISUBMARINE WARFARE } \\
\text { TRAINING CENTER }\end{array}$ & SanDiego, CA & Navy \\
\hline SAN DIEGO NAVAL MEDICAL CENTER & SANDIEGO, CA & Navy \\
\hline SANDIEGONS & SANDIEGO, CA & Navy \\
\hline SAN DIEGO NAVAL SUBMARINE BASE & SANDIEGO, CA & Navy \\
\hline AIR STATION MIRAMAR & San Diego, CA & Marine Corps \\
\hline CAMP PENDLETON & Oceanside, CA & Marine Corps \\
\hline SAN DIEGO MC RECRUITDEPOT & SANDIEGO, CA & Marine Corps \\
\hline BEALE AFB & Yuba City, CA & Air Force \\
\hline MCCLELLAN AFB & North Highlands, CA & Air Force \\
\hline TRAVIS AFB & Fairfield, CA & Air Force \\
\hline BUCKLEYANGB & Aurora, CO & Air Force \\
\hline CHEYENNE MOUNTAIN AIR STATION & Colorado Springs, CO & Air Force \\
\hline PETERSON AFB & Colorado Springs, CO & Air Force \\
\hline SCHRIEVER AFB & Colorado Springs, CO & Air Force \\
\hline U.S. AIR FORCEACADEMY & Colorado Springs, CO & AirForce \\
\hline FORT CARSON & Colorado Springs, C0 & Army \\
\hline MOUNTAIN HOMEAFB & MOUNTAIN HOME, ID & Air Force \\
\hline MALMSTROM AFB & Great Falls, MT & Air Force \\
\hline HILL AFB & HILL, UT & Air Force \\
\hline DUGWAY PROVING GROUNDS & $\begin{array}{l}\text { DUGWAYPROVING UT } \\
\text { GROUNDS, }\end{array}$ & Army \\
\hline FAIRCHILD AFB & FAIRCHILD, WA & Air Force \\
\hline WHIDBEY ISLAND NAS & WHIDBEYISLAND, WA & Navy \\
\hline FE. WARREN AFB & FE. WARREN, WY & Air Force \\
\hline FALLONNAS & FALLON, NV & Navy \\
\hline
\end{tabular}

Figure 83. Military bases by ASHRAE climate zone

(Source: Joelynn Schroeder, NREL) 


\subsubsection{HVAC Equipment Replacement}

When the HVAC equipment is at the end of its useful life and needs to be replaced, the economics of the Coolerado improve over the retrofit costs presented in the market analysis. For example, if the CRAC units in a data center need to be replaced it would be more cost effective to use that funding to supplement the installation of Coolerado units and leave the CRAC units as the backup supplementary cooling system.

\subsubsection{Facilities with No Cooling and New Construction}

The economics of the units will also improve when there is no air-conditioning system and when applied to new construction. In this case the installed costs were associated with the incremental costs above those of traditional air-conditioning equipment and the associated ductwork.

\subsubsection{Facility Types}

The technology has the best economics when applied to facilities with high internal cooling loads that require year-round cooling and when competing against air-cooled direct refrigeration-based air-conditioning systems. The top facility types are discussed here:

- $\quad$ Data centers. Data centers have the highest internal loads of any facility type. These facilities typically have no economizer cooling and can accept higher SATs.

- $\quad$ Quick service. Quick-service restaurants have very high internal loads and ventilation rates, and are typically conditioned with packaged RTUs. This facility type is also ideal for Coolerado units.

- $\quad$ Supermarket, dining/restaurant, small medical, laboratory, computer room classroom. All these building types have strict environmental regulations, high internal loads, or high ventilation rates and are good candidates for the Coolerado unit as an $\mathrm{OA}$ pre-conditioner in climate zones $2 \mathrm{~B}$ and $3 \mathrm{~B}$.

- Office, warehouse, barracks, other. All the building types with lower internal loads and ventilation rates are potential candidates for the unit, but the reduced hours of operation will increase the SPP period.

\subsubsection{Cost}

Cost is another obvious factor to consider when deciding whether Coolerado Coolers are a good option. Table 50 summarizes the potential cost components associated with the three implementation options. 
Table 50. Coolerado Cooler Cost Components

\begin{tabular}{|c|c|c|c|c|}
\hline Cost Elements & Component & $\begin{array}{c}\text { New } \\
\text { Construction }\end{array}$ & Retrofit & $\begin{array}{c}\text { Precool } \\
\text { Assist }\end{array}$ \\
\hline \multirow{6}{*}{ Installation } & Coolerado Cooler & $\checkmark$ & $\checkmark$ & $\checkmark$ \\
\hline & Installation labor & $\checkmark$ & $\checkmark$ & $\checkmark$ \\
\hline & Supporting structures & $\checkmark$ & $\checkmark$ & $\checkmark$ \\
\hline & Landscaping for water diversion & Optional & Optional & Optional \\
\hline & Envelope modifications & None & $\checkmark$ & None \\
\hline & Ducting & $\checkmark$ & $\checkmark$ & $\checkmark$ \\
\hline \multirow{2}{*}{$\begin{array}{l}\text { Annual } \\
\text { Maintenance } \\
\text { Cost }\end{array}$} & Filter replacement & \multirow{2}{*}{\multicolumn{3}{|c|}{$\checkmark$}} \\
\hline & Startup and shutdown costs & & & \\
\hline \multirow{2}{*}{$\begin{array}{l}\text { Annual } \\
\text { Operating Cost }\end{array}$} & Electricity & \multirow{2}{*}{\multicolumn{3}{|c|}{$\checkmark$}} \\
\hline & Water & & & \\
\hline
\end{tabular}

\subsection{Regulatory drivers}

Table 51 summarizes the regulatory drivers and describes how the Coolerado Cooler can help meet these requirements. 
Table 51. Federal Energy Management Program Requirements and Mandates for Energy Efficiency

\begin{tabular}{|c|c|c|}
\hline Category & Requirement & $\begin{array}{c}\text { How can implantation of a Coolerado Cooler } \\
\text { address this? }\end{array}$ \\
\hline Reduce facility energy intensity & $\begin{array}{l}\text { Reduce EUI by } 30 \% \text { by } 2015 \text {, relative to a } 2003 \text { energy } \\
\text { baseline. (EISA 2007) }\end{array}$ & $\begin{array}{l}\text { Energy simulations show that IECs can reduce } \\
\text { electrical energy use by by } 57 \%-92 \% \text { for select } \\
\text { building types in dry climates compared to } \\
\text { traditional cooling equipment }\end{array}$ \\
\hline Conserve Water & $\begin{array}{l}\text { Reduce agency industrial, landscaping, and agricultural } \\
\text { water consumption } 2 \% \text { annually, or } 20 \% \text { by the end of FY } \\
2020 \text {, relative to a FY } 2010 \text { baseline. (E.O. 13514) }\end{array}$ & $\begin{array}{l}\text { Power plants consume } 1-4 \mathrm{gal} / \mathrm{kWh} \text {, which } \\
\text { translates to } 1-4 \mathrm{gal} / \mathrm{ton} \cdot \mathrm{h} \text { for electric air- } \\
\text { conditioning. The demonstration showed that } \\
\text { Coolerado units can operate at } 3 \mathrm{gal} / \mathrm{ton} \cdot \mathrm{h} \text {, and } \\
\text { indicated a reduction in water use on a regional } \\
\text { basis. }\end{array}$ \\
\hline $\begin{array}{l}\text { Establish facility management, metering, } \\
\text { and measurement procedures for water, } \\
\text { energy, and greenhouse gases }\end{array}$ & $\begin{array}{l}\text { Meter all federal buildings by October } 1,2012 \text {, to ensure } \\
\text { efficient energy use and reduce the cost of electricity used in } \\
\text { federal facilities. (EPAct 2005) }\end{array}$ & $\begin{array}{l}\text { Electricity costs and demand charges can be } \\
\text { reduced as a direct result of reducing energy } \\
\text { consumption. }\end{array}$ \\
\hline $\begin{array}{l}\text { Plan new construction and major } \\
\text { renovations }\end{array}$ & $\begin{array}{l}\text { Ensure that major replacements of installed equipment (such } \\
\text { as heating and cooling systems) or renovation or expansion } \\
\text { of existing spaces employs the most energy-efficient } \\
\text { designs, systems, equipment, and controls that are life cycle } \\
\text { cost effective. (EISA 2007) }\end{array}$ & $\begin{array}{l}\text { Energy simulations show that Coolerado Coolers } \\
\text { can provide effective cooling with less energy than } \\
\text { traditional cooling technologies and can be } \\
\text { economically feasible in certain building types and } \\
\text { climates. }\end{array}$ \\
\hline $\begin{array}{l}\text { Reduce petroleum usage/increase } \\
\text { alternative fuel usage }\end{array}$ & $\begin{array}{l}\text { Design buildings to reduce fossil fuel-generated energy } \\
\text { consumption by } 100 \% \text { by FY } 2030 \text {. (EISA 2007) }\end{array}$ & $\begin{array}{l}\text { By using less energy than typical air-conditioning } \\
\text { units, Coolerado Coolers can help bring total site } \\
\text { energy down to a point where photovoltaics and } \\
\text { other renewable energy technologies becomes } \\
\text { economically feasible. }\end{array}$ \\
\hline
\end{tabular}




\section{Appendix A: Points of Contact}

All points of contact involved in the demonstration are provided in Table 52.

Table 52. Points of Contact

\begin{tabular}{|c|c|c|c|}
\hline $\begin{array}{l}\text { POINT OF } \\
\text { CONTACT } \\
\text { Name } \\
\end{array}$ & $\begin{array}{c}\text { ORGANIZATION } \\
\text { Name } \\
\text { Address } \\
\end{array}$ & $\begin{array}{c}\text { Phone } \\
\text { Fax } \\
\text { E-mail } \\
\end{array}$ & Role in Project \\
\hline Jesse Dean & $\begin{array}{l}\text { National Renewable } \\
\text { Energy Laboratory }\end{array}$ & $\begin{array}{c}\text { 303-384-7539 } \\
\text { Jesse.Dean } @ \text {,nrel.gov } \\
\end{array}$ & $\begin{array}{l}\text { Co-Principal } \\
\text { Investigator }\end{array}$ \\
\hline Eric Kozubal & $\begin{array}{l}\text { National Renewable } \\
\text { Energy Laboratory }\end{array}$ & $\begin{array}{c}\text { 303-384-6155 } \\
\text { Eric.Kozubal@,nrel.gov } \\
\end{array}$ & $\begin{array}{l}\text { Co-Principal } \\
\text { Investigator }\end{array}$ \\
\hline Lesley Herrmann & $\begin{array}{l}\text { National Renewable } \\
\text { Energy Laboratory }\end{array}$ & $\begin{array}{c}\text { (303) 275-4318 } \\
\text { Lesley.Herrmann } @ \text {,nrel.gov } \\
\end{array}$ & Investigator \\
\hline Scott Clark & Fort Carson DPW & $\begin{array}{c}\text { 719-526-1739 } \\
\text { scott.b.clark@us.army.mil } \\
\end{array}$ & $\begin{array}{c}\text { Site Sponsor, Fort } \\
\text { Carson Project Manager }\end{array}$ \\
\hline Tim Heaton & Coolerado & $\begin{array}{c}\text { 720-974-9612 } \\
\text { timheaton } @ \text {,coolerado.com }\end{array}$ & $\begin{array}{c}\text { Industry Partner, } \\
\text { Coolerado Vice } \\
\text { President }\end{array}$ \\
\hline Mark Eastment & Eastment Consulting & $\begin{array}{c}\text { 303-956-3927 } \\
\text { meastment@gmail.com } \\
\end{array}$ & DAS \\
\hline Ed Hancock & $\begin{array}{l}\text { Mountain Energy } \\
\text { Partnership }\end{array}$ & $\begin{array}{c}\text { (303) 517-8238 } \\
\text { CEHancock3@aol.com }\end{array}$ & DAS \\
\hline Greg Barker & $\begin{array}{c}\text { Mountain Energy } \\
\text { Partnership }\end{array}$ & $\begin{array}{c}(303) \text { 775-7646 } \\
\text { GBARKER123@aol.com }\end{array}$ & DAS \\
\hline
\end{tabular}




\section{APPENDIX B: COOLERADO DESIGN CONSIDERATIONS}

\section{External Static Pressure}

The first issue that needs to be understood is the relationship between external SP, cooling capacity, and SA flow rate. As the external SP on the SA increases, a larger fraction of the inlet air is forced through the EA channels, through the natural physics of the HMX. The SA SP consists of three potential external pressure sources:

- $\quad$ Filter pressure. As the air filter fouls with dirt and debris the SP drop across the filter start to increase. In-situ SP testing was conducted at Fort Carson at 100\% fan speed for one of the C60 units and indicated that a $75 \%$ loaded filter will introduce approximately $0.14 \mathrm{in}$. of static.

- Duct SP. Duct SP or system SP is associated with the pressure loss through the SA ductwork. The SP from this system has the potential to introduce the most SP on the system.

- $\quad$ Building $S P$ - The Coolerado unit will pressurize the space if there is no relief air path to exhaust the SA from the Coolerado unit by as much as 0.1 to $0.15 \mathrm{in}$. SP.

The total SP needs to be calculated by adding the filter pressure (if applicable), duct static, and building SP.

Figure 84 provides a representation of the SA flow rate and cooling capacity as a function of SA SP (SP of 0 in. includes clean air filter) (at inlet conditions of $63^{\circ} \mathrm{F}$ wet bulb, $95^{\circ} \mathrm{F}$ dry bulb, $80^{\circ} \mathrm{F}$ RAT, and elevation of 5,702 ft) for the Coolerado C60 unit. The graph was developed based on modeled performance and includes the SP drop of a clean air filter.

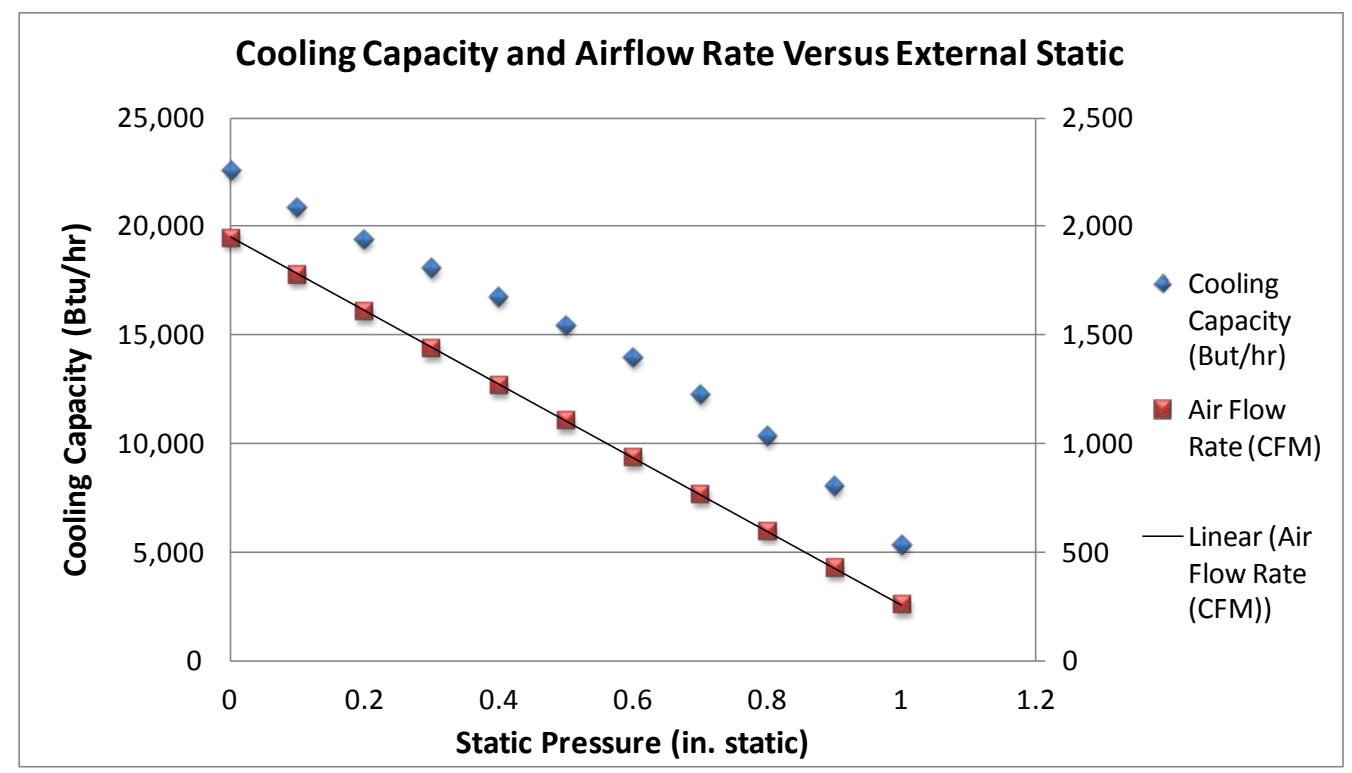

Figure 84. Coolerado cooling capacity and airflow rate versus SP

The airflow rate at 0 in. of external SP is approximately $1,950 \mathrm{cfm}$, decreasing to $<500 \mathrm{cfm}$ at 1 in. of SP. There is a similar relationship with cooling capacity versus SP. At the given set of inlet 
air design conditions, the cooling capacity at 0 in. of external SP is almost 2 tons and $<1 / 2$ ton at 1 in. of external SP. There is a nonlinear relationship between cooling capacity and external SP because the WBE slightly increases as the fraction of EA increases. The design SP needs to be carefully considered when designing the Coolerado unit and care should be taken to minimize external SP as much as possible. One application that requires caution is residential retrofits where the ductwork has a high SP at full fan speed design conditions, typically between 0.65 and 1.2 in. of static at the given flow rates. When the unit is installed as an OA pre-conditioner for an RTU or AHU, the system should be set up to operate the RTU or AHU fan when the Coolerado unit is operating. This will eliminate the SP on the Coolerado unit and will increase its cooling capacity.

Table 53 shows the relationship between SP and elevation for the C60 unit. Design engineers can use it to select an appropriate flow rate and SP.

Table 53. Volumetric Flow Rate Versus SP and Elevation
\begin{tabular}{|c|c|c|c|c|}
\hline \multicolumn{5}{|c|}{ Volumetric Flow (CFM) } \\
\hline \hline Static Pressure & \multicolumn{4}{|c|}{ Elevation } \\
\hline \hline Inches & $0 \mathrm{ft}$ & $1,500 \mathrm{ft}$ & $3,000 \mathrm{ft}$ & $5,702 \mathrm{ft}$ \\
0 & 1,949 & 1,949 & 1,949 & 1,949 \\
0.2 & 1,674 & 1,659 & 1,659 & 1,612 \\
0.6 & 1,125 & 1,080 & 1,080 & 937 \\
0.8 & 851 & 791 & 791 & 600 \\
1 & 576 & 501 & 501 & 263 \\
\end{tabular}

\section{Water Consumption Characteristics}

The Coolerado technology is configured with single pass cooling water. Some inlet water is evaporated in the EA stream and some passes through the unit and drains from the outlet piping. One $\mathrm{CoC}$ indicates half the water is evaporated and the mineral concentration of the drain water doubles (for example would go from $100 \mathrm{ppm}$ to $200 \mathrm{ppm}$ ). Two CoCs means 2 parts evaporated for 1 part drained and the mineral concentration of the drained water triples. A dip switch is used to set the $\mathrm{CoC}$ for the unit. The Coolerado units were set up with a $\mathrm{CoC}$ of 1.4-1.6 for most of the demonstration, which significantly increased onsite water consumption for most of the summer. The recommended set point for the Coolerado unit is $5 \mathrm{CoCs}$, with 4 parts evaporated for every 1 part drained. The Coolerado units were tested in the TTF with a CoC setting of 5 without compromising its WBE. As a best practice the onsite water consumption should be minimized by setting the $\mathrm{CoC}$ to 5 , reusing excess water for irrigation, and potentially capturing rainwater as a water supply for the units.

\section{Reduced Capacity at Design Conditions}

A common design issue with all standalone evaporative cooling units is associated with their cooling capacity at design conditions. At ASHRAE $0.4 \%$ evaporative design conditions, the design wet bulb temperatures reduce the temperature difference between the achievable SAT and space (or return) air temperature. The variables that affect the sizing of evaporatively cooled units include the inlet air wet bulb temperature, WBE, the space temperature set point, and 
ambient atmospheric pressure. Depending on the extremity of the climate, the cooling capacity that the Coolerado unit can provide could be as low as $25 \%$ of the cooling capacity at off-design conditions. Table 54 lists the Coolerado C60 performance characteristics at different design wet bulb and dry bulb design conditions, assuming a design RAT of $80^{\circ} \mathrm{F}$, a CoC for the water controls of 5, and an altitude of 5,702 ft.

Table 54. Coolerado C60 Performance Characteristics at Different Wet Bulb Temperatures

\begin{tabular}{|l|c|c|c|c|c|c|}
\hline \multicolumn{6}{|c|}{ Coolerado C60 Performance Characteristics with 80 F Return Temp and CoC = 5 } \\
\hline \hline Design Wet Bulb and Dry Bulb & & 50 F/ 95 F & 55 F/ 95 F & 60 F / 95 F & 65 F/ 95 F & $70 \mathrm{~F} / 95 \mathrm{~F}$ \\
Number of Cooling Cores & & 6 & 6 & 6 & 6 & 6 \\
Cooling Capacity at Design Cond. & Btu/hr & 39,615 & 32,319 & 25,139 & 18,070 & 11,109 \\
Product Flow & $\mathrm{cfm}$ & 1,780 & 1,780 & 1,780 & 1,780 & 1,780 \\
Supply Air Temperature & ${ }^{\circ} \mathrm{F}$ & 55 & 59.4 & 63.9 & 68.3 & 72.8 \\
Wet Bulb Effectiveness & $\%$ & $89 \%$ & $89 \%$ & $89 \%$ & $89 \%$ & $89 \%$ \\
Fan Power & $\mathrm{hp}$ & 0.8 & 0.8 & 0.8 & 0.8 & 0.8 \\
Coeficient of Performance & & 20.5 & 16.7 & 13 & 9.4 & 5.7 \\
Exhaust Flow & $\mathrm{cfm}$ & 1,162 & 1,162 & 1,162 & 1,162 & 1,162 \\
Percent Exhuast & $\%$ & $39 \%$ & $39 \%$ & $39 \%$ & $39 \%$ & $39 \%$ \\
Exhaust Air Temperature & $\mathrm{F}$ & 65.2 & 68.5 & 71.8 & 75.1 & 78.4 \\
Total Water Consumption & $\mathrm{gph}$ & 27.66 & 25.7 & 23.52 & 21.09 & 18.33 \\
Gal per Ton/hr OA & & 5.24 & 5.52 & 5.82 & 6.13 & 6.44 \\
\hline
\end{tabular}

Using a design wet bulb temperature of $50^{\circ} \mathrm{F}$ the unit can provide a little more than 3 tons of cooling, and a little less than 1 ton of cooling at wet bulb temperature of $70^{\circ} \mathrm{F}$. The RAT is set to a relatively high value for this analysis, and the cooling capacity would be reduced if the design RAT is lowered. This is arguably the largest barrier to the adoption of standalone evaporative cooling units because a design engineer would need to install a number of additional cooling units to meet the design space cooling load or let the space temperature increase to higher values under peak conditions. Although this needs to be addressed, two design options can be implemented to address the issue.

\section{Improved Performance at Part Load}

The WBE of the Coolerado unit and the part load performance significantly increase at partial loads. The WBE at $100 \%$ fan speed with 0 in. of external SP is $88 \%$ at an elevation of $5,702 \mathrm{ft}$; the WBE is $116 \%$ at $20 \%$ fan speed. If the external SP applied to the unit is 0.25 in. at $100 \%$ fan speed, the WBE is $91 \%$ and $119 \%$ at $20 \%$ fan speed. In addition, the part load electrical efficiency increases based on the following relationship between fan speed and power use, which furthers the energy efficiency of the unit at partial loads. $\mathrm{N}$ is typically $2.3-3$ for HVAC systems.

$$
\text { Fan Power }=(\text { Fan Speed })^{N}
$$

If the Coolerado unit is installed as an outdoor air pre-conditioner and the fan speed is set to a value $<100 \%$, the unit can continuously achieve WBE $>100 \%$ and operate with high annual EERs (Figure 85). 


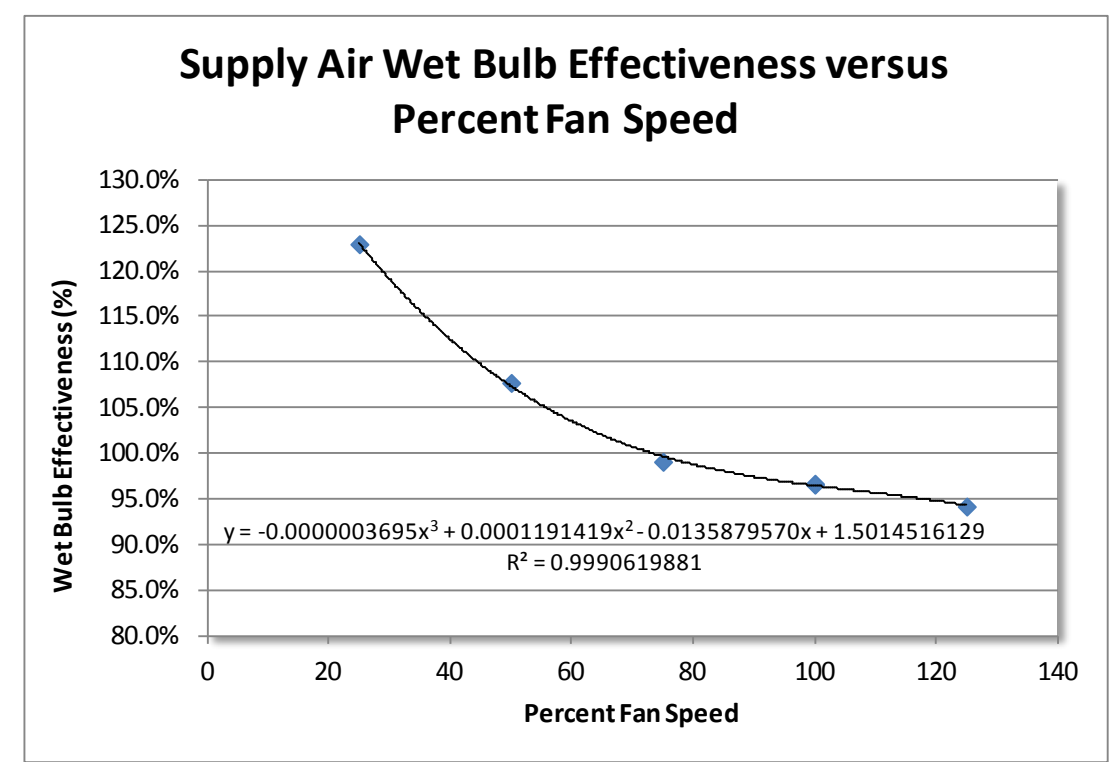

Figure 85. Coolerado energy efficiency ratio versus fan speed

\section{Additional Design Considerations}

In addition to the design considerations presented above, the following considerations should also be made when determining the feasibility of this technology when it is installed as a standalone zone cooler:

- $\quad$ Area available for base mounted units. Exterior wall installations can be more appropriate in some cases than roof installations, as illustrated at the event center, theater, and training facility when the system is installed as a standalone zone cooler. In these cases, ample space should be available for the support structures.

- Roof condition. For roof-mounted installations, the roof should be in good condition and must be able to structurally support the dead load $\left(\mathrm{lb} / \mathrm{ft}^{2}\right)$ of the unit.

- $\quad$ Need for irrigation. Drainage water from the unit can be diverted or stored and used to irrigate the surrounding landscape.

- $\quad$ Pressure relief. The building should have sufficient means for pressure relief, which could be provided by pressure relief dampers, natural building exfiltration, or the building's EA system when the system is installed as a standalone zone cooler. Pressure relief may not be necessary if the Coolerado is installed as a precooling device for an RTU or AHU. 


\section{APPENDIX C: FIELD MEASUREMENT SENSOR DESCRIPTION AND SPECIFICATION}

\section{Outside Air}

The OAT, RH, solar irradiance, and atm are monitored at a central location at Fort Carson. Before the 2011 cooling season began, OAT sensors were installed at each building to more accurately capture the local OATs (Table 55). The SAT for the Coolerado units is directly tied to the OA conditions. This monitoring point is a critical piece of the demonstration plan.

Table 55. Outside Sensor Type and Accuracy

\begin{tabular}{|c|c|c|c|c|}
\hline Sensor & Location & Vendor & Model & Accuracy Specification \\
\hline $\mathrm{OAT}$ and $\mathrm{RH}$ & Probe & Vaisala & HMP50 & $\begin{array}{c}\text { Temperature }=0.6^{\circ} \mathrm{C} \\
\text { RH } \\
\pm 3 \% \text { RH } \\
(0 \%-90 \% \mathrm{RH}) \\
\pm 5 \% \mathrm{RH} \\
(90 \%-98 \% \mathrm{RH})\end{array}$ \\
\hline Ambient pressure & Outdoor & Setra & 276 & $1 \%$ of full scale \\
\hline Pyranometer & Horizontal & $\begin{array}{l}\text { Campbell } \\
\text { Scientific }\end{array}$ & CS300 & $5 \%$ of daily total \\
\hline
\end{tabular}

The OAT measurement has an accuracy of $0.6^{\circ} \mathrm{C}$ and the $\mathrm{RH}$ has an accuracy of $3 \% \mathrm{RH}$ for most climatic conditions experienced at Fort Carson. All sensors were purchased new and were applied with their factory calibrations.

\section{Electrical Power}

The electrical power was measured with a WattNode, current transformers, and voltage leads. The WattNode is a true root mean squared (RMS) AC W-h transducer with pulse output proportional to the electrical energy $(\mathrm{kWh})$ consumed. Fifteen-amp split core current transformers are used to measure true RMS current and voltage leads are wired directly into the electrical panel. Figure 86 shows the WattNode used on the Coolerado projects. 


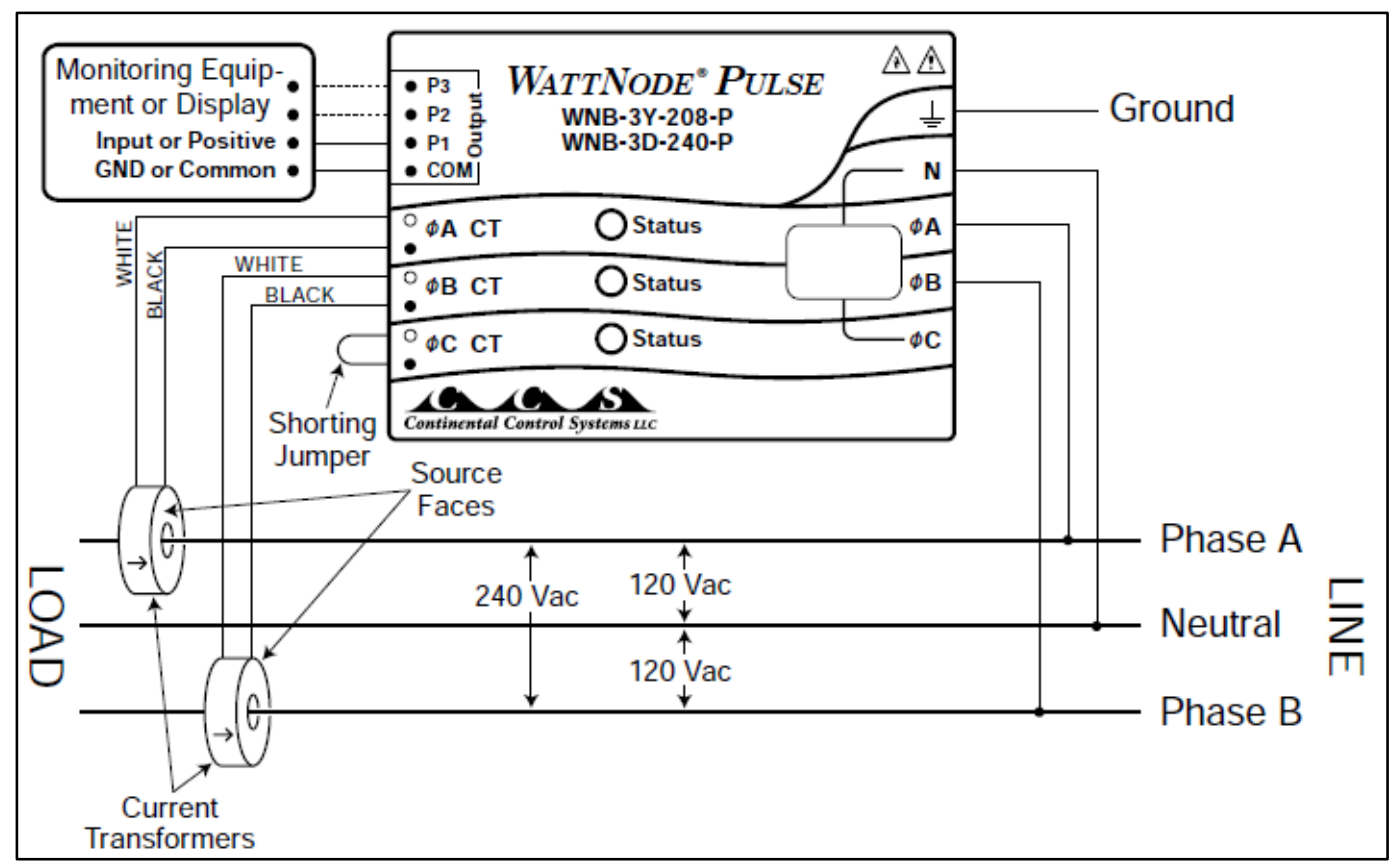

Figure 86. Electric power WattNode

(Source: NREL)

A current transformer was placed on Phase A and Phase B and voltage leads were wired into Phase A, Phase B, and the Neutral. The WattNode has an accuracy of $0.5 \%$ of the reading and the current transformer has an accuracy of $1 \%$ of the reading (see Table 56).

Table 56. Electric Power Sensor Accuracy

\begin{tabular}{|l|c|c|c|c||}
\hline \hline Sensor & Location & Vendor & Model & Accuracy Specification \\
\hline Electrical energy & $\begin{array}{c}\text { Branch } \\
\text { circuit feed } \\
\text { to unit }\end{array}$ & $\begin{array}{c}\text { Continental } \\
\text { Controls }\end{array}$ & $\begin{array}{c}\text { WNB-3D- } \\
240-\mathrm{P}, \text { Opt } \\
100 \mathrm{~Hz}\end{array}$ & $0.5 \%$ of reading \\
\hline \hline Current transformer & $\begin{array}{c}\text { Branch } \\
\text { circuit feed } \\
\text { to unit }\end{array}$ & $\begin{array}{c}\text { Continental } \\
\text { Controls }\end{array}$ & $\begin{array}{c}\text { CTM-0360- } \\
015\end{array}$ & $\begin{array}{c}1 \% \text { of reading, phase } \\
\text { angle error } \leq 2 \text { degrees }\end{array}$ \\
\hline
\end{tabular}

\section{Water Consumption and Quality}

The inlet water consumption was monitored with an in-line Omega FTB 4605 pulse output water flow meter. For $1 / 2$-in. pipe diameter, the meter can record water consumption at $0.15-13 \mathrm{gpm}$. Its accuracy at $6.6-13 \mathrm{gpm}$ is $\pm 1.5 \%$ of the measured flow rate and $\pm 2 \%$ at $6.5-0.15 \mathrm{gpm}$. The flow meter was purchased new with the factory calibration. The Coolerado units were set up with a solenoid valve that cycles from fully open to fully closed to provide water to the unit, with small bursts of water passing through the flow meter. These pulses are picked up by the flow meter and are recorded as pulses per gallon that are provided to the data logger. 
Inlet and purge water quality was measured with a TDS meter manufactured by Omega. The meter has an accuracy of $\pm 2 \%$ of the reading (see Table 57 ).

Table 57. Water Consumption Sensor Type and Accuracy

\begin{tabular}{|l|c|c|c|c|}
\hline Sensor & Location & Vendor & Model & $\begin{array}{c}\text { Accuracy } \\
\text { Specification }\end{array}$ \\
\hline $\begin{array}{l}\text { Turbine flow } \\
\text { meter }\end{array}$ & Cooling inlet water & $\begin{array}{c}\text { Omega } \\
\text { Engineering }\end{array}$ & FTB-4605 & $\begin{array}{c}6.6-13 \text { gpm is } \pm \\
1.5 \% \text { of measured } \\
\text { flow }\end{array}$ \\
\hline $\begin{array}{l}\text { Water } \\
\text { conductivity } \\
\text { probe }\end{array}$ & $\begin{array}{c}\text { Makeup water inlet and/or } \\
\text { purge water outlet }\end{array}$ & $\begin{array}{c}\text { Omega } \\
\text { Engineering }\end{array}$ & $\begin{array}{c}\text { Censor \& CDTX } \\
\text { Transmitter }\end{array}$ & $\pm 2 \%$ of reading \\
\hline \hline
\end{tabular}

Training center unit 1, event center unit 7, wastewater treatment plant pad mount unit, and standalone unit were equipped with a sump pump to measure purge water flow. The system was set up to count pump cycles and pump flow volume per cycle was established at NREL's TTF.

\section{Supply Air Flow Rate and Temperature}

SAT was measured with a Cantherm thermistor that has an accuracy of $0.2^{\circ} \mathrm{C}$. The SA flow rate was calculated based on a combination of laboratory test data and field test measurements. The laboratory test data provided information on volumetric flow rate as a function of fan speed and total SP at $100 \%$ fan speed. The fan speed was correlated to fan power from laboratory test results for the performance model that was developed to model the performance of the unit. A differential pressure meter was also installed on select units to verify the airflow correlations. The differential pressure taps are tied into a Setra pressure transducer with an accuracy of $1 \%$ of full-scale measurements (Table 58).

Table 58. SAT and Flow Rate Sensor Type and Accuracy

\begin{tabular}{|l|c|c|c|c||}
\hline Sensor & Location & Vendor & Model & Accuracy Specification \\
\hline SAT & Supply register & Cantherm & MF52 & $0.2^{\circ} \mathrm{C}$ \\
\hline $\begin{array}{l}\text { Differential } \\
\text { pressure }\end{array}$ & $\begin{array}{c}\text { Pressure taps on either side } \\
\text { of cooling core }\end{array}$ & Setra & 264 & $1 \%$ of full scale \\
\hline
\end{tabular}

In-situ airflow testing was performed on one of the Coolerado C60 units installed at the theater (see Figure 87). A new enclosure was built for a blower door fan. The enclosure was fitted around the outlet ductwork for the unit and the blower door fan and controls were used to measure air flow at different fan speeds. 


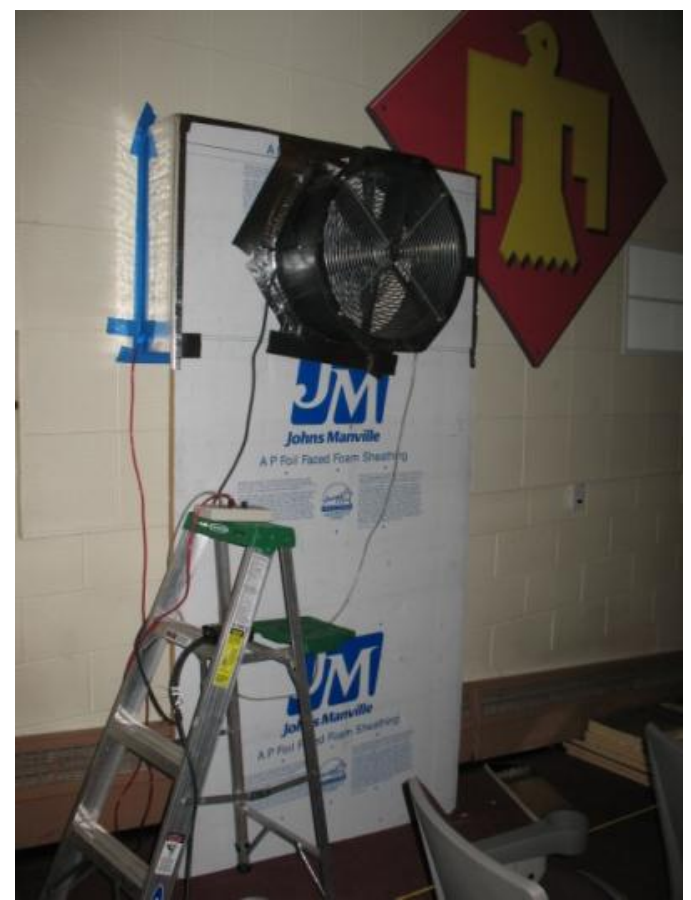

Figure 87. In-situ airflow testing

(Source: Jesse Dean, NREL)

The control board for the Coolerado was overridden and a potentiometer was used with a $0-10$ Volt-DC regulated power supply for the analogue input to the control board. The potentiometer was used to modulate the control signal from 0 to 10 Volts which directly controls the fan power. The blower door set up monitored OA pressure, building pressure, SP induced by the fan assembly and airflow rate. At each fan speed the blower door fan was adjusted to ensure it was inducing 0 in. of SP on the unit and measuring the true airflow rate at that fan speed. Four datasets were collected. The unit was tested with dirty filters that were $75 \%$ loaded and with clean filters and with the door to the outdoors open to capture the effects of building pressurization on the tests. The four tests were:

- $\quad$ Side door open, dirty filters

- $\quad$ Side door closed, dirty filters

- $\quad$ Side door open, clean filters

- $\quad$ Side door closed, clean filters

Figure 88 shows the in-situ field test curve fits of volumetric flow rate versus fan power. 


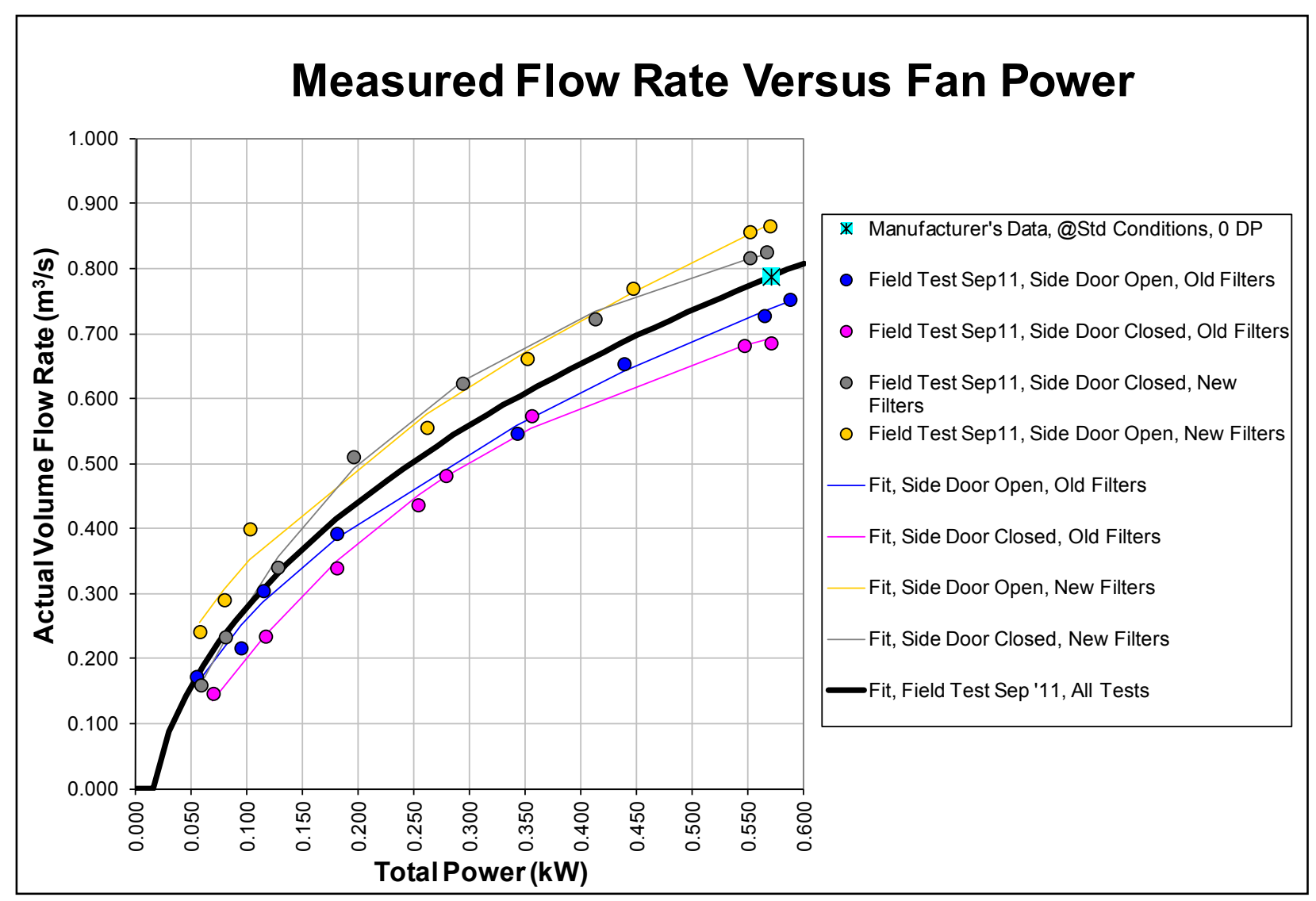

Figure 88. In-situ measured flow rate versus fan power

There was a significant difference in airflow rates between the side door open with new filters test and side door open with old filter test, which indicates that loaded filters reduce the airflow more than building pressurization for this case. The airflow is also reduced if the facility does not have an EA path for the air and the building pressurizes to as much as $0.15 \mathrm{in}$. of SP. The field tests are in line with manufacturer's data and with extrapolated laboratory tests. Laboratory testing was not conducted below 0.25 in. of SP and all units that were installed at Fort Carson had $<0.25$ in. of total SP on the SA.

Two new regressions were developed to calculate airflow rates and cooling capacity. Both were based on an average of the clean filter and dirty filter tests, because the air filter pressure drop gradually increases over the summer and this average takes this into account. The door closed test was used as the algorithm for the facilities that did not have a relief air path and the doors open correlation was used for facilities that had an EA path or leaker building envelope. The volumetric flow rate correlation is provided below. $\mathrm{P}_{\text {tot }}$ is the total power $(570 \mathrm{~W})$ and $\mathrm{P}_{\text {standby }}$ is the standby power when the unit is turned off $(15 \mathrm{~W})$. The standby power is associated with the residual power that the control board draws when the unit is turned off.

$$
\text { Volumetric Flow Rate }=\frac{P_{\text {tot }}-P_{\text {standby }}}{c_{1}+c_{2} *\left(P_{\text {tot }}-P_{\text {standby }}\right)+c_{3} *\left(P_{\text {tot }}-P_{\text {standby }}\right)^{0.5}}
$$


Table 59 shows the coefficients for each field test. For the performance model the curve fits that were derived from laboratory tests were used, which resulted in very similar volumetric flow rate predictions.

Table 59. Curve Fit Coefficients for Blower Door Tests

\begin{tabular}{||l|c|c|c|}
\hline \multicolumn{4}{|c|}{ Curve-Fits to Blower-Door Field Tests } \\
\hline Test & $\mathbf{c}_{\mathbf{1}}$ & $\mathbf{c}_{\mathbf{2}}$ & $\mathbf{c}_{\mathbf{3}}$ \\
\hline Door open, old filters & 0.069146 & 0.084794 & 0.852324 \\
\hline Door open, new filters & -0.03174 & -0.10015 & 0.975647 \\
\hline Door closed, old filters & 0.405481 & 1.081259 & -0.27468 \\
\hline Door closed, new filters & 0.257749 & 0.946362 & -0.14666 \\
\hline All tests combined & 0.078197 & 0.156421 & 0.724634 \\
\hline Door open, old and new filters combined & 0.006557 & -0.03092 & 0.941267 \\
\hline Door closed, old and new filters combined & 0.240198 & 0.668684 & 0.153157 \\
\hline
\end{tabular}

\section{Space Temperature and Humidity}

The space temperature and RH were measured in at least one location in each facility and up to two locations in select facilities (Table 60). In addition, EAT was monitored at one to two locations in select facilities. The space temperature measurement had an accuracy of $0.3^{\circ} \mathrm{C}$ and the $\mathrm{RH}$ had an accuracy of $\pm 1.5 \%$ at $10^{\circ}-60^{\circ} \mathrm{C}$.

Table 60. Space Temperature and Humidity Sensor Type and Accuracy

\begin{tabular}{||l|c|c|c|c||}
\hline \hline Sensor & Location & Vendor & Model & Accuracy Specification \\
\hline Indoor Temperature and RH & Wall mount & Vaisala & HMW $40 \mathrm{Y}$ & $\begin{array}{c} \pm 0.3{ }^{\circ} \mathrm{C}, 2 \% \mathrm{RH}, \pm 1.5 \% \\
\mathrm{RH} \text { from }-10 \text { to } 60^{\circ} \mathrm{C} \\
\text { Temperature Dependence }\end{array}$ \\
\hline
\end{tabular}

All sensors for all measurement points were purchased new sensors with their factory calibrations. Quality assurance was based on the number of units that were monitored and the comparisons to laboratory predicted performance. Results quantified ambient, supply, and indoor/exhaust psychrometric conditions, total cooling, building cooling, power consumption, and water quality, consumption, and use. The data collection approach attempted to achieve no more than $10 \%$ uncertainty in the following calculated parameters:

- $\quad \mathrm{kW} /$ ton: electric power as a function of total cooling rate

- $\mathrm{Gal} / \mathrm{ton} \cdot \mathrm{h}$ : water consumption as a function of ambient wet bulb depression

Total cooling is defined as the cooling rate $(\mathrm{Btu} / \mathrm{h})$ produced across the cooler (ENTHALPYambient- ENTHALPYsupply). Building cooling is defined as the cooling rate 
$(\mathrm{Btu} / \mathrm{h})$ effected on the building based on displacement of EA from the building (ENTHALPYbuildingexhaust- ENTHALPYsupply). Water use is defined as tap water drawn by the cooling system (what you pay for) for the systems that do not have a water reclamation system. Water was reclaimed for four of the theater units during the 2011 cooling season and the water use for this unit is defined as just that used for evaporation. For the purposes of this demonstration, gray water was considered "free" acknowledging that water use and reuse regulations vary by region and over time. Water consumption is defined as water used in the evaporative cooling process less the water that makes it back to a drain.

\section{Sampling Results}

A detailed summary of sampling results is provided in section 6 .

\section{Calibration of Equipment}

The equipment in the TTF is regularly calibrated and all equipment purchased for the Fort Carson demonstration was purchased new with the factory calibration.

\section{Quality Assurance}

Field data were checked against performance curves established at NREL's Advanced HVAC Laboratory on Coolerado units at their full operational mode. Data were collected and monitored in sufficient detail so that errors, such as malfunctioning sensors or controls, could be detected and corrected soon after they developed. For example, a CT on an event center unit came loose after the 2010 cooling season and was replaced before the 2011 cooling season. 


\section{APPENDIX D: DEVELOPMENT AND VALIDATION OF COOLERADO PERFORMANCE MODEL}

Two second-generation multi-staged indirect evaporative cooling units manufactured by Coolerado were tested at NREL's TTF in 2008. ${ }^{\text {xxiii }}$ The two model C60 units (serial numbers 540 and 539) were tested under a variety of climatic, full, and part load conditions. Seventeen laboratory tests were conducted. The results were used to develop a series of regression-based performance curves that characterize the performance of the units under any operational condition. The laboratory tests were conducted in accordance with ASHRAE Standard 143-2000 Method of Test for Rating Indirect Evaporative Coolers requirements. ${ }^{\text {xxiv }}$ The accuracy of each laboratory measurement is provided below:

- Temperature measurements have an accuracy of $\pm 0.2^{\circ} \mathrm{C}$ with $<0.1{ }^{\circ} \mathrm{C}$ deviation

- Airflow measurements have an accuracy of $\pm 2 \%$

- Humidity is calculated with dew point hydrometers and has an accuracy of $0.15^{\circ} \mathrm{C}$

- Differential pressure measurements have an accuracy of \pm 0.025 in. w.c.

- Barometric pressure has an accuracy of $0.15 \%$

ASHRAE Standard 143-2000 provides requirements for testing and rating IECs under steadystate conditions. The regression-based curve fits that were generated based on the laboratory testing were used to create a sizing program that determines the number of Coolerado cooling cores required to meet a space cooling load, given a set of building design and climatic design conditions. The sizing information is then passed to an annual simulation that calculates the part load performance of the unit to meet a space cooling load, given a set of inlet air conditions.

\section{Performance Model Correlations}

The performance model is built off five fundamental correlations. The calculated outputs from these correlations are then passed to 25 equations to characterize the performance of the Coolerado units. The five correlations and the dependent variables for each equation are provided below.

$$
\begin{aligned}
& \text { Wet Bulb Effectiveness } S_{S A}=f(S P, \text { Mass Flow }) \\
& \text { Wet Bulb Effectiveness } S_{E A}=f(S P) \\
& \text { Volumetric Flow Rate }_{S A}=f(S P, \text { Fan Speed }) \\
& \text { Volumetric Flow Rate }_{E A}=f(S P, \text { Fan Speed }) \\
& \text { Fan Power }=f(\text { Fan Speed })
\end{aligned}
$$

The dependent variables include SA SP, mass flow rate $(\mathrm{kg} / \mathrm{s})$, and percent fan speed (\%). The secondary equations then use climatic information and psychometric correlations to characterize unit performance. The predicted performance of the Coolerado units was validated with laboratory and field test results. 


\section{Coolerado Sizing Program}

The sizing subroutine determines the number of Coolerado cooling cores required to meet a space cooling load at the $0.4 \%$ ASHRAE evaporative climatic design conditions and peak cooling load conditions. The user also has the option of using the coincident OA wet bulb and dry bulb temperature from an hourly weather file at the peak cooling load hourly time step. An hourly energy modeling program is needed to generate the cooling loads on the HVAC cooling coil. The required site, climatic design, and building design characteristics are provided below.

\section{Site and Climatic Design}

- $\quad$ Site elevation. TMY elevation data are input to calculate an atm.

- $\quad$ ASHRAE $0.4 \%$ evaporative cooling design day inputs. Evaporative cooling systems are sized based on a design evaporation wet bulb temperature and a coincident dry bulb temperature. The design evaporation wet bulb temperature and MCDB temperature are input at ASHRAE $0.4 \%$ conditions.

$\circ \quad$ Design evaporation wet bulb temperature $\left({ }^{\circ} \mathrm{F}\right)$

$\circ \quad \mathrm{MCDB}$ temperature $\left({ }^{\circ} \mathrm{F}\right)$.

\section{Building Design Characteristics}

- $\quad$ Space temperature set point annual. Space temperature set point is used to calculate the cooling capacity $(\mathrm{Btu} / \mathrm{h})$ of the unit relative to the space or room temperature. The space temperature set point should correlate with the modeled space temperature set point from the energy model, and the input is used in the annual simulation model only.

- Space temperature set point sizing. The Air-Conditioning, Heating, and Refrigeration Institute test standards for rating conventional refrigeration-based air-conditioning systems uses a RAT of $80^{\circ} \mathrm{F}$. The default space temperature for sizing the Coolerado units is set to this test standard condition and can be modified by the user. The cooling capacity of the Coolerado unit is sensitive to the temperature difference between the SAT and space temperature set point. During peak conditions the cooling capacity of the unit is significantly reduced and a higher space temperature set point on the order of $80^{\circ} \mathrm{F}$ is typically needed to ensure the system is not oversized relative to surrogate annual cooling conditions.

- $\quad$ Filter pressure. Filter pressure is input to provide a degradation factor for filter fouling. The laboratory tests were conducted with a clean filter and the appropriate input for clean filters is $0 \mathrm{in.} \mathrm{SP.} \mathrm{Additional} \mathrm{SP} \mathrm{testing} \mathrm{was} \mathrm{conducted}$ at Fort Carson at 100\% flow rate for one C60 unit and indicated that a 75\% loaded filter will introduce approximately 0.14 in. of static.

- $\quad$ Duct SP. Duct SP is input based on the maximum airflow rate per heat exchanger core and is in in. w.c. A table is provided in Table 52 that lists the SA flow rate relative to SP for different elevations and SP ratings that can be used by a design engineer to select the appropriate system SP and SA flow rate. 
- $\quad$ Building SP. Building SP is provided as an input to represent the SP induced in the space or facility at $100 \%$ fan speed by the Coolerado units. The Coolerado unit will pressurize the space if there is no relief air path to exhaust the SA from the Coolerado unit by as much as $0.1-0.15$ in in. SP.

- $\quad$ Total SP. The filter, duct, and building SP are added together to calculate a total SP on the supply side of the Coolerado unit. If the unit is designed as an OA preconditioner the system should be set up to operate in conjunction with the main supply fan. In this case, the design SP should be set to zero.

$$
\text { Total }_{\text {Static }}=\text { Filter }_{\text {Static }}+\text { Duct }_{\text {Static }}+\text { Bld } g_{\text {static }}
$$

- $\quad$ Fan inlet pressure. The fan inlet pressure can be modified from the default of atm in in. SP.

- $\quad$ EA pressure. The EA outlet pressure can be modified from the default of atm in in. SP.

- $\quad$ CoCs. The Coolerado technology is configured with single pass cooling water. Some inlet water is evaporated in the EA stream and some passes through the unit and drains from the outlet piping. One $\mathrm{CoC}$ indicates that there is no evaporation as the water passes through the internal heat and mass exchanger. Two CoCs indicates that half the water is evaporated away and half drains from the unit and the dissolved mineral content in the excess water is twice as high as in the inlet water. Three CoCs means that for every 2 parts evaporated, 1 part is drained off concentrating the minerals three times. The recommended set point for the Coolerado unit is $5 \mathrm{CoCs}$, with 4 parts evaporated for every 1 part drained.

- Design fan speed. The design fan speed is input as fractional value of $0 \%-100 \%$

- $\quad$ Peak coincident cooling load. The peak coincident cooling load is input as the zone or building cooling load that occurs during the most extreme exterior wet bulb condition or based on a peak cooling load calculation for the space given the ASHRAE $0.4 \%$ design conditions.

\section{Supply Air Wet Bulb Effectiveness Calculation}

The SA WBE is characterized by two equations: a full load and a part load correlation. The first calculates SA WBE versus external SP at 100\% fan speed (see Figure 89). 


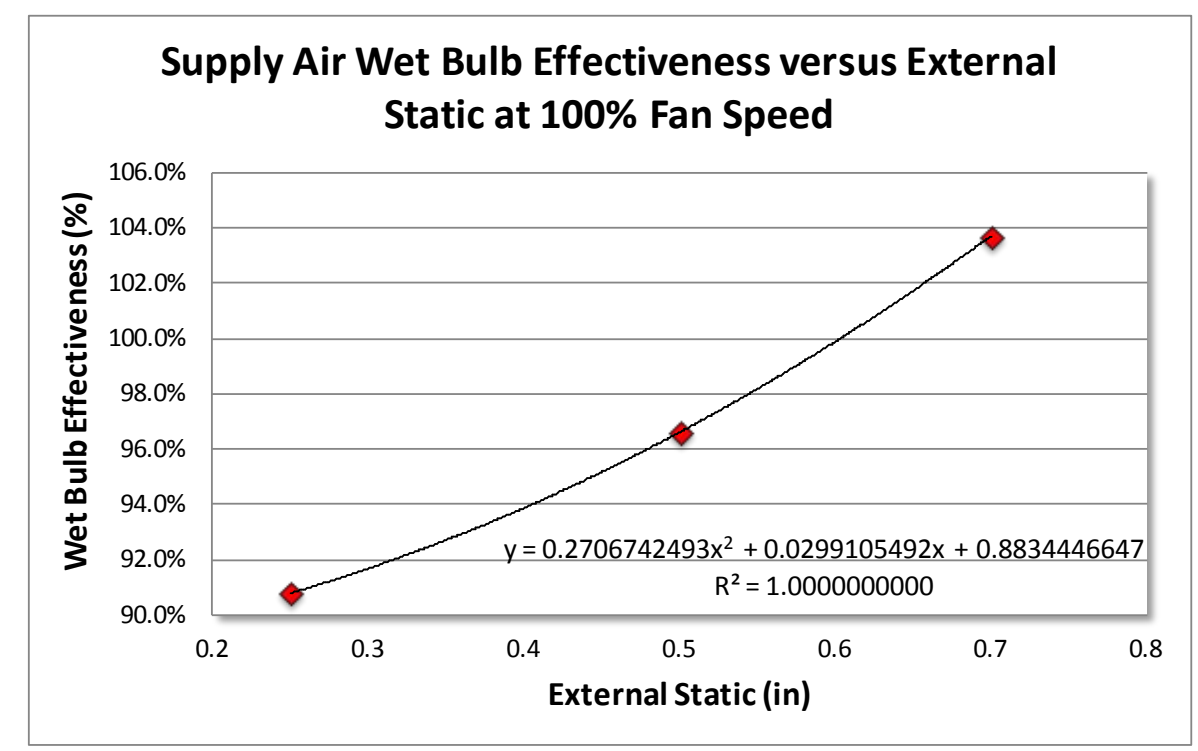

Figure 89. SA WBE versus external sp at $100 \%$ fan speed

The laboratory tests were conducted with $0.25,0.5$, and 0.7 in. of external SP at $100 \%$ fan speed. The WBE increases as a function of external SP and is $90.8 \%-103.7 \%$ at $0.25-0.7 \mathrm{in}$. of external static at $81.411 \mathrm{kPa}$. The WBE increases as SP is applied to the unit because the EA flow rates increase as SP is applied to the unit and the lower SA volumetric flow rates result in a higher WBE, and lower SAT. A second order polynomial curve fit was used to characterize the relationship between WBE and external SP and the calculated WBE is extrapolated for external $\mathrm{SP}$ readings below $0.25 \mathrm{in}$. and above $0.7 \mathrm{in}$.

All part load laboratory tests were conducted with a SA SP of 0.5 in. ( 0.5 in. SP at $100 \%$ fan speed). Figure 90 shows the SA WBE versus percent fan speed at 0.5 in. external static.

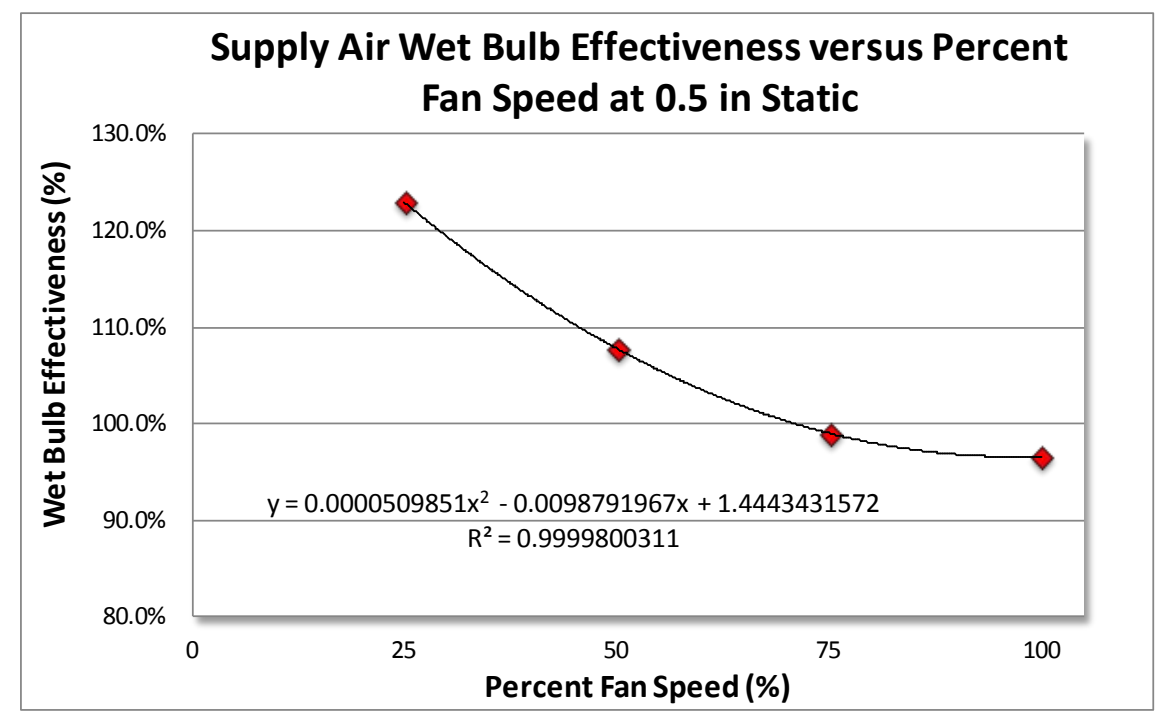

Figure 90. SA WBE versus percent fan speed at 0.5 in. external static 
The WBE significantly increases at partial fan speeds, with WBEs above $120 \%$ at $25 \%$ fan speed, 0.5 in. SP, and an atm of $81.411 \mathrm{kPa}$.

The first part of the equation, the WBE versus external SP at $100 \%$ fan speed correlation, is normalized by the SA WBE at 0.5 in. of external SP with the WBE at 0.5 in. of static in the denominator.

$$
W B E_{S} \operatorname{Part}_{1}=\frac{0.2706742493 *\left[\operatorname{Total}_{\text {Static }} *\left(\frac{P_{\text {lab }}}{P_{\text {elev }}}\right)\right]^{2}+0.0299105492 *\left[\operatorname{Total}_{\text {Static }} *\left(\frac{P_{\text {lab }}}{P_{\text {elev }}}\right)\right]+0.8834446647}{0.966068501618591}
$$

An altitude correction factor is also included in the SP term that corrects the SP reading based on the relationship between the atm of the laboratory test and the atm at the given location. For example an SP of 0.5 in. at the TTF would be equivalent to $(81.411 \mathrm{kPa} / 101.325 \mathrm{kPa}) * 0.5 \mathrm{in}$. $=$ $0.4017 \mathrm{in}$. SP at sea level. For example, the SA volumetric flow rate at sea level at 0.5 in. of static would be 1,263 cfm for a C60 unit and 1,106 cfm in Golden, Colorado, with 0.5 in. static.

In addition to the altitude correction for SP, the percent fan speed correlation was corrected to account for the differences in mass flow rate at different elevations. The new relationship is analogous to calculating WBE as a function of mass flow rate, and the mass flow rate at sea level is approximately $25 \%$ higher than at the TTF in Golden, Colorado at $100 \%$ fan speed. This relationship between $\mathrm{WBE}$ and mass flow rate is similar to the number of transfer units (effectiveness method for calculating heat transfer rate effectiveness for counterflow heat exchangers based on the temperature and mass flow rates for the two fluids.

Additional laboratory tests were conducted where the Coolerado unit fan was turned off and air was forced through the unit at flow rates higher than those achievable at $100 \%$ fan speed. The data points from these tests were used to determine WBE at $125 \%$ of the rated fan speed, which is equivalent to the mass flow rate at $100 \%$ fan speed at sea level. The part load WBE versus percent fan speed with $0.5 \mathrm{in}$. of external static is represented by the tend line equation in Figure 91. 


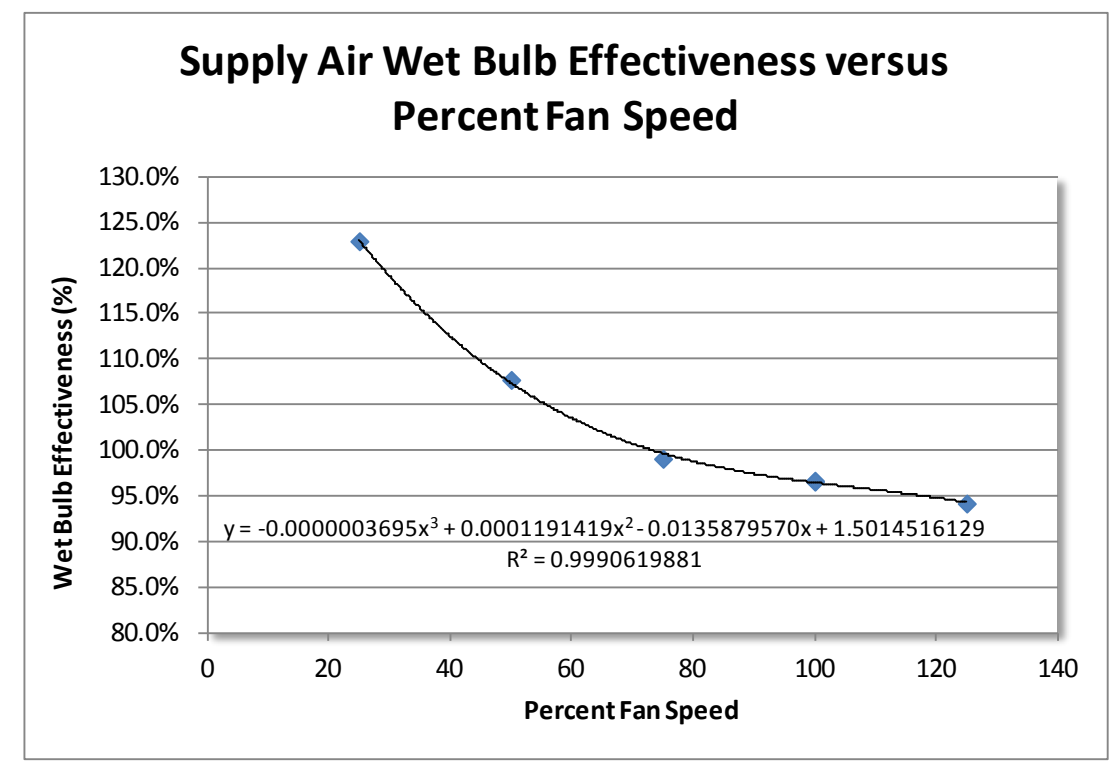

Figure 91. SA WBE versus percent fan speed at 0.5 in. static

The percent fan speed terms were corrected for altitude in the third order polynomial. The application of this correction factor is analogous to correlating the WBE to the SA mass flow rate.

$$
\begin{aligned}
W B E_{S} \text { Part }_{2}= & -0.0000003695 *\left(\text { Per }_{\text {Speed }} * \frac{P_{\text {elev }}}{P_{\text {lab }}}\right)^{3}+0.0001191419 \\
& *\left(\operatorname{Per}_{\text {Speed }} * \frac{P_{\text {elev }}}{P_{\text {lab }}}\right)^{2}-0.0135879570 *\left(\operatorname{Per}_{\text {Speed }} * \frac{P_{\text {elev }}}{P_{\text {lab }}}\right)+1.5014516129
\end{aligned}
$$

The combination of the two equations provides a means for estimating the SA WBE as a function of external SP at 100\% fan speed and partial fan speeds. The normalization of SP at 0.5 in. of static can be introduced to either equation, and is introduced in the denominator of the first.

$$
\begin{aligned}
& W B E_{S}=\left(\frac{0.2706742493 *\left[\operatorname{Total}_{\text {Static }} *\left(\frac{P_{\text {lab }}}{P_{\text {elev }}}\right)\right]^{2}+0.0299105492 *\left[\operatorname{Total}_{\text {Static }} *\left(\frac{P_{\text {lab }}}{P_{\text {elev }}}\right)\right]+0.8834446647}{0.966068501618591}\right) * \\
& \left(-0.0000003695 *\left(\operatorname{Per}_{\text {Speed }} * \frac{P_{\text {elev }}}{P_{\text {lab }}}\right)^{3}+0.0001191419 *\left(\operatorname{Per}_{\text {Speed }} * \frac{P_{\text {elev }}}{P_{\text {lab }}}\right)^{2}-\right. \\
& \left.0.0135879570 *\left(\text { Per }_{\text {Speed }} * \frac{P_{\text {elev }}}{P_{\text {lab }}}\right)+1.5014516129\right)
\end{aligned}
$$

\section{Supply Air Temperature Calculation}

The SAT is then calculated with the standard WBE equation in units of Fahrenheit $\left({ }^{\circ} \mathrm{F}\right)$.

$T_{S A D E S}=T_{O A D E S}-\left(W B E_{S} *\left(T_{o a D E S}-T_{w b D E S}\right)\right)$ 


\section{Exhaust Air Wet Bulb Effectiveness Calculation}

The EA WBE is characterized by one correlation. The correlation calculates EA WBE versus external SP at $100 \%$ fan speed (see Figure 92).

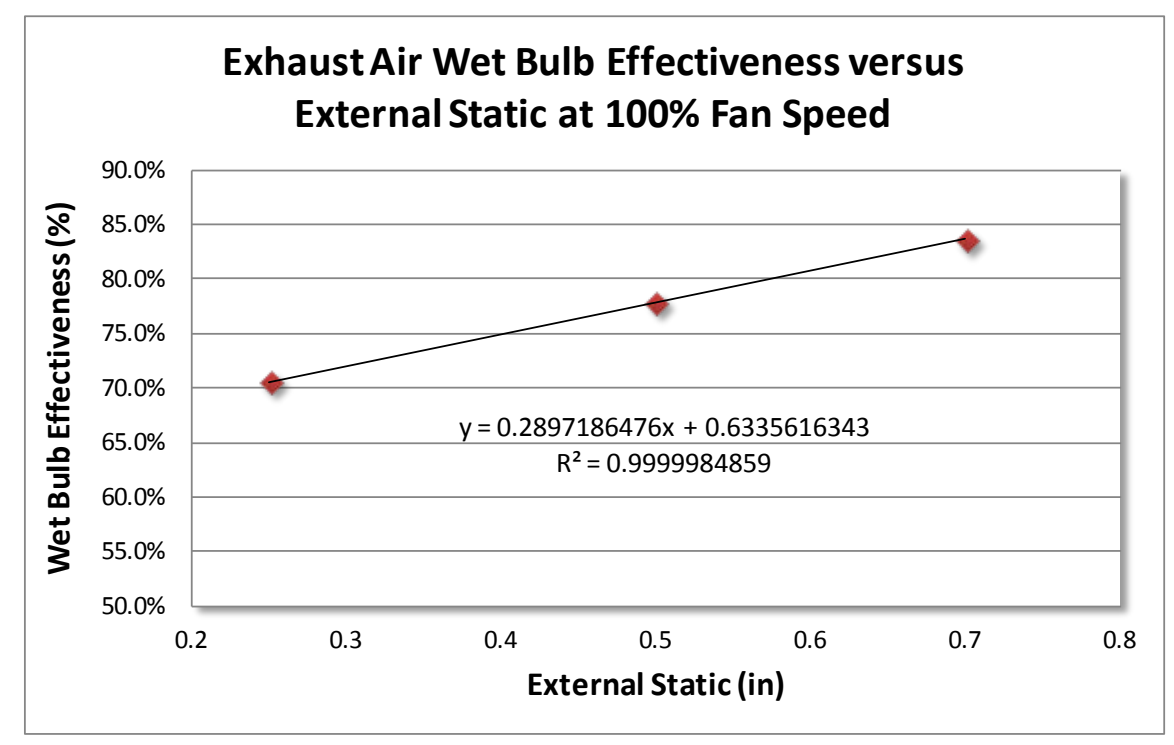

Figure 92. EA WBE versus external static at $100 \%$ fan speed

There is a linear relationship between the external SP applied to the SA and the EA WBE, with values ranging from $70 \%$ to almost $85 \%$, at an atm of $81.411 \mathrm{kPa}$. The EA WBE versus external static at $100 \%$ fan speed is represented by the following equation:

$W B E_{E}=0.2897186476 *\left[\operatorname{Total}_{\text {static }} *\left(\frac{P_{\text {lab }}}{P_{\text {elev }}}\right)\right]+0.6335616343$

The SP term in this equation is also corrected for elevation. The EA WBE is not a function of part load flow rate, because the EA RH is almost $95 \%$ (close to saturation) under all test conditions and can be characterized by the $\mathrm{WBE}_{\mathrm{E}}$ single equation.

\section{Exhaust Air Temperature Calculation}

The EAT is calculated with the standard WBE equation in units of Fahrenheit $\left({ }^{\circ} \mathrm{F}\right)$.

$T_{E A D E S}=T_{O A D E S}-\left(W B E_{E} *\left(T_{o a D E S}-T_{w b D E S}\right)\right)$

EAT is calculated as a means of predicting EAT and absolute humidity. This information is used to calculate the amount of water that is evaporated from the unit and is considered a secondary calculation to the main SA cooling capacity calculations. 


\section{Coolerado Sizing Calculation}

The SA and EA WBE calculations are not affected by the number of cooling cores in the Coolerado unit. These values are calculated outside the sizing routine, which is used to determine the number of Coolerado units required to meet a given cooling load.

The sizing calculation uses a single "do loop and if" statement to determine the number of Coolerado units required to meet a given cooling load. The program calculates the number of cooling cores (in integer values) that are required to meet the load with the following loop.

Num_CoreDes $=0$

Max_CoreDes $=300$

Do Until Num_CoreDes $=$ Max_CoreDes

Num_CoreDes $=$ Num_CoreDes +1

If Q_SpaceDes $<$ Peak_Cooling Then

....

Else

Max_CoreDes $=$ Num_CoreDes

End $\overline{\text { If }}$

Loop

The program iterates through the series of equations shown below to determine the number of Coolerado cooling cores that are required to meet a cooling load. The following equations are imbedded in the loop after the 'If $Q$ _SpaceDes < Peak_Cooling Then' statement and before the Else statement that closes out the loop.

\section{Supply Air Volumetric Flow Rate}

All airside calculations are performed on a volumetric basis. The SA volumetric flow rate is characterized by two equations, a full load correlation and a part load correlation (Figure 93). The first correlation calculates the SA volumetric flow rate as a function of external SP.

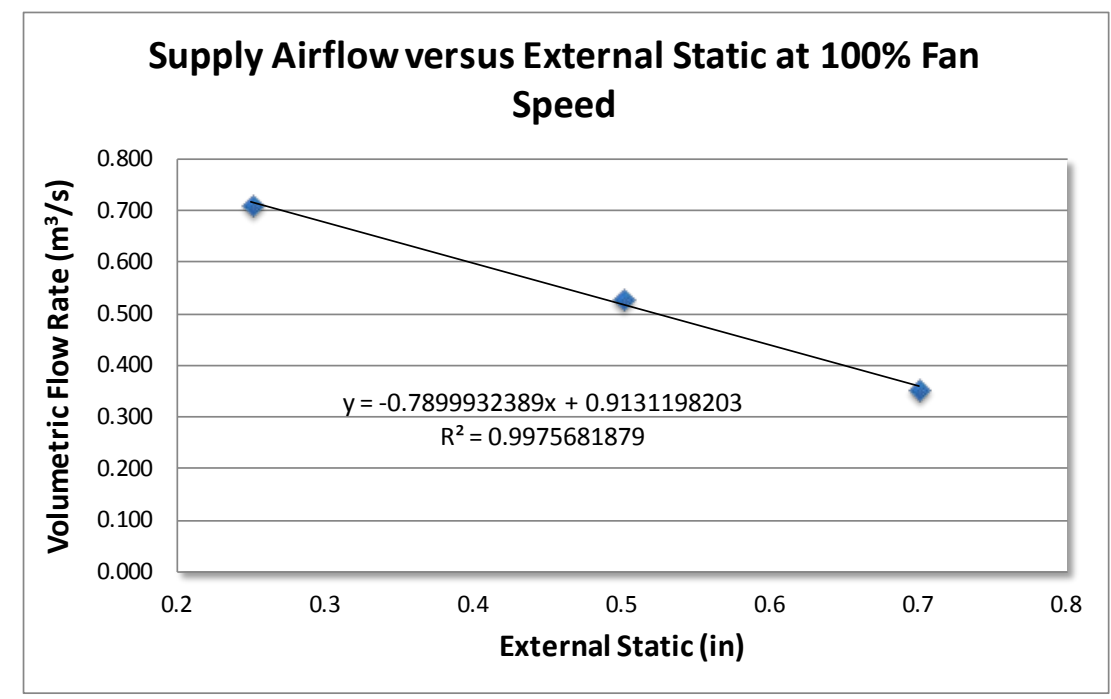

Figure 93. SA volumetric airflow rate versus external SP at $\mathbf{1 0 0 \%}$ fan speed 
The SA flow rate decreases linearly as external SP is applied to the SA. As SP is applied to the SA, the EA flow rates increase, which explains the linear relationship between SA volumetric flow rate and external SP. The slope of the line also illustrates that the unit is very sensitive to external SP. The full load SA volumetric flow rate versus external SP at $100 \%$ fan speed correlation is normalized by the SA volumetric flow rate at 0.5 in of external SP in the following equation:

Supply Vol Flow Rate Part $1=\frac{-0.7899932389 *\left[\text { Total }_{1} \text { Static }^{*}\left(\frac{P_{\text {lab }}}{P_{\text {elev }}}\right)\right]+0.9131198203}{0.528257}$

The SP correlation is corrected for altitude and an additional conditional statement is included in the sizing program that sets the SA volumetric flow rate to 0 if the $\left[\operatorname{Total}_{\text {Static }} *\left(\frac{P_{\text {lab }}}{P_{\text {elev }}}\right)\right]>$ 1.155. This relationship shows that the SA flow rate reaches zero with just 1.155 in. of external SP, corrected for altitude.

The SA volumetric flow rate at partial flow rates is characterized by the trend line equation in Figure 94.

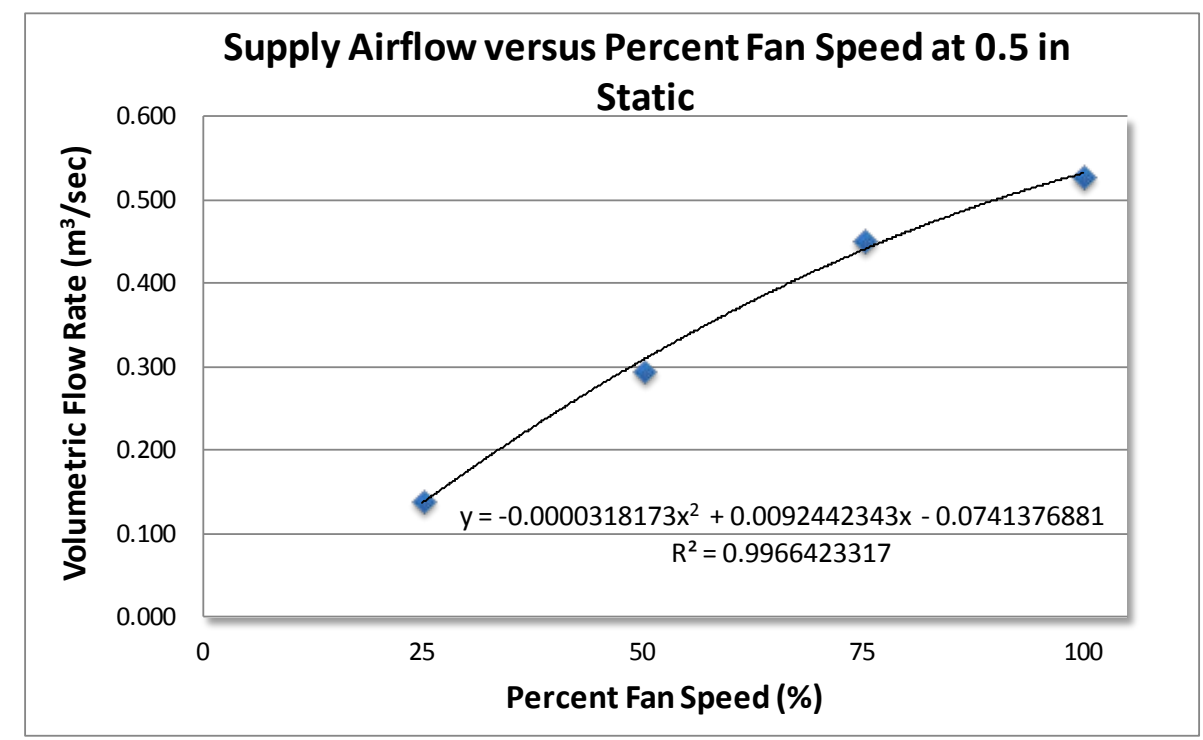

Figure 94. SA volumetric airflow rate versus percent fan speed at 0.5 in. static

The part load SA volumetric flow rate versus percent flow rate is represented by the following equation:

Supply Volumetric Flow Rate Part $2=-0.0000318173 *$ Per $_{\text {Speed }}^{2}+0.0092442343 *$ Per $_{\text {Speed }}-0.0741376881$

The combination of the two equations provides a means for estimating the SA volumetric flow rate as a function of external SP at 100\% fan speed conditions and partial fan speeds. 


$$
\begin{aligned}
& \text { Supply Volumetric Flow Rate } \\
& =\left(\frac{N u m_{\text {CorDes }}}{6}\right) \\
& *\left(\frac{-0.7899932389 *\left[\text { Total }_{\text {Static }} *\left(\frac{P_{\text {lab }}}{P_{\text {elev }}}\right)\right]+0.9131198203}{0.528257}\right) \\
& *\left(-0.0000318173 * \text { Per }_{\text {Speed }}^{2}+0.0092442343 * \text { Per }_{\text {Speed }}\right. \\
& -0.0741376881)
\end{aligned}
$$

A centrifugal fan is a volumetric device; the percent fan speed is not corrected for altitude. With the given series of equations and the SP altitude correction, the unit provides the same volumetric flow rate regardless of elevation when $0 \mathrm{in}$. SP is applied to the unit and the airflow rate changes based on altitude and applied SP. The number of cooling cores divided by 6 is added to the equation to size the unit. The C60 unit that was tested has six cooling cores per unit. Thus, the SA volumetric flow rate needs to be normalized based on the number of cooling cores in that unit.

The units for SP are in. w.c., the units for volumetric flow rate are $\mathrm{m}^{3} / \mathrm{s}$. The SA volumetric flow rate is calculated in cfm with the following equation:

Supply Volume Flow CFM $_{\text {Supply Vol }}=$ Slow $\frac{\mathrm{m}^{3}}{\mathrm{~s}} * 35.31466672 \frac{\mathrm{ft} \mathrm{t}^{3}}{\mathrm{~m}^{3}} * 60 \frac{\mathrm{s}}{\mathrm{min}}$

\section{Exhaust Air Volumetric Flow Rate}

The EA volumetric flow rate is characterized by two equations, a full load correlation and a part load correlation. The first correlation calculates the EA volumetric flow rate as a function of external SP (see Figure 95).

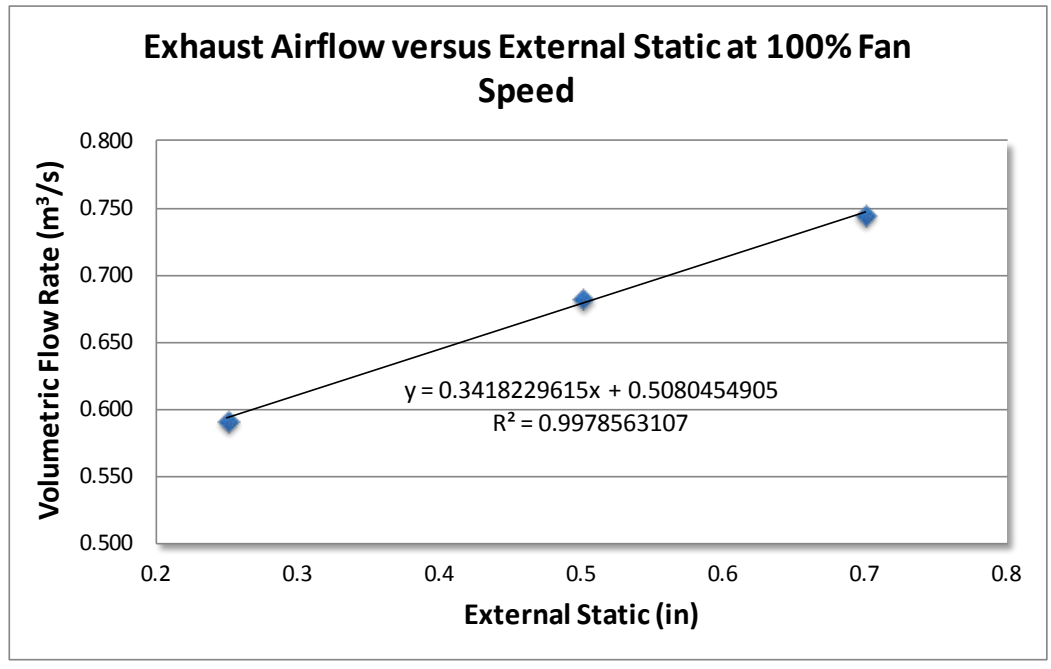

Figure 95. EA volumetric airflow rate versus external SP at $100 \%$ fan speed 
The EA volumetric flow rate correlation has an inverse relationship to the SA correlation, as the EA flow rate increases as external SP is applied to the SA. The EA volumetric flow rate at partial flow rates is characterized by the following equation (see Figure 96).

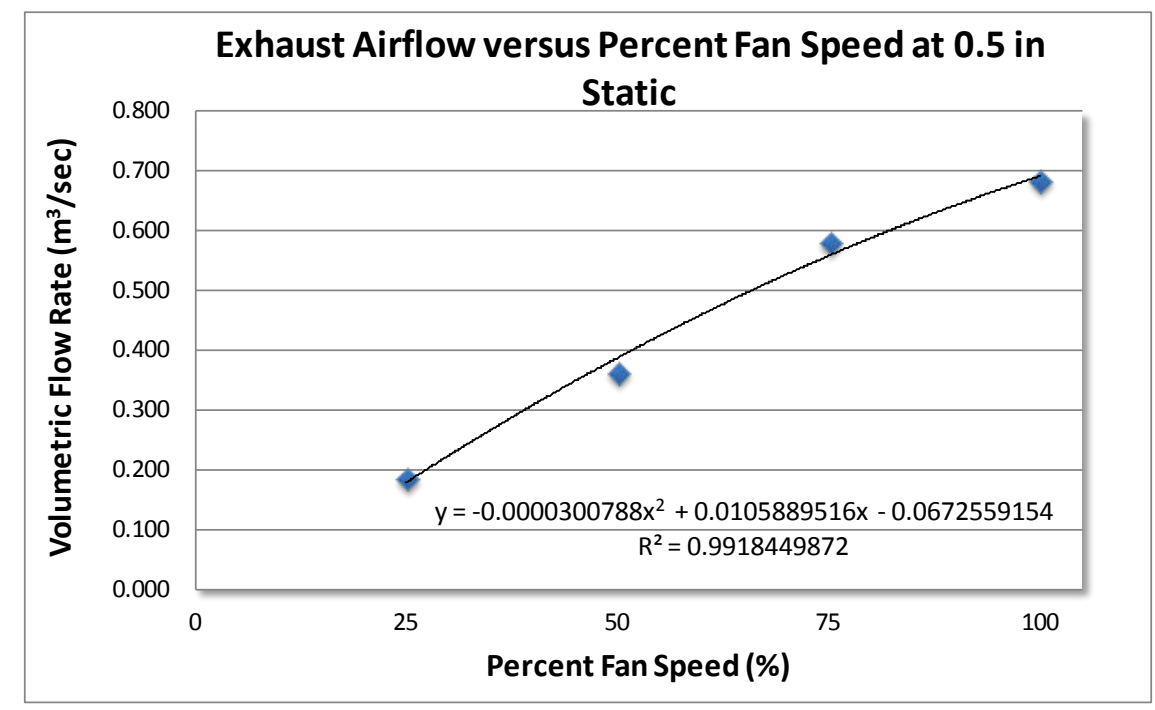

Figure 96. EA volumetric airflow rate versus percent flow rate at 0.5 in. static

The full load EA volumetric flow rate versus external SP at $100 \%$ fan speed correlation is normalized by the EA volumetric flow rate at 0.5 in of external SP in the following equation:

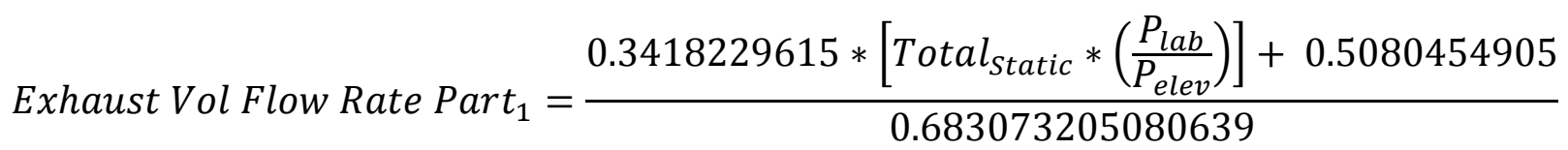

The EA SP correlation includes a correction for altitude and the part load EA volumetric flow rate versus percent flow rate is represented by the following equation:

Exhaust Vol Flow Rate Part 2

$$
=-0.0000300788 * \text { Per }_{\text {Speed }}^{2}+0.0105889516 * \text { Per }_{\text {Speed }}-0.0672559154
$$

The combination of the two equations provides a means for estimating the EA volumetric flow rate as a function of SA external SP at design flow rate conditions and partial flow rates.

Exhaust Volumetric Flow Rate $=$

$\left(\frac{\text { Num }_{\text {CorDes }}}{6}\right) *\left(\left(\frac{0.3418229615 *\left[\text { Total }_{\text {Static }} *\left(\frac{P_{\text {lab }}}{P_{\text {elev }}}\right)\right]+0.5080454905}{0.683073205080639}\right) *(-0.0000300788 *\right.$

Per $_{\text {Speed }}^{2}+0.0105889516 *$ Per $\left.\left._{\text {Speed }}-0.0672559154\right)\right)$ 
The EA volumetric flow rate equation also includes a multiplier for the number of cooling cores. The units for EA volumetric flow rate are $\mathrm{m}^{3} / \mathrm{s}$. The EA flow rate in units of $\mathrm{cfm}$ is calculated with the following equation:

$$
\text { Exhaust CFM }=\text { Exhaust } \text { Vol }_{\text {Flow }} \frac{\mathrm{m}^{3}}{\mathrm{~s}} * 35.31466672 \frac{\mathrm{ft}}{\mathrm{m}^{3}} * 60 \frac{\mathrm{s}}{\mathrm{min}}
$$

Flow Ratio

The ratio of SA to EA is calculated with the following equation:

$$
\text { Ratio }=\frac{E A_{\text {VOL FLOW }}}{\left(S A_{\text {VOL FLOW }}+E A_{\text {VOL FLOW }}\right)}
$$

\section{Outside Air and Supply Air Psychometrics}

A number of psychometric calculations are used to calculate the OA SA conditions.

- $\quad O A R H$ design. Calculated as a function of design dry bulb $\left({ }^{\circ} \mathrm{F}\right)$, design wet bulb $\left({ }^{\circ} \mathrm{F}\right)$, and atm (Units \%).

- $\quad$ SA/OA humidity ratio. Calculated as a function of design dry bulb temperature $\left({ }^{\circ} \mathrm{F}\right)$, OA RH $(\%)$, and atm. Because the Coolerado device is a sensible cooling device the SA RH is assumed to be equivalent to the inlet air humidity ratio (units $\left.1 b_{\mathrm{w}} / 1 b_{\mathrm{a}}\right)$.

- $\quad S A$ specific volume. Calculated with supply dry bulb temperature $\left({ }^{\circ} \mathrm{F}\right)$, SA humidity ratio $(\mathrm{lb} / \mathrm{lb})$ and atm. Two conversion constants are included in the calculation $35.31466672 \mathrm{ft}^{3} / \mathrm{m}^{3}$, and $2.20462234 \mathrm{lb} / \mathrm{kg}$, to calculate specific volume in units of $\mathrm{m}^{3} / \mathrm{kg}$ (units $\mathrm{m}^{3} / \mathrm{kg}$ ).

- Density. SA density is calculated as a function of specific volume. Two conversion constants are included in the calculation $35.31466672 \mathrm{ft}^{3} / \mathrm{m}^{3}$, and $2.20462234 \mathrm{lb} / \mathrm{kg}$, to calculate density in units of $\mathrm{kg} / \mathrm{m}^{3}$ (units $\mathrm{kg} / \mathrm{m}^{3}$ ).

- $\quad$ Specific heat. The specific heat is calculated as an enthalpy difference divided by a temperature difference using the SA humidity ratio and $\mathrm{a}+0.5^{\circ} \mathrm{F}$ and $-0.5^{\circ} \mathrm{F}$ from the SAT (units Btu/lb ${ }^{\circ} \mathrm{F}$ ).

\section{Exhaust Air Psychometrics}

A number of psychometric calculations are used to calculate the EA conditions.

- $\quad$ EA RH design. Assumed to be constant at $95.9087740615188 \%$. This value was calculated as the average EA RH across the 17 laboratory tests.

- EA humidity ratio. Calculated as a function of EA dry bulb temperature, EA RH, and atm (units $1 b_{\mathrm{w}} / \mathrm{lb}_{\mathrm{a}}$ ).

- $\quad$ EA density. EA density is calculated as a function of specific volume (calculated with EA dry bulb temperature, EA humidity ratio, and atm). Two conversion 
constants are included in the calculation $35.31466672 \mathrm{ft}^{3} / \mathrm{m}^{3}$, and 2.20462234 $\mathrm{lb} / \mathrm{kg}$ to calculate density in units of $\mathrm{kg} / \mathrm{m}^{3}$

\section{Sensible Cooling Capacity}

The sensible cooling capacity as a function of SAT and OAT are calculated with the following equations:

$$
\begin{aligned}
& Q_{\text {OADes }}\left(\frac{B t u}{h}\right)=\left[\left(S A_{\text {VolflowDes }}\left(\frac{\mathrm{m}^{3}}{\text { sec }}\right) * S A_{\text {DensityDes }}\left(\frac{\mathrm{kg}}{\mathrm{m}^{3}}\right)\right) * 2.20462262\left(\frac{\mathrm{lb}}{\mathrm{kg}}\right) * 3,600\left(\frac{\mathrm{s}}{\mathrm{h}}\right) *\right. \\
& \left.C_{P D e s}\left(\frac{B t u}{\mathrm{lb}-\mathrm{F}}\right) *\left(M C D B\left({ }^{\circ} \mathrm{F}\right)-S A_{\text {DBDes }}\left({ }^{\circ} \mathrm{F}\right)\right)\right]
\end{aligned}
$$

The sensible cooling capacity in units of tons of cooling is calculated with the following equation:

$$
\text { Tons }_{\text {OADes }}=\frac{Q_{\text {OADes }}\left(\frac{B t u}{h}\right)}{12,000\left(\frac{B t u}{h}\right)}
$$

The sensible cooling capacity as a function of SAT and space temperature is calculated with the following equation:

$$
\begin{aligned}
Q_{\text {SpaceDes }}\left(\frac{B t u}{h}\right) & \\
& =\left(S A_{\text {VolFlowDes }}\left(\frac{m^{3}}{S}\right) * S A_{\text {DensityDes }}\left(\frac{k g}{m^{3}}\right)\right) * 2.20462262\left(\frac{l b}{k g}\right) \\
& * 3,600\left(\frac{S}{h}\right) * C_{P D e s}\left(\frac{B t u}{l b-F}\right) *\left(\text { Space }_{T e m p}\left({ }^{\circ} \mathrm{F}\right)-S A_{\text {DBDes }}\left({ }^{\circ} \mathrm{F}\right)\right)
\end{aligned}
$$

The sensible cooling capacity as a function of SAT and space temperature is calculated with the following equation:

$$
\text { Tons }_{\text {Space }}=\frac{Q_{\text {SpaceDes }}\left(\frac{B t u}{h}\right)}{12,000\left(\frac{B t u}{h}\right)}
$$

The EA cooling capacity is calculated with the following equation:

$$
\begin{gathered}
Q_{\text {EADes }}=\left(S A_{\text {VolflowDes }} * S A_{\text {DensityDes }}\right) * 2.20462262 \frac{\mathrm{lb}}{\mathrm{kg}} * 3,600 \frac{\mathrm{s}}{\mathrm{h}} * C_{P D e s} \\
*\left(M C D B-E A_{-} D B D e s\right)
\end{gathered}
$$




\section{Fan Power Calculation}

The fan power is calculated with the following equation (Figure 97):

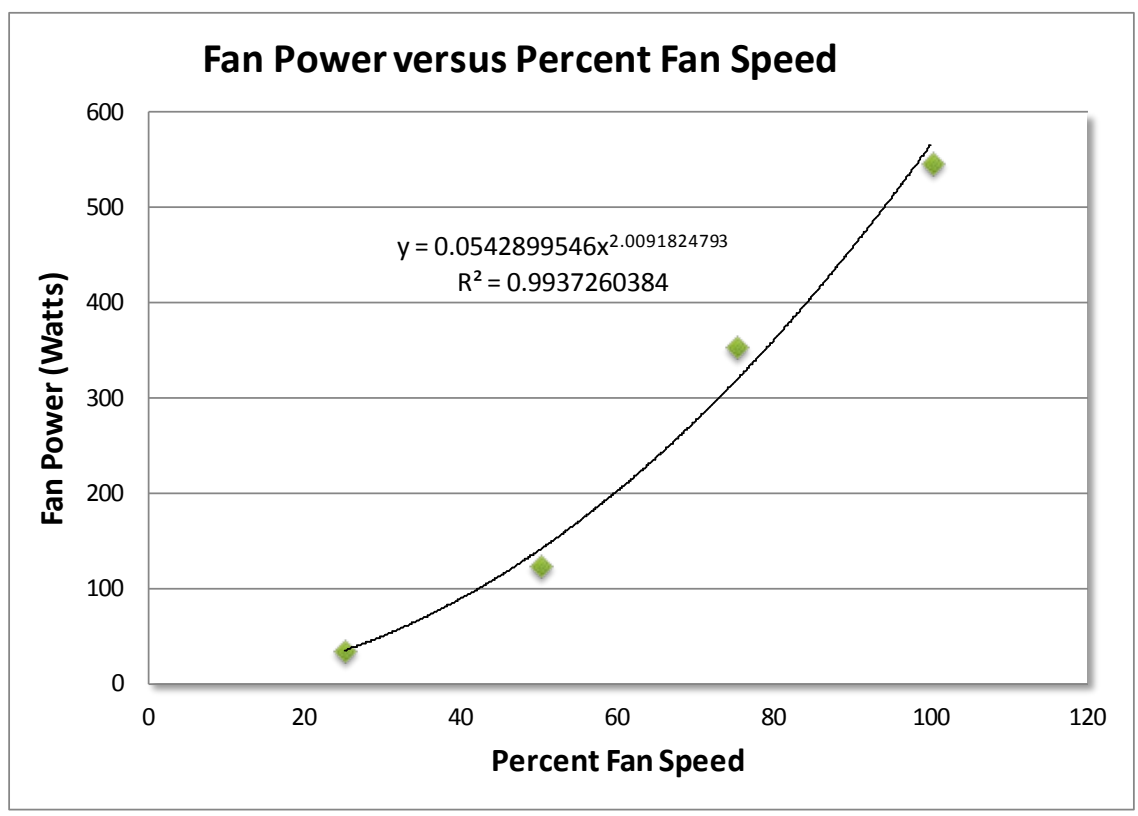

Figure 97. Fan power versus percent fan speed

Based on the fan laws, there is a linear relationship between fan power and atm.

$$
\frac{\text { Power }_{\text {Elev }}}{\text { Power }_{\text {Lab Alt }}}=\frac{Q_{\text {elev }}}{Q_{\text {Lab alt }}} * \frac{\Delta P_{\text {elev }}}{\Delta P_{\text {Lab alt }}}
$$

Volumetric flow rate is constant regardless of altitude, so the equation can be rearranged. The Power calculation is defined with the following equation.

$$
\text { Power }_{\text {Elev }}=\text { Power }_{\text {Lab Alt }} * \frac{\Delta P_{\text {elev }}}{\Delta P_{\text {Lab alt }}}
$$

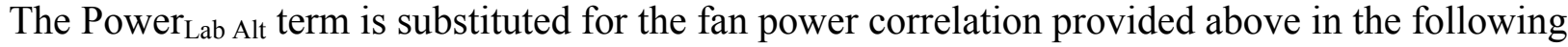
equation:

$$
\operatorname{Fan}_{\text {PowerDes }}=\left[\left(\frac{\text { Num }_{\text {CorDes }}}{6}\right) *\left(\frac{0.0542899546 * \text { PerSpeed }_{\text {Des }}^{2.0091824793}}{1,000 \frac{W}{k W}}\right)\right] *\left(\frac{\mathrm{P}_{\text {elev }}}{\mathrm{P}_{\text {lab }}}\right)
$$

Because Coolerado installs the same fan in all C60 units, the altitude correction will increase the fan power at sea level by approximately $25 \%$. In a typical RTU or AHU, the design engineer will install a larger fan at higher elevations (Golden, Colorado) to meet a given space cooling requirement with the lower density air. Thus, the unit's increased fan power at lower altitudes is the opposite of what is typically encountered with traditional HVAC systems. 


\section{Coefficient of Performance Calculation}

The coefficient of performance is calculated as a function of OAT and space temperature with the following equations:

$$
\begin{aligned}
\mathrm{COP}_{\text {OADes }} & =12 /\left(\mathrm{Fan}_{\text {PowerDes }} / \text { Tons }_{\text {OADes }}\right) / 3.41214 \\
\mathrm{COP}_{\text {SpaceDes }} & =12 /\left(\mathrm{Fan}_{\text {PowerDes }} / \text { Tons }_{\text {Spacedes }}\right) / 3.41214
\end{aligned}
$$

\section{Water Consumption}

The water consumption of the unit is calculated based on EA flow rate and the difference in humidity ratio from the EA and inlet air.

$$
\begin{aligned}
& \operatorname{Evap}_{\text {RateDes }}\left(\frac{g a l}{h}\right) \\
&=\operatorname{EA}_{\text {CFMDes }}\left(\frac{f t^{3}}{\min }\right) * 60\left(\frac{\mathrm{min}}{\mathrm{h}}\right) \\
& * \frac{\left(\mathrm{EA}_{\text {HumRatDes }}\left(\frac{\mathrm{lb}_{\mathrm{w}}}{\mathrm{lb}_{\mathrm{a}}}\right)-\mathrm{SA}_{\text {HumRatDes }}\left(\frac{\mathrm{lb}_{\mathrm{w}}}{\mathrm{lb}_{\mathrm{a}}}\right)\right)}{\left.\left(\frac{1}{\mathrm{EA}_{\text {DensityDes }}\left(\frac{\mathrm{kg}}{\mathrm{m}^{3}}\right)}\right) *\left(\frac{1}{2.20462262 \frac{\mathrm{lb}}{\mathrm{kg}}}\right) *\left(35.31466672 \frac{\mathrm{ft}^{3}}{\mathrm{~m}^{3}}\right)\right)} \\
& 8.337 \frac{\mathrm{gal}}{\mathrm{lb}}
\end{aligned}
$$

$\operatorname{ActEvap}_{\text {RateDes }}\left(\frac{g a l}{h}\right)=\operatorname{Evap}_{\text {RateDes }}\left(\frac{g a l}{h}\right) * 1.245$

The total water consumption is calculated with the CoCs and the actuation evaporation rate.

TotalEvap $_{\text {RateDes }}\left(\frac{g a l}{h}\right)=\operatorname{CoC} * \frac{\text { ActEvap }_{\text {RateDes }}\left(\frac{g a l}{h}\right)}{\operatorname{CoC}-1}$

The water consumption per ton $\mathrm{h}$ of cooling is provided based on the tons of cooling provided relative to the outdoor air conditions.

$\mathrm{Gal}_{\text {TonhDes }}\left(\frac{\text { gal }}{\text { ton }-h}\right)=\frac{\text { TotalEvap }_{\text {RateDes }}\left(\frac{\text { gal }}{h}\right)}{\text { Tons }_{\text {OADes }}(\text { tons })}$

\section{Annual Performance Model}

The annual performance subroutine uses the same series of equations. The hourly building cooling load, OAT, OA humidity, and OA atm are input as hourly inputs. The user also inputs the design SP at $100 \%$ fan speed, the water use CoC setting, the space temperature set point, and 
the number of cooling cores from the sizing calculation. The annual program pulls in hourly data and iterates through the above equations to determine the fan speed at which the unit must operate to meet a given cooling load. This is accomplished with a "for loop" that iterates through fan speeds of $0.05-100$, with a 0.05 step. If the unit cannot meet the cooling load in that hourly time step, the fan speed is set to $100 \%$. If there is an additional cooling load, the increase in space temperature is calculated, and the person operating the tool needs to either increase the number of cooling cores required to meet the space temperature or determine that the unit has to be used as an OA preconditioner.

\section{Model Validation with Laboratory Test Results}

The sizing model was validated against laboratory test data using data from 17 laboratory tests. The number of Coolerado units was hard coded as one C60 unit and the inlet dry bulb temperature, wet bulb temperature, inlet air pressure, fan speed and CoCs were input into the model. Table 61 through Table 78 show comparisons across the following parameters. The test was conducted at $100 \%$ fan speed with 0.25 in. SP, and an inlet air wet bulb temperature of $70^{\circ} \mathrm{F}$.

Table 61. Test Conditions (Test \#1)

\begin{tabular}{|c|c|c|c|c|c||}
\hline $\mathbf{T}_{\mathbf{d b}, \mathbf{F}}$ & $\mathbf{T}_{\mathbf{w b}, \mathbf{F}}$ & $\mathbf{P}_{\mathbf{k P a}}$ & S.P. $_{\text {inwc }}$ & Speed $_{\%}$ & CoC \\
\hline \hline 95 & 70 & 82 & 0.25 & $100 \%$ & 5.00 \\
\hline
\end{tabular}

The modeled performance was within $5.1 \%$ of the two laboratory measurements. The cooling capacity was calculated relative to inlet air temperature. The measured results from the two laboratory tests were all similar, other than the fan power measurement, which had some variation between tests.

Table 62. Test \#1 Modeled Versus Measured Results

\begin{tabular}{|c|c|c|c|c|c|c|c|c|c|c|c|c|c|}
\hline Test Case & 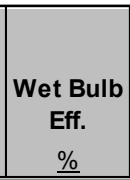 & \begin{tabular}{|c} 
Supply \\
Air \\
Temp \\
F \\
\end{tabular} & $\begin{array}{c}\text { Supply } \\
\text { Air Hum } \\
\text { lb/lb }\end{array}$ & 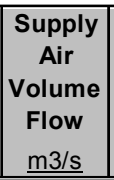 & 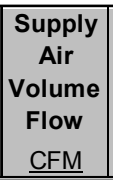 & \begin{tabular}{|c|} 
Exhaust \\
Air \\
Temp \\
$\underline{F}$ \\
\end{tabular} & 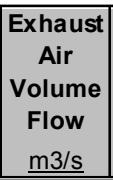 & \begin{tabular}{|c|} 
Exhaust \\
Air Hum \\
$\underline{\mathrm{lb} / \mathrm{lb}}$
\end{tabular} & 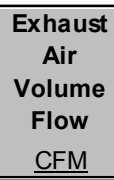 & $\begin{array}{c}\text { Cooling } \\
\text { Capacity } \\
\text { Btu/hr } \\
\end{array}$ & $\begin{array}{c}\text { Fan } \\
\text { Power } \\
\underline{\mathrm{kW}} \\
\end{array}$ & $\begin{array}{l}\text { OA } \\
\text { COP } \\
\text { COP } \\
\end{array}$ & $\begin{array}{c}\text { Water } \\
\text { Consumption } \\
\mathrm{Gal} / \mathrm{hr} \\
\end{array}$ \\
\hline Lab Test 1 & $91.0 \%$ & 72.66 & 0.01417 & 0.710 & 1,505 & 77.4 & 0.599 & 0.024 & 1,270 & 29,428 & 0.547 & 15.8 & 8.43 \\
\hline Model & $90.7 \%$ & 72.73 & 0.01393 & 0.720 & 1,526 & 77.7 & 0.601 & 0.024 & 1,273 & 29,703 & 0.564 & 15.4 & 8.62 \\
\hline Percent Diff. & $0.3 \%$ & $-0.1 \%$ & $1.7 \%$ & $-1.4 \%$ & $-1.4 \%$ & $-0.3 \%$ & $-0.2 \%$ & $0.1 \%$ & $-0.2 \%$ & $-0.9 \%$ & $-3.2 \%$ & $2.3 \%$ & $-2.2 \%$ \\
\hline Lab Test 2 & $90.6 \%$ & 72.35 & 0.01371 & 0.712 & 1,509 & 77.6 & 0.584 & 0.024 & 1,238 & 29,994 & 0.538 & 16.3 & 8.31 \\
\hline Model & $90.6 \%$ & 72.33 & 0.01346 & 0.721 & 1,527 & 77.3 & 0.600 & 0.024 & 1,272 & 30,351 & 0.566 & 15.7 & 8.76 \\
\hline Percent Diff. & $-0.1 \%$ & $0.0 \%$ & $1.8 \%$ & $-1.2 \%$ & $-1.2 \%$ & $0.3 \%$ & $-2.7 \%$ & $-0.1 \%$ & $-2.7 \%$ & $-1.2 \%$ & $-5.1 \%$ & $3.9 \%$ & $-5.2 \%$ \\
\hline
\end{tabular}

The second test was conducted at $100 \%$ fan speed with 0.7 in. SP and an inlet air wet bulb temperature of $70^{\circ} \mathrm{F}$.

Table 63. Test Conditions (Test \#2)

\begin{tabular}{|c|c|c|c|c|c||}
\hline $\mathbf{T}_{\mathbf{d b}, \mathbf{F}}$ & $\mathbf{T}_{\mathbf{w b}, \mathbf{F}}$ & $\mathbf{P}_{\mathbf{k P a}}$ & $\mathbf{S . P}_{\text {inWC }}$ & Speed $_{\%}$ & $\mathbf{C o C}$ \\
\hline \hline 95 & 70 & 82 & 0.7 & $100 \%$ & 5.00 \\
\hline
\end{tabular}


The modeled performance was within $4.4 \%$ of the two laboratory measurements. The measured results from the two laboratory tests were all similar, and the fan power calculation had the largest percent error.

Table 64. Modeled Versus Measured Results (Test\#2)

\begin{tabular}{|c|c|c|c|c|c|c|c|c|c|c|c|c|c|}
\hline Test Case & 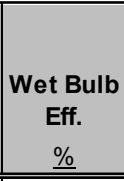 & $\begin{array}{c}\text { Supply } \\
\text { Air } \\
\text { Temp } \\
\text { F } \\
\end{array}$ & \begin{tabular}{|c|} 
Supply \\
Air Hum \\
$\underline{\mathrm{lb} / \mathrm{lb}}$ \\
\end{tabular} & \begin{tabular}{|c|}
$\begin{array}{c}\text { Supply } \\
\text { Air }\end{array}$ \\
Volume \\
Flow \\
m3/s \\
\end{tabular} & 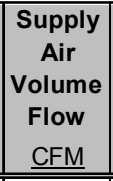 & \begin{tabular}{|c|} 
Exhaust \\
Air \\
Temp \\
$\underline{F}$ \\
\end{tabular} & 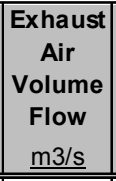 & \begin{tabular}{|c|} 
Exhaust \\
Air Hum \\
$\underline{\mathrm{lb} / \mathrm{lb}}$ \\
\end{tabular} & \begin{tabular}{|c|}
$\begin{array}{c}\text { Exhaust } \\
\text { Air }\end{array}$ \\
Volume \\
Flow \\
CFM \\
\end{tabular} & $\begin{array}{c}\text { Cooling } \\
\text { Capacity } \\
\text { Btu/hr } \\
\end{array}$ & 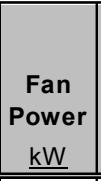 & $\begin{array}{l}\mathrm{OA} \\
\mathrm{COP} \\
\mathrm{COP} \\
\end{array}$ & $\begin{array}{c}\text { Water } \\
\text { Consumption } \\
\text { Gal/hr } \\
\end{array}$ \\
\hline Lab Test 1 & $104.0 \%$ & 68.74 & 0.01355 & 0.355 & 751 & 73.8 & 0.742 & 0.021 & 1,572 & 17,396 & 0.540 & 9.4 & 8.15 \\
\hline Model & $103.7 \%$ & 68.83 & 0.01329 & 0.361 & 765 & 73.9 & 0.757 & 0.021 & 1,603 & 17,646 & 0.565 & 9.2 & 8.53 \\
\hline Percent Diff. & $0.3 \%$ & $-0.1 \%$ & $1.9 \%$ & $-1.7 \%$ & $-1.9 \%$ & $0.0 \%$ & $-1.9 \%$ & $0.2 \%$ & $-1.9 \%$ & $-1.4 \%$ & $-4.4 \%$ & $3.0 \%$ & $-4.6 \%$ \\
\hline Lab Test 2 & $103.4 \%$ & 69.93 & 0.01442 & 0.354 & 752 & 74.8 & 0.748 & 0.022 & 1,585 & 16,624 & 0.544 & 9.0 & 8.05 \\
\hline Model & $103.6 \%$ & 69.89 & 0.01416 & 0.363 & 768 & 74.7 & 0.756 & 0.022 & 1,602 & 16,993 & 0.566 & 8.8 & 8.21 \\
\hline Percent Diff. & $-0.1 \%$ & $0.1 \%$ & $1.8 \%$ & $-2.3 \%$ & $-2.2 \%$ & $0.1 \%$ & $-1.0 \%$ & $0.8 \%$ & $-1.0 \%$ & $-2.2 \%$ & $-4.0 \%$ & $1.8 \%$ & $-2.0 \%$ \\
\hline
\end{tabular}

The third test was conducted at $100 \%$ fan speed with 0.5 in. SP and an inlet air wet bulb temperature of $70^{\circ} \mathrm{F}$.

Table 65. Test Conditions (Test \#3)

\begin{tabular}{|c|c|c|c|c|c||}
\hline $\mathbf{T}_{\mathbf{d b}, \mathbf{F}}$ & $\mathbf{T}_{\mathbf{w b}, \mathbf{F}}$ & $\mathbf{P}_{\mathbf{k P a}}$ & $\mathbf{S . P}_{\text {inWC }}$ & Speed $_{\%}$ & $\mathbf{C o C}$ \\
\hline \hline 95 & 70 & 82 & 0.5 & $100 \%$ & 5.00 \\
\hline
\end{tabular}

The modeled performance was within $5 \%$ of the two laboratory measurements. The measured results from the two laboratory tests were all similar, and the fan power calculation had the largest percent error.

Table 66. Modeled Versus Measured Results (Test \#3)

\begin{tabular}{|c|c|c|c|c|c|c|c|c|c|c|c|c|c|}
\hline Test Case & $\begin{array}{c}\text { Wet Bulb } \\
\text { Eff. } \\
\% \\
\end{array}$ & $\begin{array}{c}\text { Supply } \\
\text { Air } \\
\text { Temp } \\
\text { F } \\
\end{array}$ & \begin{tabular}{|c|} 
Supply \\
Air Hum \\
$\underline{\mathrm{lb} / \mathrm{lb}}$ \\
\end{tabular} & 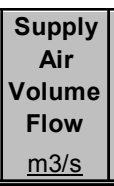 & 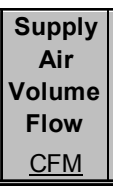 & $\begin{array}{c}\text { Exhaust } \\
\text { Air } \\
\text { Temp } \\
\underline{F} \\
\end{array}$ & 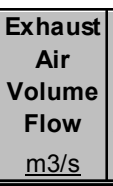 & \begin{tabular}{|c|} 
Exhaust \\
Air Hum \\
$\underline{\mathrm{lb} / \mathrm{l} \mathrm{b}}$ \\
\end{tabular} & 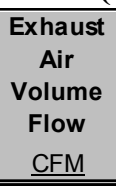 & $\begin{array}{c}\text { Cooling } \\
\text { Capacity } \\
\text { Btu/hr }\end{array}$ & $\begin{array}{c}\text { Fan } \\
\text { Power } \\
\underline{\mathrm{kW}} \\
\end{array}$ & $\begin{array}{r}\text { OA } \\
\text { COP } \\
\text { COP } \\
\end{array}$ & $\begin{array}{c}\text { Water } \\
\text { Consumption } \\
\mathrm{Gal} / \mathrm{hr} \\
\end{array}$ \\
\hline Lab Test 1 & $96.6 \%$ & 70.93 & 0.01386 & 0.531 & 1,125 & 75.5 & 0.686 & 0.023 & 1,453 & 23,743 & 0.554 & 12.6 & 8.43 \\
\hline Model & $96.5 \%$ & 70.96 & 0.01361 & 0.521 & 1,103 & 75.6 & 0.687 & 0.023 & 1,456 & 23,232 & 0.565 & 12.1 & 8.64 \\
\hline Percent Diff. & $0.1 \%$ & $0.0 \%$ & $1.8 \%$ & $1.9 \%$ & $1.9 \%$ & $-0.1 \%$ & $-0.2 \%$ & $0.2 \%$ & $-0.2 \%$ & $2.2 \%$ & $-2.0 \%$ & $4.2 \%$ & $-2.4 \%$ \\
\hline Lab Test 2 & $96.6 \%$ & 71.57 & 0.01441 & 0.526 & 1,114 & 76.2 & 0.680 & 0.023 & 1,441 & 22,923 & 0.543 & 12.4 & 8.13 \\
\hline Model & $96.5 \%$ & 71.59 & 0.01417 & 0.521 & 1,105 & 76.1 & 0.687 & 0.023 & 1,455 & 22,692 & 0.566 & 11.8 & 8.46 \\
\hline Percent Diff. & $0.1 \%$ & $0.0 \%$ & $1.7 \%$ & $0.8 \%$ & $0.8 \%$ & $0.2 \%$ & $-1.0 \%$ & $-0.1 \%$ & $-1.0 \%$ & $1.0 \%$ & $-4.0 \%$ & $5.0 \%$ & $-4.0 \%$ \\
\hline
\end{tabular}

The fourth test was conducted at $75 \%$ fan speed with 0.5 in. SP and an inlet air wet bulb temperature of $70^{\circ} \mathrm{F}$.

Table 67. Test Conditions (Test \#4)

\begin{tabular}{|c|c|c|c|c|c||}
\hline $\mathbf{T}_{\mathbf{d b}, \mathbf{F}}$ & $\mathbf{T}_{\mathbf{w b}, \mathbf{F}}$ & $\mathbf{P}_{\mathbf{k P a}}$ & $\mathbf{S . P}_{\text {inWC }}$ & Speed $_{\%}$ & $\mathbf{C o C}$ \\
\hline \hline 95 & 70 & 82 & 0.5 & $75 \%$ & 5.00 \\
\hline
\end{tabular}


The modeled performance was within $11.5 \%$ of the two laboratory measurements. The reduced percent fan speed of $75 \%$ introduced a larger percentage of error in modeled versus measured results, with a slight variation in EA flow rate, SA flow rate, and fan power. The fan power from the modeled data was consistently lower than the measured fan power for both laboratory tests, which showed some inconsistency in the SA flow and EA flow measurements between the two tests.

Table 68. Modeled Versus Measured Results (Test \#4)

\begin{tabular}{|c|c|c|c|c|c|c|c|c|c|c|c|c|c|}
\hline Test Case & 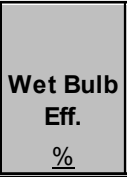 & $\begin{array}{c}\text { Supply } \\
\text { Air } \\
\text { Temp } \\
\underline{F}\end{array}$ & \begin{tabular}{|c|} 
Supply \\
Air Hum \\
$\underline{\mathrm{lb} / \mathrm{lb}}$ \\
\end{tabular} & 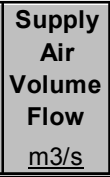 & 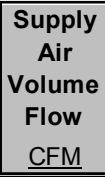 & $\begin{array}{c}\text { Exhaust } \\
\text { Air } \\
\text { Temp } \\
\underline{F} \\
\end{array}$ & \begin{tabular}{|c|}
$\begin{array}{c}\text { Exhaust } \\
\text { Air }\end{array}$ \\
Volume \\
Flow \\
m3/s \\
\end{tabular} & $\begin{array}{c}\text { Exhaust } \\
\text { Air Hum } \\
\underline{\mathrm{lb} / \mathrm{lb}} \\
\end{array}$ & $\begin{array}{c}\text { Exhaust } \\
\text { Air } \\
\text { Volume } \\
\text { Flow } \\
\text { CFM } \\
\end{array}$ & $\begin{array}{c}\text { Cooling } \\
\text { Capacity } \\
\text { Btu/hr } \\
\end{array}$ & $\begin{array}{c}\text { Fan } \\
\text { Power } \\
\text { kW } \\
\end{array}$ & $\begin{array}{l}\text { OA } \\
\text { COP } \\
\text { COP } \\
\end{array}$ & $\begin{array}{c}\text { Water } \\
\text { Consumption } \\
\text { Gal/hr } \\
\end{array}$ \\
\hline Lab Test 1 & $99.5 \%$ & 70.15 & 0.0136 & 0.450 & 953 & 75.4 & 0.590 & 0.023 & 1,251 & 20,982 & 0.355 & 17.3 & 7.36 \\
\hline Model & $99.5 \%$ & 70.14 & 0.01337 & 0.433 & 919 & 75.6 & 0.554 & 0.023 & 1,173 & 20,217 & 0.319 & 18.5 & 7.04 \\
\hline Percent Diff. & $-0.1 \%$ & $0.0 \%$ & $1.7 \%$ & $3.7 \%$ & $3.7 \%$ & $-0.2 \%$ & $6.4 \%$ & $0.2 \%$ & $6.4 \%$ & $3.7 \%$ & $10.5 \%$ & $-6.8 \%$ & $4.3 \%$ \\
\hline Lab Test 2 & $98.7 \%$ & 70.32 & 0.01372 & 0.454 & 962 & 75.8 & 0.572 & 0.023 & 1,211 & 20,924 & 0.356 & 17.2 & 7.14 \\
\hline Model & $99.7 \%$ & 70.07 & 0.01348 & 0.431 & 914 & 75.5 & 0.555 & 0.023 & 1,175 & 20,067 & 0.317 & 18.5 & 7.03 \\
\hline Percent Diff. & $-1.0 \%$ & $0.4 \%$ & $1.8 \%$ & $5.1 \%$ & $5.1 \%$ & $0.4 \%$ & $3.0 \%$ & $0.5 \%$ & $3.0 \%$ & $4.2 \%$ & $11.5 \%$ & $-7.3 \%$ & $1.6 \%$ \\
\hline
\end{tabular}

The fifth test was conducted at $50 \%$ fan speed with 0.5 in. SP and an inlet air wet bulb temperature of $70^{\circ} \mathrm{F}$.

Table 69. Test Conditions (Test \#5)

\begin{tabular}{|c|c|c|c|c|c||}
\hline $\mathbf{T}_{\mathbf{d b}, \mathbf{F}}$ & $\mathbf{T}_{\mathbf{w b}, \mathbf{F}}$ & $\mathbf{P}_{\mathbf{k P a}}$ & $\mathbf{S . P}_{\text {inWc }}$ & Speed $_{\%}$ & $\mathbf{C o C}$ \\
\hline \hline 95 & 70 & 82 & 0.5 & $50 \%$ & 5.00 \\
\hline
\end{tabular}

The modeled performance was within $13.5 \%$ of the two laboratory measurements. The reduced percent fan speed of $50 \%$ introduced a larger percentage of error in modeled versus measured results, with a slight variation in EA flow rate, and fan power. The fan power from the modeled data was consistently higher than the measured fan power for both laboratory tests (which is the opposite of the $75 \%$ speed case), and the laboratory tests had some inconsistency in the EA flow measurements between the two tests. This case had the largest percentage of error between modeled and measured performance. 
Table 70. Modeled Versus Measured Results (Test \#5)

\begin{tabular}{|c|c|c|c|c|c|c|c|c|c|c|c|c|c|}
\hline Test Case & $\begin{array}{c}\text { Wet Bulb } \\
\text { Eff. } \\
\underline{\%} \\
\end{array}$ & $\begin{array}{c}\text { Supply } \\
\text { Air } \\
\text { Temp } \\
\text { F } \\
\end{array}$ & $\begin{array}{c}\text { Supply } \\
\text { Air Hum } \\
\text { lb/lb }\end{array}$ & 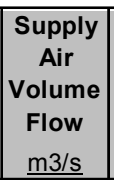 & \begin{tabular}{|c|}
$\begin{array}{c}\text { Supply } \\
\text { Air } \\
\text { Volume } \\
\text { Flow } \\
\text { CFM }\end{array}$ \\
\end{tabular} & \begin{tabular}{|c|} 
Exhaust \\
Air \\
Temp \\
$\underline{F}$ \\
\end{tabular} & 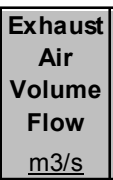 & \begin{tabular}{|c} 
Exhaust \\
Air Hum \\
$\mathrm{lb} / \mathrm{lb}$ \\
\end{tabular} & \begin{tabular}{|c|}
$\begin{array}{c}\text { Exhaust } \\
\text { Air }\end{array}$ \\
Volume \\
Flow \\
CFM \\
\end{tabular} & $\begin{array}{c}\text { Cooling } \\
\text { Capacity } \\
\text { Btu/hr } \\
\end{array}$ & $\begin{array}{c}\text { Fan } \\
\text { Power } \\
\text { kW }\end{array}$ & $\begin{array}{r}\text { OA } \\
\text { COP } \\
\text { COP } \\
\end{array}$ & $\begin{array}{c}\text { Water } \\
\text { Consumption } \\
\text { Gal/hr } \\
\end{array}$ \\
\hline Lab Test 1 & $\begin{array}{l}108.2 \% \\
\end{array}$ & 68.00 & 0.01362 & 0.293 & 621 & 75.6 & 0.380 & 0.023 & 805 & $\begin{array}{l}14,904 \\
\end{array}$ & 0.124 & 35.4 & 4.85 \\
\hline Model & $107.2 \%$ & 68.25 & 0.0134 & 0.304 & 644 & 75.6 & 0.384 & 0.023 & 814 & 15,290 & 0.141 & 31.7 & 4.88 \\
\hline Percent Diff. & $0.9 \%$ & $-0.4 \%$ & $1.6 \%$ & $-3.6 \%$ & $-3.6 \%$ & $0.0 \%$ & $-1.1 \%$ & $1.2 \%$ & $-1.1 \%$ & $-2.6 \%$ & $-13.5 \%$ & $10.9 \%$ & $-0.6 \%$ \\
\hline Lab Test 2 & $107.3 \%$ & 68.22 & 0.01377 & 0.301 & 638 & 76.3 & 0.347 & 0.023 & 736 & 15,083 & 0.128 & 34.6 & 4.57 \\
\hline Model & $107.5 \%$ & 68.18 & 0.01354 & 0.302 & 640 & 75.6 & 0.385 & 0.023 & 815 & 15,148 & 0.140 & 31.6 & 4.86 \\
\hline Percent Diff. & $-0.2 \%$ & $0.1 \%$ & $1.7 \%$ & $-0.4 \%$ & $-0.4 \%$ & $1.0 \%$ & $-10.3 \%$ & $2.8 \%$ & $-10.3 \%$ & $-0.4 \%$ & $-9.6 \%$ & $9.1 \%$ & $-6.2 \%$ \\
\hline
\end{tabular}

The sixth test was conducted at $25 \%$ fan speed with 0.5 in. SP and an inlet air wet bulb temperature of $70^{\circ} \mathrm{F}$.

Table 71. Test Conditions (Test \#6)

\begin{tabular}{|c|c|c|c|c|c||}
\hline $\mathbf{T}_{\mathbf{d b}, \mathbf{F}}$ & $\mathbf{T}_{\mathbf{w b}, \mathbf{F}}$ & $\mathbf{P}_{\mathbf{k P a}}$ & S.P. $_{\text {inWc }}$ & Speed $_{\%}$ & $\mathbf{C o C}$ \\
\hline \hline 95 & 70 & 82 & 0.5 & $25 \%$ & 5.00 \\
\hline
\end{tabular}

The modeled performance was within $5.8 \%$ of the two laboratory measurements. The fan power at $25 \%$ speed was significantly closer to the measured data. The model predicted SA and EA flow rates were slightly lower than the measured flow rates, and there was a slight inconsistency between the SA flow rates of the two laboratory measurements.

Table 72. Modeled Versus Measured Results (Test \#6)

\begin{tabular}{|c|c|c|c|c|c|c|c|c|c|c|c|c|c|}
\hline Test Case & $\begin{array}{c}\text { Wet Bulb } \\
\text { Eff. } \\
\% \\
\end{array}$ & $\begin{array}{c}\text { Supply } \\
\text { Air } \\
\text { Temp } \\
\text { F } \\
\end{array}$ & $\begin{array}{c}\text { Supply } \\
\text { Air Hum } \\
\text { lb/lb }\end{array}$ & 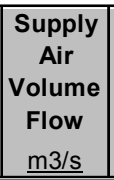 & \begin{tabular}{|c|} 
Supply \\
Air \\
Volume \\
Flow \\
CFM \\
\end{tabular} & \begin{tabular}{|c|} 
Exhaust \\
Air \\
Temp \\
$\underline{F}$ \\
\end{tabular} & 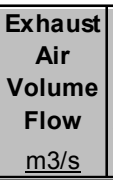 & \begin{tabular}{|c|} 
Exhaust \\
Air Hum \\
$\underline{\mathrm{lb} / \mathrm{lb}}$
\end{tabular} & \begin{tabular}{|c|}
$\begin{array}{c}\text { Exhaust } \\
\text { Air }\end{array}$ \\
Volume \\
Flow \\
CFM \\
\end{tabular} & $\begin{array}{c}\text { Cooling } \\
\text { Capacity } \\
\text { Btu/hr }\end{array}$ & $\begin{array}{c}\text { Fan } \\
\text { Power } \\
\mathrm{kW} \\
\end{array}$ & $\begin{array}{l}\text { OA } \\
\text { COP } \\
\text { COP } \\
\end{array}$ & $\begin{array}{c}\text { Water } \\
\text { Consumption } \\
\text { Gal/hr } \\
\end{array}$ \\
\hline Lab Test 1 & $123.3 \%$ & 64.16 & 0.0135 & 0.139 & 294 & 75.5 & 0.187 & 0.023 & 396 & 8,137 & 0.035 & 67.4 & 2.36 \\
\hline Model & $122.8 \%$ & 64.28 & 0.01334 & 0.135 & 286 & 75.6 & 0.177 & 0.023 & 376 & 7,870 & 0.035 & 65.6 & 2.26 \\
\hline Percent Diff. & $0.4 \%$ & $-0.2 \%$ & $1.2 \%$ & $2.8 \%$ & $2.8 \%$ & $-0.1 \%$ & $5.3 \%$ & $0.2 \%$ & $5.3 \%$ & $3.3 \%$ & $0.7 \%$ & $2.7 \%$ & $4.2 \%$ \\
\hline Lab Test 2 & $122.6 \%$ & 64.46 & 0.01364 & 0.143 & 303 & 75.8 & 0.186 & 0.023 & 394 & 8,285 & 0.037 & 65.8 & 2.39 \\
\hline Model & $122.8 \%$ & 64.40 & 0.01345 & 0.135 & 286 & 75.6 & 0.177 & 0.023 & 376 & 7,828 & 0.035 & 65.3 & 2.25 \\
\hline Percent Diff. & $-0.2 \%$ & $0.1 \%$ & $1.5 \%$ & $5.8 \%$ & $5.8 \%$ & $0.2 \%$ & $4.7 \%$ & $1.5 \%$ & $4.7 \%$ & $5.7 \%$ & $5.0 \%$ & $0.7 \%$ & $6.1 \%$ \\
\hline
\end{tabular}

The seventh test was conducted at $100 \%$ fan speed with 0.5 in. SP and an inlet air wet bulb temperature of $70^{\circ} \mathrm{F}$ and a dry bulb temperature of $105^{\circ} \mathrm{F}$.

Table 73. Test Conditions (Test \#7)

\begin{tabular}{|c|c|c|c|c|c||}
\hline $\mathbf{T}_{\mathbf{d b}, \mathbf{F}}$ & $\mathbf{T}_{\mathbf{w b}, \mathbf{F}}$ & $\mathbf{P}_{\mathbf{k P a}}$ & S.P. inWc $_{\text {S }}$ & Speed $_{\%}$ & CoC \\
\hline \hline 105 & 70 & 82 & 0.5 & $100 \%$ & 5.00 \\
\hline
\end{tabular}

The modeled performance was within $5.8 \%$ of the laboratory measurement. The modeled fan power was slightly higher than the measured fan power. 
Table 74. Modeled Versus Measured Results (Test \#7)

\begin{tabular}{|c|c|c|c|c|c|c|c|c|c|c|c|c|c|}
\hline Test Case & $\begin{array}{c}\text { Wet Bulb } \\
\text { Eff. } \\
\% \\
\end{array}$ & \begin{tabular}{|c|} 
Supply \\
Air \\
Temp \\
$\underline{F}$ \\
\end{tabular} & $\begin{array}{c}\text { Supply } \\
\text { Air Hum } \\
\underline{\mathrm{lb} / \mathrm{lb}} \\
\end{array}$ & 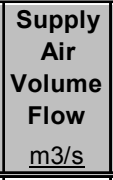 & 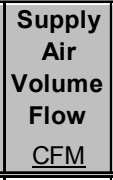 & \begin{tabular}{|c|} 
Exhaust \\
Air \\
Temp \\
$\underline{F}$ \\
\end{tabular} & 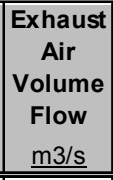 & \begin{tabular}{|c} 
Exhaust \\
Air Hum \\
$\underline{\mathrm{lb} / \mathrm{lb}}$ \\
\end{tabular} & \begin{tabular}{|c|}
$\begin{array}{c}\text { Exhaust } \\
\text { Air }\end{array}$ \\
Volume \\
Flow \\
CFM \\
\end{tabular} & $\begin{array}{c}\text { Cooling } \\
\text { Capacity } \\
\text { Btu/hr }\end{array}$ & $\begin{array}{c}\text { Fan } \\
\text { Power } \\
\underline{\mathrm{kW}} \\
\end{array}$ & $\begin{array}{l}\mathrm{OA} \\
\mathrm{COP} \\
\mathrm{COP} \\
\end{array}$ & 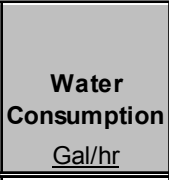 \\
\hline Lab Test 2 & $97.7 \%$ & 71.80 & 0.01233 & 0.517 & 1,096 & 78.1 & 0.667 & 0.025 & 1,414 & 31,965 & 0.538 & 17.4 & 1.17 \\
\hline Model & & 72.23 & 0.01203 & 0.522 & 1,106 & & 0.687 & & 455 & 775 & 66 & 16.4 & 2.28 \\
\hline Percent Diff. & $1.3 \%$ & $-0.6 \%$ & $2.5 \%$ & $-0.9 \%$ & $-0.9 \%$ & $-0.6 \%$ & $-2.9 \%$ & $-2.2 \%$ & $-2.9 \%$ & $0.6 \%$ & $-5.2 \%$ & $5.8 \%$ & $-9.5 \%$ \\
\hline
\end{tabular}

The eighth test was conducted at $100 \%$ fan speed with 0.5 in. SP, an inlet air wet bulb temperature of $70^{\circ} \mathrm{F}$, and a dry bulb temperature of $85^{\circ} \mathrm{F}$.

Table 75. Test Conditions (Test \#8)

\begin{tabular}{|c|c|c|c|c|c||}
\hline $\mathbf{T}_{\mathbf{d b}, \mathbf{F}}$ & $\mathbf{T}_{\mathbf{w b}, \mathbf{F}}$ & $\mathbf{P}_{\mathbf{k P a}}$ & S.P. inWc $_{\mathbf{w}}$ & Speed $_{\%}$ & CoC \\
\hline \hline 85 & 70 & 82 & 0.5 & $100 \%$ & 5.00 \\
\hline
\end{tabular}

The modeled performance was within $6.5 \%$ of the laboratory measurement. The model predicted SA flow rates were slightly lower than the measured flow rates, and there was a slight inconsistency in the SA flow rates between the two laboratory measurements.

Table 76. Modeled Versus Measured Results (Test \#8)

\begin{tabular}{|c|c|c|c|c|c|c|c|c|c|c|c|c|c|}
\hline Test Case & $\begin{array}{c}\text { Wet Bulb } \\
\text { Eff. } \\
\underline{\%} \\
\end{array}$ & $\begin{array}{c}\text { Supply } \\
\text { Air } \\
\text { Temp } \\
\underline{F} \\
\end{array}$ & \begin{tabular}{|c|} 
Supply \\
Air Hum \\
$\underline{\mathrm{lb} / \mathrm{lb}}$ \\
\end{tabular} & 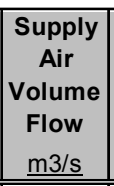 & 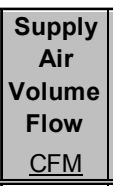 & \begin{tabular}{|c|} 
Exhaust \\
Air \\
Temp \\
$\underline{F}$ \\
\end{tabular} & 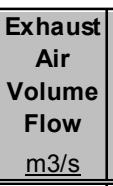 & \begin{tabular}{|c|} 
Exhaust \\
Air Hum \\
$\underline{\mathrm{lb} / \mathrm{lb}}$ \\
\end{tabular} & $\begin{array}{c}\text { Exhaust } \\
\text { Air } \\
\text { Volume } \\
\text { Flow } \\
\text { CFM } \\
\end{array}$ & $\begin{array}{c}\text { Cooling } \\
\text { Capacity } \\
\text { Btu/hr }\end{array}$ & $\begin{array}{c}\text { Fan } \\
\text { Power } \\
\underline{\mathrm{kW}} \\
\end{array}$ & $\begin{array}{l}\text { OA } \\
\text { COP } \\
\text { COP } \\
\end{array}$ & $\begin{array}{c}\text { Water } \\
\text { Consumption } \\
\text { Gal/hr } \\
\end{array}$ \\
\hline Lab Test 1 & $94.2 \%$ & 70.90 & 0.01617 & 0.548 & 1,160 & 73.9 & 0.644 & 0.022 & 1,365 & 14,344 & 0.557 & 7.5 & 4.99 \\
\hline Model & $96.6 \%$ & 70.55 & 0.01598 & 0.520 & 1,102 & 73.3 & 0.688 & 0.021 & 1,457 & 13,952 & 0.564 & 7.3 & 4.85 \\
\hline Percent Diff. & $-2.4 \%$ & $0.5 \%$ & $1.2 \%$ & $5.2 \%$ & $5.2 \%$ & $0.7 \%$ & $-6.5 \%$ & $3.3 \%$ & $-6.5 \%$ & $2.8 \%$ & $-1.2 \%$ & $4.0 \%$ & $2.9 \%$ \\
\hline Lab Test 2 & $94.5 \%$ & 70.68 & 0.01588 & 0.530 & 1,122 & 73.8 & 0.680 & 0.021 & 1,440 & 14,178 & 0.555 & 7.5 & 5.04 \\
\hline Model & $96.4 \%$ & 70.38 & 0.01569 & 0.522 & 1,106 & 73.2 & 0.687 & 0.021 & 1,455 & 14,261 & 0.567 & 7.4 & 4.94 \\
\hline Percent Diff. & $-2.1 \%$ & $0.4 \%$ & $1.2 \%$ & $1.4 \%$ & $1.4 \%$ & $0.8 \%$ & $-1.0 \%$ & $1.7 \%$ & $-1.0 \%$ & $-0.6 \%$ & $-2.1 \%$ & $1.5 \%$ & $2.1 \%$ \\
\hline
\end{tabular}

The ninth test was conducted at $100 \%$ fan speed with 0.5 in. SP, an inlet air wet bulb temperature of $70^{\circ} \mathrm{F}$, and a dry bulb temperature of $95^{\circ} \mathrm{F}$.

Table 77. Test Conditions (Test \#9)

\begin{tabular}{|c|c|c|c|c|c||}
\hline $\mathbf{T}_{\mathbf{d b}, \mathbf{F}}$ & $\mathbf{T}_{\mathbf{w b}, \mathbf{F}}$ & $\mathbf{P}_{\mathbf{k P a}}$ & $\mathbf{S . P}_{\text {inWC }}$ & Speed $_{\%}$ & $\mathbf{C o C}$ \\
\hline \hline 95 & 70 & 82 & 0.5 & $100 \%$ & 5.00 \\
\hline
\end{tabular}

The modeled performance was within $4.8 \%$ of the laboratory measurement. The modeled fan power was slightly higher than the measured fan power. 
Table 78. Modeled Versus Measured Results (Test \#9)

\begin{tabular}{|c|c|c|c|c|c|c|c|c|c|c|c|c|c|}
\hline Test Case & $\begin{array}{c}\text { Wet Bulb } \\
\text { Eff. } \\
\% \\
\end{array}$ & \begin{tabular}{|c} 
Supply \\
Air \\
Temp \\
F \\
\end{tabular} & $\begin{array}{c}\text { Supply } \\
\text { Air Hum } \\
\underline{\mathrm{Ib} / \mathrm{lb}}\end{array}$ & 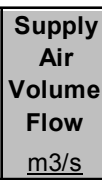 & \begin{tabular}{|c|} 
Supply \\
Air \\
Volume \\
Flow \\
CFM \\
\end{tabular} & \begin{tabular}{|c|} 
Exhaust \\
Air \\
Temp \\
$\underline{F}$ \\
\end{tabular} & 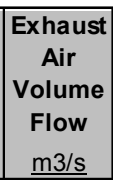 & $\begin{array}{c}\text { Exhaust } \\
\text { Air Hum } \\
\underline{\mathrm{lb} / \mathrm{lb}}\end{array}$ & \begin{tabular}{|c|}
$\begin{array}{c}\text { Exhaust } \\
\text { Air }\end{array}$ \\
Volume \\
Flow \\
CFM \\
\end{tabular} & $\begin{array}{c}\text { Cooling } \\
\text { Capacity } \\
\text { Btu/hr }\end{array}$ & $\begin{array}{c}\text { Fan } \\
\text { Power } \\
\text { kW }\end{array}$ & $\begin{array}{l}\text { OA } \\
\text { COP } \\
\text { COP } \\
\end{array}$ & $\begin{array}{c}\text { Water } \\
\text { Consumption } \\
\text { Gal/hr } \\
\end{array}$ \\
\hline Lab Test 1 & $96.8 \%$ & 70.89 & 0.01366 & 0.527 & 1,117 & 75.4 & 0.696 & 0.023 & 1,474 & 23,859 & 0.550 & 12.7 & 8.57 \\
\hline Model & $96.3 \%$ & 71.00 & 0.01342 & 0.524 & 1,111 & 75.6 & 0.686 & 0.023 & 1,453 & 23,577 & 0.570 & 12.1 & 8.71 \\
\hline Percent Diff. & $0.5 \%$ & $-0.2 \%$ & $1.7 \%$ & $0.6 \%$ & $0.6 \%$ & $-0.4 \%$ & $1.5 \%$ & $-0.2 \%$ & $1.5 \%$ & $1.2 \%$ & $-3.6 \%$ & $4.8 \%$ & $-1.6 \%$ \\
\hline Lab Test 2 & $96.6 \%$ & 71.69 & 0.01453 & 0.525 & 1,113 & 76.3 & 0.673 & 0.023 & 1,427 & 22,762 & 0.545 & 12.2 & 8.14 \\
\hline Model & $96.5 \%$ & 71.71 & 0.01428 & 0.521 & 1,105 & 76.2 & 0.687 & 0.023 & 1,455 & 22,554 & 0.566 & 11.7 & 8.41 \\
\hline Percent Diff. & $0.1 \%$ & $0.0 \%$ & $1.7 \%$ & $0.7 \%$ & $0.7 \%$ & $0.1 \%$ & $-2.0 \%$ & $0.5 \%$ & $-2.0 \%$ & $0.9 \%$ & $-3.7 \%$ & $4.6 \%$ & $-3.3 \%$ \\
\hline
\end{tabular}

The modeled data were plotted against the measured data for a number of key parameters in Figure 98 and Figure 99. The SA WBE, cooling capacity, supply volume flow rate, and EA flow rate all had an $\mathrm{R}^{2}$ correlation $>98 \%$.
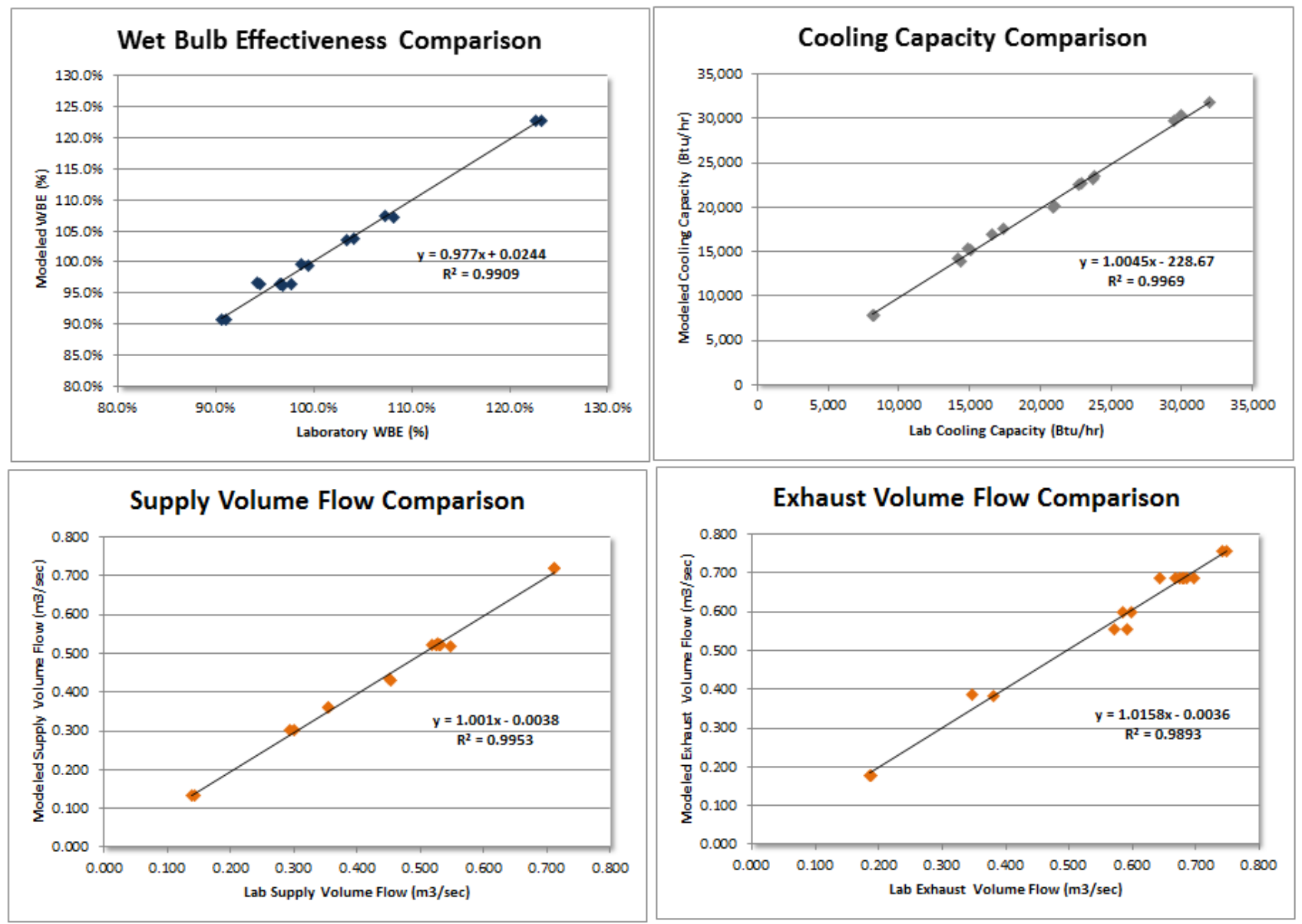

Figure 98. Modeled versus Measured Key Parameters Linear Regression

The SAT, fan power, water use, and SA humidity ratio had an $\mathrm{R}^{2}$ correlation $>99 \%$. The EAT and EA humidity ratio calculation had a slightly weaker relationship with an $\mathrm{R}^{2}$ that was approximately $95 \%$ for both cases. 

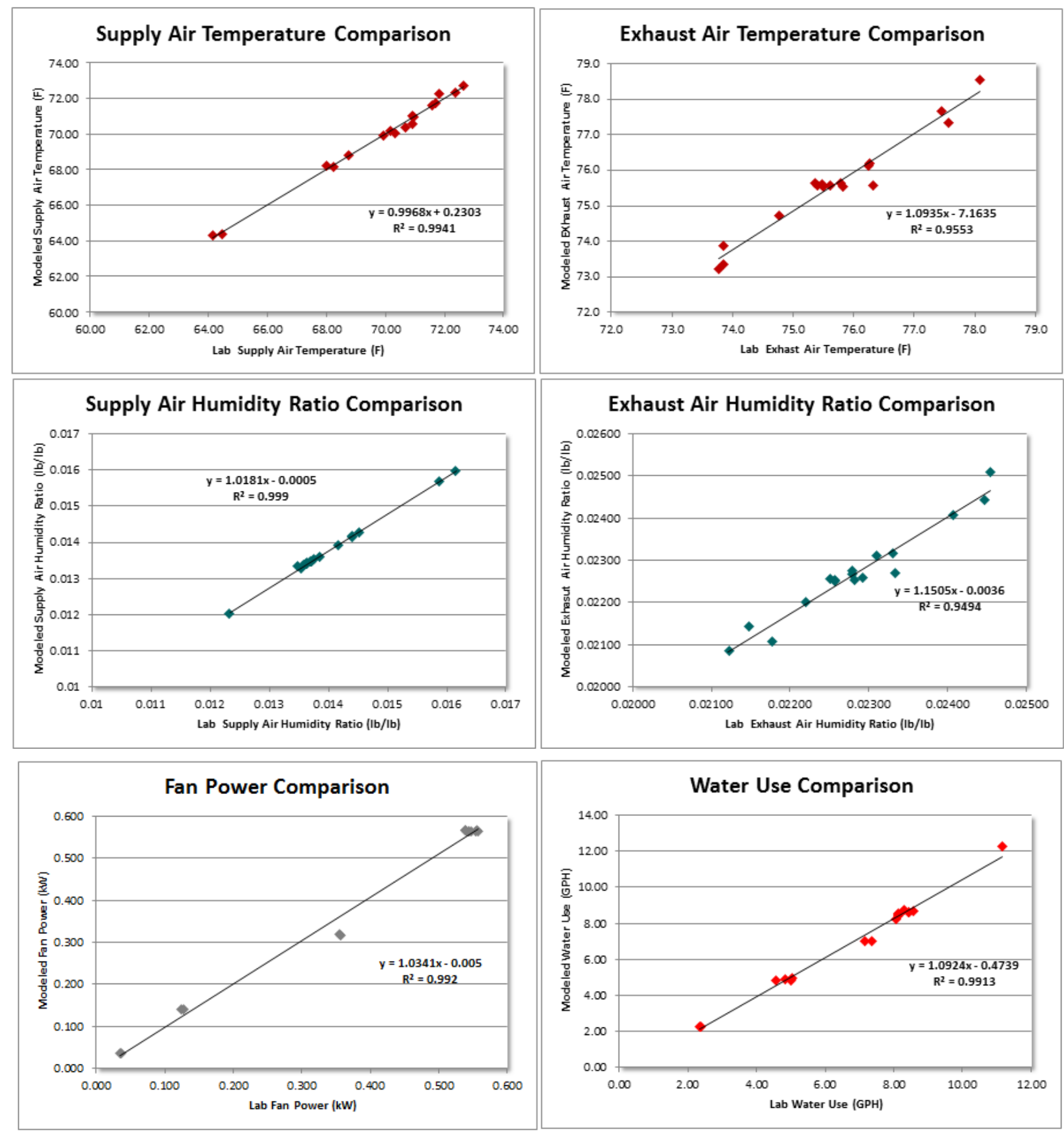

Figure 99. Modeled versus measured key parameters \#2 linear regression

\section{Model Validation with Field Test Data}

The performance model was validated against field test data for the 2011 cooling season with data on 14 C60 units. The sizing routine was modified to pull in 15-min data from the Campbell scientific data loggers. The following inputs were pulled in from the metered data: 
- $\quad$ Runtime average power $(\mathrm{kW})$. Average power during the 15-min interval while the unit was running

- $\quad$ Runtime (0-1). The unit runtime for the 15-min interval was input as a value between 0 and 1, with 1 indicating that the unit was running for the entire 15-min period

- $\quad$ Runtime average SAT. Input as the average SAT over the 15-min period while the unit was operating

- $\quad$ OA conditions. OA atm, dry bulb temperature, and RH

The sizing routine was modified to calculate the percent fan speed from the runtime average power. Using this information and the OA conditions the SAT, EA conditions, and water consumption were predicted. The fan power and energy use were predicted using a correlation to pull in the fan speed and calculate fan power and energy use. The predicted variables were compared to the measured SAT, water consumption, and total energy use. The total energy use form the metered data was compared to the model predicted energy use, thus there is a little variation between the modeled energy use and measured energy use. The energy use was the total over the 15-min interval (not the runtime energy use) and includes the residual energy use of the control board, which can account for slight variations at time steps when the unit did not operate for a significant amount of time. The CoCs were input for the first part of the summer as 1.5-1.6 and then changed to 5 at the end of the summer.

The total annual energy use, water use, and cooling provided are compared in Table 79 and Table 80 .

Table 79. Modeled Versus Measured Annual Energy Use, Water Use, and Cooling Energy

\begin{tabular}{|c|c|c|c|c|c|c|c|c|c|c|c|c|}
\hline \multirow[t]{2}{*}{ Variable } & \multicolumn{3}{|c|}{ Classroom \#1 } & \multicolumn{3}{|c|}{ Classroom \#2 } & \multicolumn{3}{|c|}{ Classroom \#3 } & \multicolumn{3}{|c|}{ Classroom \#4 } \\
\hline & $\begin{array}{c}\text { Energy } \\
\text { Use } \\
\text { (kWh) }\end{array}$ & $\begin{array}{c}\text { Water } \\
\text { Use } \\
\text { (Gal.) }\end{array}$ & $\begin{array}{c}\text { Cooling } \\
\text { Energy } \\
\text { (MMBtu) }\end{array}$ & $\begin{array}{c}\text { Energy } \\
\text { Use } \\
\text { (kWh) }\end{array}$ & $\begin{array}{c}\text { Water } \\
\text { Use } \\
\text { (Gal.) }\end{array}$ & $\begin{array}{c}\text { Cooling } \\
\text { Energy } \\
(\mathrm{MMBtu})\end{array}$ & $\begin{array}{c}\text { Energy } \\
\text { Use } \\
(\mathrm{kWh})\end{array}$ & $\begin{array}{c}\text { Water } \\
\text { Use } \\
\text { (Gal.) }\end{array}$ & $\begin{array}{l}\text { Cooling } \\
\text { Energy } \\
\text { (MMBtu) }\end{array}$ & $\begin{array}{c}\text { Energy } \\
\text { Use } \\
(\mathrm{kWh})\end{array}$ & $\begin{array}{c}\text { Water } \\
\text { Use } \\
\text { (Gal.) }\end{array}$ & $\begin{array}{l}\text { Cooling } \\
\text { Energy } \\
\text { (MMBtu) }\end{array}$ \\
\hline $\begin{array}{l}\text { Measured } \\
\text { Variable }\end{array}$ & 284 & 10,837 & 213,642 & 46 & 2,622 & 57,133 & 381 & 14,325 & 261,501 & 196 & 8,913 & 140,683 \\
\hline $\begin{array}{l}\text { Modeled } \\
\text { Variable }\end{array}$ & 281 & 10,378 & 228,542 & 44 & 2,539 & 57,997 & 376 & 13,236 & 240,504 & 193 & 7,790 & 148,987 \\
\hline \begin{tabular}{|l} 
Percent \\
Difference (\%)
\end{tabular} & $1.0 \%$ & $4.2 \%$ & $-7.0 \%$ & - & - & - & $1.2 \%$ & $7.6 \%$ & $8.0 \%$ & $1.3 \%$ & $12.6 \%$ & $-5.9 \%$ \\
\hline \multirow[t]{2}{*}{ Variable } & \multicolumn{3}{|c|}{ Event Center \#1 } & \multicolumn{3}{|c|}{ Event Center \#3 } & \multicolumn{3}{|c|}{ Event Center \#5 } & \multicolumn{3}{|c|}{ Event Center \#7 } \\
\hline & \begin{tabular}{|c|} 
Energy \\
Use \\
(kWh)
\end{tabular} & $\begin{array}{c}\text { Water } \\
\text { Use } \\
\text { (Gal.) }\end{array}$ & $\begin{array}{c}\text { Cooling } \\
\text { Energy } \\
\text { (MMBtu) }\end{array}$ & $\begin{array}{c}\text { Energy } \\
\text { Use } \\
\text { (kWh) }\end{array}$ & $\begin{array}{c}\text { Water } \\
\text { Use } \\
\text { (Gal.) }\end{array}$ & $\begin{array}{c}\text { Cooling } \\
\text { Energy } \\
(\mathrm{MMBtu})\end{array}$ & \begin{tabular}{|c} 
Energy \\
Use \\
(kWh)
\end{tabular} & \begin{tabular}{|c|} 
Water \\
Use \\
(Gal.)
\end{tabular} & $\begin{array}{l}\text { Cooling } \\
\text { Energy } \\
\text { (MMBtu) }\end{array}$ & \begin{tabular}{|c|} 
Energy \\
Use \\
(kWh)
\end{tabular} & $\begin{array}{c}\text { Water } \\
\text { Use } \\
\text { (Gal.) }\end{array}$ & $\begin{array}{l}\text { Cooling } \\
\text { Energy } \\
\text { (MMBtu) }\end{array}$ \\
\hline $\begin{array}{l}\text { Measured } \\
\text { Variable }\end{array}$ & 723 & 14,712 & 317,366 & 910 & 17,305 & 397,566 & 910 & 17,305 & 397,566 & 865 & 17,825 & 369,785 \\
\hline $\begin{array}{l}\text { Modeled } \\
\text { Variable }\end{array}$ & 703 & 13,976 & 284,302 & 882 & 16,405 & 341,556 & 882 & 16,405 & 341,556 & 844 & 16,035 & 331,113 \\
\hline \begin{tabular}{|l} 
Percent \\
Difference (\%)
\end{tabular} & $2.7 \%$ & $5.0 \%$ & $10.4 \%$ & $3.1 \%$ & $5.2 \%$ & $14.1 \%$ & $3.1 \%$ & $5.2 \%$ & $14.1 \%$ & $2.4 \%$ & $10.0 \%$ & $10.5 \%$ \\
\hline
\end{tabular}


Table 80. Modeled Versus Measured Annual Energy Use, Water Use, and Cooling Energy \#2

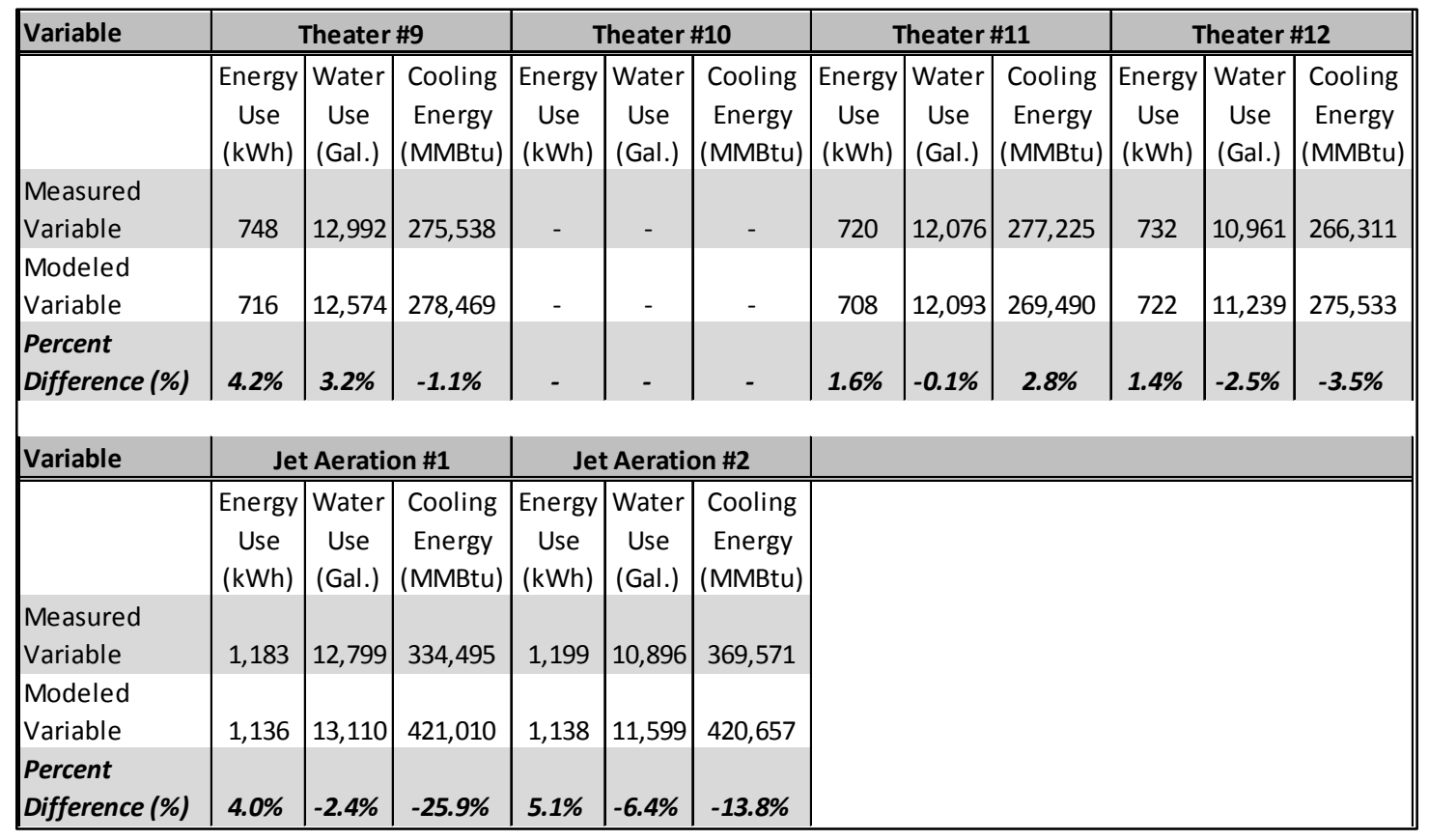

The model predicted performance correlates well for 11 of the 14 units. Theater unit 10 had some anomalies in the SAT and both of the units on the jet aeration facility performed significantly poorer than the other units. The jet aeration facility units also had a higher CoC setting than the other units and used considerably less water. Although there is a significant amount of variation in the water consumption on a 15-min and daily basis, the annual water consumption is close to the model predictions.

The modeled energy use was slightly higher than the measured energy use for all cases, but the modeled energy use was within $5 \%$ of the measured energy use. The measured water use was slightly higher than the modeled water use for 11 of the units and the modeled water use was lower than the measured water use for three of the units. The predicted water consumption is within $+10 \%$ and $-6.4 \%$ on an annual basis. The cooling capacity was calculated relative to the OAT. The model overpredicted the cooling for six units and underpredicted cooling for eight units. The predicted cooling capacity was within $\pm 5 \%$ for four units. Four units provided $10 \%-$ $12 \%$ more cooling than the model predicted and the worst-performing units provided $13.8 \%-$ $25.9 \%$ less cooling than the model predicted (Figure 100). The cooling capacity had the largest variation from one unit to another and the differences are driven by inconsistencies in water distribution through the heat and mass exchanger between units. 


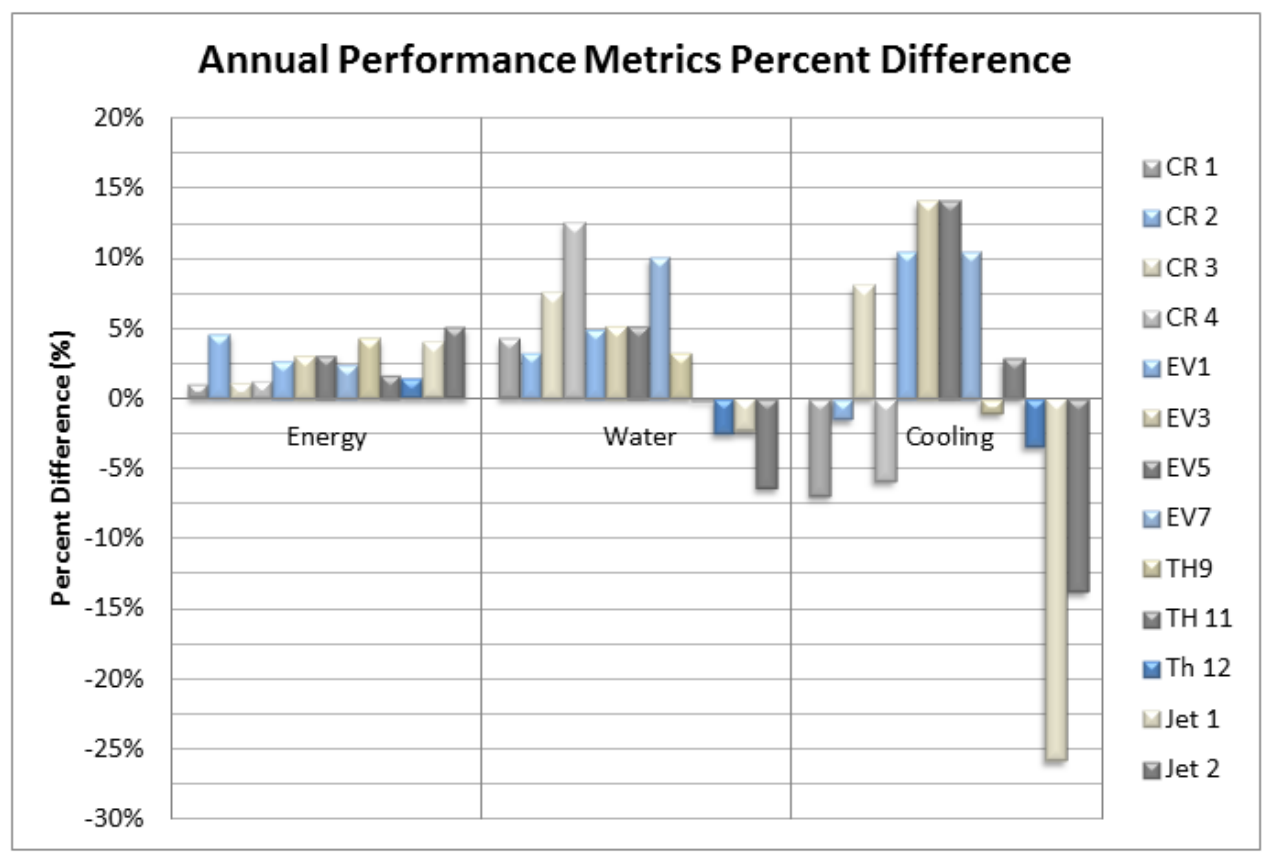

Figure 100. Modeled versus measured key parameters \#2 linear regression

Figure 101 shows the percent of time that the predicted variables were within $10 \%$ of the measured variable for SAT and cooling capacity over a 15-min interval and water use on a daily basis.

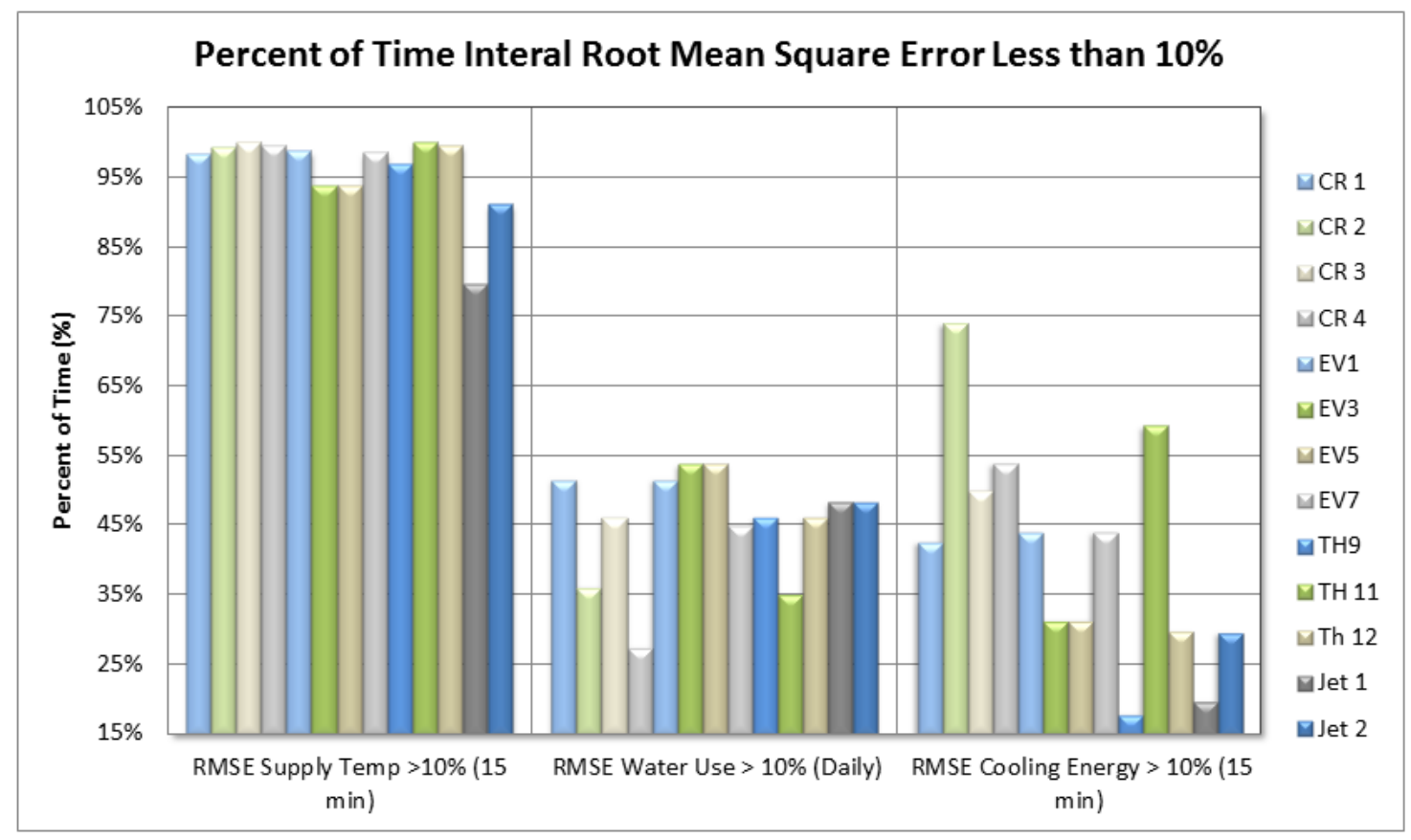

Figure 101. Modeled versus measured key parameters \#2 linear regression 
The model-predicted SAT was within $10 \%$ of the measured SAT for $>90 \%$ of the 15 -min intervals for 12 of the 14 units. The two units installed on the jet aeration facilities had higher SATs than the model-predicted SATs and were within $10 \%$ of the 15 -min measured value $78 \%-$ $87 \%$ of the time. The modeled daily water consumption was within $10 \%$ of the measured daily water consumption for about half the daily intervals. The measured cooling capacity had a larger root mean square error (RMSE) on a 15-min basis based on the sensitivity to the temperature difference between SAT and OAT.

Figure 102 through Figure 109 show the measured performance of the classroom units and one jet aeration unit. The classroom unit represents a unit with performance characteristics that are in line with the model predictions and the jet aeration unit had higher SATs and lower water consumption than the model predicted. 


\section{Classroom Unit \#1}

The $\mathrm{CoC}$ was set to 1.6 for the first part of the summer and to 5 for the second part of the summer. The predicted energy use, cooling energy, and water consumption were all within $7 \%$ on an annual basis. The predicted cooling capacity was slightly higher than the measured cooling capacity and the modeled water consumption was slightly lower than the measured water consumption. The predicted SAT was within $10 \%$ of the 15 -min measured SAT for $98 \%$ of the measurements. The daily water consumption and 15 -min cooling capacity were within $10 \%$ of the measured values $52 \%$ and $43 \%$ of the time, respectively.

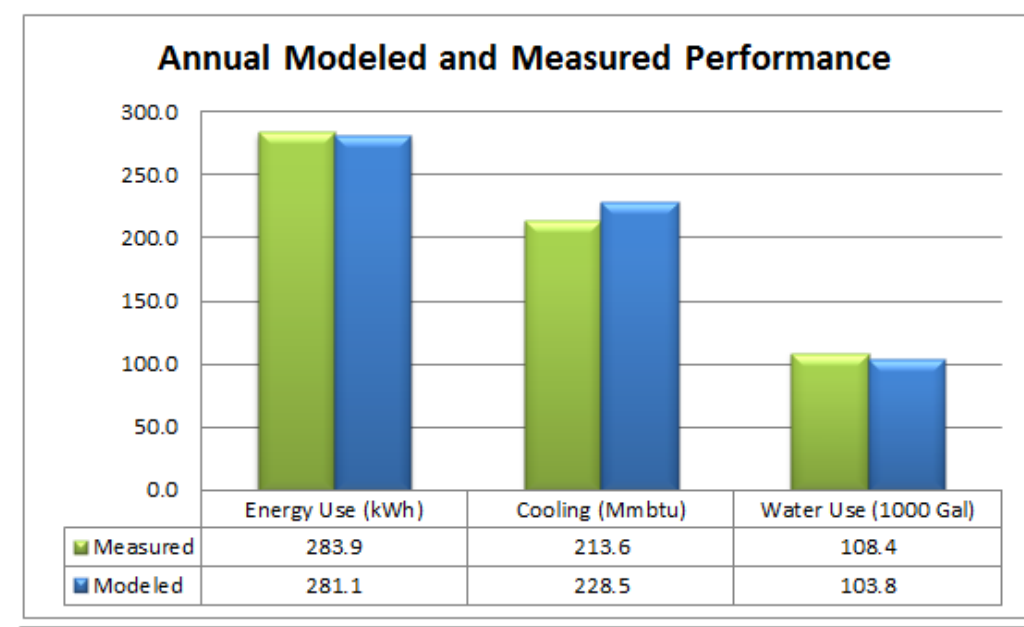

\begin{tabular}{||c|c|c||}
\hline $\begin{array}{c}\text { Measured Water } \\
\text { Use (Gal) }\end{array}$ & $\begin{array}{c}\text { Calculated Water } \\
\text { Use (Gal) }\end{array}$ & $\begin{array}{c}\text { Percent } \\
\text { Difference (\%) }\end{array}$ \\
\hline $10,837.4$ & $10,378.0$ & $4.2 \%$ \\
\hline $\begin{array}{c}\text { Measured Cooling } \\
\text { (MMBtu) }\end{array}$ & $\begin{array}{c}\text { Calculated Cooling } \\
\text { (MMBtu) }\end{array}$ & $\begin{array}{c}\text { Percent } \\
\text { Difference (\%) }\end{array}$ \\
\hline 213,642 & 228,542 & $6.97 \%$ \\
\hline $\begin{array}{c}\text { Measured Energy } \\
\text { Use (kWh) }\end{array}$ & $\begin{array}{c}\text { Calculated Energy } \\
\text { Use (kWh) }\end{array}$ & $\begin{array}{c}\text { Percent } \\
\text { Difference (\%) }\end{array}$ \\
\hline 283.9 & 281.1 & $0.96 \%$ \\
\hline \multicolumn{2}{|r}{} \\
\hline
\end{tabular}
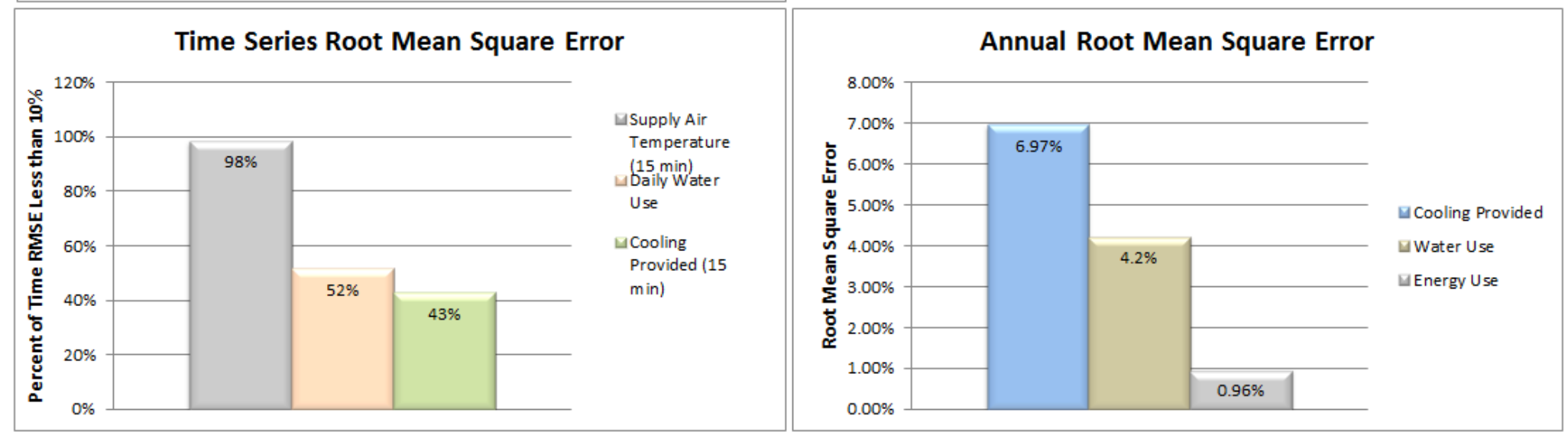

Figure 102. Modeled versus measured annual performance and 15-min RMSE 
The modeled SAT was slightly lower than the measured SATs at SATs above $60^{\circ} \mathrm{F}$. (The light blue line in the graph represents a oneto-one relationship.) In general, the modeled SAT, energy use, 15-min water use, and daily water use compared well with the measured interval data, with $\mathrm{R}^{2}$ agreements of $78 \%-99 \%$.

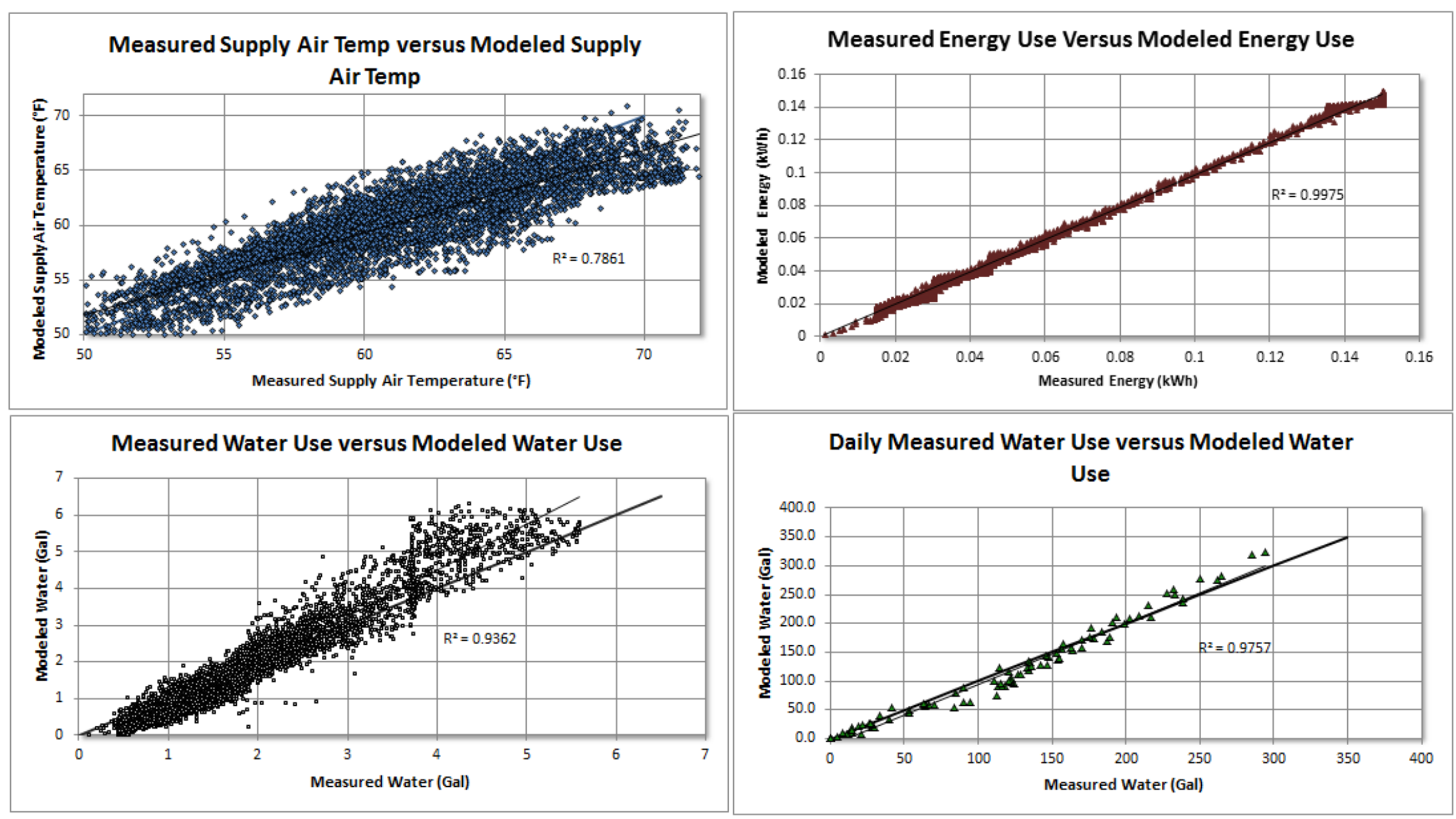

Figure 103. Modeled versus measured interval SAT, energy use, and water use 
The temperature difference between the modeled and measured SAT was $5^{\circ} \mathrm{F}$ to $\pm 5^{\circ} \mathrm{F}$; the percent difference between the measurements was typically within $\pm 5 \%$ of the measured value. The modeled SAT was not consistently higher or lower than the measured SAT; significant oscillations occurred throughout the summer. The percent difference between the 15-min and daily water consumption showed significantly more variations, although the oscillations were present in the water data as well.

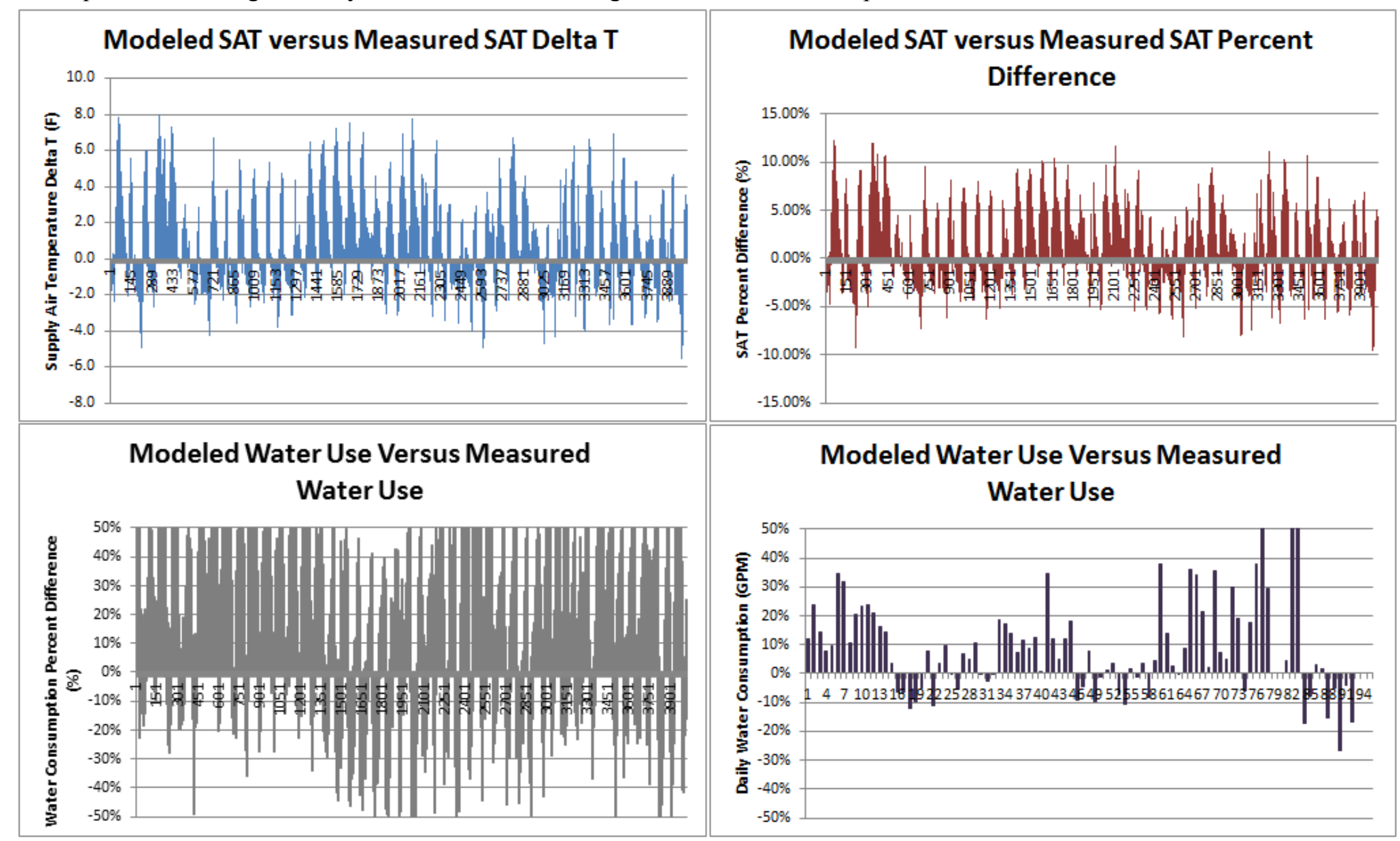

Figure 104. Modeled versus measured interval SAT, energy use, and water use 
The predicted cooling capacity had a better relationship at lower capacities, and the model predicted slightly colder SATs and greater cooling capacity at higher OATs. The RMSE was plotted as a function of SAT and the data showed that there was no consistent relationship between them. The daily water use RMSE increased when the daily water use was lower and the cooling capacity RMSE did not have a consistent relationship to OAT.

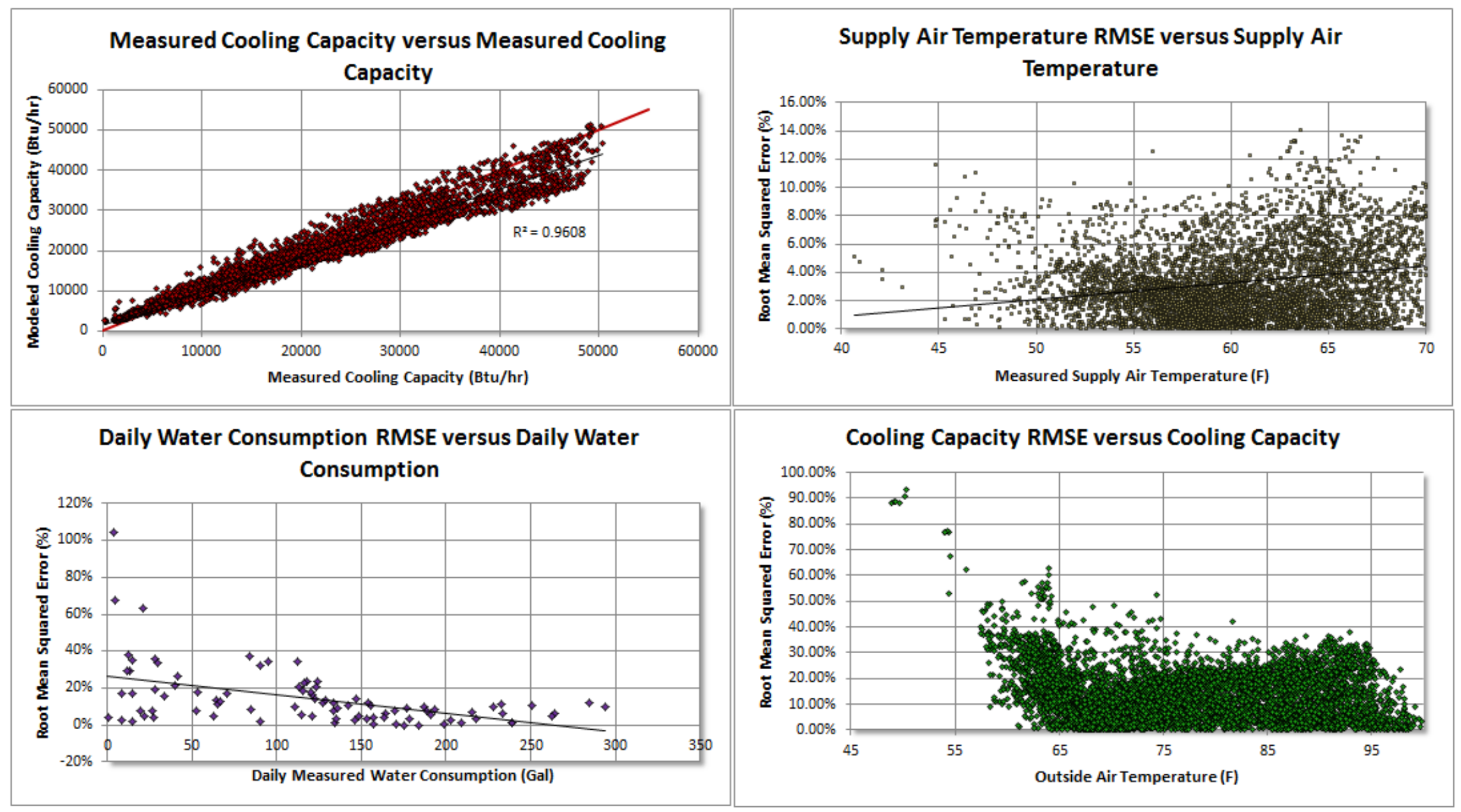

Figure 105. Modeled versus measured interval cooling capacity, SAT and daily water consumption jet aeration unit \#1 
The CoC was set to 2.4 for the first part of the summer and to 5 for the second part of the summer. The predicted annual energy use and water consumption were within 5\%. The predicted cooling capacity was more than $25 \%$ higher than the measured cooling capacity. The predicted SAT was within $10 \%$ of the 15 -min measured SAT $80 \%$ of the time. The daily water consumption and 15 -min cooling capacity were within $10 \%$ of the measured values $48 \%$ and $20 \%$ of the time, respectively. The two units with the lowest water use setting also discharged the warmest air temperatures, although all laboratory tests were conducted with a CoC of 5 and the unit's performance was in line with manufacturer claims.

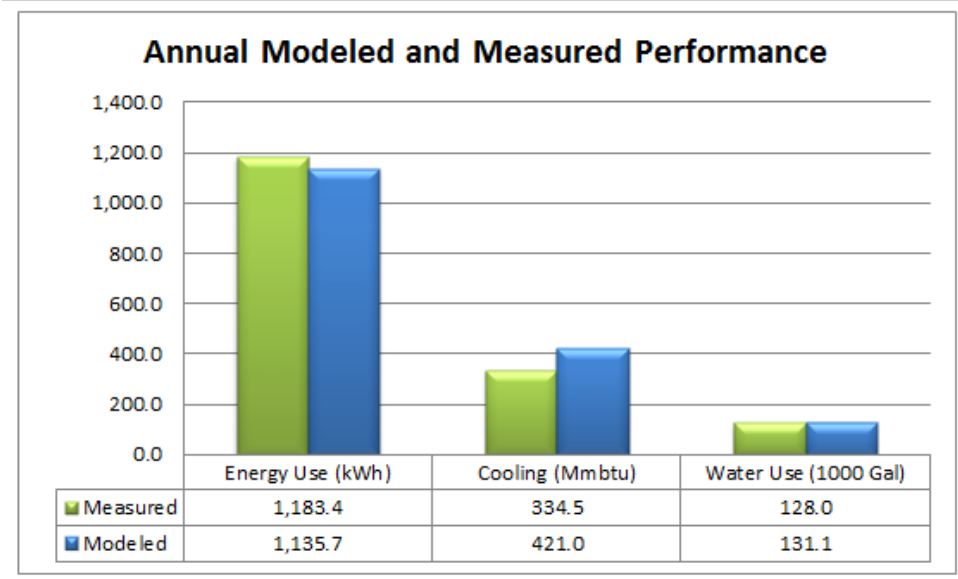

\begin{tabular}{||c|c|c||}
\hline $\begin{array}{c}\text { Measured Water } \\
\text { Use (Gal) }\end{array}$ & $\begin{array}{c}\text { Calculated Water } \\
\text { Use (Gal) }\end{array}$ & $\begin{array}{c}\text { Percent } \\
\text { Difference (\%) }\end{array}$ \\
\hline $12,798.8$ & $13,109.8$ & $2.4 \%$ \\
\hline $\begin{array}{c}\text { Measured Cooling } \\
\text { (MMBtu) }\end{array}$ & $\begin{array}{c}\text { Calculated Cooling } \\
\text { (MMBtu) }\end{array}$ & $\begin{array}{c}\text { Percent } \\
\text { Difference (\%) }\end{array}$ \\
\hline 334,495 & 421,010 & $25.86 \%$ \\
\hline $\begin{array}{c}\text { Measured Energy } \\
\text { Use (kWh) }\end{array}$ & $\begin{array}{c}\text { Calculated Energy } \\
\text { Use (kWh) }\end{array}$ & $\begin{array}{c}\text { Percent } \\
\text { Difference (\%) }\end{array}$ \\
\hline $1,183.4$ & $1,135.7$ & $4.03 \%$ \\
\hline
\end{tabular}

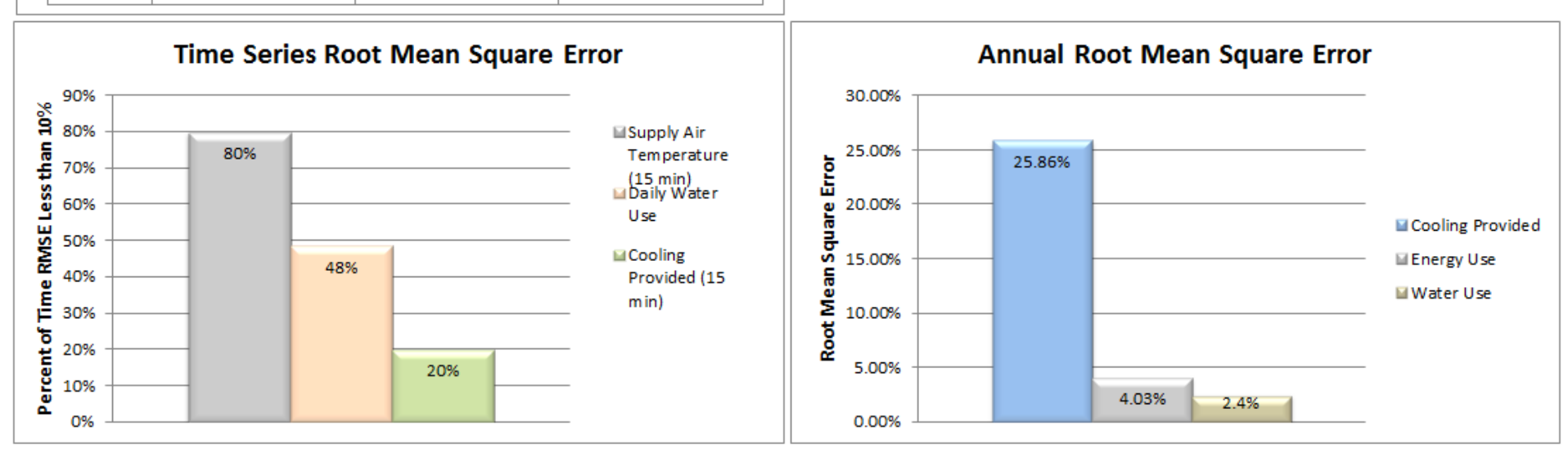

Figure 106. Modeled versus measured annual performance and 15-min RMSE 
The modeled SAT was significantly lower than the measured SATs at SATs above $60^{\circ} \mathrm{F}$. (The light blue line in the graph represents a one-to-one relationship.) The interval water use also had a weaker agreement in this case, as it was not possible to enter realistic CoC settings and achieve agreement between the measured and modeled water use.

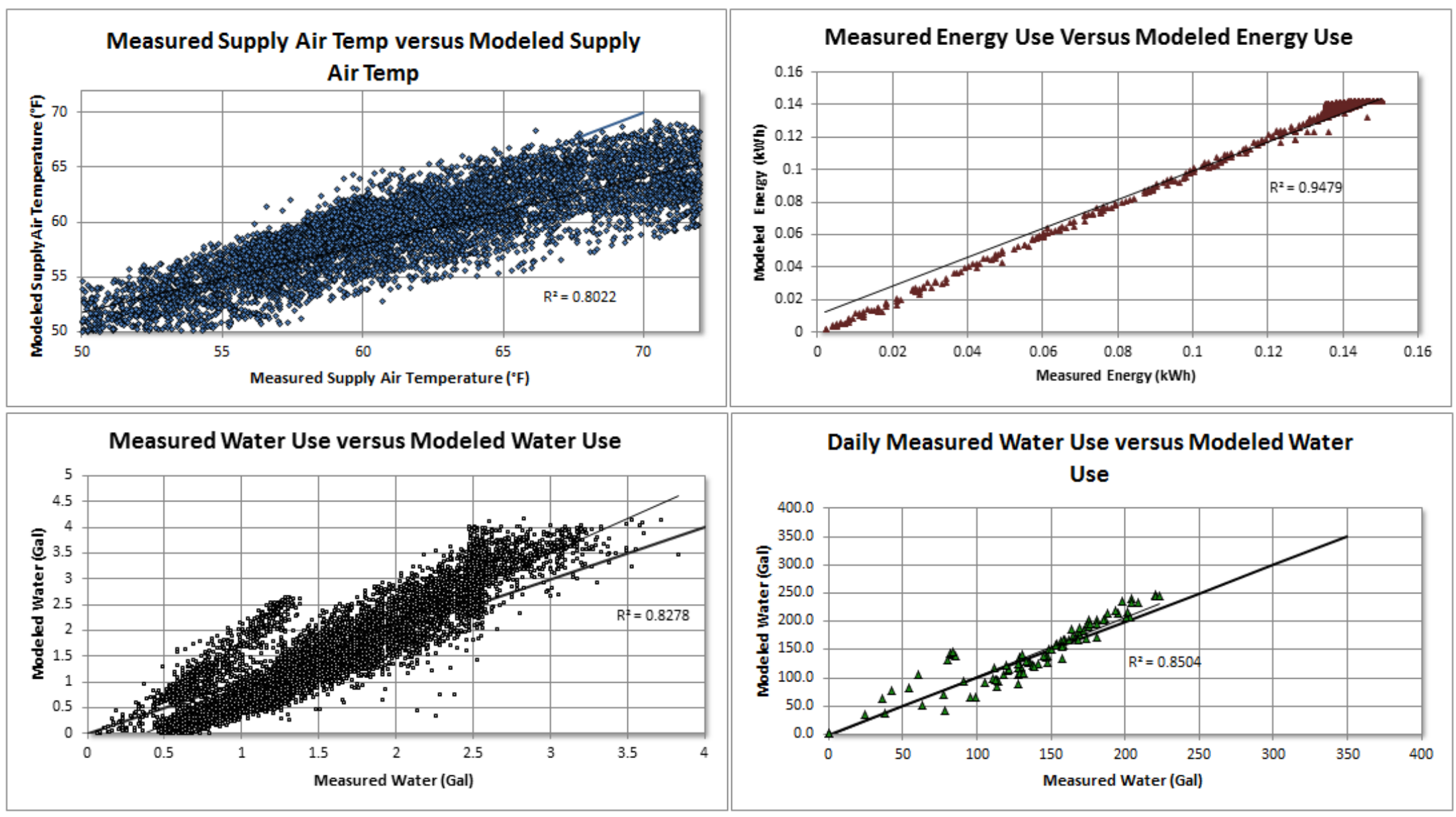

Figure 107. Modeled versus measured interval SAT, energy use, and water use 
The temperature difference between the modeled and measured SATs was between $-5^{\circ} \mathrm{F}$ and $+12^{\circ} \mathrm{F}$, with the percent difference between the measurements typically within $\pm 15 \%$ of the measured value. The modeled SAT was consistently higher than the measured SAT, with considerable periods of time where the modeled SAT was $5^{\circ}-10^{\circ} \mathrm{F}$ higher than the measured SAT. The percent difference between the 15-min and daily water consumption also showed variation. Oscillation occurred in the water data as well.

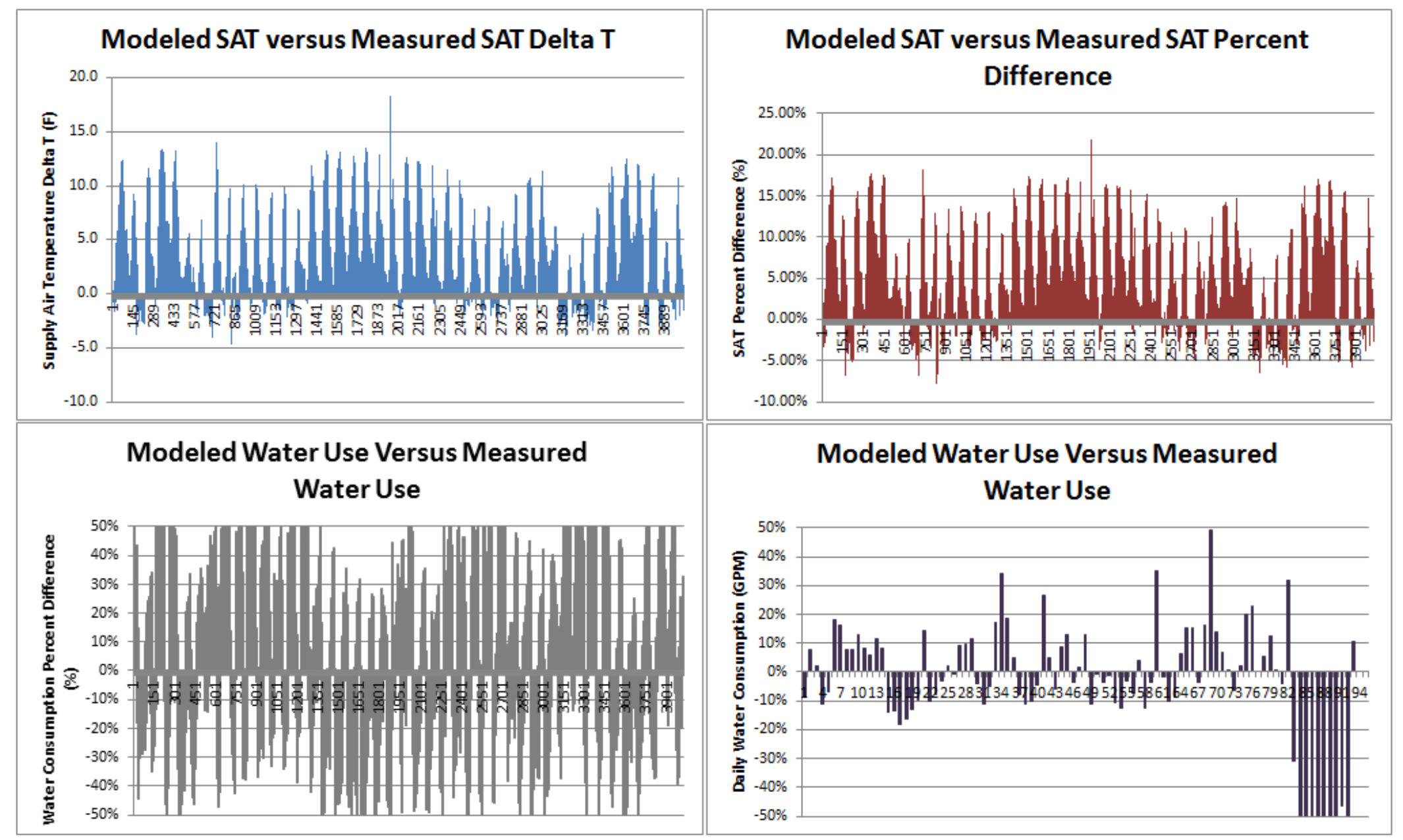

Figure 108. Modeled versus measured interval SAT, energy use, and water use 
The predicted cooling capacity had a better relationship at lower capacities, and the model predicted colder SATs and greater cooling capacity at higher cooling capacities. The RMSE was plotted as a function of SAT and the data showed that the error increased at as the SAT increased. The daily water use RMSE increased when the daily water use were lower; the cooling capacity RMSE also increased as the OAT increased.

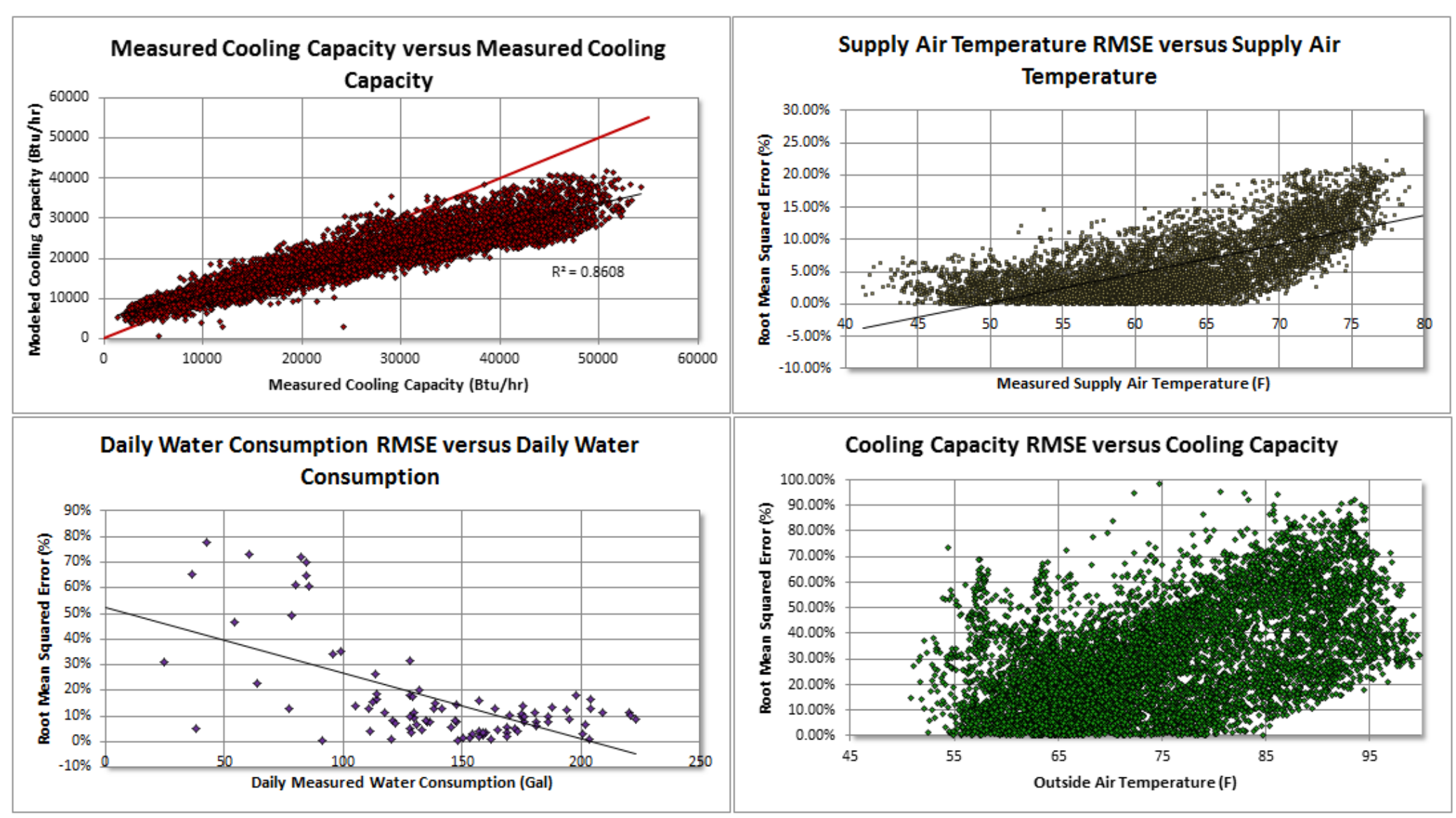

Figure 109. Modeled versus measured interval cooling capacity, SAT, and daily water consumption 


\section{Appendix E: AdDitional Analysis Results}

\section{Improved Comfort Provided by Evaporative Cooling}

\section{ASHRAE Summer Comfort Zone}

The theater units operated for 2,095 hours in 2010 and two hours were above the ASHRAE comfort zone. The maximum indoor temperature reached $80.4^{\circ} \mathrm{F}$ and the Coolerado units maintained the space within the ASHRAE comfort zone for $>99 \%$ of the operational hours (see Figure 110 and Figure 111).

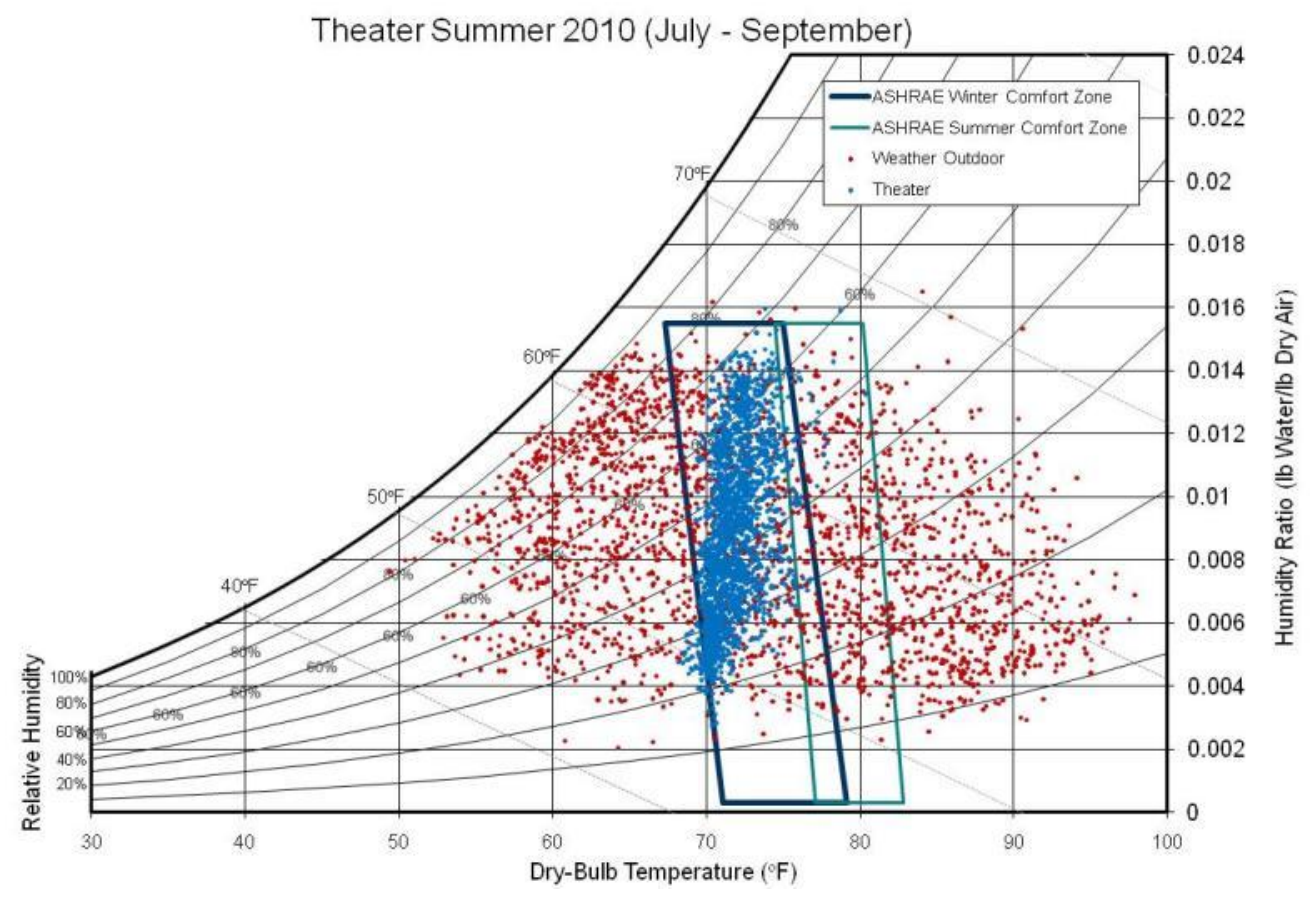

Figure 110. Theater unit summer 2010 thermal comfort 


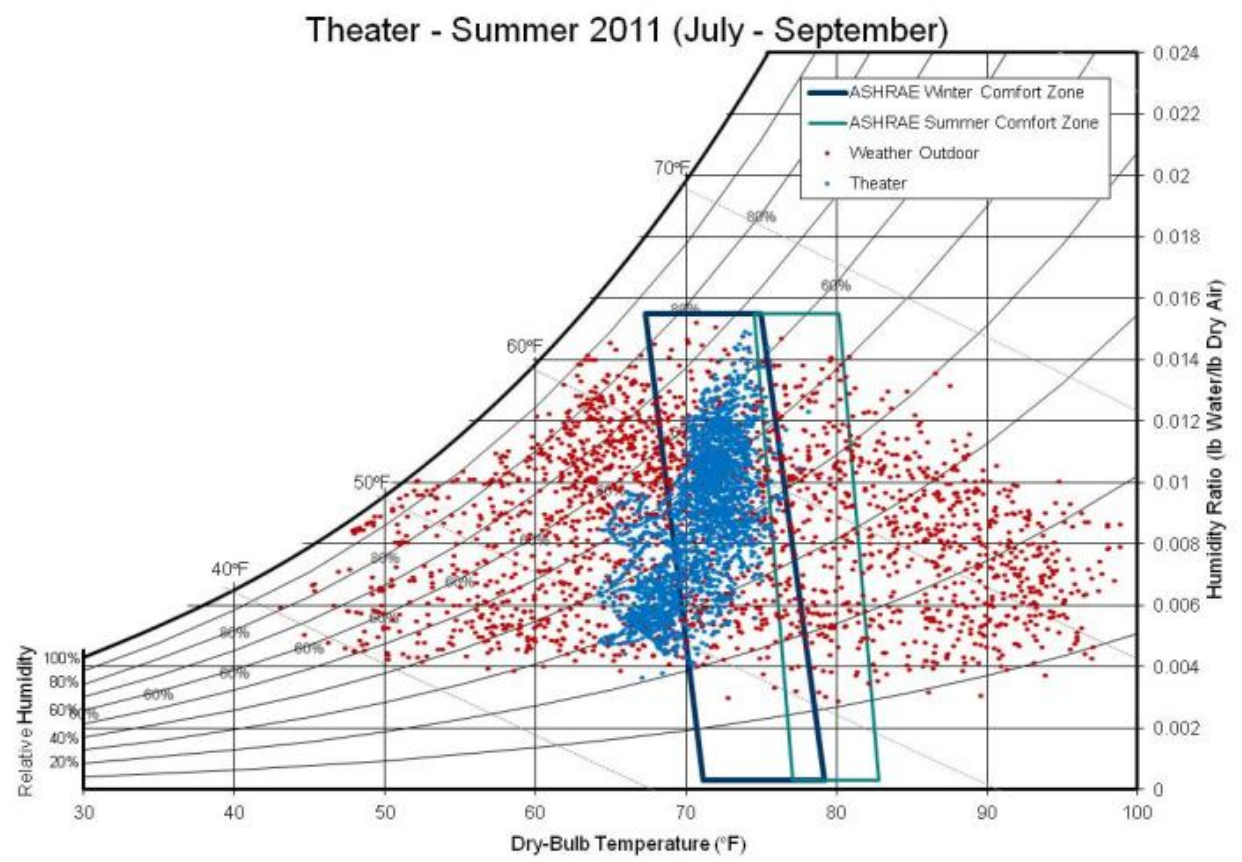

Figure 111. Theater comfort conditions, 2011

The classroom units operated for 2,209 hours in 2010 and had zero hours that were above the ASHRAE comfort zone. The maximum indoor temperature reached $81.2^{\circ} \mathrm{F}$ and the Coolerado units maintained the space within the ASHRAE comfort zone for $>99 \%$ of the operational hours (see Figure 112 and Figure 113).

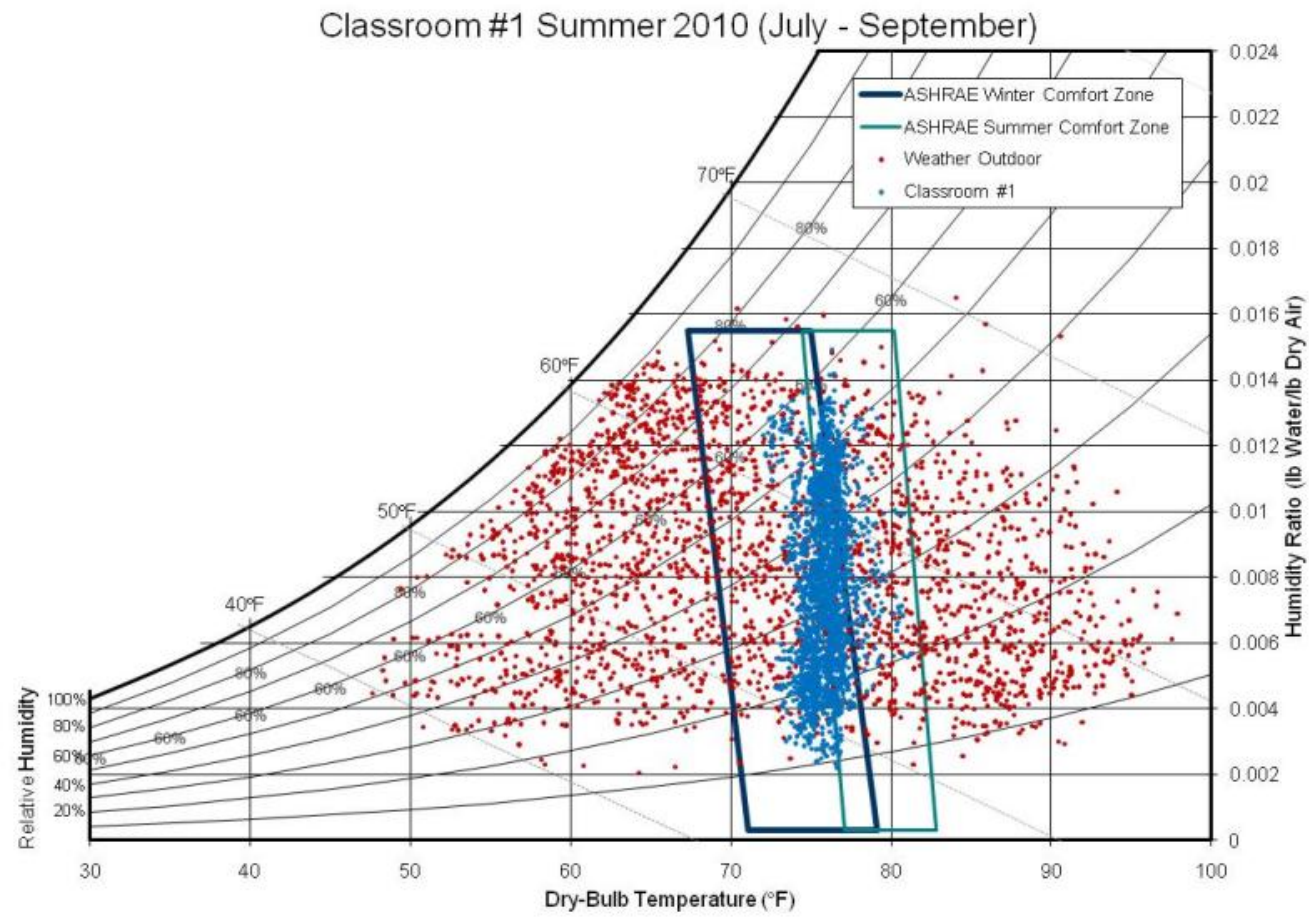

Figure 112. Classroom unit summer 2010 thermal comfort 


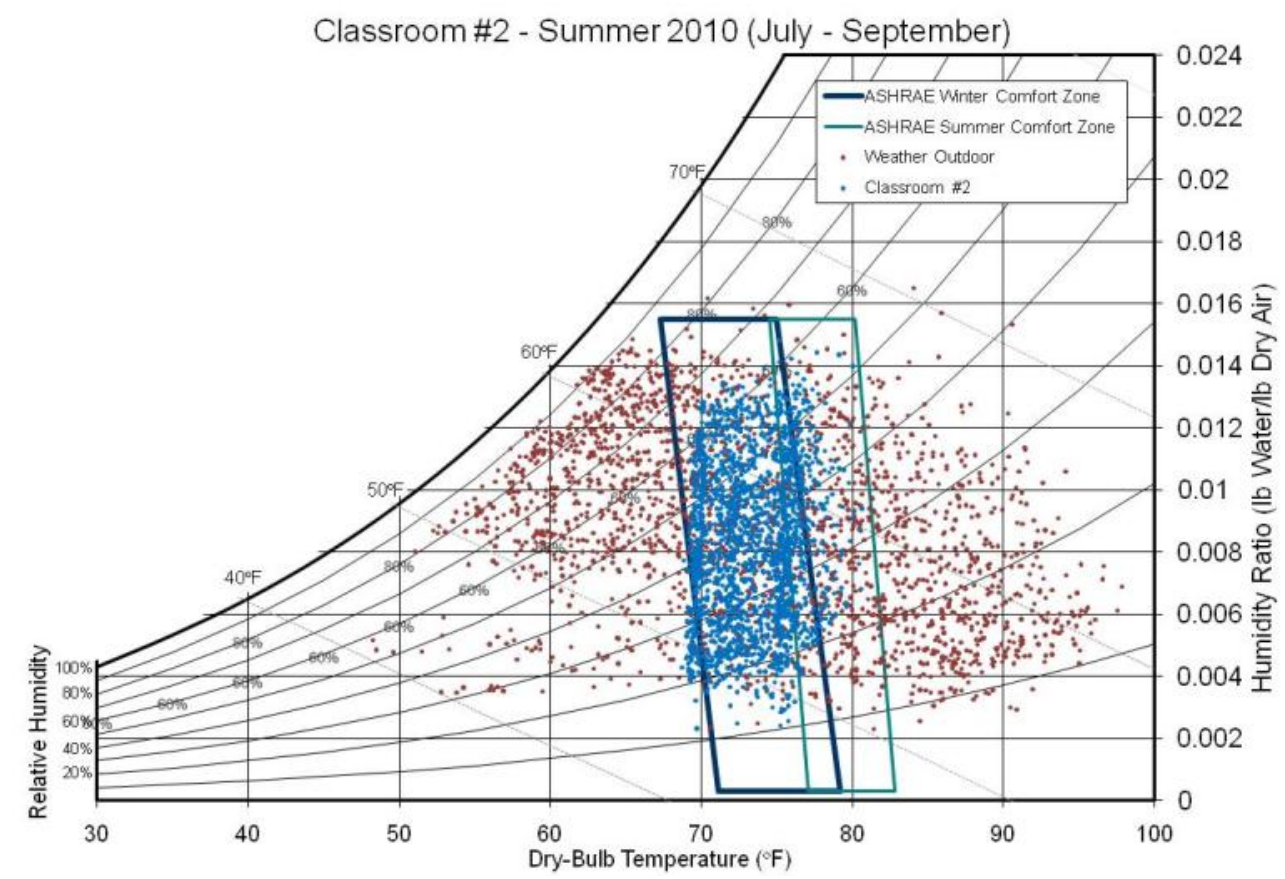

Figure 113. Classroom unit \#2 summer 2010 thermal comfort

\section{Supply Air Temperature}

Frequency of Supply Air Temperatures, Training Facility 2010

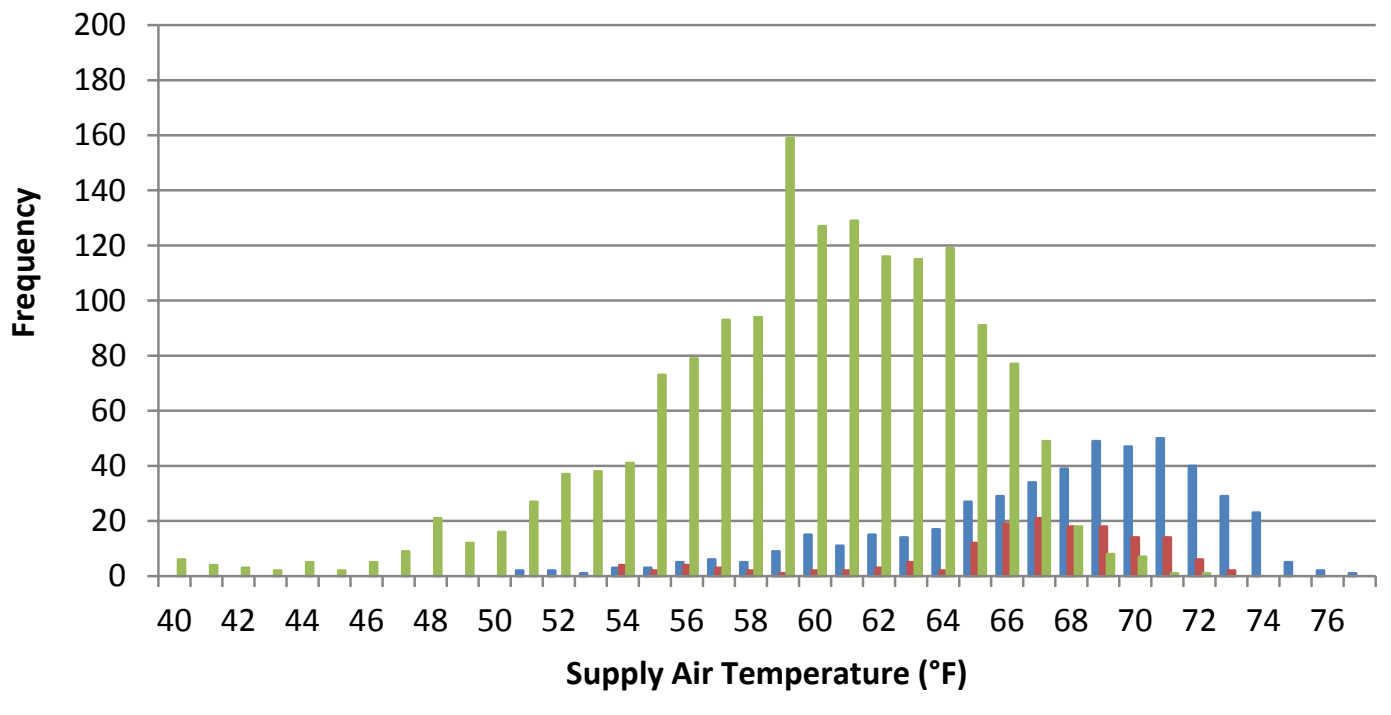

Unit 1 Unit 2 Unit 3

Figure 114. Training facility frequency of SATs $\left({ }^{\circ} \mathrm{F}\right), 2010$ 
Frequency of Supply Air Temperatures, Training Facility 2011

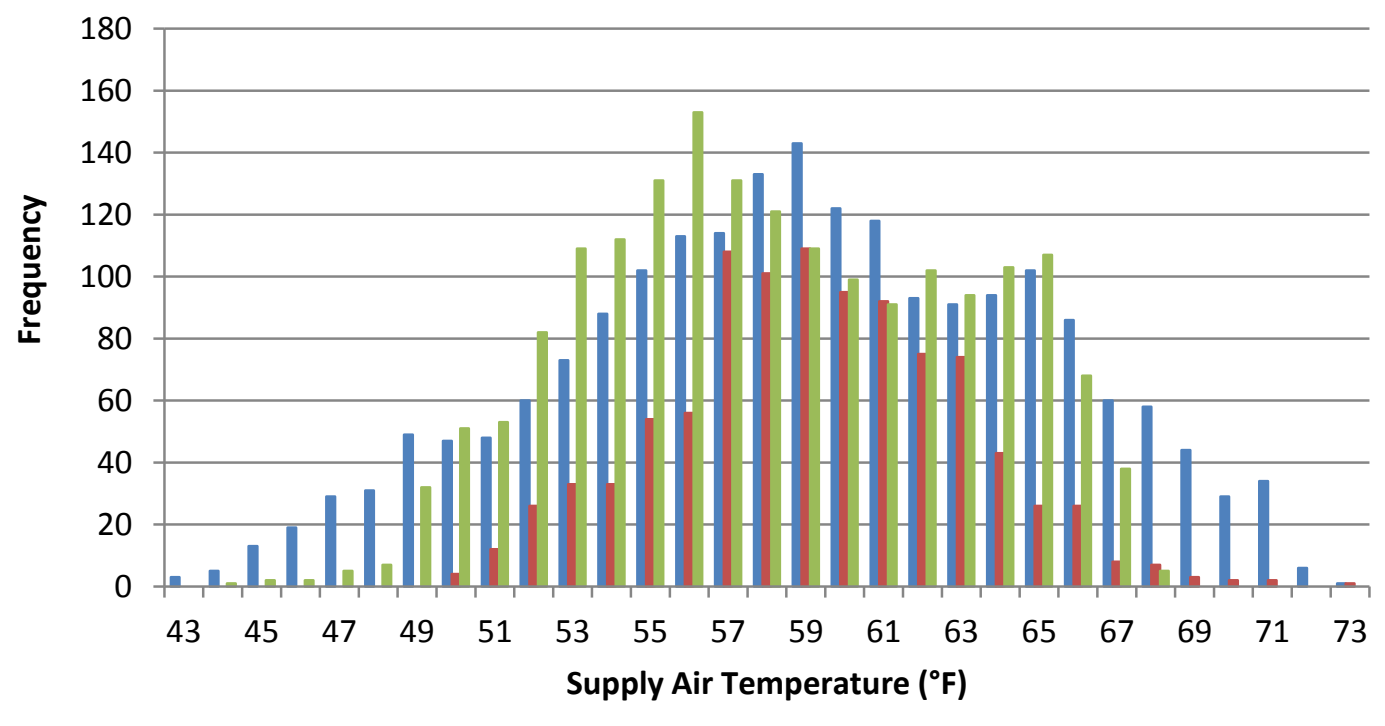

- Unit 1 Unit 2 Unit 3

Figure 115. Training facility frequency of SATs $\left({ }^{\circ} \mathrm{F}\right), 2011$

Frequency of Supply Air Temperatures, Theater 2010

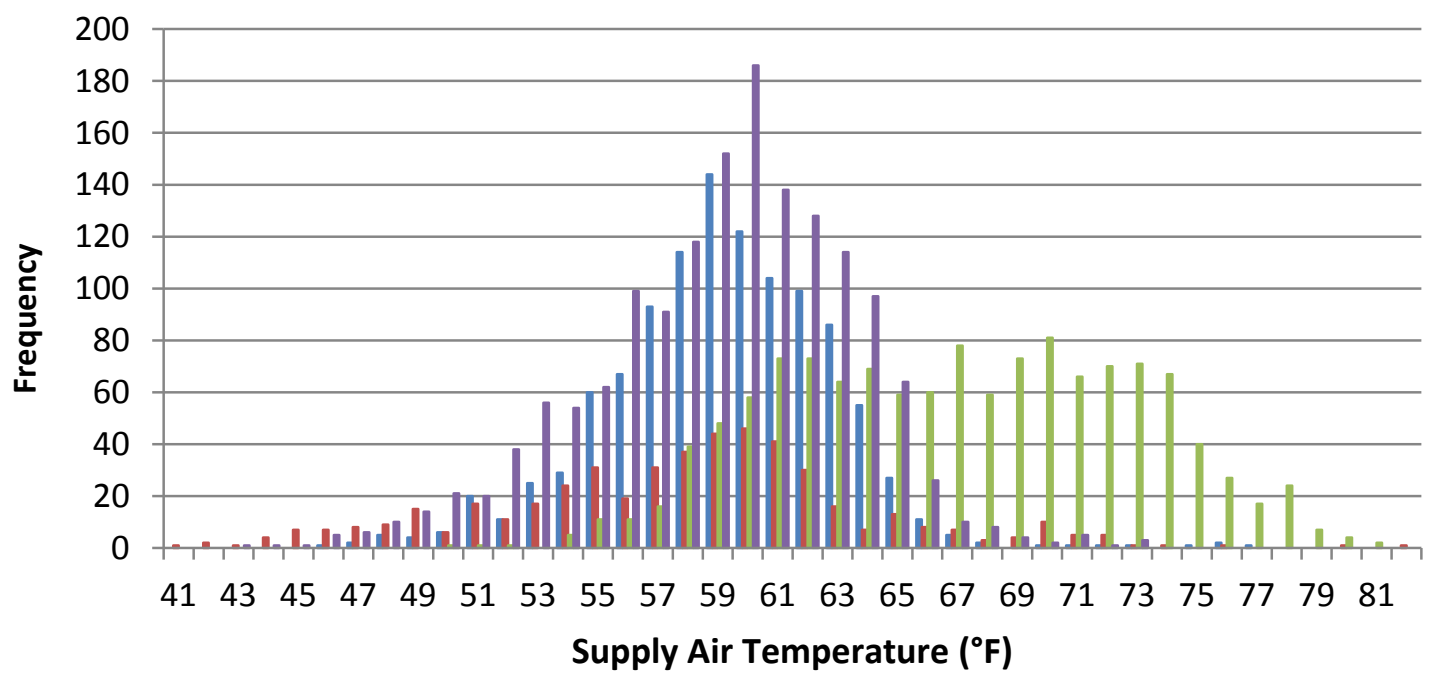

Unit $9 \square$ Unit $10 \square$ Unit $11 \square$ Unit 12

Figure 116. Theater frequency of SATs $\left({ }^{\circ} \mathrm{F}\right), 2010$ 
Frequency of Supply Air Temperatures, Theater 2011

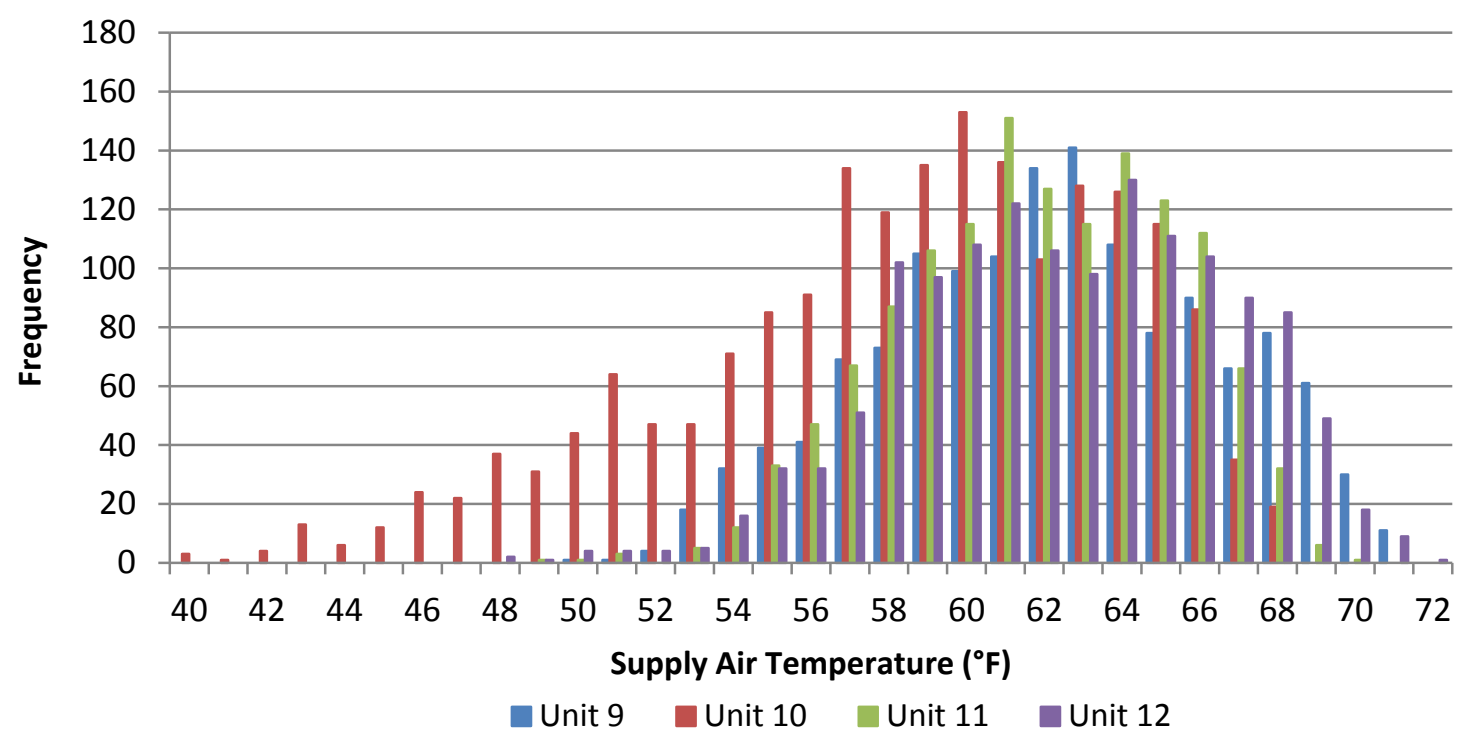

Figure 117. Theater frequency of SATs $\left({ }^{\circ} \mathrm{F}\right), 2011$

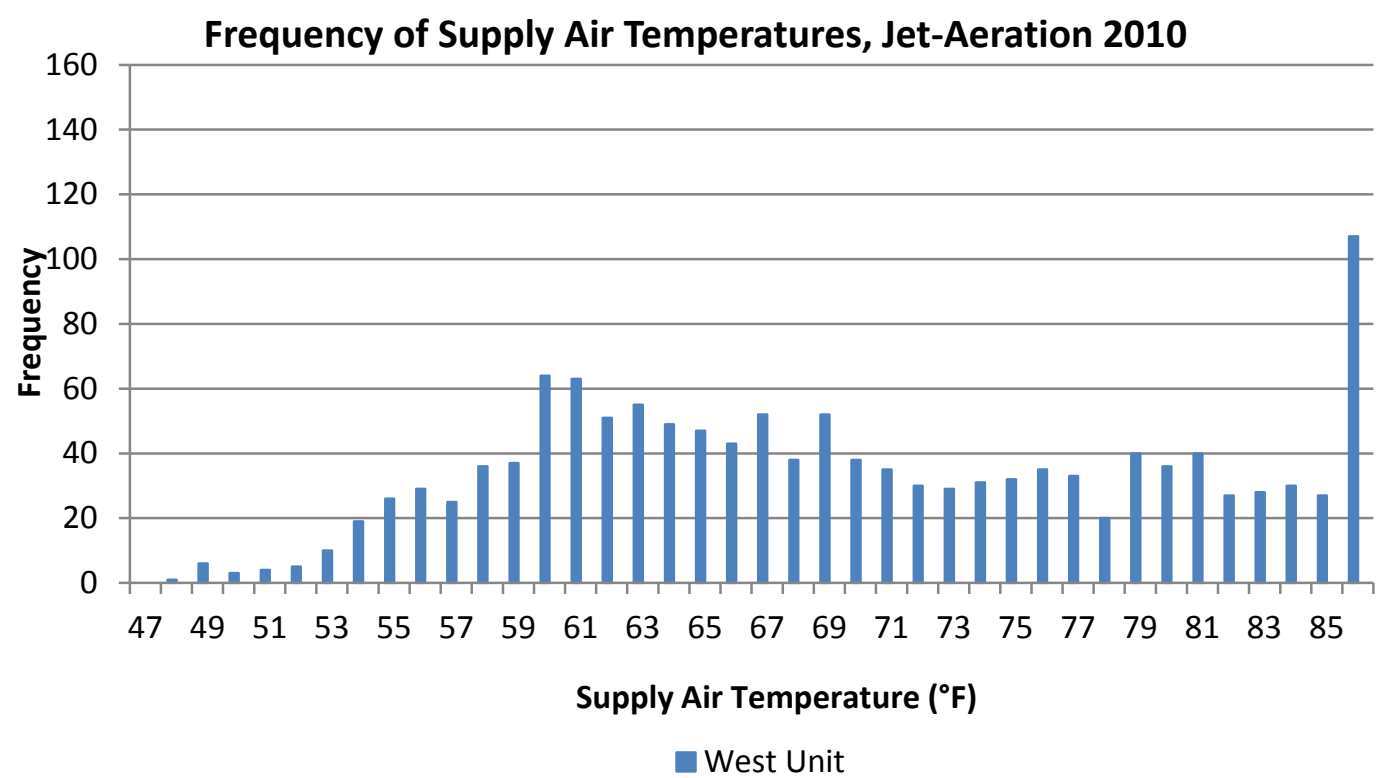

Figure 118. Jet aeration frequency of SATs $\left({ }^{\circ} \mathbf{F}\right), 2010$ 
Frequency of Supply Air Temperature, Jet-Aeration 2011

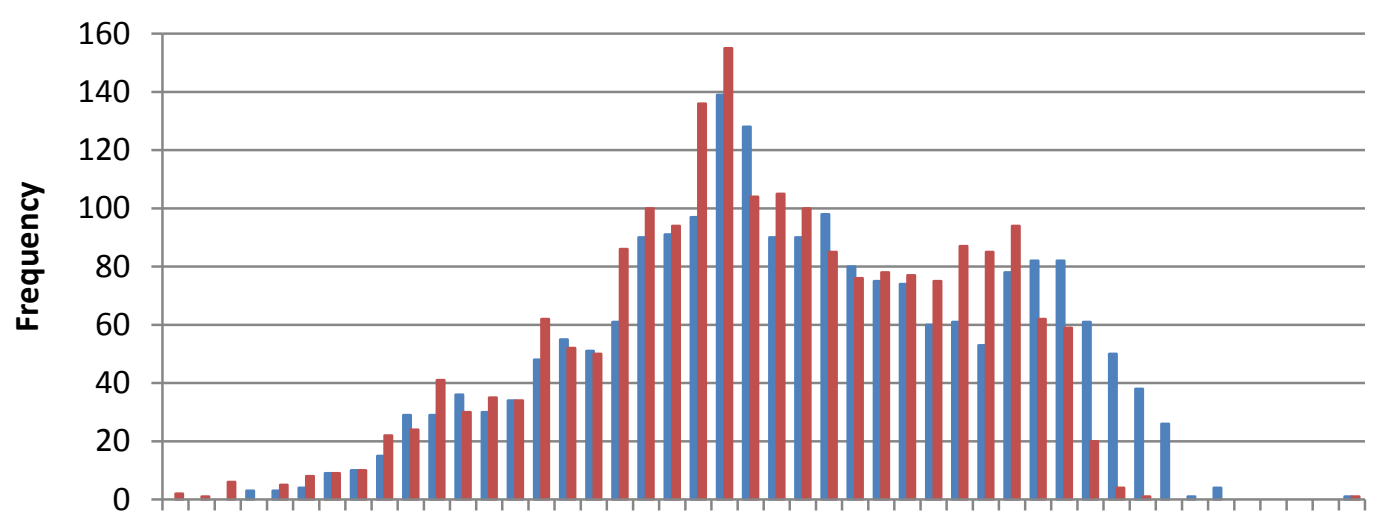

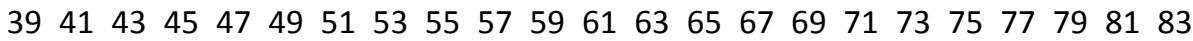

Supply Air Temperature $\left({ }^{\circ} \mathrm{F}\right)$

West Unit East Unit

Figure 119. Jet aeration frequency of SATs $\left({ }^{\circ} \mathrm{F}\right), 2011$

Frequency of Supply Air Temperatures, Wastewater Unit 2010

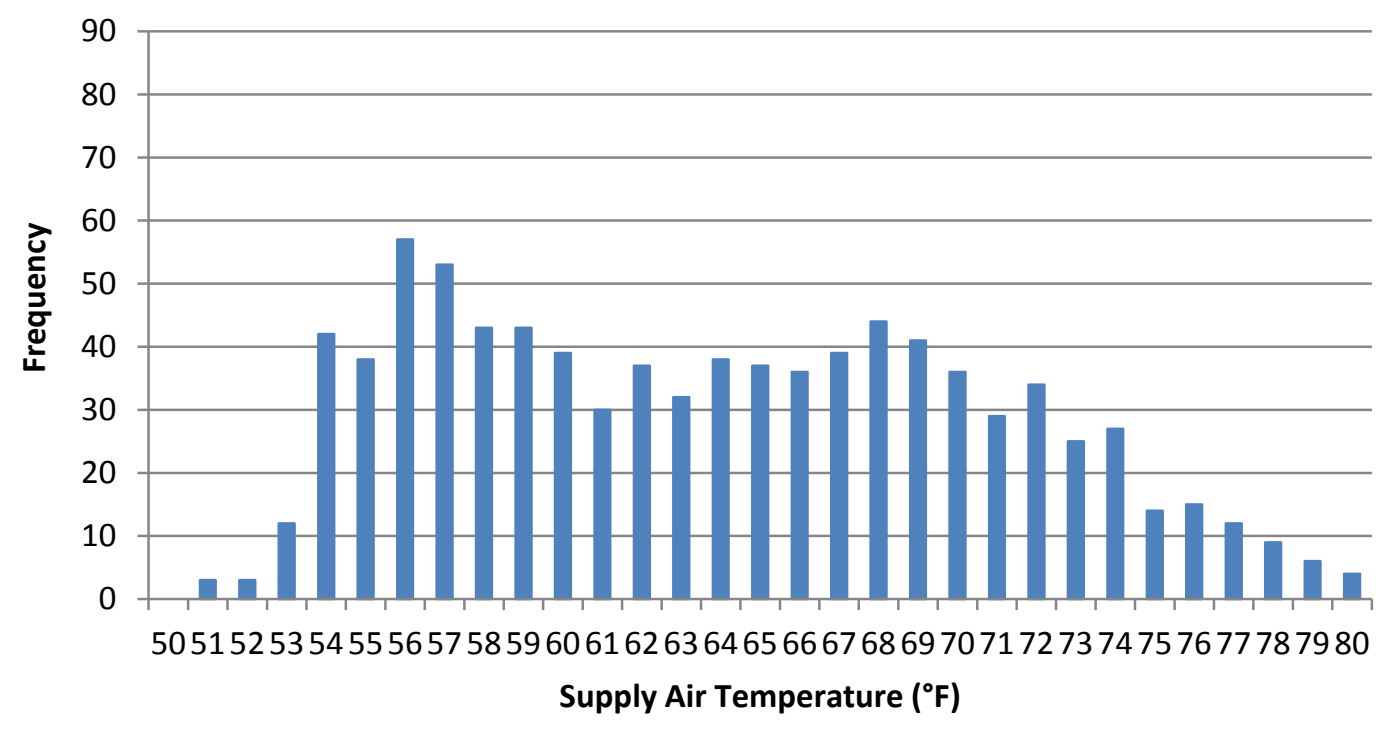

Figure 120. Wastewater unit frequency of SATs $\left({ }^{\circ}\right.$ F), 2010 


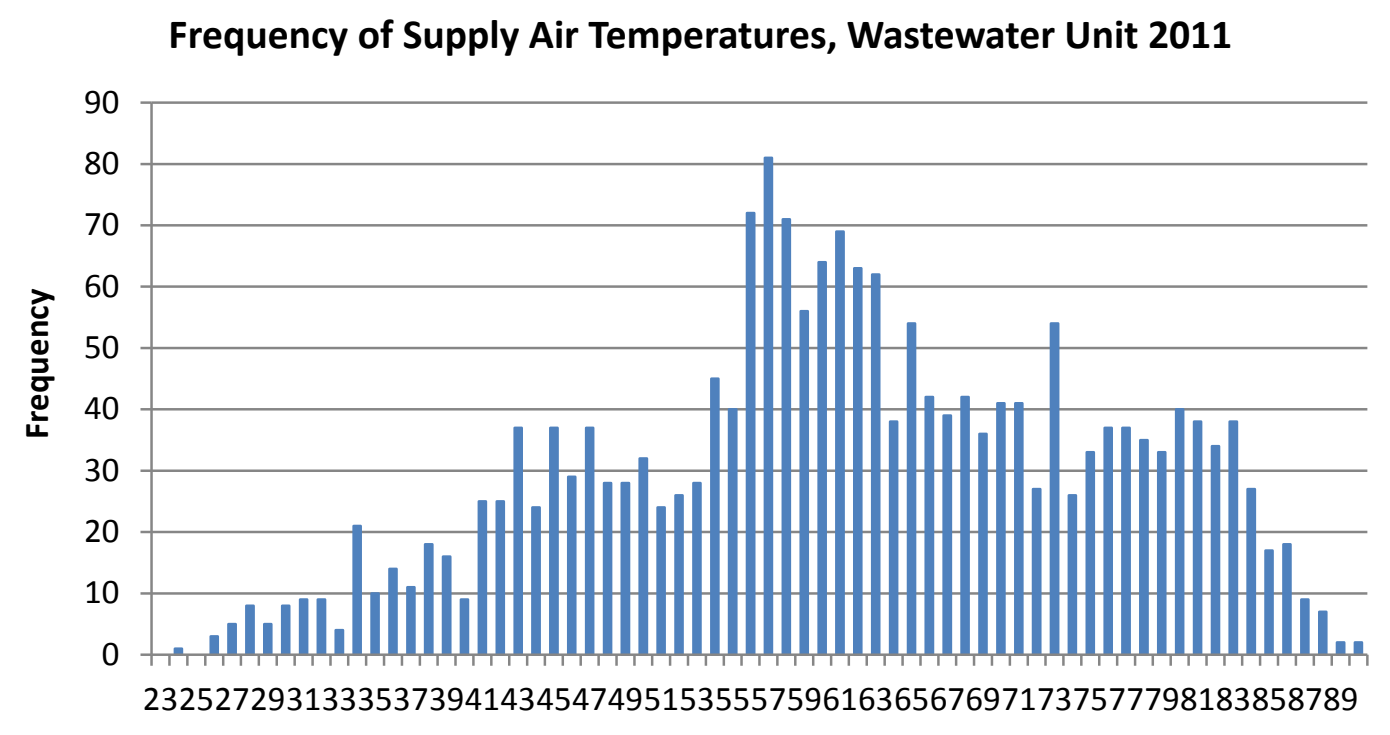

Supply Air Temperature $\left({ }^{\circ} \mathrm{F}\right)$

Figure 121. Wastewater unit frequency of SATs $\left({ }^{\circ} \mathrm{F}\right), 2011$

\section{PROVIDE HIGH EFFICIENCY COOLING}

Daily Average Electrical Efficiency

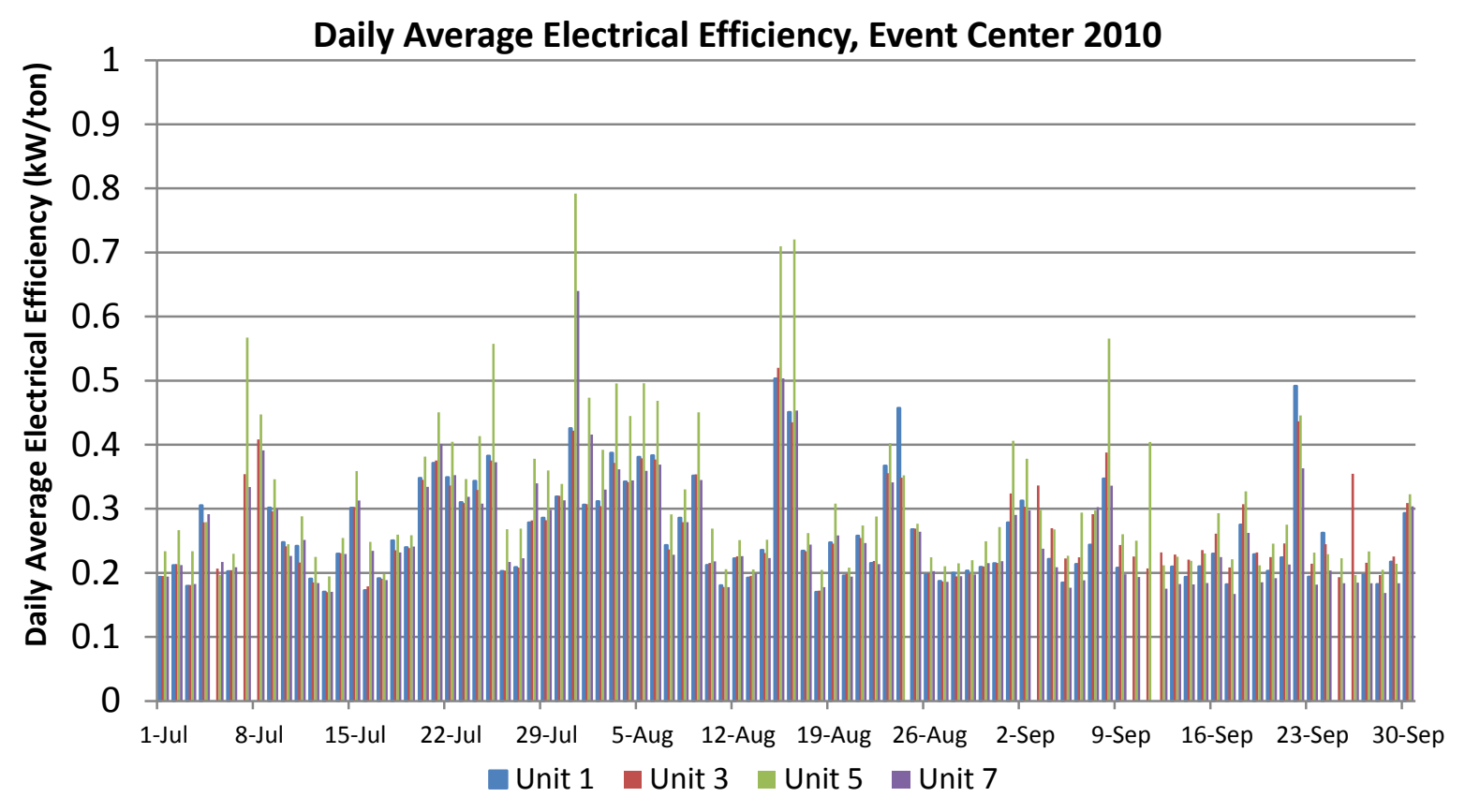

Figure 122. Event center daily average electrical efficiency (kW/ton), 2010 


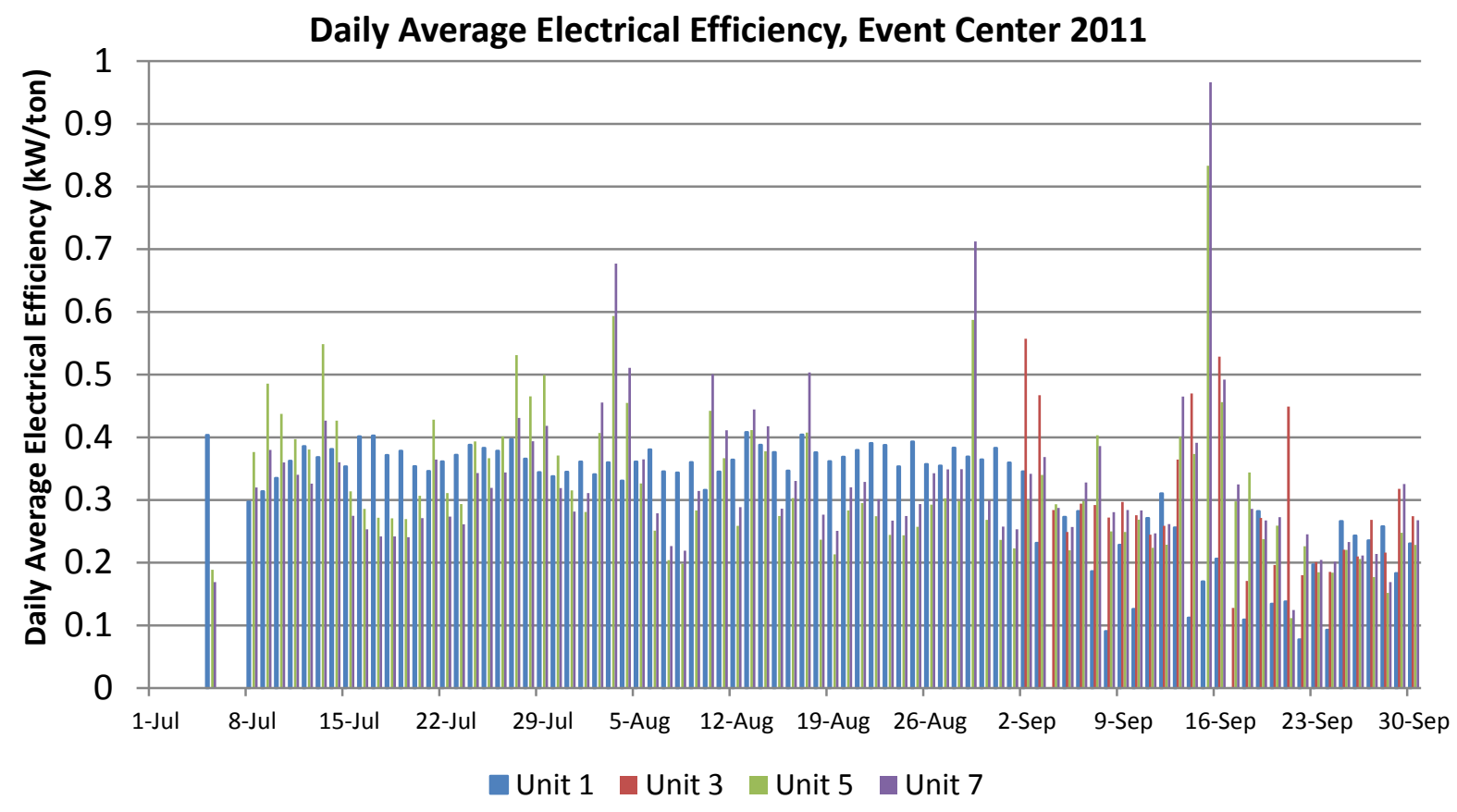

Figure 123. Event center daily average electrical efficiency (kW/ton), 2011

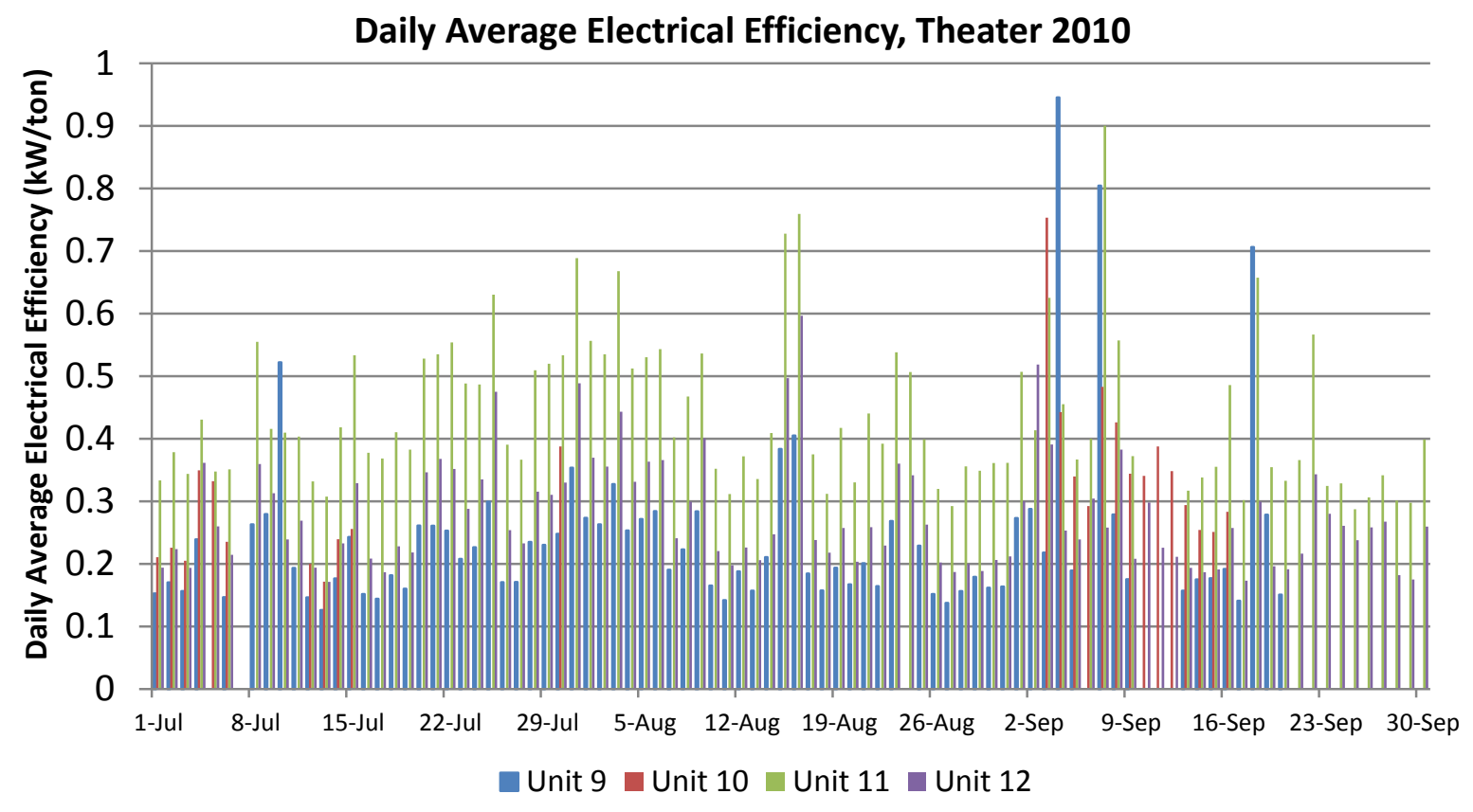

Figure 124. Theater daily average electrical efficiency (kW/ton), 2010 


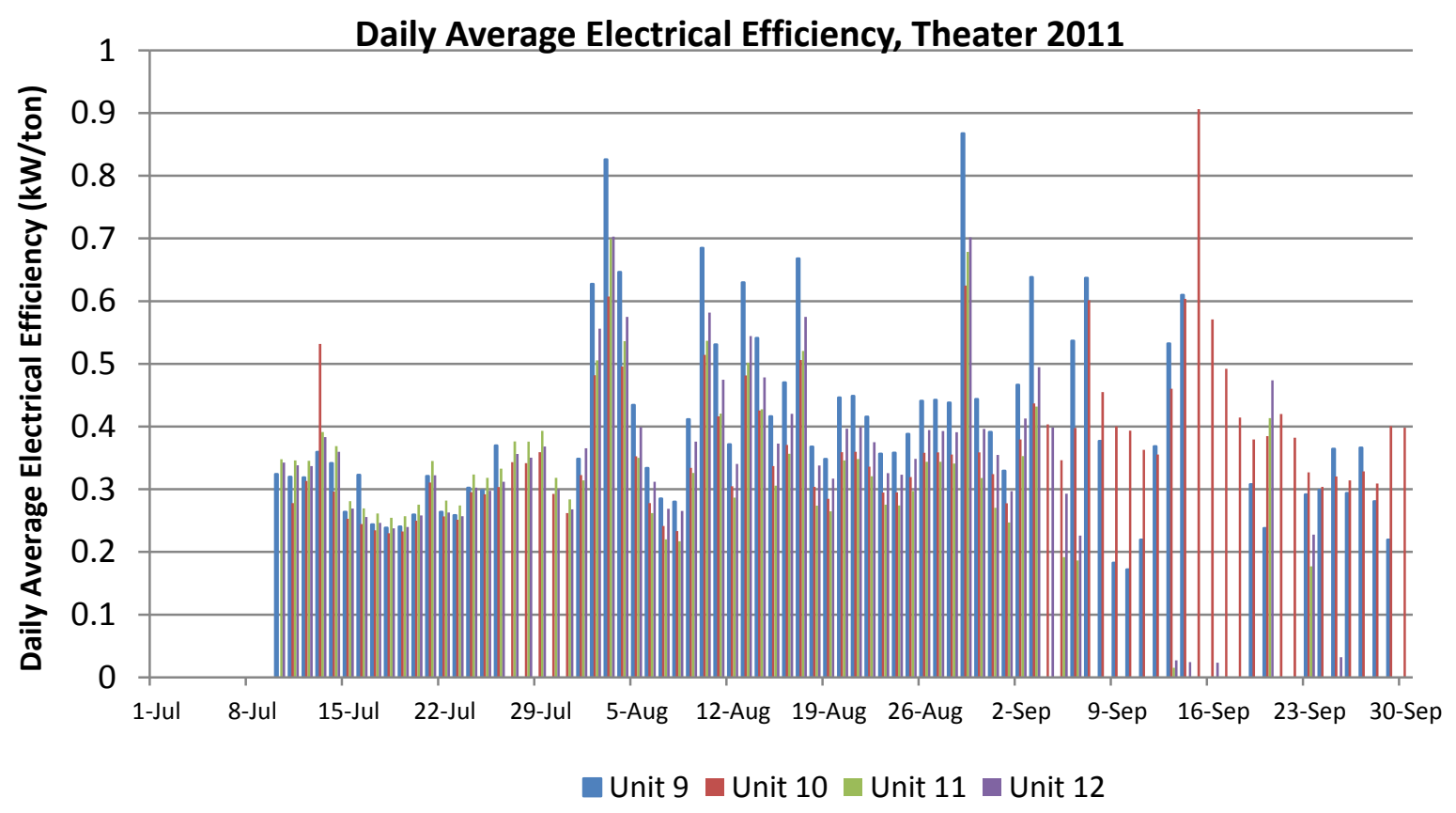

Figure 125. Theater daily average electrical efficiency (kW/ton), 2011

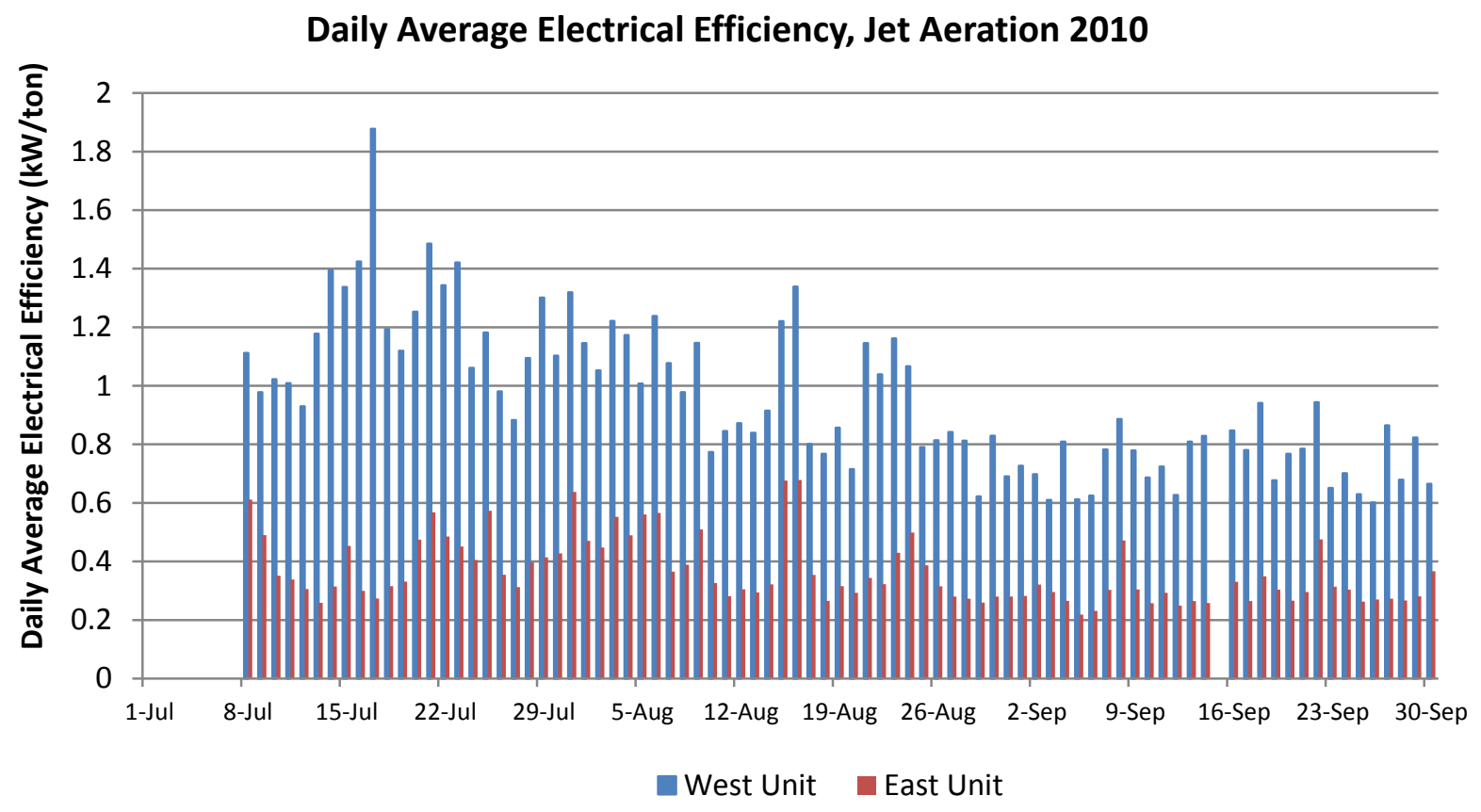

Figure 126. Jet aeration daily average electrical efficiency (kW/ton), 2010 


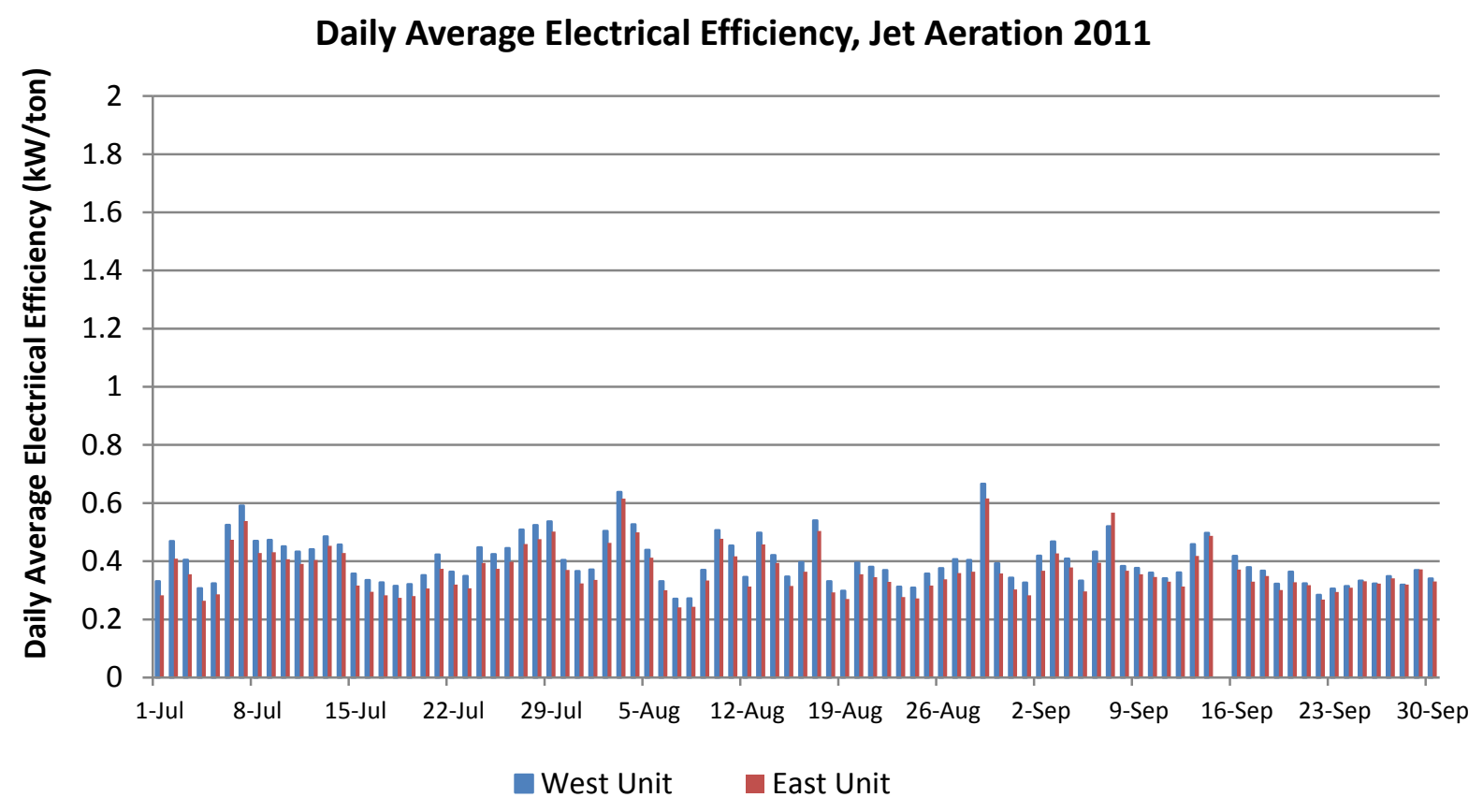

Figure 127. Jet aeration daily average electrical efficiency (kW/ton), 2011

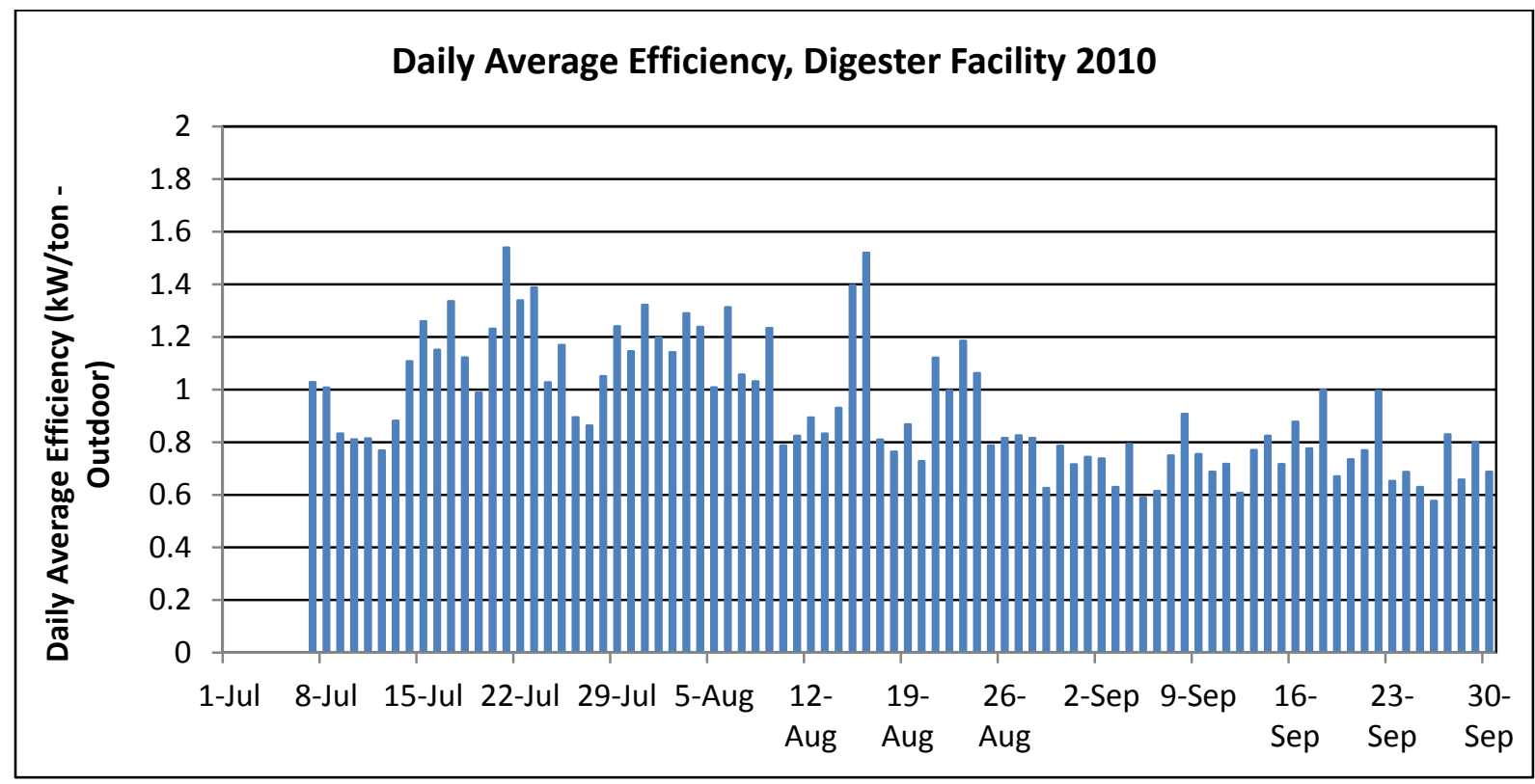

Figure 128. Digester facility daily average electrical efficiency $(\mathrm{kW} / \mathrm{ton}), 2010$ 


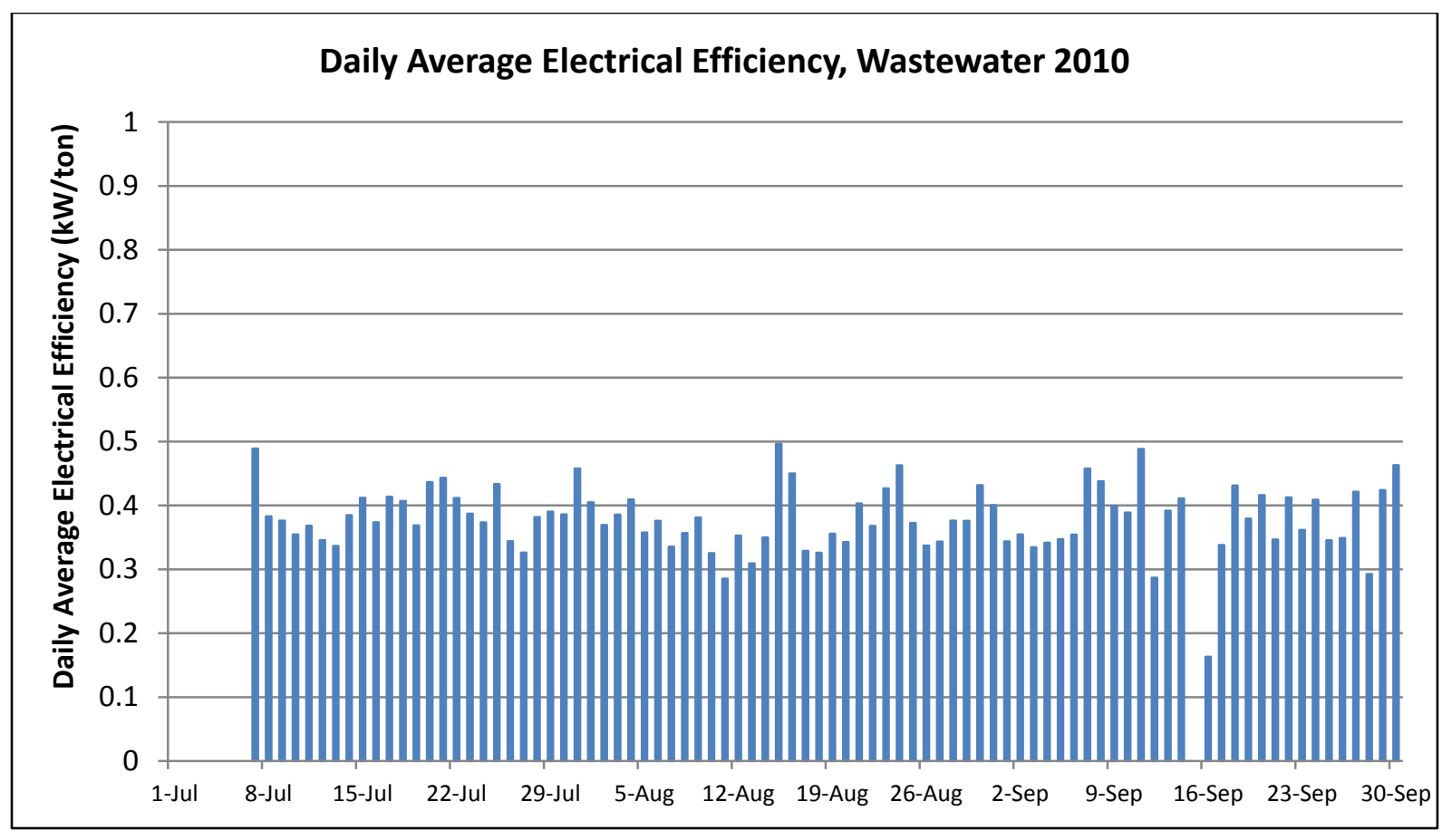

Figure 129. Wastewater unit daily average electrical efficiency (kW/ton), 2010

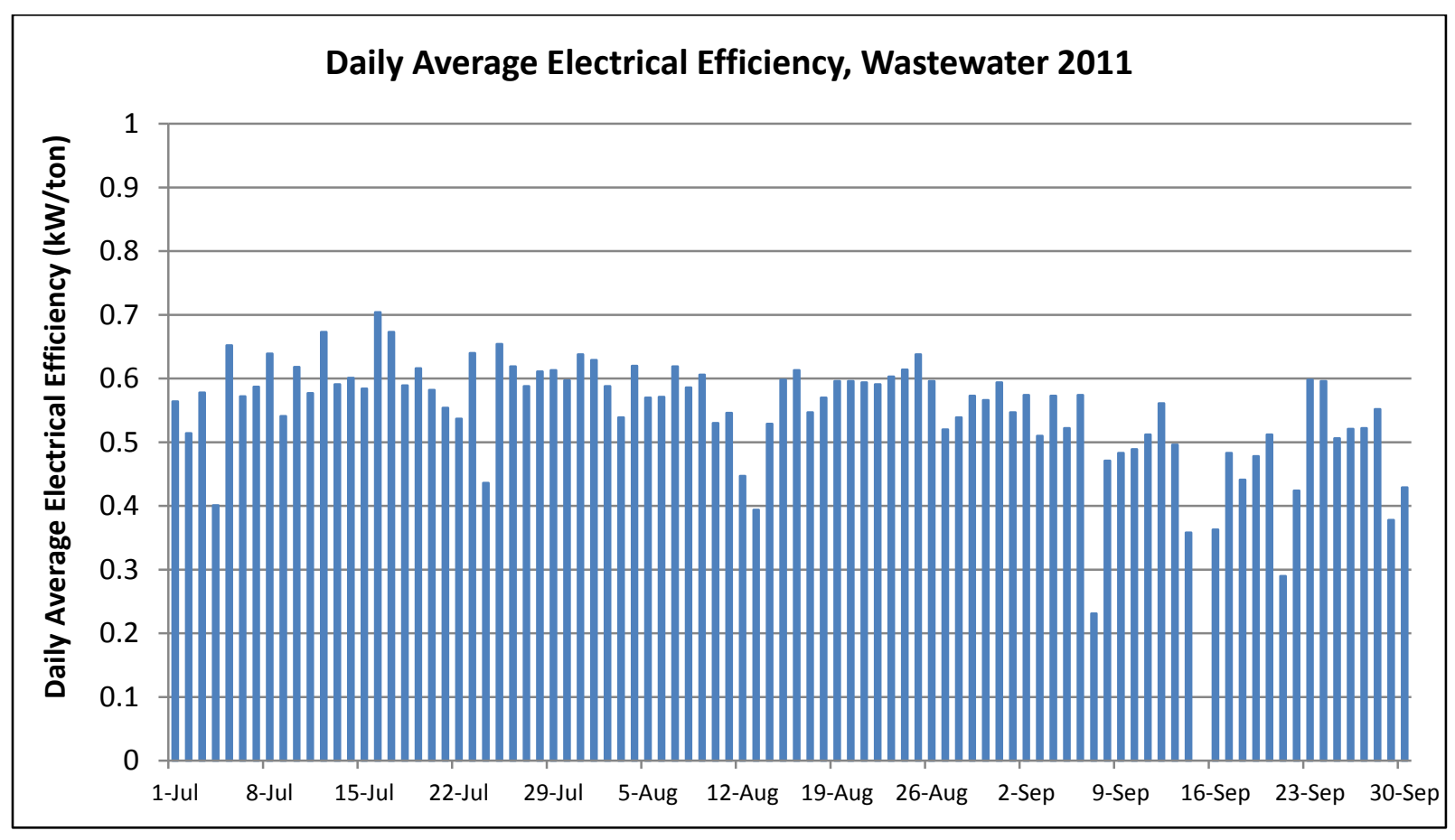

Figure 130. Wastewater unit daily average electrical efficiency (kW/ton), 2011 
Minimize Water Consumption

Water consumption per ton-hour

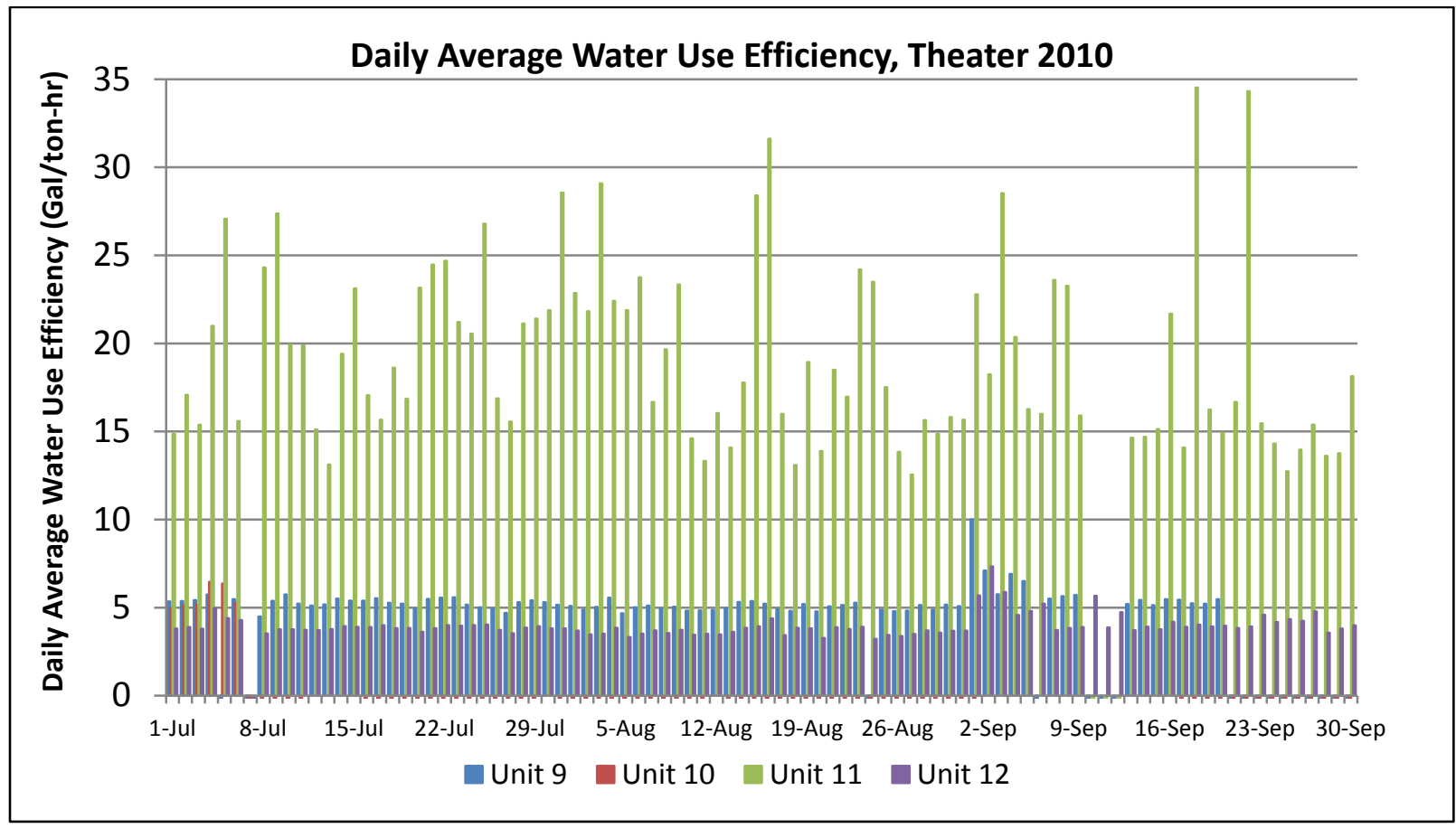

Figure 131. Theater daily average water use efficiency $(\mathrm{gal} / \mathrm{ton} \cdot \mathrm{h}), \mathbf{2 0 1 0}$

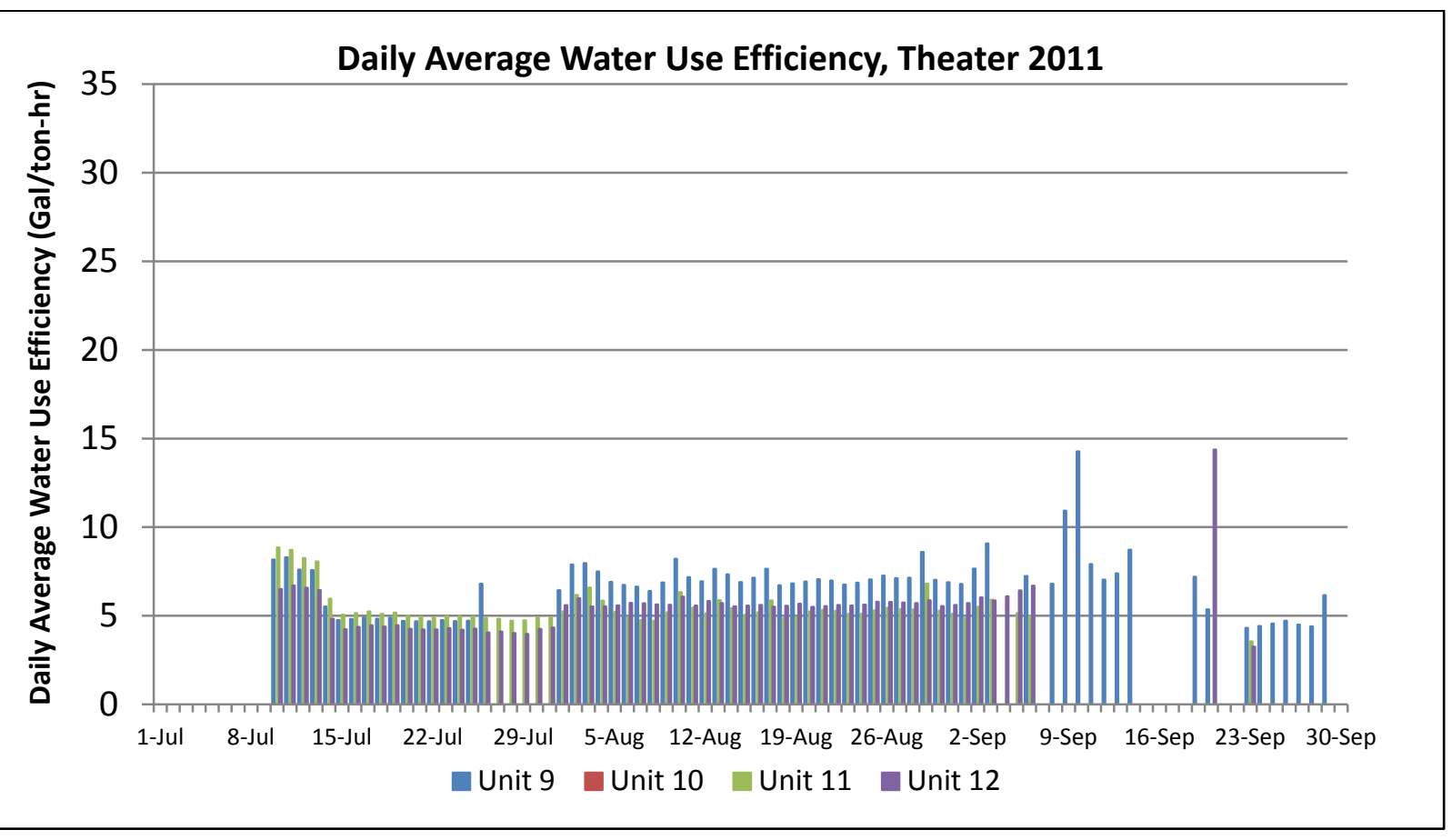

Figure 132. Theater daily average water use efficiency $(\mathrm{gal} / \mathrm{ton} \cdot \mathrm{h}), 2011$ 


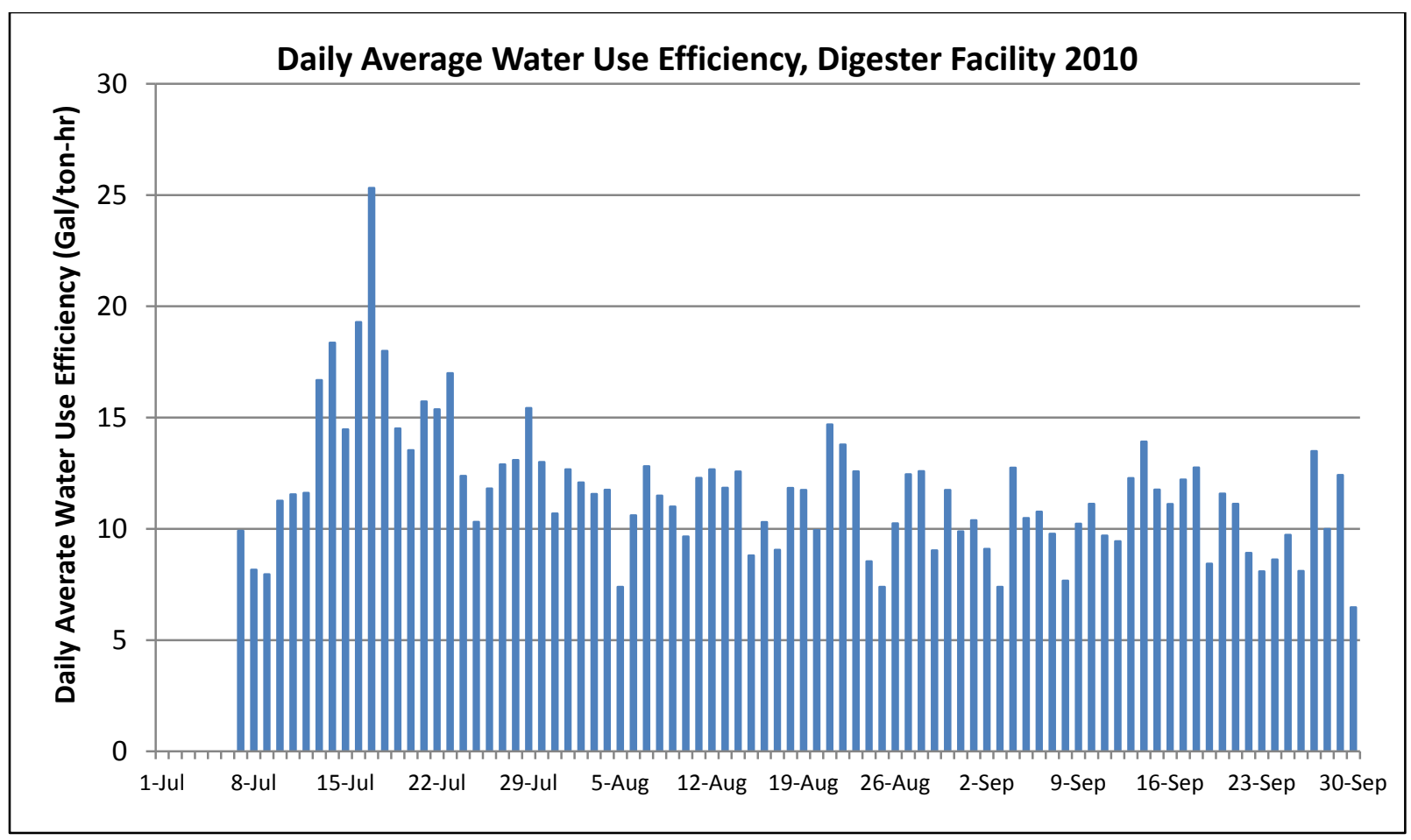

Figure 133. Digester facility daily average water use efficiency $(\mathrm{gal} / \mathrm{ton} \cdot \mathbf{h}), \mathbf{2 0 1 0}$

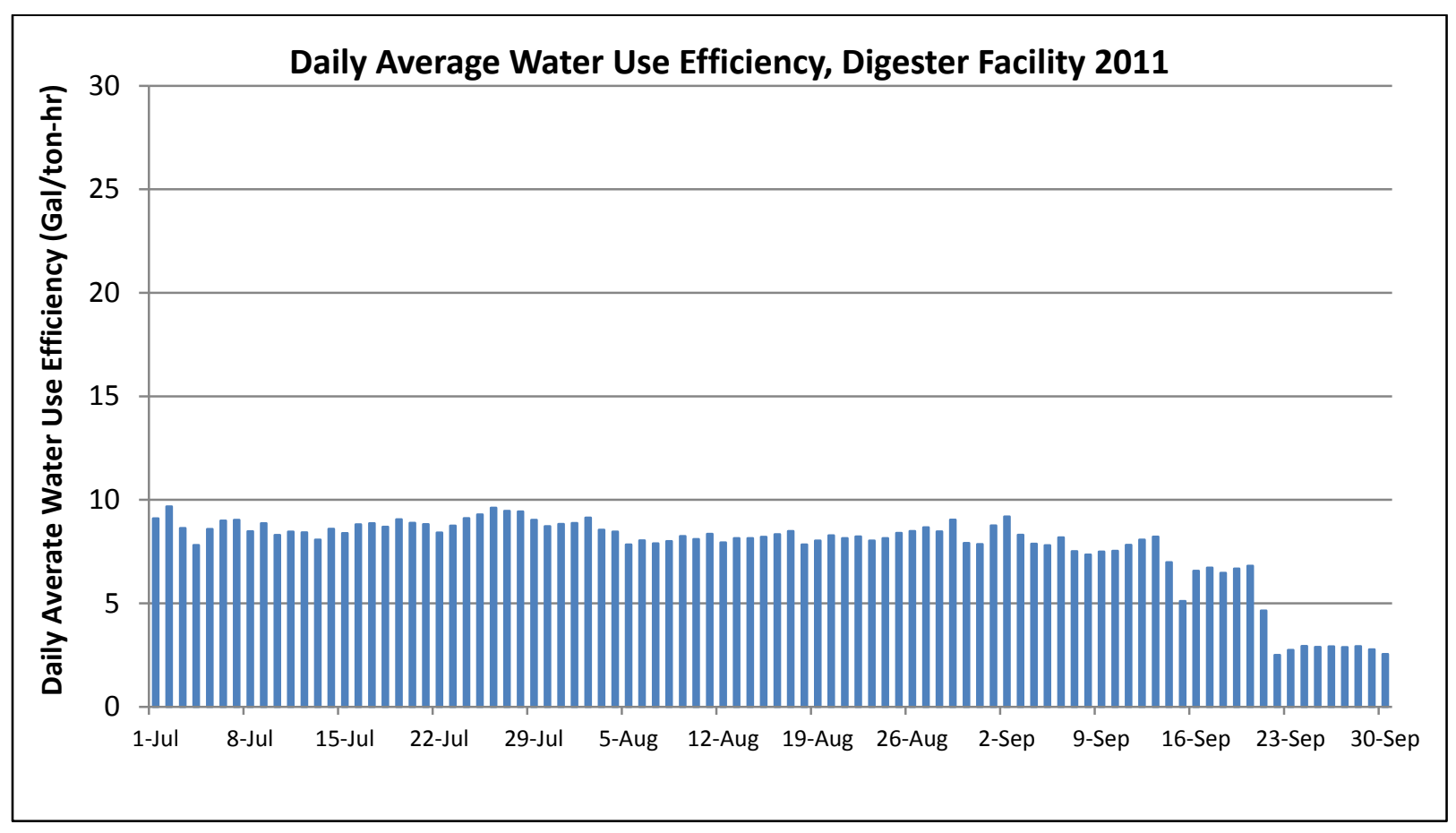

Figure 134. Digester facility daily average water use efficiency (gal/ton·h), 2011 


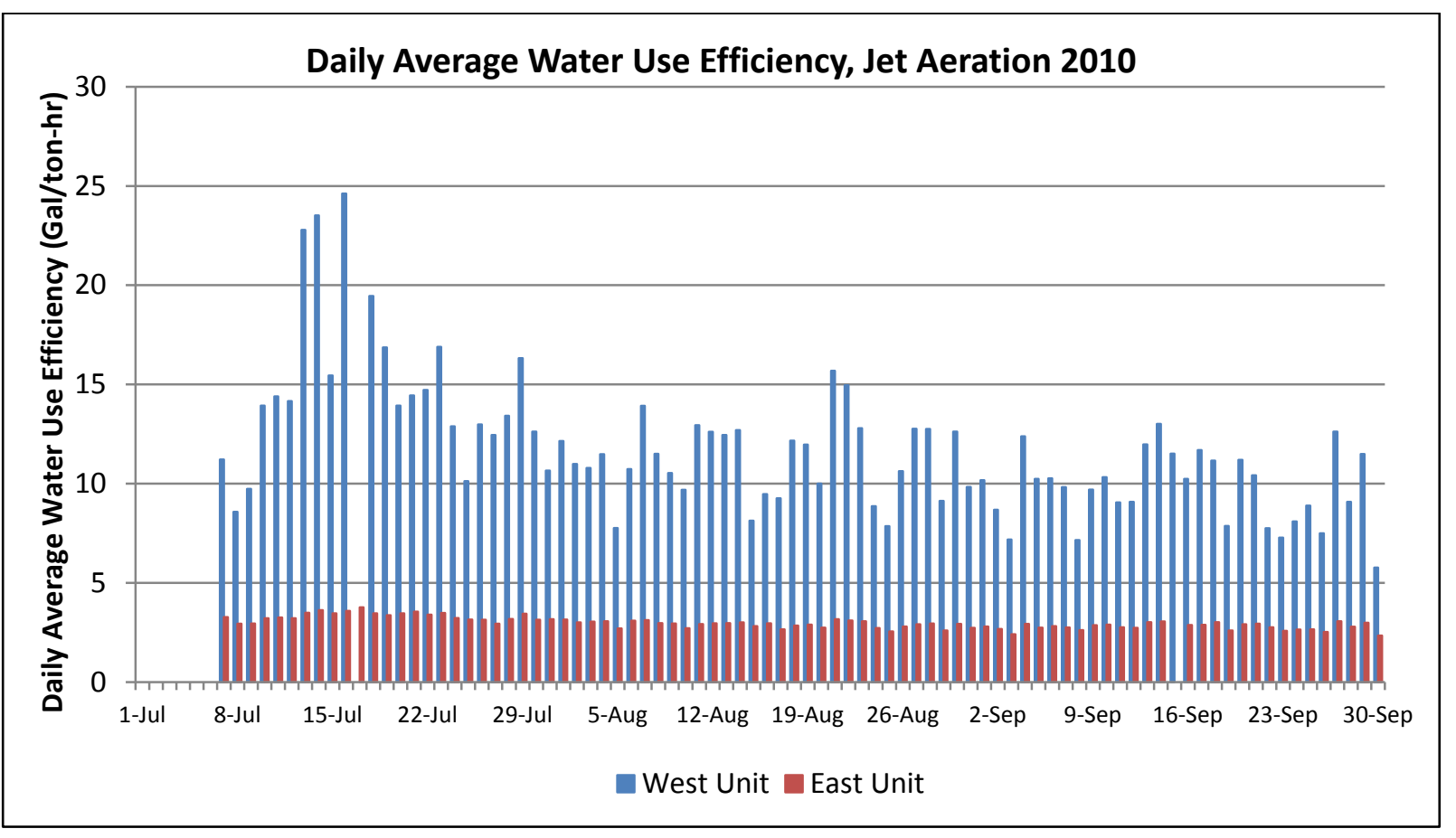

Figure 135. Jet aeration daily average water use efficiency $(\mathrm{gal} / \mathrm{ton} \cdot \mathbf{h}), 2010$

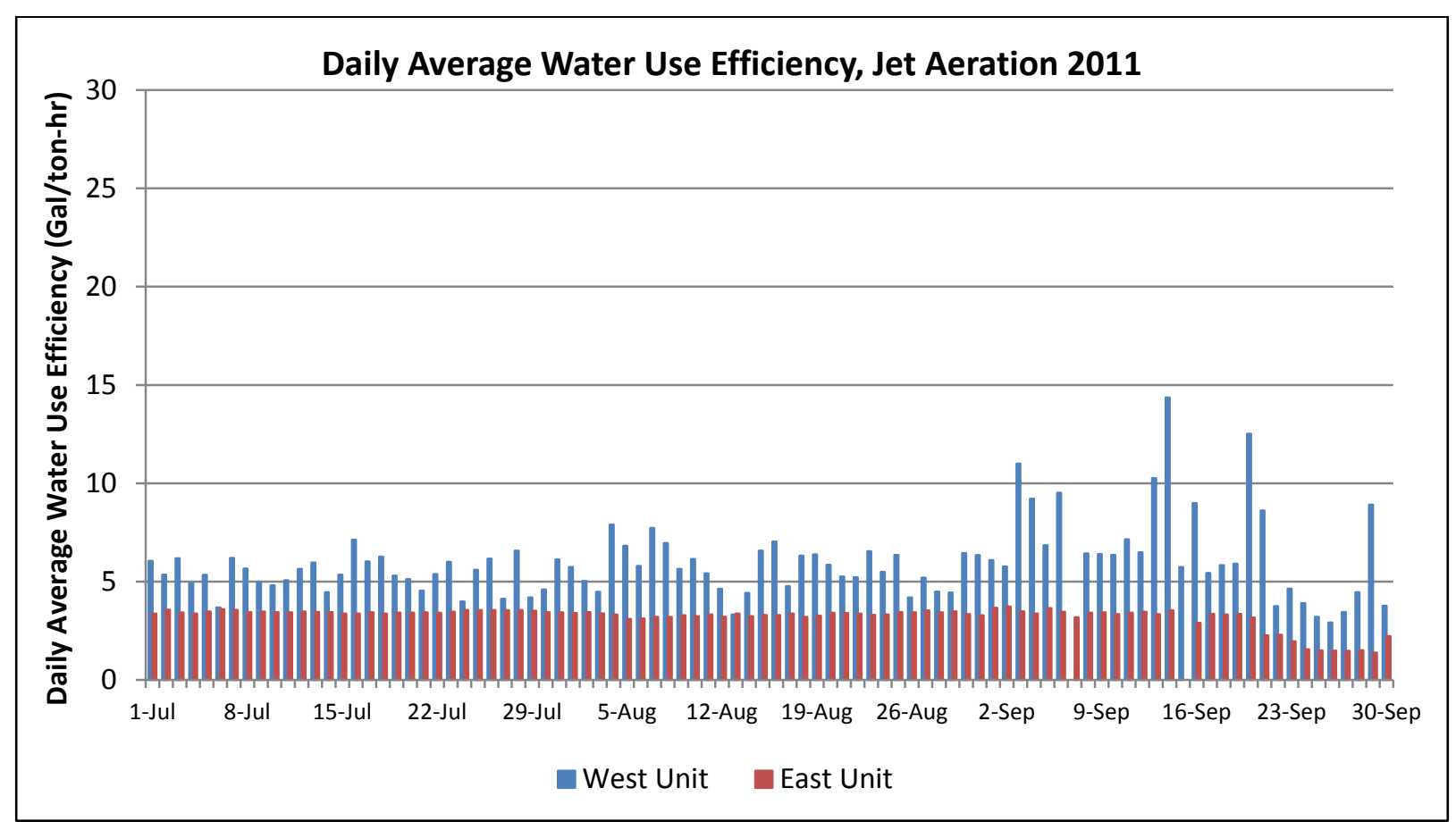

Figure 136. Jet aeration daily average water use efficiency (gal/ton $\cdot h), 2011$ 


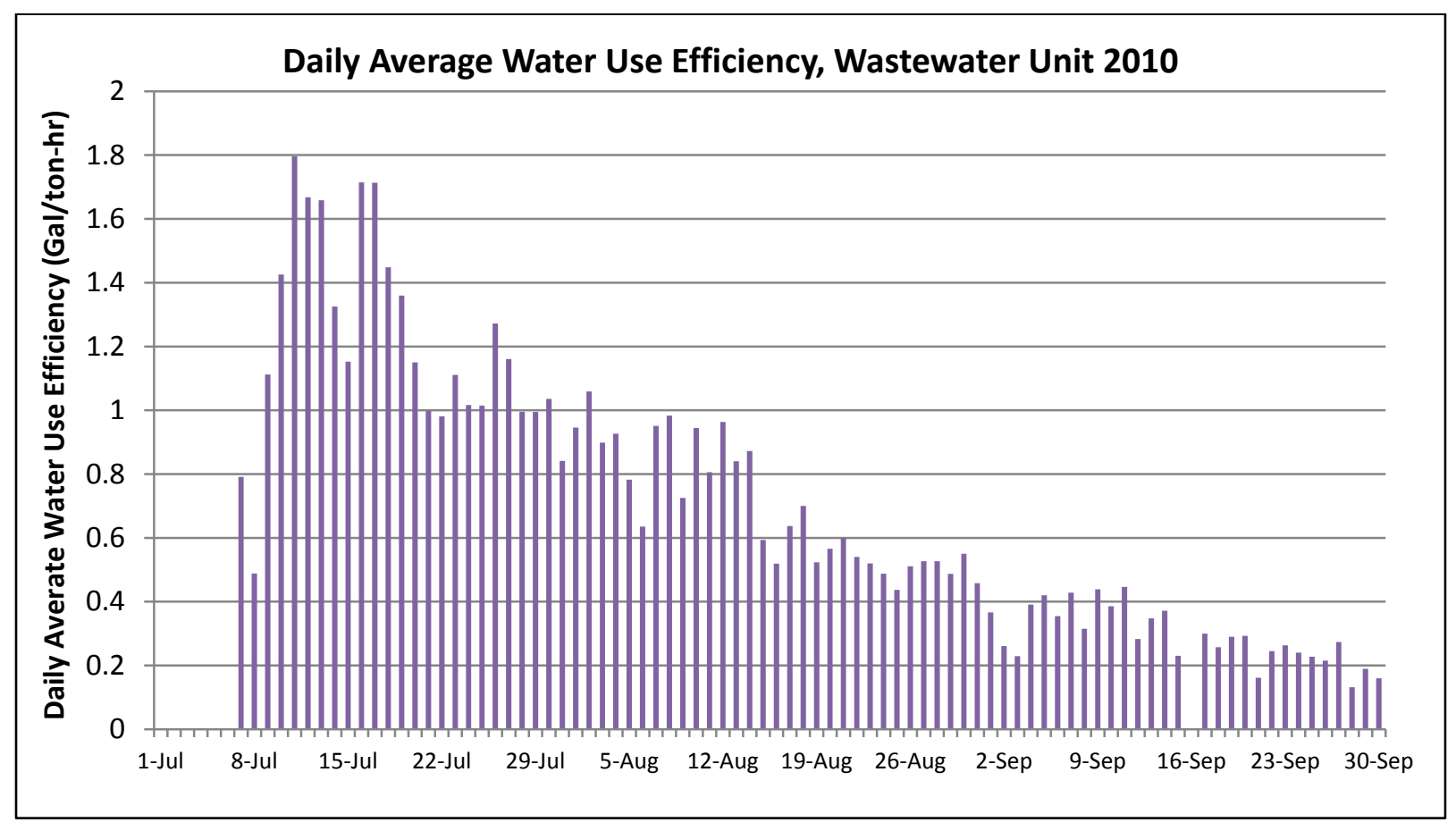

Figure 137. Wastewater unit daily average water use efficiency (gal/ton·h), 2010 


\section{APPENDIX F: TYPES OF COOLING TECHNOLOGIES}

\section{Climate Wizard}

An Australian company is manufacturing an IEC unit called the Climate Wizard. All the inlet air entering the unit passes through in the dry channels. Some SA is returned to the unit through its direct evaporative portion. The internal heat exchanger is set up as a counterflow heat exchanger and the direct evaporative portion is exhausted from the top of the unit.

Based on the counterflow heat exchanger design, the WBE of the unit is higher than that of the Coolerado under certain conditions and is rated at $125 \%$. Given that the SA is indirectly cooled, no moisture is added to the SA. The CW-H10 unit is rated at $1,695 \mathrm{cfm}$ over $0-0.8 \mathrm{in}$. of SP, so the unit provides a similar amount of SA and cooling capacity as the Coolerado C60 unit, and is less sensitive to SP. The supply fan for the CW-H10 unit is rated at 1,400 W, which is more than twice as high as the Coolerado fan $(565 \mathrm{~W})$, so although the fan power is higher the WBE is also higher. These two tradeoffs would need to be analyzed to determine the range of climate zones and economics of each system. ${ }^{\mathrm{xxv}}$ Similar to the Coolerado unit the Climate Wizard also uses an ECM and has a fully variable supply flow. The significant increase in fan power for the Climate Wizard over the Coolerado is likely driven by the increase in the SP across the core heat exchanger. The EER is advertised as 34-50, and although the unit might draw more power at full load, it might also have a higher WBE at $100 \%$ fan speed, which would increase the range of applicable climates relative to the Coolerado.

\section{OASys Two-Stage Residential}

Practical Renewable Energy Corporation currently sells an IEC/DEC for residential applications. The unit is manufactured to include an indirect evaporative coil as the first stage of cooling and a direct evaporative pad as the second stage. The unit is marketed at 2.5-3 tons and is rated to provide $1,500 \mathrm{cfm}$ of conditioned air.

The outdoor air provided is indirectly and directly evaporatively cooled in two stages to a condition that can be below the wet bulb temperature of the OA, thus outperforming a conventional single-stage DEC. The main advantage of this system over a traditional evaporative cooler is similar to the Coolerado in that it can provide colder SATs than a standard evaporative cooler and has a wider range of applicable climates. Laboratory monitoring by NREL has shown that the unit can operate with a combined WBE as high as $103 \%-112 \%$. ${ }^{\text {xvi }}$ The unit uses a $3 / 4$ $\mathrm{hp}$, three-speed fan with a rated power draw of $576 \mathrm{~W}$.

\section{FREUS Outdoor Evaporative Condenser}

The Freus outdoor evaporative condenser consists of an outdoor evaporative condenser coil that is wetted by water spray nozzles and matched to a conventional air-conditioning system (see Figure 138). 

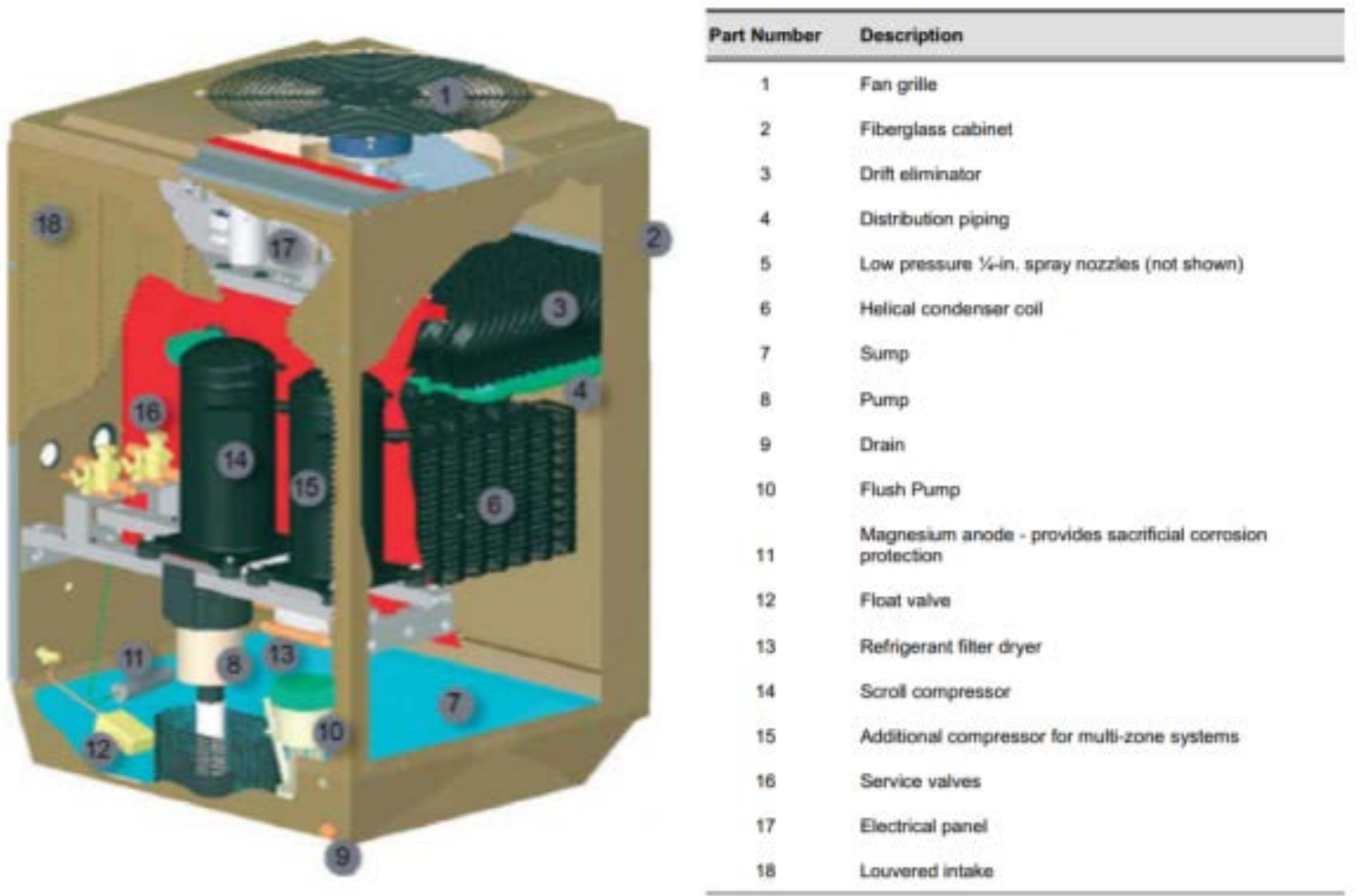

Figure 138. Freus condensing unit

(Source: NREL Report No. TP-5500-46524)

The wetted condenser allows the refrigerant in the condenser coil to approach the outdoor air wet bulb temperature, as opposed to the higher outdoor air dry bulb temperature, thus allowing for higher EERs. The Freus is designed to replace conventional air-cooled condensing units for new and retrofit applications.

\section{Packaged Rooftop Unit Technologies}

Table 81 shows a list of commercially available packaged RTUs and a list of packaged RTUs that use some sort of evaporative cooling. 
Table 81. Commercially Available Packaged RTUs

\begin{tabular}{|c|c|c|c|c|c|c|c|c|c|c|}
\hline \multirow{2}{*}{$\begin{array}{c}\text { Manufacturer } \\
\text { Trane }\end{array}$} & \multirow{2}{*}{$\frac{\text { Model }}{\text { Voyager }}$} & \multirow{2}{*}{ Description } & \multicolumn{2}{|c|}{ Cooling Size } & \multirow{2}{*}{\begin{tabular}{|c|} 
Heating \\
Gas \\
\end{tabular}} & \multirow{2}{*}{$\frac{\text { Fan Control }^{2}}{\text { CAV }}$} & \multirow{2}{*}{$\begin{array}{c}\text { Rated External } \\
\text { Static }^{1}\end{array}$} & \multirow{2}{*}{\begin{tabular}{|l|} 
EER \\
12.0 \\
\end{tabular}} & \multirow{2}{*}{\begin{tabular}{|l|} 
IEER \\
12.6 \\
\end{tabular}} & \multirow{2}{*}{\begin{tabular}{|c}
$\begin{array}{c}\text { Spread } \\
\text { (IEER - EER) }\end{array}$ \\
0.6 \\
\end{tabular}} \\
\hline & & & $150 \mathrm{Mbh}$ & 12.5 tons & & & & & & \\
\hline Trane & Voyager & Constant Speed Scroll & $150 \mathrm{Mbh}$ & 12.5 tons & Gas & VAV & 0.35 in WC & 12.0 & 14.2 & 2.2 \\
\hline Trane & Voyager & Constant Speed Scroll & $182 \mathrm{Mbh}$ & 15.1 tons & Gas & CAV & 0.35 in WC & 12.0 & 13.6 & 1.6 \\
\hline Trane & Voyager & Constant Speed Scroll & $182 \mathrm{Mbh}$ & 15.1 tons & Gas & VAV & 0.35 in WC & 12.0 & 14.2 & 2.2 \\
\hline Trane & Voyager & Constant Speed Scroll & $213 \mathrm{Mbh}$ & 17.7 tons & Gas & CAV & 0.35 in WC & 12.0 & 12.5 & 0.5 \\
\hline Trane & Voyager & Constant Speed Scroll & $213 \mathrm{Mbh}$ & 17.7 tons & Gas & VAV & 0.35 in WC & 12.0 & 13.6 & 1.6 \\
\hline Lennox & Strategos & Constant Speed Scroll & $123 \mathrm{Mbh}$ & 10.3 tons & Gas & CAV & 0.30 in WC & 12.3 & 12.5 & 0.2 \\
\hline Lennox & Strategos & Constant Speed Scroll & $123 \mathrm{Mbh}$ & 10.3 tons & Gas & MSAV & 0.30 in WC & 12.1 & 14.7 & 2.6 \\
\hline Lennox & Strategos & Constant Speed Scroll & $242 \mathrm{Mbh}$ & 20.2 tons & Gas & CAV & 0.40 in WC & 12.6 & 14.2 & 1.6 \\
\hline Lennox & Strategos & Constant Speed Scroll & $242 \mathrm{Mbh}$ & 20.2 tons & Gas & MSAV & 0.40 in WC & 12.6 & 16.6 & 4 \\
\hline Lennox & Energence & Constant Speed Scroll & $120 \mathrm{Mbh}$ & 10.0 tons & Gas & CAV & 0.30 in WC & 12.0 & 13 & 1 \\
\hline Lennox & Energence & Constant Speed Scroll & $120 \mathrm{Mbh}$ & 10.0 tons & Gas & MSAV & 0.30 in WC & 12.0 & 13.8 & 1.8 \\
\hline Lennox & Energence & Constant Speed Scroll & $240 \mathrm{Mbh}$ & 20.0 tons & Gas & CAV & 0.40 in WC & 12.0 & 13.2 & 1.2 \\
\hline Lennox & Energence & Constant Speed Scroll & $240 \mathrm{Mbh}$ & 20.0 tons & Gas & MSAV & 0.40 in WC & 12.0 & 14.5 & 2.5 \\
\hline Carrier & WeatherMaster & Constant Speed Scroll & $146 \mathrm{Mbh}$ & 12.2 tons & Gas & CAV & 0.35 in WC & 12.2 & 13 & 0.8 \\
\hline Aaon & RN Series & Constant Speed Scroll - 6 row Coil & $128 \mathrm{Mbh}$ & 10.7 tons & $?$ & $?$ & 0.30 in WC & 12.8 & 15 & 2.2 \\
\hline Aaon & RN Series & Variable Capacity Scroll - 6 row Coil & $128 \mathrm{Mbh}$ & 10.7 tons & $?$ & $?$ & 0.30 in WC & 12.8 & 15.4 & 2.6 \\
\hline Aaon & RN Series & Constant Speed Scroll - 6 row Coil & $182 \mathrm{Mbh}$ & 15.2 tons & $?$ & $?$ & 0.35 in WC & 11.7 & 12.9 & 1.2 \\
\hline Aaon & RN Series & Variable Capacity Scroll - 6 row Coil & $182 \mathrm{Mbh}$ & 15.2 tons & $?$ & $?$ & 0.35 in WC & 11.4 & 13.2 & 1.8 \\
\hline Aaon & RN Series & Constant Speed Scroll - 6 row Coil & $238 \mathrm{Mbh}$ & 19.8 tons & $?$ & $?$ & 0.40 in $W C$ & 12.4 & 14.1 & 1.7 \\
\hline Aaon & RN Series & Variable Capacity Scroll - 6 row Coil & $238 \mathrm{Mbh}$ & 19.8 tons & $?$ & $?$ & 0.40 in WC & 12.4 & 14.8 & 2.4 \\
\hline McQuay & Rebel & Variable Capacity Scroll - 6 row Coil & $123 \mathrm{Mbh}$ & 10.3 tons & Gas & CAV & 0.30 in WC & 12.4 & 16.9 & 4.5 \\
\hline McQuay & Rebel & Variable Capacity Scroll - 6 row Coil & $123 \mathrm{Mbh}$ & 10.3 tons & Gas & VAV & 0.30 in WC & 12.4 & 17.8 & 5.4 \\
\hline McQuay & Rebel & Variable Capacity Scroll - 6 row Coil & $123 \mathrm{Mbh}$ & 10.3 tons & None & VAV & 0.30 in WC & 12.6 & 18.1 & 5.5 \\
\hline McQuay & Rebel & Variable Capacity Scroll - 6 row Coil & $146 \mathrm{Mbh}$ & 12.2 tons & Gas & CAV & 0.35 in WC & 12.1 & 17.5 & 5.4 \\
\hline McQuay & Rebel & Variable Capacity Scroll - 6 row Coil & $146 \mathrm{Mbh}$ & 12.2 tons & Gas & VAV & 0.35 in WC & 12.1 & 18.4 & 6.3 \\
\hline McQuay & Rebel & Variable Capacity Scroll - 6 row Coil & $146 \mathrm{Mbh}$ & 12.2 tons & None & VAV & 0.35 in WC & 12.3 & 18.7 & 6.4 \\
\hline
\end{tabular}

\section{AAON Packaged Rooftop Unit}

AAON manufactures a line of large high-performance packaged RTUs that are manufactured to include an airside economizer, and an option for a water-cooled or evaporatively cooled condenser. The water-cooled option is available at a capacities of 25-240 tons (RN and RL series), and has to be connected to an external water source or cooling tower. The evaporatively cooled option is available at capacities of $45-240$ tons (RL series). Table 82 shows the rated cooling EERs for the three design options for the RL series unit.

Table 82: AAON RL Series EER Rating

\begin{tabular}{||c|c|c|c||}
\hline \hline Size (Tons) & Air-Cooled EER & $\begin{array}{c}\text { Evaporatively Cooled } \\
\text { EER }\end{array}$ & $\begin{array}{c}\text { Water-Cooled } \\
\text { EER }\end{array}$ \\
\hline 45 to 70 & 10.3 & 12.7 & 14.3 \\
\hline 75 to 95 & 9.8 & 12.9 & 14 \\
\hline 100 to 134 & 9.9 & 12.6 & 13.9 \\
\hline 135 to 170 & 9.9 & 12.2 & 13.6 \\
\hline 180 to 240 & 9.4 & 11.9 & 13 \\
\hline
\end{tabular}

The water-cooled condenser option has the highest efficiencies followed by the evaporatively cooled and air-cooled options. The evaporatively cooled options have a rated EER that is about $20 \%$ higher than the air-cooled options. 
The evaporatively cooled option is designed with nozzles that spray water directly on the condenser coil. The condenser fan draws across the heat exchanger, evaporating the water from the coil. The process can cool the condenser tubes close to the ambient wet bulb temperatures, and can result in $15^{\circ}-20^{\circ} \mathrm{F}$ cooler condensing temperatures in the dryer climates that are applicable for the Coolerado technology.

The AAON design also includes a de-superheater that rejects some of the heat from the condenser and reduces the refrigerant temperature before it enters the condenser coil. The claimed performance benefits from the manufacturer are:

- $\quad$ Rated EER of 11.9-12.7 at American Heating and Refrigeration Institute rating conditions

- $\quad$ Estimated $20 \%-40 \%$ reduction in compressor energy use relative to an air-cooled condenser

- $\quad$ The use of the de-superheater is advertised to reduce water consumption and the rate of mineralization on the condenser coils, and reduce the total water consumption

- Lower condenser temperature requires lower volumetric flow rates, and smaller condenser fans and fan motors. The system is also designed with variable frequency drive condenser fans, which offer better part load condenser fan performance.

Although the evaporative cooled condenser option offers savings, the product is offered only in very large capacities at which a more efficient option would be a standard variable air volume AHU with variable-speed centrifugal chillers and a water-cooled condenser loop.

\section{EVAPORCOOL}

EVAPORCOOL is manufactured as a retrofit product that can be field applied to existing RTUs. The system can be designed and applied to a variety of RTUs, air-cooled chillers, and refrigeration system condensing units. When applied to existing RTUs the system is set up to precool condenser air with an add-on DEC medium. The secondary frame that is added to the unit includes a filter that blocks larger media from entering the unit and a second frame with the spray nozzles and evaporative media.

The pre-filter and evaporative pad are mounted together in front of the condenser coil. The system also includes a secondary heat exchanger that is wrapped around the suction line in the refrigeration system. This line contains cold air after it leaves the evaporator on its way to the condenser. An onboard control system monitors the OA conditions and refrigeration system operation. This information is used to set the water consumption flow rate and control the operation of the EVAPORCOOL.

The claimed performance benefits from the manufacturer are:

- $\quad$ Estimated condenser savings of $20 \%-30 \%$, with documented case studies measuring energy savings 
- $\quad$ The suction line heat exchanger can reduce the evaporative water temperature by as much as $20^{\circ} \mathrm{F}$, which increases the effectiveness of the evaporation system

- $\quad$ The ability to retrofit this system onto any existing packaged RTU allows for a greater market share, and more potential energy savings

Although the add-on condenser air precooling will reduce the compressor energy use, it will add SP to the condenser fans and the total energy use of an entire packaged unit would need to be monitored to verify RTU level savings.

\section{Munters Oasis EPX}

Munters manufactures a line of custom-built unitary AHUs to include IEC, condenser air precooling, and an option to add DEC. The IEC is provided as the first stage of cooling; the second stage is provided by a DX coil. The indirect coil is set up as a counterflow polymer-based heat exchanger. The indirect economizer airstream is set up to capture RA that is being exhausted from the building and OA.

The EA or OA is drawn over the wetted polymer heat exchanger, which indirectly cools the OA before it enters the DX coil. The EA leaving the indirect coil is used to cool the condenser coil and provides a means of evaporatively precooling the condenser coil. The OASIS EPX packaged RTU is manufactured in 15- to 45-ton capacities, and the claimed performance benefits from the manufacturer are:

- Indirect evaporative heat exchanger can reduce the SA by as much as $30^{\circ} \mathrm{F}$

- $\quad$ The use of RA/EA in the indirect cycles allows for energy recovery from the space and increases both the effectiveness of the indirect cycle and reduces the water consumption of the indirect cycle.

- $\quad$ During heating mode operation the heat exchanger can also recover heat from the EA.

- The condenser air precooling features allows for reduced condensing temperatures and improved efficiency.

- $\quad$ The DEC option provides additional evaporative cooling in dry climates.

The manufacturer does not provide design cooling efficiency ratings, but this product includes a number of innovative features. The unit has the potential to be one of the most efficient packaged units for dry climates. The two efficiency penalties of the proposed design include the increased SP drop associated with the indirect coil for the supply fan, the increased SP drop for the condenser fan, and the pump power for the indirect evaporative coil.

\section{DUALCOOL}

DUALCOOL is manufactured as a retrofit product that can be field applied to existing RTUs. The system can be designed and applied to a variety of RTUs and is designed to precool condenser air with a direct evaporative medium, and pr-cool OA with an IEC. The direct evaporative medium uses an 8-in. deep Munters CelDek. 
The system is designed to provide evaporatively precooled condenser air. The cooled sump water is circulated through an IEC to precool ventilation air. Additional piping is installed on the condensate drain to reroute condensate drain water to the evaporative cooling sump. The claimed performance benefits from the manufacturer are:

- Can precool condenser air and OA and has resulted in energy savings of 30\% in Santa Rosa, California ${ }^{\text {xxvii }}$

- $\quad$ The cooler sump water temperatures provide for additional IEC of the OA.

- The direct evaporative effectiveness is noted as 0.84 and the indirect is noted as 0.6 , with a pump at $0.040 \mathrm{hp}$

- The installed cost for two 24-ton units is $\$ 18,043$, with an estimated installed cost of $\$ 375 /$ ton

Trane is integrating this unit into a line of packaged 14- to 17-ton RTUs, Trane Voyager DC.

\section{COOLERADO H80}

Coolerado also manufacturers a 5-ton packaged RTU that integrates the multistaged indirect evaporative technology with a DX system. The unit is designed to provide cooling, but does not include any type of furnace to heat the facility. Figure 139 shows an airflow schematic of the RTU.

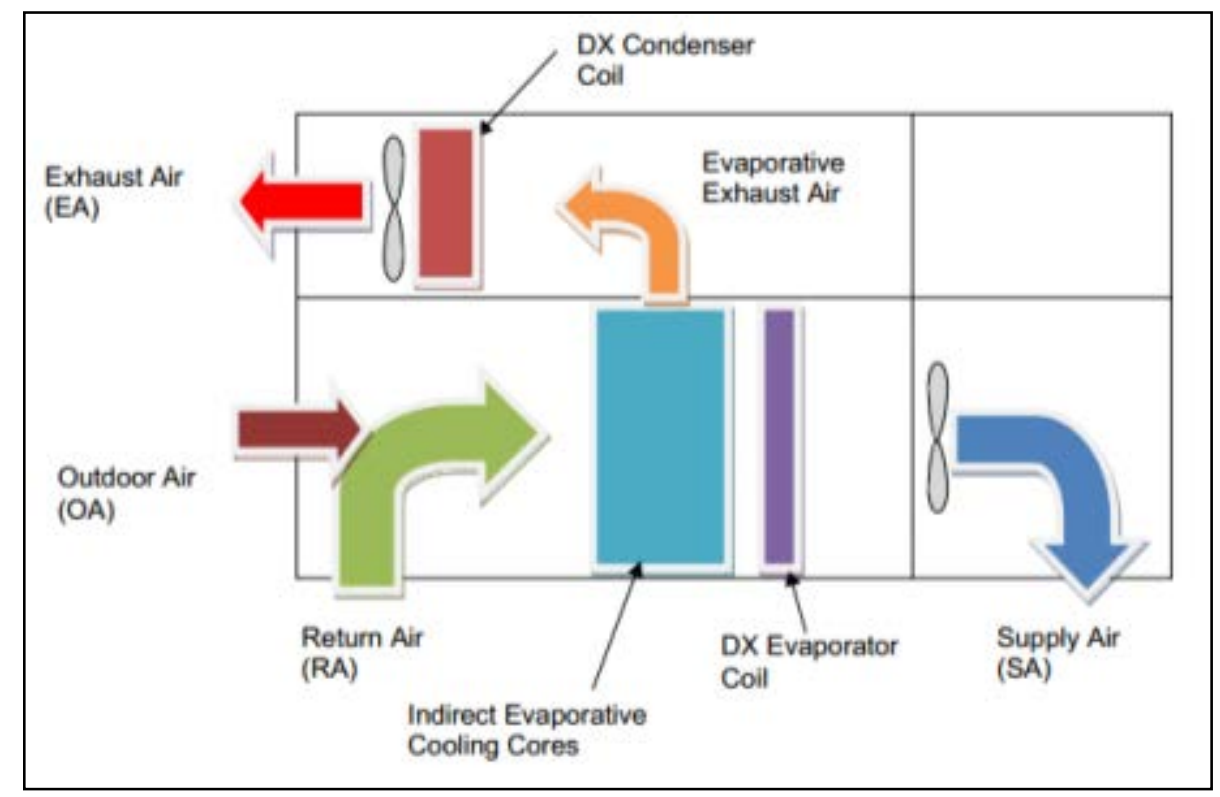

Figure 139. Coolerado H80 RTU airflow schematic

(Source: Eric Kozubal, NREL)

RA and OA are brought into the unit and cooled by an indirect evaporative medium. Between $43 \%$ and $46 \%$ of this air is used as an IEC stream. The balance is then passed through a refrigerant-based evaporator coil and supplied to the space by a high-efficiency fan. The EA from the evaporative process is generally cooler than the ambient air and is used to precool 
condenser air. The unit was tested through the Western Cooling Challenge ${ }^{\text {xxviii }}$ and had an EER of 20.1 at peak conditions and $27.8 \mathrm{Btu} / \mathrm{Wh}$ at surrogate annual conditions (see Table 83 ). ${ }^{\mathrm{xxix}}$

Table 83. Coolerado H80 Laboratory Test Results

\begin{tabular}{|c|c|c|c|c|}
\hline & & Specification & Performance & Units \\
\hline \multirow{8}{*}{$\begin{array}{l}\text { Peak } \\
\text { Conditions } \\
\left(105^{\circ} \mathrm{F} / 73^{\circ} \mathrm{F}\right)\end{array}$} & Total Credited Cooling & $36-360$ & 61.7 & $\mathrm{kBtu} / \mathrm{h}$ \\
\hline & Sensible Credited Cooling & - & 56.9 & $\mathrm{kBtu} / \mathrm{h}$ \\
\hline & Power & - & 2.84 & $\mathrm{~kW}$ \\
\hline & Credited EER & - & 21.7 & Btu/Wh \\
\hline & Sensible Credited EER & 214.0 & 20.1 & Btu/Wh \\
\hline & Outlet Humidity & s0.0092 & 0.00917 & - \\
\hline & - Water Use & - & 1.83 & galton-h (sensible credited) \\
\hline & Water Evaporation & - & 1.50 & galton $h$ (sensible credited) \\
\hline \multirow{7}{*}{$\begin{array}{l}\text { Surrogate } \\
\text { Annual } \\
\text { Conditions } \\
\left(90^{\circ} \mathrm{F} / 64^{\circ} \mathrm{F}\right)\end{array}$} & Total Credited Cooling & - & 47.7 & kBtu/h \\
\hline & Sensible Credited Cooling & - & 45.6 & kBtu/h \\
\hline & Mean Power & - & 1.64 & kW \\
\hline & Credited EER & - & 29.1 & Btu/Wh \\
\hline & Sensible Credited EER & 217.0 & 27.8 & Btu/Wh \\
\hline & - Water Use & 54.0 & 1.84 & gathon $h$ (sensible credited) \\
\hline & Water Evaporation & - & 1.50 & gahton-h (sensible credited) \\
\hline
\end{tabular}

This unit is one of the few products that has published laboratory test results and offers a number of unique features that may result in higher cooling efficiencies than the other packaged RTUs.

\section{Airmax}

The Airmax system combines IEC, DEC, and condenser air precooling into single 5-ton packaged RTU. ${ }^{\mathrm{xx}}$ The first stage of cooling is set up with an indirect evaporative coil, the second stage uses a standard DX coil, and the third stage is a direct evaporative pad. The evaporator water from the indirect cycle is used in a separate direct evaporative pad to precool condenser air.

The system is designed with four modes of operation. Not all modes operate at the same time. If the cooling load can be met with OA, the OA economizer is used and no mechanical cooling occurs. If the DEC cooler can meet the load, the fan operates with $100 \%$ outside air that is sent through it. For the third mode of operation the supply and condenser fans operate, and the IEC and DEC systems are operated, and the DX compressor remains off. If the IEC/DEC system cannot meet the cooling load, the IEC and DX coil are operated and the DX unit is turned off. Although this unit has a number of unique features and modes of operation, it did not meet the Western Cooling Challenge minimum performance requirements. Table 84 shows the sensible EERs at peak and annual surrogate conditions. 
Table 84: Summary of AirMax Western Cooling Challenge Results

\begin{tabular}{|c|c|c|c|c|}
\hline & $\begin{array}{c}\text { Peak Conditions } \\
\text { (Indirect +DX) }\end{array}$ & $\begin{array}{c}\text { Annual Conditions } \\
\text { (Indirect + DX) }\end{array}$ & $\begin{array}{c}\text { Annual Conditions } \\
\text { (Direct) }\end{array}$ & $\begin{array}{c}\text { Annual Conditions } \\
\text { (Indirect-Direct) }\end{array}$ \\
\hline $\begin{array}{c}\text { Sensible } \\
\text { Credited EER }\end{array}$ & 8.6 & 9.3 & 20.9 & 16.4 \\
\hline
\end{tabular}

\section{Medium to Large Commercial Building Technologies}

Medium to large commercial buildings typically use central chilled water plants that deliver chilled water to multiple distributed AHUs throughout the facility. The chilled water plants are typically set up with a primary/secondary chilled water loop and the condenser can be air cooled or water cooled (see Figure 140). If the system is water cooled it includes a condenser water loop with a series of condenser water pumps and is connected to a cooling tower.

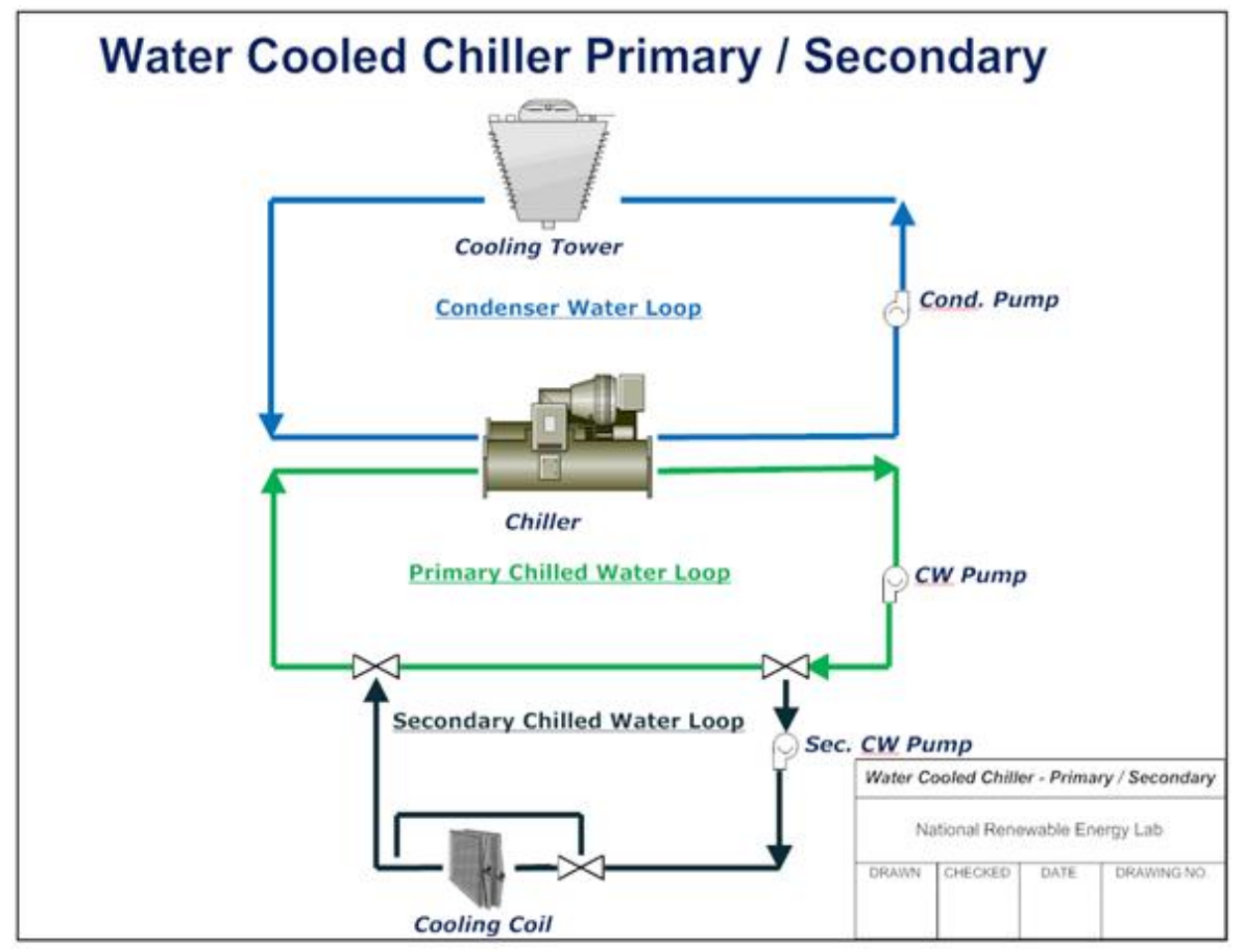

Figure 140. Water-cooled chilled water plant with primary/secondary configuration

(Source: Jesse Dean, NREL)

These larger chilled water plants with centrifugal chillers are typically much more efficient than the smaller, air-cooled packaged units, with design efficiencies as low as $0.4 \mathrm{~kW} / \mathrm{ton}$. The AHUs and terminal units that the central chilled water plants are connected to provide the cooling to the space and come in a number of configurations.

Evaporative based cooling technologies can be integrated in the central chilled water plant and the AHUs/terminal units in a variety of ways. The most common are water cooled chilled water plants, waterside economizer/IEC, DEC, and IEC/DEC. 


\section{REFERENCES}

\footnotetext{
${ }^{\mathrm{i}}$ Heat Wave Nearly Causes Rolling Blackouts in California, http:/www.nytimes.com/2000/08/02/us/heat-wave-nearly-causes-rolling-blackouts-incalifornia.html

${ }_{\text {ii Building Energy Databook 2011, http://buildingsdatabook.eren.doe.gov/ }}$

iii FEMP BLCC, http://www1.eere.energy.gov/femp/information/download blcc.html

${ }^{\text {iv }}$ Richard E. Brown, J.G.K., Electricity Use in California: Past Trends and Present Usage Patterns. Energy Policy, 2002. 31(9): p. 15.
}

ASHRAE Standard 62.1-2010, http://www.techstreet.com/ashrae/standards/ashrae/62 1_2010?product_id=1720986

${ }^{v i}$ LEED 2009, http://www.usgbc.org/DisplayPage.aspx?CategoryID=19

vii Evaporative Cooling Design Guide, http://www.emnrd.state.nm.us/ecmd/multimedia/documents/EvapCoolingDesignManual.pdf viii http://www.idalex.com/technology/how_it_works_-_technological_perspective.htm

${ }^{i x}$ FEMP Technology Installation Review, http://www1.eere.energy.gov/femp/pdfs/tir_coolerado.pdf

${ }^{\mathrm{x}}$ Coolerado H80, http://www.nrel.gov/docs/fy11osti/46524.pdf

${ }^{x i}$ National Renewable Energy Laboratory, Buildings Research - Thermal Test Facility, http://www.nrel.gov/buildings/facilities.html

${ }^{x i i}$ ASHRAE Standard 143-2000 - Method of Test for Rating Indirect Evaporative Coolers (ANSI), http://www.techstreet.com/standards/ashrae/143 2000?product id=722837

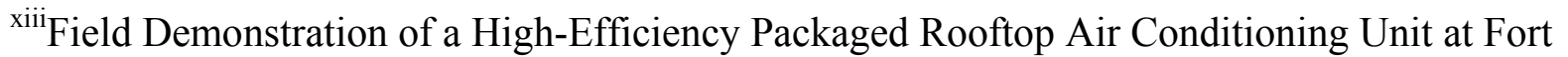
Gordon, Augusta, GA http://www.pnl.gov/main/publications/external/technical_reports/PNNL15746.pdf

${ }^{\text {xiv }}$ RS Means Facilities Maintenance and Repair Cost Data Book, http://rsmeans.reedconstructiondata.com/

${ }^{\mathrm{xv}}$ [1] Gleick, P.H. (1994). "Water and Energy" in Annual Reviews, Annu. Rev. Energy, Environ., 1994, 19:267-99.

${ }^{x v i}$ RS Means Facilities Maintenance and Repair Cost Data Book, http://rsmeans.reedconstructiondata.com/

xvii Commercial Building Benchmark, http://www1.eere.energy.gov/buildings/commercial initiative/before 1980.html ${ }^{x v i i i}$ Office of Management and Budget Federal Life Cycle Costing Procedures, http:/www.whitehouse.gov/sites/default/files/omb/memoranda/2012/m-12-06.pdf

${ }^{\text {xix }}$ Commercial Reference Buildings, http://www1.eere.energy.gov/buildings/commercial_initiative/reference_buildings.html ${ }^{\mathrm{xx}}$ Field Demonstration of Packaged Rooftop Units, http://www.pnl.gov/main/publications/external/technical_reports/PNNL-15746.pdf ${ }^{\mathrm{xxi}}$ Commercial Reference Buildings, http://www1.eere.energy.gov/buildings/commercial_initiative/reference_buildings.html 
xxii Winiarski, D.W.; Halverson, M.A. (2008). Equipment Efficiency for Existing Benchmark Buildings. Internal report. Richland, WA: Pacific Northwest National Laboratory.

${ }^{x x i i i}$ National Renewable Energy Laboratory, Buildings Research - Thermal Test Facility, http://www.nrel.gov/buildings/facilities.html

xxiv ASHRAE Standard 143-2000 - Method of Test for Rating Indirect Evaporative Coolers (ANSI), http://www.techstreet.com/standards/ashrae/143_2000?product id=722837

${ }^{x x v}$ Climate Wizard Technical Fact Sheet, http://www.climatewizard.com.au/en/technicaldownloads

${ }^{\mathrm{xxvi}}$ Projected Benefits of New Residential Evaporative Cooling Systems, http://www.nrel.gov/docs/fy07osti/39342.pdf

${ }^{x x v i i}$ UC Davis DUALCOOL Fact Sheet, http://wcec.ucdavis.edu/sandbox/search/ResearchBriefsPDF/RB DualCoolPre-

CoolerRetrofit.pdf

${ }_{\text {xxviii Western Cooling Challenge, http://wcec.ucdavis.edu/programs/western-cooling-challenge/ }}$

${ }^{\text {xxix }}$ Kozubal, E.; Slayzak, S. (2010). Coolerado 5 Ton RTU Performance: Western Cooling Challenge Results (Revised). 15 pp.; NREL Report No. TP-5500-46524.

${ }^{\mathrm{xxx}}$ Airmax http://www.airmax-solutions.com/IDEC.aspx 